UNIVERSIDADE DE SÃO PAULO

FACULDADE DE EDUCAÇÃO

\title{
APRENDENDO A ENSINAR MATEMÁTICA NAS SÉRIES INICIAIS DO ENSINO FUNDAMENTAL
}

TANIA TERESINHA BRUNS ZIMER 
TANIA TERESINHA BRUNS ZIMER

\section{APRENDENDO A ENSINAR MATEMÁTICA NAS SÉRIES INICIAIS DO ENSINO FUNDAMENTAL}

Tese apresentada à Faculdade de Educação da Universidade de São Paulo, como requisito para obtenção do título de Doutora em Educação.

Área de Concentração: Ensino de Ciências e Matemática.

Orientadora: Prof ${ }^{a}$. Dra. Maria Lúcia Vital dos Santos Abib.

São Paulo 
AUTORIZO A REPRODUÇÃO E DIVULGAÇÃO TOTAL OU PARCIAL DESTE TRABALHO, POR QUALQUER MEIO CONVENCIONAL OU ELETRÔNICO, PARA FINS DE ESTUDO E PESQUISA, DESDE QUE CITADA A FONTE.

Catalogação na Publicação

Serviço de Biblioteca e Documentação

Faculdade de Educação da Universidade de São Paulo

371.12

Zimer, Tania Teresinha Bruns

Z71a Aprendendo a ensinar matemática nas séries iniciais do ensino fundamental / Tania Teresinha Bruns Zimer ; orientadora Maria Lúcia Vital dos Santos Abib. São Paulo : s.n., 2008.

299 p.; tabs. ; figs. ; graf. ; apêndices ; anexos

Tese (Doutorado - Programa de Pós-Graduação em Educação. Área de Concentração: Ensino de Ciências e Matemática) - Faculdade de Educação da Universidade de São Paulo.

1. Formação de professores 2. Ensino de matemática 3. Curso de pedagogia 4. Estágios 5. Evolução conceitual I. Abib, Maria Lúcia Vital dos Santos, orient. 


\section{FOLHA DE APROVAÇÃO}

Tania Teresinha Bruns Zimer

Aprendendo a ensinar matemática nas séries iniciais do ensino fundamental

Tese apresentada à Faculdade de Educação da Universidade de São Paulo, como requisito para obtenção do título de Doutora em Educação.

Área de Concentração: Ensino de Ciências e Matemática.

Aprovado em:

\section{Banca Examinadora}

Prof.

Instituição:

Assinatura:

Prof.

Instituição:

Assinatura:

Prof.

Instituição:

Assinatura:

Prof.

Instituição:

Assinatura:

Prof.

Instituição:

Assinatura. 
Dedico este trabalho àqueles que o vivenciaram comigo no dia-a-dia e, principalmente, à minha querida família, Remiz, meu marido e eterno namorado e Gustavo e Tiago, meus filhos amados, pelos quais tenho profunda paixão, admiração e gratidão pela paciência, carinho e apoio externados diariamente e, principalmente, ao longo do desenvolvimento deste trabalho. 


\section{AGRADECIMENTOS}

Essas poucas palavras tentam expressar o quanto significativa foi a contribuição de cada pessoa que, de alguma maneira, perpassou o desenvolvimento deste trabalho. Deste modo, com gratidão e humildade agradeço a todos que cruzaram e ajudaram a construir o caminho trilhado para a elaboração desta pesquisa, em especial:

- Aos meus pais, Guido e Terezinha, por seus ensinamentos sobre a vida.

- Aos meus sogros, irmãos, cunhados e sobrinhos, pela compreensão durante a ausência da vida familiar.

- À minha orientadora, Maria Lúcia, pela seriedade com que me orientou neste trabalho e, principalmente, pela amizade construída ao longo do desenvolvimento desta pesquisa. Muito obrigada.

- Às amigas de longa caminhada, Flávia e Ettiène, pelas leituras, sugestões e trocas de idéias, pelo apoio e carinho e, acima de tudo, pela amizade que se fortalece constantemente.

- Aos meus colegas do grupo de estudos - GERPROF: Alfonso, Beatriz, Daniela, Helder, Ivete, Maria Antonia, Maria Nizete, Monica, Patrícia, Rita, Rosana, Sérgio, Viviane pelas imensas contribuições que fizeram ao meu trabalho e por terem me acompanhado durante todo o processo de elaboração desta tese. Um grande aprendizado e lembranças muito agradáveis.

- Aos professores, Ori e Villani, pelas valiosas contribuições oferecidas durante o processo de qualificação deste trabalho.

- Às amigas Ivanilda, Odisséa e Vilma, pelo apoio, incentivo e carinho.

- À professora de Prática Pedagógica - Estágio em Docência e amiga Sandra, pela liberdade plena concedida para o desenvolvimento deste trabalho e o constante apoio.

- Aos meus colegas da UFPR, em especial, do Departamento de Teoria e Prática de Ensino, pelos incentivos e apoio no desenvolvimento deste trabalho.

- Aos meus alunos bolsistas do Laboratório de Ensino e Aprendizagem de Matemática e Ciências Físicas e Biológicas, pelas palavras de incentivo.

- À professora Sônia Maria Zanetti pela revisão de linguagem de meu trabalho.

- Aos alunos do curso de Pedagogia da UFPR, em especial, aos matriculados nas disciplinas de Metodologia do Ensino de Matemática e Prática Pedagógica do ano de 2005, pela participação e contribuição para esta pesquisa.

- E, finalmente, aos sujeitos A1, A2 e A3, por terem me permitido compreender melhor o processo formativo para o ensino da Matemática. 


\section{RESUMO}

O presente trabalho é relativo à uma investigação sobre parte da trajetória da formação para o ensino da Matemática nas séries iniciais do Ensino Fundamental de futuras professoras - alunas de um curso de Pedagogia, cuja análise focou as concepções em relação à Matemática e seus processos de ensino e aprendizagem. O objetivo investigativo principal foi conhecer de que maneira o futuro professor estabelece conexões entre suas concepções e a prática pedagógica pré-profissional de modo a permitir a compreensão sobre o modo como ele aprende a ensinar Matemática. Para tanto, considerou-se a teoria de Mudança Conceitual como guia na estruturação do trabalho de campo e a Noção de Perfil Conceitual como fio condutor para a análise das informações obtidas no campo de pesquisa. Os dados foram obtidos por meio de questionários aplicados durante o desenvolvimento de uma disciplina curricular do curso - Metodologia do Ensino da Matemática - e, também, por meio de entrevistas reflexivas realizadas durante o período de desenvolvimento do estágio em docência proveniente de outra disciplina curricular - Prática Pedagógica C: Estágio em Docência - e, ainda, das anotações, da pesquisadora, no diário de campo relativo às observações das aulas de Matemática dos estagiários; dos videoteipes das aulas na universidade, de entrevistas e, também, de documentos (Proposta Pedagógica do curso de Pedagogia, planos de aula e relatório de estágio dos sujeitos). Para a análise em profundidade dos dados, desenvolveu-se o estudo de três casos - A1, A2 e A3 - sendo que o primeiro caso e o segundo evidenciaram certa evolução conceitual em relação às concepções sobre a Matemática e seus processos de ensino-aprendizagem, após terem vivenciado perturbações conceituais e emocionais e, também, demostrarem consciência sobre seus diferentes modos de pensar e agir em sala de aula. Já A3, não apresentou evoluções conceituais em seu perfil, possivelmente, devido a obstáculos que emergiram durante o período investigativo. Entre os resultados obtidos com as análises, constatou-se que o futuro professor vincula as próprias experiências com a escolarização como meio de estabelecer conexões entre suas concepções e a prática pedagógica. Um outro aspecto constatado é que o estágio em docência se constitui em uma etapa importante da aprendizagem da docência, pois, quando desenvolvido em paralelo com atividades de metacognição, ele se torna um elemento mediacional entre as concepções pessoais do futuro professor e as veiculadas pela escola, no caso, pela universidade. É durante o estágio que o aluno tenta colocar em prática o que concebe sobre o ensino de um certo conhecimento e, somente com a reflexão sobre os resultados obtidos com a prática pedagógica é que ele consegue estabelecer relações entre sua forma própria de pensar e agir em detrenimento dos novos referenciais teóricos. Evidenciou-se, também, a importância do professor formador como um outro elemento mediacional entre as concepções pessoais e a prática pedagógica. Assim, considera-se que a análise da evolução conceitual se constitui em um caminho interessante para as discussões relacionadas à formação de professores que vão ensinar Matemática nas séries iniciais.

Palavras-chave: formação de professores, ensino de matemática, curso de pedagogia, estágios, evolução conceitual. 


\begin{abstract}
The present work concerns a research about part of the trajectory of future teachers in their pre service Mathematics teacher education for the initial series of the Elementary school - students of Pedagogy course, which analysis focused the conceptions regarding the Mathematics processes of teaching and apprenticeship. The prime investigative goal was to know in which way the future teacher establishes connections between his conceptions and the pre-professional pedagogic practice, to allow the understanding on the way how he it learns to teach Mathematics. So, the Conceptual Change theory was considered as a guide in the structuring of the field work and the Conceptual Profile Notion like a connecting thread for the analysis of the data obtained in the inquiry field. These data were obtained through questionnaires applied during the development of a curricular discipline of the course Methodology of the Mathematics Teaching - and, also, through reflexive interviews carried out during the period of development of the teacher training originating from another curricular discipline - Pedagogic Practice C: Teacher Training - the data also came from annotations of the researcher in his field diary concerning the observations of the Mathematics' classrooms done by the teaching trainees; from the video tapes of the university classes, from interviews and documents (Pedagogic Proposal of the course of Pedagogy, classes planning and report of teacher training subjects). For the analysis in depth of the data if it developed the study of three cases - A1, A2 and A3 - being that the first case and as had evidenced certain conceptual evolution in relation to the conceptions on the Mathematics and its processes of teach-learning, after to have lived deeply conceptual and emotional disturbances and, also, to demonstrate conscience on its different ways to think and to act in classroom. Already A3, did not present conceptual evolutions in its profile, possibly, had the obstacles that had emerged during the investigated period. Among the results obtained with the analyses, it was noticed that the future teacher links his experiences with the schooling like a way of establishing connections between his conceptions and his pedagogic practice. Another noted aspect is the fact of the teacher training is constituted an important stage of the teaching apprenticeship, so, when developed in parallel with metacognition activities, it becomes a mediational element between the future teacher's personal conceptions and those conveyed by the school, in this case, for the university. It is during the teacher training that the trainee tries to put in practice what conceives like teaching of a specify knowledge, and only considering about the results obtained with his pedagogic practice is that he manages to establish relations between his own form of thinking and acting to the detriment of the new theoretical referential. It was proven, also, the importance of the formative professor as one another mediacional element between the personal conceptions and practical the pedagogical one. Thus, it is considered that the analysis of the conceptual evolution if constitutes in an interesting way for the quarrels related to the formation of professors who go to teach Mathematics in the initial series.
\end{abstract}

Key-word: formation of professors, education of mathematics, course of pedagogia, periods of training, conceptual evolution 


\section{SUMÁRIO}

1. INTRODUÇÃO

1.1 DELINEANDO O LOCUS DA PESQUISA.................................................... 13

1.2 OS PRIMEIROS PASSOS EM DIREÇÃO À PESQUISA..................................... 14

1.3 AINDA EM DIREÇÃO À PESQUISA: OUTRAS INFLUÊNCIAS........................ 17

1.4 PROPOSIÇÃO DESTA PESQUISA............................................................... 19

1.5 O PORQUÊ DA PROPOSIÇÃO DESTA PESQUISA........................................... 20

2 NATUREZA DA MUDANÇA CONCEITUAL ………………………………..... 23

2.1 DIMENSÃO FILOSÓFICA DA MUDANÇA CONCEITUAL …………………... 24

2.2 DIMENSÃO PSICOLÓGICA DA MUDANÇA CONCEITUAL........................... 28

2.3 VERTENTES TEÓRICAS DE MODELOS DE MUDANÇA CONCEITUAL (MMC).

2.3.1 Vertente Evolução do Conceito e do Perfil Conceitual................................... 36

2.3.2 Vertente Mudança Radical do Conceito e da Estrutura Cognitiva............... 43

2.4 ALGUMAS PERCEPÇÕES A PARTIR DOS MODELOS PROPOSTOS............ 50

3 CONHECIMENTOS RELATIVOS À APRENDIZAGEM DA DOCÊNCIA.... 54

3.1 ESTUDOS SOBRE PROFESSORES QUE ENSINAM MATEMÁTICA............... 60

3.2 CONHECIMENTOS SOBRE A MATEMÁTICA, SEU ENSINO E APRENDIZAGEM

3.2.1 O Conhecimento Sobre a Matéria a Ser Ensinada: História e Idéias Relativas à Matemática

3.2.2 O Conhecimento Sobre o Modo de Ensinar a Matéria: Tendências do Ensino da Matemática.

3.2.3 O Conhecimento Sobre o Aluno, Suas Aprendizagens e Desenvolvimentos:

Características das Aprendizagens em Matemática.

3.3 RELAÇÕES ENTRE OS CONHECIMENTOS RELATIVOS À APRENDIZAGEM DA DOCÊNCIA E ÀS ZONAS DOS PERFIS CONCEITUAIS.

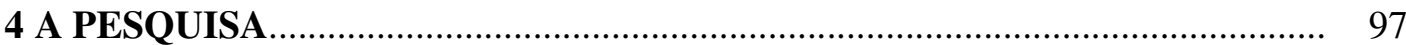

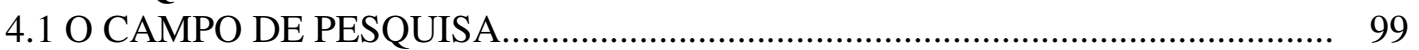

4.1.1 A Disciplina Prática Pedagógica C: Estágio em Docência............................... 101

4.1.2 A Disciplina Metodologia do Ensino de Matemática I................................... 102

4.2 OS SUJEITOS DA PESQUISA.................................................................. 104

4.3 OS INSTRUMENTOS DE PESQUISA.......................................................... 108

4.3.1 O Vídeo como Instrumento de Pesquisa......................................................... 110

4.3.2 A Entrevista como Instrumento de Pesquisa................................................ 112

4.3.3 O Questionário como Instrumento de Pesquisa............................................... 114

4.3.4 Os Documentos como Instrumento de Pesquisa............................................ 115

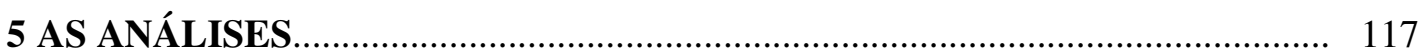

5.1 O PERCURSO PARA A ANÁLISE DOS DADOS …………………………….... 119

5.2 DESCRIÇÃO DAS INFORMAÇÕES DE CADA SUJEITO_................................. 122

5.2.1 O Relato da Trajetória de A1 .................................................................... 123

5.2.2 O Relato da Trajetória de A2 ................................................................. 124

5.2.3 O Relato da Trajetória de A3............................................................... 125 
5.3 INTERPRETAÇÃO DAS INFORMAÇÕES COLETADAS

5.4 CONSTITUIÇÃO DAS ZONAS DOS PERFIS CONCEITUAIS DE MATEMÁTICA E DO ENSINO-APRENDIZAGEM

5.4.1 Zonas do Perfil Conceitual de Matemática.

5.4.2 Zonas do Perfil Conceitual de Ensino de Matemática

5.4.3 Zonas do Perfil Conceitual de Aprendizagem em Matemática.

5.5 O PERFIL CONCEITUAL DOS SUJEITOS E SUAS CONEXÕES COM A PRÁTICA PEDAGÓGICA.

5.5.1 O Movimento Conceitual de A1.

5.5.2 O Movimento Conceitual de A2.

5.5.3 O Movimento Conceitual de A3.

5.6 GENERALIZAÇÕES A PARTIR DOS ESTUDOS DE CADA CASO. 201

6 CONCLUSÕES E CONSIDERAÇÕES FINAIS. 209

REFERÊNCIAS. 222

APÊNDICES 


\section{LISTA DE GRÁFICO, FIGURAS E QUADROS}

GRÁFICO 1 Concentração do tipo de formação em cada ano do curso de Pedagogia $-1996$.

FIGURA 1 Representação da quantidade de alunos matriculados nas disciplinas Prática Pedagógica $\mathrm{C}$ e Metodologia do Ensino de Matemática no $1^{\circ}$. semestre de 2005 .....

FIGURA 2 Organograma do campo de pesquisa - sujeitos - instrumentos.............. 109

QUADRO 1 Sujeitos da pesquisa e aulas de Matemática no estágio......................... 106

QUADRO 2 Interpretação da pesquisadora sobre as idéias de A1, A2 e A3 ............. 126

QUADRO 3 Categorização das regularidades percebidas......................................... 130

QUADRO 4 Relação entre as regularidades categorizadas e os perfis conceituais..... 139

QUADRO 5 Mapa de atividades desenvolvidas com A1 ........................................ 142

QUADRO 6 Mapeamento das zonas do perfil conceitual de Matemática de A1....... 147

QUADRO 7 Mapeamento das zonas do perfil conceitual de ensino e aprendizagem em Matemática de A1 ....................................................................... 161

QUADRO 8 Mapa de atividades desenvolvidas com A2 ...................................... 164

QUADRO 9 Mapeamento das zonas do perfil conceitual de Matemática de A2....... 169

QUADRO 10 Mapeamento das zonas do perfil conceitual de ensino e aprendizagem em Matemática de A2 .................................................................... $\quad 180$

QUADRO 11 Mapa de atividades desenvolvidas com A3 ..................................... 183

QUADRO 12 Mapeamento das zonas do perfil conceitual de Matemática de A3....... 187

QUADRO 13 Mapeamento das zonas do perfil conceitual de ensino e aprendizagem em Matemática de A3....................................................................... 198

QUADRO 14 Panorama da movimentação conceitual dos sujeitos........................... 201 


\section{LISTA DE SIGLAS}

\begin{tabular}{|c|c|}
\hline ANPED......... & Seminário de Pesquisa em Educação \\
\hline CDI... & Cálculo Diferencial e Integral \\
\hline CEI................. & Centro de Educação Infantil \\
\hline CIAEM.......... & Conferência Ibero Americana de Educação Matemática \\
\hline CINFOP......... & Centro Interdisciplinar de Formação Continuada de Professores \\
\hline EJA................... & Educação de Jovens e Adultos \\
\hline ENDIPE........ & Encontro Nacional de Didática e Prática de Ensino \\
\hline ENEM............ & Encontro Nacional de Educação Matemática \\
\hline EPREM......... & Encontro Paranaense de Educação Matemática \\
\hline GT................. & Grupo de Trabalho \\
\hline $\mathrm{HC} \ldots \ldots \ldots \ldots \ldots . . . . . . . .$. & Hospital de Clínicas \\
\hline ICM................. & Congresso Internacional de Matemática \\
\hline MC ..................... & Mudança Conceitual \\
\hline MEC............... & Ministério da Educação e Cultura \\
\hline MMC............. & Modelos de Mudança Conceitual \\
\hline MMM.............. & Movimento da Matemática Moderna \\
\hline NCTM............. & National Council of Teachers of Mathematics \\
\hline PCN................... & Parâmetros Curriculares Nacionais \\
\hline PPP................... & Proposta Política Pedagógica \\
\hline PROGRAD..... & Pró-Reitoria de Graduação \\
\hline UFPR............. & Universidade Federal do Paraná \\
\hline USP............... & Universidade de São Paulo \\
\hline ZPD.... & Zona de Desenvolvimento Proximal \\
\hline
\end{tabular}




\section{INTRODUÇÃO}

\subsection{DELINEANDO O LOCUS DA PESQUISA}

A docência é um dos exercícios profissionais que mais me fascinam. São poucas as palavras que conseguem explicar a satisfação sentida ao vivenciar ações que geram mudanças nas pessoas. Perceber nas crianças suas aproximações com o mundo escrito, ouvir de um aluno da graduação - "jamais pensei ser capaz de..." - enquanto constata seu próprio entendimento em relação a algum assunto estudado durante o curso de formação inicial de professores, ou ainda, participar da construção do conhecimento profissional de um professor em atividades de capacitação, são pequenos exemplos de situações que me honram em ser professora. Por outro lado, existem os problemas: crianças que apresentam dificuldades em aprender; professores em formação inicial e continuada que começam cursos com muitas expectativas em relação à melhoria de suas práticas pedagógicas e terminam suas capacitações angustiados e cheios de dúvidas. Casos como estes têm me mantido motivada na busca de mais conhecimento sobre possíveis fatores dos problemas existentes no quadro de formação de professores.

Em virtude destes e outros problemas, tem-se visto muitos trabalhos sobre formação de professores. Dentre as diferentes facetas há pesquisas que têm sido desenvolvidas na busca de melhorias e mais conhecimentos sobre a profissão da docência. Muitas delas caminham na direção da estreita relação entre teoria e prática na formação e da construção de um referencial do que venham a ser os saberes docentes (FIORENTINI et al, 1999; PAIVA, 1999; SZTAJN, 2001; ZIMER, 2002; CARVALHO, 2003; CURI e PIRES, 2004; PONTE, 2005; entre outros). O enfoque para isso tem grande variação, vai desde a busca pela compreensão do modo como o conhecimento profissional se constrói; das concepções que o professor possui sobre ensino, aprendizagem, avaliação e tantos outros aspectos que permeiam a sala de aula, além de questões relacionadas à maneira que a criança aprende; às novas metodologias de ensino; ao modo como se constituiu o saber científico e escolar do professor, até, a estudos centrados em estruturas curriculares de cursos tanto de formação inicial, quanto continuada. Deste modo, ressalta-se que essa pesquisa tem seu foco na vertente da formação inicial de professores que ensinam matemática nas séries iniciais do ensino fundamental.

Entre as pesquisas que tratam da formação de professores para ensinar Matemática, um fato observado na relação de trabalhos apresentados em alguns congressos na área de 
Educação e Educação Matemática (ENDIPE; ANPED; CIAEM; ENEM; EPREM) ${ }^{1}$, além de publicações em revistas e periódicos relativos às mesmas áreas (Journal for Research in Mathematics Education; Educação Matemática em Revista; Zetetiké; Bolema; Educação \& Sociedade; Educação e Pesquisa; entre outros) é que existem poucas pesquisas voltadas para os professores das séries iniciais do Ensino Fundamental. Curi e Pires (2004) destacam que autores/pesquisadores da área têm enfatizado a existência de poucos estudos sobre o ensino de Matemática e de sua Didática nos cursos de Pedagogia, assim como também o pouco conhecimento sobre os saberes matemáticos necessários aos docentes que ensinam Matemática nos anos iniciais do Ensino Fundamental. Assim sendo, o locus dessa pesquisa se insere na formação inicial de professores para ensinar Matemática nas séries iniciais do Ensino Fundamental.

\subsection{OS PRIMEIROS PASSOS EM DIREÇÃO À PESQUISA}

As experiências advindas, inicialmente, como professora atuante nas séries iniciais do ensino fundamental e atualmente como professora que trabalha com a formação docente, tanto inicial (cursos de Pedagogia - presencial e a distância e de Matemática na Universidade Federal do Paraná) quanto continuada (programas de capacitação e assessorias aos professores da rede pública de ensino) ${ }^{2}$, têm possibilitado desenvolver alguns estudos nessa temática. Em especial, no trabalho desenvolvido com o curso de Pedagogia, na Universidade Federal do Paraná (UFPR), na disciplina de Metodologia do Ensino de Matemática, ofertada aos alunos do 3. ${ }^{\circ}$ ano, provocou certa inquietação, levando à pesquisa da dissertação "Mundos de Significados: saberes e práticas de ensino de matemática na formação de professores das séries iniciais no curso de Pedagogia da Universidade Federal do Paraná". Nessa pesquisa, objetivou-se analisar o significado do conhecimento relativo às Metodologias de Ensino na formação de professores das séries iniciais. No referido estudo, fundamentado na teoria da Transposição Didática (CHEVALLARD, 1991), a investigação analisou a disciplina Metodologia do Ensino da Matemática, procurando apreender o movimento de re-criação do

\footnotetext{
${ }^{1}$ ENDIPE: Encontro Nacional de Didática e Prática de Ensino; ANPED: Seminário de Pesquisa em Educação; CIAEM: Conferência Ibero Americana de Educação Matemática; ENEM: Encontro Nacional de Educação Matemática; EPREM: Encontro Paranaense de Educação Matemática.

${ }^{2}$ Alguns exemplos de programas de capacitação são: o Fazendo Escola da Prefeitura Municipal de Curitiba, no qual os professores desenvolvem projetos de ensino sob a orientação de docentes das Instituições de Ensino Superior e o Centro Interdisciplinar de Formação Continuada de Professores (CINFOP), o qual se refere a um programa vinculado ao Ministério de Educação e Cultura (MEC) e à Pró-Reitoria de Graduação (PROGRAD) da UFPR, cuja meta é capacitar professores, em nível nacional, em temáticas específicas: avaliação da aprendizagem e gestão e avaliação da escola pública.
} 
saber científico (enquanto conhecimento matemático) em saber a ser ensinado (o conhecimento matemático didatizado). Para tanto, realizaram-se entrevistas com alunos do curso de Pedagogia, egressos da referida disciplina e atuantes como professores nas salas de aulas das séries iniciais de escolas públicas e privadas de Curitiba e Região Metropolitana. Assim, além da análise da estrutura curricular da disciplina de Metodologia, também, buscouse conhecer como os pedagogos em formação estabelecem relações entre os saberes ensinados na Metodologia e as suas práticas cotidianas de sala de aula.

Dessas análises foram identificados alguns aspectos como possíveis dificultadores de uma relação mais estreita entre teoria e prática. São aspectos como: a centralização de disciplinas ${ }^{3}$, voltadas à formação docente, no $3 .^{\circ}$ ano do curso e com carga horária considerada reduzida, além de, não haver a possibilidade curricular de se trabalhar com as concepções dos alunos, concomitantemente, ao desenvolvimento da prática pedagógica durante o estágio. Este último aspecto se revelou importante por apresentar certa discordância entre o modo como esses alunos concebem teoricamente o ensino, pautados em uma linha construtivista, e a maneira pela qual dizem desenvolver suas aulas, com indícios do tradicionalismo. Olhando esse quadro por outro ângulo, isto é, pela possibilidade de falar sobre a prática de sala de aula de modo harmônico e analisá-la teoricamente, tem-se em algumas pesquisas a proposição de trabalhos desenvolvidos em uma perspectiva colaborativa e reflexiva da formação (FERREIRA, 2003; CANCIAN 2001; FIORENTINI \& LORENZATO, 2006; entre ouros). Tal perspectiva parece contribuir, expressivamente, na formação do professor, pois o mesmo passa, a partir de orientações reflexivas, a transpor a teoria para a prática e a construir seu próprio conhecimento. No entanto, ressalta-se que para isso é essencial o acompanhamento do aluno por parte dos professores formadores de modo sistematizado e articulado. No caso desta pesquisa, tal sistemática foi viabilizada por meio das disciplinas voltadas à formação docente ${ }^{4}$, mais especificamente as Metodologias de Ensino (caráter teórico) e a Prática Pedagógica e Estágio Supervisionado (caráter teórico e prático).

Ainda, caminhando-se na estruturação desta pesquisa, existiram outros fatores que colaboraram com a proposição do trabalho e motivaram-na. Um deles está diretamente imbricado na relação cotidiana com os alunos estagiários, os quais, costumeiramente, solicitam orientações de seus professores de Metodologia de Ensino, em como ensinar

\footnotetext{
${ }^{3}$ As disciplinas voltadas à formação docente no curso de Pedagogia são as seguintes: Metodologia de Ensino das diferentes áreas do conhecimento (Matemática, Língua Portuguesa, Ciências, Geografia, História, Educação Física e Artes); Alfabetização, Didática, Prática Pedagógica - Estágio em Docência.

${ }^{4}$ A saber, a proposta curricular do curso está organizada em quatro tipos de formação: básica, complementar, docente e pedagogo. As mesmas serão melhores explicadas neste capítulo no item 1.4 e no capítulo 4 .
} 
determinados conteúdos curriculares. Ao conversar com esses alunos, é possível perceber que há uma grande dificuldade de vinculação a qualquer enfoque teórico abordado durante o curso com a prática a ser desenvolvida. Como os alunos freqüentam o estágio durante o transcorrer do ano, e as disciplinas de Metodologia de Ensino em um dos semestres do mesmo ano letivo, muitas vezes, quando eles buscam orientações e/ou esclarecimentos em virtude de situações advindas do estágio, acabam ocorrendo uma das duas situações: ele estar cursando a disciplina teórica ou já tê-la desenvolvido. Esta situação tem permitido observar que o contato dos alunos com a teoria parece ser mais significativo quando isso ocorre ao mesmo tempo em que suas ações são desenvolvidas durante o estágio, pois assim, as reflexões em torno da prática pedagógica a partir da teoria têm respaldo em suas próprias vivências como docente e, não apenas, em exemplos citados em textos ou comentados por outros.

Um outro fato, muito relevante, é o desenvolvimento de um projeto, iniciado em 2003, voltado à melhoria da formação docente nas licenciaturas, registrado na Pró - Reitoria de Graduação (PROGRAD) da UFPR, no Programa Licenciar sob o número 1603 denominado "Planejamento e implementação de atividades lúdicas no Centro de Educação Infantil 'Pipa Encantada' do Hospital de Clínicas da Universidade Federal do Paraná"5. Participam desse projeto, alunos dos cursos de Pedagogia, de Biologia e de Matemática da UFPR, os professores e as crianças das instituições de ensino, denominadas aqui de parceiras. O foco para os alunos da graduação está no desenvolvimento de atividades lúdicas que envolvam o conteúdo curricular específico da instituição parceira (matemática e ciências da natureza), tendo como fio condutor a Educação Ambiental. A dinâmica estabelecida com esses alunos é fundamentada nos referenciais teóricos das disciplinas de Metodologia do Ensino de Matemática e de Ciências e centrada na realização de reuniões semanais. Nessas reuniões são selecionadas as práticas pedagógicas a serem desenvolvidas, assim como também, são analisados os resultados obtidos em ações anteriores, desenvolvidas com as crianças das escolas parceiras.

O trabalho que, em geral, dura um semestre letivo, tem permitido perceber uma relação muito próxima entre o discurso dos alunos sobre o que acreditam a respeito do ensino, da aprendizagem e da prática pedagógica desenvolvida. Além, de certa mudança de atitudes em relação à atividade de docência, pois sugere haver o abandono gradativo de uma situação de passividade para a de autonomia e iniciativa. Isto é, percebe-se que os licenciandos tentam

\footnotetext{
5 O Centro de Educação Infantil (CEI) Pipa Encantada foi a primeira instituição de ensino parceira no desenvolvimento desse projeto. Este CEI faz parte do Hospital de Clínicas (HC) da UFPR e atende a filhos de funcionários do hospital e da fundação da universidade. A partir do segundo ano de desenvolvimento do projeto, outras instituições de ensino passaram a compor o quadro de parcerias.
} 
aplicar certos aspectos da teoria em suas práticas pedagógicas, visando não somente à aprendizagem da criança, mas também procurando entender teoricamente os resultados que tal prática proporcionou.

O tipo de conhecimento que esses alunos constroem parece ser em parte, resultante das análises desenvolvidas durante os encontros semanais, nos quais são analisados os registros das atividades das crianças e, conseqüentemente, reflete sobre as práticas pedagógicas desenvolvidas, as conversas com os professores regentes e as leituras dos textos de referência. Essa situação, experienciada por uma parcela restrita de alunos da graduação, constitui-se no panorama do curso de Pedagogia da UFPR como um dos poucos exemplos de espaço a possibilitar uma formação docente voltada à reflexão e à construção de saberes no que tange ao ensino da Matemática. Assim, essa pesquisa foi se delineando na busca de modos de implementação de práticas pedagógicas que permitissem a estreita relação entre teoria e prática durante a formação inicial de professores para ensinar matemática nas séries iniciais do Ensino Fundamental e, essa busca resultou na metodologia investigativa desenvolvida nesta pesquisa.

\subsection{AINDA EM DIREÇÃO À PESQUISA: OUTRAS INFLUÊNCIAS}

Além das experiências vivenciadas ao longo da carreira docente, também, há de se considerar as influências que algumas abordagens teóricas promovem no desenvolvimento da pesquisa. Ao entrar em contato com certas teorias de perspectivas sócio-histórica, mais especificamente, em um primeiro momento com a Teoria da Atividade (LEONTIEV, 1988; MOURA, 2001; entre outros) e em um segundo momento, a Teoria da Mudança Conceitual (ABIB,1996; PORLÁN, et al 1997, VILLANI e FREITAS, 2002; entre outros) por meio dos cursos "O conhecimento em sala de aula: a organização do ensino" e "Formação de Professores de Ciências" no Programa de Pós-Graduação em Educação da Universidade de São Paulo (USP), foi possível estabelecer parâmetros para um refinamento do foco da presente pesquisa. Assim, ao considerar o viés da Teoria da Mudança Conceitual, ter-se-á o enfoque às concepções que os professores possuem como uma das diretrizes do trabalho. Pois, por hipótese, acredita-se que as concepções dos professores norteiam a organização de suas práticas pedagógicas e se revelam nas ações em sala de aula, o que pode ser observado em pesquisas como as citadas anteriormente.

As investigações sobre as concepções dos professores têm revelado trabalhos que trilharam diferentes caminhos, isto é, há abordagens que vão desde a análise sobre concepções 
específicas, como elas são construídas e, até, a implicação com a prática. É possível encontrar pesquisas centradas nas concepções de aprendizagem, muitas vezes relacionadas à aprendizagem de certos conteúdos específicos como função de $1 .^{\circ}$ grau, adição com números naturais entre outros (REHFELDT, 2004). Há também, trabalhos voltados às concepções de ensino (BERTONI, 2001; CASTRO, 2003), de Matemática (CARVALHO, 1989; BARBOSA, 2001; JACQUES, 2002; RICCI, 2003; CYRINO, 2003) e de associações entre os vários enfoques: ensino e Matemática (SILVÉRIO, 2003; NACARATO et al, 2004; MANFREDO, 2004; ); ensino e aprendizagem (CUNHA, 1999); ensino, aprendizagem e Matemática (PAIVA, 1998; JURAMILLO QUICENO, 2003). A abordagem às concepções, também tem sido exploradas em diferentes níveis de formação: inicial (CARVALHO, 1989; BARBOSA, 2001; JURAMILLO QUICENO, 2003; NACARATO et al, 2004) e continuada (PAIVA, 1998; BERTONI, 2001; JACQUES, 2002; SILVÉRIO, 2003; REHFELDT, 2004; MANFREDO, 2004; ). Independentemente do nível de formação, há a categoria de atuação dos professores: séries iniciais do Ensino Fundamental (JACQUES, 2002; MANFREDO, 2004; NACARATO et al, 2004;) e professores das séries finais do Ensino Fundamental e Ensino Médio (PAIVA, 1998; BERTONI, 2001; JURAMILLO QUICENO, 2003).

Um aspecto comum que parece existir entre todos esses trabalhos e muitos outros pautados na investigação sobre as concepções dos professores é a convergência para o ideário dos saberes docentes em virtude de melhorias na formação de professores. Em relação ao quadro exposto, Paiva (2001) destaca que as investigações sobre a formação de professores devem atentar ao fato de que:

[...] só conhecer suas concepções e refletir sobre elas não é suficiente para garantir um maior entendimento do professor. O estudo sobre o professor e sua prática requer uma aproximação mais ampla na forma como olhamos este professor e tentamos entender a maneira como ele age em sala de aula. [grifo meu]

Questões acerca dos saberes construídos pelo professor ao longo de sua carreira e como ele lida com esses saberes fazem-se necessários para um maior conhecimento sobre o professor (p.1).

Nesse sentido, o trabalho em torno das concepções dos professores deve contemplar, também, as ações referentes ao exercício da docência. No caso desta pesquisa, que trata da formação inicial dos professores, seu olhar está orientado na investigação das concepções sobre a Matemática e seu processo de ensino-aprendizagem, sendo a atividade de estágio um meio possibilitador de observação da prática em sala de aula nas séries iniciais do Ensino Fundamental. 


\subsection{A PROPOSIÇÃO DESTA PESQUISA}

Frente a todo o exposto, e considerando a própria atuação profissional junto aos alunos do curso de Pedagogia da UFPR, na proposição desta pesquisa, toma-se como princípio, que o trabalho desenvolvido com as disciplinas do curso seja sistematizado a partir da estrutura curricular já existente, pois desta maneira, é possível envolver um maior número de alunos no ambiente institucional instalado.

A estrutura curricular em vigor, quando do momento de desenvolvimento deste estudo $^{6}$, destina suas 2.340 horas em quatro tipos de formação assim distribuídas: 840 horas para 10 disciplinas de formação básica, cuja finalidade é fundamentar o pedagogo com questões relativas à Sociologia, Filosofia, Psicologia e História da Educação; 540 horas com 10 disciplinas, de formação denominada complementar, que tratam de estudos sobre os fundamentos do ensino; 480 horas para formação específica do pedagogo, a qual é desenvolvida por meio de seis disciplinas na grade curricular do curso e mais 510 horas para a formação em docência, distribuídas entre 12 disciplinas (Didática, Metodologias de Ensino e Prática Pedagógica).

A breve explicitação da estrutura curricular do curso de Pedagogia da UFPR é feita devido ao fato de este ser o campo de trabalho desta pesquisa e os sujeitos da investigação, os alunos matriculados na disciplina destinada ao estágio em docência do $3 .^{\circ}$ ano do curso, ou seja, Prática Pedagógica C (de caráter anual com 120 horas) e na disciplina Metodologia do Ensino de Matemática (semestral com 30 horas), responsável pela formação docente teórica para o ensino de Matemática. Deste modo, o presente trabalho foca o estudo de três casos, delineando-se pelo objetivo de investigar de que maneira os alunos-estagiários vão estabelecendo conexões entre suas concepções sobre Matemática e seus processos de ensinoaprendizagem e a prática pedagógica pré-profissional ao longo do período em que cursam as disciplinas de Metodologia de Ensino de Matemática e Prática Pedagógica-Estágio em Docência. Para tanto, há de se considerar que ao aluno-estagiário foi possibilitado um curso, cujo ambiente na Metodologia esteve direcionado pela reflexão sobre as próprias concepções com vistas às futuras propostas de práticas pedagógicas. Pois, acredita-se que o ensino mediado pela reflexão possibilita ao aluno uma tomada de consciência sobre suas próprias

\footnotetext{
${ }^{6}$ Desde a implementação desta proposta curricular (1996) há uma comissão no Setor de Educação da UFPR que vem acompanhando o curso por meio de avaliações sistemáticas. Em 2003, instalou-se uma comissão com finalidade de estruturar uma nova proposta curricular, considerando para isso os resultados das avaliações sitemáticas, as orientações oficiais do governo federal, entre outros referenciais. No ano de 2009 uma nova proposta curricular será implementada.
} 
crenças, o que pode provocar mudanças em suas concepções em virtude de avaliações pessoais, de novos conhecimentos (por exemplo, os tópicos da disciplina) e da intenção em desenvolver certas práticas em sala de aula. Sendo assim, o problema de pesquisa deverá trazer subsídios que contribuam para o entendimento dos processos de como o futuro professor aprende a ensinar Matemática e o que contribui para essa aprendizagem.

\subsection{O PORQUÊ DA PROPOSIÇÃO DESTA PESQUISA}

Em princípio, parece que essa é mais uma pesquisa sobre formação de professores, e de fato é. Essa temática tem sido objeto de estudos, questionamentos, reflexões e investimentos (sociais e econômicos). A todo instante, a mídia tem divulgado programas de diversas ordens (governamentais e não governamentais) que atingem a formação de professores, seja ela inicial ou continuada, seja por meio de leis, diretrizes, parâmetros curriculares, avaliações ou projetos que prevêem verbas para essa finalidade. Apesar de todos os esforços empregados, os indicativos oficiais e resultados de pesquisas mostram que ainda há muito que fazer em relação à formação docente. Assim, entende-se que embora esse trabalho esteja inserido em uma temática já bastante discutida, seu recorte, isto é, a formação inicial de professores das séries iniciais, mais especificamente, aquela voltada ao ensino da Matemática, tem sua proposição justificada em diferentes modalidades, as quais se inserem na comunidade científica, no ambiente em que a mesma é gerada e nos anseios da própria pesquisadora.

Como pôde ser percebido na breve literatura anunciada anteriormente, não há muitas pesquisas direcionadas à temática desse trabalho. Curi e Pires (2004), ao analisarem propostas curriculares de cursos de Pedagogia, em virtude da formação docente em Matemática afirmam que:

\footnotetext{
Embora as modificações na legislação abram espaços curriculares nos cursos de formação de professores, no caso da Matemática, há poucos estudos científicos no Brasil específicos sobre formação de professores para ensinar matemática nos anos iniciais do ensino fundamental, que podem subsidiar a implementação de propostas para esses cursos (p.17).
}

Fiorentini et al (2002) e Nacarato e Paiva (2006) fazem o mesmo alerta que Curi e Pires (2004) em relação às pesquisas destinadas aos professores polivalentes. O maior enfoque das pesquisas está na formação de professores de Matemática para as séries finais do Ensino Fundamental e/ou Ensino Médio. Independentemente de ser a mesma área, isto é, a Matemática, cada segmento de formação possui especificidades próprias. No recorte aqui 
proposto, a formação se dá em um curso de Pedagogia, cujo conceito é do professor polivalente, isto é, atende a todas as áreas de saberes. Essa situação é um dos elementos que o distancia do outro segmento, cujo enfoque é somente a Matemática o que pressupõe, por exemplo, na amplitude de domínio sobre o saber matemático. De um modo genérico, esta e outras questões sobre as problemáticas em torno da formação de professores estão presentes, inclusive, nos poucos trabalhos encontrados sobre a formação dos professores das séries iniciais (SZTAJN, 2001; ZIMER, 2002; MELO, 2003; SILVEIRA, 2003; SCHMITT e BIEMBENGUT, 2003). O que essa pesquisa pretende não é somente constatar mais problemática e sim avançar, produzindo conhecimentos que permitam, por exemplo, minimizar a questão da dicotomia entre teoria e prática.

Em relação ao âmbito local da proposição desta pesquisa, tem-se que as avaliações realizadas sobre a proposta curricular do curso em questão (Pedagogia da UFPR) também apontaram para a necessidade de se re-pensar a articulação entre teoria e prática na formação docente, em especial a relação das Metodologias de Ensino com a Prática Docente. Vale ressaltar que esta proposta foi implementada em 1996 e sua re-elaboração foi orientada pelos indicativos da Lei 9394/96. Neste sentido, Curi e Pires (2004), afirmam que:

[...] as novas orientações sobre formação de professores, advindas da Lei 9394/96, aliadas à pequena quantidade de pesquisas na área e à necessidade de formar um número maior de professores em nível superior justificam a importância de aprofundar nossos estudos sobre esse tema, sempre na perspectiva de analisar a formação de professores dos anos iniciais para ensinar Matemática (p.17).

Além das relações apontadas, há ainda, os anseios da pesquisadora aqui envolvida. Sente-se que é de fundamental importância refletir de modo sistematizado sobre a modalidade de formação que vem desenvolvendo. Aprender a perceber e interpretar fatos que emergem das ações estabelecidas em sala de aula (relações entre professora, alunos e saber), de certa maneira, vem se constituindo como conseqüência de um processo de investigação iniciado com projetos de extensão desenvolvidos durante a graduação. Esse olhar investigativo se tornou mais expressivo a partir da pesquisa realizada no mestrado, a qual permitiu perceber, por exemplo, o discurso dos pedagogos em formação referente às suas crenças sobre como deve ser o ensino de Matemática. Tal discurso não correspondia à descrição da prática exercida em sala de aula ao ensinar esse saber, o que apontou para a necessidade de aprofundamento da investigação.

Olhar a própria prática, enquanto pesquisadora, tem sido um exercício de muita cautela, atenção e certo distanciamento da figura de professora, porém gratificante. Pois, o 
contato com professores das séries iniciais tem se mantido ao longo de toda minha carreira profissional, na qual os primeiros passos foram como professora de pré a 4. ${ }^{a}$ séries do Ensino Fundamental pela Prefeitura Municipal de Curitiba e agora como professora formadora de professores de Matemática, atuando com alunos do curso de Pedagogia e com alunos do curso de Matemática da UFPR. Nesse sentido, entendo que a proposição desse trabalho permite um refinamento, aprofundamento da própria formação, além é claro, da identificação pessoal com a temática escolhida.

Deste modo, nos capítulos seguintes, apresenta-se a pesquisa em si, iniciando-se com os pilares teóricos que sustentam o trabalho, os quais estão distribuídos ao longo dos capítulos dois e três, respectivamente, Natureza da Mudança Conceitual e Conhecimentos Relativos à Aprendizagem da Docência. No primeiro, é apresentado um panorama da Teoria de Mudança Conceitual a partir de perspectivas apontadas por pesquisas de diversas áreas do conhecimento. No outro capítulo, o três, são tratados os aspectos relacionados à formação docente, em especial, os relativos à aprendizagem da docência em Matemática, no qual se enfoca o conhecimento sobre a Matemática e seus processos de ensino e aprendizagem.

O capítulo quatro - A Pesquisa - apresenta o campo de pesquisa, bem como os sujeitos e instrumentos selecionados para a coleta de dados. As informações obtidas são estudadas no capítulo cinco, entitulado de As Análises, cujo texto contém os registros dos dados coletados e, também, as interpretações atribuídas aos meios por meio da análise. Este estudo é, então, concluído no capítulo seis - Conclusões e Considerações Finais - o qual contém as idéias finais sobre o estudo de cada caso e, também, as últimas considerações em relação ao desenvolvimento global desta pesquisa.

E, finalmente, ressalta-se que nos anexos estão cópias dos documentos oficiais, os quais foram obtidos junto ao campo de pesquisa como o plano de ensino das disciplinas universitárias e quadro curricular do curso de Pedagogia da UFPR. Já, os apêndices contêm cópias dos roteiros das entrevistas reflexivas e dos questionários. 


\section{NATUREZA DA MUDANÇA CONCEITUAL}

Este capítulo se refere a um dos pilares teóricos que sustentam essa pesquisa, seja ele, o trabalho com as concepções dos alunos em virtude da aprendizagem, neste caso, da docência. Pois, a abordagem dessa teoria tanto norteou a organização do campo de pesquisa no sentido da coleta de dados como se constituiu no principal fio condutor da análise das informações obtidas. Desta maneira, parte-se do princípio de que no ensino da Ciência (CARVALHO e GIL PEREZ, 2003), assim como na Matemática (FIORENTINI, 1995; D’AMBRÓSIO, 1986; 1993; 1996; 1999a; 1999b; 2001; entre outros), as tendências educacionais, apoiadas na base construtivista, a partir de 1970, tiveram grande enfoque entre os estudiosos, uma vez que, havia muitas críticas relacionadas ao modo de condução que o ensino e a respectiva aprendizagem vinham sendo desenvolvidas nas salas de aula. Essas críticas se davam, principalmente, visando-se ao progresso da sociedade e, conseqüentemente, à geração de novos conhecimentos para o enfrentamento de situações que viessem emergir a partir das necessidades postas frente ao crescimento.

Proporcionar aos jovens uma visão crítica dos instrumentos comunicativos, intelectuais e materiais que eles deverão dominar para que possam viver na civilização que se descortina, vai muito além do ler, escrever e contar. Na verdade, tornam ler, escrever e contar, na concepção tradicional, algo obsoleto (D’AMBRÓSIO, 2005, p. 119).

Considerando aspectos como os comentados por D’Ambrósio, fortaleceu-se a necessidade de formar pensadores e de estimular o desenvolvimento da criatividade, o que implicou na busca por abordagens educacionais que privilegiassem ao aluno a construção significativa de seu próprio conhecimento, dessa maneira, conduzindo-o a novos modos de relações interculturais. Esse novo olhar, atribuído ao papel do aluno, convergiu para a forma como a aprendizagem se processa nesse viés, pois a "adoção de uma nova postura educacional é, na verdade, a busca de um novo paradigma de educação que substitua o já desgastado ensino-aprendizagem, que é baseado numa relação obsoleta de causa-efeito"(D’AMBRÓSIO, 2005 , p. 118). Frente a esse quadro é que se percebe na educação ecos da abordagem construtivista, tendo-se como uma possibilidade viável de aprendizagem a teoria de Mudança Conceitual (MC).

Os estudos em torno da Mudança Conceitual surgem de uma analogia entre o crescimento do conhecimento científico e a aprendizagem das ciências. A partir da década de 1980, um grande número de propostas de ensino pautadas na teoria da MC começaram a ser desenvolvidas, por exemplo: Posner (1982; 1992); Santos (1991); Mortimer (1994); Abib 
(1996); Pozo (1997; 2002); Cabral (1998); Freitas (1998); Cunha (1999); Goded (2000); Medrano (2001). Esses trabalhos delinearam trajetórias e, por conseqüência, tendências que demarcaram modos de ativação e abordagem às idéias prévias e ao trato das mesmas, além de diversos enfoques de interpretação das mudanças conceituais que ocorrem ao longo do processo de aprendizagem. De um modo geral, o que se percebe nesses trabalhos é que, a maneira como as concepções pessoais (idéias prévias) são tratadas, no sentido da mudança conceitual, está relacionada a aspectos de uma dimensão filosófica da formação do conhecimento e de uma dimensão psicológica do processo de construção do conhecimento. Cabe salientar que a dimensão filosófica tem na história da constituição do conhecimento seu fio condutor, enquanto que a dimensão psicológica é inspirada pelos processos de ensinoaprendizagem visando-se à produção do conhecimento. Na sequiência, será delineada uma perspectiva de como essas dimensões estão sendo compreendidas.

\subsection{DIMENSÃO FILOSÓFICA DA MUDANÇA CONCEITUAL}

A dimensão filosófica da Mudança Conceitual, parece estar localizada nas estruturas do Construtivismo, enquanto escola de pensamento ${ }^{7}$, pelo modo como a produção do conhecimento científico é concebida entre as correntes filosóficas construtivistas. Cunha (1999), ao analisar as concepções de formadores de professores de Ciências em um curso sobre Mudança Conceitual, faz referência a correntes filosóficas, tais como: falsacionismo em Popper, programas de investigação científica por Lakatos, tradições de investigação com Laudan, evolucionismo em Toulmin e o revolucionismo de Kuhn. Segundo Santos (1991, p. 128), tais correntes estão entre as mais citadas para fundamentar questões relativas à Mudança Conceitual. No entanto, observa-se que além destes filósofos, as idéias de Bachelard também se fazem presentes nessa dimensão. No trabalho de Mortimer (1994), o autor, ao analisar as concepções de alunos de 8. ${ }^{a}$ série do Ensino Fundamental sobre Atomismo faz referência à noção de perfil epistemológico de Bachelard, o qual é entendido como um viés de abordagem à teoria de Mudança Conceitual.

A relação destas correntes filosóficas com a mudança conceitual se dá pelo princípio de que o conhecimento científico é uma construção social e, como tal, o homem desempenha um papel ativo, isto é, não o recebe passivamente do meio. Segundo Luffiego (2001), as

\footnotetext{
${ }^{7}$ Nussbaum, citado por Cunha (1999), indica que nos dias atuais as três escolas de pensamento mais conhecidas são: empirista-positivista, racionalista e construtivista. Esta última correspondendo à corrente filosófica mais aceita atualmente.
} 
críticas realizadas por filósofos da Ciência, como Kuhn e Lakatos, sobre a idéia positivista de que a ciência se trata de um conhecimento seguro e absoluto, possibilitaram o surgimento de questionamentos em relação a seus pressupostos. $\mathrm{O}$ autor explica, por meio de um exemplo, a idéia do progresso indefinido, cujo reflexo corresponde à intenção de dominar a natureza para colocá-la a serviço do homem. Esse pressuposto perdeu a legitimidade entre a população, pois a natureza estava longe de ser dominada e o progresso científico parecia começar a produzir mais riscos que benefícios. O conhecimento era concebido como conseqüência de um processo linear de causa-efeito. Essa visão prevaleceu entre os estudiosos até início do século XX, quando então, as sociedades modernas se depararam com a necessidade de uma ciência transformada que abandonasse a complexidade dos novos problemas, cumprisse sua função de predição e controle dos fenômenos e contribuísse para formar cidadãos críticos conscientes.

Tal situação, imprimiu uma nova imagem à Ciência, apesar de não se tratar de um conhecimento seguro, ainda assim, se fazia necessário ao sistema de conhecimentos humano como meio mais confiável de aproximação com a realidade. Considerou-se nesta percepção, além do conhecimento em si, também a relação dos sujeitos com a Ciência e destes com o contexto. Neste sentido, entende-se que:

[...] os cientistas possuem interesses e ambições que exercem influência em seu trabalho científico e que a observação dos fatos está mediatizada por seus constructos teóricos, porém a ciência possui um sistema interno de evolução que não descansa nem na autoridade e nem na democracia, senão que o faz principalmente em critérios de validez explicativa e prognóstica. De acordo com isto a ciência possui foros de comunicação e de crítica, e procedimentos de comprovação que estão a disposição de todos. Por outro lado, a tecnologia desenvolvida a partir de teorias, utilizada para o bem ou o mal, mostra sua capacidade de interagir com o meio, o qual é uma prova da objetividade dos conhecimentos e leis científicas (LUFFIEGO, 2001, p. 380 , minha tradução) ${ }^{8}$.

A mediatização entre a construção do conhecimento, supostamente o científico, e a observação do meio, evidencia um aspecto construtivista da Ciência, o qual é organizado como uma construção individual, social e interativa com a realidade. Nesse sentido, tem-se como princípio que tanto o homem, quanto a realidade, se constituem em sistemas dinâmicos

\footnotetext{
${ }^{8}$ Apresenta-se a mesma citação no idioma original: “[...] los científicos poseen intereses y ambiciones que ejercen influencia en su labor científica y que la observación de los hechos está mediatizada por sus constructor teóricos, pero la ciencia posee un sistema interno de evaluación que no descansa ni en la autoridad ni en la democracia, sino que lo hace principalmente en criterios de validez explicativa y predictiva. De acuerdo con ello, la ciencia posee foros de comunicación y crítica, y procedimientos de comprobación que están a disposición de todos. Por otra parte, la tecnología desarrollada a partir de teorías, utilizada para bien o para mal, muestra su capacidad de interaccionar con el medio, lo cual es una prueba de la objetividad de los conocimientos y leyes científicas.” (LUFFIEGO, 2001, p. 380)
} 
e não lineares. Isso mostra que, durante a evolução do sistema podem ocorrer fases estáveis, em que as causas diminuem e não conduzem a efeitos relevantes, ou fases instáveis, em que as causas conduzem a grandes efeitos. Em outras palavras, na fase estável um sistema evolui integrando um novo conhecimento aos esquemas já existentes, enquanto que na fase instável a interação entre os conhecimentos geram perturbações ao sistema conhecido.

Assim, pode-se considerar que em analogia às posições construtivistas da Ciência, a aprendizagem do conhecimento científico se configura como um "conhecimento construído pela inteligência humana, em um contexto geralmente social, tendo-se em conta o conhecimento existente" (CUNHA, 1999, p. 58), ou seja, entende-se que o aluno desempenha um papel de construtor ativo de seu próprio conhecimento a partir dos conhecimentos anteriores, os quais possuem alguma representatividade no contexto social no qual se desenvolve. Nesse sentido, algumas características presentes no modo como a mudança conceitual se processa no decorrer da aprendizagem dos alunos parecem se relacionarem aos aspectos das escolas filosóficas construtivistas. Por exemplo, para Popper, um racionalista crítico, uma teoria científica é rejeitada mediante um experimento que a contradiz (falsificações). Por esse viés, a mudança conceitual do aluno é provocada por contradições entre suas teorias prévias e experiências novas, produzindo assim conflitos e eliminação de conhecimentos antigos.

Já, para Lakatos, Laudan, Toulmin e Kuhn, as teorias científicas não podem ser rejeitadas por falsificações, em contrapartida, a mudança conceitual ocorre pela produção de conflitos de outras naturezas. Para Lakatos, outro racionalista crítico, o crescimento do conhecimento científico depende da existência de idéias concorrentes que, quando confrontadas, geram mudanças progressivas ou regressivas e se referem, respectivamente, à antecipação de fatos ainda não explicados ou à explicação de fatos já conhecidos. Esse movimento ocorre, no que ele denomina de Programa de Pesquisa ou como é citado por Cunha (1999), Programa de Investigação Científica, cuja estrutura é composta por um núcleo firme, resistente a mudanças, de uma heurística e de um cinturão protetor onde são geradas as mudanças por meio de competências entre os programas. Por essa perspectiva, Cunha (1999) explica que os estudantes são resistentes a mudanças em suas teorias (núcleo firme), mas se o novo conhecimento lhes parecer inteligível, plausível e útil frente à insatisfação do conhecimento prévio, essa situação pode levá-los à mudança conceitual, é a relação entre a heurística e o cinturão protetor.

Para Laudan, segundo a mesma autora, para haver mudança de teoria é preciso haver mudanças ontológicas e metodológicas em relação ao conhecimento científico, isto é, pode 
ocorrer mudança em diferentes esferas e em momentos distintos, no caso dos alunos, a mudança pode ser de natureza conceitual, atitudinal e/ou metodológica. Em Toulmin, as teorias científicas evoluem por pressão seletiva das populações conceituais, logo, a mudança conceitual nos alunos seria gradual e contínua, coexistindo conceitos anteriores e novos. E, em Kuhn, a mudança de paradigma científico ocorre em momentos de crise total e revolucionária, isto é, a mudança é provocada por anomalias, o que ele denomina de Ciência Normal. Essas anomalias levam a uma revolução científica e, como surgem formas distintas de se conceber o conhecimento pela incomensurabilidade científica, o período seguinte acaba por se tornar a nova Ciência Normal. Deste modo, a mudança conceitual dos alunos se traduz na forma de substituição, entre conhecimentos prévios e novos, quando do momento de crise.

Para Bachelard, em sua "Filosofia do Não", a base de um conhecimento não está restrita a uma única doutrina e sim a um pluralismo da cultura filosófica que é revelado pelo perfil epistemológico de um conceito específico, válido para um sujeito particular e um certo contexto cultural. Pois, “[...] cada filosofia fornece apenas uma banda do espectro nocional ${ }^{9}$, e é necessário agrupar todas as filosofias para termos o espectro nocional completo de um conhecimento particular" (BACHELARD, 1978, p. 29). Desta maneira, uma noção não substitui a outra e, sim, é sempre o momento da evolução do pensamento. Para Mortimer (1994), a noção de perfil epistemológico possibilita admitir, para um mesmo sujeito, a coexistência de diferentes concepções em relação a um certo conceito, não havendo portanto a troca entre o conhecimento prévio e o novo e, sim, a evolução do perfil.

Em linhas gerais, percebe-se que algumas idéias presentes na dimensão filosófica apresentam-se mais representativas ao processo de mudança conceitual, tais como: mudanças mediante situações de conflitos, insatisfações e/ou crises, podendo ocasionar substituição do conhecimento anterior pelo novo; troca de concepções quando o novo conhecimento se apresentar inteligível, plausível e útil; evolução gradual das idéias e coexistência de concepções em torno de um mesmo conceito. Conforme será visto mais adiante, características como estas acabam por definir a estruturação de Modelos de Mudança Conceitual (MCC).

\footnotetext{
${ }^{9}$ Segundo Bachelard (1978), o espectro nocional se refere ao conjunto de todas as noções/concepções que o sujeito possui a respeito de certo conceito.
} 


\subsection{DIMENSÃO PSICOLÓGICA DA MUDANÇA CONCEITUAL}

A dimensão psicológica da Mudança Conceitual tende a se guiar pelos processos de construção do conhecimento, os quais são baseados em princípios do construtivismo, mais especificamente, por teorias psicológicas da aprendizagem fundamentadas em referenciais como a Teoria da Equilibração de Piaget e a Teoria Sociocultural de Vygotsky e por vertentes psicanalíticas de análise das concepções. Alguns trabalhos evidenciam a dimensão psicológica no desenvolvimento do Modelo de Mudança Conceitual, por exemplo, Santos (1991) localiza os estudos de Piaget e Ausubel, enquanto precursores nas pesquisas sobre concepções alternativas e, Bachelard pelo viés psicanalítico do conhecimento científico. Mortimer (1994), faz referência, além de Piaget, a Vygotsky pela abordagem sociocultural da construção do conhecimento. Cabral (1998), valoriza a abordagem psicanalítica de Lacan como modo de considerar aspectos subjetivos no processo de mudança conceitual. Pozo (2002), estrutura seu estudo em torno de teorias de aprendizagem construtiva ${ }^{10}$, enfatizando mais os processos por reestruturação do que os por assimilação.

A estrutura da Teoria da Equilibração, desenvolvida por Piaget, segue à luz da idéia de que o pensamento do sujeito é tendencioso a estabilizações durante o processo de construção do conceito como reflexo compensatório em relação a situações perturbadoras, isso permite que sejam feitas descrições das dificuldades dos alunos na construção do conhecimento científico. Mortimer e Carvalho $(1996)^{11}$, chamam atenção sobre características consideradas importantes da Teoria da Equilibração, uma delas é a relacionada à natureza das perturbações. Segundo eles, as lacunas, a falta de uma noção, a inexistência de informações podem se constituir em obstáculos maiores que uma situação conflitiva. Ainda em relação às pertubações, um outro obstáculo é quando os alunos não conseguem perceber ou não interpretam uma situação como conflitiva frente a seus conhecimentos prévios, o que pode ocasionar fracassos das estratégias de ensino e não levar à necessidade de mudanças em sua forma de compreender o conceito, gerando assim, diferentes fases da construção

\footnotetext{
${ }^{10}$ Para Pozo, a aprendizagem construtiva se refere a "um processo em que o que aprendemos é o produto da informação nova interpretada à luz de, ou através do que, já sabemos. Não se trata de reproduzir informação, mas de assimilá-la ou integrá-la em nossos conhecimentos anteriores. Somente assim compreendemos e somente assim adquirimos novos significados ou conceitos. De alguma forma, compreender é traduzir algo para as próprias idéias ou palavras. Aprender significados é mudar minhas idéias como consequiência de sua interação com a nova informação." (2002, p. 126)

${ }^{11}$ No artigo "Referenciais Teóricos para Análise do Processo de Ensino de Ciências", publicado no Caderno de Pesquisas, n. 96, p. 5-14, fev. 1996, os autores apresentam descrições consistentes sobre a teoria de Piaget e de Vygotsky no intuito de evidenciar uma análise de processo de ensino-aprendizagem em sala de aula a partir de diferentes referenciais teóricos.
} 
compensatória. E, uma outra característica está relacionada à construção de totalidades em termos explicativos e generalizáveis, ou seja, muitas vezes o conhecimento do aluno se estabiliza no nível dos esquemas, enquanto procedimentos e rituais, assim, ele fica limitado a uma situação local e não consegue desenvolver explicações, nem atingir generalizações. Segundo Mortimer e Carvalho (1996), essa característica se refere à terceira forma de equilibração da teoria. Para esses autores, tem-se que:

O modelo de equilibração e suas fases da construção compensatória são úteis para descrever a evolução das idéias dentro de certo paradigma. [...] a passagem de um quadro epistêmico a outro, [...] não se realiza por reestruturação das idéias contidas no paradigma anterior, mas pela invenção de uma nova idéia, que se desenvolve paralelamente à anterior (MORTIMER e CARVALHO, 1996, p. 7 e 8).

Em suma, para que ocorra o processo de equilibração é preciso que exista uma adaptação entre a assimilação e a acomodação da nova informação em relação aos conhecimentos prévios, partindo-se do princípio que Piaget define assimilação "como incorporação de uma realidade externa qualquer a uma outra parte do ciclo de organização" (PIAGET, 1970, p. 377), isto é, refere-se ao fato de um estímulo do meio exterior modificar uma conduta, conforme acontece sua integração com as estruturas cognitivas já existentes. A assimilação é determinada pelo indivíduo, já a acomodação é determinada pelo objeto e é reflexo da necessidade em se considerar os aspectos próprios de um certo conceito a ser assimilado, ou seja, é o ajustamento do esquema à uma situação em particular. Segundo Piaget, não existe um sem o outro:

[...] como não há acomodação sem assimilação, já que é sempre a acomodação de alguma coisa que é assimilada a um esquema de conduta qualquer, de igual modo não pode haver assimilação sem acomodação denunciando que o esquema de assimilação é geral e que é preciso sempre acomodá-lo às situações particulares (PIAGET, 1978, p, 62).

Nesse sentido, entende-se que, da interação do sujeito com o meio derivam dois movimentos complementares, um de assimilação que é a incorporação dos objetos às estruturas cognitivas e outro de acomodação aos próprios objetos. Portanto, a evolução do sistema sensório motor se dá pelo progresso da assimilação correlacionada ao da acomodação.

Já, para Vygostky, o processo de evolução do conhecimento se dá pela relação entre sujeitos socioculturais e, em um certo contexto, mais especificamente, por processos interpsicológicos e intrapsicológicos, pois funções psicológicas superiores surgem, para o autor duas vezes: "primeiro, no nível social, e, depois, no nível individual; primeiro, entre pessoas (interpsicológica), e, depois, no interior da criança (intrapsicológica)" 
(VYGOTSKY, 1991, p. 64, destaques do autor). Essa maneira de perceber as relações entre sujeitos leva à necessidade de enfocar a unidade de análise do indivíduo para o plano das idéias construídas em um certo contexto e então internalizadas. Outro fator a se considerar são as análises de Vygotsky que se baseiam em mecanismos semióticos ou simbólicos, enquanto mediadores entre processos sociais e individuais, tendo-se aí, a linguagem como uma importante ferramenta mediadora das relações sociais e culturais do ensino-aprendizagem.

Para Vygotsky, a evolução ocorre no que ele denomina de Zona de Desenvolvimento Proximal (ZDP), definida como “[...] a distância entre o nível de desenvolvimento real, que se costuma determinar através da solução independente de problemas, e o nível de desenvolvimento potencial, determinado através da solução de problemas sob a orientação de um adulto ou em colaboração com companheiros mais capazes" (VYGOTSKY, 1991, p. 97), ou seja, a evolução do conhecimento de um sujeito pode ser provocada pela relação entre sujeitos com diferentes potencialidades cognitivas, pois um funciona como suporte ao outro, compartilhando idéias, concepções, conhecimentos. Por exemplo, em sala de aula ao se promover atividades em grupo para o estudo de um conteúdo escolar, a situação inicial, geralmente, apresenta-se com uma diversidade de idéias, algumas mais próximas do conceito científico e outras do senso comum. Com a troca de informações geradas entre os participantes, tais idéias tendem a um consenso, que pode representar avanços ou retrocessos em relação à situação inicial. Motirmer e Carvalho (1996) explicam que esta maneira de interpretar a ZDP a caracteriza como um sistema de suporte ou andaime no que se refere ao processo de ensino. Cabe então ao professor a ação de adequar o conhecimento a ser aprendido de acordo com o nível de desenvolvimento do aluno, visando-se, assim, à evolução do mesmo. Nesse sentido, a mudança conceitual na perspectiva vigotskiana refere-se à evolução do desenvolvimento cognitivo, a qual decorre da interação social em um certo contexto cultural, no qual são construídas as novas idéias e, então, internalizadas.

Pelo processo psicanalítico, a mudança conceitual vai além do campo cognitivo, pois sua amplitude é de dimensão sociopsicológica e de fatores ambientais. Villani e Freitas (2002), ao analisarem a MC de professores de Biologia em formação inicial, os quais eram alunos de duas disciplinas de Prática de Ensino em atividades de estágio, ressaltam que pesquisadores têm apontado para a necessidade em se considerar no processo de ensino componentes subjetivos, tais como: desejos, desprezos, tensões, medos, etc.. Tais elementos podem se constituir em variáveis com forte influência no êxito da atividade. Para os pesquisadores, estas variáveis têm sido pouco exploradas em modelos de Mudança Conceitual. Nesse sentido, a essência, na vertente psicanalítica, está voltada a aspectos 
afetivos e motivacionais, os quais podem ser compreendidos como os relacionados à emoção e às crenças e valores. Percebe-se aí, uma forma de valorizar a subjetividade dos alunos, por ora sujeitos, envolvidos no processo de ensino-aprendizagem.

Um trabalho que toma a vertente psicanalítica como meio de contemplar aspectos subjetivos é o de Cabral (1998), o qual propõe a análise do entorno da relação professor e aluno no que se refere à dinâmica de início de um processo de MC. A autora estabelece analogia entre a experiência analítica de orientação freudo-lacaniana e a experiência de aprendizagem a partir dos sujeitos envolvidos, isto é, alunos de um curso de Física, na disciplina de Cálculo Diferencial e Integral (CDI). O estabelecimento de relações entre os processos psicanalíticos e o de aprendizagem propiciam que sejam identificados instrumentos que levam a mudanças. Tais instrumentos são compreendidos pelas fases que um procedimento psicanalítico é desenvolvido e pela ênfase que se é dada à fala e à escuta entre os sujeitos envolvidos no processo de análise e de ensino (paciente/analista e aluno/professor). Pois, parte-se do princípio que somente desta maneira é possível estimular o aparecimento de esquecimentos e lapsos, ou ainda, de evidenciar o pensamento e o envolvimento do sujeito na reelaboração de suas idéias.

Em linhas gerais, a entrada em uma sessão psicanalítica é marcada por certas fases. $\mathrm{Na}$ primeira fase, a das entrevistas preliminares é quando se inaugura a análise e um compromisso é selado por meio de um contrato oral, no qual se firmam as condições de trabalho. "Este é um momento importante de sondagem para demarcar o caso e decidir se é ou não possível à pessoa entregar-se a uma análise, o que é significativamente distinto de submeter a um trabalho terapêutico" (CABRAL, 1998, p. 111). Um outro aspecto referente a esta fase, é a explicitação pelo uso da linguagem, por parte do paciente, de seu mal-estar, de suas queixas, de suas insatisfações, o que vem a converter-se em sintoma analítico ${ }^{12}$, é o que Cabral (1998) apresenta como função sintomal. Ainda, nas palavras da mesma autora,

[...] os dispositivos da clínica devem propiciar as condições para que o indivíduo possa perceber sua posição de sujeito com relação ao sintoma, passagem verificada na modificação de uma inquietação, uma insatisfação tornada angústia, para uma evocação de um saber. Complementar à insatisfação do sujeito existe a antecipação da existência de um outro - algo ou alguém - a quem se dirigir para aplacar a própria angústia" (CABRAL, 1998, p.114).

\footnotetext{
12 "Em resumo, o sintoma analítico se constitui na fala de quem suporta o trabalho de analisar o que está por trás de sua queixa ao endereçar de início o discurso para o analista” (CABRAL, 1998, p. 115).
} 
O depósito da insatisfação no outro (analista/professor), é o que se configura como função transferencial da entrevista, pois o analisado toma como suporte o saber do outro, transferindo assim suas angústias. Trata-se, também, de uma maneira de retardar mudanças, uma vez que o sujeito se recusa a enfrentar seus próprios dilemas. Da passagem do sintoma de um para o outro, faz-se a vez da função diagnóstica da entrevista, a qual refere-se à análise da estrutura clínica da fala do paciente. Em relação à estrutura clínica, classicamente, são organizadas em virtude de três diagnósticos: neurose, psicose e perversão ${ }^{13}$. "Diagnóstico e processo analítico estão em relação estreita, pois aquele serve para dar uma direção a este" (CABRAL, 1998, p. 115). O importante do diagnóstico é que sejam dadas indicações sobre a estrutura clínica para que possam ser pensadas as estratégias para darem suporte ao processo analítico.

No processo analítico, o paciente é colocado a trabalhar, ele ocupa a posição de falante, enquanto o analista faz a escuta. "Ao privilegiar o ato de falar, por parte do analisando, a análise permite e estimula a ocorrência de eventos em que a fala derrapa, se equivoca, e em que um saber que se refere ao inconsciente é posto em ato" (CABRAL, 1998, p. 120). Trata-se de um momento de fazer com que o paciente/aluno se dê conta de seu inconsciente, sendo assim, essa trajetória é constituída por três aspectos: a transferência analítica; a interpretação e o basteamento.

$\mathrm{Na}$ transferência analítica, o paciente ao falar se dirige ao outro (o analista) que o sustenta com o seu saber. Este por sua vez, conduz o processo levando o paciente a se desestruturar perante a perda de suas próprias referências. Já, a interpretação é usada para se trabalhar com a transferência. Pois, "refere-se ao que permite abrir a questão do desejo do sujeito que fala, uma vez que ele é lançado ao campo da indagação" (CABRAL, 1998, p. 121), o qual se orienta pela perspectiva do que o paciente pretendia dizer. Nesse sentido, a interpretação se constitui pelo ato de o psicanalista escutar o paciente para além do que é dito, ou seja, escutá-lo não pelo que é pronunciado e, sim, pela intenção representativa das palavras emitidas. No último aspecto, o do basteamento "pode ser relacionado com a questão da interpretação como pontuação do analista sobre os ditos do analisando como intervenção ou ato analítico" (CABRAL, 1998, p. 121). Isto é, o analista/professor, a partir de suas

\footnotetext{
${ }^{13}$ Cabral (1998) explica que na neurose há o recalque, o sujeito admite a falta (a queixa) mantendo-a em seu inconsciente. Contudo, essa falta não faz parte de seu ser. Na perversão há a recusa, isto é, o sujeito reconhece a falta e a mantém em seu imaginário, no fetiche. E, na psicose, caracterizada por sonhos de omnipotência, a falta é negada e não é conservada, é o princípio da foraclusão, onde não se pode falar sobre o que não existe, é a falta da falta.
} 
interpretações, pode apresentar questionamentos que levem o paciente/aluno a conjecturar e reorganizar suas próprias questões e desejos. Em geral, o processo de análise termina quando ocorre a dissolução da transferência, isto é, o sujeito não é mais dependente do outro (analista/professor) e passa a elaborar suas próprias maneiras de justificar e construir significados sobre certa idéia. Deste modo, a mudança é entendida em termos de atitudes e escolhas em virtude da mudança na posição do sujeito frente às suas maneiras de justificar.

Assim como na dimensão filosófica, algumas idéias presentes na dimensão psicológica, também, são significativas aos Modelos de Mudança Conceitual, tais como: a atenção dada às situações perturbadoras no processo de ensino-aprendizagem as quais compreendem os conflitos entre conhecimentos prévios e os novos; os esquecimentos, lapsos e ausência de idéias em relação ao conceito (lacunas) e a influência que variáveis subjetivas exerce sobre os sujeitos. Outro aspecto, refere-se aos modos como os sujeitos estão se relacionando com os novos conhecimentos, isto é, o enfoque de que as idéias evoluem por um movimento de assimilação e acomodação e a interação social entre indivíduos com diferentes potencialidades cognitivas é um meio favorecedor para a ocorrência da evolução das idéias. Ou ainda, a percepção de que o conhecimento prévio passa continuamente por vários estágios de mudanças até ser substituído por completo, ocorrendo assim uma mudança profunda e radical da concepção. Conforme será abordado no próximo item, características como estas acabam por delinear a estruturação de Modelos de Mudança Conceitual (MMC).

\subsection{VERTENTES TEÓRICAS DE MODELOS DE MUDANÇA CONCEITUAL (MMC)}

Investigadores que têm se dedicado a pesquisar os processos pelos quais ocorrem mudanças conceituais entre os alunos, tomam como pressuposto a existência de conhecimentos prévios ou preconcepções, os quais podem ser entendidos como: "idéias intuitivas relativamente estáveis, parcialmente consistentes, úteis para a interpretação dos fenômenos cotidianos e que constituem o "conhecimento do senso comum'"(VILLANI e ARRUDA, 1994, p. 88, destaque dos autores). Um outro pressuposto é o da resistência a mudanças, a qual é compreendida como uma maneira de os alunos tenderem a apresentar dificuldades em assimilar, incorporar, assumir, utilizar, mudar suas idéias pessoais para as concepções veiculadas pela escola e concebidas como científicas. Partindo de tais pressupostos é que os Modelos de Mudança Conceitual (MMC) têm sido desenvolvidos e é, nesse contexto, que as dimensões filosófica e psicológica, explicitadas anteriormente, se fazem relevantes, pois elas se constituem na base epistemológica dos modelos. 
Entre os trabalhos que adotam a abordagem teórica dos $\mathrm{MMC}$, percebe-se que a maioria toma como referência a estrutura desenvolvida por Posner et al (1982) e, a partir dela, desenvolveram-se refinamentos, ou seja, criaram-se estruturas que permitiram incorporar outros elementos ao processo de mudança conceitual além dos já postulados, por exemplo: aspectos subjetivos e socioculturais. Por esse viés, em alguns casos, ocorreram uma mescla das dimensões filosófica e psicológica, havendo, conseqüentemente, mais ênfase em certos aspectos de uma dimensão em relação à outra. Vale esclarecer que, o intuito neste tópico não é descrever modelos, mas sim, apresentar uma perspectiva de interpretação de vertentes teóricas contidas nos mesmos. Para isso, apresentar-se-á características consideradas essenciais em alguns MMC, no intuito de evidenciar algumas tendências nos processos de ensino-aprendizagem guiadas pelo referencial da Mudança Conceitual.

Nesse sentido, adotar-se-á como ponto de partida os componentes teóricos presentes na linha de pesquisa do modelo desenvolvido por Posner et al (1982). Esta linha traz a idéia de que a aprendizagem e o desenvolvimento da ciência são processos análogos e, portanto, acarretam uma forma de ensino que possibilita ao aluno a aquisição do conhecimento por caminhos semelhantes aos percorridos ao longo da história na constituição do saber científico. Os pressupostos de Kuhn, Lakatos e Toulmin foram a principal base deste trabalho, pois segundo os autores, para que ocorresse mudanças nos conhecimentos prévios seria preciso que houvesse um processo de assimilação e acomodação ${ }^{14}$, os quais são interpretados respectivamente como, o período de ciência normal e de revolução científica, conforme postulado por Kuhn.

$\mathrm{Na}$ assimilação, o aluno usaria seus conceitos frente a situações novas, quando tal experiência suscitasse em fracasso isso geraria anomalias em relação às preconcepções, seriam as perturbações ou os conflitos cognitivos. Deste modo, o conjunto de conhecimentos que o aluno já possuísse, o qual Toulmin denominou de ecologia conceitual, deveria mudar, de modo que o mesmo pudesse alcançar novo nível de acomodação. Mas, para que isso ocorresse, era preciso atender a quatro condições fundamentais: a insatisfação com o conhecimento prévio e a nova concepção fazer sentido ao alunos, isto é, ser inteligível. Seria preciso também, que a nova concepção resolvesse a perturbação instalada, ou seja, que ela fosse plausível e por fim, ser fértil, o que implica em possibilitar ao aluno que a estenda para outras áreas do conhecimento. A acomodação alcançada pelo atendimento do conjunto destas condições representaria uma mudança conceitual radical nas concepções do aluno.

\footnotetext{
${ }^{14}$ Posner et al (1982) inserem em nota que os termos assimilação e acomodação possuem conotação diferente à utilizada por Piaget em sua teoria.
} 
Esse modelo depende também que sejam observados alguns aspectos em torno do conjunto de conhecimentos prévios e do envolvimento do aluno no processo, pois a seleção da nova concepção é reflexo desses componentes.

A ecologia influencia na ocorrência de acomodações determinando se as condições são possíveis de serem satisfeitas ou não. Inteligibilidade e principalmente plausibilidade são claramente dependentes das características da ecologia conceitual e uma anomalia só produz insatisfação no indivíduo se ele a reconhece como tal e está comprometido com a redução das inconsistências de seu pensamento (VILLANI e ARRUDA, 1994, p. 91).

A partir dessa estrutura surgiram críticas ao modelo e, por conseqüência, o desenvolvimento de novos modelos que priorizaram desde o trato ao conhecimento pessoal do aluno até a incorporação de outros elementos à estrutura original. Por exemplo, a estrutura proposta por Hewson (apud, VILLANI e ARRUDA, 1994, p. 92), representada pela idéia do status de uma concepção, a qual corresponde de certa forma a uma hierarquização do conhecimento. Pois, refere-se ao grau de atendimento às condições de inteligibilidade, plausibilidade e fertibilidade. Strike e Posner (1992), quando revisam o modelo apontam alguns aspectos, tais como, a não linearidade das condições fundamentais (insatisfação, inteligibilidade, plausibilidade e fertibilidade), a concepção de que o processo de aprendizagem envolve, além de fatores intelectuais, também, os emocionais e que a mudança conceitual pode ocorrer em um processo de evolução do conhecimento de forma gradual, incorporando-se às preconcepções, elementos do conhecimento científico.

Aspectos como os citados anteriormente, entre outros, parecem ter contribuído para o delineamento de dois modos de mudança conceitual, o que implica em estabelecer, nos Modelos de Mudança Conceitual, a maneira como o conhecimento prévio caminhará até o conhecimento científico. Conforme observa Abib (1996. p. 29):

Primeiro, a usualmente denominada por muitos autores simplesmente de mudança conceitual, que implica em uma transformação radical e reorganização produnda das estruturas prévias e rupturas com as concepções iniciais do sujeito, (definida por Hewson, 1981, como troca conceitual). Segundo, uma transformação na qual ocorre um acréscimo e um enriquecimento da estrutura conceitual de partida que é mantida em seus aspectos básicos (denominada por Hewson, 1981, de captura conceitual).

A partir dessas considerações, percebe-se a predominância de duas grandes vertentes entre os Modelos de Mudança Conceitual, uma que considera o processo de mudança conceitual como uma transformação radical dos conceitos ou do conjunto da estrutura conceitual, com rupturas e reorganização profunda das estruturas conceituais iniciais, que será 
referida aqui por Mudança Radical do Conceito e da Estrutura Cognitiva. A outra, compreende o processo de mudança conceitual como uma maneira de ampliar os conceitos iniciais, os quais são mantidos em sua estrutura básica ou incrementados, gradualmente, até atingirem uma evolução conceitual ou do perfil do conjunto de noções sobre um conceito. Nessa vertente, referida aqui como Evolução do Conceito e do Perfil Conceitual, não ocorrem rupturas bruscas entre o novo conhecimento e o anterior, admitindo-se inclusive, a coexistência entre ambos. Pretende-se destacar, por essas duas vertentes, elementos que parecem ampliar a base epistemológica da teoria da Mudança Conceitual, em relação ao modelo revisado por Posner e colaboradores, tanto no que se refere ao modo como é estruturado quanto aos componentes considerados para a promoção da mudança.

\subsubsection{Vertente Evolução do Conceito e do Perfil Conceitual}

A mudança vista como uma perspectiva de evolução parece permitir o pensar de um processo de ensino-aprendizagem que possibilite, ao aluno, uma passagem gradual das concepções pessoais para um conhecimento científico. Nesse enfoque, a mudança pode ser entendida como um processo pelo qual o conjunto de conceitos de uma pessoa se modifica de um para outro compatível (POSNER et al, 1982), ou ainda, conforme já mencionado anteriormente, a mudança pode corresponder a uma transformação na qual ocorrem acréscimos e/ou enriquecimentos da estrutura conceitual de partida, cujo núcleo central é mantido em seus aspectos básicos. Como também, a concepção de que as estruturas cognitivas evoluem para estágios mais elaborados como resultados de sucessivas equilibrações (PIAGET, 1976) ou de interações entre indivíduos de potencialidades cognitivas diferentes (VYGOTSKY, 1998).

Uma outra idéia de evolução é a concebida na Noção de Perfil Conceitual, desenvolvida por Mortimer (1994), ao analisar as concepções sobre atomismo e suas evoluções, em um grupo de alunos da 8. ${ }^{a}$ série do Ensino Fundamental. O foco desse modelo está na perspectiva de que ao se construir um novo conceito, ele torna-se referência para explicar o antigo, sem suprimi-lo ou diminuí-lo em seu status, podendo haver a coexistência de ambos os conceitos em uma mesma pessoa. Toma-se como pressuposto que na noção de perfil conceitual “[...] um indivíduo possa apresentar diferentes visões sobre um mesmo conceito, considerando que existem diferentes formas de pensar e falar sobre a realidade a sua volta" (AMARAL e MORTIMER, 2006, p. 240). Deste modo, cada ponto de vista pode se 
constituir em uma categoria hierárquica de um determinado conceito científico e é isso que permite pensar em zonas de um perfil conceitual específico.

Assim, as concepções dos sujeitos estariam localizadas em diferentes zonas do perfil do conceito em estudo. Por exemplo, ao considerar o conceito de ensino a partir de um viés epistemológico ditado por tendências pedagógicas (LIBÂNEO, 1994, GASPARIN, 2004), pode-se sistematizar as seguintes zonas como constituintes desse perfil conceitual: intuitiva; tradicional; renovada e crítico-social. Vale ressaltar que esse exemplo é apenas ilustrativo de como poderia se apresentar o perfil conceitual de um determinado sujeito. Deste modo, esclarece-se que a primeira zona - a intuitiva - seria relativa às idéias do senso comum, as quais emergiriam das intuições primeiras do indivíduo. Já a tradicional, compreenderia uma perspectiva de ensino pautada na apresentação de conceitos desvinculados dos interesses dos alunos, cuja meta seria formar o aluno sem que o mesmo mobilizasse sua atividade mental e desenvolvesse suas capacidades intelectuais. A terceira zona, a renovada, estaria em contraposição à tradicional e seria centrada nos processos de aprendizagem e não diretamente no ensino, priorizando métodos e técnicas que levassem o aluno a pensar, a raciocinar cientificamente, a desenvolver sua capacidade de reflexão, de criação, de investigação e de autonomia. Já, a última zona do perfil conceitual, a crítico-social, conceberia que o ensino consistiria na mediação e confronto entre os conhecimentos escolares sistematizados com as experiências sócio-culturais e a vida concreta dos alunos. A evolução estaria representada na tomada de consciência do próprio espectro nocional composto entre as diferentes zonas do perfil.

Frente às percepções citadas sobre a vertente da evolução, o que se percebe como resultante é uma geração de diferentes possibilidades de abordagem ao conhecimento prévio e, de tratamento do mesmo com vistas ao conhecimento científico, assim como também, a consideração a outros componentes presentes na relação ensino-aprendizagem. Tais como, os aspectos afetivos e o contexto sociocultural, os quais podem influenciar no processo de mudança conceitual.

Para o desenvolvimento deste estudo, ou seja, das variações existentes em Modelos de Mudança Conceitual, tomou-se emprestado os elementos básicos propostos por Posner et al (1982) como guia, sejam eles: a ecologia conceitual e as condições necessárias a um modelo para se atingir a acomodação, isto é, em cada modelo analisado procurou-se delinear o modo como foi conduzido o trabalho com o conjunto das concepções pessoais dos alunos para se chegar ao conhecimento científico. 
Os Modelos de Mudança Conceitual têm pelas estratégias de ensino, uma forma de registro de como a ecologia conceitual e as condições para atingir a acomodação são desenvolvidas. Segundo Medrano (2002, p. 94), as estratégias de ensino podem ser definidas como um sistema peculiar formado por determinados tipos de atividades de ensino que se relacionam entre si mediante certos esquemas organizadores. Por exemplo, Abib (1996), cujo modelo foi inspirado em princípios da Teoria da Equilibração de Piaget e nas contribuições de Hewson (1981) e Striker e Posner (1992), apresenta uma proposta de ensino, na qual as estratégias foram organizadas, em linhas gerais, em três etapas: caracterização das concepções iniciais; caracterização de indícios sobre as práticas e caracterizações das concepções finais. Em cada etapa desenvolveu-se uma série de atividades, as quais visavam ao trabalho com a ecologia conceitual e com as condições para a evolução dos conceitos. $\mathrm{O}$ foco da pesquisa foi a análise da evolução de concepções voltadas aos processos de construção do conhecimento sobre ensino, este pautado no construtivismo. Essa investigação foi desenvolvida com professores de Física em formação inicial, no contexto das ações da disciplina de Prática de Ensino e Estágio Supervisionado de Física. O trabalho se iniciou por meio da explicitação das concepções pessoais dos alunos, o que permitiu a caracterização das mesmas e a conseqüente definição das demais atividades desenvolvidas ao longo da investigação. Essa forma de organização do ensino tem fundamento no princípio construtivista, do qual pode-se admitir alguns pressupostos:

1) o aluno é construtor de seu próprio conhecimento;

2) o conhecimento é um contínuo, isto é, todo conhecimento é construído a partir do que já se conhece;

3) o conhecimento a ser ensinado deve partir do conhecimento que o aluno traz para a sala de aula (CARVALHO, 1992, p. 9).

Deste modo, além de ser essencial a participação ativa do aluno no processo de construção de seu conhecimento, tem-se que a sistemática em considerar os conhecimentos prévios, como ponto de partida para o início do estudo de um novo conceito, não só permite ao professor conhecer o que o aluno sabe e como concebe certas idéias, como também, é relevante para a organização do ensino como um todo. Pois, torna-se possível planejar o ensino de modo a favorecer que os conhecimentos particulares (concepções pessoais) sejam tomados como fundamentos para a construção de novos referenciais.

Por outro lado, há os modelos que procuram evitar a explicitação de idéias pessoais para o início do processo de ensino-aprendizagem. Pelo modelo do Perfil Conceitual, os conhecimentos prévios são evidenciados para o aluno, à medida que eles geram conflitos em relação ao novo conhecimento, o que pode acontecer em qualquer momento do estudo, porque 
o referencial mais recente deve ser consistente a ponto de explicar o antigo. Nesse viés, as estratégias de ensino partem do estudo do novo conceito e a relação entre o conhecido e o que se quer ensinar é estabelecida por meio de analogias. Deste modo, o trabalho com o conhecimento prévio do aluno, acaba sendo incorporado no desenvolvimento do processo de ensino, pois o evidenciamento não se constitui como ponto de partida dos estudos, e sim, como uma etapa que visa à acomodação do conceito.

Em relação à acomodação, vale lembrar que o processo de ensino, segundo a estrutura de Posner et al (1982), deve contemplar estratégias que gerem insatisfações em relação às preconcepções. Em contrapartida, o conhecimento científico deve ser percebido como inteligível, plausível e fértil. Nesse sentido, Abib (1996) favoreceu que as insatisfações em relação ao conhecimento prévio emergissem por meio de "atividades que promovessem tanto situações de conflito que evidenciassem limitações das concepções iniciais apresentadas pelos alunos" (ABIB, 1996, p. 53-54), como também, possibilidades de desequilíbrios de caráter lacunar. A autora ressalta que, ao longo do processo tais atividades iam sendo ajustadas conforme os alunos apresentassem suas reflexões e ações em torno do conceito estudado. Essa forma de condução visava à superação dos conflitos instalados e à reelaboração de novas concepções.

Diante dessa idéia, pode-se pressupor que o conhecimento prévio foi concebido como um importante elemento na determinação do ponto de partida para o que se queria ensinar, enquanto que o conhecimento científico se constituiu o mote para a geração de conflitos na base pré-conceitual construída anteriormente pelos indivíduos. Uma maneira de propiciar isso foi o desenvolvimento de problematizações sobre a temática estudada. Essa estratégia leva o aluno a perceber que, seus conhecimentos são insuficientes para a resolução da questão proposta, promovendo, assim, a insatisfação em relação ao conhecimento prévio e, ao mesmo tempo, oportunizando que um novo conhecimento ganhe espaço, ou seja, torne-se inteligível, plausível e fértil frente à possibilidade de fornecer subsídios que resolvam a situação problematizadora.

Contudo, a resolução pela resolução não é suficiente para despertar no aluno a percepção da necessidade de ampliação de seu saber, é preciso que ele reflita sobre o que está fazendo e se conscientize sobre o que de fato sabe. Esse processo é concebido na literatura como metacognição, a qual pode ser entendida como uma maneira que "[...] envolve o pensar sobre o próprio pensar ou o conhecer a aprendizagem de alguém e a si próprio como aprendiz. É importante que as pessoas se compreendam como agentes do seu próprio pensar" (VILLAS BOAS, 2006, p. 44). Tal perspectiva revela o potencial que a metacognição pode atingir em 
virtude da evolução conceitual, uma vez que não só delega ao aluno o gerenciamento da própria aprendizagem, como também torna possível que o sujeito se perceba no processo ensino-aprendizagem e, conseqüentemente, atinja certa autonomia de discernimento e escolha entre um conhecimento já existente e um novo a ser incorporado.

No Perfil Conceitual, também são utilizadas estratégias de ensino que contemplam a metacognição como modo de gerar insatisfações sobre a concepção pessoal frente ao novo conceito. Por esse processo, o aluno tem condições de estabelecer comparações entre as várias concepções a partir de critérios bem delimitados, por exemplo, a coerência e a consistência lógica de uma perspectiva conceitual em relação à outra. Vale esclarecer que Mortimer (1994), de maneira geral, organizou suas estratégias de ensino em dois momentos: aquisição do conceito numa área específica do perfil e tomada de consciência do próprio perfil. Nesse sentido o autor entende que:

O primeiro corresponde a aquisição do conceito numa zona específica do perfil. [...] $\mathrm{O}$ segundo momento importante no processo ensinoaprendizagem é a tomada de consciência, pelo aluno, de seu próprio perfil, o que permite a comparação entre as diferentes zonas que o constituem, bem como a avaliação do domínio a que se aplica e do poder relativo de cada uma delas (MORTIMER, 2006, p. 143).

Esses momentos decorrem do entendimento de que a insatisfação em relação ao conhecimento prévio só pode emergir após o contato com o novo referencial teórico, o qual é exposto a situações problemáticas (perturbadoras). Mortimer (1994) explica que quando o aluno se depara com problematizações novas há uma forte tendência de ele usar suas concepções prévias para resolvê-las por conterem estruturas conceituais mais familiares, uma vez que o novo conceito está em fase de construção. E, é nesse processo, que se acredita que o aluno se conscientize de seu perfil conceitual, isto é, perceba sua concepção pessoal e a científica como modos diferentes de compreensão de um mesmo conceito, assim como também, a respectiva aplicação. Essa forma de proceder tem respaldo em Vygotsky (1991), o qual defende a idéia de que uma função só pode ser submetida ao controle e, também, reconhecida se existir consciência sobre ela após sua aquisição, ou melhor, é preciso primeiro possuir um novo referencial para então se conscientizar dele e exercer controle sobre o mesmo.

Por outro lado, as condições básicas, para a acomodação (inteligibilidade, plausibilidade e fertilidade) no Perfil Conceitual, parecem adquirir outra compreensão em relação à proposta por Posner et al (1982), uma vez que a evolução não se dá pela supressão ou diminuição do status de uma concepção em relação a outra e depende das características de 
cada zona a ser ensinada. Isso decorre da consideração sobre o contexto em que tais concepções estão situadas. Pois, as "maneiras de ver o mundo estão largamente incorporadas em nossa cultura. Suprimir essas concepções alternativas seria, [...], suprimir o pensamento do senso comum e seu modo de expressão, a linguagem cotidiana" (MORTIMER, 2006, p. 147). O que se pode fazer, segundo o autor, seria apenas indicar em qual domínio que determinada concepção é plausível e fértil, ou em que contexto pode ser considerada inteligível. Esse modo de perceber a evolução do conhecimento imprime a ela um caráter sociocultural com interferências da ação do professor; da seqüência de atividades e/ou da intervenção de indivíduos (outros alunos) com potencialidades cognitivas mais avançadas. A esse conjunto de elementos que interferem na evolução, Mortimer (1994) denomina de sistema de suporte.

Já Abib (1996), aponta como fatores influenciadores no processo de evolução conceitual alguns elementos que interferem tanto na geração e instalação de conflitos, como, na superação das situações perturbadoras, entre eles estão: as experiências vivenciadas pelos sujeitos na condição de aluno; o grau de (in)satisfação com as experiências pessoais; a dificuldade de aprendizagem e o contato com os conhecimentos provenientes de outras áreas ou disciplinas. A ocorrência desses fatores favoreceria que a evolução acontecesse gradualmente, isto é, à medida que o sujeito se conscientizasse das próprias concepções e fosse superando os conflitos instalados, ele estaria acrescentando novas informações no entorno de seu núcleo central (este tipo de modificação corresponde à captura conceitual de Hewson). O ciclo evolutivo se completaria quando as novas informações passassem do entorno para a reestruturação do próprio núcleo central conceitual, isto é, o sujeito reorganiza suas idéias e passa a assumir os referenciais do novo conhecimento.

No Perfil Conceitual, a evolução é entendida a partir de certos indícios evidenciados nos alunos, em sala de aula. Um deles tem relação com a linguagem. Pois, concebendo a sala de aula como um espaço de enculturação, tem-se que o discurso ali veiculado para a construção de novos conhecimentos, é conduzido por uma multiplicidade de vozes. Entre elas está a do professor, a qual representa o discurso científico e a evolução do aluno estaria descrita na apropriação da voz do professor. O outro indício é quando o discurso do aluno evidencia, conscientemente, em que contexto utilizaria determinada idéia do conceito em estudo, ou seja, quando ele revela seu perfil conceitual e em que circunstâncias pode utilizar cada abordagem do conceito. Em outras palavras, quando o aluno reconhece que um conceito é plausível e fértil e distingue em que contexto é inteligível.

Nesse sentido, percebe-se que a linguagem enquanto ferramenta que intermedia a relação entre professor e alunos pode se constituir em um importante elemento no processo 
ensino-aprendizagem. Pois, é por meio dela que se pode analisar em que termos está ou não ocorrendo a evolução conceitual. No trabalho de Abib (1996), as análises se desenvolveram, prioritariamente, em torno das ações, mais especificamente, das relacionadas à prática pedagógica. As ações em sala de aula, do docente, assim como a linguagem, também podem se constituir em importantes elementos no processo de ensino-aprendizagem. Deste modo, a evolução conceitual foi traçada por atitudes que perpassaram aspectos de um ensino tradicional para atitudes compatíveis com concepções de um ensino de princípios construtivistas.

Os componentes presentes nos dois modelos referenciados, sejam eles: o Perfil Conceitual e a Evolução Conceitual por acréscimos permitem certas sistematizações em relação a essa vertente (Evolução do Conceito e do Perfil Conceitual). As estratégias de ensino demonstram que o conhecimento científico pode assumir diferentes configurações em virtude do modo como as concepções pessoais são tratadas. Para um, o conhecimento científico é o mote para a geração e instalação de conflitos, para o outro (Perfil Conceitual) é o suporte para que o sujeito/aluno consiga explicar suas idéias pessoais. O contexto em que as investigações foram desenvolvidas (campo de pesquisa, sujeitos) também se revelou como importante elemento na definição do objeto de análise. Pois, enquanto que no Perfil Conceitual os olhares estavam voltados para os alunos e, conseqüentemente, para a linguagem veiculada por eles, Abib (1996) direcionou o olhar para os futuros professores, apesar de também serem alunos, convergindo, então, para as ações deles. O princípio epistemológico implícito em cada modelo, consistiu em outro fator que contribuiu para o modo como a evolução foi desenvolvida e analisada, revelou que tanto a constituição de um novo conhecimento como a relação entre as pessoas envolvidas no processo ensino-aprendizagem podem depender de aspectos socioculturais e afetivos. Para permitir que o aluno se aproprie, conscientemente, da linguagem do professor, é preciso que entre as ações dos docentes, sejam contempladas aquelas que permitam a manifestação do pensar do aluno e de uma relação de cumplicidade. E, pode-se ainda, destacar a própria concepção em si sobre o caráter de evolução, uma vez que há aqui duas percepções distintas, uma delineada no trabalho de Abib, que se refere à idéia de a evolução ir acontecendo de maneira gradual em torno do conceito, o qual vai incorporando novas informações até que o conhecimento atinja uma nova forma conceitual; a outra, postulada no Perfil Conceitual, defende a idéia de que a estrutura conceitual básica não é reestruturada, mas ela coexiste com um conjunto de idéias hierárquicas que formam a noção de um conceito, já que a evolução do conhecimento ocorre em torno do perfil conceitual. Na seqüência, abordar-se-á modelos de mudança conceitual que entendem que a mudança ocorre de forma profunda e abrupta . 


\subsubsection{Vertente Mudança Radical do Conceito e da Estrutura Cognitiva}

Uma outra possibilidade de abordagem da mudança conceitual é a delineada pela perspectiva de que o processo de ensino-aprendizagem encaminha o aluno para uma transformação que não se dá por acréscimos de conceitos e nem pela coexistência de estruturas conceituais, conforme apresentado anteriormente na vertente da evolução, mas sim, por substituições e/ou abandonos das idéias pessoais para as científicas. $\mathrm{O}$ entendimento neste viés é que a mudança se dá sob uma forma de revisão ou reorganização profunda dos conceitos centrais (POSNER et al, 1982), ou ainda, pela perspectiva postulada por Hewson e Thorley (1989) que se trata da troca ou substituição das concepções iniciais pelo novo conhecimento, no qual há uma ruptura do sujeito com as idéias pessoais. Em linhas gerais, o que se postula nesta vertente é que as concepções pessoais são abandonadas e novas concepções passam a ocupar o lugar das antigas.

É, também, pelas estratégias de ensino aplicadas em uma sala de aula que aparecem nuances de como se delineia o processo de mudança no sentido da ruptura e substituição conceitual. Assim, do mesmo modo como se encaminhou na Evolução do Conceito e do Perfil Conceitual, nessa vertente, denominada aqui por Mudança Radical do Conceito e da Estrutura Cognitiva, adotar-se-ão as estratégias de ensino presentes nos Modelos de Mudança Conceitual como referência para o modo com que a ecologia conceitual e as condições para se atingir a acomodação foram propostas no processo ensino-aprendizagem. Vale lembrar, que os aspectos para atingir a mudança conceitual ${ }^{15}$, propostos por Posner et al (1982), continuam sendo considerados como guia na estruturação das idéias aqui apresentadas. Assim, um dos modelos analisados é o que Cabral (1998) propôs, o qual foi desenvolvido com alunos do curso de Física no contexto da disciplina de Cálculo Diferencial e Integral (CDI), conforme já comentado anteriormente, cujo viés é o psicanalítico. Para essa autora, a mudança se dá por transformações cada vez mais profundas da estrutura do conceito específico, na qual o sujeito abandona suas concepções iniciais, passa durante um período se orientando pelas concepções de outro (a do professor) para, só então, reelaborar sua própria concepção, o que para ela implica em uma Mudança Radical. Uma outra perspectiva é a apresentada por Pozo (1997, 2002), a qual traz a idéia de uma revisão mais profunda da estrutura cognitiva conceitual,

\footnotetext{
15 Tais aspectos se referem ao trabalho com a ecologia conceitual e as condições para atingir a acomodação,ou seja, a insatisfação em relação ao conhecimento pessoal e à inteligibilidade, plausibilidade e fertilidade do novo saber.
} 
cujas concepções passam por sucessivas reestruturações até atingir uma profunda reestruturação do conjunto de conhecimentos de um certo domínio.

As estratégias de ensino, presentes no modelo de Mudança Radical (CABRAL, 1998), foram desenvolvidas em analogia ao processo psicanalítico, sendo respeitadas as especificações de cada campo. Deste modo, assim como a análise é desenvolvida por meio de fases, o ensino proposto também o foi. Nesse sentido, o início das atividades com os alunos foi marcado pela apresentação de um Contrato de Trabalho Alternativo ${ }^{16}$ (CABRAL, 1998), o qual instituiu a posição do professor e a dos alunos ao longo do período das aulas. Pois, assim como no processo psicanalítico, as funções que cada sujeito ocupa no decorrer do trabalho em sala de aula possuem características bem delimitadas. Para tanto, nesse instrumento foram previstos:

[...] trabalhos em pequenos grupos durante as aulas, avaliação contínua e diária do trabalho, avaliação de provas, maneira de atribuir notas, formas de realizar as provas, estratégias de organização grupal, estruturação da turma como um grande grupo, determinação dos conteúdos, estratégias para tratar os conteúdos, exposição de temas pelo professor e pelos alunos, elaboração de diários de aula e trabalho de recuparação paralela (CABRAL, 1998, p. 142).

Cada elemento presente no contrato tinha relação com a diretriz pedagógica adotada, na qual a ação docente estava orientada em desenvolver estratégias de ensino que colocassem o aluno a falar sobre os temas estudados de acordo com os seus próprios entendimentos, para que possíveis erros, equívocos, lapsos surgissem e, então, fossem analisados. Assim, no intuito de que o significado operacional representativo dos fenômenos envolvidos nas tarefas viesse a emergir, partia-se do sentido de que ela possuíam para o aluno. Para que tal ação docente se sustentasse, foi preciso que a diretriz pedagógica estivesse pautada em dois viéses, o da Didática da Problematização e o da Assimilação Solidária ${ }^{17}$ que consiste, principalmente, em ouvir o aluno e estimulá-lo à produção de elementos que permitam a incorporação do conhecimento instituído.

Deste modo, o trabalho com as concepções dos alunos ocorreu durante as atividades em grupo, quando eles iam revelando o que pensavam e explicitando lacunas, conflitos, insatisfações e desinteresse sobre determinado assunto. O professor por sua vez, ao ser solicitado no grupo, escutava o aluno, procurava despertar o interesse, problematizava

\footnotetext{
${ }^{16}$ Esse contrato, elaborado pelo professor e apresentado por escrito aos alunos, posteriormente, foi analisado e discutido no âmbito da sala de aula em conjunto com os alunos.

17 A Assimilação Solidária se refere a uma "proposta de intervenção pedagógica [...] que busca construir um ambiente de trabalho na sala, durante a hora da aula." (CABRAL, 1998, p. 142)
} 
situações, enfim, desenvolvia o que Cabral nomeou de Trabalho Produtivo ${ }^{18}$. Este dispositivo consiste de duas possibilidades: a de provocar desequilíbrio nas concepções espontâneas e levar o aluno a um estágio mais estável de equilibração ou, a de dar condições para a incorporação de novos conhecimentos. Vale ressaltar que as idéias reveladas nos grupos subsidiavam a escolha dos conteúdos e das atividades seguintes. Isso ocorria pelo fato de que as dificuldades/obstáculos que os alunos iam apresentando durante a execução das tarefas, tanto serviam de referência na determinação da continuidade do trabalho, quanto de sinalização do modo em que os mesmos estavam concebendo certo conceito. Esse jeito de conduzir o ensino, proporcionou que o trabalho com o conjunto de concepções dos alunos partisse dos modos particulares de cada um significar o conhecimento. As insatisfações em relação às concepções pessoais foram resultantes de conflitos, gerados a partir de questionamentos colocados pelo professor, no decorrer do processo de ensino-aprendizagem.

Desta maneira, as insatisfações emergiram não só durante as atividades em grupo, mas também por meio de outras estratégias de ensino, que foram implementadas, cujo intuito era favorecer a explicitação (oral e escrita) dos modos próprios de significar o conhecimento. Uma delas, denominada de Aluno no Quadro, consistia na preparação e exposição de determinado tema pelo aluno e, em decorrência dessa situação, ficava ele submetido aos questionamentos para esclarecimentos, tanto por parte do professor quanto dos demais alunos da sala. $\mathrm{O}$ intuito nesse procedimento, além de fazer com que o aluno falasse sob seu ponto de vista a respeito de certo assunto, era, também, que ele viesse a se comprometer com a própria aprendizagem. Segundo Cabral (1998), é no decorrer dessa interação do trabalho produtivo que o aluno passa a se orientar pelos referenciais do professor, é o que a autora apresenta como uma Transferência Pedagógica, a qual corresponde a um período de transição, de deslocamento do conhecimento do sujeito para o de outro, no caso, o conhecimento do professor.

Na Transferência Pedagógica, o aluno se instrumentaliza do conhecimento de outro, seja ele o professor ou um manual didático. Deste modo, a aprendizagem se processa não por elaborações próprias do sujeito, mas mediante substituições das idéias pessoais para as do outro. Esse é considerado um período de transição, o qual se destitui no momento em que o aluno passa a se orientar por suas próprias elaborações teóricas. Assim, a análise, pelo professor, das dificuldades e/ou obstáculos que os alunos apresentavam, revelou-se primordial para a continuidade do processo de aprendizagem, ou como se afirma no meio psicanalítico,

${ }^{18}$ Segundo Cabral (1998, p. 143), o dispositivo de Trabalho Produtivo também foi definido no Contrato de Trabalho como "acontecimento sobre as atividades propostas pelo professor circunscritas à Assimilação Solidária $[\ldots] "$ 
para a dissolução da transferência. Pois, o tipo de dificuldade apresentado pelo aluno fornece subsídios para que se faça o Diagnóstico Pedagógico e, conseqüentemente, sejam encaminhadas estratégias de ensino que atendam à demanda das dificuldades diagnosticadas. Villani e Cabral (1997) afirmam que o diagnóstico pedagógico é categorizado por diferentes relações entre os conhecimentos dos sujeitos e os conhecimentos instituídos ${ }^{19}$. Tais categorias foram denominadas por analogias às estruturas clínicas, sendo elas sistematizadas nos princípios: recalcado; desmentido, foracluído e admitido, os quais são entendidos pela perspectiva de que:

Os princípios gerais são admitidos enquanto sintetizadores de várias situações passadas, mas não resistem às novas situações e, a cada vez, devem ser redescobertos; [...] o princípio é "recalcado". A segunda relação é dada pela admissão de um saber único e absolutamente vinculante, mas pertencente a outros campos e ligado a alguma autoridade relevante; [...] diremos que se trata do "desmentido do princípio". A terceira relação é fornecida pela exclusão da procura de idéias gerais vinculantes; [...] diremos que estamos frente ao "princípio foracluído". Finalmente, existe o aluno que está, desde logo, à procura do essencial, das regras vinculantes e, as tendo encontrado, as utiliza sitematicamente: o princípio é "admitido" (VILLANI e CABRAL, 1997, p. 12, destaque dos autores).

As características identificadas e relacionadas em cada princípio permitem que se diagnostique a maneira como o aluno está se apropriando dos novos conhecimentos, isto é, em que dimensões o referencial mais recente está sendo percebido. Por exemplo, se está aceitando ou não os novos conceitos, e/ou se o conhecimento se constitui em uma elaboração externa ou interna ao sujeito. Deste modo, a ação didática do professor é direcionada no sentido de possibilitar que a aprendizagem ocorra por um movimento contínuo de substituição das idéias anteriores para as novas. O que se vislumbra é que o aluno atinja certa autonomia intelectual/cognitiva, desta maneira, correspondendo à dissolução da transferência pedagógica.

Uma outra estratégia instaurada, para acompanhar e orientar o processo de aprendizagem, foi a adoção do Diário de Aula. Este instrumento com orientação metacognitiva, foi entendido como um dispositivo,

[...] através do qual o aluno tinha circunstâncias que lhe eram favoráveis para poder escrever sobre o que pensava ter aprendido, de "falar" sobre suas dificuldades. [...] esse foi um momento para o aluno, essencialmente, refletir sobre suas próprias idéias e de tentar elaborá-las matematicamente (CABRAL, 1998, p. 144, grifos da autora).

Esses diários se constituíram em uma outra forma de comunicação entre professor e alunos, já que o diálogo ali estabelecido, além de informar as concepções discentes a partir de

\footnotetext{
${ }^{19}$ Cabral (1998) denomina de saber instituído aquele veiculado no ambiente escolar e tido como mais geral e rigoroso no meio acadêmico.
} 
suas próprias argumentações, ou seja, daquilo que lhes fazia sentido, também, permitia ao docente orientar o processo de aprendizagem particular de cada um, no qual formulava novas questões que provocassem reflexões sobre as elaborações do próprio jeito de pensar. Segundo a autora, a princípio esse processo não foi entendido pelos alunos como uma possibilidade de aprendizagem, uma vez que os registros eram preparados na data de entrega e evidenciavam, apenas, descrições do que havia ocorrido em sala de aula. Neste sentido, foi necessário o estabelecimento de um conjunto de diretrizes, o qual orientou o aluno na direção de ele elaborar conhecimento sobre sua própria aprendizagem ao invés de realizar cópias e descrições dos textos dos livros e/ou exercícios resolvidos em sala de aula.

O intuito, nesse procedimento, era também o da dissolução da transferência, ou seja, fazer com que o aluno deixasse de depender de um conhecimento que não havia sido construído por ele, mas emprestado do professor e reforçado pelos livros didáticos. Passando o aluno, desta maneira, a assumir o compromisso de elaborar algo sobre o conhecimento instituído. A evidência de tal situação é um modo de sinalização de que houve aprendizagem e, portanto, a ocorrência de uma mudança radical. Deste modo, a idéia de mudança inserida no modelo proposto por Cabral (1998), parece não estar somente na perspectiva de que o sujeito perceba o novo conhecimento como inteligível, plausível e fértil, conforme proposto por Posner et al (1982), mas que ele possa/consiga mudar seu posicionamento frente às suas maneiras de justificar e conceber o conceito. Para a autora, a inteligibilidade é produto de um processo de elaboração e de articulação conceitual em que o aluno se encontra envolvido. A plausibilidade se dá em duas perspectivas, stricto sensu e lato sensu. Na primeira, a nova concepção é convincente e compatível, já na segunda, acredita-se no conhecimento por seu status, é dado credibilidade.

Esse viés de mudança está atrelado, também, ao modo com que a disciplina foi estruturada e implementada. Segundo Cabral (1998), fatores inseridos no ambiente como as atividades em grupo e a tarefa do Aluno ao Quadro, favoreceram para que a subjetividade emergisse em sala de aula. Questões subjetivas permearam o processo ensino-aprendizagem e determinaram a trajetória do mesmo no que se refere às ações docentes e às maneiras de os alunos elaborarem suas soluções. Aspectos afetivos relacionados à emoção e motivacionais vinculados às crenças e valores apareceram por meio das falas dos alunos, permitindo que o professor interviesse no processo de ensino no sentido da (re) estruturação da aprendizagem. Desta forma, a linguagem foi tomada como ponto básico do estudo, em virtude de ser considerada determinante e constitutiva do sujeito. 
Em um outro modelo de mudança conceitual descrito por Pozo (1997, 2002), cujo viés é delineado pela remoção das concepções pessoais, a aprendizagem é resultado de uma reestruturação de conhecimentos, nos quais ela é entendida como consequiência da última escala de um processo em que se requer várias alterações menores até atingir uma mudança forte e profunda das estruturas conceituais. Para tanto, a aprendizagem é entendida como um processo em que:

[...] o esforço para compreender e dar sentido aos conhecimentos que se encontram embrionários dentro de nós gera mudanças mais amplas e duradouras e, portanto, há mais aprendizagem que a simples repetição da informação recebida, existe ainda uma forma mais difícil de aprender, mas cujos efeitos são mais intensos e extensos, já que implica uma reestruturação total dessa árvore de conhecimentos, uma verdadeira revolução conceitual (Thagard, 1992) que remove, como um terremoto, nossos conhecimentos desde seus próprios princípios (POZO, 2002, p. 217, destaque do autor).

Nessa perspectiva, a Revolução Conceitual ou Mudança Conceitual Radical (POZO, 1997; 2002) refere-se a uma (re)estruturação de todo o conjunto de noções que o sujeito possui, ou seja, da totalidade da árvore de conhecimentos. Para que tal situação ocorra, este modelo é estruturado em níveis/fases, cujo enfoque de trabalho são as concepções pessoais do sujeito. Segundo Pozo (2002), os processos de construção do conhecimento são direcionados no sentido de possibilitar conscientizações sobre os próprios conflitos entre os conhecimentos prévios e as novas informações assimiladas (os desequilíbrios na teoria piagetiana).

O grau dessa conscientização leva a diferentes níveis de construção (ou reconstrução) dos conhecimentos, Pozo (1997, p. 159-160 e 2002, p. 131-132) apresenta vários níveis: o primeiro é que a assimilação (ou construção estática) não cede lugar à acomodação (ou construção dinâmica), ou seja, não haveria aprendizagem uma vez que o aluno não detectasse conflitos que gerassem necessidade em mudar seus conhecimentos prévios. Um outro nível refere-se à situação em que há, pelo sujeito, a percepção de pequenas perturbações, as quais podem ser incorporadas aos conhecimentos prévios por processos de crescimento, resultando desta maneira em mudanças ínfimas nas estruturas conceituais. No entanto, quando as perturbações se tornam mais freqüentes, se faz necessário um ajuste aos conhecimentos prévios, o qual é desenvolvido por meio de processos de generalização ou de discriminação. Diz-se que, o processo de generalização refere-se à situação de expansão do âmbito de aplicação dos conhecimentos prévios e, quando a situação é de redução, trata-se então do processo de discriminação. Isso se reflete na construção de novas estruturas cognitivas que englobam ou integram as pertrubações em novas categorias do conhecimento. No nível mais 
complexo, a construção do conhecimento representa uma reorganização conceitual da estrutura das concepções pessoais. Esta estrutura conceitual é modificada mediante certos aspectos, como: a decomposição de um fenômeno, considerado único conceitualmente; a diferenciação entre casos percebidos como similares e a integração de fenômenos diferentes para a geração de um novo conceito integrador.

No entanto, segundo Pozo (1997, p. 160), todas essas mudanças alteram algumas noções conceituais e até podem produzir alguma revisão mais profunda da estrutura de certo conceito central, mas não reestruturam a árvore de conhecimentos. Por outro lado, o autor afirma que a integração do conjunto dessas mudanças se torna propício a uma reorganização da árvore de conhecimentos. Em termos dos processos de equilibração, afirma-se que "à medida que temos acesso a níveis de construção mais complexos, o equilíbrio entre conhecimentos prévios e nova informação é cada vez maior" (POZO, 2002, p. 133), ou seja, a reestruturação leva a uma reorganização de todo o conjunto de conhecimentos, o que resulta em uma nova forma de concebê-los, tal situação corresponde à mudança mais radical.

Neste sentido, percebe-se que a mudança está centrada na (re)organização global da estrutura do conhecimento de um sujeito, enquanto no modelo de Mudança Radical (CABRAL, 1998), o enfoque está na (re)significação de conceitos específicos. Para Cabral (1998), o indício de que houve mudança está associado ao fato de o sujeito se posicionar diferentemente em relação à própria aprendizagem, o que implica conceber que o indivíduo passa por um período de transição, no qual as concepções pessoais são substuídas pelo conhecimento de outro, é nessa fase que o aluno assume a fala do professor. Já para Pozo (1997; 2002), nesse período intermediário podem ocorrer pequenas mudanças, no entanto, somente em relação a um certo conceito específico e voltado a apenas uma ramificação da árvore de conhecimentos. O indício da ocorrência da mudança estaria na integração das pequenas transformações, resultando assim em uma reestruturação ampla e profunda de todo o conjunto de conhecimentos.

Ainda assim, tanto na Mudança Radical quanto na Revolução Conceitual o processo de MC seria desencadeado pela ativação das concepções pessoais por meio de conflitos em relação ao novo conhecimento. Entretanto, segundo Pozo (1997; 2002), é preciso que o sujeito se conscientize de tais perturbações para sentir necessidade de mudar. Cabral (1998), por sua vez, afirma que a conscientização pode gerar conflitos em relação às concepções espontâneas, como também, favorecer à elaboração de novos significados. Contudo, o 
abandono das concepções pessoais, torna-se um elemento comum tanto em relação ao conceito específico quanto à estrutura global do conhecimento. Os autores, ainda assim, defendem a idéia de que, caso não ocorram mudanças intensas no sentido defendido por eles, a extensão das mesmas pode se caracterizar como temporárias e, então, voltar a prevalecer as concepções que se apresentarem mais familiares ao sujeito.

\subsection{ALGUMAS PERCEPÇÕES A PARTIR DOS MODELOS PROPOSTOS}

Ao analisar os trabalhos fundamentados na teoria da Mudança Conceital, percebeu-se um caminhar de transformações da teoria em várias direções. Em relação aos primeiros estudos, surgiram críticas apontando lacunas na teoria, dificuldades de operacionalização e êxito com as mudanças conceituais no trabalho com os alunos. Portanto, outros estudos foram desenvolvidos, entre eles, alguns tiveram a intenção de tentar "preencher" as lacunas, encontrar outros modos de operacionalizar as ações didáticas e melhorar a questão do êxito. Assim, um dos primeiros aspectos a chamar atenção está atrelado à concepção em si do que venha a ser a Mudança Conceitual. Pois, passou-se de um domínio em que o enfoque girava em torno de conceitos específicos para um outro que considera o conjunto dessas noções. É a passagem do local para o global, do conceito específico para totalidade da árvore de conhecimentos. Tal aspecto, acaba por implicar na acepção de outros elementos, como os relacionados ao conhecimento, à aprendizagem, ao aluno, ao professor, ao contexto e às relações entre eles.

Não é pretensão, neste momento, apontar fatores que influenciaram na convergência dos múltiplos olhares para a MC. No entanto, não se pode deixar de considerar que as próprias concepções que predominavam o aprender e o ensinar em tempo anterior e, as que permeiam a educação nos dias atuais, podem ter se constituído em importantes elementos influenciadores na transposição do conhecimento que existia sobre Mudança Conceitual para o veiculado atualmente. Pois,

A educação formal é baseada na mera transmissão de explicações e teorias (ensino teórico e aulas expositivas), no adestramento em técnicas e habilidades (ensino prático com exercícios repetitivos). Do ponto de vista dos avanços mais recentes de nosso entendimento dos processos cognitivos, ambas são totalmente equivocadas. Não se podem avaliar habilidades cognitivas fora do contexto cultural. Obviamente, a capacidade cognitiva é própria de cada indivíduo. Há estilos cognitivos que devem ser reconhecidos entre culturas distintas, no contexto intercultural e, também, na mesma cultura num contexto intracultural (D'AMBRÓSIO, 2005, p. 117). 
Neste sentido, o modelo do Perfil Conceitual propõe que aspectos sócio-culturais sejam considerados no momento da explicitação e da aplicação das concepções. No entanto, o contexto cultural em que tais concepções foram geradas parecem se referir apenas ao conhecimento científico e ao cotidiano, deixando-se de comentar o conhecimento escolar. Segundo Chevallard et al (2001, p. 136),

[...] a matemática escolar se apresenta com algumas características próprias, que a diferenciam em muitos aspectos das obras matemáticas originais. Essas características específicas derivam do fato de que muitas obras do currículo têm de ser reconstruídas para poder ser ensinadas na escola, isto é, "recriadas" sob certas condições que não coincidem e nem podem coincidir com as condições que tornaram possíveis sua construção inicial (grifos do autor).

Estendendo-se esta idéia a outras áreas do conhecimento, é possível conceber que existem especificidades que diferenciam os contextos científico, escolar e, também, o cotidiano. Vale esclarecer, que essa relação do conhecimento pessoal para o científico, tem sido o fio condutor entre os modelos de mudança conceitual. Apesar que Pozo (1997, p. 170), já chamava atenção para o fato de que se faz necessária a tripla distinção entre problemas científicos, escolares e cotidianos em MMC. Pois, tanto o conhecimento quanto as ações, inerentes a cada contexto, apresentam características próprias que as distingue entre uma e outra. Por exemplo, as diferenças entre a atividade científica e a didática. Ainda, o mesmo autor sugere que se poderia conceber a teoria de Mudança Conceitual como uma aproximação do conhecimento pessoal ao científico por meio das situações e contextos de instruções, o que pode ser interpretado como o sistema de conhecimento escolar. É interessante retomar o que se está entendendo por conhecimento cotidiano, ou seja, a perpsepctiva relacionada às idéias intuitivas, do senso comum e, geralmente, relacionadas às concepções pessoais, conforme já comentado anteriormente.

Em tempo, defende-se a perspectiva de conhecimento escolar como um dos sistemas a serem considerados no processo de MC, pelo fato de esta pesquisa tratar das concepções de professores em formação inicial. Portanto, tal especificidade se faz relevante em consideração ao contexto cultural da atividade de docência, uma vez que, considera-se "cultura como o conjunto de mitos, valores, normas de comportamento e estilos de conhecimento compartilhados por indivíduos vivendo num determinado tempo e espaço" (D’AMBRÓSIO, 2005, p. 104). Esse modo de conceber a cultura converge para um olhar que permite perceber o conhecimento científico como um saber que ao ser ensinado aos alunos não precise, 
necessariamente, corresponder à uma aplicação na prática. Assim, uma outra possibilidade seria a idéia de que é preciso que o aluno compreenda e perceba a existência de diferentes maneiras de se referir a um mesmo conceito.

Frente a essa interpretação tradicional, baseada em critérios históricos e epistemológicos [...], alguns autores estão apresentando a possibilidade de que os mecanismos de mudança conceitual sejam mais sutis e complexos, dando lugar a uma coexistência de sistemas alternativos de conhecimentos dentro do mesmo sujeito [...]. Segundo esta concepção, a aquisição de uma nova teoria ou modelo [...] não teria por que implicar um abandono das teorias pessoais, já que ambos os tipos de conhecimentos se utilizariam em situações distintas, sem que um possa substituir o outro (POZO, 1997, p. 168-169, minha tradução) ${ }^{20}$.

Deste modo, parece fazer sentido a coexistência de teorias quando considerada a ativação contextual do conhecimento, uma vez que, a transposição do conhecimento de um contexto a outro não ocorre de modo natural, pelo fato de os problemas serem de naturezas distintas. A defesa da idéia da coexistência de concepções é observada, também, no Perfil Conceitual, cujo modelo admite que um mesmo sujeito possua concepções pertencentes a diferentes zonas de um certo conceito. Segundo essa perspectiva, as estruturas básicas não são modificadas, mas coexistem com outras mais evoluídas.

Já, no modelo da Reestruturação Conceitual, que defende a perspectiva da reorganização da estrutura conceitual básica, supõe-se que na fase intermediária poderia haver uma coexistência de concepções, a qual desapareceria no momento da integração das pequenas mudanças conceituais. Assim, a interpretação da coexistência no MMC parece implicar em duas vertentes, uma que se refere à fase intermediária do processo de mudança, vindo a desaparecer na integração das concepções e, a outra, que permanece durante o processo evolutivo. Neste sentido, ressalta-se a necessidade de observar em que termos a coexistência pode ocorrer durante a evolução do conhecimento e que relações existem com o contexto cultural (científico, escolar e cotidiano).

Um outro elemento percebido entre os modelos de MC é o grande enfoque dado à constatação das concepções nas fases iniciais e finais do processo para verificar se houve mudanças. Segundo alguns pesquisadores, existem poucos estudos sobre a fase intermediária do processo. Cabral (1998), identificou esta fase como transferência pedagógica, Pozo (1997,

\footnotetext{
${ }^{20}$ Apresenta-se a mesma citação no idioma original: "Frente a esa interpretación tradicional, basada en criterios históricos y epistemológicos [...], algunos autores están planteando la posibilidad de que lo mecanismos del cambio conceptual sean más sutiles y complejos, dando lugar a una coexistencia de sistemas alternativos de conocimiento dentro del mesmo sujeto [...]. Según esta concepción, la adquisición de una nueva teoría o modelo [...] no tendría por qué implicar um abandono de las teorías personales, ya que ambos tipos de conocimiento se utilizarían en situaciones distintas, sin que uno pueda reemplazar al otro" (POZO, 1997, p. 168-169).
} 
2002) sugeriu a existência de pequenas mudanças. Para Luffiego (2001), trata-se de uma fase de instabilidade, que é quando o novo conhecimento ou a interação entre este e o já existente geram enormes perturbações. Este aspecto confere ao sistema cognitivo grande versatilidade e adaptabilidade para as mudanças e a respectiva manutenção das mesmas. Ainda, o mesmo autor, defende a idéia de que conforme for realizada a ativação da mudança conceitual pode torná-la muito lenta ou muito rápida, pois aspectos emocionais podem influenciar na ênfase da mudança do conhecimento. Cabral (1998) também identificou aspectos subjetivos como elementos influenciadores no êxito do processo de MC.

Frente ao quadro exposto, percebe-se que vários componentes já foram apontados e trabalhados em alguns Modelos de Mudança Conceitual, tais como: aspectos emocionais como geradores de perturbações conceituais; aspectos sócio-culturais como sistema de suporte e ativadores das concepções; abordagem comunicativa como mediadora no processo de ensino-aprendizagem e a metacognição como estratégia para deflagrar insatisfações, conscientazações e produção de conhecimentos. No entanto, a análise de alguns desses elementos dentro de um mesmo trabalho parece ainda não ter sido objeto de estudo. Portanto, para esta pesquisa, tomar-se-á como pressuposto a consideração pelos aspectos emocionais provenientes da relação professor, aluno e conhecimento, assim como também, pelos aspectos sócio-culturais voltados aos contextos científico, escolar e cotidiano por se constituírem em possibilidades viáveis de análise da evolução do perfil conceitual em relação à Matemática e ao processo de ensino e aprendizagem dessa ciência. Entende-se que a associação de tais componentes pode resultar em uma outra percepção sobre a teoria de MC, cujo entendimento sobre o ensinar e o aprender tenha relação com a aprendizagem da docência.

Deste modo, se faz necessário a explicitação de um referencial teórico sobre os conhecimentos relativos à aprendizagem da docência, conforme será apresentado na seqüência. 


\section{CONHECIMENTOS RELATIVOS À APRENDIZAGEM DA DOCÊNCIA}

Este capítulo se constitui no outro pilar teórico desta pesquisa, seja ele, o conhecimento relativo à aprendizagem da docência em relação à Matemática, o qual envolve aspectos relacionados às concepções (históricas e de professores) sobre a Matemática e o processo de ensino e aprendizagem. De certo modo, esse conteúdo gera subsídios para a constituição das zonas do perfil conceitual a ser adotado para análise dos dados obtidos junto aos sujeitos. Porém, optou-se por, inicialmente, explicitar algumas idéias que delineiam tendências sobre formação de professores e, assim, evidenciar a percepção de formação docente adotada para este trabalho.

Para tanto, parte-se da idéia de que não há dúvidas sobre a diversidade de meios com que a formação docente vem sendo tratada, para que haja melhorias na preparação dos professores em virtude do atendimento de demandas necessárias à adequação do processo ensino-aprendizagem em relação ao progresso da sociedade. Políticas públicas. Reformas educacionais. Implementações de novos currículos. Pesquisas sobre processos formativos. Pode-se citar, a título de exemplo, as Leis de Diretrizes e Bases da Educação, Diretrizes para a a Formação Docente do Professor da Educação Básica, Diretrizes para o curso de Pedagogia, Parâmetros Curriculares Nacionais, entre outros. Esse processo, de busca de melhorias na educação, parece ter se intensificado a partir do final da Segunda Guerra Mundial, quando se observa um movimento no sentido de elevar os padrões da educação. Em relação ao ensino e à aprendizagem em Ciências e em Matemática, mais especificamente, compreendia-se que a maneira com que essas áreas vinham se desenvolvendo não atendiam aos anseios de progresso da sociedade. Então, não se poderia ignorar, também, nesse movimento, o modo com que o professor estava sendo formado, uma vez que ele se constitui em um importante elemento do processo educativo.

Após o final da Segunda Guerra, era preciso lançar um outro olhar para a figura do professor, que correspondesse às idealizações de ensino e aprendizagem adequadas às reformas curriculares educacionais e ao contexto social da época. Atualmente, observa-se que esse movimento de busca por melhorias na educação tem sido incessante e cíclico, fazendo com que a imagem da figura do professor e do processo ensino-aprendizagem sejam concebidas de diferentes modos a cada tempo, conforme pode ser observado nas palavras de Polettini (1999, p. 248). 


\begin{abstract}
A imagem do professor mudou de uma figura passiva para a de uma figura ativa, construindo perspectivas e escolhendo ações. O ensino deixou de ser visto apenas como transmissão de conhecimento, trabalho conduzido essencialmente de forma isolada. A nova visão é a de atividade nãorotineira, conduzida de forma colaborativa.
\end{abstract}

Nesse mesmo sentido, D’Ambrósio (1996, p. 80) afirma que, “O novo papel do professor será o de gerenciar, de facilitar o processo de aprendizagem e, naturalmente, de interagir com o aluno na produção e crítica de novos conhecimentos, [...].” Embora esses novos olhares em relação ao professor sejam decorrentes de muitas variáveis, para o caso específico deste estudo, optou-se em considerar o viés delineado pelas pesquisas sobre a formação de professores. Pois, entende-se que os resultados divulgados por esses estudos têm influenciado, ao longo dos anos, diretamente a sistematização de processos formativos e propostas curriculares. "As pesquisas brasileiras refletem uma tendência de mudança no modo como a formação inicial e continuada de professores é estudada e desenvolvida atualmente" (FERREIRA, 2003, p. 35). Portanto, as tendências apontadas por pesquisas sobre a referida temática, de certo modo, vem trilhando os caminhos pelos quais a formação docente tem passado.

Ferreira (2003) mostra que uma nova imagem de professor é uma visão que vem se constituindo ao longo da história, tanto no contexto nacional quanto internacional. Segundo a autora, até o final da década de 1960, o enfoque centrava-se, pricipalmente, na quantidade de professores formados, já que o intuito estava em atender a demanda educacional da época. Essa política de formação, conforme alguns críticos norte-americanos, foi o que contribuiu para o declínio da educação na década seguinte. No entanto, já no final do século XIX, Félix Klein, um importante matemático da época, revelava certa preocupação com a formação de professores de Matemática, uma vez que percebia a existência de um descompasso entre a Matemática ensinada nas universidades e a ensinada nas escolas secundárias. Para ele, era preciso melhorar o padrão do ensino da Matemática na escola secundária para que houvesse um impulso na Matemática pesquisada nas universidades e no desenvolvimento tecnológico das indústrias. E, para que isso ocorresse, era necessário investir na formação destes professores que ensinariam a Matemática nas escolas secundárias. No início do século XX, Klein amplia sua preocupação com a formação docente e declara ser necessário que o professor tenha conhecimentos sobre a psicologia da criança, desta maneira teria condições de capturar o interesse do aluno (KLEIN apud MIORIM, 1998, p. 69).

$\mathrm{Na}$ tentativa de reverter o quadro dos baixos padrões educacionais que assolavam a década de 1970, pesquisas e programas de formação inicial e continuada de professores se 
voltararam para a busca de um ensino eficiente, valorizando-se assim, o treinamento de professores em tarefas específicas, cuja preocupação central passou a ser de "[...] modelar o comportamento do professor e examinar os efeitos de determinadas estratégias de ensino" (FERREIRA, 2003, p. 21). Era o domínio do paradigma processo-produto, ou seja, procuravase conhecer quais comportamentos dos professores e metodologias utilizadas por ele influenciavam favoravelmente no ensino-aprendizagem.

Esse modo de conceber a formação docente manteve-se até a metade da década de 1980, quando então, começaram a surgir em todo o mundo movimentos de reformas educacionais, visando não somente a melhorias nos padrões da educação, mas também mudanças na formação docente. Vale ressaltar que até essa época, no Brasil, os estudos sobre a formação de professores de Matemática ainda eram escassos (FERREIRA, 2003). No entanto, assim como ocorreu no contexto internacional, o foco central da formação já começava a apresentar indícios de mudanças. Segundo Ferreira (2003), nesse período coexistiam visões distintas referentes à formação docente. Uma delas defendia o ensino como uma arte que não poderia se desenvolver fora da escola e, as habilidades eram consequiências da prática, isto é, quanto mais se praticava, mais se treinava os procedimentos. A outra sustentava a idéia do ensino como uma profissão que envolveria além do treinamento, também, o conhecimento sobre diferentes teorias relacionadas ao ensinar. Nesse contexto, inser-se-ia a formação desenvolvida nas universidades.

Esse novo olhar aplicado ao professor, a partir da década de 1980, possibilitou que o mesmo fosse percebido como profissional que possui suas crenças, visões, conhecimentos, modos próprios de agir e diferentes habilidades. O docente deixou de ser visto como um obstáculo à implantação de mudanças na educação. Apesar de o foco ainda permanecer nas inconsistências e inadequações da atitude docente, as investigações sobre o pensamento do professor, um novo paradigma, tornaram-se relevantes para uma considerável transformação da visão sobre a formação de professores. Percebe-se, nesse mesmo período, existir um paralelo com as investigações sobre a aprendizagem do conhecimento científico. Quando, por volta da década de 80 , surgem trabalhos relativamente significativos sobre as crenças, visões e conhecimentos dos alunos acerca de tópicos da ciência e, também, observa-se a sistematização de teorias para a análise de tais concepções, por exemplo, a Teoria da Mudança Conceitual.

Por outro lado, em meados da década de 1990, pesquisadores começaram a perceber que o impacto de mudanças nos processos de ensino e aprendizagem não estava relacionado somente às inovações educacionais, mas também, ao modo como impactavam sobre as 
crenças e valores dos professores. Resultando desta maneira, nos últimos anos, a percepção da figura do professor como um "profissional com capacidade para pensar, refletir e articular sua prática (deliberadamente ou não) a partir de seus valores, crenças e saberes (construídos ao longo de toda a sua vida), ele passa a ser valorizado como um elemento nuclear no processo de formação e mudança" (FERREIRA, 2003, p. 25). Tal percepção pode representar uma evolução do próprio conceito de formação docente, uma vez que o professor deixa de ser visto como objeto de estudo e formação (sujeito passivo) para ser percebido como elemento participativo e colaborador de sua própria formação e estudo (sujeito ativo). É a necessidade de se conhecer o pensamento do professor sobre a própria formação. "Agora, além da voz do professor começar a ser ouvida com interesse, ele passa a ser visto como parceiro, como companheiro de um processo coletivo de construção de conhecimentos" (FERREIRA, 2003, p. 33). Atualmente há uma tendência entre pesquisadores (FERREIRA, 2003; FIORENTINI e LORENZATO, 2006, entre outros) em se perceber a formação docente como um trabalho colaborativo entre professores, futuros professores e professores formadores.

Concomitantemente ao trabalho colaborativo, percebe-se que a aprendizagem da docência, também, tem estado no foco de estudiosos em formação de professores, os quais têm investigado diversas questões, tais como: de que maneira o professor aprende? Quais conhecimentos são necessários à formação docente? E, quais modos implementados nos processos formativos podem ser mais eficientes? As investigações destas questões vêm permitindo uma melhor compreensão dos processos de ensino e aprendizagem da docência. Nesse sentido, Mizukami (2006) destaca alguns dos pontos necessários à aprendizagem da docência a partir das contribuições de alguns pesquisadores nacionais e das recomendações oferecidas pelo National Research Council Report sobre pesquisas educacionais e formação de professores que ensinam Matemática.

É notório que o repertório sobre a formação inicial de professores é vasto. A diversidade de estudos na área chama atenção para vários aspectos, por exemplo, Hernández e Sancho (2006/2007) destacam dois elementos, considerados por eles importantes para constar no processo de formação, sejam eles: aprender a partir de indagações (indaga-se as experiências significativas, as quais permitem ao futuro professor se constituir como autor, aprendendo consigo mesmo e com os outros) e considerar a experiência vivida como lugar da formação (é a reflexão e consciência sobre a própria experiência de ser, com participação na produção de seu conhecimento e reconhecendo suas capacidades de ação). Outros pesquisadores se aprofundam em questões políticas e sociais e, assim, o leque de possibilidades e questões em relação à formação inicial vai se compondo. Não é intenção 
esaurir o assunto, mas explicitar nuances pelas quais está passando tal processo formativo, no que se refere à aprendizagem da docência para o ensino da Matemática.

Assim como outros pesquisadores, Mizukami (2006) afirma que a aprendizagem da docência é lenta, inicia-se antes do espaço formativo e se prolonga por toda a vida. Trata-se de uma atividade complexa e repleta de variáveis de diferentes naturezas, tanto de amplitude macro como micro. A autora destaca dois aspectos considerados importantes na preparação dos professores: a organização das situações de ensino para atender alunos com diversidades pessoais e socioculturais e a construção de conhecimentos sobre o ensino dos diferentes conteúdos curriculares. Além dos dois aspectos, ela enfatiza também, três eixos considerados essenciais à constituição da base do conhecimento para a docência, sejam eles: conhecimento sobre os alunos, suas aprendizagens e desenvolvimento; conhecimento sobre a matéria que os professores ensinam e conhecimento sobre o ensino dessa matéria.

Essa base de conhecimentos para a formação docente não é estática, está em constante transformação e, portanto, requer investimentos de natureza político-social, institucional e pessoal. Tais investimentos se dão ao longo da vida do professor, contudo se percebe que a formação inicial se constitui em um importante momento da aprendizagem da docência, isto é, do desenvolvimento profissional do docente.

Ao se considerar aprendizagem e desenvolvimento profissional da docência como processos que se desenvolvem ao longo da vida, a formação inicial do professor deve ser destacada como um momento formal em que processos de aprender a ensinar e aprender a ser professor começam a ser construídos de forma mais sistemática, fundamentada e contextualizada. [...] Para tanto, [a formação inicial] deve oferecer aos futuros professores uma formação teórico-prática que alavanque e alimente processos de aprendizagem e desenvolvimento profissional ao longo de suas trajetórias docentes (MIZUKAMI, 2006, p. 216).

$\mathrm{Na}$ formação de professores para as séries iniciais, a promoção de situações que levem à reflexão sobre a prática docente, pode permitir a percepção de que o ensino de Matemática seja visto como um processo em constante desenvolvimento e contextualizado às atividades do dia-a-dia de uma determinada realidade escolar. Pois, é na formação inicial do professor que recai o grande peso de dar a ele condições para ter uma concepção sobre o ensino, neste caso o de Matemática, que o possibilite dimensionar sua experiência escolar. É o desenvolvimento de um profissional, cuja imagem seja o de um professor reflexivo, conhecedor do conteúdo específico e das formas de produção do mesmo, consciente de seu papel político na sociedade em virtude da formação do aluno para a cidadania, enfim, 
responsável pela própria formação cujas habilidades atendam uma nova situação econômica e a conseqüente reorganização social.

Mizukami (2006) ressalta ainda que, nos cursos de formação inicial, devem ser propiciados aos futuros professores trocas colaborativas, de modo a favorecer $o$ desenvolvimento de atitudes investigativas. Essas trocas implicam em auxiliar os professores a controlarem o que aprendem e, também, obterem meios para analisarem situações de sala de aula consideradas complexas. Deste modo, os currículos dos cursos de formação inicial devem ser constituídos a partir de conhecimentos relacionados ao que os professores precisam conhecer para entrar em sala de aula. Esses programas seriam contemplados, por exemplo, com estudos sobre problemas centrais do aprender a ensinar; da complexidade do ensino a partir da análise da aprendizagem; da reflexão sobre a própria aprendizagem em relação ao ensino; da possibilidade em elaborar, desenvolver e aplicar estratégias de ensino se compreendendo o porquê, o como e quando usá-las. Não esquecendo ainda, da relação entre o conhecimento pessoal e o científico, isto é, das pré-concepções sobre uma ciência específica, o ensino e a aprendizagem com que os futuros docentes chegam aos cursos em virtude de aproximações com os novos conceitos. Pois,

Caso não sejam explicitadas, trazidas à tona, discutidas, compreendidas e problematizas essas aprendizagens podem comprometer a aprendizagem de novos conceitos ou mesmo possibilitar a tradução equivocada dos novos conceitos de forma que se conformem às 'aprendizagens por observação' 21 anteriores, servindo o curso de formação, sob essa perspectiva, para reafirmar teorias pessoais dos professores (MIZUKAMI, 2006, p. 218, destaque da autora).

Em outras palavras, para que a aprendizagem de novos conceitos, relacionados ao ensinar e aprender Matemática, cause certo impacto sobre os tópicos já aprendidos, é preciso que seja dada atenção às pré-concepções com que os futuros professores chegam aos cursos de formação inicial. Segundo Thompson (1997, p. 30), “os professores possuem concepções sobre o ensino que são gerais e não específicas do ensino da Matemática. Eles também têm concepções sobre seus estudantes e sobre a constituição social e emocional de sua classe." São muitos os fatores que parecem interagir com as concepções dos professores e estas, por sua vez, afetam suas decisões e comportamento. Assim, considera-se que a formação inicial

\footnotetext{
${ }^{21}$ A aprendizagem por observação se refere "às aprendizagens decorrentes de experiências ao longo das trajetórias de escolarização em ambientes tradicionais de sala de aula e que têm impacto na construção de préconcepções sobre ensino e aprendizagem que os futuros professores trazem ao entrarem em curso de formação para a docência." (MIZUKAMI, 2006, p. 217)
} 
tem por função auxiliar o aluno do curso de licenciatura a compreender seu processo de formação e a conceber a profissão da docência como uma ação dinâmica.

Entende-se que o estudo aqui proposto procurou viabilizar aos sujeitos de pesquisa que analisassem a própria prática pedagógica pré-profissional. Pois, quando tiveram que ensinar Matemática em suas atividades de estágio, além do resgate do conhecimento prévio, proporcionou-se a eles certos momentos para conversarem sobre o modo de organizarem e desenvolverem o ensino dos conteúdos matemáticos. Nessas conversas com os sujeitos, procurou-se evidenciar o porquê de algumas escolhas e atitudes desempenhadas nas salas de aula. Foi nesse contexto que se pôde perceber melhor as conexões que cada sujeito fez entre suas concepções sobre a Matemática e seus processos de ensino-aprendizagem e a prática pedagógica. Vale esclarecer que o modo como foi conduzido o trabalho com os futuros professores será retomado nos capítulos seguintes, quando de fato, apresentar-se-ão os dados, o contexto em que os mesmos foram coletados e a respectiva análise.

No entanto, pode-se perguntar: por onde caminha a preparação dos docentes das séries iniciais, mais especificamente, em relação à área de Matemática? Uma das respostas à essa questão está delineada nas pesquisas. Percebe-se que as investigações sobre a formação de professores que ensinam Matemática vêm caminhando no mesmo sentido em que Ferreira (2003) e Mizukami (2006) apontam. Houve, não só um aumento de estudos sobre a temática nas últimas três décadas, como também, uma correlação com os focos investigativos de cada época. Na sequiência, delineia-se alguns aspectos de estudos sobre a formação de professores que ensinam Matemática nas séries iniciais.

\subsection{ESTUDOS SOBRE PROFESSORES QUE ENSINAM MATEMÁTICA}

Pesquisas sobre a temática - formação de professores em Matemática - têm revelado saberes docentes, concepções, orientações e re-orientações às propostas de formação inicial e continuada (PAIVA, 1998; FIORENTINI et al, 2002; FERREIRA, 2003; SILVÉRIO, 2003; JURAMILLO QUICENO, 2003; CYRINO, 2003; RICCI, 2003; CURI e PIRES, 2004, NACARATO e PAIVA, 2006). O enfoque investigativo dessa temática tem sido amplo, contemplando por exemplo: saberes docentes, trabalho colaborativo, avaliação/análise de projetos e/ou políticas públicas de formação de professores, entre outros. Dos resultados obtidos com as pesquisas, pode-se destacar algumas das questões detectadas e apontadas pelos pesquisadores para maior aprofundamento, tais como: de que maneira ocorre a passagem de aluno a professor de Matemática? Como é a formação matemática dos professores que atuam 
nas séries iniciais? Como o conhecimento matemático é proposto nos cursos de nível superior aos futuros docentes? Quais são as condições do trabalho docente e da formação do formador de professores? No entanto, certas nuances sobre questões como estas podem ser percebidas em estudos, como os de Nacarato et al (2004) e Curi e Pires (2004), os quais envolvem a formação inicial de professores que ensinam Matemática nas séries iniciais. Nessas pesquisas, observa-se, de modo mais específico, algumas características do conhecimento matemático presentes em programas curriculares de formação docente e, também de futuros docentes. A seguir delineia-se alguns elementos desses estudos que levam a perceber que a maneira como o conhecimento matemático é abordado no ensino das séries iniciais, durante a formação, pouco tem contribuído para que os futuros professores aprendam o conhecimento necessário à docência, ou seja, conhecer a Matemática, como ensiná-la e como o aluno a aprende.

Nacarato et al (2004) procuraram compreender como as filosofias pessoais sobre a formação matemática de estudantes de Pedagogia, pertencentes a três diferentes instituições paulistas (Faculdade Padre Anchieta, em Jundiaí; Universidade São Francisco, campus de Bragança Paulista e Universidade Federal de São Carlos), interferem nas relações estabelecidas com a Matemática e seu ensino. O estudo foi desenvolvido a partir da explicitação das concepções, crenças e valores com relação à Matemática, reveladas pelos graduandos em Pedagogia, ao analisarem um caso de ensino de Matemática, durante o desenvolvimento das aulas de Metodologia do Ensino da Matemática. O intuito da análise do caso de ensino foi o de, também, provocar reflexões e de permitir a reorganização das próprias idéias, pois as autoras acreditam "haver uma forte relação entre as crenças e valores em matemática e a prática pedagógica referente a essa área do conhecimento" (NACARATO et al, 2004, p. 12).

Da análise desenvolvida, Nacarato et al (2004) identificaram que os estudantes apresentaram, em sua maioria, uma visão dualista sobre o ensino da Matemática. Com base em Ernest, as autoras explicam que o dualismo refere-se a uma visão bifurcada e dicotômica sobre o conhecimento, o qual se divide em verdades e falsidades.

Tal visão é tão forte e marcante que o sujeito, muitas vezes, não consegue nem se dar conta do que está sendo solicitado. Sua preocupação centra-se em olhar se a resposta dada pela criança está certa ou errada. É a necessidade de rotular. Não há preocupação em entender os procedimentos que foram utilizados, sua lógica e coerência com a situação proposta (NACARATO et al, 2006, p. 23-24).

Além do aspecto certo ou errado sobre as estratégias de resolução apresentadas pelas crianças, há também, nessa visão dualista, a autoridade absoluta. Os graduandos explicitaram 
conceber que o professor representa uma figura de autoridade. "A questão da autoridade - do "eu" do professor enquanto autoridade - esteve muito presente. Muitos graduandos [...] querem ter o controle da prática pedagógica em suas mãos; é o professor quem mostra, quem explica, quem justifica" (NACARATO et al, 2004, p. 25). Essa perspectiva reforça a idéia de que para aprender basta o professor mostrar o conteúdo ou como se faz para resolver uma questão proposta. Segundo as autoras, visões como essas é que contribuem para a construção de valores negativos com relação à Matemática.

Por outro lado, Nacarato et al (2004, p. 28) evidenciaram que entre a minoria dos graduandos está se disseminando uma outra visão sobre o ensino da Matemática, seja ela, a multiplicista ou pluralista. Por essa visão, "admite-se uma multiplicidade de caminhos e a questão de validação passa mais por critérios de preferência pessoal ou de base pragmática". Nesse sentido, as autoras identificaram que para parte dos futuros professores, o docente deve conceber como válido tudo que o aluno desenvolve, tendo o raciocínio respeitado e se aceitando a variedade de métodos para atingir o resultado, o qual ainda, é o foco das atenções. As autoras apontam a necessidade, de além de explicitar as filosofias pessoais dos estudantes, também trabalhar com elas, para que possam ser (re)significadas, como também, acompanharse os graduandos em suas práticas docentes, seja em formação inicial ou na continuada.

Deste modo, o trabalho de Curi (2004), de certo modo, permite que se entenda um dos motivos da visão sobre o ensino da Matemática ainda ser, predominantemente, a dualista e não a pluralista, conforme apontado por Nacarato et al (2004). Na pesquisa de Curi (2004), o objetivo se centrou na análise dos conhecimentos dos professores polivalentes para ensinar Matemática nas séries iniciais e, também, no estudo das crenças e atitudes que interferem na constituição desses conhecimentos. Para tanto, a autora analisou as grades curriculares de 36 cursos de Pedagogia do país e as ementas das disciplinas da área de Matemática, no intuito de refletir sobre o conhecimento desenvolvido nos cursos para ensinar Matemática e, assim, identificar quais saberes esperar dos alunos egressos. Alguns elementos que a autora chama atenção como resultantes dessa análise estão relacionados à produção restrita de livros e materiais didáticos específicos para esse tipo de formação e amplitude da carga horária média destinada à formação para a área de Matemática, que gira em torno de 36 a 72 horas, correspondendo de $4 \%$ a $5 \%$ da totalidade do curso de 2.200 horas.

Curi (2004), fundamentada em Shulman, analisou o conhecimento matemático existente nos cursos de Pedagogia sob três vertentes: do conteúdo da disciplina; do conhecimento didático do conteúdo da disciplina e do currículo. Deste modo, identificou que o conhecimento matemático é tratado, no decorrer da formação, por meio de quatro 
disciplinas relacionadas à área de Matemática, sejam elas: Metodologia do Ensino de Matemática; Conteúdos e Metodologia do Ensino de Matemática; Estatística aplicada à Educação e Matemática Básica. Porém, entre a maioria dos cursos existia apenas uma destas disciplinas. Segundo a autora, em aproximadamente $90 \%$ dos cursos, a preocupação estava centrada na metodologia de ensino, ou seja, as grades curriculares continham a disciplina Metodologia do Ensino de Matemática ou Conteúdos e Metodologia do Ensino de Matemática. Nesse sentido,

[...] nossa investigação mostra principalmente a pouca presença de conteúdos matemáticos e de suas didáticas nos currículos dos cursos de Pedagogia. Cabe destacar que a organização da disciplina de Metodologia do Ensino de Matemática, em algumas instituições, era unificada à outra referente aos conteúdos matemáticos. Na maioria, porém, a disciplina tinha caráter mais metodológico, com predominância de temas de caráter mais geral do ensino de Matemática em detrimento de discussões metodológicas sobre temas matemáticos previstos para serem desenvolvidos nos anos iniciais do ensino fundamental (CURI e PIRES, 2004, p. 10).

Portanto, a autora aponta que o foco da formação docente para a área de Matemática está mais voltado ao conhecimento didático do conteúdo da disciplina, abordando-se temas como: análise das teorias do conhecimento (racionalismo e empirismo) e estudos de métodos de ensino e aprendizagem. Ou, ainda, tópicos que lembram os Parâmetros Curriculares Nacionais (PCN), como: papel da Matemática no currículo e Matemática e a construção da cidadania. Segundo Curi e Pires (2004), apesar da preocupação com o viés didático do conteúdo, nenhuma ementa analisada apresentou o estudo da Resolução de Problemas e/ou da historicidade do conteúdo matemático, conforme orientações dos PCN para o ensino de Matemática. Em relação ao estudo do conteúdo matemático em si, segundo as autoras, há pouco enfoque para a geometria, medidas e tratamento da informação, centrando-se mais na construção dos números naturais e nas quatro operações básicas (adição, subtração, multiplicação e divisão). A disciplina de Matemática Básica parece ter um caráter de revisão dos conteúdos das séries iniciais do Ensino Fundamental, enquanto que a de Estatística aplicada à Educação privilegia conceitos básicos de estatística descritiva (organização de dados; técnicas de amostragem; medidas de tendência central e de dispersão). Em $10 \%$ dos cursos analisados, essa última disciplina, é a única da área de Matemática. Já, a de Matemática Básica, quando possuía caráter obrigatório, era acompanhada pela disciplina de Metodologia do Ensino.

Um outro aspecto apontado pelas autoras é em relação à formação acadêmica dos professores formadores que atuam nas disciplinas da área de Matemática nos cursos de 
Pedagogia. A constatação é de que praticamente inexistem educadores matemáticos ou com alguma formação em Matemática atuando nessa área, mesmo em relação à disciplina de Estatística. Segundo Curi e Pires (2004), essa situação permite conjecturar sobre dificuldades em desenvolver conhecimentos tão específicos, conforme são apontados por pesquisadores como Shulman. Além da formação acadêmica há, ainda, as práticas pedagógicas propostas para os alunos das disciplinas anteriormente citadas, as quais parecem não ir além de estudos de textos, seminários e resolução de exercícios. Tais aspectos podem se constituir em variáveis desfavoráveis à formação docente. Pois,

[...] de nada adianta se falar no trabalho com resolução de problemas no ensino fundamental, se o futuro professor, durante sua formação, não teve oportunidade de resolvê-los. Ninguém promove a aprendizagem de um conteúdo que não domina, nem constrói significados que ainda não têm construído, nem pode promover autonomia de seus alunos se sempre foi dependente de seus professores (CURI e PIRES, 2004, p. 11).

Deste modo, as autoras alertam que não basta investigar os conhecimentos pessoais, crenças, valores que os alunos já possuem para, então, provocar mudanças. É preciso, também, um olhar cuidadoso para o modo como se está propondo a formação inicial dos futuros professores, uma vez que as pesquisas têm mostrado como é frágil o conhecimento matemático dos docentes, seja ele advindo das experiências pessoais com a escolarização básica ou o proposto por meio de disciplinas no curso de formação, como identificado por Curi (2004) ao analisar as grades curriculares de cursos de Pedagogia. O re-pensar sobre o conhecimento veiculado nos cursos de formação inicial, assim como as práticas pedagógicas desenvolvidas nos mesmos, parecem se constituir em variáveis significativas na aprendizagem da docência, além é claro, do pensamento do professor. Portanto, o que se percebe é uma desarticulação entre a formação docente que, de fato, vem acontecendo e aquela estruturada nas atuais tendências de formação de professores, como Ferreira (2003) aponta.

Frente a esse quadro, a busca pelo conhecimento sobre a aprendizagem da docência, conforme ressaltado por Mizukami (2006), parece se constituir em uma maneira de compor a base de conteúdos essenciais à formação de professores de modo a lhes possibilitar serem bem sucedidos na aprendizagem de seus alunos. Ao mesmo tempo, o enfoque aos três eixos da aprendizagem da docência permite apresentar os referenciais relativos à Matemática, ao ensino e à aprendizagem dessa ciência como parte de um processo de construção da humanidade, que varia ao longo do tempo e com o avanço do conhecimento. Tal enfoque viabiliza a sistematização de zonas do perfil conceitual relacionado à visão sobre a Matemática, seu ensino e aprendizagem. Segundo Amaral e Mortimer (2006), para a 
caracterização das zonas do perfil se deve levar em consideração estudos sobre a evolução histórica do conceito, os dados obtidos na pesquisa e os relatados em outras investigações sobre concepções informais ou alternativas. Por essa razão, entende-se que é relevante discutir, na seqüência, aspectos relativos tanto à constituição dessas zonas quanto essenciais ao conhecimento da aprendizagem da docência.

\subsection{CONHECIMENTOS SOBRE A MATEMÁTICA, SEU ENSINO E APRENDIZAGEM}

A necessidade que o professor conheça a matéria a ser ensinada e tenha domínio sobre as estruturas conceituais da disciplina, neste caso a Matemática, não é algo novo entre os pesquisadores, já vem sendo difundido há certo tempo (GUÉRIOS, 1992; BERTONI, 1995, entre outros). Ainda hoje esse olhar é reforçado em virtude da aprendizagem da docência, articulando-o a dois outros eixos: a aprendizagem do aluno e o modo de ensinar a matéria, já que cada eixo é constituído por certas características. Assim Mizukami (2006), informa que:

- o conhecimento sobre a matéria a ser ensinada: refere-se ao domínio das estruturas conceituais da matéria. O essencial sobre o conhecimento matemático é que o professor tenha condições de decidir sobre o quê e o porquê de ensinar certos conteúdos específicos, visandose à organização da disciplina e ao desenvolvimento de planos curriculares articulados entre as séries e os níveis de ensino para um efetivo apoio à aprendizagem do aluno;

- conhecimento sobre como ensinar a matéria: a partir da organização e seleção dos temas centrais, o professor precisa construir modos particulares de tornar a Matemática acessível a uma ampla variedade de alunos. Para tanto, é importante que ele crie múltiplos exemplos, demonstrações, analogias e representações desses conceitos, de modo a "propiciar relações entre as novas idéias ainda não-familiares aos alunos àquelas já presentes em seus repertórios" (MIZUKAMI, 2006, p. 225). Em outras palavras, este eixo refere-se ao conhecimento pedagógico que o professor precisa ter sobre o conteúdo específico da matéria;

- conhecimento sobre os alunos, suas aprendizagens e seus desenvolvimentos: para tornar possível a relação entre as novas idéias e as presentes, no repertório dos alunos, é necessário que o professor compreenda como o aluno aprende e se desenvolve. Por consequiência, é preciso que ele considere a natureza construtiva do ato de conhecer; a maneira como eles lidam, percebem e processam informações, os interesses e as préconcepções dos alunos. A configuração desse quadro leva, novamente, à necessidade que o 
professor conheça diversos tipos de tarefas e de adaptações do conteúdo com o intuito de manter os alunos motivados e envolvidos no processo ensino-aprendizagem.

Com o delineamento de cada eixo componente do conhecimento sobre a aprendizagem da docência, obtém-se a configuração de um viés de como pode acontecer a articulação entre eles. Por outro lado e estendendo o olhar para a docência em Matemática, lançam-se algumas conjecturas, tais como: qual definição de Matemática o professor considera na organização da disciplina e seleção dos conteúdos matemáticos? Qual é a importância de ensinar Matemática? As atividades escolhidas pelo professor são apropriadas para representar de diferentes maneiras os conceitos matemáticos? Quais representações são úteis para auxiliar os alunos a aprenderem os conceitos? Quais práticas têm se mostrado efetivas na promoção da aprendizagem dos alunos? Como os alunos aprendem e desenvolvem proficiência em Matemática?

Frente a esses questionamentos, entende-se que tanto a história e a filosofia da Matemática e do seu ensino, quanto estudos da psicologia cognitiva referente à aprendizagem do conhecimento matemático fornecem subsídios para uma reflexão sobre tais conjecturas e, por conseqüência, para uma melhor compreensão do significado desses conhecimentos na aprendizagem da docência em Matemática. As múltiplas visões atribuídas ao conhecimento matemático e ao ensino e aprendizagem da Matemática também auxiliarão, mais adiante, na sistematização das categorias que constituem as zonas do perfil conceitual e na interpretação das concepções dos sujeitos dessa pesquisa.

\subsubsection{O Conhecimento sobre a Matéria a ser Ensinada: História e Idéias sobre a Matemática}

A consideração à Matemática será a de que o conhecimento sobre a história de sua constituição se confunde com a história da própria humanidade. Isto significa entendê-lo como um produto cultural e social, que assume diferentes visões conforme a época e o contexto. Assim, ao enfocar uma situação corriqueira de sala-de-aula, onde um professor, ao conversar com seus alunos sobre certos tópicos da Matemática, vê algumas questões virem à tona, por exemplo: qual a origem desse conhecimento? O que o caracteriza? Como foi e é sua construção? Tanto a história quanto a filosofia da educação matemática são campos que fornecem subsídios para se refletir sobre conjecturas como essas.

Deste modo, pode-se supor, em um primeiro momento, que para cada uma destas questões haja, pelo menos, duas possibilidades de respostas. Por exemplo, uma delas relacionada a uma visão sobre a Matemática como uma área fria e austera, como um 
conhecimento com características gerais de objetividade, precisão, vigor, neutralidade do ponto de vista ideológico e passível de utilização em qualquer lugar do mundo por ser um saber universal (MACHADO, 1994) e por se tratar de um corpo fixo de conceitos. Na outra visão, a Matemática varia de acordo com o espaço geográfico e com a história de grupos culturais, assim ela é vista "como uma estratégia desenvolvida pela espécie humana ao longo de sua história para explicar, para entender, para manejar e conviver com a realidade sensível, perceptível e com o seu imaginário, naturalmente dentro de um contexto natural e cultural" (D’AMBRÓSIO, 2001, p. 82). Essas visões distintas sobre a Matemática são resultados de concepções construídas ao longo da história da humanidade, na qual se observa que a Matemática é resultado da resolução de problemas, das invenções, introspecções e abstrações que as pessoas, individualmente, em sua época, faziam e, ainda hoje fazem, em virtude de tendências filosóficas, necessidades básicas e diárias para um melhor convívio social.

Alguns pesquisadores consideram que a Matemática e a Filosofia sempre se influenciaram e se alimentaram uma da outra (SILVA, 1999), para outros, o conhecimento matemático se funde à história da humanidade, pois as "idéias matemáticas comparecem em toda a evolução da humanidade, definindo estratégias de ação para lidar com o ambiente, criando e desenhando instrumentos para esse fim, e buscando explicações sobre os fatos e fenômenos da natureza e para a própria existência" (D’AMBRÓSIO, 1999, p. 97) da Matemática. Ainda, essa mesma história revela que a visão sobre a Matemática variou de um povo para outro, de uma classe social para outra, de uma época para outra, possivelmente, devido ao surgimento de algum obstáculo com atividades práticas ou princípios teóricos. "Nesta evolução aparecem sucessivamente períodos em que o trabalho matemático inspira-se diretamente na experiência sensível e períodos onde as noções, os resultados mal-estruturados da fase anterior são sistematizados e generalizados, de forma aparentemente abstrata" (MACHADO, 1994, p. 11), o que vai resultar em uma variação de percepção desse conhecimento. Deste modo, delinear-se-á, na seqüência, o processo pelo qual a Matemática foi se constituindo como uma área da ciência. Adota-se uma perspectiva histórico-temporal como meio de evidenciar as principais idéias sobre o conhecimento matemático em relação ao contexto sócio-cultural de cada época.

Assim, desde a Antigüidade, são encontrados indícios de como esse conhecimento foi se constituindo. Para egípcios e babilônios, a Matemática tinha um caráter empírico em virtude de suas necessidades diárias, como: distribuição de terras para a agricultura ao longo do rio Nilo e atividades com o pastoreio às margens dos rios Tigre e Eufrates. Esta situação propiciou o desenvolvimento de conhecimentos relacionados à geometria e à aritmética. Já, 
entre os gregos, se valorizava o caráter racional da Matemática, a qual era vista como uma fonte rica de conhecimento que ajudava os pensadores, filósofos da época, a encontrarem princípios fundamentais das idéias ordenadas em seqüências lógicas e, também, eles viam nas matemáticas a possibilidade de desenvolvimento da inteligência, como pode ser observado nesta passagem do livro VII da República de Platão.

Então, ó Glaucon, é esta uma espécie de conhecimento que conviria implantar por lei, tentando persuadir os que vão exercer as mais altas funções na cidade a que se acerquem da Aritmética e a cultivem não como amadores, mas até que cheguem a contemplar a natureza dos números com a ajuda exclusiva da inteligência; não como fazem os comerciantes e revendões, com mira nas compras e vendas, mas pela sua utilidade na guerra e pela maior facilidade com que a própria alma se pode voltar da geração para a verdade e a essência (PLATÃO, 1999, p. 161).

Para os gregos, a Matemática se tornou um instrumento de diferenciação entre a educação daqueles que seriam os governantes e os não governantes. Pois, aqueles que trabalhavam com os conceitos matemáticos seriam superiores aos demais. Era uma Matemática que não se relacionava às questões práticas e sim à contemplação divina. Para Platão, a Matemática era importante pela sua capacidade de despertar o pensamento do Homem por meio de "um processo que privilegiava as descrições dos objetos matemáticos e das relações e estruturas que os unem" (BICUDO e GARNICA, 2001, p. 27). Os objetos matemáticos - as Formas ou as Idéias - eram concebidos como modelos ideais, perfeitos e com existência objetiva e real no mundo físico, independente da ação humana. Mas, conseqüente de um profundo trabalho mental de perseguição da verdade. Trata-se de uma visão absolutista da Matemática, a qual só é possível de se captar por meio da razão, cujas descobertas são verdades sobre entes matemáticos a partir de sua existência objetiva e absoluta. Já para Aristóteles, as verdades são decorrentes dos fatos. Ele reabilita o mundo empírico e os enunciados matemáticos agem como representações abstratas dos objetos da percepção sensível.

Começa assim um modelo de explicações que vai dar origem às ciências, à filosofia e à matemática abstrata. É muito importante notar que duas formas de matemática, uma que poderíamos chamar matemática utilitária e outra, matemática abstrata (ou teórica ou de explicações), conviviam e são perfeitamente distinguíveis no mundo grego (D’AMBRÓSIO, 1996, p. 35).

A distinção se dava, principalmente, a quem se destinava cada uma das matemáticas: a teórica, a abstrata servia para formar os mais bem-dotados, aqueles que tinham maior facilidade de aprender e de memorizar, eram os mais dedicados; a prática, utilitária servia para fornecer elementos técnicos necessários às várias profissões e, também, era base de 
estudo das crianças, uma vez que fornecia os elementos necessários aos estudos posteriores. Assim, pode-se perceber a existência de dois tipos de concepções sobre a Matemática: as referentes ao platonismo (racionalismo) e as idealizadas pela corrente aristotélica (empirismo). Na primeira, as conquistas matemáticas são descobertas independentemente do mundo físico e as verdades são construídas por meio da razão. Na segunda, pelo viés aristotélico, as conquistas da Matemática são resultantes do mundo sensorial pela idealização de objetos empíricos.

No século III a.C., quando o Império Grego entra em declínio, Arquimedes de Siracusa começa a desenvolver com a mesma habilidade as duas matemáticas, a utilitária e a abstrata. É quando se inicia um movimento da Matemática voltado às aplicações. Com o declínio grego, há a expansão do Império Romano, cujo foco de preocupação era a vida social e política. Desta maneira, a contribuição dos romanos para o desenvolvimento da Matemática é pouco significativa. Pois,

Durante toda a sua longa história, a Roma antiga pouco contribuiu para a ciência e a filosofia e menos ainda para a matemática. Tanto durante a república como durante o império, os romanos mostraram pouca inclinação para a investigação especulativa ou lógica. As artes práticas como a medicina e a agricultura eram cultivadas com algum interesse, e a geometria descritiva era olhada favoravelmente. Projetos notáveis de engenharia e monumentos arquitetônicos se relacionavam com os aspectos mais simples da ciência, mas os construtores romanos se satisfaziam com técnicas práticas elementares que requeriam muito pouco conhecimento da grande massa de pensamento grego (BOYER, 2002, p. 120).

O importante para os romanos era a fundação de cidades e a reorganização urbana. Assim, na obra Dez Livros de Arquitetura de Marcus Vitruvius Pólio (Séc. I a.C.), consta tudo o que era considerado de mais importante na Matemática no Império Romano. Ao mesmo tempo, é durante este império que se vê o nascimento do cristianismo e, com isso, o crescimento da Igreja Cristã, a qual passou a exercer, por um pequeno período, um poder paralelo ao do império, vindo este, mais tarde, se subordinar à Igreja. Este fato é o que marca, intelectualmente, o fim da Idade Antiga e início da Idade Média.

Na Europa, durante o período medieval, os clérigos desenvolviam a filosofia cristã em mosteiros, enquanto isso as idéias gregas eram desprezadas, inclusive as relacionadas às matemáticas. Por volta do ano 1000 foram organizadas as Cruzadas em direção ao Império Islâmico. Assim, os europeus passaram a ter contato com o conhecimento matemático que estava sendo produzido nas costas ao sul do Mediterrâneo, norte da África e Oriente Médio. Vale ressaltar que havia entre os povos dessas regiões uma forte influência por parte do conhecimento grego. Foi desta maneira, por exemplo, que o sistema posicional de numeração 
e de operações aprendido com os árabes pôde ser publicado, em 1202, na obra Líber Abbaci, por Fibonacci. Segundo D’Ambrósio (1996), esse foi um importante livro no desenvolvimento da matemática européia, nele se explica todo o sistema posicional e as regras de operações aritméticas. Obras como essa representaram um marco para o modo como o conhecimento matemático era concebido na época.

A época foi de transição de um ponto de vista antigo para um mais novo. $\mathrm{O}$ ressurgimento começou, inevitavelmente, com uma série de traduções. A princípio essas foram quase exclusivamente do árabe para o latim, mas pelo século treze havia muitas variantes - do árabe para o espanhol, do árabe para o hebraico, do grego para o latim, ou combinações como o do árabe para o hebraico para o latim (BOYER, 2002, p. 171).

Com as traduções, a Europa teve acesso a um novo conhecimento gerado a partir dos fundamentos da Grécia. Deste modo, foi possível não só aos banqueiros e comerciantes estabelecerem as bases para a economia moderna na Europa, como também, aos monges organizarem esse novo conhecimento em função da filosofia teológica cristã que estava sendo gerada nos mosteiros, cujos espaços eram fechados para os hereges. Ao mesmo tempo, as pessoas, clérigos ou não, discutiam sobre o conhecimento que estava sendo desenvolvido fora dos mosteiros, em outros espaços criados para tal fim, como as universidades (Bolonha, Paris, Oxford e Cambridge). É quando se dá, então, um impulso no conhecimento por meio de invenções práticas. As grandes navegações, o estudo da astronomia e da lógica foram fatos importantes para que, no século XV, o conhecimento começasse a ser organizado por especialidades. É nesse período que se inicia a estruturação da Matemática nos moldes como é conhecida hoje. A queda de Constantinopla, em 1453, marca um novo período no desenvolvimento da humanidade e, conseqüentemente, do conhecimento.

Para a Matemática, o Renascimento é um período de recuperação das obras matemáticas ainda existentes da Antigüidade e, conseqüentemente, o contato entre idéias antigas e novas, entre pontos de vista de artesãos e eruditos. "Na matemática do século dezesseis há tendências variadas e conflitantes, mas podemos perceber nela, tanto quanto na ciência, os resultados de uma confrontação entre idéias estabelecidas e novos conceitos, e entre a visão teórica e as exigências de problemas práticos" (BOYER, 2002, p. 217). Tais confrontações resultaram, no século seguinte, em uma mudança no conceito de ciência que, além das reflexões sobre o homem e sua natureza intelectual, sentiu-se, também, a necessidade de criação de instrumentos próprios para a observação de fenômenos da natureza. Esse período denominado de Ciência Moderna foi uma época de avanços tecnológicos e intelectuais. René Descartes, com a obra Discurso do Método (1637), representa um 
importante marco de ruptura com o passado em relação ao raciocínio matemático, uma vez que ele procura princípios da razão que organizem todo o conhecimento. Um outro importante referencial para a filosofia moderna da Ciência foi a obra de Isaac Newton, Principia. Princípios Matemáticos da Filosofia Natural (1687). Nessa obra, Newton apresenta um novo sistema de explicações apoiado no método cartesiano. Esse outro olhar lançado à Ciência atribuiu um novo e importante papel para a Matemática.

Com o início da ciência moderna, que combinou pela primeira vez os métodos experimental e indutivo com a dedução matemática, ou seja, que rompeu a barreira existente entre a tradição artesanal e a culta, entre a razão e a experiência, que teria em Galileu Galilei (1564-1642) e em Isaac Newton (1642-1727) seus principais representantes, as matemáticas passaram a desempenhar um novo e importante papel: o de ferramenta necessária à explicação dos fenômenos. Não apenas como auxiliar nos desenvolvimentos lógicos, sobre bases preestabelecidas, mas como elemento fundamental para a formação, comprovação e generalização de resultados que podem, ou não, ser confirmados na prática (MIORIM, 1998, p. 41).

Na Ciência Moderna, há uma inversão de foco na Matemática, a qual passa da preocupação com o estudo qualitativo dos fenômenos para o enfoque central nas artes práticas e mecânicas, com a explicação dos fenômenos por meio de relações quantitativas. Um outro filósofo e matemático da mesma época, Leibniz, cuja história de vida se entrelaça à de Newton, propôs uma visão universal do conhecimento pelo uso da linguagem. Atribui-se aos dois estudiosos a invenção do Cálculo Diferencial (BOYER, 2002, p. 277). Apesar de os inventores terem tido objetivos distintos, essa descoberta se tornou o pivô de grande desavença entre os intelectuais ingleses e os europeus continentais. A conseqüência, deste feito, foi o isolamento da Inglaterra em relação ao desenvolvimento da matemática européia. As notações de Leibniz foram recusadas pelos ingleses, enquanto que as idéias de Newton não se propagaram fora da Inglaterra. Sendo assim, Leibniz além de contribuir com o Cálculo para o desenvolvimento da Matemática, teve na Lógica sua contribuição mais significativa. Para ele, todas as coisas poderiam ser reduzidas a discussões lógicas, de forma sistemática e compreensível em todas as línguas. Sua visão era a de uma lógica simbólica e formal, a qual expressava os pensamentos humanos por meio de símbolos universais ou ideogramas, como as fórmulas desenvolvidas em Matemática e, então reduzidas a uma espécie de cálculo. As controvérsias filosóficas sobre a questão da verdade, conforme ocorreu com Platão e Aristóteles, seriam apenas conseqüências de cálculos corretos ou não. As idéias de Leibniz vêm a se constituir, no século XIX a base de uma importante corrente filosófica para a Matemática, o Logicismo. 
O final do século XVII é marcado por uma crise cultural que figura a decadência das universidades frente à criação de centros de pesquisa científica e o menosprezo das redescobertas do mundo antigo para a valorização das capacidades produtivas e culturais do mundo moderno. É o período da construção e desenvolvimento do capitalismo, bem como, da expansão colonialista européia. Nesse contexto, a conjugação do capitalismo e o fortalecimento do conhecimento científico foram fatores que contribuíram para a ocorrência de revoluções (Francesa, Industrial, Americana) nos séculos seguintes. O século XVIII é um período considerado pouco produtivo para o desenvolvimento da Matemática, pois foi uma época que sucedeu o tempo da superação da matemática grega com o descobrimento da geometria analítica e do cálculo infinitesimal e precedeu o século do desenvolvimento de florescência da geometria e do rigor matemático.

Por outro lado, é no século XIX que se vê o maior crescimento da Matemática, o qual ultrapassa a soma de tudo o que havia sido gerado nos séculos anteriores. Foi considerada a Idade de Ouro da Matemática (BOYER, 2002, p. 343). A introdução de certos conceitos (geometrias não-euclidianas, espaços n-dimensionais) no repertório matemático contribuiu para uma radicalização das definições e aparência da Matemática. Nesse mesmo período, observa-se uma mudança na distribuição geográfica da atividade matemática, pois em outros séculos havia certa concentração de produção em alguns lugares. Foi um período de interpretação geométrica da análise e da álgebra, de introdução de técnicas analíticas na teoria dos números, do cálculo vetorial e matrizes com Hamilton, do retorno à Matemática discreta com Boole, das equações diferenciais e teoria das probabilidades com Lagrange e Laplace, do impulso à ciência da computação com Babbage, Hollerith e outros. No entanto, a natureza de tais idéias matemáticas converge, a partir da segunda metade do século XIX, para três grandes correntes filosóficas que fundamentam a produção do conhecimento, de seu ensino e da relação com o mundo, são: o Logicismo, o Formalismo e o Intuicionismo. Essas três correntes, praticamente, monopolizaram o século XX apresentando uma visão absolutista da Matemática. "Com essa percepção, muitos passaram a acreditar na existência de uma verdade única e absolutamente certa dos resultados matemáticos. Mais que isso, passa a conceber que a Matemática é, talvez, o único reino da certeza, com conhecimento objetivo e inquestionável" (SILVÉRIO, 2003, p. 39).

No Logicismo, cujos principais representantes são Frege e Russel, a verdade de um enunciado matemático pode ser descoberta pela razão, ela é objetiva. O princípio metodológico desta corrente foi tornar verdadeiro um pensamento lógico, uma proposição, para isso se utilizando de definições produzidas a partir de leis gerais da lógica. Essas leis 
foram deduzidas da teoria dos números (aritmética), cujos resultados eram conhecidos e, portanto, independentes dos fatos empíricos.

No Formalismo, "os teoremas em Matemática decorrem, sem dúvidas, dos axiomas, de acordo com as leis da lógica. [...] Admitem que esses axiomas vêm da descrição dos dados obtidos da percepção sensível do espaço e do tempo" (SILVÉRIO, 2003, p. 40). Esta corrente consiste no processo de descrever objetos e construções concretas por meio de teorias formais consistentes. As teorias formais se referem aos sistemas axiomáticos e são compostas por termos primitivos, regras de formação de fórmulas, axiomas, regras de inferências e teoremas. Nesse sentido, Machado (1994, p. 30) explica que:

Os termos primitivos descrevem os objetos concretos de que trata a teoria. As regras de formação de fórmulas organizam o discurso a respeito destes objetos, distinguem as fórmulas bem-formadas das que carecem de significado. Os axiomas são as verdades básicas, iniciais, que devem se apoiar na evidência empírica. As regras de inferência determinam as inferências legítimas e distinguem, dentre as fórmulas bem-formadas as que constituem os teoremas, que são verdades demonstráveis a partir dos axiomas, em última análise.

Em suma, trata-se de uma organização rigorosa da teoria em um sistema dedutível. A intenção dos formalistas no início do século XX, como Hilbert, era de se obter um sistema formal, unificado, consistente e completo para envolver toda a Matemática a partir da articulação de teorias formais referentes a cada ramo deste conhecimento. No entanto, em 1931, essa corrente é abalada com a publicação de um artigo de Gödel, um matemático alemão com 25 anos de idade. Neste artigo, ele mostrou que em uma classe ampla de sistemas formais é possível construir proposições bem formadas, das quais não se pode deduzir se são verdadeiras ou falsas. Portanto, evidencia-se que o conhecimento matemático, como um todo, não pode ser formalizado de maneira consistente e completa, pois há uma limitação do método axiomático e isto propiciou que se percebesse a necessidade de desenvolvimento de novos princípios de demonstração. Mas, tal inconsistência do Formalismo já havia sido percebida anteriormente por Brouwer, o mais típico representante do Intuicionismo.

Para os intuicionistas, "a Matemática é uma construção de entidades abstratas, a partir da intuição do matemático, e tal construção prescinde de uma redução à linguagem especial que é a Lógica ou de uma formalização rigorosa em um sistema dedutivo" (MACHADO, 1994, p. 40). Isto significa que as verdades das proposições matemáticas seriam evidenciadas a partir de uma introspecção do matemático sobre determinado objeto, não estabelecendo nenhuma relação com o mundo exterior. Nessa corrente, a linguagem matemática possui uma função essencialmente pedagógica e os sistemas formais são produtos resultantes de uma atividade autônoma da Matemática. 
Embora existissem divergências entre os pensadores matemáticos sobre as idéias de cada corrente filosófica, havia, também, convergências. Como pontos comuns entre as três escolas filosóficas tradicionais (ou clássicas), podem-se apontar o interesse em reformular ou reinterpretar a Matemática e a concepção de que esse conhecimento não é influenciado pelo empírico, desconsiderando-se sua história. Segundo Silva (1999), essas escolas tradicionais da Matemática, não são resultado de uma reflexão sobre a natureza da Matemática, como ocorreu em outros momentos históricos. Mas sim, foram criadas como ferramentas ideológicas de justificação para a fundamentação a que se destinava o conhecimento. Em termos das discordâncias, podem-se citar a crença dos logicistas de que era insuficiente relacionar teoremas matemáticos com axiomas não necessariamente lógicos, conforme ocorria no Formalismo. E, também, o ponto de vista dos formalistas em não aceitarem a teologia platônica, as restrições do Intuicionismo e, ainda, consideravam, não-matemático e irrelevante qualquer atribuição de significação às fórmulas. Neste sentido, percebe-se que "os logicistas acreditavam que a Matemática, sendo pura e lógica, não está ligada à experiência. Para os formalistas, a Matemática era apenas um jogo formal; e os intuicionistas acreditavam que a Matemática apenas descreve certos aspectos da nossa vida mental" (SILVÉRIO, 2003, p. 44). Tais divergências entre uma escola e outra foram concebidos como possíveis fracassos da teoria fundacional. Esse tipo de situação é que propicia ao surgimento de novas visões sobre a Matemática.

Assim, ao considerar que as três correntes filosóficas tradicionais absolutistas desconsideraram a história da Matemática, constatou-se que os filósofos desenvolveram visões pouco realistas sobre a natureza da Matemática. Nesse sentido, a história da Matemática se encaixa como uma importante peça para uma reflexão filosófica, para uma reinterpretação dos conceitos matemáticos e para uma percepção de que a Matemática não é insensível à sua dimensão prática. Pois, sua evolução sempre esteve condicionada pelas suas aplicações à ciência e às necessidades do cotidiano. As questões de ordem prática ou científica são determinantes no que pode ser considerado relevante na Matemática. Nesse sentido, percebe-se que o olhar sobre a Matemática, atualmente, está distante das escolas nascidas da crise dos fundamentos (Logicismo, Formalismo e Intuicionismo). Pois,

Antes de buscar reservar à matemática uma posição privilegiada no sistema do conhecimento humano, a filosofia da matemática hoje busca aproximá-la do conhecimento empírico, tornando-a tão falível e aberta à revisão quanto este. O apriorismo e o caráter de necessidade do conhecimento matemático estão sendo duramente contestados nas modernas filosofias da matemática, certamente como consequiência da própria evolução matemática (SILVA, 1999, p. 54). 
Trata-se do delineamento de uma tendência empiricista e revisionista em Matemática, na qual a história dessa ciência e o próprio conhecimento são tomados como elementos de reflexão para se compreender esse conhecimento como mais um esforço da humanidade na organização de suas experiências no mundo. Hoje, uma das visões sobre a Matemática afirma que ela deve se submeter à utilidade prática e teórica ou a adequação da evidência empírica, do mesmo modo que as ciências naturais estão sujeitas em relação aos critérios de excelência e de verdade. As grandes escolas filosóficas da Matemática pretendiam resolver o problema de como esta ciência deveria ser para garantir a verdade de modo consistente. No entanto, ao focalizar a Matemática como uma ciência em permanente evolução, ligada a processos cognitivos e sócio-culturais que intervêm na construção do saber matemático, conclui-se que as grandes escolas são de alcance limitado à atual problemática deste conhecimento. O que está em pauta não é como a Matemática deveria ser e, sim, como ela é na prática diária das pessoas, sejam elas especialistas ou não.

São novos olhares lançados à Matemática. Uma vez que se vê o Homem como um ser racional, intuitivo, emocional e espiritual e não se aceita uma verdade como única e definitiva, o entendimento sobre a natureza da Matemática e suas verdades não pode ser representado de uma forma só. Trata-se de uma visão multifacetada da Matemática. Por essa linha, seria função da Filosofia da Matemática estabelecer a certeza sobre o conhecimento. Na perspectiva filosófica de Lakatos, o Falibilismo concebe a construção da Matemática como um processo que envolve discussão crítica, conjecturas, provas e refutações. Cabe ressaltar que Ernest (1988, apud Ponte, 1992) considera três concepções sobre a Matemática: resolução de problemas, platônica e instrumentalista. Na resolução de problemas, a Matemática é vista como um campo humano de conhecimentos e como um processo de enriquecimento do conjunto de conhecimentos. Está em contínua expansão e invenção e não é concebida como um produto acabado. Na visão platônica, a Matemática é vista como um corpo de conhecimentos estático e imutável, seus elementos são descobertos e não criados. Na instrumentalista, a Matemática é concebida como um conjunto de regras e de fatos que não se relacionam, mas que são úteis.

Assim como Ernest, outros pesquisadores também sistematizaram certas visões sobre a Matemática. Tais olhares, em alguns casos se entrelaçam, em outros se afastam, conforme observado por Thompson (1997). Esta pesquisadora ao investigar concepções de professores acerca da Matemática e seu ensino, faz uma revisão da literatura sobre o referido assunto, destacando quatro classificações possíveis sobre as concepções relativas à Matemática, sendo uma delas a de Ernest (1988), apresentada anteriormente. Uma outra seria a de Skemp (1978), 
em que distingue a Matemática como instrumental (conjunto de indicações determinadas e bem definidas, numa seqüência de passos a seguir) e como relacional (conjunto de estruturas conceituais que permite aos seus detentores a elaboração de vários planos com vista à realização das tarefas matemáticas). Uma terceira classificação seria a de Copes (1979), que concebe a Matemática como absolutista (coleção de fatos, cuja veracidade é passível de ser verificada no mundo dos objetos físicos); multiplista (conteúdos matemáticos não precisam ser observados em fenômenos físicos que admite coexistência de sistemas matemáticos diferentes e contraditórios entre si); relativista (deixa de querer provar a consistência lógica dos diferentes sistemas e aceita a coexistência, sendo todos igualmente válidos) e dinâmica (caracterizada pela adesão a um sistema particular definido no âmbito da concepção relativista). E, uma última classificação seria a proposta por Lerman (1983), cuja concepção vê a Matemática como absolutista (todo conhecimento se baseia em fundamentações universais e absolutas) e falibilista (o conhecimento se desenvolve por meio de conjecturas, provas e refutações, na qual a incerteza é aceita como inerente à Matemática). De uma maneira geral, estes estudos revelam que as concepções dos professores tendem a uma visão absolutista e instrumental da Matemática, pelo acúmulo de fatos, regras, procedimentos e teoremas. Por outro lado, há também, aqueles que assumem uma concepção dinâmica do conhecimento matemático, concebendo-o como um domínio em evolução, conduzido por problemas e sujeito à revisão.

Em um outro estudo sobre concepções de professores acerca da Matemática e do processo ensino-aprendizagem, desenvolvido por Ponte (1992), o enfoque ao conhecimento matemático é centrado nos processos cognitivos e sociais que intervêm na construção desse saber. Para tanto, o autor salienta que a Matemática pode ser caracterizada como produto ou como atividade. Na primeira, o conhecimento é constituído por um conjunto de teorias bem determinadas e, na segunda, como um conjunto de processos característicos, tais como: definir, exemplificar, representar, conjecturar, testar, especializar, generalizar e demonstrar. Pois, ele considera que a Matemática,

[...] é uma ciência em permanente evolução, com um processo de desenvolvimento ligado a muitas vicissitudes, dilemas e contradições. [...] é um saber científico. Distingue-se das outras ciências pelo facto de que enquanto nestas a prova de validade decisiva é a confrontação com a experiência, na Matemática esta prova é dada pelo rigor do raciocínio. [...] Os formalismos da Matemática disciplinam o raciocínio dando-lhe um carácter preciso e objetivo. Os raciocínios matemáticos podem por isso ser sempre sujeitos a verificação. Por vezes podem haver controvérsias, mas nunca fica por muito tempo a dúvida se um dado raciocínio é ou não correto [...]. Possibilita a elaboração de uma imensa variedade de estruturas intelectuais. Fornece, por isso, um mecanismo disciplinado que proporciona quadros de referência nos quais se enquadram os factos obtidos empiricamente pelas diversas ciências (PONTE, 1992, p. 11-12). 
A partir dessa percepção da Matemática, Ponte (1992) anuncia quatro características fundamentais do conhecimento matemático: a formalização (refere-se à uma lógica bem definida); a verificabilidade (permite estabelecer consensos sobre a validade de cada resultado); a universalidade (caráter transcultural do conhecimento e a possibilidade de aplicá-lo aos mais diversos fenômenos e situações) e a generatividade (possibilidade de levar a descobertas de coisas novas).

No trabalho de Silvério (2003), a partir de uma perspectiva histórica e filosófica do conhecimento matemático, o autor sistematiza as concepções de professores em visão absolutista, visão empirista e visão social. Na primeira, a "Matemática é vista como um corpo de conhecimento com coerência interna, produto das mentes brilhantes e desvinculado do mundo real “(SILVÉRIO, 2003, p. 86). A visão empirista, para o autor, está contraposta à visão absolutista e permite perceber que o conhecimento não é infalível, pois depende de interpretações de um observador que retira dados do mundo. Finalmente, a visão social concebe a Matemática como uma representação da construção humana, localizada histórica e espacialmente. Nessa visão, a "produção matemática passa também a ser um reflexo da conjuntura social e política e, portanto, suas verdades não têm caráter absoluto e isento de ações humanas, como que vindos de um mundo superior"(SILVÉRIO, 2003, p. 88). O saber matemático é influenciável e dependente da cultura, técnica e linguagem da sociedade envolvida e, também, pode ser relativo, prático, mutável e se apresentar de modo sistematizado ou não.

Uma outra abordagem sobre concepções da Matemática e de seu processo de ensinoaprendizagem é apresentada no trabalho de Graça et al (2004). Os autores estudam as representações sociais que professores fazem sobre o referido tema a partir de uma dimensão epistemológica da Matemática, destacando as visões sobre a origem da Matemática; natureza da Matemática e certeza da Matemática. Em relação à origem da Matemática consideram três posições associadas com o papel da experiência e da razão constituídos ao longo da história em termos da produção e evolução do conhecimento matemático, sendo elas: racionalista (todo conhecimento assenta-se na razão, parte de axiomas e chega a verdades independentemente da observação); empirista (todo conhecimento tem origem na experiência) e racionalista-empirista (é a coexistência de dois tipos de conhecimento: conhecimento $a$ 
priori e conhecimento a posteriori) ${ }^{22}$. Os autores ressaltam que a perspectiva atual parece enfatizar mais a base empírica do conhecimento matemático. Sobre a natureza da Matemática, o enfoque está na origem dos entes matemáticos, os quais estão condicionados pelas construções dos matemáticos em relação às suas realidades. Tais realidades são percebidas por uma perspectiva idealista - a qual é inconcebível fora da relação do ente com o sujeito que a estrutura, pois existe apenas na medida em que, é por ele construído - ou realista - que possui uma realidade autônoma e exterior ao homem, este se limita a descobri-la, para ele fazer Matemática consiste na atividade de descrever e descobrir os entes, obedecendo-se a uma lógica e leis internas do conhecimento. Na certeza da Matemática, os autores consideraram as posições epistemológicas das escolas filosóficas, as fundacionais, "cujo propósito essencial foi estabelecer fundamentos inabaláveis que garantissem a certeza, a verdade, e o carácter absoluto de todo o conhecimento matemático acumulado" (GRAÇA et al, 2004, p. 12), sendo elas: logicismo, formalismo e intuicionismo. Também, ressaltam o falibilismo pelo valor atribuído ao erro no processo de produção do conhecimento matemático.

A importância da sistematização apresentada sobre as visões relativas à Matemática se justifica pela influência que esses olhares têm em relação ao ensino e à aprendizagem. Não há uma prática ou teoria pedagógica que não apresente algum reflexo, consciente ou não, de uma concepção sobre a Matemática. Deste modo, concepções sobre Matemática podem ser sistematizadas a partir das diferentes percepções explicitadas pela história e pela filosofia deste conhecimento, assim como também, por pesquisas conforme as apresentadas anteriormente. A partir desses vários olhares é possível perceber a transição da essência do conhecimento matemático entre o caráter teórico, abstrato, formal, estático, absolutista e instrumental para um utilitário, prático, relativo, dinâmico e próximo à realidade do mundo sensorial. Essa trajetória da transição de uma percepção para a outra, de certo modo, delineia o percurso de evolução pelo qual concepções sobre a Matemática vem caminhando. Deste modo, ao analisar as concepções dos sujeitos desta pesquisa, tomar-se-á como fio condutor na definição das categorias essa transitoriedade entre um conhecimento racional e formal para um relacional e social. Pois, conforme for a visão dos sujeitos sobre a Matemática, isso possibilitará entender suas opções para o processo de ensino-aprendizagem desenvolvidos nas

\footnotetext{
${ }^{22}$ Os conhecimentos a priori e a posteriori se referem, o primeiro ao "conhecimento universal, necessário e intemporal, que se fundamenta na razão e é independente da experiência, consistindo, pelo contrário, o conhecimento a posteriori, ou empírico, em proposições fundamentadas na experiência, ou seja nas observações do mundo físico" (GRAÇA et al, 2004, p. 11).
} 
aulas durante o estágio. Assim, faz-se necessário, também, uma sistematização sobre as tendências de ensino na Matemática, para uma melhor compreensão das idéias reveladas pelos sujeitos. Portanto, na sequiência, delinear-se-á o outro eixo da aprendizagem da docência, seja ele, o conhecimento sobre como ensinar a matéria.

\subsubsection{O Conhecimento sobre o Modo de Ensinar a Matéria: Tendências do Ensino de Matemática}

Muito do que ocorre atualmente no ensino da Matemática, segundo Miorim (1998), parece ter suas raízes em idéias defendidas no período da Idade Antiga até o início da Idade Média. Por exemplo: do Egito antigo vem o ensino baseado no treino de algoritmos por meio da repetição de procedimentos. Da concepção platônica há a noção mística da Matemática, a qual eleva a Ciência a um patamar superior em relação às outras formas de conhecimento. Em Platão, tem-se a valorização filosófica do caráter teórico, abstrato do conhecimento. Em Isócrates, a educação é baseada na retórica e, a preocupação está nas coisas práticas. Destes dois últimos, o que se herda é a discussão sobre o modo mais adequado entre um ensino teórico ou prático, contextualizado ou sem ligação com o ambiente social. Naquela época, o interesse nos estudos das matemáticas era quase, exclusivamente, instrumental. Por exemplo, o interesse dos clérigos ao cálculo que determina, precisamente, a data da Páscoa no calendário em função de um melhor entendimento das escrituras sagradas.

O primeiro esforço em restaurar o caráter especulativo (teórico) das matemáticas ocorre no período do Renascimento Carolíngio, séculos VIII e IX, com o imperador Carlos Magno criando escolas e organizando o sistema de ensino em elementar, secundário e superior, cujo propósito era a melhoria do nível cultural da população, em especial, dos monges. $\mathrm{O}$ intuito do imperador era enfatizar o valor das matemáticas para o desenvolvimento do raciocínio. Tal idéia foi incorporada pela escolástica, séculos $\mathrm{X}$ ao $\mathrm{XV}$, cujo objetivo era justificar a fé cristã por meio da razão. Assim, adotou-se a lógica aristotélica como meio de organizar o sistema de idéias e se valorizou o formal, o abstrato e o imaterial. A Lógica foi a base para a organização dos conhecimentos a serem transmitidos pela escola, uma vez que, a maior preocupação se centrava no ensino dos elementos necessários para o desenvolvimento de discursos formais. Essa forma de se ver a Matemática e seu ensino perduraram até meados da Idade Média, mais especificamente, até o surgimento da Ciência Moderna.

Nesse novo período, que é o da construção e desenvolvimento do capitalismo, da expansão colonialista européia e da Ciência Moderna, a visão sobre a Matemática e seu 
crescimento é influenciada pelo impulso do desenvolvimento do conhecimento científico, da criação de instrumentos para observação de fenômenos naturais e, também, por Revoluções como a Industrial. É quando o ensino da Matemática começa a se desenvolver e a se modificar na Europa. Surgem as escolas práticas para atender uma nova classe emergente. Nelas, desenvolviam-se novos ramos do conhecimento matemático por meio de cursos de aritmética prática, álgebra, contabilidade, navegação e trigonometria. As aulas ocorriam no próprio local de trabalho dos mestres que ensinavam os conhecimentos práticos de sua profissão.

Na mesma época, surge o movimento Humanista ${ }^{23}$, no qual emerge uma proposta de ensino preocupada com a formação dos homens nascidos livres e nobres e centrada no ensino das ciências clássicas. Essa proposta conviveu paralelamente à das escolas práticas, cujo ensino era o das novas ciências. Porém, tal paralelismo não durou, a proposta dos humanistas foi totalmente implantada na educação e, assim como o ensino proposto pelos escolásticos, a educação humanística, praticamente, não valorizava os estudos das matemáticas.

Quando se fazia alguma concessão e incluíam-se as matemáticas, era apenas devido ao valor formal desses estudos, de acordo com a concepção platônico-aristotélica. Nenhuma preocupação com as aplicações práticas, mas apenas com o desenvolvimento do raciocínio, do pensamento, das faculdades mentais (MIORIM, 1998, p. 35).

Entretanto, comerciantes, banqueiros e pessoas relacionadas à indústria já sentiam necessidades de um outro tipo de formação, o qual fizesse uma composição entre a proposta humanística e a das escolas práticas, mas isso não aconteceu de imediato. Na segunda metade da Idade Média, em pleno Renascimento, Leonardo da Vinci se opõe aos humanistas da época e defende a idéia de uma educação voltada para a realidade, relacionada à experiência e à observação, na qual as matemáticas desempenhariam um papel fundamental. Pois, ele percebera haver um descompasso entre o desenvolvimento da sociedade e das novas ciências e o ensino proposto nas universidades e escolas. Contudo, Da Vinci não era o único que se opunha, Roger Bacon também defendia a importância dos estudos das matemáticas e, embora não tenham explicitado uma proposta para o ensino das matemáticas, de certo modo, foram os primeiros a defenderem um movimento de renovação do ensino da Matemática.

\footnotetext{
${ }^{23}$ O humanismo era um movimento aristocrático que objetivava recuperar a cultura clássica se contrapondo, então, a toda cultura dominante. "Contra a escolástica, contra a universidade e contra a proposta da educação vigente. Pela liberdade individual, pela alegria de viver, pela apreciação do belo e por uma educação menos repressiva, mais humana, mais culta, que levasse em consideração a natureza do estudante, que colocasse novamente a gramática, a retórica e a poética como centro do ensino, ou seja, que essas disciplinas assumissem o lugar que a lógica havia ocupado dentre as artes liberais desde o século XII, e que, principalmente, estivessem baseadas na leitura direta dos clássicos gregos e latinos" (MIORIM, 1998, p. 35).
} 
Assim, no séc. XVII, as matemáticas tiveram um novo papel, como ferramenta necessária à explicação de fenômenos. $\mathrm{O}$ foco da Matemática passou a ser as artes práticas (conhecimento prático das profissões) e mecânicas e, as relações quantitativas estabelecidas para explicar os fenômenos. Essa nova tendência moderna em educação foi sintetizada na obra Didática Magna de Comenius, a qual serviu de base para o desenvolvimento educacional dos séculos seguintes. No entanto, o ensino da Matemática, praticamente, não foi influenciado nem pelas idéias de Comenius e nem pelo novo papel da Ciência. No século XVIII, foram as idéias de Rousseau que revolucionaram o processo educativo. Pois, além de ele exigir que houvesse uma preocupação com o estudo das crianças, passou a valorizar, também, a educação como um processo. Nesse sentido, Miorim (1998, p. 43) explica que esse processo no ensino da Matemática se daria, "[...] partindo dos objetos sensíveis, deveria chegar, gradualmente, aos objetos intelectuais - e propor que o ensino das matemáticas ocorresse apenas à medida que fosse necessário ao desenvolvimento de outras atividades." Definitivamente, a Matemática era concebida como uma ferramenta e o elemento fundamental de seu ensino (abordagem dedutiva e euclidiana) era posto de lado.

Deste modo, apesar das contribuições de Rousseau à educação, para o ensino da Matemática ele deixou de lado a relação teoria-prática. Porém, esse aspecto foi considerado por um outro movimento surgido ainda no século XVIII, o Iluminismo. Com os iluministas se desperta um olhar diferenciado sobre os aspectos práticos e de aplicação do conhecimento, chamado por eles de "artes mecânicas". Eles atribuíam o mesmo valor tanto para as artes mecânicas quanto para as artes liberais. Estas se referiam às disciplinas clássicas da ciência dos antigos (trivium - gramática, retórica e dialética. Quadrivium - aritmética, geometria, música e astronomia). Portanto, os iluministas entendiam que, para uma formação ser satisfatória, o ensino não poderia se separar em conhecimento intelectual e experimental, seria então, o emprego de um ponto de vista utilitário no ensino. Com a caracterização da moderna Matemática e com a inclusão de elementos dessa nova ciência em cursos de nível médio se configurou a modernização do ensino da Matemática.

No entanto, ao final do século XIX, essa situação gerou preocupação, visto que o ensino desenvolvido nas escolas secundárias - pautado na ciência dos antigos (ensino da geometria grega, da álgebra elementar e do cálculo aritmético) - não correspondia ao novo contexto sócio-político-econômico e nem à Matemática estudada nas universidades, a qual era voltada aos últimos progressos da ciência. Félix Klein foi um dos defensores da necessidade em se melhorar o ensino da Matemática nas escolas secundárias. Ele entendia que, melhorando a formação matemática dos alunos secundarista, isso tanto impulsionaria o desenvolvimento industrial, quanto permitiria avanços à Matemática desenvolvida nas universidades (D’AMBRÓSIO, 1996 e MIORIM, 1998). Mas, para se alcançar essa melhoria 
era preciso, também, investir na formação dos professores que lecionariam a Matemática nas escolas secundárias. Nesse sentido, Klein,

[...] acreditava que as universidades deveriam aumentar o padrão dos estudos matemáticos oferecidos aos futuros professores, de forma a possibilitar-lhes não apenas o contato com os assuntos sobre os quais iriam ensinar, mas também com os últimos desenvolvimentos da Matemática, [...] (MIORIM, 1998, p. 68).

Porém, esse tipo de intervenção não obteve o resultado esperado em relação ao ensino da Matemática nas escolas secundaristas e à formação dos professores. Por outro lado, a preocupação em modernizar o ensino da Matemática propiciou o surgimento, em diversos países, de diferentes propostas para as escolas secundárias. Segundo Miorim (1998, p. 61-65), tais propostas iam desde a preocupação de tornar o ensino mais simples e intuitivo, com a introdução de temas estudados na universidade até a presença da experimentação no ensino de Matemática e da importância atribuída às aplicações práticas. Entretanto, tais idéias se limitavam aos países de origem das mesmas, como: França, Inglaterra e Alemanha. Mas, essa situação começou a tomar outros rumos a partir do século XX.

As propostas, que surgiram inicialmente de forma isolada em diferentes países, foram ampliadas após a criação da Comissão Internacional para o Ensino de Matemática, em 1908.

Os trabalhos realizados pela Comissão acabaram influenciando de maneira decisiva o ensino de Matemática de muitos países, daquele momento em diante (MIORIM, 1998, p. 50).

Essa Comissão nasceu durante o Quarto Congresso Internacional de Matemática (ICM), ocorrido em Roma, 1908. O que motivou a criação desta Comissão foi o fato de não ter sido discutido, nos três Congressos anteriores, questões relativas ao ensino da Matemática. A missão dessa Comissão, presidida por Felix Klein, foi examinar a situação em que se encontrava o ensino da Matemática em todos os níveis das escolas dos vários países participantes do evento, cujos informes foram apresentados no Congresso seguinte. Segundo Miorim (1998), o trabalho realizado pela Comissão Internacional do Ensino de Matemática desencadeou o Primeiro Movimento Internacional para a Modernização do Ensino de Matemática, em seis anos de existência, antes da Primeira Guerra Mundial, a Comissão fez o seguinte:

[...] identificou questões-chaves para o ensino de Matemática, recolheu uma quantidade de informações nunca antes, e nem depois, reunidas, propiciou o surgimento de uma enorme quantidade de publicações sobre Educação Matemática e levou as discussões acerca desse tema aos mais variados países (MIORIM, 1998, p. 75). 
O século XX foi o período que assistiu a grandes reformas no ensino da Matemática no sentido da modernização e, conseqüentemente, ao delineamento de tendências referentes às melhores maneiras de ensinar e aprender Matemática. Nesse sentido, a partir do início do século XX, o ensino da Matemática é influenciado tanto pelas orientações da Comissão Internacional do Ensino da Matemática, quanto pelas correntes filosóficas fundacionais e falibilista, pelos estudos da Psicologia, Sociologia e Antropologia. Tal influência pode ser percebida na elucidação de certas tendências pedagógicas. Nesse sentido, Onuchic (1999) e Onuchic e Allevato (2005) evidenciam quatro tendências do ensino da Matemática, sejam elas: o ensino da Matemática por repetição, o ensino da Matemática com compreensão, a Matemática Moderna e a Resolução de Problemas. Tais tendências estão explicitadas na seqüência.

i) O ensino da Matemática por repetição: essa tendência se caracterizou no início do século XX, cuja prática pedagógica se apoiava na transmissão de informações pelo professor ao aluno, este por sua vez, deveria memorizá-las e, então, repetir por meio de exercícios e/ou testes.

ii) $\quad$ ensino de Matemática com compreensão: essa tendência descartava a anterior. Nela, condenavam-se os treinos e o aluno deveria compreender o que fazia. No entanto, assim como a anterior essa tendência também não logrou êxito. Pois, além de a prática pedagógica ter continuado do mesmo jeito, ainda, o aluno“[...] não participava da construção de seu conhecimento. [...] O trabalho se resumia a um treinamento de técnicas operatórias que seriam utilizadas na resolução de problemas-padrão ou para aprender algum conteúdo novo" (ONUCHIC, 1999, p. 201).

iii) A Matemática Moderna: foi uma tendência influenciada pelo Movimento da Matemática Moderna. Esse Movimento correspondia a uma proposta de renovação do ensino da Matemática que influenciou tanto o Brasil quanto outros países nas décadas de 1960 - 1970. O ensino da Matemática, por essa tendência, se dava por meio da abordagem aos símbolos e à teoria dos conjuntos, com ênfase nas propriedades e na formalização. Apresentava-se uma Matemática com muitas abstrações e apoiada em estruturas lógica, algébrica, topológica e de ordem, cuja linguagem era de característica universal, concisa e precisa. Essa tendência também renegou as anteriores. 
iv) A Resolução de Problemas: na década de 1970 começaram a surgir alguns indícios dessa tendência, que é quando educadores matemáticos dedicaram mais atenção ao desenvolvimento da capacidade de se resolver problemas.

A caracterização da Educação Matemática, em termos de Resolução de Problemas, reflete uma tendência de reação a caracterizações passadas, que a configuravam como um conjunto de fatos, como o domínio de procedimentos algorítmicos ou como um conhecimento a ser obtido por rotina ou por exercício mental. No fim dos anos 70, a Resolução de Problemas emerge, ganhando espaço no mundo inteiro (ONUCHIC e ALLEVATO, 2005, p. 215).

Essa tendência, desde então, vem passando por "ajustes" ao modo de concebê-la. Na década de 1980, nos Estados Unidos, o National Council of Teachers of Mathematics $\mathrm{NCTM}^{24}$, por meio do documento An Agenda for Action, recomenda que o foco da Matemática escolar deva ser o de resolver problemas. Assim, nessa década, se enfocou o processo de resolução, não ficando somente na solução do problema. Apesar de o processo continuar associado à busca da resposta. Desta maneira, foram desenvolvidos materiais com coleções de problemas, listas de estratégias, sugestões de atividades e orientações para a avaliação, cujo intuito foi auxiliar o professor a centrar o foco de seu trabalho na Resolução de Problemas.

Ao final da década de 80, a Resolução de Problemas começa a ser aceita como uma metodologia de ensino, a qual passa a ser lema de pesquisas nos anos 90. Nesse mesmo período, no Brasil, a Resolução de Problemas está entre as orientações dos Parâmetros Curriculares Nacionais como uma possibilidade metodológica para o ensino da Matemática. Nessa metodologia, o foco está na ação do aluno, isto é, são propostos problemas que propiciem a construção do conhecimento e contribuam na formação dos conceitos, ainda antes, da apresentação do mesmo em linguagem matemática. Deste modo, o "ensinoaprendizagem de um tópico matemático começa com uma situação-problema que expressa aspectos-chave desse tópico e são desenvolvidas técnicas matemáticas como respostas razoáveis para problemas razoáveis" (ONUCHIC, 1999, p. 207). Por esse viés, o aprendizado é visto como um movimento do concreto para o abstrato. Onuchic e Allevato (2005, p. 217) ressaltam que a abordagem à "Resolução de Problemas como meio de desenvolver os conteúdos matemáticos e fazer conexões com outras áreas” está entre as recomendações do

${ }^{24}$ O NCTM - Conselho Nacional de Professores de Matemática "é uma organização profissional, sem fins lucrativos. Conta com mais de 12.500 associados e é a principal organização para professores de Matemática desde K-12 (pré-primário-Escola Secundária)”(ONUCHIC e ALLEVATO, 2005, p. 215). 
NCTM, em documentos publicados em 1989, 1991, 1995 e 2000. Esses documentos configuram os Standards para a melhoria dos programas de Matemática de todos os níveis escolares. Portanto, a Resolução de Problemas se mantém como uma tendência atual no ensino da Matemática.

Um outro estudo sobre as tendências do ensino da Matemática é o estado da arte realizado por Fiorentini (1995), que enfoca prioritariamente o contexto histórico brasileiro. O autor identifica seis tendências e aponta mais outras duas consideradas emergentes: formalista-clássica, empírico-ativista, formalista moderna, tecnicista, construtivista e socioetnoculturalista e mais a histórico-crítica e a sociointeracionista-semântica. Tais tendências, de certo modo, se entrelaçam às apontadas no estudo anterior, conforme pode ser observado a seguir pela descrição das mesmas.

i) Formalista-clássica: essa tendência enfatiza as idéias e as formas da Matemática Clássica, seguindo o modelo euclidiano de sistematização lógica do conhecimento matemático. Aspectos da concepção platônica estão presentes nessa tendência como a promoção de uma visão estática, a-histórica e dogmática das idéias matemáticas. Tratava-se de um ensino livresco e expositivo, o qual perdurou no Brasil até meados de 1950.

ii) Empírico-ativista: é uma tendência que se opõe à forma clássica de ensinar Matemática, conforme ocorria na tendência anterior. Nessa, o conhecimento matemático emergiria do mundo sensível por manipulações e experimentações desenvolvidas pelos alunos. O currículo seria organizado a partir dos interesses psicológicos e pedagógicos dos alunos. Privilegiar-se-iam atividades em pequenos grupos com a utilização de muito material didático, cujo intuito seria possibilitar a descoberta do conceito matemático a partir de situações vivenciadas. Segundo Fiorentini (1995), o foco dessa tendência era o desenvolvimento da criatividade e das potencialidades individuais dos alunos. Essa perspectiva de ensino contribuiu para que a Matemática fosse unificada em uma única disciplina na Reforma Francisco Campos, em 1931.

[...] no âmbito da Matemática, os ideais da Reforma Francisco Campos, não foram incorporados em sua totalidade, particularmente em relação ao método de ensino. As diretrizes propostas pela Reforma para o Ensino Secundário eram fazer a junção das disciplinas Aritmética, Álgebra e Geometria em uma só, a Matemática, além de incluir o método heurístico. Tais medidas idealizadas pelo eminente catedrático do Colégio Pedro II, Euclides Roxo, passariam a vigorar no Ensino Secundário em nível nacional (PINTO, 2004, p. 10). 
Os ideais dessa tendência conviveram em paralelo aos da Formalista-clássica, uma vez que pouco influenciou autores de obras didáticas da época. Euclides Roxo é um dos poucos representantes dessa vertente de ensino. Tal enfoque ressurge no Brasil nos anos 1970.

iii) Formalista-moderna: essa é uma tendência que sofreu influência do Movimento da Matemática Moderna (MMM) e sua ênfase pedagógica estava na formação do especialista em Matemática. As primeiras propostas pautadas nessa tendência foram apresentadas, no Brasil, no início da década de 1960 com o objetivo de melhorar a qualidade do ensino dessa disciplina. Para isso, priorizaram-se os aspectos estruturais e lógicos do conhecimento matemático e o uso rigoroso e preciso da linguagem formal por meio de justificativas e propriedades estruturais. O ensino era baseado por uma concepção estrutural-formalista da Matemática.

iv) Tecnicista: fundamentada em uma concepção funcionalista, essa tendência tinha a pretensão de aperfeiçoar os resultados da escola e torná-la eficiente e funcional. A relação do MMM com o Tecnicismo Mecanicista resultou em um ensino da Matemática voltado à ação de seguir regras mediante uma série de técnicas, além de fazer e re-fazer exercícios até que se alcançassem os objetivos instrucionais. Segundo Fiorentini (1995, p. 17), a finalidade dessa tendência "seria a de desenvolver habilidades e atitudes computacionais e manipulativas, capacitando o aluno para a resolução de exercícios ou de problemas-padrão". Foi uma concepção de ensino que vigorou muito tempo entre os livros didáticos, cujo texto matemático era organizado em passos seqüenciais, na forma de instrução programada, com uma série de exercícios do tipo siga o modelo.

v) Construtivista-interacionista: nessa tendência o aluno é levado a observar e manipular o que vê, para produzir significados, representar imagens, fazer comparações entre objeto real e o imaginado, errar e enxergar no erro a possibilidade de construção do conceito estudado. Para o ensino de Matemática, o foco passou do desenvolvimento de estruturas mentais para a construção ou formação de conceitos. Por essa perspectiva são consideradas as influências sociais e culturais na elaboração do conhecimento matemático.

vi) Socioetnocultural: a finalidade dessa tendência é desmistificar e compreender a realidade e o principal fundamento para a mesma é o Programa Etnomatemática estruturado por Ubiratan D'Ambrósio. O ponto de partida para o ensino seriam os problemas oriundos do meio cultural, das práticas cotidianas. Professor e alunos 
trocariam seus conhecimentos e a Matemática seria concebida como uma atividade própria do ser humano e fruto espontâneo das relações sociais e políticas do meio no qual o indivíduo está inserido. Isso se evidencia pelo trabalho pedagógico a partir da abordagem de temas envolvendo o conhecimento cotidiano dos alunos.

Fiorentini (1995) aponta, ainda, outras duas tendências emergentes na década de 1990, sejam elas: Histórico-crítica e a Sociointeracionista-semântica. A primeira entende que para ensinar Matemática é necessário contextualizar o conhecimento produzido historicamente, identificando-se os significados atribuídos à linguagem matemática. A tendência Sociointeracionista-semântica, fundamentada em Vygotsky, concebe que ensinar é mediar as relações que o aluno estabelece com o conhecimento matemático. E, também, planejar atividades repletas em significados. Busca-se a compreensão do pensamento matemático presente nos discursos dos indivíduos.

Pinto (2004), em um outro estudo sobre as tendências no ensino da Matemática, parte do trabalho de Fiorentini para analisar as pesquisas apresentadas no Grupo de Trabalho de Educação Matemática (GT-19) da Associação Nacional de Pesquisa em Educação (ANPED), no período compreendido entre 1998 e 2003. Segundo esta autora, as pesquisas apontam para um ensino da Matemática como uma prática social concreta e com forte influência da Didática da Matemática francesa. Essa influência leva em consideração certos elementos, tais como: relação didática entre professor, aluno e conhecimento matemático; seqüência didática; contrato didático; transposição do saber científico para o escolar, entre outros.

Porém, além das tendências de ensino, as pesquisas também revelam modos com que o ensino da Matemática é percebido, concebido entre os professores. Por exemplo, Silvério (2003), ao analisar as concepções de professores referentes à natureza do ensino da Matemática, evidencia três categorias: Visão Tradicional Clássica, Visão Tecnicista e Visão Alternativa. A primeira, Tradicional Clássica, é baseada na idéia de que o ensino ocorre por meio da transmissão do conhecimento e exposição de conteúdos ou por contemplação dos fenômenos do mundo. O professor deposita no aluno o conhecimento, este por sua vez, aprende memorizando o que lhe foi apresentado. Os conteúdos não possuem relação entre si e nem com outras áreas científicas. Na visão Tecnicista, o aluno aprende por repetição de processos algorítmicos. "Esse processo se difere do anterior uma vez que possui bases didáticas no behaviorismo. [...] $\mathrm{O}$ ensino é formado por padrões de comportamento que podem ser alterados através de treinamento segundo os objetivos anteriormente estabelecidos" (SILVÉRIO, 2003, p. 89). A aprendizagem se baseia em fixação de conceitos e técnicas para a resolução de exercícios tipo padrão. E, a Visão Alternativa se contrapõe às duas anteriores, 
já que se baseia em correntes educacionais contemporâneas como a construtivista e a reflexiva. $\mathrm{O}$ aluno aprende construindo mentalmente e observando fenômenos, refletindo e elaborando modelos mediante estruturas do pensamento lógico-matemático. Nessa categoria, se valoriza a influência social, cultural e política e, ainda, o conhecimento trazido pelo aluno.

Em um outro estudo, Graça et al (2004), ao apresentarem a Dimensão Pedagógica relativa às representações sociais sobre a Matemática e seu ensino e aprendizagem enfatizam três visões associadas aos processos de ensino e aprendizagem. Sejam elas: Visão Construtivista da Matemática, Visão Platonista da Matemática e Visão Instrumental da Matemática. Na primeira, a Visão Construtivista, o ensino é organizado em uma perspectiva de resolução de problemas e de atividades investigativas, enfatizando-se os processos matemáticos (busca de regularidades, elaboração, teste, justificativa e prova de conjecturas, reflexão e generalização). O aluno desempenha um papel ativo na construção do conhecimento matemático. O professor, por sua vez, para promover uma aprendizagem significativa deve privilegiar certas atitudes. Por exemplo: averiguar o conhecimento prévio que o aluno possui antes de ensinar os conceitos; adotar estratégias que propiciem o desenvolvimento de atitudes de iniciativa, de interação entre alunos e professor, favorecer a negociação de significados matemáticos, utilizar materiais variados e tarefas que desafiem o aluno a pensar. A Matemática é organizada como um conhecimento sujeito a revisão, em constante criação e recriação e conduzida por problemas relativos a diversas áreas e contextos. Na Visão Platonista, os conteúdos são organizados em função de uma estrutura hierárquica da Matemática, cuja construção é dedutiva e cumulativa. É uma percepção relacional da Matemática, na qual o aluno realiza as tarefas impostas pelo professor, enquanto este transmite conhecimentos, apresenta exercícios e organiza estratégias de ensino para que os alunos compreendam os conceitos abstratamente. E, na Visão Instrumental os conteúdos estão organizados por uma hierarquia de competências e conceitos, sob uma perspectiva absolutista da Matemática. O professor exerce o papel de instrutor, demonstrando, explicando e definindo a matéria por meio de um ensino expositivo. $\mathrm{O}$ aluno deve utilizar as regras e a matéria para resolver mecânica e, repetitivamente, os exercícios propostos pelo professor. As tarefas são "habitualmente organizadas na forma de esquemas e seguem de perto os exercícios apresentados no livro de texto, propondo freqüentemente a resolução de um conjunto de exercícios a partir de exercícios resolvidos que servem de modelo" (GRAÇA et al, 2004, p. 16). A intenção desta organização é propiciar aos alunos que reproduzam, eficazmente, todas as regras e procedimentos ensinados em sala de aula. 
Aspectos da história mostram que as dificuldades para ensinar Matemática sempre existiram e, também, que não há uma única maneira de ensiná-la. As tendências de ensino, expressas por Fiorentini (1995), Onuchic (1999), Pinto (2004) e Onuchic e Allevato (2005) evidenciam o grande avanço na melhoria do ensino dessa disciplina, especialmente a partir do século XX, se comparado aos séculos anteriores. O que não implica entender que as dificuldades com o ensino da Matemática tenham terminado. Muito pelo contrário, as próprias visões sobre esse ensino, as quais estão relacionadas a concepções reveladas por professores, evidenciam que condutas de ensino praticadas na Antigüidade ainda permeiam as salas de aula atualmente. Por exemplo, Miorim (1999) apontou o treino de algoritmos por meio da repetição de procedimentos, cujo resultado é a aprendizagem mecânica do conteúdo. Por outro lado, se não existe uma única maneira de ensinar a Matemática o mesmo vale para a sua aprendizagem.

Apesar da relação de interdependência entre o ensino e a aprendizagem, para efeito de análises considerar-se-á, neste caso, tais elementos da didática como distintos, embora participantes de um mesmo processo. O direcionamento desse viés ocorre em virtude do outro eixo da tríade de conhecimentos essenciais à aprendizagem da docência, seja ele, o conhecimento sobre o aluno, suas aprendizagens e desenvolvimentos, conforme tratado na seqüência.

\subsubsection{O Conhecimento sobre o Aluno, suas Aprendizagens e Desenvolvimentos: Características da Aprendizagem em Matemática}

Assim como foi com o ensino, a aprendizagem em Matemática também teve um grande impulso a partir do século XX, em especial, pelos estudos realizados no campo da Psicologia. Mas, o que é aprender Matemática? Como os alunos aprendem Matemática? As teorias psicológicas, como os estudos de Skinner (teoria behaviorista) Piaget (teoria do desenvolvimento cognitivo), Ausubel (teoria da aprendizagem significativa) e Vygotsky (teoria da mediação), têm fornecido subsídios para o entendimento destas questões, porém esse não é o único viés de compreensão. As práticas pedagógicas adotadas pelos professores ao ensinar Matemática, de certo modo, refletem as visões que os professores possuem sobre a forma como o aluno aprende Matemática. Em muitos casos, essa visão é desconectada das teorias, mas decorrente da experiência com a sala de aula (Thompson, 1997). O conhecimento sobre como o aluno aprende Matemática tem variado com o tempo, tanto histórico quanto 
psicológico. “Aprender Matemática é sobretudo aprender uma certa forma de pensar, que evolui, como todas as formas de pensar, e é por isso que não se aprende Matemática hoje como se fez ontem e se fará amanhã" (GRAÇA et al, 2004, p. 13). Deste modo, considerandose as múltiplas visões que o conhecimento matemático vem assumindo ao longo da história de sua constituição e, também, as diversas percepções advindas dos modos de ensinar a Matemática, entende-se que esta aprendizagem é, também, influenciada por diferentes olhares.

Historicamente, segundo Pozo (2002), o tipo de aprendizagem predominante da Antigüidade até o surgimento da imprensa na segunda metade da Idade Média foi a aprendizagem memorística ou repetitiva e a aprendizagem mecânica, esta derivada dos ensinamentos dos mestres de ofícios. Naquela época, o "exercício da memorização e o uso de regras mnemônicas passam a ser habilidades concebidas como virtudes a ser cultivadas" (POZO, 2002, p. 28). Para o autor, a invenção da imprensa é um marco cultural que contribuiu para o declive da relevância social da memorização repetitiva. A partir desse momento, toda informação e conhecimento passaram a ser armazenados e divulgados por meio da escrita, permitindo-se que a memória fosse liberta da função de conservação da sabedoria de um povo. A nova cultura da aprendizagem é marcada tanto pelo impulso da pesquisa científica quanto pelas novas teorias psicológicas e, também, pelas mudanças sociais, tecnológicas e culturais que foram moldando as modernas sociedades industriais. A partir de então, a imagem tradicional da aprendizagem “[...] sofre uma deterioração progressiva, devido ao desajuste crescente entre o que a sociedade pretende que seus cidadãos aprendam e os processos que põem em marcha para consegui-lo" (POZO, 2002, p. 30).

Em relação à Matemática, essa visão tradicional da aprendizagem começou a ser abalada, mais expressivamente, no início do século $\mathrm{XX}$, quando estudos psicológicos desenvolvidos por Edward Lee Thorndike questionaram a possibilidade de transferência do que era aprendido em Matemática para outros domínios. Conforme observado por Miorim (1999, p. 56), tem-se que:

A posição de Thorndike gerou uma reação imediata da comunidade de educadores matemáticos, que acabaria levando ao desenvolvimento, durante as primeiras décadas do século $\mathrm{XX}$, de uma série de outros estudos psicológicos sobre as possibilidades de transferência, ao redimensionamento das justificativas utilizadas para o ensino de Matemática e a um longo debate sobre o valor da disciplina mental dos estudos matemáticos. 
Estava abalada a crença de que a aprendizagem da Matemática se restringia a moldar, disciplinar a mente dos estudantes. Era necessário se lançar novos olhares e, os estudos desenvolvidos a partir do questionamento de Thorndike, juntamente, com as orientações da Comissão Internacional do Ensino da Matemática culminaram em propostas de renovação e modernização do ensino da Matemática a partir do século XX, conforme apresentado no item 3.2.2 deste capítulo. As tendências de ensino da Matemática apresentam diferentes visões sobre a aprendizagem e, também, oscilam entre duas imagens: a tradicional e a nova cultura. Assim, observa-se que, prioritariamente, as tendências Formalista Clássica (FIORENTINI, 1995) e Matemática por Repetição (ONUCHIC, 1999), além das visões, Tradicional Clássica (SILVÉRIO, 2003), Platonista e Instrumental (GRAÇA et al, 2004) apresentam características próprias da imagem tradicional da aprendizagem. Pois, segundo os autores, a aprendizagem nessas tendências ocorre, primordialmente, por meio da memorização e da repetição ou reprodução de idéias e procedimentos anunciados pelo professor ou pelos livros-texto. Os alunos, agentes passivos de suas aprendizagens, deveriam reproduzir fielmente os raciocínios e procedimentos ditados por seus professores e apresentarem um encadeamento lógico do raciocínio matemático pela visão Formalista Clássica. "Media-se o conhecimento do aluno, recebido através de repetição, com a aplicação de testes em que, se ele repetisse bem o que o professor havia feito, concluía-se que sabia" (ONUCHIC, 1999, p. 201). Essa situação favorecia somente alguns poucos alunos que tinham habilidades para memorizar o que faziam. Mas, a grande maioria, acabava se esquecendo do que havia aprendido.

Possivelmente, nas tendências: Tecnicista e Formalista Moderna (FIORENTINI, 1995), Tecnicista de Silvério (2003), Matemática com Compreensão e Matemática Moderna (ONUCHIC, 1999), tenham-se exemplos de iniciativas de mudanças de postura em relação à aprendizagem matemática do aluno. Apesar de privilegiarem a memorização e repetição de procedimentos algorítmicos, a sistematização destas tendências ocorre sob uma outra orientação. Por exemplo, a Tecnicista fundamenta sua aprendizagem no behaviorismo (mudanças comportamentais por meio de estímulos), consistindo no desenvolvimento de habilidades e atitudes e na fixação/memorização de conceitos, princípios, fórmulas e fatos. As habilidades se referem à manipulação de algoritmos ou de expressões algébricas e à resolução de problemas-padrão. Na Matemática com Compreensão, o aluno deveria entender o que fazia solucionando problemas por meio de estratégias ensinadas pelo professor. Porém, a aprendizagem se resumiu ao treino de técnicas operatórias para resolver problemas-padrão ou para aprender um novo conteúdo. Por outro lado, percebe-se nessas visões alguns indícios de 
reação à imagem tradicional da aprendizagem, ou seja, a preocupação em dar sentido ao que se aprende.

A nova cultura de aprendizagem se apresenta como uma reação à imagem tradicional da aprendizagem e atribui ao aluno um papel de destaque neste processo. Teorias psicológicas, sociológicas e antropológicas auxiliam a entender como se aprende. Valoriza-se mais os processos de aprendizagem e os meios para desenvolver as capacidades e as habilidades intelectuais dos alunos. As tendências Empírico-ativista, Construtivista, Socioetnocultural, Histórico-crítica e Sociointeracionista-semântica (FIORENTINI, 1995) e, também, a Resolução de Problemas (ONUCHIC, 1999), a visão Alternativa (SILVÉRIO, 2003) e a influência da Didática Francesa (PINTO, 2004) são exemplos desse outro olhar da aprendizagem.

Na Empírico-ativista, tem-se como pressuposto básico que o aluno aprende fazendo. O acesso às idéias matemáticas ocorre por meio da descoberta. Essa descoberta acontece pela contemplação da natureza e de objetos ou réplicas de figuras geométricas, por associação entre o elemento observado e o símbolo matemático, por manipulação de objetos e atividades experimentais que permitam a redescoberta de noções matemáticas já conhecidas. Pois, entende-se que, "a partir da manipulação e visualização de objetos ou de atividades práticas envolvendo medições, contagens, levantamento e comparações de dados, etc., a aprendizagem da Matemática pode ser obtida mediante generalizações ou abstrações de forma indutiva e intuitiva" (FIORENTINI, 1995, p. 12). Valorizam-se os processos de aprendizagem e o desenvolvimento da criatividade e das potencialidades e interesses individuais. $\mathrm{Na}$ Construtivista, cuja base está nos estudos de Piaget e Vygotsky, o foco está na construção das estruturas do pensamento lógico-matemático e na idéia de que o aluno tem que aprender a aprender. Para tanto se propicia que o aluno veja o objeto real, manipule-o, produza significado, represente-o por imagem, faça comparações entre a representação e o objeto real, desenhe, erre, corrija e construa a partir do erro. O erro é visto de forma positiva no processo de construção do conhecimento. Na tendência Socioetnocultural, entende-se que a relação com o cotidiano e com a cultura do aluno torna, para ele, a aprendizagem mais significativa, além de se privilegiar os modos de pensar e saber do aluno como ponto de partida do processo de aprendizagem. Na Sociointeracionista, aprender é estabelecer relação entre as idéias e suas representações, enquanto que a Histórico-crítica concebe a aprendizagem como um meio de dar sentido e significado às idéias matemáticas.

Em relação à Resolução de Problemas, segundo Onuchic (1999), a perspectiva de aprendizagem seria a visão do movimento do concreto para o abstrato, ou seja, de um 
problema referente ao mundo real que exemplifica o conceito ou técnica operatória para a representação simbólica de uma classe de problemas e técnicas que operam com esses símbolos. Na compreensão da autora, a aprendizagem da Matemática, implica na idéia de que entender é essencialmente relacionar. Nesse sentido, ela explica que o entendimento aumenta quando:

O aluno é capaz de relacionar uma determinada idéia matemática a um grande número ou a uma variedade de contextos; o aluno consegue relacionar um dado problema a um grande número de idéias matemáticas implícitas nele; o aluno consegue construir relações entre as várias idéias matemáticas contidas num problema (ONUCHIC, 1999, p. 208).

Deste modo, concebe-se ser mais interessante para a aprendizagem da Matemática, quando esta é gerada pelo próprio aluno. O trabalho pelo viés da Resolução de Problemas propicia o desenvolvimento da própria compreensão. Segundo Onuchic (1999), a habilidade do aluno em usar a Matemática para resolver problemas aumenta à medida que a compreensão do mesmo se torna mais profunda. Para Huete e Bravo (2006), o objetivo da Resolução de Problemas é facilitar o conhecimento das habilidades básicas, dos conceitos fundamentais e das relações entre os dois. Essa aprendizagem consiste em um processo no qual se combinam diferentes elementos dos alunos: conhecimento prévio, as regras, as habilidades, a reflexão e a compreensão dos conhecimentos. "É importante que essa aprendizagem sustente-se na realidade (situações da vida) e que quem aprenda o faça atribuindo, na aplicação matemática, à utilidade que representa" (HUETE e BRAVO, 2006, p. 72). Para tanto, são consideradas como base as proposições piagetianas e a psicologia cognitiva pelo modelo de processamento da informação.

Segundo Pais (2006), um dos desafios dos educadores matemáticos é articular memorização e compreensão. A Aprendizagem Memorização, referida por Huete e Bravo (2006), não é aquela relacionada ao armazenamento inexpressivo de informações ou àquela conseqüente da repetição de fórmulas, modelos e regras como concebidas nas tendências e visões da aprendizagem tradicional. Os autores se referem à memória operativa, cuja idéia de operatividade "é alcançada quando se realiza uma aprendizagem sobre estruturas significativas de conhecimentos" (HEUTE e BRAVO, 2006, p. 69). Nesse sentido, Pais (2006) vai além. Para ele, a memorização deve estar em sintonia com a compreensão do conteúdo, mesmo que resulte entre os alunos compreensões em diferentes níveis em virtude das diferenças inerentes a cada um. Essa memorização associada à compreensão é o que configura para Huete e Bravo (2006) a Aprendizagem Algorítmica. Para esses autores, a aprendizagem dos algoritmos requer possibilitar aos alunos que conheçam o fundamento lógico de uma operação matemática de maneira significativa. Deste modo, eles exemplificam com a aprendizagem da tabuada, conforme pode ser observado a seguir. 
Dar significado a essa automatização é um passo prévio e consiste em possibilitar a conhecer o fundamento de tal operação em função da soma, sempre de uma maneira lógica e significativa. Experimentemos com nossos alunos construir as tabuadas do 11 , do 12 , do 1.000 , do $2.000 .000 \ldots$ ou do 8 desde o 11 até o 20, do 4 desde o 100 até o 110 . Sempre que o fizermos a partir da fundamentação da soma, surpreenderemo-nos ao verificar como a motivação é maior (HUETE e BRAVO, 2006, p. 71).

Essa relação do algoritmo com o seu fundamento seria o modo de atribuir significado para a memória operativa. A necessidade de significados também está associada à Aprendizagem de Conceitos que é concebida como uma construção hierárquica de conceitos, uns sobre a base de outros. Segundo Huete e Bravo (2006), não é fácil definir o conceito matemático pelo caráter abstrato que a Matemática possui. Assim, sugere-se a utilização de exemplos, trabalhos práticos ou a resolução de problemas como meios auxiliares nas definições matemáticas do conceito. Essa sugestão pode ser interpretada como um modo de proporcionar uma contextualização do conhecimento. Pois assim, o aluno pode atribuir significado a sua aprendizagem à medida que consegue articular o contexto proposto e os conceitos envolvidos. Nesse sentido, Pais (2006, p. 63) reforça a idéia afirmando que a contextualização "[...] trata-se de inserir os conceitos em situações nas quais o aluno tem maiores condições de compreender o sentido do saber. Essa é uma noção voltada para a expansão do significado do saber escolar." Tal idéia, a contextualização, volta de certo modo, à Resolução de Problemas enquanto aprendizagem e, também, movimento de modernização do ensino da Matemática.

Uma outra percepção sobre a aprendizagem é referente à idéia daquelas pessoas que concebem que saber Matemática é fazer Matemática, ou seja, usar uma linguagem própria e com estrutura lógica para desenvolver uma atividade com propósito definido. Seria a construção de um conhecimento. Enquanto que, para outras pessoas saber Matemática é conseguir identificar os conceitos e procedimentos básicos necessários para o registro de uma atividade, seria o uso do conhecimento. Essa diferença de percepção entre a construção de um conhecimento e o uso do mesmo por meio do registro, pode ser melhor percebida pela seguinte analogia entre a Matemática e a Música.

Como a matemática, a música tem muitos ramos categorizados em uma variedade de formas (clássica, jazz, rock, instrumental, vocal); ela tem um esparso sistema notacional para preservar informação (notas, indicação de compasso, claves) e teorias que descrevem a estrutura das composições (escalas, modelos). Entretanto, não importam quantos artefatos musicais se tenha aprendido, isso não é a mesma coisa que fazer música. É somente quando se executa que se sabe música. Analogamente, em matemática, pode-se aprender os conceitos sobre números, como resolver equações e, assim por diante, mas isso não é fazer matemática. Fazer matemática envolve resolver problemas, abstrair, inventar, provar e assim por diante. (ROMBERG, 2007, p. 127) 
Portanto, do mesmo modo como a Música, a Matemática também se trata de um conhecimento com características próprias tanto no que diz respeito à sua forma, registro, ensino, aprendizagem quanto às teorias que compõem esse saber. Frente ao quadro exposto, percebe-se que aprender Matemática não está restrito à memorização de certos conceitos e/ou procedimentos para aplicações, como se acreditava antes. Hoje, a tendência está concatenada às atuais visões tanto da Matemática quanto de seu ensino, isto é, a uma aprendizagem de caráter dinâmico e com interações entre professor e alunos e dos dois com o conhecimento.

As perspectivas sobre a aprendizagem matemática delineadas aqui vão subsidiar mais adiante a sistematização das categorias sobre a concepção de aprendizagem de Matemática reveladas pelos sujeitos desta pesquisa.

\subsection{RELAÇÕES ENTRE OS CONHECIMENTOS RELATIVOS À APRENDIZAGEM DA DOCÊNCIA E AS ZONAS DOS PERFIS CONCEITUAIS}

O delineamento dos três eixos relativos à aprendizagem da docência (conhecimentos sobre a Matéria, o modo de ensiná-la e a aprendizagem do aluno) não só torna claro o movimento com que tais conhecimentos foram sendo percebidos com o passar do tempo, como também, fornece subsídios para a sistematização das zonas dos perfis conceituais relativos à Matemática, ao ensino e à aprendizagem dessa ciência. Entende-se portanto que:

[...], o perfil conceitual se constitui em um instrumento para a compreensão das relações entre os novos significados que são gerados em sala de aula e aqueles que já existiam em função da vivência cotidiana dos alunos, considerando as relações entre formas de pensar e modos de falar (AMARAL e MORTIMER, 2006, p. 242).

Ao propiciar compreensões sobre a aprendizagem da docência, considera-se para esse trabalho que cada um dos conhecimentos se refere a um conceito específico, isto é, o conhecimento sobre a matéria é relativo ao perfil conceitual da Matemática. O conhecimento sobre o modo de ensinar a matéria se refere ao perfil sobre o ensino da Matemática. E, o conhecimento sobre o aluno, seus desenvolvimentos e aprendizagens tem relação com o perfil conceitual sobre a aprendizagem em Matemática. Deste modo, constituir-se-ão três perfis conceituais e cada qual composto por diferentes zonas conceituais. Segundo Amaral e Mortimer (2006), para a caracterização das zonas que compõem o perfil de um determinado conceito se faz necessário considerar a evolução histórica do mesmo e as sua concepções 
informais que constam na literatura, por exemplo, os resultados divulgados por pesquisas. E, ainda, os dados obtidos em sala de aula, isto é, as concepções reveladas pelos sujeitos de pesquisa.

Vale ressaltar que existe uma relação hierárquica e evolutiva entre as zonas que caracterizam um perfil conceitual. Deste modo, cada categoria é representativa de uma visão histórico-cultural relativa ao conhecimento em estudo. Informa-se ainda que a apresentação de tais zonas é feita no capítulo 5 deste trabalho em virtude das primeiras análises sobre as idéias que os sujeitos de pesquisa revelaram ao longo do processo investigativo. Assim, na seqüência se apresenta o delineamento teórico que fundamenta o desenvolvimento metodológico desta investigação. 


\section{A PESQUISA}

O presente capítulo tem por finalidade apresentar as características gerais da metodologia utilizada, principalmente, no que se refere ao campo de pesquisa, sujeitos e instrumentos para coleta de dados. Contudo, ressalta-se primeiramente, entender que a dinâmica de uma sala de aula parece ter seu centro na interação entre indivíduos, particularmente, alunos e professores. Cada um com sua bagagem sociocultural. Porém, inseridos em um mesmo contexto e, geralmente, com interesses comuns. Essa situação, social e coletiva, pode ser percebida como uma espécie de manifestação entre sujeitos que se encontram e intercambiam conhecimentos e comportamentos, em ritmos e maneiras distintas como conseqüência de prioridades determinadas por fatores diversos, por exemplo: condições ambientais, modos de produção do conhecimento, sistemas de comunicação e estruturas de poder. Reconhecer o espaço escolar/acadêmico desta maneira implica entender que:

Todo indivíduo vivo desenvolve conhecimento e tem um comportamento que reflete esse conhecimento, que por sua vez vai-se modificando em função dos resultados do comportamento. Para cada indivíduo, seu comportamento e seu conhecimento estão em permanente transformação, e se relacionam numa relação que poderíamos dizer de verdadeira simbiose, em total interdependência (D’AMBRÓSIO, 2001, p. 18).

Esses aspectos dinâmicos das interações vêm delinear a necessidade em se lançar um olhar interpretativo para o objeto desta pesquisa, uma vez que o fio condutor é investigar como os alunos-estagiários vão estabelecendo conexões entre suas concepções e a prática pedagógica pré-profissional, de modo a se compreender como eles vão aprendendo a ensinar Matemática e o que está impulsionando-os para essa aprendizagem. É uma relação entre conhecimentos (pessoais, científicos, escolares) e comportamentos, os quais podem ser registrados por meio de atitudes e explicações, manifestações orais ou gráficas. Esses acontecimentos, ao serem observados, refletem nuances do objeto em investigação, o que requer, por parte da pesquisadora, uma imersão no contexto vivenciado pelos atores dessa pesquisa. Assim sendo, o planejamento inicial para o presente trabalho foi traçado pelo desenvolvimento de uma série de atividades, as quais constituíram as fontes dos dados coletados.

Tem-se o entendimento que um fato de ordem social e cultural, como é o caso do processo de ensino-aprendizagem, manifesta-se por diferentes perspectivas. A compreensão da situação posta pode ser alcançada por uma análise que englobe mais de um ângulo de visão, isso pode ser garantido pela variedade de métodos e dados. Nesse sentido, 
desenvolveu-se essa pesquisa por uma perspectiva qualitativa interpretativa. Segundo Bogdan e Biklen (1994, p.48):

Os investigadores qualitativos freqüentam os locais de estudo porque se preocupam com o contexto. Entendem que as ações podem ser melhor compreendidas quando são observadas no seu ambiente habitual de ocorrência. Os locais têm de ser entendidos no contexto da história das instituições a que pertencem. Quando os dados em causa são produzidos por sujeitos, como no caso de registros oficiais, os investigadores querem saber como e em que circunstâncias é que eles foram elaborados. Quais as circunstâncias históricas e movimentos de que fazem parte? Para o investigador qualitativo divorciar o acto, palavra ou gesto do seu contexto é perder de vista o significado.

Por esse viés, o investigador deve ter claro qual será seu local de investigação, quem serão os sujeitos envolvidos, quais funções eles desempenham, em que contexto histórico, social, cultural as situações ocorrem. Em suma, deve-se procurar entender o ambiente em seu estilo próprio e natural.

Para essa pesquisa, o local se constitui no curso de Pedagogia da Universidade Federal do Paraná, mais precisamente, as disciplinas de Metodologia do Ensino de Matemática e de Prática Pedagógica C- Estágio em Docência. Os sujeitos são alunos do 3. ${ }^{\circ}$ ano cursando as referidas disciplinas. Ainda, em relação ao campo da pesquisa, há de se considerar certos componentes presentes ao ambiente da investigação, como: as professoras regentes das disciplinas da universidade; as professoras regentes e os alunos das escolas campo-de-estágio. Vale esclarecer que a professora da disciplina Metodologia do Ensino de Matemática é quem, também, desenvolve esta pesquisa e, portanto, assume o duplo papel, ou seja, o de professora e o de pesquisadora. Para tanto, procurou-se caracterizar a função em cada papel pelas atividades desenvolvidas ao longo do período de permanência no campo de pesquisa e pela escolha dos instrumentos com que os dados foram recolhidos.

No intuito de acompanhar de modo sistemático os acontecimentos do grupo de alunos, o trabalho esteve pautado na utilização de alguns instrumentos para a coleta de informações mais precisas, sejam eles: documentos oficiais da instituição e documentos pessoais produzidos pelos alunos, observações e notas de campo, entrevistas com os alunos e com a professora da disciplina de Prática Pedagógica e videoteipes das aulas. A adoção do vídeo como instrumento de pesquisa ocorreu pela possibilidade de registrar um evento em sua forma natural e, ainda, de consultá-lo após o distanciamento do campo de pesquisa. A finalidade das entrevistas está na intenção de resgatar e esclarecer algumas idéias registradas nos questionários e, ainda, de complementar as informações coletadas. Assim, o questionário foi o meio escolhido para o registro sistematizado das concepções dos sujeitos sobre a Matemática e o processo ensino-aprendizagem. Estas concepções estão registradas, também, 
em outros documentos, os quais estão sendo considerados como instrumentos de pesquisa. A característica multimetodológica empregada consiste na idéia da triangulação dos dados (ALVES-MAZZOTTI e GEWANDSZNAJDER, 2001), isto é, possibilitar que um mesmo evento seja analisado em diferentes perspectivas. Isso é viável frente à adoção de diferentes fontes. É relevante na pesquisa de abordagem qualitativa o contexto em que estas fontes estão inseridas. Assim, na seqüência apresentar-se-á aspectos particulares pertencentes ao campo de pesquisa.

\subsection{O CAMPO DE PESQUISA}

O campo de pesquisa, conforme anunciado anteriormente, refere-se ao curso de Pedagogia da UFPR, mais especificamente às disciplinas Metodologia do Ensino de Matemática I (EM 079) e Prática Pedagógica C- Estágio em Docência (EM 444) ${ }^{25}$. Vale ressaltar que as mesmas compõem o quadro das disciplinas obrigatórias e estão localizadas no 3. ${ }^{\circ}$ ano do curso.

O currículo vigente do curso, no momento da coleta de dados, implantado em 1996, habilita os alunos ao Magistério das Séries Iniciais e das Disciplinas Pedagógicas do Ensino de 2. ${ }^{\circ}$ Grau e à função de Pedagogo. O curso é desenvolvido em 4 anos, totalizando 2.430 horas e a formação está organizada em quatro tipos: Básica com 840 horas (relativa aos fundamentos da educação); Docência com 510 horas (conhecimentos específicos à formação do professor); Pedagogo com 480 horas (conhecimentos específicos à função do pedagogo) e Complementar com 540 horas (conhecimentos que ampliam as formações anteriores).

As disciplinas que constituem o foco do campo de pesquisa estão localizadas no tipo de formação "Docência", a qual compreende além da Prática Pedagógica C e a Metodologia do Ensino de Matemática, mais dez disciplinas que se referem às Metodologias das demais áreas específicas (Língua Portuguesa, Ciências, Geografia, História, Educação Física e Artes); Alfabetização; Didática, Métodos e Concepções do Trabalho Pedagógico e Metodologia das Disciplinas Pedagógicas do Curso de Magistério.

Um outro aspecto sobre as disciplinas foco do campo de pesquisa é o momento em que os alunos chegam até elas, ou seja, o período (ano/série) em que as mesmas são ofertadas ao longo do curso. A programabilidade ${ }^{26}$ (CHEVALLARD, 1991) do curso apresenta uma concentração da formação para Docência no $3 .^{\circ}$ ano, conforme pode ser observado no Gráfico 1.

\footnotetext{
${ }^{25}$ A disciplina Metodologia do Ensino de Matemática e a Prática Pedagógica C são identificadas, na UFPR, pelos códigos EM 079 e EM 444, respectivamente.

${ }^{26}$ Para Chevallard, a programabilidade se refere à organização sistematizada e gradativa da aprendizagem em relação ao conhecimento, a qual está declarada na proposta curricular do curso.
} 
GRÁFICO 1 - CONCENTRAÇÃO DO TIPO DE FORMAÇÃO EM CADA ANO DO CURSO DE PEDAGOGIA-1996

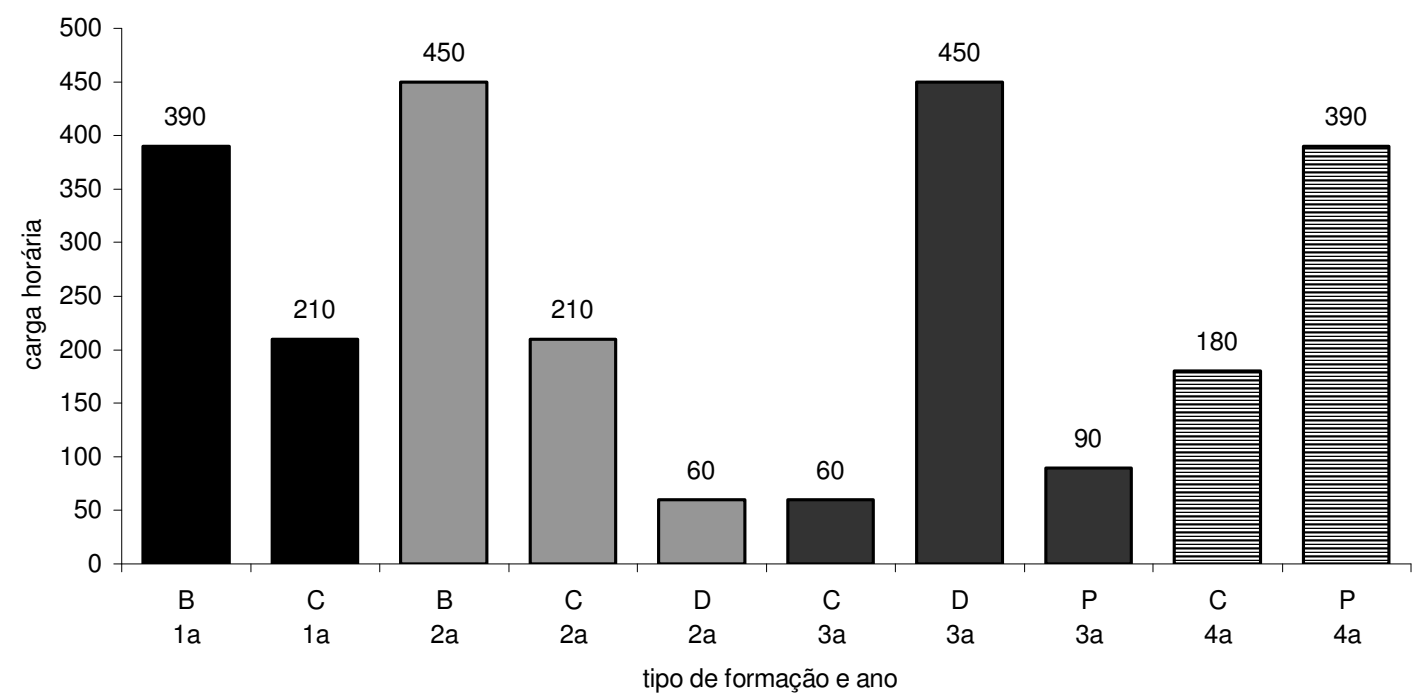

\begin{tabular}{|l|} 
Legenda-tipo de formação \\
B: Básica \\
D: Complementar \\
P: Pedagogonte \\
\end{tabular}

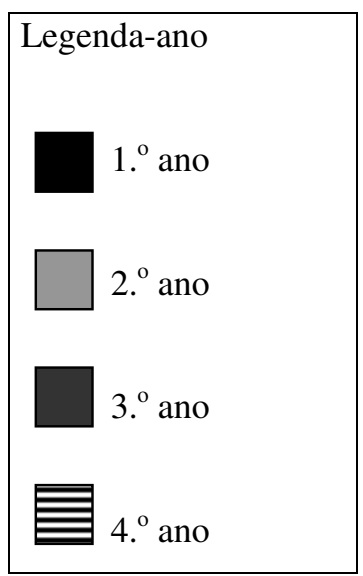

FONTE: UFPR. Proposta Curricular para o curso de Pedagogia. 1996.

NOTA: Dados trabalhados pela autora

(ZIMER, 2002, p. 32).

Essa configuração da organização das disciplinas ao longo do curso implica na situação de que os sujeitos participantes da pesquisa sejam alunos do $3 .^{\circ}$ ano, ou no mínimo, tenham passado por quase toda formação Básica e Complementar desenvolvidas pelas disciplinas componentes da grade curricular (ANEXO 1), referentes ao $1 .^{\circ}$ e $2 .^{\circ}$ anos do curso. 


\subsubsection{A Disciplina Prática Pedagógica C - Estágio em Docência}

A disciplina de Prática Pedagógica C - Estágio em Docência (EM 444), localizada no 3. ${ }^{\circ}$ ano do curso, está estruturada em 120 horas, é de caráter anual e em 2005 foi ofertada a cinco turmas do curso (três noturnas e 2 matutinas). Desse total, acompanhou-se a trajetória de apenas uma turma, a qual tinha quatro aulas na segunda-feira à noite e 35 alunos estavam regularmente matriculados. O critério de escolha foi a compatibilidade de horários com a disciplina Metodologia do Ensino de Matemática e a acessibilidade à turma e professora regente da mesma.

Pela ementa da disciplina EM 444 apresentada em seu Plano de Ensino - Ficha 2 (ANEXO 2), ela se destina à "contextualização do processo educativo. Intervenção e análise crítica da ação pedagógica em espaços escolares e não escolares. Planejamento e prática de ensino na educação básica. A prática pedagógica e a indissociabilidade entre teoria e prática" (UFPR [a], 2005). As atividades, desenvolvidas ao longo do ano, estiveram intercaladas por momentos na universidade e na escola campo-de-estágio, conforme roteiro de trabalho (APÊNDICE 1) sistematizado a partir das observações do desenvolvimento das aulas dessa disciplina.

Os momentos na universidade se destinaram a estudos sobre o sentido do estágio na formação profissional, a conversas sobre caracterização das escolas campo-de-estágio e à organização dos planos de aulas e relatórios. E, os momentos na escola compreenderam duas etapas bem delimitadas pelos períodos letivos, isto é:

- no 1. ${ }^{\circ}$ semestre: os alunos foram orientados a buscarem escolas para realizar o estágio e, então, fazerem estudos sobre o entorno da sala de aula que caracterizassem o campo-de-estágio. Para isso, deveriam utilizar como referência documentos oficiais da escola como a Proposta Política Pedagógica (PPP); entrevistas com o diretor e/ou pedagogo para esclarecimentos sobre o contexto escolar (sócio-econômico, político, físico, etc.) e observações da estrutura da escola (espaço físico, materiais, alunos, professores, etc.). As reflexões sobre as questões que giram ao redor da sala de aula culminaram em um relatório ao final do semestre letivo, o qual foi orientado por meio de sessões de atendimento aos grupos de cada escola. Vale ressaltar que, neste momento, os alunos não adentraram o espaço da sala de aula;

- no 2..$^{\circ}$ semestre: os alunos foram orientados a adentrar o espaço da sala de aula. Realizaram algumas observações e firmaram o contrato de suas aulas, como docentes das turmas que estavam observando. Esse contrato se referia ao desenvolvimento de 7 
aulas sobre conteúdos indicados pelos professores regentes das instituições que receberam os estagiários. Essa dinâmica resultou em novas sessões, individualizadas, de orientação para a (re) organização dos planos das aulas. Essa etapa do estágio também culminou com a elaboração de um relatório ao final do semestre letivo.

Com o transcorrer das aulas da disciplina Prática Pedagógica, observou-se que a elaboração dos relatórios consistiu no foco das atenções de cada encontro, tanto por parte dos alunos quanto por parte da professora regente. Estes documentos se tornaram os instrumentos de comunicação sobre os acontecimentos no campo de estágio. A dinâmica das aulas, nesta disciplina, permitiu que se conhecessem os alunos-estagiários que iriam ministrar aulas de Matemática no estágio, somente no $2 .^{\circ}$ semestre, uma vez que a decisão sobre os conteúdos escolares a serem ensinados pertencia à professora regente da escola campo-de-estágio. Tal situação revelou que os professores em formação inicial experimentam a prática pedagógica pré-profissional relacionada a algumas áreas do conhecimento. Pois, praticamente 2/3 da turma não exerceram a docência no ensino da Matemática. Isso resultou na identificação dos sujeitos desta pesquisa, apenas, na metade do $2 .^{\circ}$ semestre letivo, quase ao final do estágio.

\subsubsection{A Disciplina Metodologia do Ensino de Matemática I}

A disciplina Metodologia do Ensino de Matemática I (EM 079), ministrada no 3. ano do curso, está estruturada em 30 horas, é de caráter semestral e, em 2005, foi ofertada no $1 .^{\circ}$ semestre a duas turmas do noturno e, no $2 .^{\circ}$ semestre, a duas turmas do matutino e uma do noturno. Desse total, acompanhou-se apenas uma turma, a qual tinha duas aulas na quartafeira à noite, no $1 .^{\circ}$ semestre e 38 alunos regularmente matriculados. O critério de escolha foi a compatibilidade de horários com a mesma turma da disciplina Prática Pedagógica C Estágio em Docência.

A ementa da disciplina EM 079, apresentada no Plano de Ensino - Ficha 2 (ANEXO 3), se refere às "implicações dos diferentes enfoques teórico-metodológicos da Matemática no processo educativo. Análise dos conceitos e métodos próprios da disciplina de Matemática, suas inter-relações com o processo ensino-aprendizagem e com a produção de conhecimento, produção de material didático e propostas pedagógicas.” (UFPR [b], 2005) ${ }^{27}$. Conforme já anunciado, a professora desta disciplina é também a pesquisadora desta pesquisa.

A organização da dinâmica da disciplina (APÊNDICE 2) esteve pautada, além dos referenciais específicos da área, também nos princípios da teoria de Mudança Conceitual

\footnotetext{
27 Vale ressaltar que as ementas das demais disciplinas de Metodologia de Ensino seguem a mesma estrutura, diferenciando-se apenas pela especificidade da área de conhecimento.
} 
respaldada, principalmente, em Abib (1996). Assim, as atividades desenvolvidas no semestre se relacionavam ao conhecimento específico da disciplina e ao objetivo de registrar, em diferentes momentos, as concepções dos alunos acerca da Matemática (como Ciência) e sobre o respectivo processo ensino-aprendizagem. Estas atividades, geralmente, propiciavam a troca de idéias em pequenos grupos e depois passavam a ser discutidas com o grande grupo, ou seja, a turma toda. Os registros das mesmas se davam por escrito ou por meio de explicações orais, as quais foram gravadas (vídeo e/ou áudio). Neste sentido, as aulas foram organizadas de modo a registrar as concepções dos alunos em três fases: no início do período letivo, durante o processo de contato com novos referenciais e no final do período letivo. As atividades desenvolvidas em cada fase se referem:

- Fase 1 - no início do período letivo: na fase inicial, objetivou-se explicitar as concepções dos alunos sobre Matemática e o respectivo processo ensinoaprendizagem. $\mathrm{O}$ intuito era conhecer e registrar a diversidade de idéias presentes na sala antes do contato com os referenciais específicos da disciplina e, assim, começar a sensibilizar os alunos para a percepção da multiplicidade de enfoques para uma mesma idéia. Essa etapa envolveu, por parte do planejamento, quatro aulas, nas quais se desenvolveram atividades realizadas na seguinte seqüência: leitura de um texto literário "A Fábula" (análise da proposta de ensino presente no texto - atividade em grupo com registro escrito em pequenos grupos e explicações orais ao grande grupo); quadro ação didática (construção de proposta de ensino de algum conteúdo matemático - atividade em grupo com registro escrito e explicação oral para o grande grupo) e questionário 1 (instrumento escrito, individual, contendo questões relacionadas às características da Matemática e seu processo de ensino-aprendizagem).

- Fase 2 - durante o processo de contato com novos referenciais: essa fase demandou um tempo maior, envolveu praticamente as 10 aulas restantes do período letivo, em termos de planejamento. À medida que os referenciais específicos da disciplina iam sendo estudados, procurava-se resgatar, no início das aulas, as idéias anteriormente registradas. $\mathrm{O}$ intuito era que o novo conhecimento gerasse perturbações às concepções iniciais, provocando certo desequilíbrio em relação às crenças pessoais e busca por novos referenciais, ou seja, a acomodação (POSNER et al, 1982). Tal trajetória se configura pelos pressupostos básicos da Teoria de Mudança Conceitual. Neste sentido, as atividades propostas consistiram em análises de $\operatorname{textos}^{28}$ (os textos eram estudados fora do horário da aula e então, discutidos em sala, com o grande grupo. A temática de cada texto se referia aos assuntos do programa da disciplina); elaboração e resolução de problemas matemáticos (atividade dos Caitités e uso de

\footnotetext{
${ }^{28}$ Os textos analisados no decorrer das aulas estão citados no anexo 3 e no apêndice 2.
} 
texto jornalístico) e jogos didáticos matemáticos (criação de proposta de um jogo didático com a respectiva construção e teste do protótipo). Essas atividades geraram discussões reveladoras do modo como os alunos concebiam certos aspectos da Matemática e o processo de ensino-aprendizagem, os quais foram gravados em vídeo e/ou áudio.

- Fase 3 - final do período letivo: essa fase ocorreu concomitantemente ao término da fase anterior, ou seja, ocupou uma parte das duas últimas aulas, nas quais se propôs aos alunos que registrassem suas idéias sobre as características da Matemática e o respectivo processo de ensino-aprendizagem a partir das impressões desenvolvidas até aquele momento. A estratégia utilizada era a de permitir que os alunos comparassem suas idéias no início do período letivo e ao final do mesmo e, então, refletissem sobre a própria aprendizagem, assim eles produziram os seguintes registros escritos: questionário 2 (registro das idéias sobre Matemática e o respectivo processo ensinoaprendizagem); revisão do questionário 1 (comparar idéias entre os questionários e complementar ou mudá-las) e auto-avaliação (registro sobre as impressões da própria aprendizagem). $\mathrm{O}$ intuito foi de provocar certa conscientização sobre o modo como cada um estava concebendo a Matemática e o respectivo processo ensinoaprendizagem.

Com o campo de pesquisa delineado, é possível caracterizar os elementos do corpus da pesquisa (BAUER e AARTS, 2004), o qual se refere à escolha de modo sistemático do material (fonte dos dados) e de um grupo de pessoas (os sujeitos). Pois, "para selecionar pessoas a serem entrevistadas ou documentos para uma pesquisa qualitativa, nós escolhemos indivíduos e fontes de acordo com critérios externos: estratos sociais, funções e categorias" (BAUER e AARTS, 2004, p. 58). Assim, passar-se-á à configuração do grupo de sujeitos deste trabalho.

\subsection{OS SUJEITOS DA PESQUISA}

É interessante começar esclarecendo algumas características comuns dos sujeitos desta pesquisa. Em estudo anterior sobre este campo (ZIMER, 2002), em relação à atividade de docência, constatou-se a possibilidade de encontrar um grupo de alunos com características bem distintas, tais como:

- alunos com experiência em docência e outros não;

- atividade de docência em exercício ou desenvolvida anteriormente;

- alunos sem experiência de sala de aula. 
O reconhecimento de tais características, a princípio, parece se constituir em um elemento relevante a ser considerado em relação à prática pedagógica pré-profissional, uma vez que a definição dos sujeitos pode estar subordinada a influências de variáveis externas ao objeto de investigação, como por exemplo, a atividade profissional. Por outro lado, esse aspecto pode se tornar em um elemento que auxilie na interpretação dos dados obtidos. Assim, independentemente da função profissional ocupada, os sujeitos participantes desse trabalho são alunos que freqüentaram as disciplinas de Prática Pedagógica e Metodologia de Matemática ao mesmo tempo, isto é, no primeiro semestre de 2005, no turno da noite, conforme pode ser observado na Figura 1.

\section{FIGURA 1 - REPRESENTAÇÃO DA QUANTIDADE DE ALUNOS MATRICULADOS NAS DISCIPLINAS PRÁTICA PEDAGÓGICA C E METODOLOGIA DO ENSINO DE MATEMÁTICA NO 1․ SEMESTRE DE 2005.}

Prática Pedagógica C

Alunos matriculados

Metodologia Ensino Matemática

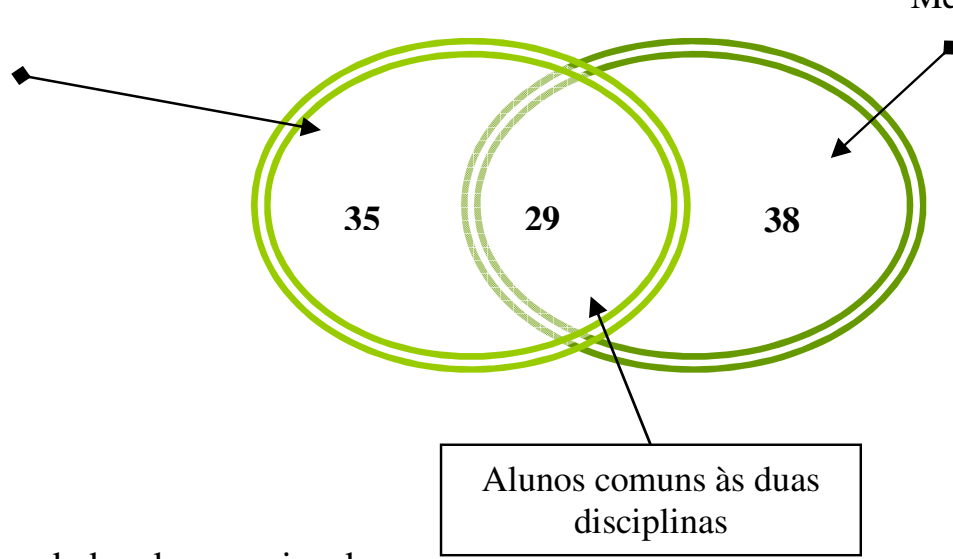

Fonte: dados da pesquisa de campo.

Pela Figura 1, é possível observar que o grupo inicial de sujeitos foi composto por 29 alunos, ou seja, dos 35 alunos matriculados regularmente na disciplina de Prática Pedagógica e dos 38 matriculados na Metodologia, somente 29 freqüentavam as duas disciplinas ao mesmo tempo e eram da mesma turma. Vale ressaltar que, esta configuração não representa o universo dos alunos que estavam na mesma situação naquele período, pois havia uma outra turma com as mesmas características. No entanto, a opção pela turma representada na Figura 1 ocorreu devido ao acesso, desta pesquisadora, à disciplina de Prática Pedagógica, o qual esteve associado à disponibilidade da professora titular da disciplina, à confluência de horários entre as disciplinas e à disposição dos alunos em participar da pesquisa. O resultado dessa situação, representada na Figura 1, sinaliza o primeiro critério de seleção dos sujeitos, isto é, estar matriculado e freqüentando ao mesmo tempo as duas disciplinas. É interessante 
enfatizar que esse critério norteou o acompanhamento dos sujeitos durante o primeiro semestre letivo.

No segundo semestre letivo, das duas disciplinas, os alunos estavam freqüentando apenas a Prática Pedagógica. O encaminhamento dado ao estágio revelou a necessidade de um segundo critério para a seleção dos sujeitos, o qual estava associado às aulas a serem desenvolvidas pelos alunos nas escolas campo-de-estágio. Pois, muitos alunos não iriam ministrar aulas de Matemática e, logo, não estariam exteriorizando suas concepções em torno da Matemática e da respectiva relação ensino-aprendizagem na/para a organização da prática pedagógica.

O estabelecimento desse segundo critério delimitou o grupo em 11 sujeitos, os quais planejaram aulas de Matemática a serem desenvolvidas em turmas das séries iniciais do Ensino Fundamental, durante o período do estágio. Cada sujeito recebeu um codinome, no intuito de garantir o sigilo de suas identificações. Sejam eles:

\section{QUADRO 1 - SUJEITOS DA PESQUISA E AULAS DE MATEMÁTICA NO ESTÁGIO}

\begin{tabular}{|c|c|}
\hline SUIEITOS & \\
\hline ALUNA 1 (A1) & $\begin{array}{l}\text { Ministrou apenas aulas de Matemática para alunos da } 1 .^{\mathrm{a}} \text { a } 4 .^{\mathrm{a}} \text { séries da } \\
\text { Educação de Jovens e Adultos (EJA). Planejou } 5 \text { aulas e realizou } 4 \text {, } \\
\text { sobre o conteúdo Sistema de Medidas (comprimento, massa, capacidade } \\
\text { e tempo). }\end{array}$ \\
\hline ALUNA 2 (A2) & $\begin{array}{l}\text { Ministrou aulas de Matemática, Língua Portuguesa, História e Geografia } \\
\text { para crianças da } 1 \text { a }^{a} \text { série. Planejou e realizou } 2 \text { aulas de Matemática } \\
\text { sobre adição e subtração, unidade e dezena, antecessor e sucessor, } \\
\text { tabelas. }\end{array}$ \\
\hline ALUNA 3 (A3) & $\begin{array}{l}\text { Ministrou aulas de Matemática, Língua Portuguesa e Geografia para } \\
\text { alunos de } 3 .^{\mathrm{a}} \text { e } 4 .^{\mathrm{a}} \text { séries da EJA. Planejou e realizou uma aula de } \\
\text { Matemática sobre tabelas e gráficos. }\end{array}$ \\
\hline ALUNA 4 (A4) & $\begin{array}{l}\text { Ministrou aulas de Matemática e Língua Portuguesa para crianças da } 2 .^{a} \\
\text { série. Planejou e realizou } 2 \text { aulas de Matemática sobre multiplicação } \\
\text { (tabuada). }\end{array}$ \\
\hline ALUNA 5 (A5) & $\begin{array}{l}\text { Ministrou aulas de Matemática, Língua Portuguesa e Ciências para } \\
\text { alunos da } 2 .^{a} \text { série da EJA. Planejou } 3 \text { aulas e realizou apenas uma sobre } \\
\text { multiplicação e divisão (operações e situações-problema), tabelas e } \\
\text { gráficos. }\end{array}$ \\
\hline ALUNA 6 (A6) & $\begin{array}{l}\text { Ministrou aulas de Matemática, História e Geografia para alunos de } 3 .^{\mathrm{a}} \mathrm{e} \\
\text { 4. }^{\mathrm{a}} \text { séries da EJA. Planejou e realizou } 7 \text { aulas de Matemática sobre } \\
\text { sistema monetário. }\end{array}$ \\
\hline ALUNA 7 (A7) & $\begin{array}{l}\text { Ministrou aulas de Matemática, Língua Portuguesa e Ciências para } \\
\text { alunos da } 3 .^{\mathrm{a}} \text { e } 4 .^{\mathrm{a}} \text { séries da EJA. Planejou e realizou uma aula de } \\
\text { Matemática sobre tabelas e fração. }\end{array}$ \\
\hline ALUNA 8 (A8) & $\begin{array}{l}\text { Planejou aulas de Matemática, Língua Portuguesa e Geografia para } \\
\text { crianças da } 2 .^{\text {a }} \text { série. As duas aulas de Matemática sobre figuras } \\
\text { geométricas não foram realizadas. }\end{array}$ \\
\hline
\end{tabular}


conclusão

\begin{tabular}{|l|l|}
\hline \multicolumn{1}{|c|}{ SUJEITOS } & \multicolumn{1}{c|}{ AULAS DE MATEMÁTICA } \\
\hline ALUNA 9 (A9) & $\begin{array}{l}\text { Planejou aulas de Matemática e Língua Portuguesa para alunos da 1.a } \\
\text { série da EJA. As duas aulas de Matemática sobre adição, subtração e } \\
\text { sistema monetário não foram realizadas. }\end{array}$ \\
\hline ALUNA 10 (A10) & $\begin{array}{l}\text { Planejou aulas de Matemática, Ciências e Geografia para alunos da 3. }{ }^{\mathrm{a}} \text { e } \\
4^{\text {a }} \text { séries da EJA. A aula de Matemática sobre números decimais não foi } \\
\text { realizada. }\end{array}$ \\
\hline ALUNA 11 (A11) & $\begin{array}{l}\text { Planejou aulas de Matemática e Língua Portuguesa para alunos da 1. } \\
\text { série da EJA. As duas aulas de Matemática sobre adição e subtração, } \\
\text { antecessor e sucessor e tabela não foram realizadas. }\end{array}$ \\
\hline
\end{tabular}

Fonte: dados do campo de pesquisa.

Ao final do ano letivo, configuraram-se algumas características impostas pelo contexto social em que os sujeitos vinham desenvolvendo suas atividades de estágio, ou seja, todos planejaram aulas de Matemática, mas nem todos exerceram a prática dessa aula, restringindo-se tal vivência aos sujeitos A1, A2, A3, A4, A5, A6 e A7. Essa diferenciação entre as atividades desenvolvidas pelos sujeitos, em relação ao exercício de docência em Matemática, pode trazer implicações para a construção dos dados em relação às concepções dos sujeitos sobre Matemática e o ensino-aprendizagem, e como isso se evidencia em suas práticas, uma vez que foi possível relacionar tais crenças somente com a intenção da aula, isto é, com o planejamento, com o que se pretendia desenvolver com os alunos. As idéias advindas da prática, isto é, do saber ensinado (CHEVALLARD, 1991), limita-se ao grupo dos sete primeiros sujeitos, apresentados no Quadro 1.

Nesse sentido, empregou-se um terceiro critério, isto é, considerar apenas os sujeitos que planejaram e realizaram as aulas de Matemática durante o estágio, sejam eles A1, A2, A3, A4, A5, A6 e A7. Entretanto, foi possível observar a prática pedagógica de somente três sujeitos, o que configura uma outra característica imposta pelo contexto social e, por consequiência, um quarto critério de seleção dos sujeitos, ou seja, considerar somente aqueles cuja prática pedagógica pôde ser observada por esta pesquisadora. Desta maneira, o grupo fica delimitado a 3 sujeitos, sejam eles: A1, A2 e A3.

Por outro lado, entende-se que a análise das informações obtidas de cada um desses sujeitos equivale ao estudo de um subcaso, considerando-se como caso maior o contexto de formação docente proporcionado pelas disciplinas de Prática Pedagógica e Metodologia de Ensino de Matemática, no curso de Pedagogia. Pois, segundo Ponte (2006), quando não se quer conhecer propriedades gerais de uma população, o estudo de caso pode ser usado para:

[...] compreender a especificidade de uma dada situação ou fenômeno, para estudar os processos e as dinâmicas da prática, com vista à sua melhoria, ou para ajudar um dado organismo ou decisor a definir novas políticas, ou ainda para melhor compreensão de um caso específico e ajudar a formular hipóteses de trabalho sobre o grupo ou a situação em causa (PONTE, 2006, p. 123, destaque do autor). 
Logo, no intuito de compreender, em profundidade, aspectos relativos à aprendizagem da docência em Matemática e considerando-se o movimento das concepções dos sujeitos, conduz-se para esta pesquisa o estudo dos três casos, ou seja, dos sujeitos A1, A2 e A3. Pretende-se mais adiante, no momento da apresentação de dados e a respectiva análise, apresentar também o contexto que envolveu cada sujeito. Deste modo, discorre-se na sequiência sobre os instrumentos adotados para a coleta dos dados desta pesquisa.

\subsection{OS INSTRUMENTOS DE PESQUISA}

Uma característica predominante na pesquisa qualitativa, apontada por pesquisadores dessa abordagem, é o caráter multimetodológico nela empregado (BAUER e GASKELL, 2004; D’AMBRÓSIO, 2004; ALVES-MAZZOTTI e GEWANDSZNAJDER, 2001; BOGDAN e BIKLEN, 1994, entre outros). O reflexo desta concepção é a adoção de vários procedimentos e instrumentos para a coleta dos dados. Bogdan e Biklen (1994, p. 149, grifo dos autores), explicam que:

$\mathrm{O}$ termo dados refere-se aos materiais em bruto que os investigadores recolhem do mundo que se encontram a estudar; são os elementos que formam a base de análise. Os dados incluem materiais que os investigadores registram activamente, tais como transcrições de entrevistas e notas de campo referentes a observações participantes. Os dados também incluem aquilo que outros criaram e que o investigador encontra, tal como diários, fotografias, documentos oficiais e artigos de jornais.

Alves-Mazzotti e Gewandsznajder (2001, p. 163) ampliam a idéia sobre as anotações de campo, as quais podem se referir, também, a observações não participantes. Nesse sentido, há possibilidade em se coletar uma grande variedade de materiais, o que pode ser interessante na perspectiva de se analisar um mesmo objeto por mais de um ângulo. Por outro lado, Bauer e Aarts (2004, p. 60) alertam que o tamanho do corpus de pesquisa deve ser coerente ao tempo, no projeto, para lidar com as fontes dos dados, caso contrário, o trabalho pode terminar sem que todo o material tenha sido explorado ou analisado com alguma profundidade. Frente a todas essas observações, tomou-se o cuidado, em um primeiro momento da pesquisa, em selecionar instrumentos que garantissem a maior variedade de registros sobre as idéias dos sujeitos. Deste modo, priorizaram-se gravações em vídeo das aulas nas disciplinas de Prática e de Metodologia; entrevistas; questionários, documentos oficiais e pessoais. Na Figura 2 é possível observar os instrumentos priorizados em cada etapa do trabalho em campo. 
FIGURA 2 ORGANOGRAMA DO CAMPO DE PESQUISA-SUJEITOS-INSTRUMENTOS

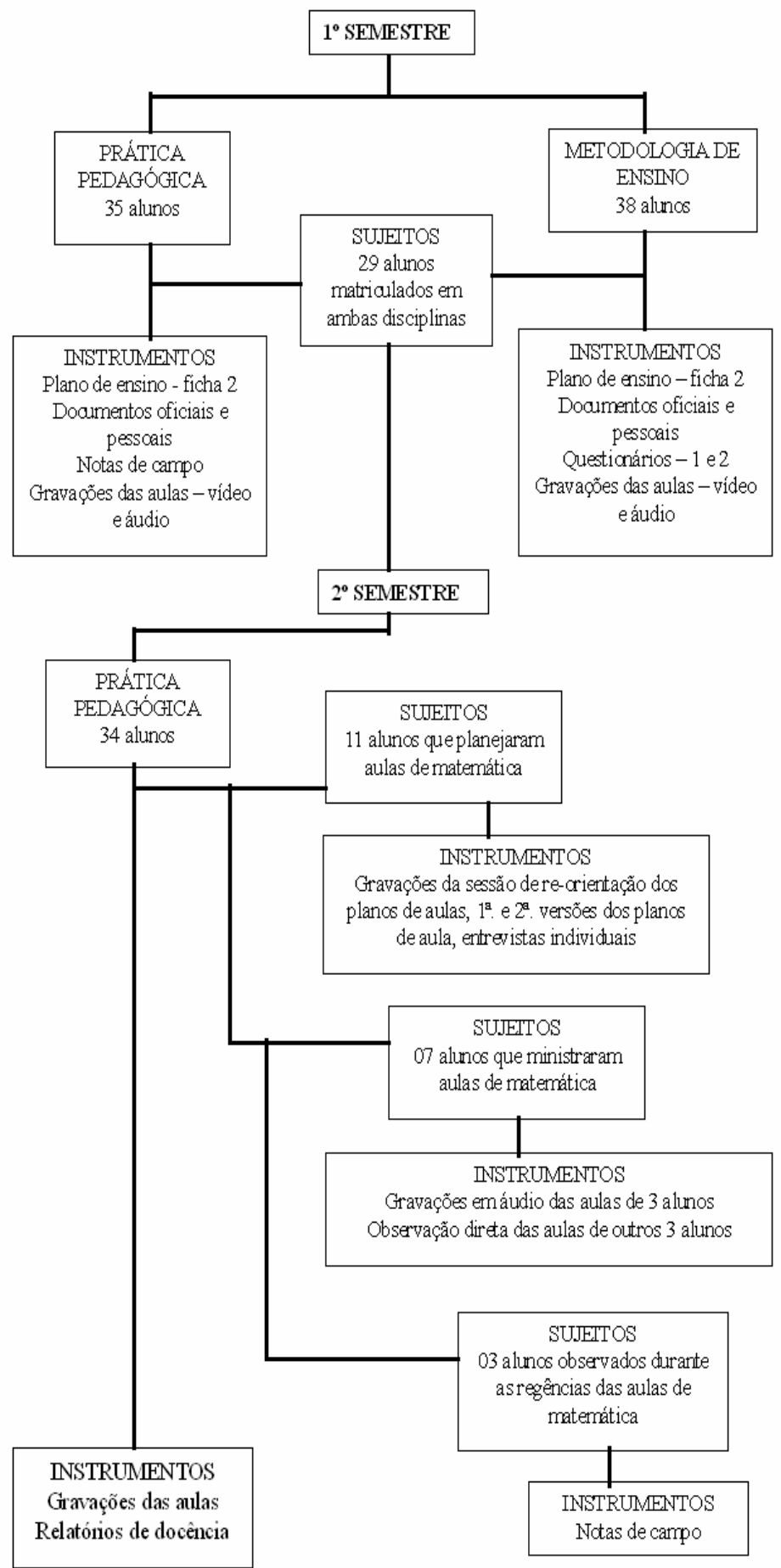

Fonte: pesquisa de campo

A abordagem a cada um dos instrumentos será aprofundada na seqüência. 


\subsubsection{O Vídeo como Instrumento de Pesquisa}

A escolha pelo uso do vídeo como instrumento de pesquisa ocorreu pela possibilidade de descrever o que se passa em sala de aula, resguardando aspectos exatos aos ocorridos. Pois, “[...] a imagem, com ou sem acompanhamento de som, oferece um registro restrito, mas poderoso das ações temporais e dos acontecimentos reais - concretos, materiais" (LOIZOS, 2004, p. 137). E, isso se torna muito interessante quando é levado em consideração que a pesquisadora deste trabalho, também atua como professora, em uma das etapas da atividade em campo. Martin, citado por Powell et al (2004, p. 91), comenta que “[...] gravações em vídeo habilitam o pesquisador a interagir com os aprendizes enquanto estes trabalham e, consequientemente, a testar teorias nascentes". Desta maneira, as interações com os sujeitos de pesquisa, vivenciadas como professora, poderão ser analisadas posteriormente pela pesquisadora, mediante os registros efetuados por meio das gravações das aulas.

No entanto, o uso de videoteipes (POWELL et al, 2004) não se restringe ao aspecto de analisar uma situação em que o investigador e o professor se referem à mesma pessoa, mas, principalmente, por ser uma fonte estável para coleta de dados orais e visuais e permitindo que tais informações sejam reexaminadas continuamente. Esse instrumento, também viabiliza que sejam realizados estudos de momentos em que alunos revelam seus modos particulares de pensar e explicitam compreensão ou divergência sobre uma idéia. No caso desta pesquisa, interessa os registros em torno das concepções dos sujeitos sobre a Matemática e o respectivo processo ensino-aprendizagem, sejam eles explicitados por meio de falas ou de expressões faciais e corporais (gestos), ao longo do processo de ensinoaprendizagem.

Assim sendo, os videoteipes foram feitos no ambiente das aulas das disciplinas de Metodologia do Ensino de Matemática e de Prática Pedagógica. Há 28 horas/aula daquela e 48 horas/aula desta disciplina. As gravações nas aulas da Prática foram realizadas pela própria pesquisadora, situação essa que não pôde se repetir na Metodologia, sendo então, desenvolvida por uma outra pessoa ( 3 alunas de outra turma que se revezaram durante o semestre letivo). Vale ressaltar que antes do início das gravações, ou seja, do início do trabalho de campo em si, todos os alunos de ambas as turmas foram consultados e esclarecidos sobre o propósito desta pesquisa. Desta maneira, coletando-se um termo de consentimento de suas participações para o desenvolvimento do trabalho.

Pesquisadores que se utilizam da prática dos videoteipes para a coleta de dados têm desenvolvido diferentes metodologias de análise deste tipo de material. Um dos primeiros 
aspectos apontados é sobre a decisão de qual será a fonte dos dados, isto é, a gravação em si ou a transcrição do que foi gravado? Segundo Powell et al. (2004, p. 93), cada posição tem seus méritos e deméritos, pois a análise desenvolvida sobre as fitas requer o uso de equipamentos tecnológicos específicos para serem visualizadas, fato esse que não ocorre com as transcrições por não necessitarem de aparatos especiais para serem acessadas. Por outro lado, os videoteipes, considerados fontes ricas em dados, tornam visíveis nuances sutis nas falas e nos comportamentos não-verbais. Com a transcrição, tais características podem se perder, ou ainda, a riqueza de informação contida no vídeo pode dificultar a análise do foco do estudo quando realizada a transcrição dos dados.

Frente a essas considerações, o que parece prevalecer é uma tendência em mesclar a análise sobre as gravações e as transcrições das mesmas, por meio da seleção de episódios do vídeo. Entende-se por episódio:

Àquele momento em que fica evidente a situação que queremos investigar. Essa situação pode se relacionar com as perguntas do investigador, pode ser por exemplo, a dos alunos levantando hipóteses num problema aberto, as falas dos alunos após uma pergunta desestruturadora, a discussão de um texto histórico, os tipos de perguntas que os professores fazem para os seus alunos, os momentos das discussões em grupo onde os alunos debatem as suas concepções, ou o conjunto de ações que desencadeia os processos de busca da resposta do problema a ser pesquisado (CARVALHO, 1996, p. 6).

O episódio é caracterizado também, por não ser contínuo, isto é, o fenômeno estudado pode ser observado em momentos não seqüenciais, podendo ocorrer, inclusive em aulas de dias diferentes. Neste sentido, o tratamento dos dados desta pesquisa será desenvolvido a partir da construção de episódios do vídeo, para tanto Powell et al. (2004, p. 98) sugerem o emprego de sete fases interativas e não lineares, sejam elas: observação atenciosa aos dados do vídeo; descrição dos dados do vídeo; identificação de eventos críticos; transcrição; codificação; construção do enredo e composição da narrativa. "Um evento é chamado crítico quando demonstra uma significativa ou contrastante mudança em relação a uma compreensão prévia, um salto conceitual em relação a uma concepção anterior [...]" (POWELL et al., 2004, p. 104, grifo dos autores). Assim, nesta pesquisa se fez a transcrição dos episódios relacionados aos videoteipes das entrevistas desenvolvidas com cada um dos sujeitos. Nestas transcrições, o foco foi localizar eventos críticos como modo de evidenciar mudanças conceituais e, também, momentos que revelaram as concepções antes e após os eventos críticos. Vale ressaltar que esses episódios são complementados por dados provenientes de outras fontes, tais como as notas de campo e os questionários. 


\subsubsection{A Entrevista como Instrumento de Pesquisa}

A entrevista, usada como instrumento de pesquisa, tem se constituído em uma possibilidade amplamente empregada. Pois, seu uso permite ao entrevistador compreender aspectos das percepções pessoais dos entrevistados, ou seja, conhecer e entender o mundo e o jeito de vida de cada pessoa. Para tanto, tem-se como objetivo, “[...] a compreensão detalhada das crenças, atitudes, valores e motivações, em relação aos comportamentos das pessoas em contextos sociais específicos" (GASKELL, 2004. p. 65). Bogdan e Biklen (1994. p. 134) afirmam que, em investigação qualitativa, as entrevistas podem ser utilizadas como estratégia dominante na coleta de dados ou utilizadas em conjunto com outras técnicas. Entretanto, independentemente da situação, "[...] a entrevista é utilizada para recolher dados descritivos na linguagem do próprio sujeito, permitindo ao investigador desenvolver intuitivamente uma idéia sobre a maneira como os sujeitos interpretam aspectos do mundo.” Idéia essa, também defendida por Alves-Mazzotti e Gewandsznajder (2001, p. 168), afirmando que o interesse do investigador é "compreender o significado atribuído pelos sujeitos a eventos, situações, processos ou personagens que fazem parte de sua vida cotidiana”.

Em pesquisas qualitativas, geralmente, as entrevistas possuem um caráter mais aberto, como se fossem diálogos entre os indivíduos envolvidos. O grau de controle de tais diálogos faz com que existam diferentes modalidades de entrevistas. Por exemplo, AlvesMazzotti e Gewandsznajder (2001) comentam sobre as entrevistas não estruturadas, semiestruturas e mistas. Em relação ao primeiro tipo, o entrevistador solicita que o entrevistado fale sobre si próprio e sobre alguns tópicos específicos que são introduzidos no decorrer da conversa. Esse tipo é mais utilizado no início da coleta de dados, quando se necessita aprofundar certos tópicos, geralmente, emprega-se a entrevista semi-estruturada, na qual o entrevistador solicita que o entrevistado fale sobre certos assuntos, mas também deixa que ele fale de acordo com suas próprias percepções. E, quando a entrevista tem partes mais estruturadas e outras menos, esta é então considerada do tipo mista.

Nesse sentido, realizou-se nesta pesquisa, ao longo do período de desenvolvimento do estágio e, também, após todos os sujeitos terem ministrado suas aulas de Matemática, entrevistas semi-estruturadas com cada um deles, cujos roteiros encontram-se no Apêndice 3. O objetivo dessas entrevistas era refletir, juntamente com o entrevistado, sobre suas concepções de Matemática e o processo de ensino-aprendizagem. Mais especificamente, para esclarecer idéias evidenciadas nas atividades escritas no decorrer da disciplina de Metodologia de Ensino ou nos planos das aulas de Matemática e, ainda, suscitar reflexões 
durante as sessões de orientação que antecediam cada aula do estágio. Houve, também, o propósito de evidenciar para os sujeitos seus modos de pensar a Matemática e o processo ensino-aprendizagem ao longo do período de coleta de dados, os quais foram revelados por meio de suas palavras (escritas) e ações, observadas pela investigadora durante o exercício da prática pedagógica pré-profissional dos mesmos. Destinou-se, para o mesmo momento, a busca por elementos que apresentassem, pelo viés da formação e da atuação profissional, quem são os sujeitos investigados, futuros professores que ensinarão matemática. Pois, ao conhecer aspectos pertencentes à história de vida dos sujeitos, pode-se representar explicações relativas aos seus modos de pensar e agir, em certas situações. Não é intenção explorar a história de vida dos sujeitos, mas apenas conhecer parte do contexto sociocultural em que cada um está inserido.

Para essas entrevistas, procurou-se privilegiar um caráter reflexivo em torno das questões guias e da atitude entre entrevistadora e entrevistados. Pois, a preocupação não estava centrada apenas em aprofundar certas informações, mas possibilitar que cada sujeito pudesse refletir sobre sua própria aprendizagem em relação à formação inicial de professores. Para isso, tomou-se como princípio de que a entrevista consiste em uma situação de interação humana. Nas palavras de Szymanski et al. (2004, p. 14):

A entrevista também se torna um momento de organização de idéias e de construção de um discurso para um interlocutor, o que já caracteriza o caráter de recorte da experiência e reafirma a situação de interação como geradora de um discurso particularizado. Esse processo interativo complexo tem um caráter reflexivo, num intercâmbio contínuo entre significados e o sistema de crenças e valores, perpassados pelas emoções e sentimentos dos protagonistas.

Nesse contexto, os protagonistas são entendidos como: entrevistador e entrevistado. Essa modalidade de entrevista é chamada de reflexiva, por se conceber que trata de um momento de encontro entre pessoas e que o significado atribuído para um conhecimento é construído por meio da interação com outros. As autoras explicam que um significado pode ser construído mediante a situação em que o entrevistado precisa refletir e organizar suas idéias para serem comunicadas ao entrevistador. É nesse movimento que muitas vezes o entrevistado revela uma organização de seu pensamento, de tal modo que, nem ele mesmo a havia percebido. A tomada de consciência atingida pelo entrevistado pode se configurar como uma situação decorrente do processo de interação com o entrevistador. Nesse sentido, entende-se que a entrevista reflexiva se constitui, também, em uma atividade de metacognição, pois o sujeito é levado a refletir sobre o próprio processo de aprendizagem. 
Ressalta-se que, tal situação foi viabilizada no decorrer das sessões de re-orientação aos planos de aula.

Deste modo, no decorrer das entrevistas, foram resgatados todos os registros escritos durante o período da coleta de dados, com ênfase maior nos questionários aplicados na Metodologia do Ensino da Matemática e na primeira versão dos planos de aula. As reflexões centraram-se, principalmente, na relação entre as idéias escritas e a prática pedagógica préprofissional desenvolvida no estágio.

\subsubsection{O Questionário como Instrumento de Pesquisa}

No início da coleta de dados, o grupo observado era composto por 29 alunos. Isso ocorreu em virtude das especificidades do contexto do campo desta pesquisa, conforme já explicitado anteriormente. Tal situação inviabilizou o desenvolvimento de entrevistas individualizadas para se investigar as concepções de cada um, em pelo menos, dois momentos distintos do período de trabalho sobre a formação docente para o ensino de Matemática, mais especificamente, durante a disciplina de Metodologia do Ensino de Matemática. Devido a essa circunstância, optou-se pela aplicação de dois questionários (ANEXO 4) a todo o grupo de alunos.

Segundo Thiollent (1982), o questionário se diferencia da entrevista semi-estruturada e não diretiva pela extensividade daquele (muitas pessoas e questões fechadas) e, pela intensividade desta (poucas pessoas e possibilidade de aprofundamento das questões), apesar de serem consideras técnicas complementares. Neste sentido, o questionário,

contém uma lista de perguntas, cuja temática corresponde, em princípio, a uma 'tradução' das hipóteses de pesquisa sob forma interrogativa. [...] $\mathrm{Na}$ estrutura do questionário, a ordem das perguntas pode ser temática, ou em grupos correspondentes às hipóteses ou totalmente arbitrária (THIOLLENT, 1982, p. 32, grifo do autor).

Em relação aos questionários aplicados nesta pesquisa, a hipótese que orientou sua construção foi a de que as concepções dos sujeitos, sobre Matemática e o processo ensinoaprendizagem, poderiam apresentar nuances de mudanças conceituais ao longo do trabalho com o conhecimento específico da Metodologia do Ensino de Matemática. Em virtude disso, havia necessidade de registrar, ao mesmo tempo, o que cada um estava pensando sobre a referida temática. Nesse sentido, entendeu-se que o questionário seria uma maneira interessante de obter tais dados. 
Um outro aspecto relacionado à estrutura dos questionários se refere aos tipos de questões presentes no instrumento, as quais podem ser fechadas ou abertas. Optou-se, neste instrumento, pelas perguntas abertas, não se predefinindo assim as respostas a serem dadas. Pois, a intenção foi a de permitir que cada aluno respondesse as questões a partir de suas próprias percepções. Vale ressaltar que, além desses registros escritos, os alunos produziram outros documentos escritos, mas não com a mesma diretiva em que este instrumento foi construído.

\subsubsection{Os Documentos como Instrumentos de Pesquisa}

Ao longo de todo o processo de coleta de dados, reuniram-se outras fontes de informação, além das já apresentadas. São documentos escritos, cuja origem e formato são variados, pois se referem a: planos de ensino das disciplinas; relatórios de estágio dos alunos; anotações sobre observações do campo de pesquisa e atividades/tarefas de aula da disciplina de Metodologia do Ensino de Matemática.

Segundo Alves-Mazzotti e Gewandsznajder (2001, p. 169), "qualquer registro escrito que possa ser usado como fonte de informação", é considerado como documento. E, a finalidade da análise de documentos é que "[...] pode ser usada, tanto como uma técnica exploratória (indicando aspectos a serem focalizados por outras técnicas), como para 'checagem' ou complementação dos dados obtidos por meio de outras técnicas." (ALVESMAZZOTTI E GEWANDSZNAJDER, 2001, p. 169, grifo dos autores). Nesse sentido, os documentos aqui coletados, a princípio, tendem a complementar as informações obtidas por meio dos outros instrumentos, por exemplo, aspectos sobre o plano das aulas desenvolvidas pelos sujeitos durante o estágio. Estes planos estão inseridos nos relatórios de estágio, assim como também, um texto reflexivo sobre o desenvolvimento das mesmas aulas. As informações, contidas nesse registro escrito, revelam aspectos de como cada sujeito pensa e se organiza para a docência em Matemática. Tal informação pode se constituir em um elemento interessante no entendimento de dados coletados por outras fontes.

Para Bogdan e Biklen (1994), os registros escritos enquanto documentos de pesquisa podem ser de diferentes naturezas, as quais estão relacionadas à origem de suas produções, isto é, quem os produziu. Em linhas gerais, os autores apresentam três perspectivas de documentos: notas de campo; documentos pessoais e documentos oficiais. As notas de campo 
referem-se ao "[...] relato escrito daquilo que o investigador ouve, vê, experiencia e pensa no decurso da recolha e reflectindo sobre os dados de um estudo qualitativo" (BOGDAN e BIKLEN, 1994, p. 150). Em relação aos documentos pessoais, seriam aqueles produzidos/escritos pelos próprios sujeitos de pesquisa e, os documentos oficiais, seriam então, aqueles textos produzidos por uma instituição.

Conduzindo-se por esse fio, os documentos oficiais coletados se referem aos planos de ensino das disciplinas e à grade curricular do curso de Pedagogia da UFPR (ANEXOS: 1, 2 e 3). Os documentos pessoais são relativos aos relatórios de estágio, planos de aula (ANEXO 5) e atividades/tarefas de aula da Metodologia de Ensino. Em termos das notas de campo (ANEXO 6), cabe ressaltar que elas se referem, principalmente, às observações das aulas de Matemática, desenvolvidas pelos sujeitos A1, A2 e A3, às impressões obtidas das sessões de orientação aos planejamentos destas mesmas aulas e de leitura dos relatórios. Ainda em tempo, esclarece-se que o conjunto de documentos coletados está arquivado em pastas, as quais correspondem, de certo modo à pasta da Prática Pedagógica, à pasta da Metodologia e a do campo-de-estágio. A organização dessas pastas é guiada pela ordem com que os registros escritos foram produzidos ou obtidos. Adotou-se tal sistemática pela necessidade de admitir, no diário de bordo, documentos de outras naturezas além das anotações de campo da própria investigadora, e, também, por facilitar a visualização de todo o processo de interação com os sujeitos desta pesquisa.

Na sequiência são apresentados os dados obtidos por meio dos instrumentos indicados e a respectiva análise em relação ao caso de cada um dos sujeitos. 


\section{AS ANÁLISES}

A análise dos dados, de certo modo, foi iniciada desde o início da coleta dos mesmos. Vale destacar que, essa primeira análise se deu apenas no sentido de se tomar consciência sobre o campo de pesquisa e, mais especificamente, sobre as idéias que os sujeitos iam revelando ao longo do processo investigativo. Esse movimento permitiu não só um refinamento dos instrumentos adotados na coleta dos dados, como também, oportunizou que fossem provocadas reflexões junto aos sujeitos de pesquisa, cujo intuito era o de refletirem sobre suas idéias e a prática pedagógica que desenvolviam em seus estágios em relação à Matemática. Para a análise dos dados, a trajetória percorrida esteve submetida a alguns fatos próprios do contexto em que a pesquisa foi desenvolvida e, também, da abordagem teórica que fundamentou o trabalho. Nesse sentido, a configuração dos dados analisados partiu das seguintes considerações:

a) todas as atividades desenvolvidas pelos alunos, durante o primeiro semestre, na disciplina de Prática Pedagógica não estiveram voltadas a questões relacionadas, diretamente, à prática pedagógica pré-profissional em relação à Matemática, ou seja, ao exercício da docência propriamente dito;

b) em decorrência da situação do item "a", os sujeitos de pesquisa foram identificados somente no segundo semestre, selecionando-se somente aqueles que desenvolveram atividades de estágio voltadas à Matemática. Neste período os alunos já haviam concluído a disciplina Metodologia de Ensino de Matemática;

c) por conseqüência, os videoteipes desenvolvidos na Metodologia de Ensino estiveram voltados para o conjunto de alunos matriculados na disciplina. Uma vez que, não se havia determinado, ainda, quem seriam os sujeitos de pesquisa;

d) as perspectivas reveladas pelo conjunto de alunos na Metodologia de Ensino, geralmente, referiram-se a considerações discutidas em pequenos grupos e, então, apresentadas no grande grupo. Deste modo, explicitando-se consensos gerados pelo conjunto de alunos da turma.

Assim, constatou-se que a formação docente em Matemática estava submetida a certas restrições. Pois, apesar de os alunos estarem estudando e discutindo aspectos teóricos sobre a temática, não tiveram possibilidades de estabelecer associações com situações de sala de aula a partir de observações e/ou experiências vivenciadas por si mesmos, enquanto futuros professores, uma vez que ainda não desenvolviam atividades de estágio relacionadas à prática pedagógica. Essa constatação despertou o interesse para o entendimento de processos de 
como o futuro professor aprende a ensinar Matemática e o que contribui para essa aprendizagem a partir de subsídios da questão central de investigação que é a de conhecer como o aluno-estagiário vai estabelecendo conexões entre suas concepções e a prática pedagógica.

Um outro elemento de constatação é em relação às fontes dos dados. Pois, o contexto sócio-cultural em que a formação docente em Matemática foi desenvolvida permitiu que, no primeiro semestre, se considerasse, apenas, as fontes dos dados relacionados à Metodologia do Ensino de Matemática e, no segundo semestre, somente aquelas relacionadas aos alunos que desenvolveram atividades de estágio voltadas ao ensino da Matemática. Os dados obtidos nos videoteipes das aulas da Metodologia, de modo genérico, evidenciam as concepções do conjunto de alunos, cujas idéias veiculadas oralmente na sala de aula por meio de debates nos pequenos grupos ou com a totalidade da turma, caracterizam, de certo modo, o pensar coletivo dos alunos. Já, os obtidos nos questionários e, também, durante o período do desenvolvimento da prática pedagógica refletem o pensamento particularizado de cada sujeito. Assim, apesar de se entender que possam haver influências do pensar coletivo na estrutura conceitual particular de cada aluno, entende-se que é mais significativo considerar as fontes dos dados relacionadas diretamente aos sujeitos A1, A2 e A3 em virtude do desenvolvimento do estudo de casos aqui proposto.

Em relação à abordagem teórica, constatou-se, ao iniciar esse processo de análise mais sistematizado e articulado à noção de Perfil Conceitual, que tal estudo deveria ser desenvolvido sob duas perspectivas de maneira que a primeira desse suporte à segunda. Assim,

É importante destacar que, no processo de análise, esses dados são tratados sob duas perspectivas: na primeira, as idéias que emergiram na sala de aula são consideradas para a caracterização das zonas do perfil, e orientam a forma de abordar as concepções presentes no contexto histórico e na literatura em educação em ciências. $\mathrm{Na}$ segunda perspectiva, eles são tratados como elementos constitutivos do discurso produzido no contexto da sala de aula, [...]. (AMARAL e MORTIMER, 2006, p. 244)

No caso da presente investigação, o foco de análise na primeira perspectiva se direciona na constituição dos perfis conceituais a partir do conjunto das idéias reveladas pelos sujeitos e dos referenciais teóricos. Tais perfis possibilitam, na segunda perspectiva, que se olhe o movimento conceitual dos sujeitos e, conseqüentemente, interprete-se o que tal movimentação representa para a aprendizagem do futuro professor, no que se refere ao ensino da Matemática. Com o delineamento dessas considerações é que se prossegue com o detalhamento dos dados e das respectivas análises. 


\subsection{O PERCURSO PARA A ANÁLISE DOS DADOS}

A imersão no campo de pesquisa e o contato com os sujeitos, alunos das disciplinas Metodologia do Ensino de Matemática I e Prática Pedagógica C - Estágio em Docência, possibilitou a obtenção de certa variedade de instrumentos de pesquisa. Conforme anunciado no capítulo anterior, os instrumentos são: videoteipes das aulas na universidade, entrevistas reflexivas, questionários, diário de campo e documentos (pessoais e oficiais) que se constituíram nas fontes dos dados. Pesquisadores da abordagem qualitativa apontam que trabalhos dessa natureza podem gerar "[...] um enorme volume de dados que precisam ser organizados e compreendidos” (ALVES-MAZZOTTI e GEWANDSZNAJDER, 2001, p. 170). Assim, as informações foram obtidas a partir da seleção de muitos instrumentos que continham os dados mais relevantes e significativos em relação às conexões que os sujeitos estabeleceram entre as concepções acerca da Matemática e do processo ensino-aprendizagem e a prática pedagógica desenvolvida.

Com o término da coleta das informações, iniciou-se a análise qualitativa dos dados, a qual "[...] se apresenta como uma atividade de interpretação que consiste no desvelamento do oculto [...]. Trata-se de uma prática que auxilia o pesquisador a superar intuições ou impressões precipitadas e possibilita a desocultação de significados invisíveis à primeira vista” (SZYMANSKI et al, 2004, p. 63). Os procedimentos adotados para uma análise dessa natureza visam à maximização da confiabilidade dos resultados alcançados no estudo. Nesse sentido, Bardin (1977) sugere que a análise se inicie por uma leitura flutuante dos dados, isto é, seja feita uma primeira aproximação com a totalidade dos dados coletados, cujo foco é o de se familiarizar com o conteúdo das informações contidas nas fontes. Tal procedimento foi adotado neste trabalho. A partir do momento que se concluiu a coleta dos instrumentos de pesquisa, passou-se à leitura flutuante de todo o material obtido, da seguinte maneira:

a) assistiu-se aos videoteipes das aulas;

b) leu-se os questionários e demais documentos;

c) ouviu-se as entrevistas e as sessões de orientações das aulas de Matemática para o estágio.

Deste modo, dos instrumentos obtidos durante o desenvolvimento da Metodologia do Ensino de Matemática, optou-se pelos questionários 1 e 2 (Q1 e Q2), os quais foram aplicados, respectivamente, no início e no final do período letivo da referida disciplina. As informações contidas nesses documentos além de revelarem as idéias de cada sujeito em momentos pontuais e significativos do processo investigativo (no começo e no fim da 
Metodologia de Ensino e, ainda, antes do início da prática pedagógica no estágio), também, viabilizaram aos sujeitos o resgate posterior de seus pensamentos. Essa estratégia permitiu que os alunos estagiários refletissem sobre seus modos particulares de conceber a Matemática e o ensino-aprendizagem da mesma.

Em virtude dos dados obtidos durante o período em que os sujeitos desenvolveram seus estágios em docência, optou-se pelos seguintes instrumentos: entrevistas reflexivas (reuniões individuais entre a professora de Metodologia e os sujeitos), diário de campo da pesquisadora e documentos pessoais (planos de aula e relatórios de estágio). Cabe esclarecer que as entrevistas foram realizadas em duas circunstâncias:

a) antes de cada aula de Matemática que os sujeitos desenvolveram durante seus estágios em docência;

b) após o término do estágio em docência.

Assim, com o fim da leitura de todo o material, iniciou-se a transcrição das entrevistas, quando se procedeu à passagem dos diálogos da forma oral para a escrita. Nesse processo, procurou-se resguardar as informações essenciais, contudo, na medida do possível se optou pela correção de alguns elementos da linguagem (concordâncias verbal e nominal, erros gramaticais, vícios de linguagem, repetição de palavras, entre outros), cujo intuito foi o de melhorar a compreensão do texto. Porém, percebeu-se que as informações em relação às concepções e à prática pedagógica, de cada sujeito, estavam distribuídas ao longo das várias entrevistas e, também, nos demais documentos (questionários, planos de aula e relatório de estágio).

Deste modo, com o intuito de rearticular as informações contidas nas entrevistas, tornando-as compreensíveis e literalmente agradáveis, fez-se a textualização de algumas partes das transcrições das entrevistas, ou seja, desenvolveu-se um novo texto, o qual foi utilizado na apresentação de cada sujeito e da respectiva trajetória no estágio em docência em relação à Matemática. A textualização consiste na idéia de transformar a entrevista em um texto sem perguntas e respostas, ou seja, trata-se da elaboração de uma narrativa como se essa fosse contada pelo próprio entrevistado, mantendo-se a fidelidade às informações fornecidas. (FONSECA, 1997; GUÉRIOS, 2002; CYRINO, 2003).

Do restante das transcrições, selecionou-se as partes que continham informações sobre as concepções de Matemática e do processo de ensino-aprendizagem para comporem os episódios de pesquisa. A escolha pela apresentação de episódios ocorre pela possibilidade de ressaltar informações relacionadas a momentos considerados importantes do processo investigativo. Pois, evidenciam as conexões que os sujeitos fizeram entre as suas concepções 
e a prática pedagógica e, principalmente, os momentos de conflitos que levaram à reflexão e, por conseqüência, à aprendizagem de novos conceitos. Assim, permitindo o entendimento do processo de evolução do perfil conceitual que cada sujeito vivenciou durante o seu estágio em relação à área de Matemática. Guiando-se por Moura (1992, p. 77), os episódios correspondem ao "conjunto de ações que desencadeia o processo de busca da resposta do problema em questão". Em outras palavras, nos episódios, os dados são organizados de modo a revelarem uma seqüência de ações que caracterizam a maneira própria de cada um pensar e agir. A captura destes momentos exige um corte na totalidade das informações de pesquisa obtidas, permitindo-se o aprofundamento das situações observadas à luz da questão central de investigação.

Após rever as entrevistas, reler atentamente as transcrições e selecionar os momentos de cada depoimento para compor os episódios, conduziu-se o olhar na busca de maiores aproximações com as idéias dos sujeitos. Esse processo permitiu a percepção de alguns aspectos comuns entre os dados. Vale lembrar que, em linhas gerais, o olhar esteve orientado pela intenção em identificar as concepções e as conexões que os sujeitos fizeram com suas práticas pedagógicas. No entanto, essas percepções ainda estavam no nível das impressões pessoais, necessitando-se assim, de maiores sistematizações dos dados. Pois, conforme os dados são lidos é possível perceber a repetição de certos eventos, como: palavras, frases, atitudes, acontecimentos e modos de pensamento dos sujeitos. Essas repetições se configuram como uma forma de destaque nos dados, os quais se tornam propícios para a identificação de algum tipo de regularidade.

O desenvolvimento de um sistema de codificação envolve vários passos: percorre os seus dados na procura de regularidades e padrões bem como de tópicos presentes nos dados e, em seguida, escreve palavras e frases que representam estes mesmos tópicos e padrões. Estas palavras ou frases são categorias de codificação. As categorias constituem um meio de classificar os dados descritivos que recolheu [...], de forma a que um material contido num determinado tópico possa ser fisicamente apartado dos outros dados (BOGDAN E BIKLEN,1994, p.221).

Então, foram feitos pequenos recortes das transcrições e dos demais documentos, os quais expressavam, de certo modo, as visões sobre a Matemática e o respectivo processo ensino-aprendizagem. A partir desses recortes se atribuiu uma primeira interpretação às idéias dos sujeitos (APÊNDICE 4). Essas interpretações auxiliaram tanto na compreensão em como cada um esteve pensando durante o período da coleta de dados, quanto contribuiu para a categorização das idéias do sujeitos e dos perfis conceituais. 
A partir da sistematização das idéias dos sujeitos e de referenciais teóricos, procedeuse à constituição das zonas dos perfis relacionados à Matemática, ao ensino e aos referentes da aprendizagem da Matemática. Assim, na seqüência, apresenta-se a descrição individualizada dos dados de cada sujeito, seguida da definição das zonas dos perfis conceituais. Realizada a sistematização das categorias das idéias dos sujeitos e dos perfis conceituais se faz uma análise em profundidade do movimento evolutivo das concepções à luz da aprendizagem da docência em Matemática.

\subsection{DESCRIÇÃO DAS INFORMAÇÕES DE CADA SUJEITO}

Essa descrição está organizada no sentido de apresentar os sujeitos de pesquisa, contando-se as trajetórias que cada um vivenciou em relação à formação para a docência e, também, sobre a experiência com a docência em Matemática vivenciada no período do estágio. Tais informações permitem o entendimento de algumas das conexões que os sujeitos fizeram entre suas concepções e a prática pedagógica pré-profissional. Vale esclarecer que, uma parte das informações textualizadas foi coletada ao longo do ano letivo e, então, confirmadas e complementadas por meio de uma entrevista no final do ano, demarcando-se assim, o término do processo de coleta de dados. E, também, que os referidos textos apresentam uma linguagem coloquial, em primeira pessoa. Pois, segundo Guérios (2002), é um modo de proporcionar maior aproximação com a linguagem dos participantes de pesquisa, conforme a autora explica.

Isto se deve ao fato de que as vozes pertencem a pessoas que ao se expressarem como se expressam, dizem mais do que aquilo que as palavras escolhidas por elas têm para dizer. Por trás do texto, portanto, ocorre um outro não escrito, nem falado, que permanece nos espaços entre as linhas e entre as palavras (GUERIOS, 2002, p. 36).

Assim, entende-se que tanto a proximidade com as vozes expressas quanto o estudo do conteúdo de tais espaços entre as linhas e as palavras permitem uma leitura das conexões entre as concepções dos sujeitos e suas práticas pedagógicas. Portanto, na seqüência se apresenta o relato dos três casos em estudo, sejam eles: A1, A2 e A3. 


\subsubsection{O Relato da trajetória de A1}

Sou aluna do $3^{\circ}$ ano do curso de Pedagogia e fiz meu estágio em docência no período da noite em uma escola municipal de Curitiba em uma turma multi-seriada, ou seja, em uma mesma sala havia alunos da Educação de Jovens e Adultos (EJA) desde a alfabetização até a 4. ${ }^{a}$ série do Ensino Fundamental. Quando fiz meu estágio em docência já trabalhava como professora há dois anos, com crianças da Educação Infantil. No ano passado, em um estágio não obrigatório e, agora, em uma creche da prefeitura de Curitiba. Minha experiência profissional sempre foi como professora na Educação Infantil. Em meu estágio desenvolvi somente aulas de Matemática. Foram planejadas cinco aulas sobre os conteúdos: Medidas de Comprimento, Medidas de Massa, Medidas de Capacidade e Medidas de Tempo com unidades não padronizadas e padronizadas, das quais pude desenvolver somente as quatro primeiras. A professora regente dessa turma não me indicou conteúdos das outras disciplinas porque ela informou que quase não trabalhou com a Matemática e os alunos sentem mais dificuldade com essa área. Porém, o que eu conhecia de Matemática até fazer a Metodologia de Ensino era só aquilo que tinha aprendido. Era só aquilo. Então, como não gostei de geometria, tinha esquecido, nem lembrava. Era aquilo que eu tinha aprendido, só conta. Eu não gostava de Matemática. Assim, ficou aquilo na minha cabeça. Só depois que fiz a Metodologia de Ensino fui pegar gosto pela Matemática. Porque vi como ela é diferente. Não é aquilo que é para ser ensinado e que nos deixa nervosos, igual a maneira que foi ensinada para mim, tudo tradicional. Acho que, por isso, senti muita dificuldade quando fui fazer os meus planos de aula. Pois, além de não encontrar nada de diferente nos livros didáticos, também, não sabia o que selecionar dos conteúdos para desenvolver nas aulas. Veja, cheguei a pegar esses conteúdos nos Parâmetros ${ }^{29}$ de primeira a quarta e não clareou. E, ainda, estava com medo de fazer alguma coisa muito infantil, os alunos da EJA são muito diferentes. Vi que eles não gostam de ficar recortando figurinhas para fazer histórias em quadrinho como fazemos com as crianças. Mas, eu queria que eles aprendessem e participassem, não ficassem só naquele esquema do professor falando e eles ouvindo, com medo de perguntar. Com o fim do estágio vejo que para a minha aprendizagem em relação à formação docente para o ensino da Matemática foi muito bom ter tido a ajuda da professora de Metodologia, porque eu não sabia por onde começar. Tenho certeza que seria um fracasso a minha aula. Eu tinha na minha cabeça aquilo tradicional de explicar. Por quê? Porque eu sempre via assim. Sei lá, de repente uma aula para criança, explica, explica e dá atividade, explica, explica. Porque eu não sabia se tinha outra forma de saber. Foi assim que aprendi. Aí, depois fui ver a aula de uma estagiária e ela fez igual. Aquilo me deixou revoltada. Quando chegou na última observação falei que não ia fazer, mas a professora regente falou que eu precisava fazer porque as meninas não fizeram como tinha que ser feito. Aí percebi que tinha alguma coisa errada. Então, observei a aula da professora. Era bem diferente do que as meninas tinham feito. Fiz minhas anotações comparando elas com a professora, para criar um jeito meu. Só que quando chegou na hora de elaborar o plano fiquei no tradicional, porque não sabia fazer outra coisa. Não tinha idéia de como deixar mais dinâmico, de questionar os alunos. Não imaginava que podia ser feito isso. Das experiências, não imaginava. Até tinha uma idéia de, talvez, levar uma balança. Só, que até o último momento, eu ia fazer a experiência. Eu ia fazer. Então, continuei no tradicional. Só depois entendi que não era assim. Porque, na verdade, na Educação de Jovens e Adultos nunca tinha trabalhado antes. Nunca tinha entrado em uma sala de aula com eles. Nem observado, nem conversado com ninguém que fizesse EJA, com professor, com nada. Só com o que está escrito. Só que, nenhum texto que li estava: é assim, assim, assim. Mesmo lendo Paulo Freire, é difícil entender.

\footnotetext{
${ }^{29}$ Os Parâmetros se referem aos Parâmetros Curriculares Nacionais.
} 


\subsubsection{O Relato da trajetória de A2}

Sou aluna do $3 .^{\circ}$ ano do curso de Pedagogia, desenvolvi meu estágio na mesma escola que A1, porém no período da tarde com crianças da $1 .^{a}$ série do Ensino Fundamental. A minha experiência profissional sempre foi em administração. Agora que estou lá na escola em estágio remunerado e não obrigatório como auxiliar de educação infantil. Mas, é a primeira vez na área da educação. Até o ano passado trabalhava em uma instituição filantrópica que faz trabalho educativo com as crianças, eu ficava lá no escritório, fechadinho, fazendo contas. No Ensino Médio fiz Contabilidade. Mas, eu não gostava do meu curso. A Pedagogia surgiu com o trabalho voluntário. Dava algumas aulas, principalmente religiosas, na igreja que freqüento. Comecei mesmo, o primeiro passo que dei foi no hospital, com quinze anos, no HC e no Pequeno Príncipe. Fazia um trabalho recreativo. Havia uma equipe que se vestia de palhaço e eu ficava na sala com eles. Depois que cantavam e faziam palhaçadas com as crianças, eu desenvolvia uma atividade com elas. Hoje, chamo de pedagógica, mas na época não. Então, contava uma história e depois fazia uma dobradura. É tudo o que fazemos hoje no hospital pela disciplina Pedagogia Hospitalar ${ }^{30}$. Fiz alguns cursos gratuitos de psicologia infantil. E tudo isso foi me encantando até que surgiu a oportunidade e fui fazer o vestibular para Pedagogia. Quando saí da instituição filantrópica, no ano passado, continuei lá como voluntária, dando aulas em um projeto que eles tinham. Para o meu estágio elaborei planos de aula sobre conteúdos de Língua Portuguesa, Ciências, Geografia e Matemática. Para as duas aulas de Matemática desenvolvidas por mim, planejei trabalhar com os conteúdos de adição e subtração envolvendo unidades e dezenas nas operações, leitura de tabelas, composição e decomposição de unidades e dezenas e o estudo do antecessor e sucessor de um número. Quando pensei na aula, justamente o que veio à minha cabeça foi tirar essa idéia da Matemática como um monstro e fazer dela uma coisa agradável. Por isso a intenção do jogo, principalmente, do material dourado. Quando descobri o material dourado me encantei. Se tivesse isso na minha infância! Tive dificuldade para entender o material dourado porque só tinha visto ele no papel. Pegar no papel para ler é uma coisa, pegar no material é outra. Vi, mas o que é esse negócio? Olhava, olhava. Em uma outra disciplina resolvi pesquisar sobre Montessori. Olhava, mas não é possível! Vou falar sobre a mulher e não sei como mexe nesse negócio! Se alguém me perguntar, o que falo? Até quebrei um pouco a cabeça, fui à site, procurei e achei um que está na bibliografia do plano, até que entendi. Daí, quando descobri pensei: "vou ter que ensinar isso aqui na minha docência". No estágio vou ter que fazer isso porque, para mim, é a mesma coisa que não ensinar Matemática. Pois, é tão lógico, tão mais fácil para eles aprenderem. Então, quando planejei a aula, pensei nessa intenção de tirar o terror da cabeça dos alunos, para eles verem que é uma coisa gostosa, o jogo, fazer conta brincando e, também, de dialogar com os alunos, de construir o conceito em conjunto ao invés de eu dar tudo pronto e eles só copiarem. Em meu histórico dentro da Matemática não tive muita dificuldade. Fazia, gostava, não sentia medo da Matemática como a maioria dizia ter medo. Ah, eu gosto! Não era minha paixão. Não dizia assim: ah, que legal! Não era assim. Mas, não a via como um bicho papão. Apesar de que, em meu aprendizado não se podia questionar em Matemática, era exata. Por isso que dava esse terror, $e$ se eu errasse? Só consegui enxergar que não precisa ser assim depois que começamos a trabalhar na Metodologia com os problemas matemáticos, os tipos de problemas. Aí percebi essa diferença. Após terminar meu estágio considero como primeiro aprendizado em relação à formação docente para a Matemática que tenho que ir devagar. Uma coisa de cada vez. Primeiro ver com os alunos o que eles já têm de noção. Mas, ali no concreto, não na forma como fiz, muito superficial. Ver, realmente, no concreto o que eles já compreendem de Matemática. Digamos que no ano que vem eu pegue uma turma de primeira série. Então, quero primeiro saber o que cada aluno já sabe de Matemática, para daí começar um conteúdo, fazer o programa do que vou ensinar para eles. Não adianta pensar no que

${ }^{30}$ A Pedagogia Hospitalar é uma disciplina optativa para os alunos do curso de Pedagogia. 
vou fazer se ainda não sei o que eles sabem. E, principalmente, a questão do método tradicional que ainda tenho e achava que não tinha mais. Não percebi que ainda tinha. Então, essas conversas me fizeram observar que tinha. Eu não parava para observar a minha fala, a forma como eu conduzia algumas coisas. Isso fez com que eu prestasse mais atenção de agora em diante. Até na hora que replanejei minha segunda aula, replanejei pensando nisso: permitir mais a participação dos alunos sem direcionar tanto e tentar cuidar disso na hora da aula. Pois, senão, põe no papel e chega lá na hora e faz tudo diferente. Isso é o que vou levar de maior aprendizado: observar mais a minha metodologia para fazer isso que tenho de teoria. Pois, na prática acabamos fazendo diferente.

\subsubsection{O Relato da trajetória de A3}

Sou aluna do $3 .^{\circ}$ ano do curso de Pedagogia, fiz estágio no período da noite, em uma escola municipal de Curitiba, com uma turma de $3 .^{a}$ e $4 .{ }^{a}$ séries da Educação de Jovens e Adultos (EJA). Lembro que tive muita dificuldade para aprender fração e, até hoje, têm algumas coisas que não sei para que servem, como o logaritmo. Mas, adoro fazer contas. Até pensei em fazer vestibular para Matemática ou Matemática Industrial, mas a minha mãe ficou com receio de que eu não gostasse e acabasse desistindo. Como era muito nova, só tinha 17 anos, não sabia muito o que queria. Então, acabei optando pelo curso de Pedagogia, conforme sugestão de minha mãe. Comecei trabalhar com 15 anos de idade em uma escola de Educação Infantil. Mas, era uma espécie de "quebra-galho". Pois, fazia um pouco de tudo, brincava com as crianças, trocava fraldas e substituía os professores que faltavam. Estive lá durante 8 meses. Voltei a trabalhar somente agora, coordenando o laboratório de informática de uma das escolas municipais da prefeitura de Curitiba. Nessa função, auxilio as professoras regentes na elaboração de atividades a serem desenvolvidas com as crianças no laboratório de informática e oriento os alunos no manuseio com o equipamento. No estágio ministrei aulas de Matemática, Língua Portuguesa e Geografia. Em relação à Matemática, elaborei um plano sobre tabelas e gráficos, o qual foi desenvolvido ao longo de três aulas. A idéia do meu trabalho ocorreu durante uma conversa com a professora regente, a qual me deu as apostilas da rede municipal. Aí, lá tinha gráfico, porcentagem, bastante coisa. Perguntei se eles já tinham visto esses conteúdos. Ela disse que alguns sim. Mas, que tinha sido bem superficial. Então, como trabalho com informática e queria trabalhar com a informática básica, cujo campo entra o Excel, vi que era possivel associar uma coisa com a outra. Dava para fazer a aula de Matemática relacionada com a informática. Trabalho com a informática só auxiliando os professores. Então, o planejamento que faço é diferente deste do desenvolvido no estágio. E, só agora que vi que é bem complicado tentar conciliar a sala de aula com o laboratório de informática, por isso fiz meus planos tudo fechadinho, sem relação entre as disciplinas. E, sempre cobrei tanto das professoras! Após o término do estágio percebo que cresci muito, abriu. Achava que todo mundo ia saber quanto era tanto, que ia saber tal coisa. Não é assim. Como nunca fui para a sala de aula, vi isso. Claro, ainda falta muito para aprender. Reclamo, não reclamo, mas às vezes, falo, falo, falo das professoras de $4 .{ }^{a}$ série e se for ver o que fiz em minha aula, fiz igual a elas. Depois, tentei trazer mais para o lado do aluno. Falo para minha mãe que do jeito que penso sou meio tradicional. Então, acho que a experiência desse ano ajudou a me centrar. Mas, acho que é um crime fazer Metodologia em um só semestre, porque é tanta coisa. Adorei fazer aquele jogo, me empolguei. Mas, é tanta coisa. Dava para construir tanto mais, trocar de material, se fosse um an!. Reclamo tanto, por que dois anos de Filosofia e de Psicologia? Sei que são importantes, mas a Metodologia eu acho que é mais. Ajuda mais, porque é lá no dia-adia, precisa daquilo. 


\subsection{INTERPRETAÇÃO DAS INFORMAÇÕES COLETADAS}

Com a textualização das informações coletadas ao longo do trabalho de campo e com o intuito de compreender em profundidade aspectos relativos à aprendizagem da docência em Matemática, as idéias dos sujeitos foram sistematizadas de modo a evidenciar os pensamentos de cada um em relação à Matemática e seu processo de ensino-aprendizagem. Esse procedimento foi adotado no intuito de desenvolver o primeiro nível de análise em virtude da constituição dos perfis conceituais. Deste modo, organizou-se um quadro contendo as interpretações sobre as idéias dos sujeitos.

Nesse quadro, as idéias estão organizadas em concepções iniciais (informações coletadas do questionário 1), intermediárias (informações coletadas do questionário 2) e finais (informações coletadas durante a prática pedagógica por meio das entrevistas, planos de aula, relatório de estágio e diário de campo), correspondendo, respectivamente, a três momentos específicos do processo investigativo, o início da Metodologia do Ensino de Matemática, o término da disciplina e o período de desenvolvimento do estágio em docência. O intuito dessa organização é de acompanhar o movimento evolutivo das idéias sobre a Matemática e o processo ensino-aprendizagem de A1, A2 e A3 no sentido da ampliação e/ou permanência do espectro nocional de partida dos sujeitos e, também, de capturar as conexões realizadas em cada período.

Assim, cada idéia interpretada recebeu um código numérico a fim de facilitar futuras articulações deste estudo. Nesse processo de significação, consideraram-se as impressões e intuições percebidas sobre as conexões entre as concepções e a prática pedagógica a partir das informações apresentadas. Ainda, cabe esclarecer que as idéias reveladas estão identificadas, no quadro 2, pelo código do sujeito (A1, A2, e/ou A3), enquanto que a ausência do código implica na não revelação da idéia para aquele período. Logo, é possível observar se uma determinada idéia se refere à uma concepção relativa ao início do processo investigativo, ao período intermediário ou ao final da coleta de dados.

QUADRO 2 - INTERPRETAÇÃO DA PESQUISADORA SOBRE AS IDÉIAS DE A1, A2 e A3

continua

\begin{tabular}{|l|c|c|c|}
\hline \multicolumn{1}{|c|}{ CÓDIGOS E IDÉIAS INTERPRETADAS } & $\begin{array}{c}\text { CONCEPÇ } \\
\text { INICIAIS }\end{array}$ & $\begin{array}{c}\text { CONCEPÇ } \\
\text { INTERMED }\end{array}$ & $\begin{array}{c}\text { CONCEPÇ } \\
\text { FINAIS }\end{array}$ \\
\hline $\begin{array}{l}\text { 1-A Matemática tem seu foco na aritmética, é } \\
\text { centrada nos cálculos e nos números. }\end{array}$ & $\mathrm{A} 1-\mathrm{A} 3$ & $\mathrm{~A} 1$ & $\mathrm{~A} 2$ \\
\hline $\begin{array}{l}\mathbf{2}-\mathbf{E} \text { Énase no raciocínio e na lógica do } \\
\text { conhecimento matemático. }\end{array}$ & $\mathrm{A} 2$ & $\mathrm{~A} 1-\mathrm{A} 2$ & $\mathrm{~A} 2$ \\
\hline $\begin{array}{l}3-\text { Relevância ao aspecto formal e exato do } \\
\text { conhecimento matemático. }\end{array}$ & $\mathrm{A} 2-\mathrm{A} 3$ & $\mathrm{~A} 1-\mathrm{A} 2-\mathrm{A} 3$ \\
\end{tabular}




\begin{tabular}{|c|c|c|c|}
\hline CÓDIGOS E IDÉIAS INTERPRETADAS & $\begin{array}{l}\text { CONCEPÇ } \\
\text { INICIAIS }\end{array}$ & $\begin{array}{l}\text { CONCEPÇ } \\
\text { INTERMED }\end{array}$ & $\begin{array}{l}\text { CONCEPÇ } \\
\text { FINAIS }\end{array}$ \\
\hline $\begin{array}{l}4 \text { - As idéias matemáticas estão prontas e foram } \\
\text { criadas pelos povos antigos. }\end{array}$ & $\mathrm{A} 1-\mathrm{A} 3$ & $\mathrm{~A} 1$ & \\
\hline $\begin{array}{l}5 \text { - O conhecimento matemático é resultado da } \\
\text { racionalização de alguns pensadores. }\end{array}$ & A1 & A1 & \\
\hline $\begin{array}{l}6 \text { - O acesso ao conhecimento matemático é } \\
\text { privilégio de poucas pessoas. }\end{array}$ & A1 & A1 & \\
\hline 7 - A Matemática possui caráter utilitário. & $\begin{array}{l}\mathrm{A} 1-\mathrm{A} 2 \\
\mathrm{~A} 3\end{array}$ & $\mathrm{~A} 1-\mathrm{A} 3$ & $\mathrm{~A} 2-\mathrm{A} 3$ \\
\hline $\begin{array}{l}8 \text { - O conhecimento matemático é amplo, não se } \\
\text { restringe à aritmética e fórmulas. }\end{array}$ & & A2 & $\mathrm{A} 1-\mathrm{A} 3$ \\
\hline $\begin{array}{l}9 \text { - O conhecimento matemático é acessível a } \\
\text { todos. }\end{array}$ & & $\mathrm{A} 2$ & \\
\hline $\begin{array}{l}10 \text { - O conhecimento matemático é vinculado ao } \\
\text { mundo real. }\end{array}$ & & $\mathrm{A} 2-\mathrm{A} 3$ & A3 \\
\hline 11 - O conhecimento matemático é construído. & & $\mathrm{A} 2$ & $\mathrm{~A} 2$ \\
\hline 12 - O conhecimento matemático é falível. & & $\mathrm{A} 2-\mathrm{A} 3$ & \\
\hline $\begin{array}{lllll}3-\text { Sentimento de } & \text { afinidade com a } \\
\text { Matemática. } & & & & \\
\end{array}$ & & & $\mathrm{A} 1-\mathrm{A} 2-\mathrm{A} 3$ \\
\hline $\begin{array}{l}14 \text { - Sente dificuldade com } \text { o conteúdo } \\
\text { matemático. }\end{array}$ & & & $\mathrm{A} 1-\mathrm{A} 2-\mathrm{A} 3$ \\
\hline $\begin{array}{l}15-\text { O professor, principal fonte de } \\
\text { informações, repassa ao aluno o conhecimento } \\
\text { como pronto e acabado. }\end{array}$ & A1 & $\begin{array}{c}\mathrm{A} 1-\mathrm{A} 2 \\
\mathrm{~A} 3\end{array}$ & $\mathrm{~A} 1-\mathrm{A} 3$ \\
\hline $\begin{array}{l}16 \text { - O professor propõe problemas relacionados } \\
\text { ao mundo real para exemplificar a técnica } \\
\text { operatória ou o conceito. }\end{array}$ & $\begin{array}{c}\mathrm{A} 1-\mathrm{A} 2 \\
\mathrm{~A} 3\end{array}$ & $\mathrm{~A} 1-\mathrm{A} 3$ & A1 \\
\hline $\begin{array}{l}17 \text { - O professor enfoca o ensino de símbolos, } \\
\text { apresenta linguagem matemática universal, } \\
\text { concisa e precisa e se preocupa com abstrações } \\
\text { do conceito. }\end{array}$ & A1 & & A1 \\
\hline $\begin{array}{l}18 \text { - O professor valoriza tarefas que levem à } \\
\text { certeza, não-questionamento e à resposta única } \\
\text { e verdadeira. }\end{array}$ & $\mathrm{A} 1-\mathrm{A} 3$ & A1 & \\
\hline 19 - O professor exerce o papel de instrutor. & $\begin{array}{c}\mathrm{A} 1-\mathrm{A} 2 \\
\mathrm{~A} 3\end{array}$ & A1 & A3 \\
\hline $\begin{array}{l}20 \text { - O professor desenvolve um ensino livresco e } \\
\text { expositivo, apresentando definições, teoria e } \\
\text { exercícios de aplicação do conteúdo. }\end{array}$ & & A2 & $\mathrm{A} 1-\mathrm{A} 2-\mathrm{A} 3$ \\
\hline $\begin{array}{l}21 \text { - O professor propõe exercícios para } \\
\text { desenvolver a memorização de princípios e } \\
\text { fórmulas, as habildiades de manipulação de } \\
\text { algoritmos e resolução de problemas-padrão. }\end{array}$ & A1 & & $\mathrm{A} 1-\mathrm{A} 3$ \\
\hline $\begin{array}{l}22 \text { - O professor usa material didático, } \\
\text { estruturado ou não, para que o aluno veja e } \\
\text { descubra a técnica operatória ou o conceito. }\end{array}$ & A1 & $\mathrm{A} 1-\mathrm{A} 2$ & $\mathrm{~A} 1-\mathrm{A} 2-\mathrm{A} 3$ \\
\hline $\begin{array}{l}23 \text { - O professor propicia ao aluno o contato } \\
\text { visual e/ou táctil com os materiais didáticos. }\end{array}$ & $\begin{array}{l}\mathrm{A} 1-\mathrm{A} 2 \\
\mathrm{~A} 3\end{array}$ & $\mathrm{~A} 1-\mathrm{A} 2$ & $\mathrm{~A} 1-\mathrm{A} 2$ \\
\hline $\begin{array}{l}24 \text { - O professor desenvolve o conteúdo por } \\
\text { meio de problemas e atividades investigativas. }\end{array}$ & & A1 & A1 \\
\hline
\end{tabular}




\begin{tabular}{|c|c|c|c|}
\hline CÓDIGOS E IDÉIAS INTERPRETADAS & $\begin{array}{l}\text { CONCEPÇ } \\
\text { INICIAIS }\end{array}$ & $\begin{array}{l}\text { CONCEPÇ } \\
\text { INTERMED }\end{array}$ & $\begin{array}{l}\text { CONCEPÇ } \\
\text { FINAIS }\end{array}$ \\
\hline $\begin{array}{l}25 \text { - O professor estabelece vínculo com o } \\
\text { mundo sensível, por meio de atividades práticas } \\
\text { e com materiais didáticos, manipulados pelos } \\
\text { alunos. }\end{array}$ & $\mathrm{A} 2-\mathrm{A} 3$ & $\mathrm{~A} 3$ & $\mathrm{~A} 1-\mathrm{A} 2-\mathrm{A} 3$ \\
\hline $\begin{array}{l}26 \text { - O professor, um mediador entre o } \\
\text { conhecimento e o aluno, estabelece uma relação } \\
\text { dialógica em sala de aula. }\end{array}$ & & & $\mathrm{A} 1-\mathrm{A} 2-\mathrm{A} 3$ \\
\hline $\begin{array}{l}27 \text { - O ponto de partida do ensino são os } \\
\text { problemas / problematizações. }\end{array}$ & & & $\mathrm{A} 1-\mathrm{A} 2$ \\
\hline $\begin{array}{l}28-O \text { professor adota estratégias que } \\
\text { propiciem o desenvolvimento de atitudes de } \\
\text { iniciativa, de interação entre alunos, favorece a } \\
\text { negociação do significado e a construção de } \\
\text { conceitos. }\end{array}$ & & A2 & $\mathrm{A} 1-\mathrm{A} 2-\mathrm{A} 3$ \\
\hline $\begin{array}{l}29 \text { - O professor resgata e parte do } \\
\text { conhecimento do aluno para explicar o } \\
\text { conteúdo. }\end{array}$ & & & $\mathrm{A} 1-\mathrm{A} 2-\mathrm{A} 3$ \\
\hline $\begin{array}{l}30 \text { - O professor revela preocupação com a } \\
\text { organização didática da aula para que o aluno } \\
\text { possa elaborar o conhecimento: disposição das } \\
\text { carteiras, uso da lousa, adequação do enunciado } \\
\text { das tarefas. }\end{array}$ & & & $\mathrm{A} 1-\mathrm{A} 2-\mathrm{A} 3$ \\
\hline $\begin{array}{l}31 \text { - O professor, ao ensinar, adota estratégias } \\
\text { que possibilitem estabelecer conexões entre os } \\
\text { conteúdos matemáticos em si e/ou com outras } \\
\text { áreas do conhecimento. }\end{array}$ & & $\begin{array}{l}\text { A2 } \\
\text { A3 }\end{array}$ & A3 \\
\hline $\begin{array}{l}32 \text { - O professor propõe atividades adequadas } \\
\text { ao conhecimento prévio do aluno. }\end{array}$ & & & A2 \\
\hline $\begin{array}{l}33 \text { - O professor estabelece contrato didático } \\
\text { com os alunos. }\end{array}$ & & & A2 \\
\hline $\begin{array}{l}34 \text { - Sentimento aversivo em relação ao } \\
\text { desenvolvimento da aula. }\end{array}$ & & & $\mathrm{A} 1-\mathrm{A} 3$ \\
\hline $\begin{array}{l}35 \text { - O aluno aprende com o contato visual da } \\
\text { prática e da explicação feitas pelo professor. }\end{array}$ & A1 & $\begin{array}{l}\mathrm{A} 1-\mathrm{A} 2 \\
\mathrm{~A} 3\end{array}$ & $\mathrm{~A} 1-\mathrm{A} 3$ \\
\hline $\begin{array}{l}36 \text { - O aluno aprende memorizando mediante a } \\
\text { reprodução de raciocínios e procedimentos } \\
\text { ditados pelo professor. }\end{array}$ & $\begin{array}{l}\mathrm{A} 1-\mathrm{A} 2 \\
\mathrm{~A} 3\end{array}$ & & A1 \\
\hline $\begin{array}{l}37-\quad \text { O aprendizado matemático é um } \\
\text { movimento do concreto para o abstrato. }\end{array}$ & $\begin{array}{l}\mathrm{A} 1-\mathrm{A} 2 \\
\mathrm{~A} 3\end{array}$ & $\mathrm{~A} 2$ & $\mathrm{~A} 1-\mathrm{A} 2-\mathrm{A} 3$ \\
\hline $\begin{array}{l}38 \text { - O aluno deve ter desempenho correto, ele } \\
\text { deve acertar nas respostas. }\end{array}$ & & A1 & \\
\hline $\begin{array}{l}39 \text { - O aluno aprende desenvolvendo o modo } \\
\text { próprio de pensar, independentemente de o } \\
\text { procedimento estar certo ou errado. }\end{array}$ & & A1 & $\mathrm{A} 1-\mathrm{A} 2$ \\
\hline $\begin{array}{l}40-O \text { aluno aprende o conhecimento } \\
\text { matemático investigando, expondo suas idéias, } \\
\text { resolvendo situações problemáticas. }\end{array}$ & & A1 & $\mathrm{A} 1-\mathrm{A} 2$ \\
\hline $\begin{array}{l}41 \text { - O aluno aprende perante a realização de } \\
\text { jogos e experimentos e/ou pelo contato visual e } \\
\text { táctil de materiais didáticos. }\end{array}$ & & & $\mathrm{A} 1-\mathrm{A} 2-\mathrm{A} 3$ \\
\hline
\end{tabular}




\begin{tabular}{|c|c|c|c|}
\hline CÓDIGOS E IDÉIAS INTERPRETADAS & $\begin{array}{l}\text { CONCEPÇ } \\
\text { INICIAIS }\end{array}$ & $\begin{array}{l}\text { CONCEPÇ } \\
\text { INTERMED }\end{array}$ & $\begin{array}{l}\text { CONCEPÇ } \\
\text { FINAIS }\end{array}$ \\
\hline $\begin{array}{l}42 \text { - Saber Matemática é ser capaz de realizar } \\
\text { tarefas propostas pelo professor, as quais se } \\
\text { constituem em aplicações do conceito, reforço } \\
\text { ou motivação para a aprendizagem. }\end{array}$ & $\mathrm{A} 2$ & & A1 - A3 \\
\hline $\begin{array}{l}43 \text { - A participação do aluno, seu interesse e } \\
\text { idéias pessoais são fundamentais para a } \\
\text { aprendizagem do novo conhecimento. }\end{array}$ & & $\mathrm{A} 2-\mathrm{A} 3$ & $\mathrm{~A} 1-\mathrm{A} 2$ \\
\hline $\begin{array}{l}44-\text { O aluno aprende fazendo, isto é, } \\
\text { construindo relações entre as idéias } \\
\text { matemáticas já conhecidas e as novas. }\end{array}$ & & & $\mathrm{A} 1-\mathrm{A} 2$ \\
\hline $\begin{array}{l}45 \text { - Aprender Matemática é poder aplicar, usar } \\
\text { o conhecimento matemático no mundo real. }\end{array}$ & A2 & A2 & A1 \\
\hline $\begin{array}{l}46 \text { - A aprendizagem é resultante da ação } \\
\text { interativa/reflexiva do aluno com o meio e com } \\
\text { as tarefas. }\end{array}$ & & & $\mathrm{A} 1-\mathrm{A} 2$ \\
\hline $\begin{array}{l}47 \text { - O erro é visto como inerente ao processo de } \\
\text { aprendizagem. }\end{array}$ & & A3 & A2 \\
\hline $\begin{array}{l}48 \text { - Os alunos não aprendem da mesma } \\
\text { maneira. }\end{array}$ & & & A3 \\
\hline $\begin{array}{l}49-O \text { aluno aprende memorizando os } \\
\text { procedimentos e conceitos, mas com } \\
\text { compreensão em relação ao conteúdo. }\end{array}$ & & & A3 \\
\hline
\end{tabular}

Fonte: dados organizados pela autora

Em tempo, esclarece-se que no quadro 2 a partir do tópico 1 até o 14 estão relacionadas as idéias relativas à Matemática. O intervalo que compreende o tópico 15 ao 34 corresponde às percepções sobre o ensino da Matemática e, do 35 em diante estão os pensamentos voltados para a aprendizagem da Matemática. Ao analisar esse quadro é possível perceber que os sujeitos de pesquisa mostraram terem ampliado seus espectros nocionais de partida, já que, ao final do processo investigado, eles revelaram conceber outras idéias sobre a Matemática e o processo de ensino-aprendizagem, além das apresentadas nos registros iniciais. Contudo, percebe-se também que a maioria das idéias apresentadas na etapa inicial permaneceu até o final. Tal situação implica pensar em uma perspectiva de coexistência dos pensamentos. Pela noção do perfil conceitual, essa idéia leva ao entendimento de que "apesar de essas diferentes interpretações ou visões de mundo não ocorrerem simultaneamente ou no mesmo contexto, elas fornecem informações da realidade que não são excludentes [...]" (AMARAL e MORTIMER, 2006, p. 240), logo os diferentes pensamentos existem ao mesmo tempo para o sujeito. Então, além dessa característica imprimir certa imagem ao perfil conceitual de cada sujeito, ou seja, há indícios de ter ocorrido evolução nas estruturas 
cognitivas de partida, também, é interessante no sentido de se perceber que a compreensão dos sujeitos em relação à Matemática e ao ensino-aprendizagem dessa ciência é cada vez maior. Entretanto, essa organização dos dados permitiu que fossem percebidas algumas regularidades em relação às idéias reveladas pelos sujeitos, as quais estão evidenciadas no quadro a seguir. Cabe ainda esclarecer que os códigos numéricos indicados no quadro 3 se referem aos números listados juntamente com as idéias interpretadas no quadro anteriormente apresentado.

\section{QUADRO 3 - CATEGORIZAÇÃO DAS REGULARIDADES PERCEBIDAS}

\begin{tabular}{|l|l|l|}
\hline \multicolumn{1}{|c|}{ CONCEPÇÕES } & IDÉIAS INTERPRETADAS & \multicolumn{1}{|c|}{$\begin{array}{c}\text { REGULARIDADES } \\
\text { PERCEBIDAS }\end{array}$} \\
\hline \multirow{2}{*}{ MATEMÁTICA } & $5 ; 10$ & Origem \\
\cline { 2 - 3 } & $2 ; 7 ;$ & Finalidade \\
\cline { 2 - 3 } & $1 ; 3,4 ; 6 ; 8 ; 9 ; 11 ; 12$ & Características gerais \\
\cline { 2 - 3 } & $13 ; 14$ & Aspectos subjetivos \\
\hline \multirow{2}{*}{ ENSINO DA MATEMÁTICA } & $15 ; 17 ; 19 ; 25 ; 26 ; 28 ; 31$ & Função do professor \\
\cline { 2 - 3 } & $16 ; 18 ; 20 ; 21 ; 22 ; 23 ; 24 ; 27 ;$ & Como o professor ensina \\
\cline { 2 - 3 } & $29 ; 30 ; 32 ; 33$ & Aspectos subjetivos \\
\cline { 2 - 3 } & 34 & Características do aluno \\
APRENDIZAGEM & $38 ; 39 ; 40 ; 42 ; 43 ; 45 ; 46 ; 48$ & Como se aprende Matemática \\
\cline { 2 - 3 } & $35 ; 36 ; 37 ; 41 ; 44 ; 47 ; 49$ & \\
\hline
\end{tabular}

Fonte: dados do campo de pesquisa.

A sistematização apresentada no quadro 3 evidencia aspectos comuns ao conjunto das idéias reveladas pelos sujeitos analisados. Então, em relação à Matemática se percebe que os sujeitos revelaram suas percepções sobre a origem e finalidade do conhecimento matemático, assim como também, características gerais que descrevem essa ciência e aspectos subjetivos relacionados a sentimentos de afinidade/aversão e facilidade/dificuldade com o conteúdo. No entanto, os pensamentos são múltiplos em relação a uma mesma regularidade. Por exemplo, sobre a origem do conhecimento matemático, tem-se que a Matemática é resultado da racionalização de alguns pensadores (tópico 5); e, também, que é resultado da observação do mundo real (tópico 10). Essa situação é decorrente da perspectiva de coexistência das visões conceituais dos sujeitos. Conforme pode ser observado nos seguintes registros, vale esclarecer que a indicação de A1, A2 e A3 se refere aos sujeitos e Q1 e Q2 aos questionários de onde foram coletadas as evidências. 
Estudiosos formaram conceitos como adição, multiplicação e divisão (A1, Q1).

A Matemática surgiu através de muitas pesquisas que hoje são reconhecidas como grandes gênios (A1, Q2).

A Matemática vem do instinto humano (A2, Q1).

A Matemática deve ser construída através de problemas e situações abordando questões do dia-a-dia (A2, Q2).

[a Matemática surgiu] quando a humanidade começou a utilizar diversos meios para contar e efetuar cálculos, antes mesmo do surgimento "simbólico" dos números (A3, Q1).

Desta maneira, entende-se que apesar de todas essas idéias se referirem a um mesmo assunto - origem do conhecimento matemático - elas fornecem informações distintas, são de naturezas diferentes. Pois, enquanto A1 e A2 sinalizam compreender que a Matemática tem sua origem na racionalização dos homens: "Estudiosos formaram conceitos [...]" ou "A Matemática vem do instinto humano", A3 e, novamente A2, indicam entender que essa ciência tem origem nas situações do cotidiano: "deve ser construída através de problemas e situações abordando questões do dia-a-dia" e "quando a humanidade começou a utilizar diversos meios para contar e efetuar cálculos”, em outras palavras, são várias as formas de pensar e falar sobre a Matemática.

Portanto, esclarece-se que pelas regularidades percebidas, a Matemática pode ter sua origem em uma perspectiva racional ou empírica, isto é, no mundo das idéias ou no mundo sensível. Já a finalidade da Matemática pode ser de caráter prático, no sentido de ter alguma aplicação, utilidade nas atividades cotidianas da humanidade ou de caráter abstrato, por exemplo, servir para o desenvolvimento da mente, do raciocínio das pessoas. Em termos das características gerais, as regularidades percebidas se referem à constituição do conhecimento (em construção, ciência pronta, estática); aos elementos que a compõe (foco na aritmética, fórmulas, cálculos, conhecimento amplo) e à linguagem que a caracteriza (precisa, formal, falível, cultural). Ressalta-se que, não se está julgando qual pensamento é o certo ou o errado e, sim, apenas evidenciando que cada regularidade percebida e apresentada no quadro 3 pode representar mais de um viés epistemológico, ou seja, é pluralista em sua representação. O mesmo ocorre em relação às concepções sobre o ensino e a aprendizagem em Matemática.

Sobre o ensino da Matemática, constam as regularidades relativas às visões sobre a função do professor e o modo como ele desenvolve o ensino da Matemática. Em relação à função do professor, agregou-se regularidades relativas ao papel desempenhado em sala de aula (instrutor ou mediador do processo) e à visão de Matemática adotada pelo docente (origem na razão ou no mundo sensível). Já, sobre o modo como desenvolve o ensino, as 
regularidades se referem à maneira que o professor trata o conhecimento a ser ensinado, os tipos de atividades e recursos didáticos que privilegia ao ensinar a Matemática e a dinâmica da aula em si. Em relação à aprendizagem em Matemática são considerados os aspectos relacionados às idéias sobre como um aluno entra em contato com o conhecimento matemático (características: observa a prática desenvolvida pelo professor; participa da elaboração de novos conhecimentos; reproduz conhecimento elaborado por outro) e as atitudes esperadas no desenvolvimento de tarefas em virtude de como se aprende Matemática (resolução de exercícios; manuseio de materiais didáticos). As evidências de tais regularidades estão presentes nos registros e depoimentos dos sujeitos de pesquisa, conforme pode ser observado nos seguintes trechos relativos a propostas de ensino de um conteúdo matemático.

Levar para a sala de aula diversas medidas de garrafas e copos, a partir disso indagar os alunos: o que é 1 e $\mathrm{ml}$ que aparece nas embalagens. Mostrar uma escala de unidades para saberem que essas não são as únicas para capacidade, porém são as mais importantes. Explicar o que é litro e mililitro e realizar experiência para os alunos verem. Convidá-los para fazerem a experiência também (A1, Plano da 3. a aula - 1. . versão).

[...] colocar sobre suas mesas embalagens em forma de garrafas e copos. [...] Cada grupo faz uma experiência, ou seja, coloca água do copo para a garrafa e vice-versa para conhecer a relação entre litro (l) e mililitro (ml) (A1, Relatório de Estágio, p. 17, 2005).

Para entender frações equivalentes mostraria um bolo inteiro. Primeiro dividiria-o em dois pedaços e concluiria junto com as crianças que se separarmos os pedaços teremos $1 / 2$ bolo. Depois juntaria os pedaços e dividiria o bolo em 8 pedaços e separaria 4 deles, conluindo que agora temos $4 / 8$ de bolo, o que equivale a $1 / 2$ bolo também. Com essa mesma atividade trabalharia sobre divisão, lançando em seguida alguns exercícios algorítmicos de divisão e compararia ao bolo (A2, Q2).

Esses depoimentos ilustram algumas das diferentes percepções sobre uma mesma regularidade, por exemplo, em cada citação é possível identificar um ou dois tipos de atividades que foram escolhidas pelo sujeito para ensinar a Matemática. Conforme o tipo de atividade selecionada pela professora para o desenvolvimento de uma aula, é possível se constatar que perspectiva de ensino está sendo privilegiada e, portanto, passível de se caracterizar um princípio epistemológico. Nesse sentido, quando um sujeito sinaliza a utilização de material didático, estruturado ou não, para que o aluno veja e descubra a técnica operatória ou o conceito (tópico 22), de problemas relacionados ao mundo real para exemplificar a técnica operatória ou o conceito (tópico 16). E, ainda, o desenvolvimento do conteúdo por meio de problemas e atividades investigativas (tópico 24), supõe-se que a intenção do sujeito é tornar o conteúdo matemático menos árido e formal, ou seja, mais prático e real. Por outro lado, quando o 
sujeito privilegia atividades em que os alunos devem resolver exercícios para desenvolver a memorização de princípios e fórmulas, as habilidades de manipulação de algorítmos e resolução de problemas-padrão (tópico 21), percebe-se que o ensino está pautado em outros princícios, isto é, os da valorização aos aspectos formais e lógicos do conhecimento matemático.

Assim, adotam-se esses padrões ou regularidades como categorias, cuja finalidade é orientar a análise do movimento conceitual nos perfis de cada sujeito. Desta maneira, a utilização dessa estrutura, representada no quadro 3, auxiliará na caracterização das concepções dos sujeitos em relação aos perfis conceituais, assim como também, na constituição das zonas de cada perfil, conforme abordado a seguir.

\subsection{CONSTITUIÇÃO DAS ZONAS DOS PERFIS CONCEITUAIS DE MATEMÁTICA E DO ENSINO-APRENDIZAGEM}

Para essa pesquisa foi necessário o delineamento de três perfis conceituais, já que, o objetivo invetigativo abrange as concepções de Matemática, de ensino de Matemática e de aprendizagem em Matemática. Deste modo, cada perfil é composto por diferentes zonas conceituais, de modo que

A caracterização das zonas do perfil é feita, dessa forma, a partir de dados obtidos em sala de aula, daqueles relatados em estudos da literatura sobre concepções informais ou alternativas dos estudantes e, finalmente, com base no estudo da evolução histórica do conceito, [...] (AMARAL e MORTIMER, 2006, p. 243).

Tal sistematização permite a confrontação dos dados obtidos junto aos sujeitos com reconstrução histórica dos conceitos. Assim, cada zona foi definida a partir da sistematização geral das interpretações das idéias de A1, A2 e A3 (quadro 2), dos referenciais teóricos relacionados à história e à filosofia da Matemática e, também, dos resultados de algumas pesquisas sobre concepções de professores relativas à Matemática e ao processo de ensinoaprendizagem e, ainda, dos referenciais teóricos relacionados à história do ensino da Matemática e das tendências de ensino-aprendizagem no âmbito da didática geral, conforme apresentados no capítulo 3. Deste modo, constituiram-se as zonas do perfil conceitual de Matemática pelas categorias: Abstrata Racionalista; Abstrata Empirista e Dinâmica. Em relação às zonas do perfil conceitual do ensino de Matemática, foram sistematizadas as categorias: Reprodução; Matemática Moderna e Elaboração. As categorias relativas às zonas do perfil conceitual de aprendizagem em Matemática, estão organizadas em: Tradicional, Comportamental e Nova Cultura. Desta maneira, cabe esclarecer o que se está concebendo para cada uma das zonas que compõem os perfis conceituais. 


\subsubsection{Zonas do Perfil Conceitual de Matemática}

- Abstrata Racionalista

É uma visão que tem forte relação com as idéias das escolas filosóficas fundacionais (logicismo, formalismo e intuicionismo) e que se aproxima de algumas categorias encontradas em outros trabalhos, por exemplo: a Absolutista de Copes (1979), de Lerman (1983) e de Silvério (2003); a platônica de Ernest (1991) e a racionalista de Graça et al (2004). Ressaltase que tais tendências e categorias foram detalhadas no capítulo 3.

Assim, buscando-se uma proximidade com os aspectos de tais categorias, concebe-se para essa zona - Abstrata Racionalista - a idéia de um conhecimento clássico, de características objetivas e racionais, prevalencendo o rigor, a precisão e a formalidade das idéias matemáticas. Nessa visão, a Matemática é um tipo de conhecimento proveniente do

pensamento de alguns "gênios" e, portanto, acessível a poucos e deslocado da realidade do mundo sensível. Logo, esse conchecimento é algo "criado" por outro em algum momento do passado, o corpo de conceitos é fixo, está pronto e acabado. Prevalece a visão de verdade única e absolutamente certa dos resultados matemáticos e que valoriza o caráter racional, formal, lógico e abstrato da Matemática.

- Abstrata Empirista

As características dessa zona são muito próximas a da anterior em termos da idéia de um conhecimento clássico com características de objetividade, formalidade e precisão. No entanto, essa visão se contrapõe em relação à origem do objeto matemático, isto é, o conhecimento tem origem na experiência, no mundo sensorial. Deste modo, concebe-se a Matemática como um conjunto de regras e fatos que não se relacionam, mas que são úteis. Portanto, é uma visão que tem como fio condutor as seguintes categorias: Instrumentalista de Skemp (1979) e de Ernest (1991) e a Empirista de Silvério (2003) e de Graça et al (2004).

- Dinâmica

Nessa visão é imprescindível o vínculo da Matemática com o mundo sensorial. Trata-se de uma visão dinâmica da Matemática, cujo conhecimento possui um domínio em evolução e é conduzido por problemas sujeito à revisão. Logo, se aproxima da concepção 
filosófica falibilista e, também, de outras visões como: a Social de Silvério (2003); a Racionalista Empirista de Graça et al (2004); a Resolução de Problemas de Ernest (1991); a Falibilista de Lerman (1983) e a Relacional de Skemp (1979).

Sendo assim, entende-se que na zona Dinâmica, a reflexão ocorre no sentido de se compreender a Matemática como mais um esforço da humanidade na organização de suas experiências no mundo. Nessa visão, valorizam-se os aspectos históricos e sócio-culturais, uma vez que se admite a variação do conhecimento de acordo com o espaço geográfico e com a história dos grupos culturais. Desta maneira, a Matemática é construída a partir da experiência com o mundo sensível como uma estratégia desenvolvida pela espécie humana ao longo de sua história para explicar, entender, manejar e conviver com a realidade empírica. Assim, não se aceita uma verdade como única e definitiva porque o conhecimento não está pronto e pode ser representado de mais de uma maneira, já que a Matemática está submetida à utilidade prática.

\subsubsection{Zonas do Perfil Conceitual de Ensino da Matemática}

- Reprodução

Nessa categoria há predomínio da idéia de que o ensino se pauta, principalmente, na reprodução de um conhecimento matemático acumulado. É uma visão que se aproxima das tendências: Ensino por Repetição de Onuchic (1999); Formalista Clássica de Fiorentini (1995) e das categorias Tradicional Clássica de Silvério (2003); Platonista de Graça et al (2004). Ressalta-se que tais tendências e categorias foram detalhadas no capítulo 3.

Deste modo, concebe-se por esta categoria uma visão de ensino, cuja prática pedagógica do professor está apoiada na transmissão de informações ao aluno. Assim, o docente exerce o papel de instrutor, demonstrando, explicando e definindo a matéria por meio de um ensino expositivo. O conhecimento matemático repassado enfatiza formas e idéias da Matemática Clássica e está organizado, essencialmente, em estruturas lógica, algébrica, topológica e de ordem. Valoriza-se uma visão estática, a-histórica e dogmática dos conceitos e se apresenta a Matemática como uma linguagem universal, concisa e precisa. Os conteúdos não possuem relação entre si e nem com outras áreas do conhecimento. 
- Matemática Moderna

A visão de ensino nessa zona do perfil conceitual se aproxima das seguintes tendências: a Matemática Moderna de Onuchic (1999); a Formalista Moderna e a Tecnicista de Fiorentini (1995) e pelas categorias Tecnicista de Silvério (2003) e Instrumental de Graça et al (2004).

A ênfase nesse viés de ensino está na formação do especialista em Matemática. Portanto, prioriza-se o uso rigoroso e preciso da linguagem formal. É uma perspectiva fortemente influenciada pelo Movimento da Matemática Moderna e com uma concepção funcionalista, isto é, o ensino é baseado na ação de seguir regras mediante uma série de técnicas e é formado por padrões de comportamento alteráveis por meio de treinamento. Assim, o professor exerce o papel de instrutor, demonstrando, explicando e definindo a matéria por meio de um ensino expositivo. As tarefas são organizadas em forma de esquemas visando a que os alunos reproduzam, eficazmente, todas as regras e procedimentos ensinados em sala de aula.

- Elaboração

O ensino visto como um processo de Elaboração, de certo modo, contrapõe-se ao ensino concebido como uma reprodução do conhecimento, como os descritos nas zonas anteriores. Nessa visão o ensino se baseia, principalmente, por correntes e paradigmas educacionais que privilegiam mais o processo que o produto da construção do conhecimento, o professor atua como um mediador entre o conhecimento historicamente produzido e o aluno. A prática pedagógica está apoiada em uma perspectiva de Resolução de Problemas e de atividades investigativas, valorizando-se então, o resgate do conhecimento do aluno, as influências sociais e culturais na elaboração do conhecimento matemático, a produção de significados na construção de conceitos, a utilização de materiais didáticos variados e de tarefas que desafiem o pesamento do aluno. Nessa visão, a Matemática é vista como um conhecimento sujeito à revisão, em constante construção e reconstrução e conduzido por problemas de diversas áreas do conhecimento.

Portanto, é uma categoria que se aproxima das tendências: Ensino com Compreensão e Resolução de Problemas de Onuchic (1999); Empírico-ativista, Construtivistainteracionista e Socioetnocultural de Fiorentini (1995). Como também, das categorias Alternativa (Silvério, 2003) e Construtivista (Graça et al, 2004). 


\subsubsection{Zonas do Perfil Conceitual da Aprendizagem em Matemática}

- Tradicional

Essa zona conceitual tem por inspiração a imagem tradicional da aprendizagem, assim como postulada por Pozo (2002), a qual corresponde, essencialmente, a uma concepção na qual aprender é memorizar e repetir, mecanicamente, técnicas e procedimentos. Conforme explicitado no capítulo 3, essa visão sobre a aprendizagem em Matemática se aproxima das seguintes categorias e tendências: Tradicional Clássica (SILVÉRIO, 2003); Platonista (GRAÇA ET AL, 2004); Formalista Clássica (FIORENTINI, 1995); Matemática por Repetição (Onuchic, 1999).

Deste modo, além do viés principal que é de memorização e repetição mecânica de técnicas e procedimentos, concebe-se, também, para essa categoria, a idéia de que o aluno exerce um papel passivo em sua aprendizagem. Portanto, a aprendizagem matemática se caracteriza por certos aspectos, como: a fixação de regras ensinadas na aula, a aquisição do conhecimento matemático por meio do exercício mental, o desenvolvimento de habilidades e atitudes de raciocínios a partir de conceitos abstratos, a falta de elo entre as propriedades anunciadas pelo professor e a Matemática usada fora da escola, o fornecimento pelo aluno de respostas certas.

\section{- Comportamental}

Nessa zona saber Matemática é ser capaz de usar a linguagem matemática e suas propriedades, de maneira precisa e correta, para resolver exercícios ou problemas seguindo o modelo, fazer demonstrações e dominar processos algorítmicos. O foco está na mudança de comportamento por meio de estímulos (punitivos ou incentivos) para o desenvolvimento de habilidades e atitudes a partir da fixação de conceitos, princípios, fórmulas e fatos. As idéias pertinentes à essa visão se aproximam das seguintes tendências e categorias de análise: Matemática Moderna de Onuchic (1999); Formalista Moderna e Tecnicista de Fiorentini (1995); Tecnicista de Silvério (2003) e Instrumental de Graça et al, (2004). 
- Nova Cultura

Nessa zona conceitual, o aluno exerce um papel de destaque em sua aprendizagem, pois ele está envolvido de modo significativo nesse processo. Desta maneira, a aprendizagem em Matemática se pauta no desenvolvimento de certas atitudes do aluno, por exempo, pela construção de relações entre as várias idéias matemáticas contidas em um problema; pela relação de um determinado conceito matemático a uma variedade de contextos socioculturais; pela resolução de questões que ampliam as fronteiras da ciência; pela assimilação do conteúdo com o estabelecimento de articulações entre o novo tópico e aqueles já estudados e por uma discussão de processos e de confrontamentos com outros pontos de vista na resolução de problemas. Enfim, aprender Matemática por essa visão é fazer uso de uma linguagem própria, com estrutura lógica para desenvolver procedimentos pessoais de resolução de problemas, e ainda, enxergar o erro como inerente ao processo de produção de significados e construção do conceito, memorizando conceitos com compreensão em relação ao conteúdo e ao contexto e, também, conhecendo os fundamentos lógicos de um algoritmo, de uma operação matemática de maneira significativa.

O entendimento sobre o aprender, se comparado a épocas passadas e baseado nos conhecimentos e hábitos culturais da moderna sociedade industrializada leva à necessidade de se esboçar uma outra perspectiva de aprendizagem. Segundo Pozo (2002), a sociedade impulsionada pela pesquisa científica, por teorias psicológicas, sociológicas e antropológicas direcionam o olhar para uma nova cultura da aprendizagem. Deste modo, as característas dessa categoria - Nova Cultura - apresentam certa proximidade com as seguintes categorias e tendências: a Alternativa de Silvério (2003); a Construtivista de Graça et al, (2004); a Empírico-ativista, a Construtivista, a Socioetnocultural, a Histórico-crítica e a Sociointeracionista de Fiorentini (1995) e a Resolução de Problemas de Onuchic (1999). Cabe lembrar que o detalhamento de tais tendências e categorias de análise também foi apresentado no capítulo 3.

Assim, com o delineamento das zonas conceituais de cada perfil, torna-se possível estabelecer correspondências destas com as regularidades categorizadas anteriomente (quadro 3, p. 130) em relação à Matemática, ao ensino e à aprendizagem dessa ciência, conforme pode ser observado a seguir. 
QUADRO 4 RELAÇÃO ENTRE AS REGULARIDADES CATEGORIZADAS E AS ZONAS DO PERFIS CONCEITUAIS

\begin{tabular}{|c|c|c|c|}
\hline REGULARIDADES & \multicolumn{3}{|c|}{ ZONAS DOS PERFIS CONCEITUAIS } \\
\hline \multicolumn{4}{|c|}{ MATEMÁTICA } \\
\hline & $\begin{array}{c}\text { ABSTRATA } \\
\text { RACIONALISTA }\end{array}$ & $\begin{array}{l}\text { ABSTRATA } \\
\text { EMPIRISTA }\end{array}$ & DINÂMICA \\
\hline ORIGEM & 5 & 10 & 10 \\
\hline FINALIDADE & 2 & 2 & 7 \\
\hline $\begin{array}{c}\text { CARACTERÍSTICAS } \\
\text { GERAIS }\end{array}$ & $1-3-4-6$ & $1-3-4-6$ & $8-9-11-12$ \\
\hline \multicolumn{4}{|c|}{ ENSINO DE MATEMÁTICA } \\
\hline & REPRODUÇÃ̃O & $\begin{array}{c}\text { MATEMÁTICA } \\
\text { MODERNA }\end{array}$ & ELABORAÇÃO \\
\hline $\begin{array}{c}\text { FUNÇÃO } \\
\text { PROFESSOR }\end{array}$ & 15 & $17-19$ & $25-26-28-31$ \\
\hline $\begin{array}{c}\text { COMO PROFESSOR } \\
\text { ENSINA }\end{array}$ & 18 & $16-20-21-22$ & $23-24-27-29-30-32-33$ \\
\hline \multicolumn{4}{|c|}{ APRENDIZAGEM EM MATEMÁTICA } \\
\hline & TRADICIONAL & COMPORTAMENTAL & NOVA CULTURA \\
\hline $\begin{array}{c}\text { CARACTERÍSTICAS } \\
\text { ALUNO }\end{array}$ & 38 & $42-45$ & $39-40-43-46-48$ \\
\hline COMO APRENDE & 36 & 35 & $37-41-44-47-49$ \\
\hline
\end{tabular}

Fonte: campo de pesquisa.

Ressalta-se que os códigos numéricos indicados neste quadro são relativos aos apresentados no quadro 2 (p. 126) em virtude da listagem de idéias interpretadas a partir dos dados dos sujeitos. Esta correspondência entre as zonas conceituais e as regularidades categorizadas auxiliarão na identificação do perfil de cada sujeito, conforme abordado na seqüência.

5.5 O PERFIL CONCEITUAL DOS SUJEITOS E SUAS CONEXÕES COM A PRÁTICA PEDAGÓGICA

Com a constituição das zonas dos perfis conceituais e com a definição das categorias relativas às idéias dos sujeitos, esclarece-se que a partir deste ponto os dados passam a ser analisados por uma outra perspectiva, ou seja, nesse segundo nível, o foco de análise está na dinâmica estabelecida pelos sujeitos entre suas concepções e a prática pedagógica. Para tanto, adotou-se como unidade de análise os episódios, pois se entende que pelos episódios é possível detectar e evidenciar as conexões que os sujeitos revelaram entre as idéias sobre a Matemática e seu processo de ensino e aprendizagem e a prática pedagógica e, também, 
momentos de conflito (evento crítico). Desta maneira, a construção do enredo e composição da narrativa dos textos foi direcionada pela perspectiva de que "esses episódios são divididos em segmentos e cada um deles constitui uma unidade de análise a partir da qual é reconstituída toda a seqüência, no movimento de síntese" (AMARAL e MORTIMER, 2006, p. 263). Assim, considerou-se que os segmentos dos episódios correspondiam a cenas, as quais se complementam no sentido de revelar o movimento conceitual percebido durante o período investigativo em relação ao objeto desta pesquisa.

Nesse sentido, observou-se manifestos mais representativos em relação à concepção sobre a Matemática nos registros dos questionários e uma oscilação mais expressiva entre as concepções referentes ao ensino e à aprendizagem dessa ciência a partir do momento em que os sujeitos começaram a pensar no objeto matemático como um conhecimento a ser ensinado. Entende-se que essa situação possa ter ocorrido pelo fato de A1, A2 e A3 começarem a associar o conhecimento matemático ao contexto escolar. Segundo Chevallard (1991), um saber científico, quando transposto para a sala de aula, assume outro caráter, o do saber didatizado. Logo, o saber a ser ensinado em sala de aula passa por um tratamento de modo a torná-lo compreensível para os alunos. A transposição didática de um saber a ser ensinado em saber ensinado é, também, permeada por uma série de fatores influenciadores no modo como esse conhecimento chega até o aluno. Alguns desses fatores se articulam com as conexões que os sujeitos fizeram entre suas concepções e a prática pedagógica.

Vale lembrar que os registros contidos nos episódios são relativos às transcrições das entrevistas (reuniões) e às respostas dos questionários. Portanto, apresentam algumas codificações que possuem os seguintes significados:

i - Q1 e Q2: questionário 1 e questionário 2.

ii - OP: $1 .^{\text {a }}$ reunião de orientação ao plano de aula.

iii - RP-AU2: reunião de re-orientação ao plano da aula 2.

iv - RP-AU3: reunião de re-orientação ao plano da aula 3.

v - RP-AU5: reunião de re-orientação ao plano da aula 5.

vi - EF: entrevista final.

vii - P: professora de Metodologia e pesquisadora.

viii - PP: professora de Prática Pedagógica.

ix - ... (reticências): usado para indicar que uma frase não foi terminada.

Em linhas gerais, o cenário em que os episódios ocorreram corresponde aos momentos de reuniões entre os sujeitos e a professora de Metodologia de Ensino de Matemática (autora deste trabalho). Cada episódio é composto por cenas que constituem a 
menor unidade de análise em relação às zonas do perfil conceitual de Matemática e de ensino e aprendizagem. Cada cena é representativa de um momento considerado relevante para o movimento conceitual do sujeito, caracterizando inclusive algumas mudanças de zonas de perfil.

Deste modo, os episódios relativos às concepções de Matemática são constituídos por cenas que explicitam os conhecimentos prévios (cena 1 - no início do ano letivo), as concepções finais (cena 2) e as explicações sobre mudanças de visões e/ou tomada de consciência sobre seus pensamentos (cena 3). Já, os episódios relativos às concepções sobre o ensino e aprendizagem da Matemática estão organizados de maneira que os quadros da Cena $\underline{4}$ correspondem à reunião realizada antes da primeira aula de Matemática desenvolvida no estágio, cujo foco de atenção foi a análise do plano de aula organizado para a respectiva prática de sala. Pois, entende-se que nesse momento se encontra a evidência das concepções pessoais dos sujeitos antes da vivência da prática pedagógica pré-profissional. A $\underline{\text { Cena } 5}$ evidencia um dos eventos críticos, isto é, as perturbações vivenciadas por A1, A2 e A3 após o desenvolvimento de uma das aulas de Matemática no estágio. Restando para a Cena 6 os quadros que configuram momentos de tomada de consciência dos sujeitos sobre seus modos particulares de pensar o ensino e a aprendizagem, ou seja, é quando eles apresentam reelaborações sobre suas concepções em relação à Matemática e ao modo de ensiná-la para viabilizar uma melhor aprendizagem da mesma. Sendo assim, segue o estudo de caso de cada sujeito a partir da estrutura de análise representada no quadro 4 e à luz da noção de perfil conceitual.

\subsubsection{Movimento Conceitual de A1}

Com o intuito de permitir um melhor entendimento das ações desse sujeito, elaborouse um mapa das atividades desenvolvidas por A1 ao longo do período investigativo. $\mathrm{O}$ objetivo desse mapa é mostrar o contexto global de onde foram extraídos os dados que compõem os episódios, informando-se os tipos de atividades e o momento em que as mesmas foram desenvolvidas, como também, o assunto abordado nelas. Esclarece-se ainda que, na coluna dos dados selecionados, estão indicadas, também, as fontes de onde os mesmos foram extraídos, inclusive com a minutagem das entrevistas. Por exemplo, OP 16:14 a 24:30, referese ao período compreendido dos 16 minutos e 24 segundos aos 24 minutos e 30 segundos da reunião de orientação para a elaboração dos planos de aula. 


\section{QUADRO 5 MAPA DE ATIVIDADES DESENVOLVIDAS COM A1}

continua

\begin{tabular}{|c|c|c|c|}
\hline PERÍODO & ATIVIDADES & PRINCIPAIS TEMAS & DADOS SELECIONADOS \\
\hline $1 .^{\circ} \mathrm{sem} / 2005$ & $\begin{array}{l}\text { Aulas de Metodologia do Ensino } \\
\text { de Matemática. }\end{array}$ & $\begin{array}{l}\text { Resgate das concepções } \\
\text { informais e confronto } \\
\text { das mesmas com novos } \\
\text { conceitos. }\end{array}$ & $\begin{array}{l}\text { Concepções em relação à } \\
\text { Matemática. } \\
\text { Iniciais e Finais. } \\
\text { Q1 e Q2 }\end{array}$ \\
\hline $\begin{array}{l}11 / 10 / 2005 \\
45 \mathrm{~min}\end{array}$ & $\begin{array}{l}\text { Reunião de A1 com a professora } \\
\text { de Metodologia de Ensino de } \\
\text { Matemática. }\end{array}$ & 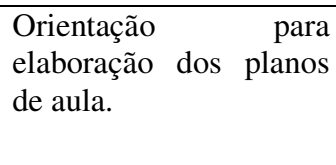 & $\begin{array}{l}\text { Concepções pessoais em } \\
\text { relação ao ensino-aprendizagem } \\
\text { Participação e material didático. } \\
\text { OP } 16: 14 \text { a } 24: 30\end{array}$ \\
\hline $\begin{array}{l}18 / 10 / 2005 \\
45 \mathrm{~min}\end{array}$ & $\begin{array}{l}\text { Reunião de A1 com a professora } \\
\text { de Metodologia do Ensino de } \\
\text { Matemática. }\end{array}$ & 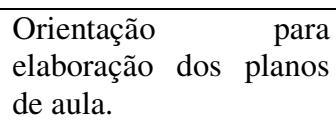 & \\
\hline $\begin{array}{l}24 / 10 / 2005 \\
2 \mathrm{~h} 30 \mathrm{~min}\end{array}$ & $\begin{array}{l}\text { Desenvolvimento da primeira } \\
\text { aula no estágio com observação } \\
\text { direta. }\end{array}$ & $\begin{array}{l}\text { Conteúdo da aula: } \\
\text { unidades de medidas } \\
\text { não padronizadas. Há } \\
\text { interação entre A1 e } \\
\text { alunos. }\end{array}$ & \\
\hline $\begin{array}{l}25 / 10 / 2005 \\
50 \mathrm{~min}\end{array}$ & $\begin{array}{l}\text { Reunião de A1 com a professora } \\
\text { de Metodologia de Ensino de } \\
\text { Matemática. }\end{array}$ & $\begin{array}{l}\text { Reflexão sobre os } \\
\text { resultados da } 1 .^{\text {a }} \text { aula e } \\
\text { orientação para a } \\
\text { elaboração do plano da } \\
\text { aula } 2 \text {. }\end{array}$ & \begin{tabular}{l} 
Concepções pessoais em \\
\multicolumn{3}{l}{ relação ao ensino-aprendizagem } \\
Conhecimento prévio \\
participação. \\
RE-AU2 02:10 a 04:50
\end{tabular} \\
\hline $\begin{array}{l}31 / 10 / 2005 \\
2 \mathrm{~h} 30 \mathrm{~min}\end{array}$ & $\begin{array}{l}\text { Desenvolvimento da segunda } \\
\text { aula no estágio com observação } \\
\text { direta. }\end{array}$ & $\begin{array}{l}\text { Conteúdo da aula: } \\
\text { sistema de medidas de } \\
\text { comprimento. Alunos } \\
\text { não participam. }\end{array}$ & \\
\hline $\begin{array}{l}08 / 11 / 2005 \\
55 \mathrm{~min}\end{array}$ & $\begin{array}{l}\text { Reunião de A1 com a professora } \\
\text { de Metodologia de Ensino de } \\
\text { Matemática. }\end{array}$ & $\begin{array}{l}\text { Reflexão sobre os } \\
\text { resultados da } 2 .^{a} \text { aula e } \\
\text { orientação para a re- } \\
\text { elaboração do plano da } \\
\text { aula 3. }\end{array}$ & $\begin{array}{l}\text { Evento crítico em relação ao } \\
\text { ensino-aprendizagem. } \\
\text { Aula frustrada. } \\
\text { RE-AU3 } 04: 34 \text { a } 05: 43 \\
\text { 06:50 a 07:19 } \\
\text { 19:30 a } 21: 39 \\
\text { Acomodação em relação ao } \\
\text { ensino aprendizagem e nova } \\
\text { dinâmica de aula. } \\
\text { RE-AU3 24:15 a 26:21 } \\
\quad 51: 26 \text { a } 51: 45\end{array}$ \\
\hline $\begin{array}{l}21 / 11 / 2005 \\
2 \mathrm{~h} 30 \mathrm{~min}\end{array}$ & $\begin{array}{l}\text { Desenvolvimento da terceira aula } \\
\text { no estágio com observação } \\
\text { direita. }\end{array}$ & $\begin{array}{l}\text { Conteúdo da aula: } \\
\text { sistema de medidas de } \\
\text { capacidade. Mudança } \\
\text { de estratégia de ensino. }\end{array}$ & \\
\hline $\begin{array}{l}28 / 11 / 2005 \\
2 \mathrm{~h} 30 \mathrm{~min}\end{array}$ & $\begin{array}{l}\text { Desenvolvimento da quarta aula } \\
\text { no estágio com observação direta }\end{array}$ & $\begin{array}{l}\text { Conteúdo da aula: } \\
\text { sistema de medidas de } \\
\text { massa. Adota mesma } \\
\text { estratégia da aula } 3 \text {. }\end{array}$ & \\
\hline $\begin{array}{l}30 / 11 / 2005 \\
30 \mathrm{~min}\end{array}$ & $\begin{array}{l}\text { Reunião de A1 com a professora } \\
\text { de Metodologia de Ensino de } \\
\text { Matemática. }\end{array}$ & $\begin{array}{l}\text { Reflexão sobre os } \\
\text { resultados da } 3 .^{\mathrm{a}} \mathrm{e} \text { da } 4 .^{\mathrm{a}} \\
\text { aula e entrevista final. }\end{array}$ & $\begin{array}{l}\text { Acomodação em relação ao } \\
\text { ensino-aprendizagem. } \\
\text { Participação dos alunos. } \\
\text { EF 02:21 a 03:30 } \\
\text { Alunos da EJA. } \\
\text { EF 06:12 a 06:23 } \\
\text { 08:30 a 09:34 } \\
\text { Resol. de Problemas } \\
\text { EF 16:52 a 17:30 } \\
\quad 19: 27\end{array}$ \\
\hline
\end{tabular}




\begin{tabular}{|c|c|c|c|}
\hline PERÍODO & ATIVIDADES & PRINCIPAIS TEMAS & EPISÓDIOS/CENAS \\
\hline & & & $\begin{array}{l}26: 50 \text { a } 28: 22 \\
\text { Material didático. } \\
\text { EF 26:50 a } 28: 22 \\
\text { Tomada de consciência em } \\
\text { relação à concepção de } \\
\text { Matemática. } \\
\text { EF } 11: 17 \text { a } 14: 08\end{array}$ \\
\hline $\begin{array}{l}08 / 11 / 2005 \\
55 \mathrm{~min}\end{array}$ & $\begin{array}{l}\text { Reunião de A1 com a professora } \\
\text { de Metodologia de Ensino de } \\
\text { Matemática. }\end{array}$ & $\begin{array}{l}\text { Reflexão sobre os } \\
\text { resultados da } 2 .^{a} \text { aula e } \\
\text { orientação para a re- } \\
\text { elaboração do plano da } \\
\text { aula 3. }\end{array}$ & $\begin{array}{l}\text { Evento crítico em relação ao } \\
\text { ensino-aprendizagem. } \\
\text { Aula frustrada. } \\
\text { RE-AU3 04:34 a 05:43 } \\
\text { 06:50 a 07:19 } \\
\text { 19:30 a } 21: 39 \\
\text { Acomodação em relação ao } \\
\text { ensino aprendizagem e nova } \\
\text { dinâmica de aula. } \\
\text { RE-AU3 24:15 a 26:21 } \\
\quad 51: 26 \text { a 51:45 }\end{array}$ \\
\hline $\begin{array}{l}\text { 21/11/2005 } \\
2 \mathrm{~h} 30 \mathrm{~min}\end{array}$ & $\begin{array}{l}\text { Desenvolvimento da terceira aula } \\
\text { no estágio com observação } \\
\text { direita. }\end{array}$ & $\begin{array}{l}\text { Conteúdo da aula: } \\
\text { sistema de medidas de } \\
\text { capacidade. Mudança } \\
\text { de estratégia de ensino. }\end{array}$ & \\
\hline $\begin{array}{l}\text { 28/11/2005 } \\
2 \mathrm{~h} 30 \mathrm{~min}\end{array}$ & $\begin{array}{l}\text { Desenvolvimento da quarta aula } \\
\text { no estágio com observação direta }\end{array}$ & $\begin{array}{l}\text { Conteúdo da aula: } \\
\text { sistema de medidas de } \\
\text { massa. Adota mesma } \\
\text { estratégia da aula } 3 \text {. }\end{array}$ & \\
\hline $\begin{array}{l}30 / 11 / 2005 \\
30 \mathrm{~min}\end{array}$ & $\begin{array}{l}\text { Reunião de A1 com a professora } \\
\text { de Metodologia de Ensino de } \\
\text { Matemática. }\end{array}$ & $\begin{array}{l}\text { Reflexão sobre os } \\
\text { resultados da } 3 .^{a} \text { e da } 4 .^{a} \\
\text { aula e entrevista final. }\end{array}$ & $\begin{array}{l}\text { Acomodação em relação ao } \\
\text { ensino-aprendizagem. } \\
\text { Participação dos alunos. } \\
\text { EF 02:21 a 03:30 } \\
\text { Alunos da EJA. } \\
\text { EF 06:12 a 06:23 } \\
\text { 08:30 a 09:34 } \\
\text { Resol. de Problemas } \\
\text { EF 16:52 a 17:30 } \\
\quad \text { 19:27 } \\
\text { 26:50 a 28:22 } \\
\text { Material didático. } \\
\text { EF 26:50 a 28:22 } \\
\text { Tomada de consciência em } \\
\text { relação à concepção } \\
\text { Matemática. de } \\
\text { EF 11:17 a 14:08 }\end{array}$ \\
\hline
\end{tabular}

Fonte: dados organizados pela autora

Frente ao quadro 5, observa-se que foram desenvolvidas cinco reuniões com A1 durante o período do estágio e que essas reuniões ocorreram em momento posterior ao desenvolvimento da disciplina de Metodologia do Ensino da Matemática. Assim, de cada reunião foram extraídas cenas consideradas representativas das idéias que emergiram da discussão sobre as concepções de Matemática e do ensino e aprendizagem dessa ciência. Essas cenas constituem os episódios sobre as concepções de A1. Para melhor compreensão dos episódios se apresenta o esquema da estrutura de cada um. 
Episódio 1 - Concepções de A1 em relação à Matemática.

Cena 1 - Concepções pessoais sobre o que é a Matemática.

Cena 2 - Concepções finais sobre o que é a Matemática.

Cena 3 - Tomada de consciência.

Episódio 2 - Concepções de A1 em relação ao processo de ensino e aprendizagem de Matemática.

Cena 4 - Concepções pessoais sobre o ensinar e aprender Matemática.

Cena 5 - Perturbação conceitual sobre o ensinar: alunos não participam da aula.

Cena 6 - A acomodação: tomada de consciência e mudança de estratégia de ensino.

Na seqüência, apresenta-se o episódio relativo às concepções sobre a Matemática.

- Episódio 1 - Concepções de A1 em relação à Matemática.

Cena 1 - Concepções pessoais sobre o que é a Matemática.

Ao iniciar o ano letivo na disciplina de Metodologia do Ensino de Matemática, A1 respondeu a um questionário (Q1) antes de entrar em contato com os conteúdos específicos da referida matéria. Nesse instrumento se questionou: um leigo lhe pergunta "de onde vem a Matemática?" Como você explicaria essa questão? Ela apresentou a seguinte resposta.

Eu lhe diria que os números foram criados há muito tempo atrás para facilitar a vida das pessoas. Mas, não bastava criá-los, era necessário dar a eles uma melhor utilização. Foi a partir disto que estudiosos formaram conceitos como adição, multiplicação e divisão para facilitar, ainda mais, a vida do homem. Pois, para "tudo", hoje em dia, são necessários cálculos. Exemplo: é necessário para fazer compras, entre outros. A Matemática surgiu para ajudar o homem na sua cidadania (Q1,23/mar/2005).

Além dessa resposta, A1 ainda apresentou uma outra idéia em relação ao seguinte questionamento: Se incluísse em sua explicação as principais características da Matemática, quais você apresentaria?

Ela trabalha com números e sua finalidade é calcular. As principais operações são: adição (somar), subtração (diminuir), multiplicação e divisão (Q1, 23/mar/2005).

Idéias como essas, constituíram-se para A1 no ponto de partida para seus estudos dos conteúdos da Metodologia de Ensino de Matemática. Ou seja, ela iniciou a disciplina concebendo a Matemática como resultado da racionalização de algumas poucas pessoas e como um campo de conhecimento pronto e limitado aos números e às operações básicas. A1 entende que a Matemática serve para ajudar o homem em suas atividades diárias, isto é, 
alguém mais capacitado cria um conceito para ser utilizado no dia-a-dia pelas pessoas de uma sociedade. Essa maneira de ver a Matemática corresponde à uma visão cuja origem do conhecimento se dá a partir das idéias de alguns, da razão dos estudiosos. O grande enfoque aos números e às operações valoriza o caráter aritmético da Matemática, aspecto valorizado pelos lógicos. A referência dada ao cotidiano é apenas de menção instrumental, ou seja, é um conhecimento que serve para auxiliar o Homem nas tarefas do dia-a-dia, um instrumento. Até esse momento, segundo A1, seu sentimento em relação à Matemática era de aversão, ou seja, ela não gostava dessa matéria. $\mathrm{Na}$ Cena 2, A1 re-afirma essa visão sobre a Matemática.

\title{
Cena 2 - Concepções finais sobre a Matemática
}

No último dia de aula da Metodologia de Ensino, A1 respondeu ao questionário 2. Nesse instrumento ela apresentou a seguinte explicação sobre a origem e características da Matemática.

\begin{abstract}
A Matemática surgiu há muito tempo através de muitas pesquisas de pessoas que hoje são reconhecidas como grandes gênios. Ela surgiu para auxiliar o homem em tudo que vai fazer: a criar estratégias para problemas, a ir a supermercados e ter dinheiro suficiente para pagar as contas, para que um engenheiro construa uma casa e não a deixe cair. A Matemática utilizase do cálculo. A Matemática trabalha com números (Q2, 22/jun./2005).
\end{abstract}

A1 continua apresentando quase a mesma visão que a explicitada na cena 1 . Nesse registro há um aspecto a ser destacado, é a idéia de que a Matemática surgiu para auxiliar o Homem "a criar estratégias para problemas" (A1). Essa idéia permite pressupor que esse sujeito tenta expor um conhecimento matemático criado a partir de necessidades do cotidiano e que não seja estático. Essa vertente é ressaltada quando A1 revê seu registro do Q1 após ter respondido ao Q2, assim, gerando outra perspectiva em suas respostas.

A Matemática surgiu para auxiliar o homem a criar estratégias para resolver problemas. Com ela aprende-se a raciocinar. Ela serve para que o indivíduo aprenda a raciocinar (Q2, 22/jun./2005).

Porém, ao mesmo tempo em que A1 estabelece vínculo entre o conhecimento matemático e a elaboração de estratégias para resolver problemas, ela entende, também, que a Matemática serve para desenvolver o raciocínio do Homem, ou seja, ainda permanece a concepção de que esse conhecimento se destina ao desenvolvimento da razão. Mas, apresenta indícios de uma outra percepção quando ressalta tal relação entre a criação de estratégias e a Matemática. Por outro lado, A1 alega na entrevista final ter compreendido que a Matemática é diferente e, portanto, seu sentimento também é outro, isto é, passou a gostar dessa matéria, conforme pode ser observado na Cena 3. 
Cena 3 - Tomada de consciência

No decorrer da entrevista final, solicitou-se a A1 que revisasse seus registros nos questionários, quando ela leu o que havia escrito no Q1 e no Q2 em relação à Matemática, fez o seguinte depoimento:

A1 - Nossa! Fiquei só no cálculo. Só cálculo. [referindo-se ao Q1].

$\mathrm{P}$ - É como se a Matemática fosse só número.

A1 - É. Acho que hoje tiraria isso daqui [ela lê o texto de seu questionário]: "Matemática utiliza-se do raciocínio das pessoas, utiliza-se do cálculo e trabalha com números." Agora ficou uma idéia mais interessante.

$\mathrm{P}$ - Aqui [referindo-se à re-escrita do Q1 no Q2] você retoma. Isso foi quando pedi para ver o que você complementaria na sua primeira resposta. Nessa re-escrita você traz a Resolução de Problemas e isso esteve em sua prática no estágio.

A1 - Sim. [risos].

$P$ - Essas suas respostas me dão a seguinte impressão: nesse primeiro momento [no Q1], a Matemática para você ainda era aquele conhecimento científico. Quando você reviu ao final do semestre já trouxe uma idéia de Matemática enquanto um conhecimento a ser ensinado.

A1 - Isso! E acho que aquilo que eu conhecia de Matemática até fazer Metodologia de Ensino era só aquilo que eu tinha aprendido. Era só aquilo. Então, se eu não gostei de geometria, eu tinha esquecido, nem lembrava. Então, era aquilo que eu tinha aprendido, era conta e eu não gostava de Matemática. Então, ficou aquilo na minha cabeça. Acho que depois que teve a Metodologia de Ensino é que fui pegar gosto pela Matemática. Porque daí eu vi como ela é diferente. Não é aquilo que é para ser ensinado. A gente chegava a ficar nervosa quando tinha daquela maneira que foi ensinado para mim, tudo tradicional (EF, 11:17 a 14:08, 30/nov./2005).

Nesse momento, A1 explicita sua mudança de visão e o motivo que gerou isso. Nos trechos sublinhados nesse depoimento ela explica que sua visão sobre a Matemática era decorrente de sua escolarização básica e somente a partir da disciplina de Metodologia do Ensino é que começou a perceber essa ciência de uma outra maneira. Para ela, o conhecimento matemático se torna mais amplo, não fica restrito à aritmética e é diferente da visão tradicional. Supondo-se que a visão tradicional citada por A1 seja relativa ao modo como ela apresentou a Matemática no Q1 (origem idealista, ciência pronta e acabada, centrada na aritmética e finalidade utilitária), então, entende-se que ela está negando aquela visão. Porém, ainda não conseguiu explicitar, em palavras, como seria esse novo modo de ver a Matemática. No entanto, essa nova percepção de A1 sobre a Matemática contribuiu para que ela passasse a gostar dessa área do conhecimento. Compreende-se que, no decorrer do processo investigativo, esse sujeito conseguiu constatar a existência das diferentes visões em 
relação à Matemática. Contudo, ao final do processo ainda não conseguia explicitar como era sua nova visão.

Frente ao exposto nas cenas que compõem o episódio 1, é possível se mapear as concepções que A1 revelou sobre a Matemática. Para tanto, são considerados os aspectos relativos à origem, finalidade e características gerais da Matemática, conforme evidenciados no quadro 3. No quadro 6, que segue, tais aspectos estão relacionados a um código numérico e às zonas que constituem esse perfil conceitual conforme apresentado no quadro 4 , sendo que as zonas conceituais recebem a seguinte codificação: Zona Abstrata Racionalista (AR); Zona Abstrata Empirista (AE) e Zona Dinâmica (D). Deste modo, apresenta-se a configuração do movimento conceitual de A1 em relação à Matemática.

\section{QUADRO 6 MAPEAMENTO DAS ZONAS DO PERFIL CONCEITUAL DE MATEMÁTICA DE A1}

\begin{tabular}{|c|c|c|c|}
\hline \multirow[t]{2}{*}{ CENAS } & \multicolumn{3}{|c|}{ ASPECTOS DA CONCEPÇÃO DE MATEMÁTICA } \\
\hline & ORIGEM & FINALIDADE & CARACTERÍSTICAS \\
\hline CENA 1 & 5 - racional (AR) & 7 - utilitário (D) & $\begin{array}{l}1 \text { - aritmética (AR) } \\
4 \text { - ciência pronta (AR) }\end{array}$ \\
\hline CENA 2 & $\begin{array}{l}10-\text { necessidades } \\
\text { do } r \text { cotidiano } \\
\text { (AE) }\end{array}$ & $\begin{array}{l}2 \text { - raciocínio lógico (AE) } \\
7 \text { - utilitário (D) }\end{array}$ & $\begin{array}{l}1 \text { - aritmética (AE) } \\
4 \text { - ciência pronta (AE) } \\
11 \text { - construção (D) }\end{array}$ \\
\hline CENA 3 & Não comentado & 7 - utilitário (D) & $\begin{array}{l}4 \text { - ciência pronta (AE) } \\
8 \text { - conhecimento amplo (D) } \\
11 \text { - construção (D) }\end{array}$ \\
\hline
\end{tabular}

Fonte: dados organizados pela autora

Assim, percebe-se pelo quadro 6 que a visão de A1 em relação à Matemática, durante o primeiro semestre letivo (cenas 1 e 2) foi ampliada, isto é, enquanto a disciplina de Metodologia do Ensino de Matemática foi desenvolvida, este sujeito partiu de uma visão pautada na zona Abstrata Racionalista (AR) chegando a uma percepção que transitava entre a zona Abstrata Empirista (AE) e a Dinâmica (D), pois, em relação à finalidade do conhecimento matemático, percebe-se que houve permanência e ampliação das idéias entre as cenas 1 e 2, apresentando nesta última uma coexistência de zonas conceituais, isto é, ao mesmo tempo em que ela concebe que a finalidade da Matemática está voltada para atender a demanda das atividades diárias das pessoas (7), essa ciência, também, serve para desenvolver o raciocínio lógico (2). O mesmo ocorre em relação às características da Matemática, ou seja, há permanência e ampliação das idéias e coexistências de zonas conceituais na cena 2, uma vez que A1 entende que o conhecimento está pronto (4) e, 
também, pode ser construído (11). No que se refere à origem do conhecimento matemático, ela partiu, na cena 1, de uma perspectiva que o considera como um resultado da racionalização de alguns poucos pensadores (5) para uma outra visão na cena 2 , ou seja, a de que a origem da Matemática está vinculada ao mundo real (10) pelas necessidades das pessoas em suas atividades diárias. Essa diferença de perspectiva é o que permite supor que possa ter ocorrido certa evolução conceitual no perfil de Matemática de A1

Somente após o desenvolvimento da prática pedagógica pré-profissional (cena 3) que ela se deu conta sobre a visão que possuía ao iniciar o ano letivo, negando então, aspectos relacionados à Zona Abstrata Racionalista. Nesse sentido, supõe-se que os aspectos voltados à Zona Abstrata Empirista e à Dinâmica ainda eram aceitos por A1. Entende-se que, só pelo fato de ela ter percebido tais características sobre sua concepção e, ainda, de tê-las negado, pode-se admitir que ocorreu uma evolução no perfil conceitual de A1. Segundo Mortimer (1994) a tomada de consciência se constitui em uma das etapas para que isso aconteça. A partir deste momento, o próximo passo seria ela se apropriar de um conhecimento elaborado por outro para então construir sua própria percepção, ou já partir para uma sistematização particular sua. Contudo, o ano letivo havia terminado, impossibilitando que se continuasse acompanhando A1 em seu processo formativo. Na seqüência, apresenta-se o episódio relativo às concepções sobre o ensino e a aprendizagem em Matemática.

- Episódio 2 - Concepções de A1 em relação ao processo de ensino e aprendizagem de Matemática

Cena 4 - Concepções pessoais sobre o ensinar e o aprender Matemática

No segundo semestre do ano letivo, A1 desenvolveu suas aulas de Matemática no estágio. Antes da primeira regência, ela e a professora de Metodologia de Ensino (esta pesquisadora) estiveram reunidas para conversarem sobre os planos de aula elaborados previamente por A1. Nessa conversa esse sujeito revelou suas concepções pessoais, isto é, ela contou como gostaria de ensinar a Matemática de modo que seus alunos participassem da aula. Conforme pode ser observado a seguir.

A1 - Sabe o que eu estava pensando, usar jogos? Não sei se pode?

P - Pode.

A1 - Porque eu acho que eles são assim, eu até percebi ontem quando fui ver a aula das meninas que estavam terminando o estágio delas, elas levaram uns gibis. Eu não faria, não sei. Daí um senhor lá ... Mas, ele tem uns sessenta anos, deve ter trabalhado o dia inteiro e foi lá para 
estudar, falou ... Ele foi para a escola para estudar e não para ficar fazendo esse negócio de artes. Ele falou assim: "a gente fica perdendo tempo fazendo figurinha, esse negócio de teatro." Eles fizeram teatro e daí não ficam estudando e a matéria vai ficando. E, ele falou muito sério, a professora estava nervosa e nem falou nada.

P - Talvez, você possa pensar em equilibrar isso, dizer que é uma atividade para dar uma descansada na mente.

A1 - É, por pouco tempo, faz o joguinho e depois faz outra atividade.

$\mathrm{P}$ - Isso. Eles podem fazer um exercício enfocando o jogo. Faz um jogo de memória. Por exemplo, que relacione o conteúdo e o aluno consiga ver o conteúdo que está trabalhando. Porque nesse seu caso não é a ocasião de propor exercício, por exemplo, de calcular a distância de um lugar para o outro. No que você está propondo, vai trabalhar os conceitos das medidas. $\mathrm{O}$ que é medir, as medidas não-padronizadas e as medidas padronizadas.

A1 - E nada assim, por exemplo, de medir. Eles até podem pegar uma trena e medir uma mesa, tudo coisas bem leve. Pois, eu acredito que eles tenham bastante dificuldade. Porque eu vi ontem, tudo eles perguntavam como era que escrevia isso, como escrevia aquilo. E, era tudo bem básico.

P - Aqui vale a pena você investigar no decorrer das aulas como eles fazem para medir. Na primeira aula você pode propor que eles meçam sem usar instrumentos. Por exemplo, para medir a quantidade de água usando copinhos, diferentes objetos. Você vai propondo e conversando com eles: como fariam para resolver a situação?

A1 - Mostrando tudo.

$\mathrm{P}$ - Isso. Mostrando e perguntando. Possivelmente esse senhor de sessenta anos já tenha manuseado o metro, então perguntar: para que ele usa? Como usa? Que tipo de medidas obtém? Que tipos de instrumentos se usa para as diferentes medidas?

A1 - Ir relacionando.

$\mathrm{P}$ - Exatamente. Agora, as medidas de áreas temos que ver o que pode ser feito.

A1 - Porque eu acho assim, se eu for lá ensinar para eles que área do quadrado é igual a lado vezes lado, não dá. Não tem lógica. É muito superficial. Acho que tem que ser uma coisa diferente.

$\mathrm{P}$ - O que você está pensando? Está pensando em uma aula mais tradicional ou uma aula mais construtivista?

A1 - Eu não sei, eu queria que eles aprendessem. Sei lá. Não ficassem com dúvidas. Que fosse diferente do que assisti das outras meninas. Porque eu achei que elas fizeram tudo de qualquer jeito, porque precisam estar lá. Eu achei ruim do jeito que elas fizeram. Eu queria fazer diferente. Aquele senhor de sessenta anos me sensibilizou muito. Eu achei ele uma pessoa que precisa de muito conhecimento. Ele não sabe muita coisa e eu fiquei sensibilizada. Ele perguntava muita coisa, tinha muita dúvida, ele tinha medo de falar. Sabe, tinha uma palavra escrita errada no quadro, ele percebeu. Mas, perguntou primeiro para mim para aí falar. Então, eu queria coisas diferentes que fizesse eles participarem, fizesse eles se sentirem como se estivessem cooperando. Isso é um pouco construtivista, não é?

P - É mais construtivista. Agora, vai muito da forma como você vai colocar esse conteúdo. Porque, mesmo você tendo essa idéia é preciso pensar na maneira como irá colocar o conteúdo. Você chega na sala, explica o conteúdo e passa exercícios para eles fazerem? Você vai colocar questões problematizadoras para que o aluno possa ir pensando sobre 
o conteúdo e você vai falando sobre esse conteúdo à medida que essas questões estão sendo debatidas?

A1 - Sim. Um medo que eu tenho é chegar na hora e eu nem saiba o que falar. Acabe me perdendo.

P - Aí, você amarra na suas questões. Quais são as suas questões? O que estará propondo aos seus alunos? Quais são as suas atividades? Pode pensar nas questões como se fossem atividades. Que atividade você quer propor? Qual é a finalidade dessa atividade? Além de provocar um pensar coletivo na turma, o que aluno estará registrando, fazendo? Você tem que pensar que ao longo de sua aula o seu aluno terá que desenvolver algum exercício, além do debate, da problematização, em função da avaliação desta aula. Essa avaliação pode ser com uma ou duas questões, por exemplo, propõe um problema a partir do experimento desenvolvido na sala.

A1 - É, porque não adianta ficar só naquilo do falar, pode ser que eles tenham necessidade de escrever (OP, 16:14 a 24:30, 11/out/2005).

Nesse momento, para A1 a Matemática é um objeto a ser ensinado. Pois, ela ainda não desenvolveu nenhuma aula de Matemática no estágio, apenas observou as aulas da professora regente da turma multiseriada de EJA e de outras estagiárias. Nesse depoimento, ela traz a idéia de ensinar Matemática por meio de atividades práticas com os alunos, ou seja, a proposição de jogos e o manuseio de instrumentos de medidas, conforme sublinhado no depoimento. É uma idéia que ela também apresentou tanto no registro do questionário 1 quanto do questionário 2. Naqueles instrumentos ela afirmou acreditar ser uma boa prática o ensino pautado no uso de materiais didáticos.

No entanto, ao explicar como seria a aula proposta nos questionários veio à tona características de um ensino pautado na repetição de procedimentos desenvolvidos pelo professor, sujeito este que também detém o conhecimento. Pois, é ele quem passa e mostra ao aluno as informações necessárias para a resolução dos exercícios, conforme o seguinte registro sobre a explicação de como ensinaria a noção de fração: "Começaria levando para a sala de aula um bolo inteiro, na frente dos alunos dividiria em dois e explicaria que cada parte é $1 / 2$, então dividiria cada pedaço em dois e explicaria que cada parte é $1 / 4$ do bolo e assim prosseguiria" (Q1, 23/mar/2005). Ela ainda afirma ter escolhido essa forma de ensinar por entender que "vendo a prática, o aluno aprende com mais facilidade" (Q1, 23/mar/2005), ou seja, pela memorização dos procedimentos visualizados.

Por outro lado, quando ela afirma no trecho de entrevista apresentado anteriormente que seu desejo é que os alunos participem da aula, sintam-se como se estivessem cooperando, A1 sinaliza seu entendimento de como o aluno aprende. Emergem aí elementos de uma percepção sobre a aprendizagem em Matemática, uma vez que, A1 está concebendo a interação entre professor e alunos e a atribuição de atitude ativa ao aluno como características 
importantes na aprendizagem do discente. Aparentemente, para ela, a participação do aluno na aula, a visualização do conceito por meio do manuseio de materiais didáticos (estruturados ou não) são meios que possibilitam a elaboração e criação dos próprios significados conceituais.

Com essa visão, A1 terminou a elaboração do plano de sua primeira aula de Matemática sobre unidades de medidas não padronizadas e a desenvolveu para uma turma multiseriada de EJA, conforme evidenciado na cena 2.

Cena 4 - Perturbação conceitual sobre o ensinar: alunos não participam da aula.

Para se fazer entender a percepção desta perturbação conceitual, apresenta-se inicialmente um relato de como ocorreu a primeira aula de A1 no estágio com a respectiva avaliação sobre os resultados obtidos e, depois, uma narração sobre a aula que desencadeou o evento crítico selecionado para esta cena.

Assim, durante a primeira aula, A1 conversou muito com os alunos. Seu ponto de partida foi saber o que eles conheciam sobre medidas e se usavam algum tipo de medida em suas atividades diárias e profissionais. Os alunos participaram desta conversa relatando sobre suas experiências pessoais e apresentando algumas unidades de medidas não padronizadas desconhecidas de A1 e desta pesquisadora, como a chave ${ }^{31}$ que equivale a $15 \mathrm{~cm}$. Mas, essa participação dos alunos serviu apenas de mote para que ela, então, apresentasse as unidades de medidas não padronizadas mais usuais (passo, palmo, polegada). "Após a conversa inicial, A1 considerou apenas o conteúdo apresentado por ela, entregando aos alunos uma folha com um texto sobre o conteúdo e exercícios para que eles a respondessem usando os conceitos recém apresentados" (DIÁRIO DE CAMPO, p. 35). Ela pediu aos alunos que fizessem a leitura do texto e enquanto realizaram seus exercícios, A1 acompanhou as resoluções passando pelas carteiras. Essa tarefa tomou o restante do tempo da aula. Esse modo de conduzir a aula esteve pautado na apresentação do conceito seguido da aplicação do mesmo por meio da resolução de exercícios. A aula terminou com A1 solicitando aos alunos que levassem instrumentos de medidas para a próxima aula e com os alunos emitindo elogios para A1, informando que a atividade não havia sido chata como achavam antes de ela começar. Apoiadas nessa experiência, A1 e a professora de Metodologia de Ensino realizam uma nova reunião para refletirem sobre essa aula, conforme observado a seguir.

\footnotetext{
${ }^{31}$ Segundo a explicação do aluno da turma a unidade chave seria a distância entre as pontas dos dedos indicador e polegar quando estes estão dispostos na forma da letra L.
} 
P - Quais eram suas expectativas em relação à essa primeira aula e que avaliação você faz dela?

A1 - Na verdade eu queria que eles participassem. Queria ver o que eles achavam, se eles já tinham algum conhecimento. Se isso era uma coisa infantil para eles, não sei. Até cheguei a pensar se não era ridículo para eles. Teve uma menina que falou para mim, ontem na hora de ir embora: "eu achei que ia ser tão chato, tão chato! Quando você falou achei que ia ser tão ridículo. Mas, foi tão legal." Então, quer dizer, ela teve uma expectativa e que bom que foi ... Até no começo eu estava pensando, por que eu vou dar aula disso? Vão dar risada de mim que é uma coisa de criança. Daí, quando começaram: "mas a gente usa, a gente usa". Ela mesma falou: "claro que sim, não viu que ela explicou que a gente usa." Então, eu achei que foi legal. Que foi bem positivo. Para mim não tem nada para rever.

P - Você estava com bastante receio com a questão da infantilização do conteúdo por parte dos alunos?

A1 - Isso, isso mesmo.

P - Você falou de participação dos alunos. Estou lhe perguntando isso porque preciso entender o que você está pensando. Essa participação seria aquela em que os alunos estariam contando sobre as suas experiências ou era uma participação no sentido dos alunos estarem resolvendo os exercícios que você propunha?

A1 - Acho que tanto falando, contando sobre as experiências, quanto participando na resolução dos exercícios. Eu queria que eles participassem. Eu achei assim, se eles falassem eles iam se sentir iguais a mim. Eu estava falando e eles estavam falando também. Só que eu fui infeliz naquela hora em que eu pedi para lerem. A professora fez uma cara que não era para fazer isso. Então, não era para eles lerem. Mas, fazer eles contarem achei que foi bom. Eles falaram sobre outras coisas que não tinha nada haver com a aula. Mas, foi bom saber. Eu achei que fazer eles falarem foi bom e eles se proporem a ir ao quadro. Achei que ninguém ia querer. Mas, foram. Então eu achei essas duas coisas positivas na participação deles (REAU2, 02:10 a 04:50, 25/out/2005).

A1 se sente satisfeita com os resultados obtidos na primeira aula, considerando não haver necessidade de rever o planejamento da segunda aula, conforme sublinhado no depoimento. Ela reforça a importância da participação do aluno no processo de ensino e aprendizagem, inclusive explicitando o que significa essa participação para ela: "acho que tanto falando, contando sobre as experiências, quanto participando na resolução dos exercícios"(RE-AU2, 04:50), ou seja, é um meio de estabelecer um ambiente de interação e cooperação em sala de aula. O professor deixaria de ser visto como uma figura de autoridade, detentor do saber e o ensino do conteúdo tomaria como ponto de partida o conhecimento prévio do aluno. Assim, percebe-se que seus pressupostos teóricos de como deve ser o ensino estão pautados em uma visão mais construtivista e reflexiva. No entanto, quando ela desenvolveu a primeira aula, sua prática apresentou outras características de ensino, ou seja, a concepção expressa na intenção de ensino não era exatamente a mesma da que permeou a 
prática pedagógica, uma vez que foi o conhecimento matemático valorizado em sala de aula foi aquele apresentado por $\mathrm{A} 1 \mathrm{e}$, as idéias dos alunos apenas serviram de ilustração do conteúdo, conforme já evidenciado anteriormente.

Um outro elemento a destacar no depoimento de A1 e que a esteve acompanhando durante todo o período do estágio foi a preocupação com a aprendizagem dos alunos em virtude da faixa etária dos mesmos, ou seja, ela tinha a concepção de que os alunos da EJA aprendem de modo diferente das crianças. A1 revelou se sentir pouco preparada para ensinar adultos por não saber como eles aprendem. Esse sentimento foi um dos fatores que contribuiu para a vivência da frustração ocorrida durante o desenvolvimento da segunda aula de Matemática.

Na segunda aula, A1 já não se sentia tão nervosa como afirmava estar na primeira. Nesse dia ela desenvolveu a aula da mesma maneira que fez na anterior, trabalhando com os alunos o conteúdo medidas de comprimento - unidades padronizadas mais usuais (metro, quilômetro, centímetro e milímetro). Assim, A1 iniciou com uma breve revisão da aula anterior e com uma conversa sobre os instrumentos de medidas (fita métrica, trena e metro de carpinteiro), nesse momento, os alunos participaram informando que já conheciam tais instrumentos. Na sequiência, ela apresenta o conteúdo matemático, narrando fatos históricos sobre o surgimento do metro e fazendo anotações na lousa sobre a relação entre as unidades de medidas padronizadas (metro, decímetro, centímetro e milímetro) e não-padronizadas (polegada, pé, jarda). Os alunos faziam alguns comentários aleatórios e copiavam as informações da lousa. Depois disto, A1 propôs aos alunos que medissem alguns objetos com a régua e, então, ela anotou no quadro as relações das demais unidades das medidas de comprimento (quilômetro, hectômetro, decâmetro, alqueire, légua) para que os alunos copiassem. A última tarefa da aula foi a entrega, aos alunos, de uma folha com exercícios para que os mesmos a resolvessem, enquanto A1 explicava passando de carteira em carteira. No entanto, a aula não transcorreu como no primeiro dia. Após a conversa inicial os alunos se dispersaram e pouco participaram da aula, resultando no seguinte relato.

A1 - Eu tenho a impressão que a aula não tenha chamado atenção deles. Talvez a matéria, ou eles já sabiam, ou acharam que para eles não era necessário.

P - Ou talvez a falta da professora da turma na sala de aula.

A1 - É, também. Porque queira ou não queira se ela estivesse eles estariam diferentes. Eles não podem fazer isso. Aí vão pensar: "não respeitam."

P - Exatamente. Ela também direciona no fazer ou não fazer? Eu não sei, qual é a autonomia que ela dá para eles? Eles entram na sala e podem fazer outra atividade enquanto ela está propondo uma? Você chegou a observar isso? 
A1 - Não, ela não deixa. Ela é bem daquele tipo, se tem que ir ao banheiro, então vá. Mas, se vai embora antes, então, tem que dizer por que vai. Ela é cheia de explicaçãozinha assim:- Por que chegou atrasado? - Por que não fez aquele exercício?

P - Talvez eles precisem desse direcionamento. Você os deixou bem à vontade.

A1 - Bem à vontade. É que eu achei ruim fazer de outra forma.

$P$ - Você tem que pensar que eles estão na posição de alunos. E na posição de alunos eles têm que receber uma orientação do que deve ser feito naquele momento.

A1 - Eu deveria, talvez, ter pedido para que não copiassem a prova.

$\mathrm{P}$ - Exatamente isso. Porque aí começaram a perguntar da prova, se viu, se ia passar a limpo. Foi aí que eles começaram a se dispersar. Você disse também que talvez seja o modo como você organizou sua aula?

A1 - É, não sei. Eu acho assim, quando cheguei lá não tinha ninguém. Já eram sete e dez e não tinha ninguém. Aí pensei, pelo menos o $\mathrm{N}$ estava tão interessado, parece uma pessoa tão interessada, quando ele saiu mais cedo eu fiquei pensando assim: "estava chato." Eu acho que ele pensou assim: "eu já sei isso, não preciso ficar." Eu tenho a impressão que ele sabe bastante coisa. Então, por que ficar ali perdendo tempo se já sabe? Será que eles não pensaram assim? Dá a impressão. Não sei ... Eu vi que ele é uma pessoa que sempre perguntava muito. Agora, tenho até medo de voltar. Estava pensando naquele dia, ui que medo de voltar, dá vontade de ir embora, porque é triste você ver todo mundo indo embora. Mas, eu vi que com todo mundo aconteceu. Eles falaram assim: "foi espertinho saindo da aula." Claro, eu entendo assim, eles pensam: "não é a minha professora que está lá, o que essa aí vem querer me ensinar, olha o tamanho dela!" Na verdade eles estão certos.

P - Mas eu acho que o carisma deles você já conquistou. Talvez, você repensasse as questões, a re-organização da aula em si. Deixar os alunos livres, eles estão se dispersando, eles estão saindo, estão fazendo outras coisas que não é a atividade do momento. Então, repensar se é essa a estratégia que você quer adotar mesmo, de deixálos livres, de entregar todos os exercícios de uma só vez, sem fazer uma leitura em conjunto. De repente, até separar em momentos: "turma de terceira e quarta, vamos ler o exercício de vocês. Agora, turma de primeira e segunda, vamos ler o exercício de vocês." Marcar os momentos da aula. $\mathrm{O}$ momento em que o aluno vai copiar alguma coisa, o momento que ele estará participando da conversa, o momento em que ele vai fazer o exercício. Não necessariamente na ordem em que estou dizendo, mas pensar bem nesses momentos. Isso, talvez, facilite até a tua organização. O que você vai fazer em cada seqüência.

A1 - Hum, é, vamos mudar algumas coisas. [risos e A1 começa a fazer anotações] (RE-AU3, 04:34 a 07:19, 08/nov/2005).

A vivência da situação exposta no relato anterior desencadeia em A1 um sentimento de frustração e medo, conforme evidenciado no relato anterior. Pois, ela vinha concebendo que a participação dos alunos era um elemento essencial na relação do ensino e aprendizagem. No entanto, isso não aconteceu nesta aula. Segundo Cabral (1998), as perturbações conceituais podem ser decorrentes, também, de aspectos subjetivos como um sentimento de 
frustração, de descontentamento e tristeza gerados a partir de uma situação que contrarie a expectativa inicial. Para A1, o fato de os alunos terem saído da sala antes de a aula terminar e, ainda, não resolverem os exercícios propostos e fazerem tarefas alheias lhe causou um desequilíbrio conceitual em relação ao processo de ensino e aprendizagem, uma vez que, para ela, a participação se constituía em uma espécie de termômetro que sinalizava o grau de motivação e envolvimento do aluno em relação à aula, significava a possibilidade de aprendizagem. A hipótese levantada por ela é que a estrutura da aula, o modo como ela organizou o ensino não contribuía para um maior envolvimento dos alunos. A maneira como ela vinha desenvolvendo o ensino da Matemática não desencadearia a aprendizagem esperada nos alunos. Pode-se supor que além da estrutura da aula havia, pelo menos, outro motivo que gerou essa situação, seja ele, a insegurança que A1 sentia ao trabalhar com alunos de uma turma de jovens e adultos. Tal aspecto pode ser percebido quando ela afirma que achou ruim fazer diferente do modo como havia feito, isto é, de deixar os alunos livres, sem direcionamento sobre a atividade que deveriam fazer durante a sua aula, conforme sublinhado no depoimento. Assim, percebe-se que as conexões que A1 vai estabelecendo entre as suas concepções e a prática pedagógica têm forte vínculo com os aspectos subjetivos (imagem pessoal e insegurança frente aos alunos da EJA, medo de voltar e assumir a turma), já que tais elementos acabaram influenciando no modo como ela desenvolveu o ensino da Matemática. Frente ao exposto, constatou-se que era preciso re-elaborar a terceira aula para que os alunos voltassem a participar. Assim, a conversa entre A1 e a professora de Metodologia de Ensino se direcionou na estruturação de uma nova proposta de ensino, conforme pode ser observado na seqüência pela cena 6 .

Cena 6 - A acomodação: mudança de estratégia de ensino e tomada de consciência.

Partindo-se da hipótese de que a estrutura da aula deveria ser modificada, A1 e a professora de Metodologia de Ensino começaram a analisar o plano da terceira aula que já estava elaborado nos mesmos moldes das duas aulas anteriores, isto é, a estrutura da aula estava direcionada em: conversa informal sobre o assunto, apresentação do conteúdo e de instrumentos de medidas, proposição de exercícios. A análise do plano foi se desenvolvendo até que em certo momento A1 formula uma proposta para o ensino das medidas de capacidade (unidades padronizadas mais usuais - litro e mililitro) e a apresenta, desencadeando o seguinte diálogo. 
A1 - Será que ao invés de começar todos separadinhos, já fazer grupos? Grupo de primeira e segunda e grupo de terceira e quarta. Não sei. Que daí faz ...

P - Não sei. Formar o grupo para fazer o quê? Vamos pensar.

A1 - Até, de repente, não sei. Isso das embalagens, conversar com todos para ver o que eles falam e aí depois essas experiências em cada grupo. Põe lá na mesa as jarrinhas em cada grupo, os copos em cada grupo. O que vocês acham? Sei lá. Eles partirem de alguma coisa para depois eu propor alguma coisa. O que dá para fazer? Como a gente vai medir com isso aí? Como vocês mediriam?

P - Certo. Pode ser bem por aí.

A1 - É, são adultos, não tem problema de dar água.

P - Pode dar água e até pode cair. Onde não cai água quando está se mexendo com ela? Só tem que prever um paninho para secar o chão, se for o caso. Aí, seria interessante pensar em um exercício em que eles fossem registrando a experiência deles.

A1 - Ah, ao invés de um exercício prático como aquele que eu fiz na outra aula, um registro da experiência. O que eles observaram? Um copinho de tantos ml. Quantos copinhos ele usou para encher a vasilha?

P - Aí você tem que pensar o seguinte: o grupo de primeira está com muita dificuldade de leitura e escrita. Então, para eles talvez fosse interessante pedir que registrem em forma de esquema, de desenho.

A1 - Ou até ... Estava pensando agora ... Fazer aqueles textos em que a gente monta um cartaz e vai fazendo junto.

P - Um texto coletivo?

A1 - É, um texto coletivo ou por itens. Eles vão me dizendo e eu vou anotando por eles. É, um texto coletivo (RE-AU3, 24:15 a 26:21, 08/nov/2005).

A conversa continuou no sentido de se pensar como o experimento seria proposto aos

alunos. Quais questões A1 iria apresentar aos alunos enquanto desenvolviam o experimento com as embalagens? Que tipo de registro escrito ela solicitaria para cada grupo? Entre outros itens. Esse diálogo acabou da seguinte maneira.

P - Você viu que agora nós mudamos o sentido da sua aula?

A1 - Hum, hum. É que foi sufocante a outra. [sorrisos]

$\mathrm{P}$ - É, ela estava mais em um molde de aula tradicional na forma como está na primeira versão do plano.

A1 - É, hum, hum. [concordando].

P - Agora você está fazendo as mesmas coisas que havia proposto ...

A1 - Mas, de outra maneira né?

$\mathrm{P}$ - De outra maneira.

A1 - Nossa, é verdade. Deixar mais livre para que eles tenham ações. Estava difícil. É mesmo.

$P$ - E, não criamos nada de novo.

A1 - É mesmo. Tudo, tudo igual.

$\mathrm{P}$ - Só foi reestruturado.

A1 - É. Nossa, que interessante! (RE - AU3, 51:26 a 52:02, 08/nov/2005).

Nessa nova maneira de organizar o ensino, a participação do aluno continuou como um dos centros da aula. No entanto, o conhecimento prévio do aluno deixou de ser mote para 
a apresentação do conteúdo e passou a ser necessário para que o mesmo pudesse realizar os experimentos propostos por A1. Na re-elaboração do plano da aula, A1 propôs a mudança da organização física da sala de aula, colocando os alunos em grupos. Esses grupos eram relativos às séries em que os alunos estavam cursando (um grupo com alunos da alfabetização, primeira e segunda séries e outro grupo com alunos da terceira e quarta séries). Ela fez isso pelo fato de perceber, a partir da mediação da Professora de Metodologia, que os alunos apresentavam dificuldades em diferentes níveis e, organizados em grupos, ela teria condições de melhor atendê-los, conforme o seguinte exemplo: "Aí você tem que pensar o seguinte: o grupo de primeira está com muita dificuldade de leitura e escrita. Então, para eles talvez fosse interessante pedir que registrem em forma de esquema, de desenho" (P, RE-AU3, 26:03). O material didático deixou de ser ilustrativo e passou a ser elemento essencial no desenvolvimento do experimento. Pois, os alunos precisariam manusear os materiais para que pudessem responder as questões problematizadoras que norteavam o desenvolvimento do experimento. A nova proposta estava fundamentada nos princípios da Resolução de Problemas.

Com esse novo plano, A1 inicia a terceira aula na qual ela organizou as carteiras da sala em dois grupos, colocando em cima das mesmas várias embalagens (garrafas pet de um litro e meio e dois litros, copos descartáveis de quatro tamanhos diferentes e um balde com água). Na sequiência, ela apresentou o primeiro questionamento: "é possível fazer alguma medida usando essas embalagens?" Os alunos responderam que sim. Então, A1 fez a seguinte proposição: "cada grupo deverá encontrar alguma relação entre as medidas das embalagens" (NOTAS DE CAMPO, p. 41) e solicitou que registrassem suas descobertas da seguinte maneira: alunos da primeira e segunda séries por meio de desenhos e alunos da terceira e quarta séries por meio de um pequeno texto. A atitude de A1 mudou completamente nessa aula, até o tom de sua voz transmitia mais segurança. Ela deixou os alunos livres para estabelecerem suas próprias relações e tentou valorizar a opção, a estratégia de resolução de cada um. Todos os alunos se envolveram na atividade e ficaram em sala até o final da aula, inclusive, pedindo para irem ao quadro resolverem as operações referentes à quantidade de água utilizada na experiência. O conteúdo matemático foi explicado por A1 a partir dos resultados obtidos pelos alunos no experimento. Deste momento em diante, em virtude da avaliação na aula desenvolvida, foram propostos aos alunos os outros problemas matemáticos para serem resolvidos. Vale esclarecer que a professora de Prática Pedagógica solicitou aos alunos estagiários que realizassem uma avaliação de cada aula por meio de um instrumento escrito, ou seja, pelo desenvolvimento de uma atividade para esta finalidade. 
A1 considerou essa nova estrutura de aula satisfatória e passível de ser utilizada na última aula do estágio, na qual tratou do assunto medidas de massa (unidades padronizadas mais usuais - quilograma, grama e miligrama). A questão do experimento dessa última aula era estimar a massa de diferentes objetos (embalagens de diferentes formas e tamanhos, as quais estavam preenchidas com água), apenas manuseando-os. Os alunos confirmaram suas estimativas conferindo as medidas em uma balança. Assim, com o desenvolvimento das aulas 3 e 4, percebe-se que A1 adotou uma outra maneira de interagir com os alunos. A sua abordagem passou de uma percepção de ensino na qual várias pessoas participaram com seus pontos de vista, considerados na sistematização do conteúdo específico, mas somente o viés do professor era considerado por representar o conceito escolar e partiu para uma concepção de ensino em que várias pessoas, inclusive o professor, participam com seus diferentes pontos de vista na sistematização do conteúdo específico, conforme A1 procedeu em sua terceira aula ao iniciar a explicação do conteúdo matemático a partir das idéias elaboradas pelos alunos com o desenvolvimento do experimento. Em outras palavras, antes da vivência do conflito, A1 concebia que a participação do aluno era necessária, porém não era aproveitada no desenvolvimento do conteúdo. Após o evento crítico, a participação se voltou para a produção do conhecimento matemático a partir das elaborações do próprio aluno. Durante a entrevista final, A1 revela ter consciência sobre a sua mudança de enfoque em relação ao ensino e aprendizagem da Matemática, conforme pode ser observado no seguinte relato.

$\mathrm{P}$ - O que você acha que fez mudar sua estratégia de aula?

A1 - Eu acho que foi eles não corresponderem à segunda aula. Ah, que desânimo, que vontade de chorar. Chegou uma hora que eu não estava mais... Meu Deus! Estava lá fazendo por obrigação. Porque não tinha nem ânimo, não tinha nem motivação. Nossa, foi horrível aquela segunda aula. [risos] Ah, que horrível! Fiquei preocupada porque eles fizeram outras matérias, um monte de gente saiu antes, ninguém prestou atenção. Tanto é que aquela aula lá eu só peguei uma folha inteira resolvida, completa.

P - Eles estavam bem dispersos mesmo. E nas aulas seguintes isso não aconteceu.

A1 - É, porque deu para segurar eles com atividades. Nunca com tempo vazio, sempre segurando alguma coisa para eles fazerem.

P - Agora, fazendo uma avaliação dessa caminhada desse ano o que você considera que aprendeu em relação à sua formação docente e ao ensino da Matemática?

A1 - Eu acho que foi muito bom ter a ajuda da professora porque eu não sabia por onde começar. Eu tenho certeza que seria um fracasso a minha aula. Eu tinha na minha cabeça aquilo tradicional de explicar. Por quê? Porque eu sempre via assim, sei lá, de repente uma aula para criança, explica, explica e dá atividade, explica, explica, porque eu não sei se tem outra forma de saber, foi assim que eu aprendi. Aí, depois fui ver a aula de uma estagiária e ela fez igual, aquilo me deixou revoltada. Aí, quando chegou na última observação eu falei 
que não ia fazer, e a professora regente falou que eu precisava fazer porque as meninas não fizeram como tinha que ser feito. Aí que eu percebi que tinha alguma coisa errada. Só que eu já tinha feito o plano de aula, estava tudo pronto. Aí observei na última, vi como ela fez, é bem diferente do que elas tinham feito. Fiz as minhas observações comparando elas com a professora. Tudo para criar um jeito meu. $\underline{\text { Só }}$ que quando chegou na hora de elaborar o plano fiquei no tradicional, porque não sabia fazer outra coisa. Não tinha idéia de como deixar mais dinâmico, de questionar eles. Não imaginava que podia ser feito isso. Das experiências não imaginava. Até tinha uma idéia de, talvez, levar uma balança, só que até o último momento eu ia fazer a experiência. Eu ia fazer. [risos] Então, eu continuei no tradicional. Só depois entendi que não era assim. Porque, na verdade, na Educação de Jovens e Adultos eu nunca tinha tido uma aula. Nunca tinha entrado em uma sala de aula com eles. Nem observado, nem conversado com ninguém que faça EJA, com professor, com nada. Só com o que está escrito. Só que em nenhum texto que eu li estava: é assim, assim, assim. Mesmo lendo Paulo Freire é difícil entender (EF, 02:21 a 03:20 e 19:27, 30/nov/2005).

Nesse último relato, A1 destaca os elementos que lhe surgiram como obstáculos para o desenvolvimento de sua prática pedagógica, sejam eles: como trabalhar com alunos da EJA e a organização do ensino de modo diferente do tradicional. Supõe-se que a dificuldade em relação ao aluno da Educação de Jovens e Adultos tenha aparecido pelo fato de A1 possuir certa experiência em docência com alunos da Educação Infantil, assim, causando para ela um contraste de realidades em termos da faixa etária e dos elementos que envolvem o desenvolvimento do ser humano. Em um extremo, ela interagia com crianças de até 4 anos de idade e, no outro extremo, com senhores e senhoras de até 60 anos. Estes com uma bagagem cultural relativa à história de toda uma vida, enquanto aqueles estão em pleno processo de descoberta do mundo. Para A1, foi muito difícil se colocar na figura de professora perante a um grupo com uma significativa experiência de vida, ela não se via na figura de professora, mas como uma aluna, que assim como eles, estava naquela sala de aula para aprender.

O obstáculo em relação à organização do ensino surgiu em virtude da concepção que A1 possuía sobre o ensino e a aprendizagem da Matemática, ou seja, acreditava que para ensinar Matemática era importante conhecer o que os alunos sabem, usar materiais didáticos e, entendia que, a participação dos discentes favorecia a aprendizagem. Quando A1 colocou em prática essas idéias, ou seja, desenvolveu as duas primeiras aulas no estágio tais elementos estiveram presentes. No entanto, o conhecimento prévio do aluno ficou limitado ao relato das experiências pessoais, o qual se constituiu em um modo de participação. O material didático serviu apenas para que A1 ilustrasse o conceito estudado, sendo o mesmo manuseado pela própria professora estagiária ou pelos alunos a partir de instruções fornecidas por ela, assim surgindo um outro modo de participação. Nesse processo, a aprendizagem desencadeada 
correspondia a uma memorização descontextualizada de procedimentos e o conhecimento matemático era apresentado como um conjunto de conceitos prontos e elaborados por especialistas da área.

Com a ocorrência do evento crítico, sua visão sobre como desenvolver o ensino da Matemática foi abalada, quando ficou evidente que a forma como ela pensava não correspondia à prática pedagógica desenvolvida no estágio, pois prevaleceu até aquele momento, a prática que A1 vivenciou como aluna da escolarização básica. Somente com a reflexão, intermediada pela professora de Metodologia de Ensino, sobre os resultados insatisfatórios é que ela percebeu que a maneira de abordar tais elementos deveria ser outra, assim, resultando na re-estruturação das aulas 3 e 4 . Deste modo, o ponto de partida do ensino passou a ser a proposição de problematizações, as quais eram resolvidas a partir do conhecimento prévio do aluno e do manuseio do material didático. A perspectiva empregada a estes elementos permitiu que os alunos interagissem tanto com os materiais quanto com seus pares. Desta maneira, oportunizou-se aos alunos elaborarem novas estruturas conceituais a partir daquelas que eles já possuíam e estavam utilizando para a resolução das primeiras questões problematizadoras. A concepção de que a participação do aluno se constitui em um importante elemento para a aprendizagem se manteve. Porém, o significado do que é essa participação foi re-elaborado. Após o evento crítico, participar da aula passou a ser entendido como uma ação em que o aluno usa de suas próprias estruturas cognitivas para comunicar seu entendimento sobre uma determinada questão ou assunto, deste modo, suscitando na construção gradativa dos conceitos matemáticos.

A partir das cenas expostas nesse episódio, a configuração do movimento conceitual de A1 em relação ao ensino e aprendizagem da Matemática está representada no quadro 7 que segue. Esclarece-se que as zonas relativas ao perfil conceitual do ensino da Matemática estão identificadas do seguinte modo: Zona Reprodução (R); Zona Matemática Moderna (MM) e Zona Elaboração (E). As zonas referentes ao perfil conceitual da aprendizagem em Matemática são apresentadas, no quadro 7, da seguinte maneira: Zona Tradicional (T); Zona Comportamental (C) e Zona Nova Cultura (NC). Os aspectos considerados em relação à concepção de ensino são: função do professor (F. PROF.) e o modo como ensina a Matemática (COMO ENSINA), enquanto que, os relativos à concepção de aprendizagem são: características do aluno (CARC. ALUNO) e como ele aprende Matemática (COMO APREN.). A relação entre as zonas conceituais e as categorias em relação ao ensino e aprendizagem segue a mesma estrutura apresentada no quadro 4, conforme pode ser observado a seguir. 
QUADRO 7 MAPEAMENTO DAS ZONAS DO PERFIL CONCEITUAL DE ENSINO E APRENDIZAGEM DE MATEMÁTICA DE A1

continua

\begin{tabular}{|c|c|c|c|c|}
\hline \multirow[t]{2}{*}{ CENAS } & \multicolumn{4}{|c|}{ ASPECTOS CONCEPÇÃO DE ENSINO E APRENDIZAGEM DE MATEMÁTICA } \\
\hline & F. PROF. & COMO ENSINA & CARC. ALUNO & COMO APREN. \\
\hline CENA 4 & $\begin{array}{lr}15 \text { fonte de um } \\
\text { conhecimento pronto e } \\
\text { acabado }(\mathbf{R}) \\
25 \text { o conhecimento } \\
\text { surge do r mundo } \\
\text { sensível- } & \text { materiais } \\
\text { didáticos }(\mathbf{E}) & \end{array}$ & $\begin{array}{l}23 \text { propicia ao } \\
\text { aluno contato } \\
\text { visual e táctil com } \\
\text { material didático } \\
\text { (E) }\end{array}$ & $\begin{array}{l}43 \text { participação } \\
\text { (NC) } \\
46 \text { interação com } \\
\text { professor, alunos e } \\
\text { materiais (NC) }\end{array}$ & 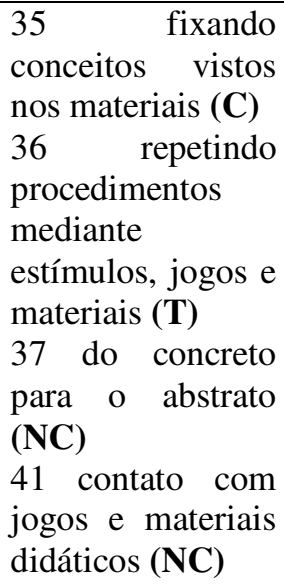 \\
\hline CENA 5 & $\begin{array}{l}15 \text { fonte de } \\
\text { conhecimento }(\mathbf{R}) \\
17 \text { mostra } \\
\text { conhecimento abstrato, } \\
\text { símbolos (MM) } \\
19 \text { instrutor }(\mathbf{M M}) \\
26 \text { mantém diálogo } \\
\text { alunos (E) }\end{array}$ & $\begin{array}{l}16 \text { conhecimento } \\
\text { prévio e material } \\
\text { didático romo } \\
\text { exemplo do } \\
\text { conceito (MM) } \\
20 \text { ensino livresco } \\
(\mathbf{M M}) \\
22 \text { professor usa } \\
\text { instrumento } \\
\text { medidas (MM) } \\
23 \text { contanto visual } \\
\text { dos materiais (E) } \\
29 \text { parte do } \\
\text { conhecimento } \\
\text { prévio do aluno (E) }\end{array}$ & $\begin{array}{l}43 \text { participação } \\
\text { (NC) } \\
46 \text { interação com } \\
\text { professor (NC) } \\
48 \text { aluno EJA (NC) }\end{array}$ & $\begin{array}{l}35 \text { fixando } \\
\text { conceitos vistos } \\
\text { na explicação }(\mathbf{C}) \\
36 \text { repetindo } \\
\text { procedimentos } \\
(\mathbf{T})\end{array}$ \\
\hline CENA 6 & $\begin{array}{l}25 \text { conhecimento surge } \\
\text { do mundo sensível - } \\
\text { experimento }(\mathbf{E}) \\
26 \text { mediador }(\mathbf{E}) \\
28 \text { visa à autonomia } \\
\text { aluno }(\mathbf{E})\end{array}$ & $\begin{array}{l}23 \text { material didático } \\
\text { para resolver } \\
\text { problematização } \\
(\mathbf{E}) \\
24 \text { desenvolvendo a } \\
\text { problematização } \\
\text { (E) } \\
27 \text { problematização } \\
\text { ponto de partida } \\
\text { (E) conhecimento } \\
29 \text { pé para resolver } \\
\text { prévio problematização(E) } \\
\text { proble }\end{array}$ & $\begin{array}{l}39 \text { desenvolve modo } \\
\text { próprio de pensar } \\
\text { (NC) } \\
40 \text { resolve } \\
\text { problematização e } \\
\text { expõe suas idéias } \\
\text { em sala (NC) } \\
43 \text { participação } \\
\text { (NC) } \\
46 \text { interação com } \\
\text { professor, aluno e } \\
\text { material (NC) } \\
48 \text { aluno EJA (NC) }\end{array}$ & $\begin{array}{l}37 \text { do } \\
\text { para } \\
\text { (NC) abstrato } \\
41 \text { fazendo } \\
\text { experimentos } \\
\text { (NC) } \\
44 \text { construindo } \\
\text { relações entre } \\
\text { idéias novas e } \\
\text { antigas (NC) }\end{array}$ \\
\hline
\end{tabular}


conclusão

\begin{tabular}{|c|c|c|c|c|}
\hline \multirow[t]{2}{*}{ CENAS } & \multicolumn{4}{|c|}{ ASPECTOS CONCEPÇÃO DE ENSINO E APRENDIZAGEM DE MATEMÁTICA } \\
\hline & F. PROF. & COMO ENSINA & CARC. ALUNO & COMO APREN. \\
\hline & & $\begin{array}{l}30 \text { forma grupos } \\
\text { com os alunos }(\mathbf{E}) \\
32 \text { experimento } \\
\text { com } \\
\text { conhecimento } \\
\text { prévio }(\mathbf{E})\end{array}$ & & \\
\hline
\end{tabular}

Fonte: dados organizados pela autora.

O quadro 7 mostra, de modo sintético, o movimento conceitual de A1 em relação à sua concepção sobre o ensino e a aprendizagem em Matemática durante o período em que ela desenvolveu seu estágio em docência. Tem-se a clareza de que o quadro só faz sentido a partir do contexto que possibilitou a geração do mesmo. Contudo, por essa síntese, é possível perceber que, da cena 4 até a cena 6 , o modo como A1 percebia o ensino e a aprendizagem da Matemática foi se tornando uma visão mais harmoniosa, ou seja, sua intenção de ensino foi ficando mais próxima daquilo que ela concebia em relação à aprendizagem do aluno, como também, da prática pedagógica em virtude de, pelo menos, dois fatores: a influência da professora de Metodologia de Ensino e o próprio esforço para superar as dificuldades provenientes das perturbações relacionadas aos aspectos subjetivos.

Na cena 4, os aspectos revelados por A1 ainda estão no nível do saber a ser ensinado (CHEVALLARD, 1991), isto é, estão restritos ao planejamento da aula. Portanto, há o predomínio de uma concepção de caráter teórico/acadêmico e, também, advindo da experiência com a própria escolarização. Percebe-se que A1 privilegia o uso de materiais didáticos e jogos como meio de propiciar aos alunos o contato visual e/ou táctil (23) do conhecimento matemático, como também, de estabelecer vínculo com o mundo sensível (25), estes aspectos são próprios da zona Elaboração. Mas, ela revela entender que o professor é a principal fonte de informações e deve mostrar ao aluno esse conhecimento já elaborado (15) no material didático, uma idéia própria da zona Repetição. Em outras palavras, há uma distinção entre o papel desempenhado pelo professor e a intenção de ensino planejada, estes aspectos estão em zonas diferentes. Tal situação implica no entendimento de uma coexistência de idéias, visto que se referem a diferentes características e ambas se relacionam à concepção de ensino. O mesmo ocorre sobre o aprendizado em Matemática, cujas características esperadas para o aluno também não estão coerentes com alguns 
elementos do modo como a aprendizagem seria viabilizada, ou seja, espera-se que os alunos participem (43) e interajam com seus pares e com os materiais didáticos (46) (zona Nova Cultura), mas observando o professor manusear o material didático (35) (zona Comportamental) enquanto explica o conteúdo e repetindo os procedimentos ditados (36) (zona Tradicional). Mais uma vez características pertencentes a diferentes zonas e relacionadas a uma mesma concepção, nesse caso a de aprendizagem.

A cena 5 é reflexo do desenvolvimento da prática pedagógica, ou seja, é quando A1 tenta colocar em prática aquilo que havia planejado. Nesse contexto, a pouca coerência entre sua intenção de ensino e a expectativa em relação à aprendizagem do aluno vem à tona, revelando-se em uma perturbação conceitual. Percebe-se que o papel desempenhado por A1, como docente, esteve pautado, principalmente, nos princípios da zona Matemática Moderna, apesar de ela manter a intenção de valorizar o diálogo em sala de aula (26), o conhecimento prévio do aluno (29) e o uso de materiais didáticos-instrumentos de medidas (23). Contudo, esses elementos serviram apenas de incentivo para que o aluno reproduzisse o procedimento apresentado pela professora estagiária (36). Por outro lado, a concepção de aprendizagem se manteve, praticamente, a mesma da apresentada na cena 4, gerando um contraste entre esta e a concepção de ensino revelada pela prática pedagógica. Entende-se que tal situação foi o pivô da perturbação conceitual, resultando assim, em um sentimento de frustração e medo de continuar ministrando aula, ou seja, percebe-se aí indícios de que os aspectos subjetivos influenciam de modo significativo nas conexões estabelecidas entre as concepções e a prática pedagógica.

Deste modo, a cena 6 representa tanto a tomada de consciência de A1 como a reelaboração de sua prática pedagógica, pois ela percebeu que havia uma incoerência entre seu modo de pensar e de agir. Por exemplo, A1 entendeu que não bastava mostrar o conceito no material didático, era preciso permitir que o aluno visualizasse, a partir de suas próprias percepções, o conceito no material didático. A atitude de A1, como docente mudou, propiciando que a expectativa em relação à aprendizagem dos alunos fosse alcançada e conseqüentemente se revelasse como satisfação em relação aos resultados obtidos com a nova estrutura de aula. Assim, na cena 6, a concepção de ensino esteve pautada na zona Elaboração e a de aprendizagem na zona Nova Cultura. 


\subsubsection{Movimento Conceitual de A2}

Para A2 também se elaborou um mapa das atividades desenvolvidas ao longo do período investigativo, cujo intuito é mostrar o contexto global de onde foram extraídos os episódios e permitir um melhor entendimento do movimento conceitual dela.

\section{QUADRO 8 MAPA DE ATIVIDADES DESENVOLVIDAS COM A2}

\begin{tabular}{|c|c|c|c|}
\hline PERÍODO & ATIVIDADES & PRINCIPAIS TEMAS & EPISÓDIOS \\
\hline $1^{\circ} \mathrm{sem} / 2005$ & $\begin{array}{l}\text { Aulas de Metodologia do Ensino } \\
\text { de Matemática. }\end{array}$ & $\begin{array}{l}\text { Resgate das concepções } \\
\text { informais e confronto } \\
\text { das mesmas com novos } \\
\text { conceitos. }\end{array}$ & $\begin{array}{lll}\text { Concepções em } & \text { relação } & \text { à } \\
\text { Matemática. } & & \\
\text { Iniciais e Finais. } & & \\
\text { Q1 e Q2 } & & \end{array}$ \\
\hline $\begin{array}{l}20 / 09 / 2005 \\
1 \mathrm{~h} 15 \mathrm{~min}\end{array}$ & $\begin{array}{l}\text { Reunião de A2 com a professora } \\
\text { de Metodologia de Ensino de } \\
\text { Matemática. }\end{array}$ & $\begin{array}{lr}\text { Orientação } & \text { para } \\
\text { elaboração dos } & \text { planos } \\
\text { de aula. } & \end{array}$ & $\begin{array}{l}\text { Concepções iniciais em relação } \\
\text { ao ensino e aprendizagem. } \\
\text { Material didático } \\
\text { conhecimento prévio. } \\
\text { OP } 21: 22 \text { a } 22: 05 \\
\quad 00: 00 \text { a } 01: 18 \\
\quad 04: 52 \text { a } 05: 17\end{array}$ \\
\hline $\begin{array}{l}07 / 10 / 2005 \\
4 \text { horas }\end{array}$ & $\begin{array}{l}\text { Desenvolvimento da quarta aula } \\
\text { no estágio com observação direta. }\end{array}$ & $\begin{array}{l}\text { Conteúdo da aula: } \\
\text { Sistema de Numeração } \\
\text { Decimal - unidade e } \\
\text { dezena, composição de } \\
\text { números, adição e } \\
\text { subtração. A2 afirma } \\
\text { não ter atingido seus } \\
\text { objetivos. }\end{array}$ & \\
\hline $\begin{array}{l}11 / 10 / 2005 \\
1 \mathrm{~h} 20 \mathrm{~min}\end{array}$ & $\begin{array}{l}\text { Reunião de A2 com a professora } \\
\text { de Metodologia de Ensino de } \\
\text { Matemática. }\end{array}$ & $\begin{array}{l}\text { Reflexão sobre os } \\
\text { resultados da } 4 .^{\mathrm{a}} \text { aula e } \\
\text { orientação para a } \\
\text { elaboração do plano da } \\
\text { aula 5. }\end{array}$ & $\begin{array}{l}\text { Evento crítico em relação ao } \\
\text { ensino-aprendizagem. } \\
\text { Material Didático. } \\
\text { RE-AU5 12:36 a } 13: 30 \\
\text { Frustração. } \\
\text { RE-AU5 00:00 a 03:04 } \\
\text { 08:43 a 14:23 } \\
\text { 18:24 }\end{array}$ \\
\hline $\begin{array}{l}14 / 10 / 2005 \\
4 \text { horas }\end{array}$ & $\begin{array}{l}\text { Desenvolvimento da quinta aula } \\
\text { no estágio com observação direta. }\end{array}$ & $\begin{array}{l}\text { Conteúdo da aula: } \\
\text { SND, adição } \quad \text { e } \\
\text { subtração com unidades } \\
\text { e dezenas e antecessor e } \\
\text { sucessor de um número. } \\
\text { A2 apresenta outra } \\
\text { organização } \\
\text { condução da aula. }\end{array}$ & \\
\hline $\begin{array}{l}\text { 18/10/2005 } \\
1 \mathrm{~h} 31 \mathrm{~min}\end{array}$ & $\begin{array}{l}\text { Reunião de A2 com a professora } \\
\text { de Metodologia de Ensino de } \\
\text { Matemática. }\end{array}$ & $\begin{array}{l}\text { Reflexão sobre os } \\
\text { resultados da } 5 .^{\mathrm{a}} \text { aula e } \\
\text { entrevista final. }\end{array}$ & $\begin{array}{l}\text { Acomodação em relação ao } \\
\text { ensino-aprendizagem. } \\
\text { Frustração superada. } \\
\text { EF 00:00 a 04:50 } \\
\text { 12:43 a } 15: 49 \\
\text { 05:07 } \\
\text { Evento crítico em relação à } \\
\text { Matemática. } \\
\text { 01:10:14 a 01:12:49 }\end{array}$ \\
\hline
\end{tabular}

Fonte: dados organizados pela autora 
Pelo quadro 8 , observa-se que, além do $1 .^{\circ}$ semestre letivo com a disciplina de Metodologia do Ensino de Matemática, existiram mais cinco momentos de contato com A2, dois deles acontecem por meio da observação da aula no estágio e os três restantes com as entrevistas. Assim, esclarece-se que as cenas destacadas de cada momento foram consideradas representativas das idéias que emergiram da discussão sobre as concepções de Matemática e do ensino e aprendizagem dessa ciência. Seguindo a mesma linha de organização adotada em relação aos episódios de A1, apresenta-se na seqüência, o esquema da estrutura sistematizada para os episódios de A2.

Episódio 1 - Concepções de A2 em relação à Matemática.

Cena 1 - Concepções pessoais sobre o que é a Matemática.

Cena 2 - Concepções finais sobre o que é a Matemática.

Cena 3 - Tomada de consciência.

Episódio 2 - Concepções de A2 em relação ao processo de ensino e aprendizagem de Matemática.

Cena 4 - Concepções pessoais sobre o ensinar e aprender Matemática.

Cena 5 - Desequilíbrio conceitual lacunar: falta de conhecimento pedagógico em relação aos alunos.

Cena 6 - A acomodação: mudança de estratégia de ensino e objetivos atingidos.

Sendo assim, apresenta-se na seqüência o episódio relativo às concepções sobre a Matemática.

- Episódio 1 - Concepções de A2 em relação à Matemática.

Cena 1 - Concepções pessoais sobre o que é a Matemática

As respostas de A2 no questionário 1 são, relativamente, breves e objetivas, conforme pode ser observado em seus registros às seguintes questões:

Um leigo lhe pergunta “de onde vem a Matemática?" Como você explicaria essa questão?

Vem do instinto humano e da capacidade que ele tem em desenvolver o pensamento lógico.

Se incluísse em sua explicação as principais características da Matemática, quais você apresentaria?

Proporciona o desenvolvimento do raciocínio lógico e é exata (Q1, 23/mar/2005). 
A2 iniciou o ano letivo na disciplina de Metodologia do Ensino de Matemática com a concepção de que a Matemática trata de um conhecimento proveniente da racionalização do homem. A2 valoriza o aspecto lógico e exato da ciência. Tais características são suficientes para compreender que a visão inicial dela é absolutista e racional. Pois, ela enfatizava a idéia de que o conhecimento vem do instinto humano. Com o andamento do semestre letivo, este sujeito entrou em contato com os conteúdos específicos da referida disciplina. Durante esse período, A2, sempre que possível, manifestava seus modos particulares de pensar em relação ao tópico que estava estudando e no último dia de aula, ao responder o questionário 2, ela demonstrou ter ampliado sua referência em relação à Matemática, conforme destacado na cena 2.

Cena 2 - Concepções finais sobre o que é a Matemática.

Imbuída de novos referenciais, ao ser questionada, A2 registra no questionário 2 que explicaria sobre a origem da Matemática e suas características da seguinte maneira a um suposto aluno que pretendia escrever um livro sobre o que aprendeu dessa ciência.

Bem, você poderia começar seu livro contando que a Matemática surgiu há muito tempo com os povos egípcios, gregos e atenienses. Depois, conte sobre as características da Matemática: que ela desenvolve no ser humano o raciocínio lógico, a percepção do todo. Das várias possibilidades e que ela deve ser construída através de problemas e situações abordando questões do dia-a-dia e que todos devem participar ativamente dando suas opiniões e entendimentos para uma construção em conjunto (Q2, 22/jun./2005).

Apesar de A2 manter a percepção sobre o aspecto lógico da Matemática, ela amplia seu modo de ver essa ciência. Nesse momento, percebe-se que ela passa a considerar que o conhecimento matemático tem sua origem localizada na Antigüidade, com os povos daquela idade histórica, conforme sublinhado no registro anterior. Isso sugere que A2 está concebendo a Matemática como uma ciência pronta e, também, que possui uma história de sua constituição. Esta última percepção, de certo modo, complementa-se com a idéia de que a Matemática é resultado de uma construção derivada da resolução de problemas do cotidiano e, conseqüentemente, do trabalho coletivo dos indivíduos envolvidos. Uma outra característica a destacar é que A2 ao responder o segundo questionário deixa de mencionar o aspecto da exatidão e passa a incluir a idéia de variedade de possibilidades, ou seja, passa a perceber o conhecimento como falível. No entanto, já na seqüência, quando A2 revê seus 
registros realizados no questionário 1 o aspecto da exatidão surge novamente entre suas idéias em relação à Matemática.

Acrescentaria que além de a Matemática vir do instinto humano e da capacidade em desenvolver o pensamento do homem, ela surgiu com os povos do Egito, Grécia e Atenas como uma ciência. Explicaria que a questão da exatidão é relacionada às respostas dos cálculos matemáticos. Mas, que para chegar a essas respostas não há exatidão no raciocínio, ou seja, pode haver vários caminhos e isso depende do conhecimento de quem resolve (Q2, 22/jun./2005).

Por essa explicação, A2 deixa transparecer que sua concepção em relação à Matemática não só se ampliou como também foi re-elaborada em certos aspectos. A menção da Matemática como uma ciência permite compreender que ela pode estar percebendo esse conhecimento por diferentes vieses, por exemplo: o científico, o escolar e o cotidiano. A idéia da exatidão permanece, quando relacionada ao resultado das operações matemáticas. Segundo a argumentação de A2: “[...] a questão da exatidão é relacionada às respostas dos cálculos [...], para chegar a essas respostas não há exatidão no raciocínio [...], pode haver vários caminhos[...]" (A2, Q2). Assim, supõe-se que ela está entendendo que uma mesma idéia matemática pode ser percebida por diferentes aspectos e apesar de o conhecimento ser universal, ele não é único. Conforme D’Ambrósio (2001), cada povo, cada grupo social, cada indivíduo percebe e elabora estruturas conceituais a partir de diferentes realidades e experiências. Isso resulta em um mesmo conhecimento advindo de diferentes vertentes. $\mathrm{Na}$ entrevista final, A2 revela em que momento ela toma consciência desse outro modo de ver a Matemática, conforme apresentado na cena 3.

Cena 3 - Tomada de consciência

$\mathrm{Na}$ última reunião realizada com $\mathrm{A} 2$, fez-se uma retrospectiva de toda a trajetória pela qual esse sujeito passou ao longo do ano letivo em relação à sua formação docente na área da Matemática. Deste modo, propiciou-se a ela que revisse os registros realizados nos questionários. Feita tal leitura, A2 emite a seguinte explicação.

P - Uma questão que observei com a idéia que você traz de Matemática, dessa primeira [Q1] para a segunda versão [Q2]... Aqui você traz bem a idéia do raciocínio lógico, da exatidão, pensamento lógico.

A2 - Que é isso que faz com que a gente tenha terror. Puxa, três mais três são seis, se não for seis está errado. Tem um vermelhão lá, um risco vermelho da professora. Não é mais aquele negócio de: se não fez, pronto. Eu acho que é isso que causa o terror da Matemática.

P - Quando se fala a Matemática não muda, é exata, pensa-se apenas no resultado. Não se pensa no processo, no como se chega nesse seis. 
A2 - Mas porque tem essa visão tradicional da área.

P - Isso você traz um pouco aqui [Q2], veja o que você escreveu: "você pode começar seu livro contando que surgiu há muito tempo com os povos gregos, egípcios. Depois conte sobre as características da Matemática, que ela desenvolve no ser humano o raciocínio lógico, a percepção do todo, das várias possibilidades e que ela deve ser construída abordando problemas e questões do dia-a-dia. Que todos devem participar ativamente, dando suas contribuições para uma construção em conjunto. Você traz uma idéia de ... Continua sim a questão do raciocínio lógico porque é uma questão implícita da área. Mas, a idéia do exato, do pronto, do acabado, você passa para uma idéia de processo.

A2 - Sabe em que momento eu consegui enxergar isso? Depois que a gente trabalhou os problemas. Os tipos de problemas. [referindo-se a um conteúdo da Metodologia de Ensino de Matemática]

$\mathrm{P}$ - Os problemas padrão e ... O problema dos Caitités?

A2 - Principalmente. Aí que eu percebi essa diferença. Porque para mim era do jeito que eu tinha escrito aqui [Q1] exata, sem questionamento, é essa idéia e pronto. É o que a gente teve como aprendizado. Eu aprendi assim, exato, não tem como questionar, é isso e pronto. Por isso que dá esse terror, eu vou errar? E se eu erro? É o mesmo terror que me dava na hora do vestibular.

P - Só tem um jeito para resolver e pronto (EF, 01:10:14 a 01:12:49, 18/out/2005).

Nesse depoimento, A2 revela que toma consciência de uma outra percepção da Matemática a partir do momento que realiza uma das atividades propostas na disciplina de Metodologia de Ensino da Matemática, a qual era relativa ao estudo da Etnomatemática e da Resolução de Problemas, seja ela, o problema dos Caitités ${ }^{32}$, conforme sublinhado no depoimento anterior. Deste modo, entende-se que a Metodologia de Ensino lhe possibilitou ampliar as estruturas cognitivas de partida em relação à visão da Matemática e, também, reelaborar o significado do caráter da exatidão dessa ciência. Relacionando com o exemplo de uma situação escolar citado por A2, o risco vermelho traçado pela professora para indicar o erro, possivelmente seja relativo ao entendimento de que a exatidão da Matemática esteja na idéia de que o aluno tenha que repetir procedimentos exatamente da mesma forma daqueles mostrados pelo professor, caso contrário, o pensamento do aluno estava errado. Pela perspectiva da Resolução de Problemas e da Etnomatemática, o procedimento desenvolvido pelo aluno é tão válido quanto o do professor, ou seja, por esse viés A2 passou a conceber que uma mesma noção conceitual e/ou resultado operacional pode ser encontrada de formas diferentes. Portanto, entende-se que A2 ampliou sua percepção sobre a Matemática.

\footnotetext{
${ }^{32}$ O problema dos Caitités é de autoria do professor Manoel Oriosvaldo de Moura. Esse problema foi proposto pelo autor durante o desenvolvimento da disciplina - $\mathrm{O}$ conhecimento em sala de aula: a organização do ensino pelo Programa de Pós Graduação da Faculdade de Educação da USP no ano de 2004, com uma finalidade distinta à daqui.
} 
Por outro lado, com a explicação sobre o erro, A2 revela uma conexão estabelecida por ela para explicar um fenômeno relativamente comum na Matemática, que é o medo, o terror que muitas pessoas dizem sentir em relação à essa área do conhecimento. Tal sentimento seria decorrente de uma visão tradicional da Matemática, isto é, de uma concepção de ciência exata e absoluta, própria das zonas Absolutista Racionalista e Empirista. Então, pressupõe-se que se uma pessoa conceber que a Matemática é uma ciência que reconhece nas manifestações culturais o caráter matemático e se refere a um conhecimento relativo, mutável e prático, isso faz com que o sentimento de medo e terror apareça com menos freqüência. Em termos da aprendizagem do aluno é um aspecto positivo, uma vez que sentimentos como os citados se constituem em obstáculos. Tal percepção norteou o desenvolvimento das aulas de Matemática ministradas por A2 no estágio, conforme será observado no episódio 2. Segue no quadro 9, a síntese da concepção de A2 sobre a Matemática ao longo das cenas que compõem o episódio 1.

\section{QUADRO 9 MAPEAMENTO DAS ZONAS DO PERFIL CONCEITUAL DE MATEMÁTICA DE A2}

\begin{tabular}{|c|c|c|c|}
\hline \multirow[t]{2}{*}{ CENAS } & \multicolumn{3}{|c|}{ ASPECTOS DA CONCEPÇÃO DE MATEMÁTICA } \\
\hline & ORIGEM & FINALIDADE & CARACTERÍSTICAS \\
\hline CENA 1 & $\begin{array}{l}5 \text { instinto } \\
\text { humano (AR) }\end{array}$ & $\begin{array}{l}2 \text { desenvolve o raciocínio } \\
\text { lógico (AR) }\end{array}$ & 3 exata $(\mathbf{A R})$ \\
\hline CENA 2 & $\begin{array}{l}5 \\
\text { humano (Anstinto } \\
10 \text { questões do } \\
\text { dia-a-dia (D) }\end{array}$ & 2 raciocínio lógico $(\mathbf{A R})$ & $\begin{array}{l}4 \text { ciência pronta (AR) } \\
8 \text { conhecimento amplo: científico e } \\
\text { cotidiano }(\mathbf{D}) \\
9 \text { todos participam da construção }(\mathbf{D}) \\
11 \text { é construído }(\mathbf{D}) \\
12 \text { várias possibilidades }(\mathbf{D})\end{array}$ \\
\hline CENA 3 & Não comentado & Não comentado & $\begin{array}{l}8 \text { conhecimento amplo: científico e } \\
\text { escolar }(\mathbf{D}) \\
11 \text { construído (D) }\end{array}$ \\
\hline
\end{tabular}

Legenda: $\quad$ AR - Abstrata Racionalista $\quad$ D - Dinâmica

Fonte: dados organizados pela autora

Analisando a cena 1 e a 2, é possível perceber que há certa ampliação dos aspectos revelados por A2 em relação à Matemática. Tal ampliação não se restringe aos aspectos, mas também abrange as zonas do perfil conceitual, uma vez que os citados na cena 1 eram referentes à zona Repetição e os presentes na cena 2 são relativos à zona Repetição e Dinâmica, situação essa que configura uma coexistência de zonas conceituais. Observa-se 
essa situação principalmente em relação à origem da Matemática, em que A2 concebe que o conhecimento matemático vem do instinto humano (5) e também das questões do dia-adia, ou seja, a Matemática se origina nas idéias das pessoas e nas situações sócio-culturais (10). No entanto, nada pode se afirmar sobre essa coexistência após a prática pedagógica no estágio, uma vez que A2 não emitiu nenhum comentário sobre os aspectos relacionados à origem e à finalidade da Matemática, apenas explicou os motivos que a levaram a perceber os aspectos destacados na cena referentes às características da Matemática. Portanto, entende-se que a tomada de consciência e a respectiva evolução conceitual esteve associada à característica sobre a natureza da Matemática, isto é, A2 deixou de ver o conhecimento matemático como pronto e acabado (4), passando a compreendê-lo como o resultado de um processo de construção (11), uma visão própria da zona Dinâmica do perfil conceitual de Matemática.

- Episódio 2 - Concepções de A2 em relação ao processo de ensino e aprendizagem de $\underline{\text { Matemática }}$

Cena 4 - Concepções pessoais sobre o ensinar e aprender Matemática.

Quando A2 elaborou os planos das aulas de Matemática, organizou uma proposta para ensinar aos alunos de uma turma da 1. ${ }^{a}$ série do Ensino Fundamental a noção de unidade e dezena, antecessor e sucessor de um número a partir de um viés lúdico, priorizando-se o manuseio de um material didático, ou seja, o material dourado. Esse instrumento didático seria manuseado pelos alunos tanto na resolução de exercícios como no desenvolvimento do jogo matemático "Nunca Dez. ${ }^{33, " ~ N o ~ r e l a t o ~ a ~ s e g u i r, ~ A 2 ~ e x p l i c a ~ s u a ~ i n t e n c ̧ a ̃ o ~ d e ~ e n s i n o ~ t a n t o ~}$ para a professora de Prática Pedagógica (PP) quanto para a professora de Metodologia de Ensino (P).

PP - O que eu queria ver é o seguinte: o que você acha que ensinaria para as crianças de antecessor e sucessor confeccionando esse trem? [referindo-se a uma das atividades propostas no plano de aula]

A2 - Eu vejo que o material dourado concretiza aquilo. Então, eu penso assim: eles entenderem essa seqüência. Mas, visualizando essa sequiência. Não porque é mecânico. Eu vejo pelas crianças lá da escola onde eu trabalho. Elas começam contar: um, dois e vão no

\footnotetext{
${ }^{33} \mathrm{O}$ objetivo do jogo Nunca Dez é fazer com o jogador junte 10 unidades do material que estiver manuseando e as troque por um elemento deste material representativo de uma dezena. No caso de A2, escolheu-se o material dourado, cuja estrutura já possui os elementos representativos das unidades e dezenas.
} 
embalo. Mas, elas não sabem por que o dois depois do um? Porque o dois significa o um mais um.

PP - Você acha que confeccionando esse trenzinho você garante isso?

A2 - Eu imaginei que sim. Eu imaginei que se eles iam conseguir no concreto, trabalhando lá os bloquinhos, os cubinhos, eles iam ver no concreto e iam conseguir.

PP - Com o material dourado você vai conseguir.

A2 - É com o material dourado que vou elaborar esse trem. Talvez não ficou claro aí, porque eu vou começar com um cubinho, depois com dois cubinhos, talvez não coloquei tudo. Aquela coisa, a gente tem a idéia, mas não passa para o papel direito e quem está lendo não está entendendo a idéia que eu tive.

$\mathrm{PP}-\mathrm{E}$, porque aqui não está escrito isso.

A2 - É. Mas, é com material dourado. Aí, vai ficar com cara de trem. Porque o vagão um tem um cubinho, o vagão dois tem dois cubinhos, o vagão três tem três cubinhos, o quatro e assim vai até formar a barrinha. Até chegar no dez que é a barrinha e, aí vai chegar na frente do trenzinho. Aí vai ficar com uma carinha de trem (OP, 21:22 a 22:05, 29/set/2005).

Mais adiante, A2 e a professora de Metodologia de Ensino continuam conversando sobre o planejamento da aula.

P - A idéia que você propôs para trabalhar com antecessor e sucessor está boa. Eu senti duas coisas: primeiro o que você colocou lá: "Ah, eu não consegui perceber essa conexão", ou seja, a falta de conexão entre as áreas e a falta de conexão entre os próprios conteúdos de Matemática que você propõe para trabalhar. Preciso que você me esclareça algumas coisas antes de comerçarmos a mexer em seus planos. Por que você pensou nessa sequiência de aula? Nesse formato da tua aula de Matemática?

A2 - Da estratégia você diz?

$\mathrm{P}$ - Da tua aula propriamente dita.

A2 - Então, primeiro eu tenho que apresentar o material dourado porque eu não sei se eles conhecem o material, se já mexeram e eu também nunca trabalhei. Vai ser uma novidade para eles e para mim também. Então, é uma oportunidade para eu ver como é que trabalha. A idéia do dado, eu até mudei isso também, porque eu tinha feito uma estrutura e depois achei que não estava boa, eu teria que dar todo o material para eles mexerem livremente, todos não, mas uma boa quantidade. Se eu fosse fazer essa brincadeira depois que é uma coisa lúdica, para eles aprenderem brincando, eles iam ter que me devolver e, eu achei ruim isso, dá e depois: "agora vocês me devolvam que eu vou fazer outra brincadeira" [risos]. Entendeu? Se eles partissem com alguma coisa na mão, também ia tirar um pouco da expectativa deles irem adquirindo os cubinhos vistos lá de longe e estão doidos para pegar. Apesar que, quando pensei nessa aula com esse material a minha intenção é que eles ficassem com esse material, que eles pudessem usar isso nas próximas aulas, quando tivesse que calcular alguma coisa que eles pudessem utilizar. A idéia é incentivar que eles utilizem os materiais (OP, 00:00 a 01:18, 29/set/2005). 
A conversa sobre a estratégia da aula continua, até que em certo momento volta o assunto relativo ao material dourado.

P - No material dourado é interessante que eles percebam bem a relação da barrinha com o cubinho. Que a barrinha tem que corresponder a dez cubinhos.

A2 - Na apresentação inicial eu já vou trabalhar com esse conceito para que percebam isso. E, até na brincadeira do Nunca Dez, tem que juntar dez cubinhos. Primeiro, vou querer saber se eles já conhecem, de repente tem uma criança que já conhece. Sempre fazer deles antes, muitas das aulas estou pensando nesse sentido. De repente vou lá, olha o que eu trouxe para vocês, se eles já conhecem, aí cai minha cara. Quero sempre saber deles o que eles já sabem. E, quando eu estiver trabalhando esse jogo: "ah, deu seis mais dois, são oito, ainda não vai ganhar a barrinha porque não chegou no dez." Ele sempre vai estar fazendo essa soma, a adição. "Ah, consegui dez, ganhei essa barrinha”. Então, ele vai estar sempre estimulado a ganhar esses dez (OP, 04:52 a 05:17, 29/set/2005).

A maneira como A2 elaborou o plano de suas aulas, em um primeiro momento, apresenta características de um viés construtivista pela idéia de partir do conhecimento prévio do aluno, por exemplo, quando afirma: "Primeiro, vou querer saber se eles já conhecem. [...] Sempre fazer deles antes, [...]. Quero sempre saber deles o que eles já sabem” (A2). No entanto, a justificativa em que ela apresenta para essa necessidade permite se conjecturar sobre a finalidade dessa estratégia, uma vez que, sua preocupação parece se centrar no aspecto de não repetir atividades conhecidas pelos alunos, como no seguinte depoimento: "De repente vou lá, olha o que eu trouxe para vocês, se eles já conhecem, aí cai minha cara." Tal afirmação não reflete uma intenção de tratar o conhecimento prévio como ponto de partida do ensino, apenas evidencia uma constatação, ou seja, é o mote para a proposição de atividades.

Um outro elemento a destacar é o viés lúdico em que A2 sistematiza as aulas de Matemática, conforme sublinhado no depoimento anterior. Pois, ela parte da idéia de que o aluno aprende brincando, isto é, enquanto brinca ele desenvolveria novas noções da estrutura conceitual sobre a composição da unidade e dezena. Então, o aluno não aprenderia pela repetição de procedimentos e sim pela construção de conceitos organizados a partir da interação do aluno com o ambiente e com seus pares. Tal interação é reforçada, também, no intento de que os alunos usem o material dourado para a realização de cálculos. Nesse sentido, o material didático parece se constituir, para A2, em uma ferramenta que auxiliaria os alunos e, também, tornaria o conceito menos abstrato, ou seja, real, concreto. Logo, a aprendizagem se daria por meio da visualização e construção do conceito. Esse procedimento não deixa de ser uma maneira de estabelecer vínculos entre o conceito e a sua aplicação em uma realidade 
conhecida. Vale ressaltar que nos questionários 1 e 2, este sujeito apresentou propostas para ensinar as noções de fração e divisão com o mesmo fio condutor, seja ele: atividades lúdicas e o manuseio, pelo aluno, de materiais didáticos, conforme o seguinte registro: "distribuiria aos alunos massa de modelar para que cada um modele a fruta que mais gosta. Depois, pediria para dividi-la em 4 partes iguais e, então separar uma delas. Assim, explicaria que essa ação significa que eles acabaram de separar $1 / 4$ da fruta.”(A2, Q1). Por outro lado, ao desenvolver a primeira aula de Matemática no estágio, A2 sente não ter atingido seus objetivos, conforme ela relata na cena 2 .

Cena 5 - Desequilíbrio conceitual lacunar: falta de conhecimento pedagógico em relação aos alunos

A aula de A2 começou exatamente do modo como ela planejou, isto é, com a investigação sobre o conhecimento dos alunos em relação ao material dourado. Com a constatação de que a "ferramenta" já era conhecida pelos alunos, ela partiu para o uso da mesma, isto é, propôs aos alunos que seguissem suas orientações e representassem com o material dourado vários números a fim de evitar que os mesmos ficassem brincando, montando carrinhos e casinhas com as peças do material didático. Esta tarefa acabou se constituindo em uma preparação dos alunos para o desenvolvimento do jogo Nunca Dez, o qual foi realizado na sequiência. No jogo, A2 lançava dois dados, os alunos calculavam, mentalmente ou contando nos dedos, a soma das quantidades sorteadas e, então, a professora estagiária entregava aos alunos a quantidade de cubinhos e/ou barrinhas (unidades e/ou dezenas) relativa a cada jogada. A2 fazia o registro da representação numérica relativa à quantidade sorteada no quadro de giz e com o material dourado, enquanto os alunos copiavam os procedimentos. Ela adotou essa estratégia em quase todas as tarefas.

Deste modo, apesar de A2 organizar o ensino sob uma ótica mais lúdica, a maneira como ela desenvolveu a aula retratou uma outra perspectiva do ensino, isto é, a professora estagiária apresentava o conteúdo e demonstrava os procedimentos que o aluno deveria seguir para resolver as situações do jogo e os exercícios propostos durante a aula. Enquanto isso, a aprendizagem ocorreria por meio da memorização de imagens e procedimentos ditados pelo docente. Durante o intervalo entre a primeira e a segunda parte da aula, no momento em que os alunos lanchavam. A2 afirmou achar que seria mais fácil trabalhar com o material dourado, uma vez que estava sentindo dificuldades de trabalhar esse material com os alunos. No transcorrer da aula, outras dificuldades foram surgindo, como, o desconhecimento de A2 em 
relação ao que os alunos conheciam sobre certas noções matemáticas ${ }^{34}$ abordadas nas tarefas. Tal contexto gerou o seguinte depoimento.

P - Antes de começarmos a conversar e já pegando o gancho com as suas reflexões, por escrito, de sua aula, quero voltar em uma coisa que você me disse quando terminou sua primeira aula de Matemática. Você me disse ao final da aula: minha aula não foi produtiva. E eu fiquei com isso na cabeça, não produtiva, não foi produtiva. Em que sentido para você não foi produtiva?

A2 - Eu considero aula produtiva quando consigo atingir os objetivos.

$\mathrm{P}$ - Certo, que no caso seriam os objetivos propostos em seu plano?

A2 - Isso, que era de conseguir trabalhar com o material dourado e que eles fizessem a soma, adição e subtração. E, eu não consegui isso. Até estava comentando agora há pouco com a professora PP que a maior dificuldade que acabou acontecendo é de eu não conhecer o nível de conhecimento deles. Não só por falta de conhecimento da turma, mas por falta de conhecimento pedagógico mesmo! Eu não tinha noção que aquele nível que eu estava levando para eles de exercício era muito além do nível deles de primeira série. Eu levei para a minha irmã ver e ela disse que pareciam exercícios de quarta série. Então, um nível muito elevado. Eu achando que aquilo era simples e não era tão simples. Eles precisam de algo mais simples. Quando a professora pediu exercícios simples, na minha cabeça estava levando exercícios simples. Mas, não eram simples.

$\mathrm{P}$ - Simples que você diz que seriam enunciados curtos?

A2 - Isso.

P - Com ações diretas: escreva o número que você obteve com o material dourado.

A2 - É. Para começar não faria cinco rodadas do jogo. Acho que só faria duas rodadas. Assim, só dariam duas somas. Foram quatro somas. Com quatro elementos. Eles ainda não sabem soma com quatro elementos. Com três elementos que coloquei na avaliação [A2 pega a folha com o exercício]. Veja lá com três elementos, já é mais complicado para ele fazer, porque vai acabar dando a sobra.

$P$ - Essa sobra [referindo-se à operação com reserva] dá até com duas parcelas. Inclusive temos que olhar essas atividades que você me mandou. Estava observando exatamente essa questão e tem algumas ali que vão dar a sobra igual. Vai dar a sobra mesmo só tendo as duas parcelas. Então, temos que analisar para ver se mantém do mesmo jeito que está ou se adota aquela estratégia que você usou de fazer a contagem do todo [estratégia desenvolvida durante a aula do estágio]. Então, temos que ver qual é o procedimento que você quer adotar.

A2 - Eu senti assim: eu tive que reestruturar toda a aula durante a aula mesmo. Eu senti que não estava, que não estava saindo do jeito que eu tinha imaginado. Sabe quando você vê que o negócio está escapando, aí eu pensei: mas, não foi isso que eu imaginei! [...] Eu estava falando para a professora PP, eu me considerei satisfeita nas outras aulas porque atingi os objetivos, consegui fazer no tempo previsto, eles tiveram facilidade para compreender. Não precisei explicar, explicar, explicar, aquele desgaste que tenta, que remodela, que não deu certo nessa explicação, que tem que explicar de outro

\footnotetext{
${ }^{34}$ As noções matemáticas desconhecidas pelos alunos que mais chamaram atenção, tanto de A2 quanto desta pesquisadora foram: o sinal da adição, o algoritmo da adição com reserva e seu cálculo efetuado na posição vertical e a noção de números ordinais.
} 
jeito. Essas pedrinhas no caminho não tive nas outras aulas. Foram questões tranqüilas, não digo fáceis, mas que em uma explicação eles compreenderam (RE-AU5, 00:00 a 08:43, 11/out/2005).

Mais adiante, quando A2 e a professora de Metodologia analisavam os resultados obtidos com uma das tarefas propostas após a execução do jogo Nunca Dez, seja ela, o preenchimento de uma tabela com os dados sobre o jogo, este sujeito volta a explicar os motivos de sua frustração com a aula desenvolvida.

P - Você observou como é que essas crianças fazem a leitura da tabela? Por que nesses seus exercícios ... "Qual a soma de pontos entre o grupo 2 e o grupo 3 na quarta rodada?"

A2 - É a leitura da tabela. Essa era a minha intenção também. Mas, eu achei que ia ser fácil, mas não foi. Na minha cabeça eu achava que tudo era fácil, mas na cabeça deles não foi.

P - É uma questão simples. Mas, ela requer que o aluno pare e identifique onde está o grupo 2, onde está o grupo 3 e a quarta rodada.

A2 - Exatamente. Até porque a minha intenção não era deixar eles fazerem isso sozinhos. Era fazer junto mesmo. Eu imaginei que eles iam ter dificuldade para ler a tabela. Então, por isso eu queria fazer junto com eles. Mas, eu acho que não precisava ter colocado tanto, porque isso cansou a cabeça deles também. Eles estavam só no automático ali, copiando o que eu estava pondo, eles não estavam nem acompanhando o raciocínio. Eu queria fazer para eles acompanharem o raciocínio da leitura. Mas eles não acompanharam porque ficou muito pesado para eles. Eles já estavam cansados do jogo, estavam cansados. Então, eu já diminuíria ali. Aqui, esse espaço do total, isso fiz em casa, porque eu não deixei um espaço para eles colocarem o total. É coisa simples também, foi resolvido a tempo ali, foi jogo de cintura na hora. As somas na vertical e na horizontal, isso é falta de conhecimento pedagógico dentro da Matemática. Nem me passou pela cabeça que eles fazem primeiro um em cima do outro para depois fazer a expressão. Isso aqui era, é minha leitura, é comum para mim. Então, eu não lembrei que para eles o início é diferente. Eles começam com um em cima do outro.

P - Eles começaram com o algoritmo para daí passar para a expressão. Eu vi a professora deles te pedindo para passar para essa sistemática. Inclusive a identificação dos símbolos, eles não sabiam qual era o sinal da adição e da subtração.

A2 - Pois é, isso para mim é uma coisa que eles já deveriam saber. Acho que eu teria que ter assistido uma aula de Matemática para ter essa noção. E, até tendo essa noção, antes de iniciar isso aqui eu ia rever com eles os sinais, rever essas coisas antes. Igual o primeiro, segundo, quarto, eles não sabem essa leitura também. Eu percebi, eles liam quatro, não liam quarto. Aí um lá que sabia gritava é quarto, é segundo. Mas eles não sabiam disso. Eu contaria com eles na tabela ou teria escrito por extenso, a palavra quarto, terceiro.

P - Você falou uma coisa agora muito importante: ter assistido antes uma aula de Matemática na escola, talvez te desse muito mais embasamento desse conhecimento pedagógico que você fala.

A2 - Exatamente, eu fui crua. [...] Mas é ..., o que eu assim ... Sou de personalidade, eu me cobro muito. Quando eu vou fazer uma coisa quero que ela saia direitinho. Não quero que ela tenha falhas e se tem 
falhas fico me auto-analisando o tempo inteiro. Então, por que eu não considerei produtiva também? Porque eu faço isso em várias aulas, não só o estágio, fora de sala, aqui, em outras experiências. Eu sempre procuro saber do aluno o que ele sabe daquilo para depois ... Até na faculdade, aqui: como você montaria tal aula? Primeiro saberia dele, o que ele sabe. Aquela história da explosão de idéias, primeiro saber deles o que eles já sabem daquele assunto. Tem até uma das aulas que vou fazer isso, uma das aulas que planejei, não sei se é de história ou de geografia. Explosão de idéias, é saber o que eles já sabem, para que eu não fique falando coisa de mais ou de menos achando que eles já sabem. E eu vim achando que eles já sabiam. Então, o que eu fiquei me cobrando também foi isso, por que eu não fui saber deles o que eles já sabiam? Eu perguntei: conhecem o material dourado? Já. Mas, eles conhecem. Só. Deveria ter perguntado: como é que usa? Alguém pode vir aqui na frente me mostrar como é que usa esse material? O que quer dizer, o que isso significa? Não, eles simplesmente disseram sim e eu acreditei (REAU5, 14:23 a 18:24, 11/out/2005).

Antes mesmo de A2 terminar a aula de Matemática, já mostrou se sentir insatisfeita com os resultados que estava obtendo. A reflexão que ela desenvolveu foi registrada em um texto, o qual compôs seu relatório de estágio entregue ao final do semestre letivo e, também, serviu de base para a conversa desenvolvida entre este sujeito e a professora de Metodologia de Ensino. Para A2 essa situação foi gerada devido a certos fatores, tais como: necessidade de explicar mais de uma vez um procedimento e/ou conceito; falta de noção sobre o conhecimento prévio dos alunos em relação ao conteúdo e proposição de tarefas inadequadas ao nível das crianças. Ela denominou esses elementos de conhecimento pedagógico. A falta deste conhecimento se constituiu em um desequilíbrio lacunar, ou seja, pela perspectiva de A2, a perturbação conceitual em relação ao ensino e aprendizagem da Matemática foi desencadeada pela falta de conhecimento pedagógico em relação aos alunos da 1. a série.

A partir do momento em que esse sujeito tomou consciência do quadro vivenciado, começou a buscar motivos que contribuíram para a geração da insatisfação, entre os quais cita a questão de não ter observado nenhuma aula de Matemática antes das suas. Possivelmente, se isso tivesse ocorrido, teria evitado que ela elaborasse tarefas inadequadas ao nível de conhecimento do aluno, como também, permitisse que fossem percebidos quais conteúdos matemáticos eram de domínio das crianças. Outro aspecto explicitado por ela, foi a questão de ter que explicar um conceito mais de uma vez e de modos diferentes. Como isso não havia ocorrido nas aulas anteriores (Língua Portuguesa e Ciências), provavelmente, ela não tivesse se preparado para uma situação como essa, assim, gerando certa instabilidade na condução da aula. Deste modo, guiada por tais constatações, A2 começa a apontar alternativas para o que havia feito em sala de aula, culminando, então, com a necessidade de re-elaborar a sequiência 
dessa aula. Na cena 6 , observa-se que A2 consegue alcançar os objetivos propostos na nova versão de aula.

Cena 6 - A acomodação: mudança de estratégia de ensino e objetivos atingidos.

Na re-elaboração do plano de aula, A2 centrou o olhar na adequação das tarefas em relação ao que já conhecia dos alunos e, também, considerou o aspecto de como desenvolver essa nova proposta por ter percebido que sua prática pedagógica girava em torno de pressupostos de um ensino tradicional, isto é, o professor explica o conteúdo que foi acumulado ao longo dos anos, enquanto os alunos repetem os procedimentos ditados pelo docente. Deste modo, A2 re-elaborou sua segunda aula de Matemática considerando certos fatores, como: permitir que os alunos participassem com suas próprias formas de pensar ao invés de ela pensar pelos discentes na resolução dos exercícios; propor atividades adequadas ao nível de conhecimento matemático que os alunos apresentaram na primeira aula e frisar o objetivo do uso do material dourado. Tomando-se tais cuidados, A2 desenvolveu sua segunda aula de Matemática obtendo resultados considerados por ela satisfatórios, conforme seu depoimento.

$\mathrm{P}$ - O que você achou da sua segunda aula?

A2 - Essa eu fiquei mais satisfeita. Eu me senti com os objetivos alcançados. Porque eu consegui observar neles uma participação melhor. Eles conseguiram demonstrar o que compreenderam e o que não compreenderam. Isso tudo ficou muito nublado na primeira. Pois, não fui pontual em algumas coisas, não esclareci outras e aí ficou mais difícil para eles também. Então, nessa, já conhecendo a dificuldade da turma, já sabia por onde começar também. Já comecei explicando como seria a utilização do material dourado. Eu imaginava que eles iam pegar o material dourado e iam sair fazendo contas e não foi o que aconteceu. Na segunda eu já me preveni disso e fiz alguns combinados com eles antes: "é para montar joguinho? Não é. É para fazer o quê, mesmo? É para fazer contas, ajudar fazer contas."

P - Será que essa abordagem da utilização do material dourado já havia sido conversada com eles em outra situação?

A2 - Eu não sei. Se foi conversado faz muito tempo, porque não é uma coisa que eles usam no dia-a-dia deles.

$\mathrm{P}$ - É, porque parecia que eles até conheciam o material dourado. Mas, essa perspectiva do serve para quê, como usa o material dourado, me deu a impressão que não havia essa consciência na primeira aula.

A2 - Na primeira não. Eles até poderiam saber que era para fazer conta. Mas, era muito mais interessante montar pecinhas. Brincar com eles.

P - Eu tive essa impressão. Mas, quando você perguntou na segunda aula eles responderam imediatamente: fazer contas.

A2 - Eles até poderiam saber. Mas, talvez pensassem: "como não foi dito que é para fazer contas, então vamos brincar" (EF, 00:00 a 04:50, $18 / 10 / 2005)$. 
Mais adiante, A2 complementa a explicação do motivo de se sentir satisfeita com o desenvolvimento da segunda aula.

P - Você chegou a olhar as atividades dos alunos depois da aula? Qual é a sua avaliação?

A2 - Nossa, foi bem mais produtiva. Quase não tiveram dificuldades. Até durante a aula eles tiveram mais dificuldade com a leitura do enunciado e da tabela. Mas, para resolver depois que entendiam o enunciado era tranqüilo para fazer.

$\mathrm{P}$ - $\mathrm{E}$ a atividade em que eles tinham que criar, a da máquina?

A2 - Eu gostei muito. Principalmente porque eles queriam fazer bem difícil para o amigo. Aí, eles colocaram uns números bem altos. Até a professora $\mathrm{F}$ veio me falar que estavam colocando o número novecentos. Perguntei o que fazer e ela disse para deixar e ver o que aconteceria. Então eu deixei. Tive que ajudar alguns alunos. Mas, eles conseguiram resolver. O que mais eu gostei dessa foi assim, depois que eu guardei o material dourado, em todos os exercícios que eu passava eles vinham me pedir o material dourado. Aí que eu percebi que eles realmente entenderam para que servia o material dourado. Não na hora em que eu perguntei. Na hora em que perguntei era somente fixação do conceito, da utilidade do material dourado. Mas, eles começaram a pedir, o primeiro que veio pedir foi o L, que sentou bem na minha frente e tinha bastante dificuldade.

P - Eu percebi que foi um pedir, daí outro, e outro e de repente eles começaram a usar o material dourado espontaneamente para fazer os exercícios. O objetivo era a utilização do material dourado?

A2 - Isso, reforçar a utilização do material dourado, que era o da primeira aula também. Aliás, coloquei aqui [no plano] que era para utilizar o material dourado em todos os exercícios. Eu não iria guardar. Mas, uns começaram a guardar. Aí, deixei só para ver o que ia acontecer lá para frente, se iam pedir ou não iam precisar. Mas, no fim, eles pediram. Ali foi a minha realização. [risos]. Ai que bom! Não precisei nem cogitar a idéia (EF, 12:43 a 15:49, 18/10/2005).

Com a nova proposta de aula, A2 consegue atingir seus objetivos e isso se traduz em satisfação. Ela partiu do princípio que conhecia melhor os alunos no que se refere ao conteúdo matemático e adotou uma outra perspectiva de prática pedagógica, ou seja, suas atitudes e a abordagem comunicativa em sala de aula giraram em torno da intenção de permitir que os alunos expusessem seus modos de pensar e não repetissem os procedimentos da professora estagiária. Alguns fatores se constituíram como determinantes nessa nova perspectiva de prática pedagógica, tais como: o esclarecimento sobre o conhecimento prévio dos alunos, a conversa sobre o que iriam fazer antes das tarefas (os combinados), a proposição de atividades em que os alunos puderam ter iniciativa como solicitar o material dourado para resolver problemas matemáticos (caixa surpresa de problemas matemáticos) ${ }^{35}$ e autonomia sobre seus

\footnotetext{
35 A caixa surpresa de problemas matemáticos era uma tarefa que consistia de uma coleção de problemas matemáticos guardados em uma caixinha. Os alunos sorteavam aleatoriamente os problemas e os resolviam.
} 
pensamentos (construção da máquina de calcular) ${ }^{36}$. Percebeu-se, também, que o discurso de A2 foi mais dialógico e suas atitudes mais interativas que na primeira aula de Matemática. Deste modo, entende-se que ela se orientou por uma outra concepção de ensino e aprendizagem da revelada antes do evento crítico (cena 4). Pois, o fato de os alunos terem usado espontaneamente o material dourado foi um indicativo do novo entendimento que os mesmos desenvolveram sobre a finalidade desse material didático. Apesar de, aparentemente, o objetivo último representar uma perspectiva instrumental do material dourado, a idéia de aprendizagem pautada na visão de que os alunos busquem por si sós os meios e instrumentos que os auxiliem na resolução das questões matemáticas imprime uma imagem que valoriza a construção de conceitos. Sobre essa nova perspectiva de ensino e aprendizagem da Matemática, A2 concluiu sua entrevista com a seguinte afirmação.

A2 - Mas eu nunca imaginava que eu ia me encantar pela Matemática. Por
isso eu reforcei em todos os meus textos que tem que levar para o dia-
a-dia, que tem que tirar o terror. Porque eu acho que a Matemática é
uma coisa tão gostosa de aprender, só que ninguém consegue ver isso.
E, como é que eu vou fazer as crianças verem isso? Por isso a idéia do
jogo, a idéia do bolo, para deixar gostosa a aula e eles aprenderem
brincando e utilizar aquilo. Não é só para escrever no papel. Apesar
que eu usei muito em minhas aulas, ainda acho que está muito no
papel. Eu gostaria de ter usado outros métodos, menos contas. Apesar
de ter sido construtivo. Mas, eu gosto de trabalhar mais na vivência.
Tinha a necessidade do papel, tinha a necessidade do registro, até
porque a avaliação exige um registro escrito (EF, 05:07,
18/10/2005)

Nesse último relato, A2 torna evidente que ela acredita que o ensino da Matemática deve ser desenvolvido por um viés lúdico e relacionado com o dia-a-dia, seja essa relação por meio das brincadeiras ou do manuseio de materiais didáticos. Essa maneira de conduzir o ensino contribuiria para que as pessoas deixassem de temer essa ciência, uma vez que o contato com o conhecimento matemático se daria de modo prazeroso e útil. A aprendizagem seria conseqüência da vivência dos alunos com tais procedimentos, isto é, a partir da interação com o ambiente e com os pares.

Com o exposto nas cenas 4, 5 e 6 do episódio 2, tem-se um panorama geral do movimento conceitual que A2 revelou ao longo do período em que desenvolveu seu estágio em docência. Assim, representa-se no quadro 10 a configuração desse movimento conceitual percebido em A2 em relação ao ensino e à aprendizagem da Matemática.

\footnotetext{
${ }^{36}$ A máquina de calcular era uma tarefa na qual os alunos teriam que desenhar uma máquina que apresentava números e sinais de adição e/ou subtração em uma certa seqüência e o resultado era calculado por outro aluno.

${ }^{37}$ Esclarece-se que essa parte da entrevista se refere à segunda parte da gravação, por isso o tempo indicativo é de 05:07.
} 
QUADRO 10 MAPEAMENTO DAS ZONAS DO PERFIL CONCEITUAL DE ENSINO E APRENDIZAGEM DE MATEMÁTICA DE A2

\begin{tabular}{|c|c|c|c|c|}
\hline \multirow[t]{2}{*}{ CENAS } & \multicolumn{4}{|c|}{ ASPECTOS CONCEPÇÃO DE ENSINO E APRENDIZAGEM DE MATEMÁTICA } \\
\hline & $\begin{array}{l}\text { F. PROF. } \\
\end{array}$ & COMO ENSINA & CARC. ALUNO & COMO APREN. \\
\hline CENA 4 & $\begin{array}{l}25 \text { conhecimento } \\
\text { vinculado ao mundo } \\
\text { sensível a partir do } \\
\text { material dourado. (E) } \\
28 \text { disponibilizar } \\
\text { material didático para } \\
\text { aluno usar quando sente } \\
\text { necessidade. (E) }\end{array}$ & $\begin{array}{l}16 \text { material didático } \\
\text { como mote para } \\
\text { exemplificar a téc. } \\
\text { operatória. (MM) } \\
23 \text { aluno manuseia } \\
\text { o material dourado. } \\
\text { (E) } \\
29 \text { precisa saber } \\
\text { antes o que os } \\
\text { alunos já sabem. } \\
\text { (E) }\end{array}$ & $\begin{array}{lr}45 \text { usa o } & \text { material } \\
\text { dourado } & \text { na } \\
\text { resolução } & \text { das } \\
\text { atividades. (C) } \\
46 \text { interage com o } \\
\text { material dourado e } \\
\text { jogos. (NC) }\end{array}$ & $\begin{array}{l}37 \text { do concreto } \\
\text { para o abstrato. } \\
\text { (NC) } \\
41 \text { contato visual } \\
\text { e tátil com o } \\
\text { concreto/real. } \\
\text { (NC) } \\
44 \text { construindo } \\
\text { conceitos. }(\mathbf{N C )}\end{array}$ \\
\hline CENA 5 & $\begin{array}{l}15 \text { fonte de } \\
\text { informações. (R) } \\
19 \text { instrutor. (MM) } \\
25 \text { conhecimento } \\
\text { vinculado ao mundo } \\
\text { sensível a partir do } \\
\text { material dourado. (E) }\end{array}$ & $\begin{array}{l}21 \text { exercícios para } \\
\text { memorizar relação } \\
\text { unidade/dezena } \\
\text { mediante } \\
\text { incentivos (jogo) } \\
\text { (MM) } \\
22 \text { professor usa } \\
\text { material dourado e } \\
\text { jogo Nunca } 10 . \\
\text { (MM) } \\
23 \text { aluno visualiza } \\
\text { o material dourado. } \\
\text { (E) } \\
29 \text { constatar o que } \\
\text { os alunos já sabem. } \\
\text { (E) }\end{array}$ & $\begin{array}{l}42 \text { realiza as tarefas } \\
\text { propostas pelo } \\
\text { professor mediante } \\
\text { incentivos } \\
\text { modelos. (C) }\end{array}$ & $\begin{array}{l}35 \text { visualizando o } \\
\text { professor } \\
\text { manuseando o } \\
\text { material didático. } \\
\text { (C) } \\
36 \text { memorizando } \\
\text { e repetindo o que } \\
\text { o professor. fez } \\
\text { com o material } \\
\text { didático. }(\mathbf{T})\end{array}$ \\
\hline CENA 6 & $\begin{array}{l}25 \text { conhecimento } \\
\text { vinculado ao mundo } \\
\text { sensível a partir do } \\
\text { material dourado e do } \\
\text { jogo. (E) } \\
26 \text { mediador e diálogo. } \\
\text { (E) } \\
28 \text { propõe atividades } \\
\text { que valorizam atitudes } \\
\text { de iniciativa. (E) }\end{array}$ & $\begin{array}{l}23 \text { aluno manuseia } \\
\text { o material dourado. } \\
\text { (E) } \\
29 \text { parte do } \\
\text { conhecimento do } \\
\text { aluno. (E) } \\
30 \text { preocupação em } \\
\text { adequar tarefas } \\
\text { com o } \\
\text { conhecimento } \\
\text { prévio aluno. (E) } \\
33 \text { estabelece } \\
\text { combinados. (E) }\end{array}$ & $\begin{array}{l}39 \text { desenvolve modo } \\
\text { próprio de pensar. } \\
\text { (NC) } \\
40 \text { expõe suas idéias } \\
\text { aos colegas de sala. } \\
\text { (NC) } \\
42 \text { realiza tarefas } \\
\text { propostas pelo } \\
\text { professor. (C) } \\
43 \text { participação. } \\
\text { (NC) } \\
45 \text { usa o material } \\
\text { didático } \\
\text { espontaneamente. } \\
\text { (NC) }\end{array}$ & $\begin{array}{l}41 \text { utilizando o } \\
\text { material didático. } \\
\text { (NC) } \\
44 \text { construindo } \\
\text { relações entre o } \\
\text { conhecimento } \\
\text { prévio e as novas } \\
\text { idéias. (NC) }\end{array}$ \\
\hline
\end{tabular}

\begin{tabular}{|c|c|c|}
\hline Legenda: & R - Reprodução MM - Matemática Moderna & E - Elaboração \\
\hline & $\mathrm{T}-$ Tradicional $\mathrm{C}-$ Comportamental & NC - Nova Cultura \\
\hline
\end{tabular}

Fonte: dados organizados pela autora 
Pelo quadro 10, percebe-se que o movimento conceitual de A2 ocorre em virtude do desenvolvimento da prática pedagógica em si. Pois, enquanto ela estava somente planejando a prática, o saber a ser ensinado, sua intenção de ensino e aprendizagem reveladas na cena 4 apresentavam, prioritariamente, aspectos das zonas de Elaboração e da Nova Cultura, respectivamente. Embora, ela também tivesse revelado idéias correspondentes à zona Matemática Moderna do perfil conceitual de Ensino em relação ao aspecto "como ensina", uma vez que A2 deixa transparecer que o conhecimento prévio dos alunos servirá de mote para exemplificar o conceito e propor atividades (16), e ainda, nessa mesma categoria, observa-se a coexistência da zona Matemática Moderna com Elaboração, isto é, este sujeito também considera que ao ensinar matemática o aluno precisa ter um contato visual ou táctil do conceito a partir dos materiais didáticos (23), ou seja, manipulando o material dourado durante o jogo Nunca Dez e na resolução dos exercícios. Já, em relação à função do professor, A2 evidencia a intenção de ensinar o conhecimento matemático vinculando-o ao mundo sensível (25) a partir da utilização de materiais didáticos e, também, revela valorizar estratégias de ensino que permita a interação entre os alunos e a construção de conceitos (28) como o jogo Nunca Dez. Tais aspectos são próprios da zona Elaboração do perfil de ensino da Matemática. Sobre o perfil de aprendizagem, observa-se a coexistência de zonas conceituais no aspecto relacionado às "características do aluno", visto que A2 evidencia entender que um indício da aprendizagem está no fato de o aluno aplicar, utilizar o conceito matemático aprendido (45), característica relativa à zona Comportamental e, também, na idéia de que a ação interativa com o meio e com as tarefas levam ao aprendizado (46), característica própria da zona Nova Cultura. Já, a categoria "como se aprende" apresentou aspectos relacionados somente à zona Nova Cultura. Percebe-se que o vínculo com o mundo real por meio dos materiais didáticos determinam o modo como A2 tenta expressar uma visão de ensino e aprendizagem da Matemática mais prazerosa. Mais uma vez, aspectos subjetivos influenciam as conexões entre as concepções e a prática pedagógica.

Observa-se na cena 5 que, a partir do momento em que esse planejamento foi colocado em prática, o saber ensinado segundo Chevallard (1991), a concepção de ensino e aprendizagem priorizada em sala de aula também esteve pautada em princípios de mais de uma zona conceitual, como a Repetição, a Matemática Moderna e a Elaboração no perfil de ensino e a Comportamental e a Tradicional no perfil de aprendizagem. Contudo, tal coexistência de zonas conceituais implicam em certo distanciamento entre os perfis de ensino e aprendizagem apresentados na cena 1, visto que A2 evidencia entender que o professor é a 
principal fonte de informações (15) - zona Repetição do perfil de ensino - e deve exercer o papel de instrutor (19) - zona Matemática Moderna - ou seja, informa aos alunos os procedimentos a serem seguidos por meio de demonstrações do modo de manuseio do material dourado (21-22-23). Assim, percebe-se que alguns aspectos relativos à cena 4 permaneceram e outros (25-23-29) e outros novos surgiram. A coexistência de zonas conceituais continuou ocorrendo no perfil de aprendizagem, entretanto os aspectos evidenciados na cena 5 não são os mesmos da cena anterior, ou seja, a visão de aprendizagem que A2 revelou durante sua prática pedagógica é diferente daquela registrada em plano de aula, isto é, relacionada a aspectos das zonas Tradicional e Comportamental. Ela deixou de evidenciar aspectos da zona Nova Cultura. Essa diferença entre a concepção teórica e a evidenciada na prática pedagógica foi o que fez suscitar na perturbação conceitual, resultando desta maneira, na re-elaboração da aula, focando-se principalmente a ação docente em virtude da aprendizagem do aluno.

Portanto, a cena 6 evidencia a concepção de ensino e aprendizagem praticadas durante a última aula de Matemática no estágio e que representam um modo de pensar que se traduz em satisfação para A2, uma vez que houve harmonia entre a intenção de ensinoaprendizagem e a prática pedagógica pré-profissional e, além dessa harmonia, percebe-se certa ampliação das idéias do sujeito em relação ao ensinar e aprender Matemática, uma vez que A2 procura agir como mediadora entre o conhecimento e o aluno (26) ao invés de apenas repassar informações ou fazer demonstrações de procedimentos. Um outro aspecto está atrelado ao conhecimento prévio do aluno, o qual esteve presente durante todo o período, porém deixou de ser visto como mote para a exemplificação do conceito e passou a ser entendido como o ponto de partida para o estudo dos novos conceitos (29), como referência para a proposição de tarefas (30) e para a elaboração de relações entre as idéias já conhecidas e as novas idéias (44) e, ainda, valorizando-se o modo próprio de pensar do aluno (39), isto é, A2 deixou de demonstrar os procedimentos que o aluno deveria seguir para resolver as tarefas propostas por ela. Entende-se que a superação da frustração vivenciada na cena 5 e a mediação da professora de Metodologia de Ensino de Matemática tenham sido fatores que contribuíram com a configuração desse perfil, nas palavras de A2:

Por dois motivos: um porque eu estava mais tranqüila e outro porque você [a professora de Metodologia de Ensino] me deu um toque naquela conversa sobre a primeira aula. Então, eu ficava prestando atenção, sempre que eu ia com a mãozinha... opa! [gesticula escondendo a mão] [risos] e até... às vezes o que você fala, porque fala já dando a entender o que é para ser feito ao invés de você instigar ele [o aluno] a pensar nisso por si mesmo. (EF, 18:05, 18/10/2005) 
Assim, entende-se que na cena 6 , as concepções que A2 revelou, localizadas na zona Elaboração do perfil conceitual de Ensino e na zona Nova Cultura do perfil conceitual de Aprendizagem representam uma evolução desse sujeito em relação à sua aprendizagem da docência.

\subsubsection{Movimento Conceitual de A3}

Do mesmo modo como foi feito para A1 e A2, também, para A3 se elaborou um mapa das atividades desenvolvidas ao longo do período investigativo, no qual se apresenta o contexto global de onde foram extraídos os episódios que constituem a análise dos perfis conceituais desse sujeito.

\section{QUADRO 11 MAPA DE ATIVIDADES DESENVOLVIDAS COM A3}

\begin{tabular}{|c|c|c|c|}
\hline PERÍODO & ATIVIDADES & PRINCIPAIS TEMAS & EPISÓDIOS \\
\hline $1 .^{\circ} \mathrm{Sem} / 2005$ & $\begin{array}{l}\text { Aulas de Metodologia do Ensino } \\
\text { de Matemática. }\end{array}$ & $\begin{array}{l}\text { Resgate das concepções } \\
\text { informais e confronto } \\
\text { das mesmas com novos } \\
\text { conceitos. }\end{array}$ & $\begin{array}{l}\text { Concepções em relação } \\
\text { Matemática. } \\
\text { Iniciais e Finais. } \\
\text { Q1 e Q2 }\end{array}$ \\
\hline $\begin{array}{l}23 / 09 / 2005 \\
33 \mathrm{~min}\end{array}$ & $\begin{array}{l}\text { Reunião de A3 com a professora } \\
\text { de Metodologia de Ensino de } \\
\text { Matemática. }\end{array}$ & $\begin{array}{lr}\text { Orientação } & \text { para } \\
\text { elaboração dos } & \text { planos } \\
\text { de aula. } & \end{array}$ & $\begin{array}{l}\text { Concepções pessoais em } \\
\text { relação ao ensino-aprendizagem } \\
\text { Dinâmica pretendida da aula. } \\
\text { OP 05:21 a } 12: 33\end{array}$ \\
\hline $\begin{array}{l}17 / 11 / 2005 \\
3 \mathrm{~h}\end{array}$ & $\begin{array}{l}\text { Desenvolvimento da segunda } \\
\text { aula no estágio com observação } \\
\text { direta. }\end{array}$ & $\begin{array}{l}\text { Conteúdo da aula: } \\
\text { elaboração e leitura de } \\
\text { tabela e gráfico de } \\
\text { barras. Aula em sala e } \\
\text { no laboratório de } \\
\text { informática. A3 tem } \\
\text { atitudes distintas em } \\
\text { cada ambiente. }\end{array}$ & \\
\hline $\begin{array}{l}29 / 11 / 2005 \\
54 \mathrm{~min}\end{array}$ & $\begin{array}{l}\text { Reunião de A3 com a professora } \\
\text { de Metodologia de Ensino de } \\
\text { Matemática. }\end{array}$ & $\begin{array}{l}\text { Reflexão sobre os } \\
\text { resultados da aula e } \\
\text { entrevista final. }\end{array}$ & $\begin{array}{l}\text { Evento crítico em relação ao } \\
\text { ensino-aprendizagem. } \\
\text { Frustração. } \\
\text { EF 00:40 a 04:59 } \\
\text { Nova dinâmica da aula. } \\
\text { EF 08:39 a 11:59 } \\
\text { Construção ou memorização. } \\
\text { EF 34:00 a 36:32 } \\
\text { Experiência profissional. } \\
\text { EF 38:37 a perturbação } \\
\text { Inexistência da } \\
\text { conceitual em relação a } \\
\text { Matemática. } \\
\text { EF 29:28 a 33:30 }\end{array}$ \\
\hline
\end{tabular}

Fonte: dados organizados pela autora

Seguindo a mesma linha de organização adotada em relação aos episódios de A1 e A2, na seqüência, apresenta-se a estrutura dos episódios de A3 a partir das cenas selecionadas 
de cada reunião. Vale esclarecer que, tais cenas revelam elementos significativos desse sujeito sobre suas concepções de Matemática, de ensino e aprendizagem dessa ciência.

Episódio 1 - Concepções de A3 em relação à Matemática.

Cena 1 - Concepções pessoais sobre o que é a Matemática.

Cena 2 - Concepções finais sobre o que é a Matemática.

Cena 3 - Inexistência da perturbação conceitual.

Episódio 2 - Concepções de A3 em relação ao processo de ensino e aprendizagem de Matemática.

Cena 4 - Concepções pessoais sobre o ensinar e aprender Matemática.

Cena 5 - Perturbação conceitual: uso do quadro, conteúdo matemático, interferências externas e participação dos alunos.

Cena 6 - A busca pela acomodação: mudança de estratégia de ensino.

Sendo assim, apresenta-se na sequiência o episódio relativo às concepções sobre a Matemática.

- Episódio 1 - Concepções de A3 em relação à Matemática.

Cena 1 - Concepções pessoais sobre o que é a Matemática.

No questionário 1, A3 apresentou o primeiro registro escrito sobre suas concepções pessoais em relação ao que venha a ser a Matemática. Assim, ela escreveu o seguinte para cada questão.

\footnotetext{
Um leigo lhe pergunta "de onde vem a Matemática?" Como você explicaria essa questão?

Explicaria que a Matemática "surgiu" há muitos anos atrás quando a humanidade começou a utilizar diversos meios para contar e efetuar cálculos antes mesmo do surgimento "simbólico" dos números.

Se incluísse em sua explicação as principais características da Matemática, quais você acrescentaria?

Acrescentaria que a Matemática está em todos os lugares e que nós a utilizamos com mais freqüência do que imaginamos. Exemplo: formas geométricas nas construções, aritmética indo ao supermercado, shopping, etc. (Q1, 23/mar/2005).
}

A3 acredita, no início do processo investigativo, que a Matemática está assentada em uma perspectiva racionalista e formal do conhecimento matemático. Pois, ao se referir à Matemática não a nomeia como ciência e nem como disciplina, apenas ressalta a aritmética pelo viés da contagem, dos cálculos e do surgimento simbólico dos números, conforme sublinhado no registro da resposta de $\mathrm{A} 3$ no questionário 1 . O enfoque, dado por ela, de que a 
Matemática surgiu há muitos anos pode ser um indício do entendimento de que os entes matemáticos usados atualmente foram elaborados em um passado distante. Isto é, além de as pessoas de hoje receberem um conhecimento pronto, também, não participaram da construção do mesmo. Por outro lado, A3 considera que a Matemática é útil para a vida das pessoas, mesmo que elas não saibam que a estão utilizando e, também, que a origem da Matemática está na utilidade dessa ciência em virtude das atividades da humanidade. Portanto, entende-se que a concepção de A3 em relação à origem e finalidade da Matemática está atrelada ao mundo sensível. Ao final do semestre letivo, este sujeito apresentou uma outra perspectiva conceitual de Matemática, conforme observado na cena 2.

Cena 2 - Concepções finais sobre o que é a Matemática

Após A3 ter participado das aulas da disciplina de Metodologia do Ensino da Matemática lhe foi proposto que respondesse a um outro questionário (Q2). Nesse novo registro, ela apresentou a seguinte idéia em relação à Matemática.

Você pode contar em seu livro que este ano você aprendeu que a Matemática surgiu há milhares de anos atrás e que no início a Matemática não era assim como nós a conhecemos hoje. A Matemática foi sendo aprimorada na medida em que os povos começaram a sentir a necessidade de que isto fosse feito a fim de simplificar e facilitar suas vidas. Exemplo: surgimento dos algarismos romanos, etc. (Q2, 22/06/2005).

Ela revelou, no questionário 2, perceber que o conhecimento matemático não é absolutamente único. Pois, afirmou que a Matemática conhecida hoje não é a mesma da que surgiu há milhares de anos, uma vez que foi evoluindo ao longo do tempo. Um outro aspecto destacado por A3, antes de iniciar suas aulas no estágio, é que o conhecimento matemático é aprimorado a partir da percepção do mundo sensorial, isto é, a produção da Matemática e sua evolução se davam em virtude das necessidades das vidas dos povos. Por outro lado, quando $\mathrm{A} 3$ revê suas respostas no Q1 não emitiu nenhum comentário em relação às mesmas, ou seja, ela não propôs outra resposta e nem complementou o que havia escrito sobre a Matemática, somente apresentando comentários sobre as propostas de ensino. Assim, pressupõe-se que ela ainda mantinha a idéia de uma Matemática mais racional e absoluta, contudo, também compreendia que esse conhecimento não se manteve da mesma maneira como foi "criado". Nessa segunda resposta, tem-se a impressão que A3 tentou imprimir uma imagem de movimento ao conhecimento matemático em relação à idéia de uma ciência estática, conforme a seguinte passagem: "A Matemática foi sendo aprimorada na medida em que [...]." Deste modo, considerando o conjunto dos aspectos apresentados por A3 nesse questionário se 
entende que sua concepção sobre a Matemática se encontrava em uma fase instável (LUFFIEGO, 2001), cuja interação entre os conhecimentos (antigos e novos) ainda não havia sido percebido por A3. Na entrevista final este sujeito revê os registros realizados nos questionários, conforme a ser observado na cena 3.

\section{Cena 3 - Inexistência da perturbação conceitual}

Ao final de todo o processo investigativo, ou seja, depois de A3 ter concluído a disciplina de Metodologia do Ensino de Matemática (1. ${ }^{\circ}$ semestre letivo) e terminado as aulas de Matemática no estágio pela disciplina de Prática Pedagógica (2. ${ }^{\circ}$ semestre letivo), ela reviu suas respostas fornecidas nos questionários e apresentou as seguintes idéias.

A3 - [ela faz a leitura dos questionários] Nossa, eu ia confundir muito a cabeça da criança. Ele ia perguntar para mim se $2+2$ não ia ser 4 ? [risos]. Eu não sei porque escrevi isso: "a Matemática não era assim como nós a conhecemos hoje."

$\mathrm{P}$ - Acho que tem relação com o que você escreveu na re-elaboração das propostas de ensino do Q1. Veja, você diz que procuraria se fundamentar na Etnomatemática. Lembro que quando esse assunto foi estudado [na Metodologia de Ensino] se conversou sobre a possibilidade de considerar mais de um viés de percepção da Matemática.

A3 - Acho que era assim, o homem das cavernas não tinha o número dois assim [ela escreve o símbolo numérico dois - 2], e demorou muitos anos para chegar nesse conceito que é conhecido mundialmente, que o dois é dois. Mas, agora falando da complexidade, como é que você vai falar para a criança que o dois não era dois, mas que, já significava que era dois? Para ela entender até o som, entender a palavra dois. Eu tenho uma irmã de dois anos em casa, ela sabe o que significa dois, eu achei o máximo! Você pergunta: "quantos tem aqui?" [ela mostra dois dedos]. Ela diz: "dois.” E, tem crianças da 3. ${ }^{\text {a }}$ série com dificuldade de aprendizagem lá na escola que não conseguem identificar que tudo isso aqui [mostra um punhado de canetas] significa uma quantidade, um número. Até elas entenderem, compreenderem, assimilarem tudo aquilo, aí vem outro grande problema: o símbolo do número, a escrita, a alfabetização matemática. É bem complexo (EF, 29:28 a 33:30, 29/nov/2005).

Ao rever as respostas nos questionários, A3 afirma: "Eu não sei por que escrevi isso", referindo-se a uma das idéias registradas no Q2. Mais adiante, durante a entrevista final, ela revela que quando respondeu o Q1 não sabia o que responder porque ainda estava muito no início do ano letivo. Então, pressupõe-se que o trabalho desenvolvido na Metodologia de Ensino da Matemática com esse sujeito não lhe possibilitou ampliar, conscientemente, suas estruturas cognitivas em relação à Matemática, uma vez que A3 não pareceu ter se sentido 
insatisfeita com suas idéias iniciais, apesar de ter apresentado outras noções no questionário 2. Contudo, após as aulas no estágio, ela explica que está entendendo o aprimoramento da Matemática, idéia registrada no Q2, pelo viés da notação matemática, mais especificamente, em relação às transformações que a simbologia numérica passou ao longo do desenvolvimento da humanidade. Logo, entende-se que A3 está concebendo que o conhecimento matemático não é absoluto e único porque pode ser modificado.

Por outro lado, ainda em relação ao mesmo depoimento, A3 também revela perceber que o conhecimento matemático é conhecido mundialmente, isto é, a Matemática desenvolvida e praticada por diferentes povos e em vários lugares do planeta é a mesma e não recebe influências de caráter sócio- cultural e político em sua organização. Ela ainda ressalta o aspecto da complexidade do conhecimento, isso pode se traduzir no entendimento de que a Matemática não está acessível a todos. Tal entendimento pode ser verdadeiro, principalmente, se o contexto considerado por A3 for a sala de aula, isto é, a Matemática vista como um conhecimento a ser ensinado, conforme ela exemplifica ao relacionar com alunos da escola onde trabalha. Deste modo, entende-se que A3 não apresentou evoluções conceituais em seu perfil sobre a Matemática, visto que ela não revelou ter tomado consciência das diferentese percepções conceituais. Ao final do ano letivo, A3 ainda não havia entrado em um processo de análise sobre sua própria estrutura conceitual em relação à Matemática. Frente ao exposto, na seqüência se apresenta o movimento conceitual, deste sujeito, em relação à Matemática.

\section{QUADRO 12 MAPEAMENTO DAS ZONAS DO PERFIL CONCEITUAL DE MATEMÁTICA DE A3}

\begin{tabular}{|l|l|l|l|}
\hline \multirow{2}{*}{ CENAS } & \multicolumn{3}{|c|}{ ASPECTOS DA CONCEPÇÃO DE MATEMÁTICA } \\
\cline { 2 - 4 } & \multicolumn{1}{|c|}{ ORIGEM } & \multicolumn{1}{c|}{ FINALIDADE } \\
\hline CENA 1 & $\begin{array}{l}10 \text { está em todo } \\
\text { lugar. (AE) }\end{array}$ & $\begin{array}{l}\text { CARACTERÍSTICAS } \\
\text { supermerio: construções e }\end{array}$ & $\begin{array}{l}\text { 1 para cálculos. (AE) } \\
3 \text { surgimento simbólico do número. } \\
\text { (AE) } \\
4 \text { ciência pronta. (AE) }\end{array}$ \\
\hline CENA 2 & $\begin{array}{l}10 \text { necessidades } \\
\text { da vida. (AE) }\end{array}$ & $\begin{array}{l}7 \text { utilitário: facilitar a vida. } \\
\text { (D) }\end{array}$ & $\begin{array}{l}12 \text { conhecimento foi sendo aprimorado. } \\
\text { (D) }\end{array}$ \\
\hline CENA 3 & Não comentado. & Não comentado. & $\begin{array}{l}\text { 3 linguagem formal e universal. (AE) } \\
12 \text { aprimoramento da linguagem } \\
\text { matemática. (D) }\end{array}$ \\
\hline
\end{tabular}

Legenda: $\quad$ AE - Abstrata Empirista $\quad$ D - Dinâmica

Fonte: dados organizados pela autora 
$\mathrm{O}$ quadro 12 sintetiza o movimento conceitual de A3 em relação à Matemática. $\mathrm{Na}$ cena 1, pelo fato de A3 conceber que a Matemática tem sua origem no mundo sensível (10), e também, por possuir características de um conhecimento assentado na percepção absolutista, formal e lógica (1-3-4) é que se entende que sua concepção sobre a Matemática, no início do ano letivo, se caracteriza pela zona Abstrata Empirista. É pelo mesmo viés da percepção do mundo sensível que A3 entende que a finalidade da Matemática está relacionada às atividades sócio-culturais da humanidade (7), representando então, um único indício da visão Dinâmica da Matemática.

$\mathrm{Na}$ cena 2, os aspectos percebidos parecem ter se direcionado mais para a visão Dinâmica, principalmente pelo fato de A3 revelar que o conhecimento matemático evolui, é aprimorado (12). Mas, ainda assim, considera-se que sua visão também está assentada na zona Abstrata Empirista pelo fato de continuar concebendo que a origem do conhecimento matemático está vinculado ao mundo sensível e de ela não ter apresentado nenhuma justificativa para o que tinha revelado na cena 1. Portanto, entende-se que as características apresentadas anteriormente ainda eram aceitas e as novas complementaram aquela visão antiga. Porém, quando o ano letivo termina, na cena 3, entendeu-se que a evolução citada na cena anterior estava limitada às mudanças na notação da linguagem matemática e não na ciência como um todo. Compreende-se que essa situação não implica em uma ampliação da estrutura cognitiva desse sujeito em relação à sua concepção sobre a Matemática e, também, que não representa uma evolução, já que A3 não apresentou indícios de tomada de consciência sobre tais visões. Deste modo, percebe-se que a concepção de A3 em relação à Matemática apresenta uma coexistência de zonas conceituais, principalmente sobre o aspecto relacionado às características gerais dessa ciência.

- Episódio 2 - Concepções de A3 em relação ao processo de ensino e aprendizagem de Matemática.

Cena 4 - Concepções pessoais sobre o ensinar e aprender Matemática.

A3 elaborou apenas um plano de aula de Matemática para ser desenvolvido com os alunos de uma turma da EJA. Ela apresentou uma proposta para trabalhar em todas as suas aulas no laboratório de informática da escola, pois era o tipo de atividade que desenvolvia em sua rotina profissional. A professora de Prática Pedagógica considerou a proposta interessante, apesar da necessidade de revisar os planos de aula em virtude do modo como os 
mesmos haviam sido estruturados, isto é, sem articulação entre as diferentes áreas do saber e com atividades que privilegiavam apenas a repetição mecânica dos procedimentos apresentados pelo professor. A3 revelou ter sentido muita dificuldade para elaborar seus planos e, em virtude disso, não estabeleceu nenhuma relação entre os mesmos. Na concepção de A3, para ensinar Matemática é preciso relacionar com o cotidiano, principalmente em se tratando de alunos da Educação de Jovens e Adultos e desenvolver estratégias que lhes permitam visualizar o conteúdo, conforme pode ser observado a seguir em sua explicação de como pretendia desenvolver a aula sobre gráficos.

A3 - O que quero fazer com eles, em sala, é fazer a tabela e o trabalho com régua para eles entenderem que os eixos se encontram em tal lugar, tal ponto e que aquele é o referencial de tanto. Explicar bem direitinho e estar bem preparada porque estava morrendo de medo de $\underline{\text { dar aula. }}$ Porque assim eles entendem. Quando chegar no computador... acho que vai dar umas duas aulas, só disso.

$\mathrm{P}$ - Vai. Porque tem todo um procedimento específico. Quando for trabalhar com tabela e gráfico é importante lembrar dos elementos mínimos de uma tabela: título, como os dados são organizados, fonte e a mesma coisa para o gráfico. Você já pensou quais gráficos serão construídos com os alunos?

A3 - Então, aqui [no plano], não sei onde coloquei. Mas, pensei em apresentar, mostrar aos alunos alguns tipos de gráficos. Têm vários tipos de gráficos. Mas, para uma primeira aula vamos trabalhar com um que é mais fácil para a visualização deles.

$\mathrm{P}$ - O que você espera que seus alunos aprendam?

A3 - Realmente, espero que tenham uma noção, que consigam olhar para esse gráfico simples, sem comparação, sem nada e consigam dizer que tantas pessoas tiveram contato e tantas não. Consigam analisar. Igual criança, primeiro leitura do gráfico e depois consigam identificar os elementos principais.

P - Você tem que pensar que é uma alfabetização, apesar de serem adultos e possuírem certa vivência, tem que pensar que é uma alfabetização. Mesmo porque você está trazendo como uma linguagem matemática.

A3 - Linguagem matemática. Eles estão habituados só com número e conta. Vi na aula de geografia em observação, eles têm problema em interpretar coisas. Eles lêem o problema e não entra na cabeça deles, bem abstrato. $\underline{O}$ gráfico é abstrato, mas ao mesmo tempo pode ser trabalhado com o elemento concreto, eles podem visualizar e fica bem mais fácil para eles. Acho que terei facilidade, tenho que me preparar bem.

P - Como você pensou em começar o conteúdo com eles?

A3 - Em sala, conversando com eles, fazendo o levantamento de dados.

P - Quem vai fazer esse levantamento, quem vai anotar esses dados?

A3 - Eu, na sala, no quadro. Utilizar o quadro e ir explicando no quadro, acho que vou levar uma reportagem de alguma revista, mostrar. Perguntar se alguém entende. Como eles são adultos já tem toda uma experiência e não dá para ir chegando. Como não tenho experiência, nunca dei aula de primeira a quarta série. Com criança só trabalho com informática e no laboratório. Está sendo uma experiência ótima. Com criança em sala de aula só trabalhei na educação infantil, então eu não ... 
P - Uma idéia, justamente por se tratar de adultos e existir toda uma vivência, seria partir da vivência deles. Poderia levar para a sala de aula vários exemplos de gráficos.

A3 - Pensei em uma idéia bem legal, seria levar gráficos de eleições, de candidatos, de porcentagem, de pesquisa.

P - Essa semana saiu na Gazeta uma pesquisa sobre os possíveis candidatos à presidência. Aceitação. Tem uma porção de gráficos. Meu filho estava olhando e gritou: "mãe quanto gráfico tem aqui!" Você tem acesso a esse jornal? [A3 sinaliza com a cabeça que não] Vou guardálo para você. [P e A3 combinam horário para que a professora possa repassar o material citado]. Poderia-se começar com os gráficos dessa reportagem, perguntando-se: se eles já viram? Se sabem o que é? Se alguém pode ir no quadro e desenhar o que viu? Para ter uma idéia do que eles pensam. Para você começar a ter uma idéia. Puxar dos alunos a vivência que eles têm. Fazer com que essa sua conversa não parta do teu ponto de vista, mas do ponto de vista do aluno. Você entedeu?

A3 - Entendi. Fazer eles levarem a aula.

$\mathrm{P}$ - Fazer eles se envolverem na sua aula.

A3 - Não ficar aquela coisa que eu estou falando e eles anotando (OP, 05:21 a 12:33, 23/09/2005).

A3 estruturou uma dinâmica de aula em que o foco estaria em conversar com os alunos e mostrar a eles, no quadro, o conteúdo (os tipos de gráficos). Apesar da interação pretendida entre professora e alunos se observou que a atitude docente girava em torno da imagem de um professor instrutor, ou seja, daquele que repassa aos alunos o conhecimento pronto e acumulado.

Um outro elemento destacado por A3, em relação à aprendizagem, é que ela concebe como necessário que o aluno visualize o conceito para aprender. Nesse sentido, é preciso estruturar um ensino mediado por elementos que concretizem o conteúdo estudado, por exemplo, os materiais didáticos. Para essa aula, A3 considerou o gráfico presente em textos da mídia escrita (reportagens de jornais ou revistas) como um material concreto. Pois, os alunos teriam condições de ver os dados organizados por meio de uma outra linguagem matemática o gráfico. Entende-se que a visualização do conceito, propiciada desta maneira, contribui para a memorização do mesmo ao invés de possibilitar ao aluno re-organizar sua estrutura cognitiva. Essa perspectiva de ensino e aprendizagem também esteve presente nas propostas registradas por A3 nos questionários, ou seja, ela privilegiou o uso de materiais didáticos como meio de apresentar o conteúdo matemático, conforme o registro sobre a proposta de ensino da divisão, realizado no questionário 1: “Pegaria palitos de sorvete, cada aluno com um número igual e pediria que eles distribuíssem os palitos igualmente nos retângulos desenhados na carteira. Exemplo: cada aluno com 10 palitos e 2 retângulos desenhados na carteira" (A3, Q1). 
Na explicação da dinâmica pretendida para a aula de Matemática no estágio, observa-se que a fala de A3 é permeada por aspectos presentes no entorno da aula propriamente dita, por exemplo, o medo de dar aula, sentir dificuldade em elaborar o plano, revelar a necessidade de se preparar bem e a preocupação com os alunos da EJA por serem adultos e já possuírem uma história de vida. Tais aspectos podem ser decorrentes de um conhecimento superficial em relação ao conteúdo matemático, à convivência com crianças pelo exercício profissional e/ou referências limitadas em relação à Educação de Jovens e Adultos. Esses aspectos acabaram se constituindo nos motivos dos obstáculos ocorridos no desenvolvimento desta aula, conforme ilustrado na cena 5.

Cena 5 - Perturbação conceitual: uso do quadro, conteúdo matemático, interferências externas e participação dos alunos.

A3 iniciou sua aula informando aos alunos que a mesma seria desenvolvida em dois momentos: o primeiro em sala e o segundo no laboratório de informática. Em sala, após explicar o cronograma da aula, ela começou a passar um texto no quadro e solicitou aos alunos que o copiassem em seus cadernos. Esse texto era referente aos resultados de uma pesquisa sobre o referendo da proibição do comércio de armas no Brasil, desenvolvida pelo IBOPE em 2005. Após a cópia do texto, A3 desenhou uma tabela no quadro, a qual foi preenchida enquanto ela explicava o conteúdo e destacava as informações necessárias. A professora regente da turma ia complementando as explicações de A3 durante o desenvolvimento da aula. Depois que a professora estagiária explicou a tabela, voltou a passar o conteúdo no quadro, nesse momento, os tipos de gráficos (colunas, barras e setores). Após, retomou as explicações desenhando cada um dos gráficos a partir dos mesmos dados contidos na tabela. Nessa primeira parte da aula, a participação dos alunos foi limitada em copiar a matéria e resolver um exercício no quadro a partir de orientações fornecidas por A3.

A segunda parte da aula aconteceu no laboratório de informática. Nesse ambiente, os alunos construíram o mesmo gráfico elaborado no exercício em sala de aula. Cada aluno se sentou em frente a um computador e, enquanto A3 circulava entre as fileiras de mesas, passava as orientações sobre como os alunos deveriam proceder para realizarem a referida tarefa. Observou-se que, no laboratório, o comportamento de A3 foi diferente do apresentado em sala de aula, na qual ela esteve o tempo todo na frente do quadro, segurando suas folhinhas relativas ao plano de aula e falando muito baixo. No laboratório, ela circulava entre 
os alunos, falava alto e não consultou seu plano de aula em nenhum momento. A conseqüência dessa aula foi a seguinte.

A3 - Achei que minha aula foi um fiasco. Porque não sei lidar com o quadro, não tenho noção de espaço, não tenho metodologia alguma para usar o quadro, nunca usei, estava nervosa, para mim era um conteúdo meio pesado e ainda na primeira vez que ia usar o quadro. $\underline{A}$ professora da turma ficava interferindo, me atrapalhou muito, muito, apesar de eu gostar muito dela. Quando fui para lá ela me ajudou e em algumas horas ela ficou tentando ajudar e eu perdia o que estava falando. Eu sou uma pessoa que tem dificuldade em criar vínculo. Tem pessoa que tem facilidade em chegar e apresentar uma aula. Eu não. O que é meu, é meu. Então, não consigo ... Até com o meu trabalho, por exemplo a $\mathrm{G}$ ela tem uma rotina de cada dia estar em uma escola. Eu não me adaptaria, preciso dessa rotina para criar vínculo para poder me soltar e daí meu trabalho deslanchar. Daí eu já estava pensando, será que eu posso fazer isso com os alunos? Aí, ela já se intrometia, eu me perdia, não sabia o que estava falando. Mas, apesar de tudo acho que foi legal.

$P$ - É, em um primeiro momento eu senti dificuldade em relação à professora. Pois, você estava falando e de repente ela interrompia, mudava o assunto, chamava aluno, olhava e comentava. Pensei que era muita interferência para uma mesma aula. Por outro lado, senti uma diferença muito grande em você, quando fomos para o laboratório. Você se transformou, não era a mesma A3. Ali você não estava nem na frente do computador, nem via a tela, transitava pelo laboratório, ia de um lado para o outro. E, na sala, você estava presa ao quadro, na frente com suas folhinhas nas mãos e falava baixo. A sua voz foi a primeira coisa que me chamou atenção, porque lá no laboratório sua voz era alta, firme, segura. Na sala de aula era frágil, devagar. Era outra pessoa, mudou completamente.

A3 - Eu deveria estar muito mais concentrada porque trabalho com isso o dia interinho, orientando as crianças e fico correndo entre os computadores. Porque, quando as professoras tem alguém para ajudar elas não fazem nada. Você não fica para ajudar, fica para fazer. Então, elas sabem, mas chamam "oh, aqui está dando um probleminha". Então, você tem que sair correndo para ver o que está acontecendo, com 18 computadores, com a média de 3 crianças em cada um, fora o barulho. Então, a minha voz acaba se alterando, além que estou com segurança no que estou falando.

$\mathrm{P}-\mathrm{E}$, a segurança pode ter sido um dos fatores.

A3 - Falo de segurança porque algumas vezes já entrei em sala de aula, não para dar aula. Mas, como trabalho com projetos ... Então, vejo com as professoras para ver se tem alguma idéia ou, realmente, algumas professoras não tem domínio da turma. Então, por eu ser uma professora extra-classe e eles gostam de se divertir, então, se acalmam comigo na sala. Então, elas acabam me chamando para eu falar com eles, e eu me sinto à vontade. Agora, para explicar aquela matéria, meu Deus, eu não ... [...] Mas, eu acho assim, teve alguns que não pegaram nada da idéia que eu quis passar ali. Porque eu via no caderno deles, eles não ... Não sei se eu não soube desenhar direito. Explicar desenhando. Não tenho esse costume de desenhar e ir mostrando. Então, não tinha nada no caderno deles (EF, 00:40 a 4:59, 29/nov/2005). 
Apesar de A3 ter tomado como ponto de partida para o ensino da Matemática uma reportagem retratando uma situação do cotidiano relativa ao conteúdo a ser ensinado, nota-se que tal recurso serviu apenas de mote para o desenvolvimento das explicações desenvolvidas durante a aula. A3 desenvolveu uma aula em que passou o conteúdo, apresentou exemplos, fez um exercício juntamente com os alunos para que eles pudessem ver a técnica de construção de um gráfico e, então, propôs a construção de outros gráficos a partir do manuseio de computadores.

Embora A3 tenha organizado sua aula com um recurso considerado inovador para o ensino da Matemática - o computador -, o modo como ela fez a mediação entre o desenvolvimento do conteúdo e os alunos propiciou somente que houvesse memorização de conceitos (imagens de cada tipo de gráfico) e de procedimentos (a técnica de construção de um gráfico no caderno e no computador). Tais características são condizentes com a visão de aprendizagem em que se destina para o aluno um papel de passividade. Pois, A3 propiciou aos alunos que repetissem a mesma modalidade de exercício várias vezes, cuja meta era a memorização das informações e procedimentos. Essa maneira de conduzir o ensino e a aprendizagem da Matemática causou em A3 certa insatisfação, inicialmente, a perturbação foi gerada pelos seguintes fatores: falta de noção de uso do quadro de giz, interferência da professora regente e insegurança em relação ao conteúdo matemático específico. Para concluir, a perturbação conceitual se confirmou com a constatação de que os alunos não haviam registrado nada em seus cadernos. Pressupõe-se que a falta de participação dos alunos, representou para $\mathrm{A} 3$, a confirmação de que o ensino proposto por ela não permitiu que os alunos aprendessem. Portanto, resultando em um sentimento de frustração e desapontamento, conforme sua afirmação: "Achei que minha aula foi um fiasco." A aula desenvolvida por A3 não foi interativa e nem dialógica, ou seja, somente a professora estagiária é quem falava. $\mathrm{O}$ ponto de vista dos alunos não foi considerado na apresentação do conteúdo.

A3 não teve oportunidade de desenvolver a prática pedagógica dentro de uma outra perspectiva, uma vez que lhe foi possibilitado o desenvolvimento de somente uma aula de Matemática no estágio. Vale esclarecer que essa aula foi desenvolvida durante três dias, já que os alunos da turma em que A3 estagiou, levaram mais tempo que o previsto para resolver os exercícios no computador. Deste modo, a acomodação conceitual em relação ao ensino e à aprendizagem se manteve apenas como uma intenção desse sujeito, conforme pode ser observado na cena 6 . 
Cena 6 - A busca pela acomodação: mudança de estratégia de ensino.

Após a constatação de A3 que sua aula não havia atingido suas expectativas e com a impossibilidade de desenvolver uma outra aula se optou em refletir sobre o que ela poderia ter feito de diferente. Nesse sentido, A3 fez o seguinte depoimento.

$\mathrm{P}$ - O que você faria de diferente na sua aula?

A3 - Bastante coisa. Iria trabalhar mais aulas sobre esse assunto. Pois, eu acho que foi muito rápido. Aliás, eu iria trabalhar só isso. Trabalharia o texto, partir do texto para construir o gráfico, depois eu vi: "Ah! Meu Deus, porque não pensei nisso antes?" Porque eu joguei muito as coisas para eles. Então, leria o texto, grifaria as partes importantes do texto, as quais poderiam ajudar a construir o gráfico. Eu fui jogando as coisas. Mas, eu pensei nisso porque a professora tinha me falado que eles já tinham visto uma aula de gráficos. Só que tinham 3 ou 4 que não tinham tido essa aula de gráfico. Então, ela liberou para eu dar essa aula de gráfico. Então, eu fui assim, de um ponto e eu me embananei! Porque eu acho que não adequei a minha linguagem ao nível que eles estavam.

P - Talvez você tivesse que ter tido mais aulas de Matemática. Uma primeira para sentir, conhecer o que os alunos já sabem e, pelo menos outras duas, para trabalhar o assunto.

A3 - Hum, hum! Acho que sim, porque só na observação é muito ruim. Como eu fui na segunda-feira era muita correção. Ela [a professora regente] passava muita lição. $\mathrm{Na}$ segunda-feira, até a hora do intervalo ela ficava só corrigindo as continhas e os probleminhas que ela tinha passado. Então, eu não acabava percebendo qual era o nível dos alunos. Então, ficou uma dificuldade. Acho que o estágio não deveria ser em uma segunda-feira. Segunda-feira acabada sendo assim para todo mundo, um dia de correção, retomada. Então, foi assim, eu só vi eles corrigindo continhas, alguns probleminhas e teve uma aula de leitura de texto. Fora os problemas que tinham de não ter aula. Então, meu calendário ficou atrasado, minha ficha de freqüência está toda errada, vou ter que fazer outra. Mas, assim ... eu acho, com certeza iria fazer assim, ia pegar uma aula, pedir para fazer com mais tempo, não o dia cheio. Por mais que depois do intervalo foi para o computador, cansa, eu canso. Quando a aula era no computador eles iam para lá das sete e meia até as dez e eles não queriam ir embora. Se não fechasse, eles ficavam lá.

P - Mas era porque eles estavam se sentindo motivados, estavam aprendendo a mexer no computador.

A3 - É, então eu jogaria para mais aulas, talvez dez aulas quebradas.

$\mathrm{P}$ - Talvez menos conteúdos?

A3 - É, eu trabalharia assim: só os gráficos. Mas faria assim, parceladinho: a parte de teoria usando a sala, menos tempo. O laboratório poderia usar o dia inteiro, porque só duas horas lá não me resolve. Demora eles chegarem a entender o princípio. Nessa última aula que eu tive foi toda usando aquela mesma tabela para fazer os três gráficos no computador. Eu não quis que, eu me preocupei que eles vissem o trabalho como era desenvolvido. Então, cheguei lá, tivemos quatro aulas para fazer o três gráficos. Não dá tempo. Acabava de fazer um, eles já não lembravam mais como iniciava. Então, foi bem corrido, muito puxado para eles. Mas, aí eu fiquei meio sem saber o que fazer 
e preferi fazer para eles verem, pelo menos repetir seguidamente para ver se eles gravavam alguma coisa. Uns gravaram, outros não, nem com dez aulas conseguiriam gravar. Às vezes, um ano, talvez conseguissem aprender. Porque pessoas mais velhas aprendem com certa dificuldade, um pouco mais devagar.

$\mathrm{P}$ - Talvez essa dificuldade tenha aparecido porque o laboratório é o único acesso, dos alunos, ao computador.

A3 - Mas, eu ia trabalhar o texto, em uma aula, para eles entenderem que a tabela e o gráfico são, realmente, uma forma de leitura do que está escrito lá. Que, às vezes, eles não precisam ler uma reportagem de página inteira. Porque, se baterem o olho lá saberão sobre o que a reportagem está falando. Então, essa é a idéia que eu queria passar lá e não consegui porque faltou tempo.

$\mathrm{P}$ - Acho que essa idéia eles compreenderam. Mas, a equivalência entre os três tipos de gráficos não.

A3 - É, essa idéia não cheguei nem perto. Talvez alguns tenham conseguido perceber, mas a maioria não (EF, 08:39 a 11:59, 29/nov/2005).

Percebe-se que A3 tomou consciência de que poderia ter utilizado o recurso do texto jornalístico (reportagem sobre a pesquisa do IBOPE) de uma outra maneira da que ela fez, conforme sublinhado no depoimento anterior, ou seja, ao invés de apenas ter passado o texto e o conteúdo para os alunos copiarem, poderia te-lo trabalhado, explorando-o em virtude do conteúdo matemático. No entanto, nota-se que o modo como esse texto seria utilizado ainda está mais centrado nas atitudes do professor do que na interação com o aluno e deste com o texto. A3 revela, também, conceber a necessidade de conhecer o que os alunos sabem para adequar sua linguagem com a deles. Nesse sentido, pressupõe-se que ela está tomando o conhecimento prévio do aluno como o ponto de partida para o ensino a ser proposto. E, um outro elemento a destacar é a concepção de que memorização é sinônimo de aprendizagem, isto é, se aprende pela repetição seguida de procedimentos ditados pelo professor, conforme A3 afirma: "fazer para eles verem, pelo menos repetir seguidamente para ver se eles gravavam alguma coisa." Em um outro trecho da entrevista tal concepção de aprendizagem em relação à Matemática é complementada por A3.

A3 - Decoreba. Bem interessante isso. Tenho um conflito na minha cabeça. Eu aprendi a tabuada muito cedo. Decorei a tabuada. Aprendi a ler e escrever a tabuada do 3 e do 4 com 4 anos. Do dois não. Porque minha mãe era meio maluca, se você fosse na minha casa, tinha tabuada colada na casa inteira, na minha mamadeira tinha tabuada colada, eu ia mamando e vendo. A minha mãe tirava e ia tomando a tabuada de mim. Olha o crime! Mas, minha mãe conta que eu pedia isso. Não sei porque. E isso me ajudou muito. Até hoje eu sei. Se alguém me perguntar ... claro que me atrapalho um pouquinho porque hoje não uso tanto assim. Mas, eu sei. Eu fui ter a compreensão do processo de construção da tabuada, acho que já estava na $8 .^{\mathrm{a}}$ série, quando fui entender que eu não precisava saber quanto era seis vezes sete se eu sabia quanto era seis vezes oito, que eu podia chegar 
naquele resultado. E, até demorei muito para descobrir aquilo ali. Mas, quando descobri foi um achado na minha vida, um alívio. Porque, às vezes, dá branco e aí? Só que hoje eu vejo que se está trabalhando muito só a construção e não decorar. Decorar facilita. Porque, querendo ou não, a gente vive num mundo ainda que precisa saber, vai prestar vestibular, como?

P - Eu não diria nem só vestibular. Situações diárias ...

A3 - No mercado, vai comprar alguma coisinha e precisa.

P - Situações diárias, no mercado alguém compra 15 caixinhas de suco e vai passar no caixa. O funcionário passa de um por um, não poderia fazer vezes 15? Têm algumas situações no dia-a-dia, no trabalho, que necessitam de um cálculo mais rápido.

A3 - Isso facilita.

P - Facilita. Por que ocorre isso? Porque houve uma crítica muito grande com relação a questão da memorização na Matemática. Mas, aí, era só memorização.

A3 - Mas daí não sabia pensar também. Também não ajudava. Mas, ir para o outro extremo?

$P$ - Eu penso no equilíbrio entre a memorização e a construção.

A3 - Teve uma situação de uma menina. A mãe dela contou para nós que a professora dela pediu para ela docorar a tabuada do seis. Olha o que ela fez! Ela encheu de abelhinha, figurinha, purpurina, flor. Ela não sabia nem o significado, quais significados, quais interpretações do decorar. Eu tive que dar risada daquilo porque não tinha sentido, decore, enfeite, mas ...

$\mathrm{P}$ - Ah! Decorar no sentido de enfeitar! Agora entendi.

A3 - Sabe se perdeu tanto isso, que hoje não se sabe nem o que significa o termo (EF, 34:00 a 36:32, 29/nov/2005).

A3 deixa transparecer que sua concepção sobre a aprendizagem é permeada pelas próprias experiências de aprendizagem. Em um primeiro momento, a memorização da tabuada na infância, na seqüência, o benefício da construção, isto é, o descompromisso de ter que guardar certa informação se é possível aplicar outras estratégias que a levem ao mesmo conceito. E, apesar de ter prevalecido em sua aula a idéia de que se aprende pela memorização, A3 tem consciência que esse viés de aprendizagem não possibilita ao aluno desenvolver sua autonomia de pensamento, logo não amplia e nem aprofunda as estruturas cognitivas. Para ela é tão importante a construção do conceito quanto a memorização de procedimentos. A memorização de procedimentos e conceitos a partir de uma certa compreensão em relação ao conteúdo é uma das características esperadas para a aprendizagem da Matemática. Assim, entende-se que tal perspectiva se aproxima de uma tendência atual de aprendizagem em Matemática. Entretanto, mesmo A3 não tendo desenvolvido outra aula de Matemática, ela relata que a experiência do estágio a ajudou a rever sua prática profissional, conforme se observa a seguir.

A3 - Nossa, primeiro eu acho que é um crime fazer Metodologia em um só semestre. Porque é tanta coisa. Adorei ter que fazer aquele jogo, me 
empolguei. Mas, é tanta coisa. Dava para ter construído tanto mais, ter trocado de material. Se fosse um ano! Eu cresci muito, abriu. Eu achava que todo mundo ia saber quanto era tanto, que ia saber fazer tal coisa. Não é assim. Como nunca fui para a sala de aula eu vi isso. Claro, ainda falta muito para aprender. Eu falo para minha mãe que do jeito que penso sou meio tradicional, sou neo-tradicionalista, um termo novo. Foi nesse ano que eu disse para ela, eu falava tanto das professoras, mas eu pensava igual. Então, eu acho que me ajudou a me centrar. Estou trabalhando muito agora com a linguagem LOGO, vou ficar até o final de novembro só vendo aquela tartaruguinha. Então, para explicar ângulo para as crianças eu vi que sabia para mim. Mas, não sabia como explicar para eles. Então, comecei a ver o que posso fazer? Explicar um pouquinho diferente. Comecei a mudar, disso de trazer para a realidade deles fica melhor: "se você quer virar em uma rua", daí eles: "ah!" Daí eles entendiam. Eu falava para eles: "quando vocês vêem o desenho animado, que vai trocando a figura, lembram como era antigamente?" Eles começaram a assimilar bem mais do que aquele "é assim e assim." Isso porque eu aprendi Matemática desse jeito, tive bastante conteúdo. Então, eu achava que eles iam aprender assim também. Aí, comecei trazer um pouquinho mais para realidade deles. Eu aprendi a explicar para eles planejando e colocando para eles. Aí, eu via que não dava certo, retomava tudo. Pedi para a professora ensinar ângulo para eles na sala porque senão não daria conta. Aí, ela retomou, ensinou. Quando falei com eles no laboratório já tinham uma noção, foi melhor. Enquanto estava abstrato foi muito difícil. Quando eles puderam ver a tartaruguinha virando para o lado certo parece que caiu a ficha deles (EF, 39:37, 29/nov/2005).

Pelo relato sobre uma das atividades que A3 desenvolveu em sua atividade profissional, ela parece ter conseguido estabelecer conexões entre suas concepções sobre o ensinar e aprender Matemática com a prática pedagógica. A partir do momento que A3 compreendeu que estava desenvolvendo uma atitude que não correspondia ao que ela concebia de ensino e aprendizagem, buscou novos elementos que a possibilitassem atingir suas expectativas. Para tanto, A3 compreendeu que não bastava conhecer o conteúdo matemático, é preciso saber como transpô-lo para a sala de aula, conforme destaques no depoimento apresentado anteriormente. Nesse sentido, a relação com atividades pertinentes ao cotidiano das pessoas lhe pareceu a maneira adequada de possibilitar aos alunos visualizarem o conceito e, por conseqüência, aplicá-lo na situação proposta em sala de aula. Enfim, permitir que os alunos aprendam. Esse depoimento de A3 permite perceber que ela ampliou sua estrutura cognitiva em relação às concepções de ensino e aprendizagem a partir da tomada de consciência sobre o modo como desenvolvia a prática pedagógica em relação ao que concebia sobre o ensinar e aprender em Matemática. Frente ao exposto, o quadro 13 que se segue representa a configuração do movimento conceitual de $\mathrm{A} 3$ em relação ao ensino e à aprendizagem da Matemática. 
QUADRO 13 MAPEAMENTO DAS ZONAS DO PERFIL CONCEITUAL DE ENSINO E APRENDIZAGEM DE MATEMÁTICA DE A3

\begin{tabular}{|c|c|c|c|c|}
\hline \multirow[t]{2}{*}{ CENAS } & \multicolumn{4}{|c|}{ ASPECTOS CONCEPÇÃO DE ENSINO E APRENDIZAGEM DE MATEMÁTICA } \\
\hline & F. PROF. & COMO ENSINA & CARC. ALUNO & COMO APREN. \\
\hline CENA 4 & $\begin{array}{l}15 \text { fonte de } \\
\text { conhecimento. }(\mathbf{R}) \\
19 \text { instrutora. }(\mathbf{M M}) \\
25 \text { conceito está } \\
\text { vinculado ao mundo } \\
\text { sensível. }(\mathbf{E}) \\
26 \text { estabelece diálogo. } \\
(\mathbf{E}) \\
31 \text { estabelece relação } \\
\text { conceito com cotidiano. } \\
(\mathbf{E})\end{array}$ & $\begin{array}{l}22 \text { usa texto } \\
\text { jornalístico e } \\
\text { computador. (MM) } \\
23 \text { contato visual } \\
\text { pelo recurso } \\
\text { didático. (E) } \\
29 \text { consideração ao } \\
\text { conhecimento } \\
\text { prévio. (E) }\end{array}$ & $\begin{array}{l}42 \text { resolve } \\
\text { exercícios aplicando } \\
\text { o conceito. (C) } \\
45 \text { aplica o conceito } \\
\text { (NC) } \\
48 \text { aluno EJA } \\
\text { aprende de forma } \\
\text { diferente. (NC) }\end{array}$ & $\begin{array}{l}35 \text { memorizando } \\
\text { conceitos a partir } \\
\text { de estímulos. (C) } \\
37 \text { concreto para } \\
\text { o abstrato. (NC) }\end{array}$ \\
\hline CENA 5 & $\begin{array}{l}15 \text { fonte de } \\
\text { informações. }(\mathbf{R}) \\
17 \text { usa linguagem } \\
\text { universal, concisa e } \\
\text { abstrata. (MM) } \\
19 \text { instrutor. }(\mathbf{M M})\end{array}$ & $\begin{array}{l}16 \text { cotidiano é mote } \\
\text { para exemplificar o } \\
\text { conceito. (MM) } \\
20 \text { ensino livresco. } \\
(\mathbf{M M}) \\
22 \text { uso de } \\
\text { computador. (MM) }\end{array}$ & $\begin{array}{l}38 \text { deve copiar e } \\
\text { realizar as tarefas no } \\
\text { caderno. }(\mathbf{T}) \\
42 \text { aplica o conceito } \\
\text { nos exercícios. (C) }\end{array}$ & $\begin{array}{l}35 \text { visualizando a } \\
\text { explicação - } \\
\text { memorização. (C) } \\
36 \text { reproduz } \\
\text { raciocínios. }(\mathbf{T})\end{array}$ \\
\hline CENA 6 & $\begin{array}{l}15 \text { fonte } \\
\text { conhecimento. }(\mathbf{R}) \\
25 \text { conceito vem do } \\
\text { cotidiano. }(\mathbf{E})\end{array}$ & $\begin{array}{l}22 \text { uso do texto } \\
\text { jornalístico e de } \\
\text { computador. (MM) } \\
27 \text { partir do texto. } \\
\text { (E) } \\
29 \text { consideração ao } \\
\text { conhecimento } \\
\text { prévio. (E) } \\
30 \text { adequação de } \\
\text { linguagem entre } \\
\text { professor e alunos. } \\
\text { (E) }\end{array}$ & $\begin{array}{l}48 \text { aluno } \text { EJA } \\
\text { aprende de forma } \\
\text { diferente. (NC) }\end{array}$ & $\begin{array}{l}36 \text { reproduz } \\
\text { raciocínios } \\
\text { repetidamente. } \\
(\mathbf{T}) \\
44 \text { construindo } \\
\text { conceitos. (NC) } \\
49 \text { memoriza com } \\
\text { compreensão o } \\
\text { conceito. (NC) }\end{array}$ \\
\hline
\end{tabular}

\begin{tabular}{|c|c|c|}
\hline \multirow[t]{2}{*}{ Legenda: } & R - Reprodução MM - Matemática Moderna & E - Elaboração \\
\hline & $\mathrm{T}-$ Tradicional $\mathrm{C}$-Comportamental & NC - Nova Cultura \\
\hline
\end{tabular}

Fonte: dados organizados pela autora

O quadro 13 representa o movimento conceitual de $\mathrm{A} 3$ em relação à sua concepção de ensino e de aprendizagem em Matemática. Observa-se na cena 4 que, enquanto ela estava no nível da intenção, isto é, do saber a ser ensinado, sua concepção de ensino apresenta mais aspectos localizados na zona Elaboração, embora também se veja em menor incidência aspectos da zona Reprodução e da Matemática Maderna. Já, no perfil de aprendizagem há 
aspectos da zona Comportamental e da Nova Cultura. Nesse momento, ela revelou o entendimento de que é função do professor apresentar o conceito (15), o qual deve ser memorizado pelo aluno (35). Essa última percepção sobre o ensino e a aprendizagem em Matemática corresponde às zonas Matemática Moderna e Comportamental, respectivamente. Portanto, compreende-se que enquanto A3 estava apenas planejando sua aula de Matemática, ela apresentava uma concepção de ensino e aprendizagem com coexistência de zonas conceituais em todas as categorias, ou seja, em relação à função do professor se observa que, além da zona Reprodução pelo aspecto 15 este sujeito também evidenciou que o professor exerce o papel de instrutor (19) - zona Matemática Moderna - e ao mesmo tempo a de estabelecer diálogo em sala de aula (26) e relações entre o conceito matemático e o mundo real (31), características próprias da zona Elaboração. Em relação ao aspecto "como ensina" do perfil de ensino, A3 revela a intenção de usar um texto jornalístico em sua aula como meio de ilustrar o conceito de gráficos, ou seja, utilizar um material didático para que o aluno veja o conceito (22) apresentado por ela. Tal característica é própria da zona Matemática Moderna, uma vez que se constitui em uma estratégia que visa estimular o aluno a memorizar conceitos e procedimentos (35), assim configurando a zona Comportamental do perfil de aprendizagem no que se refere ao modo "como aprende" a Matemática. O uso do material didático implica, também, no entendimento de que A3 concebe que a aprendizagem se constitui em um movimento do concreto para o abstrato (37), caracterizando um aspecto da zona Nova Cultura relacionado ao "como aprende", pois o aluno partiria de algo real e já conhecido por ele, para então, fazer novas elaborações conceituais. Nesse sentido, A3 deixa transparecer o intuito de resgatar o conhecimento dos alunos para partir para a explicação do conteúdo (29), ou seja, ela revela conceber que o ensino de um novo conteúdo deve ser iniciado a partir do conhecimento prévio do aluno, desta maneira, constituindo-se em uma característica da zona Elaboração do perfil de ensino de Matemática. Assim, percebe-se que na primeira cena, os perfis conceituais de A3 apresentam uma configuração bastante variada em termos das zonas conceituais.

Na cena 5, configura-se a concepção do saber ensinado, o qual é caracterizado por aspectos pautados, principalmente, na zona Matemática Moderna do perfil conceitual de Ensino. Pois, o ensino que esse sujeito adotou em sua aula se baseou na ação de apresentar regras para serem seguidas mediante uma série de técnicas. $O$ perfil conceitual de aprendizagem se caracterizou, ainda, pela coexistência de zonas conceituais, sejam elas, a Tradicional e a Comportamental, pela idéia de incentivar a repetição seguida de certo procedimento para a elaboração dos gráficos até que o mesmo fosse memorizado. A diferença 
de configuração no perfil de ensino entre a pretensão e a prática pedagógica desenvolvida no estágio resultou em A3 certo desiquilíbrio conceitual, pois ela constatou diferenças entre seu planejamento e o modo como o colocou em prática em sala de aula. Assim, observa-se que características relativas às zonas Elaboração e Nova Cultura deixaram de permear as concepções de A3 durante o exercício da docência no estágio, sobressaindo-se aspectos próprios da zona Matemática Moderna do perfil de ensino, tais como: a apresentação de uma linguagem matemática concisa e precisa durante o desenvolvimento da aula (19) e o desenvolvimento de um ensino livresco, isto é, pautado na demonstração de definições, repasse de conteúdo e proposição de exercícios de aplicação (20). Em relação ao perfil de aprendizagem, destaca-se uma característica relativa à zona Tradicional, é a idéia de que o aluno deve copiar e realizar as tarefas, em outras palavras, durante o desenvolvimento de sua aula no estágio, A3 considerou como um indício de aprendizagem a situação na qual o aluno apresenta um desempenho correto, sem cometer erros na execução das tarefas (38), isto é, quando os alunos não copiaram o conteúdo e os exercícios passados na lousa em seus cadernos e, ainda, não conseguiam repetir os procedimentos para a elaboração dos gráficos no computador e fazendo com que ela tivesse que explicá-los várias vezes, supõe-se que tal situação para ela implicou em um desempenho incorreto em que os alunos cometiam erros na execução da terefa.

Na cena 6, observa-se que ela tenta retomar a visão de ensino e aprendizagem reveladas na cena 4 , isto é, suas concepções voltam a serem permeadas por aspectos relativos às zonas Elaboração e Nova Cultura dos perfis conceituais. Embora tal percepção seja advinda da reflexão sobre o ocorrido no desenvolvimento da aula no estágio e de algumas situações provenientes do exercício da atividade profissional, entende-se que essa visão representada nesta cena apontam indícios do caminho que A3 busca em virtude de uma equilibração de suas concepções. Portanto, entende-se que o fato de ela revelar ter constatado que poderia ter utilizado, em sua aula, o texto jornalístico de uma outra maneira, isto é, tornando-o o ponto de partida para o desenvolvimento de problematizações (27) e, ainda, de ter demonstrado preocupações com o uso da lousa e adequação da sua linguagem com a dos alunos (30), não implica em uma ampliação de seu espectro nocional de modo a permitr evoluções no perfil conceitual de ensino, mas a direção que ela está buscando. Essa percepção também se estende ao perfil conceitual de aprendizagem quando A3 evidencia, conscientemente, uma perturbação conceitual no que diz respeito à memorização e à construção de conceitos como modos de se aprender Matemática, cuja reflexão mediada pela professora de Metodologia de Ensino à leva concluir que o aluno aprende construindo relações entre as idéias matemáticas já conhecidas e as novas (44) e, também, 
memorizando procedimentos e conceitos a partir de certa compreensão em relação ao conteúdo específico (44), como é o caso exemplificado por A3 em relação à tabuada. Cabe lembrar que a cena 6 , para esse sujeito, refere-se à intenção de ensino elaborada após o evento crítico. Supõe-se que a coexistência de zonas poderia ter sido melhor definida se A3 tivesse oportunidade de ter desenvolvido outra aula com uma nova estrutura.

$\mathrm{Na}$ seqüência, apresentam-se as generalizações percebidas no panorama dos movimentos conceituais dos sujeitos pelas zonas dos perfis a partir dos episódios descritos anteriormente.

\subsection{PERCEPÇÕES A PARTIR DO ESTUDO DE CADA CASO}

Ao longo deste capítulo, narrou-se toda a trajetória que compôs parte da formação inicial para a docência de A1, A2 e A3 nas aulas de Matemática. O estudo de cada caso possibilitou um olhar em profundidade sobre os dados coletados, permitindo que a análise feita do contexto particular de cada sujeito, considerasse a percepção de que certas informações eram comuns a alguns indivíduos do grupo e o entendimento de certos aspectos sobre a aprendizagem da docência. Assim, no intuito de ilustrar uma síntese dos casos estudados, elaborou-se um panorama dos movimentos conceituais dos sujeitos, o qual está representado no quadro 14 que se segue.

\section{QUADRO 14 PANORAMA DA MOVIMENTAÇÃO CONCEITUAL DOS SUJEITOS}

\begin{tabular}{|c|c|c|c|c|c|}
\hline \multirow[t]{2}{*}{ SUJ } & \multicolumn{2}{|c|}{ PERFIS } & \multicolumn{3}{|c|}{ CENAS } \\
\hline & & ASPECTOS & CENA 1 e CENA 4 & CENA 2 e CENA 5 & CENA 3 e CENA 6 \\
\hline \multirow[t]{7}{*}{$\overline{\mathrm{A} 1}$} & \multirow[t]{3}{*}{ MATEM } & ORIGEM & Abstr. Racionalista & Abstr. Empirista & Não comentado \\
\hline & & FINALIDADE & Dinâmica & $\begin{array}{l}\text { Abstr. Empirista } \\
\text { Dinâmica }\end{array}$ & Dinâmica \\
\hline & & CARACTERÍS & Abstr. Racionalista & $\begin{array}{l}\text { Abstr. Racionalista } \\
\text { Dinâmica }\end{array}$ & $\begin{array}{l}\text { Abstr. Empirista } \\
\text { Dinâmica }\end{array}$ \\
\hline & \multirow[t]{2}{*}{ ENSINO } & $\begin{array}{l}\text { FUNÇÃO } \\
\text { PROFESSOR }\end{array}$ & $\begin{array}{l}\text { Reprodução } \\
\text { Elaboração }\end{array}$ & $\begin{array}{l}\text { Reprodução } \\
\text { Matem. Moderna } \\
\text { Elaboração }\end{array}$ & Elaboração \\
\hline & & $\begin{array}{l}\text { COMO } \\
\text { ENSINA }\end{array}$ & Elaboração & $\begin{array}{l}\text { Matem. Moderna } \\
\text { Elaboração }\end{array}$ & Elaboração \\
\hline & \multirow[t]{2}{*}{ APREND } & CAR. ALUNO & Nova Cultura & Nova Cultura & Nova Cultura \\
\hline & & $\begin{array}{l}\text { COMO } \\
\text { APRENDE }\end{array}$ & $\begin{array}{l}\text { Tradicional } \\
\text { Nova Cultura }\end{array}$ & $\begin{array}{l}\text { Tradicional } \\
\text { Comportamental }\end{array}$ & Nova Cultura \\
\hline \multirow[t]{3}{*}{ A2 } & \multirow[t]{3}{*}{ MATEM } & ORIGEM & Abstr. Racionalista & $\begin{array}{l}\text { Abstr. Racionalista } \\
\text { Dinâmica }\end{array}$ & Não comentado \\
\hline & & FINALIDADE & Abstr. Racionalista & Abstr. Racionalista & Não comentado \\
\hline & & CARACTERÍS & Abstr. Racionalista & $\begin{array}{l}\text { Abstr. Racionalista } \\
\text { Dinâmica }\end{array}$ & Dinâmica \\
\hline
\end{tabular}


conclusão

\begin{tabular}{|c|c|c|c|c|c|}
\hline \multirow[t]{2}{*}{ SUJ } & \multicolumn{2}{|c|}{ PERFIS } & \multicolumn{3}{|c|}{ CENAS } \\
\hline & \multicolumn{2}{|c|}{ ASPECTOS } & CENA 1 e CENA 4 & CENA 2 e CENA 5 & CENA 3 e CENA 6 \\
\hline & \multirow[t]{2}{*}{ ENSINO } & $\begin{array}{l}\text { FUNÇÃO } \\
\text { PROFESSOR }\end{array}$ & Elaboração & $\begin{array}{l}\text { Reprodução } \\
\text { Matem. Moderna } \\
\text { Elaboracão }\end{array}$ & Elaboração \\
\hline & & $\begin{array}{l}\text { COMO } \\
\text { ENSINA }\end{array}$ & $\begin{array}{l}\text { Matem. Moderna } \\
\text { Elaboração }\end{array}$ & $\begin{array}{l}\text { Matem. Moderna } \\
\text { Elaboração }\end{array}$ & Elaboração \\
\hline & \multirow[t]{2}{*}{ APREND } & CAR. ALUNO & $\begin{array}{l}\text { Comportamental } \\
\text { Nova Cultura }\end{array}$ & Comportamental & $\begin{array}{l}\text { Comportamental } \\
\text { Nova Cultura }\end{array}$ \\
\hline & & $\begin{array}{l}\text { COMO } \\
\text { APRENDE }\end{array}$ & Nova Cultura & $\begin{array}{l}\text { Tradicional } \\
\text { Comportamental }\end{array}$ & Nova Cultura \\
\hline \multirow[t]{7}{*}{ A3 } & \multirow[t]{3}{*}{ MATEM } & ORIGEM & Abstr. Empirista & Abstr. Empirista & Não comentado \\
\hline & & FINALIDADE & Dinâmica & Dinâmica & Não comentado \\
\hline & & CARACTERÍS & Abstr. Empirista & Dinâmica & $\begin{array}{l}\text { Abstr. Empirista } \\
\text { Dinâmica }\end{array}$ \\
\hline & \multirow[t]{2}{*}{ ENSINO } & $\begin{array}{l}\text { FUNÇÃO } \\
\text { PROFESSOR }\end{array}$ & $\begin{array}{l}\text { Reprodução } \\
\text { Matem. Moderna } \\
\text { Elaboração }\end{array}$ & $\begin{array}{l}\text { Reprodução } \\
\text { Matem. Moderna }\end{array}$ & $\begin{array}{l}\text { Reprodução } \\
\text { Elaboração }\end{array}$ \\
\hline & & $\begin{array}{l}\text { COMO } \\
\text { ENSINA }\end{array}$ & $\begin{array}{l}\text { Matem. Moderna } \\
\text { Elaboração }\end{array}$ & Matem. Moderna & $\begin{array}{l}\text { Matem. Moderna } \\
\text { Elaboração }\end{array}$ \\
\hline & \multirow[t]{2}{*}{ APREND } & CAR. ALUNO & $\begin{array}{l}\text { Comportamental } \\
\text { Nova Cultura }\end{array}$ & $\begin{array}{l}\text { Tradicional } \\
\text { Comportamental }\end{array}$ & Nova Cultura \\
\hline & & $\begin{array}{l}\text { COMO } \\
\text { APRENDE }\end{array}$ & $\begin{array}{l}\text { Comportamental } \\
\text { Nova Cultura }\end{array}$ & $\begin{array}{l}\text { Tradicional } \\
\text { Comportamental }\end{array}$ & $\begin{array}{l}\text { Tradicional } \\
\text { Nova Cultura }\end{array}$ \\
\hline
\end{tabular}

Legenda: caixas sombreadas indicam coexistência de zonas conceituais

CARACTERIS - Características

CAR ALUNO - Características do aluno

Fonte: dados organizados pela autora.

Pelo quadro 14 é possível fazer a leitura de cada perfil em relação ao indivíduo e também ao conjunto de sujeitos e, ainda, do movimento conceitual do sujeito em cada cena. Desta maneira, sobre o perfil de Matemática na cena 1, identificou-se que a visão dos sujeitos A1 e A2 era fundamentada principalmente na zona Abstrata Racionalista, enquanto A3 foi categorizada na Abstrata Empirista. Entende-se que essa configuração ocorreu pelo fato de que quando os sujeitos se referiram à Matemática como ciência, inicialmente, emergiram crenças pessoais como verdades, mas sem fundamentos a serem referendados. Já na cena 2 , algumas das explicações que os sujeitos apresentaram sobre a Matemática continham características derivadas dos referenciais da disciplina Metodologia do Ensino de Matemática, por exemplo: as questões relativas à Matemática passaram a ser relacionadas com a realidade e não mais distanciadas de aspectos sociais e culturais, conforme relações estabelecidas com a Resolução de Problemas e a Etnomatemática. Nesse sentido, observa-se que o perfil de 
Matemática de A1 se apresenta com certa tendência para uma coexistência de zonas, sejam elas a Abstrata Empirista e a Dinâmica. Ressalta-se que as coexistências estão sinalizadas no quadro 14 pelos espaços sombreados. A coexistência de zonas também é observada em A2, pois este sujeito apresentou um perfil pautado nas zonas Abstrata Racionalista e Dinâmica. Ainda nesta cena, o perfil de A3, também esteve direcionado pela coexistência de zonas conceituais, sejam elas Abstrata Empirista e Dinâmica. Assim, observando-se a cena 3, a qual se refere à tomada de consciência dos sujeitos sobre o perfil de Matemática, percebe-se a tendência de eles visualizarem a Matemática como um conhecimento mais próximo das questões do mundo sensível, já que o perfil de Matemática de A1 e A3 esteve pautado nas zonas Abstrata Empirista e Dinâmica e de A2 na Dinâmica. Frente ao panorama sobre o perfil de Matemática, entende-se que apesar das coexistências de zonas, durante o período investigado houve certa evolução conceitual para A1 e A2. Já, A3, até o final da coleta de dados ainda se encontrava em uma fase instável de suas elaborações conceituais, assim, não implicando evoluções conceituais.

Sobre o perfil de ensino da Matemática, é possível observar que, na cena 4, os sujeitos apresentaram coexistência de zonas. Para A1, ensinar Matemática estava pautado nas zonas Reprodução e Elaboração, para A2, nas zonas Matemática Moderna e Elaboração. Já, o perfil de A3, foi identificado nas zonas Reprodução, Matemática Moderna e Elaboração. Percebeu-se que o perfil que cada sujeito revelou, neste momento, era decorrente do contato com os referenciais de disciplinas do curso de Pedagogia e, também, das referências das próprias experiências consideradas não bem sucedidas em relação ao ensino da Matemática, uma vez que justificaram propor aulas com o auxílio de materiais didáticos ou situações relacionadas a temas do cotidiano como meio de proporcionar vivências agradáveis no processo de ensino-aprendizagem da Matemática. No entanto, na cena 5, o perfil de ensino priorizado durante a prática pedagógica parece ter sido decorrente dos referenciais que emergiram das crenças pessoais. Nesse sentido, A1 continuou apresentando coexistência de zonas, porém ela manteve as zonas Reprodução e Elaboração e passou a considerar, também, a Matemática Moderna. A2 apresentou o mesmo perfil de A1. Somente A3 deixou de considerar uma das zonas apresentadas na cena anterior, isto é, a Elaboração, deste modo seu perfil esteve delineado na Reprodução e na Matemática Moderna. Na cena 6, que é quando os sujeitos tomam consciência de suas concepções em relação à prática pedagógica desenvolvida, observa-se que A1 e A2 apresentaram um perfil pautado na zona Elaboração. Já A3, não teve a mesma oportunidade que os outros sujeitos de desenvolver outras aulas no estágio, ficando apenas na re-elaboração do plano de aula, voltou a apresentar o mesmo perfil 
evidenciado na cena 4, isto é, nas zonas Reprodução, Matemática Moderna e Elaboração. Frente a esse quadro, percebe-se que o perfil de ensino de Matemática de cada sujeito foi fortemente influenciado pela prática pedagógica, tanto no que se refere à experiência acumulada como aluno, quanto à adquirida pelo desempenho da ação docente. Deste modo, entende-se que A1 e A2 apresentaram certa evolução do perfil de ensino e A3 se manteve com o mesmo evidenciado no início do processo analisado.

Em relação ao perfil de aprendizagem em Matemática, observa-se na cena 4 que há, também, coexistência de zonas para todos os sujeitos, as quais se referem às zonas Tradicional e Nova Cultura para A1, Comportamental e Nova Cultura para A2 e A3. É interessante ressaltar que na cena 4 o desenho do perfil conceitual de ensino é o mesmo do perfil conceitual de aprendizagem para cada sujeito, inclusive com as características das coexistências, uma vez que os fatores referendados para a composição dos perfis se constituem nos mesmos, isto é, os referenciais do curso de Pedagogia e as experiências frustradas com a aprendizagem da Matemática. Entretanto, percebe-se que na cena 5 o perfil de aprendizagem para A2 e A3 esteve referendado mais pelas experiências pessoais com a aprendizagem da Matemática. O mesmo ocorreu para A1, uma vez que se identificou as zonas Tradicional e Comportamental como constituinte do perfil de aprendizagem neste momento. Porém, A1 evidenciou conceber outras características para a aprendizagem, as quais são pertencentes à zona Nova Cultura, logo esse sujeito na cena 5 apresentou coexistência de zonas em seu perfil conceitual de aprendizagem, assim como A2 e A3 que evidenciaram um perfil pautado nas zonas Tradicional e Comportamental. Já na cena 6, após o desenvolvimento da prática pedagógica se constatou que o perfil conceitual de aprendizagem de A1 se referia à zona Nova Cultura, enquanto que A2 e A3 apresentaram um perfil com coexistência de zonas, sendo para aquele a Comportamental e a Nova Cultura e, para este, a Tradicional e a Nova Cultura. Frente ao exposto, tem-se que A2 apresentou o mesmo perfil nas cenas 4 e 6 , o qual está pautado nas zonas Comportamental e Nova Cultura. Em relação às mesmas cenas, A3 continuou apresentando a coexistência de zonas, Comportamental e Nova Cultura e passou a considerar, também, a zona Tradicional. Somente A1 deixou de conceber a aprendizagem em Matemática por características pertencentes a mais de uma zona conceitual passando apenas para a zona Nova Cultura na cena 6. Tais aspectos sobre A1 podem ser considerados indícios da evolução conceitual do perfil de aprendizagem deste sujeito.

Além da leitura de cada perfil conceitual em relação aos sujeitos, o interesse pelo Quadro 14 é, também, o de ressaltar os aspectos comuns às concepções de A1, A2 e A3, tanto no que se refere ao perfil conceitual quanto às conexões que eles fizeram das concepções em 
relação à prática pedagógica, uma vez que se percebeu que as conexões identificadas correspondem à parte dos fatores contribuintes no processo de aprendizagem dos sujeitos em relação ao como ensinar Matemática. Deste modo, na seqüência se evidenciam os pontos comuns percebidos no perfil conceitual de Matemática e, em seguida, nos demais perfis conceituais, sejam eles, de Ensino e de Aprendizagem em Matemática.

Assim, em relação à concepção de Matemática, um primeiro elemento a destacar são as conexões que A1 e A2 revelaram sobre as visões apresentadas na cena 1 e na cena 2. Esses sujeitos relataram que o contato com a disciplina de Metodologia do Ensino de Matemática permitiu a elas que ampliassem suas visões sobre essa ciência. Comparando-se a cena 1 com a cena 2 , no quadro 14 , é possível perceber nesta última a coexistência de zonas em relação a um mesmo aspecto do perfil conceitual. A1 revela conceber que a finalidade e as características de Matemática são relativas às zonas Abstrata Empirista e Dinâmica e, A2 concebe que a origem e as características de Matemática são pertencentes às zonas Abstrata Racionalista e Dinâmica. Contudo, tomou-se o conhecimento de que as concepções iniciais tinham como fundamento a própria escolarização básica, ou seja, a visão evidenciada por elas correspondia à imagem da disciplina escolar que lhes propiciou os primeiros contatos com o conhecimento matemático. Já, nas concepções finais (cena 2), acredita-se que os sujeitos estavam concebendo a Matemática como um objeto a ser ensinado, logo, um campo de conhecimento didatizado, cujos referenciais disponibilizados pela Metodologia de Ensino tratavam a Matemática enquanto um objeto de ensino e tinham o propósito de desencadear a percepção das diferentes visões sobre essa ciência e o reflexo disso para o ensino. Entretanto, para A3 o panorama é o de permanência de zonas conceituais entre a cena 1 e a cena 2 (Abstrata Empirista e Dinâmica), o que permite supor que o contato com os referenciais da Metodologia de Ensino não lhe possibilitaram a re-elaboração de sua estrutura cognitiva em profundidade, então prevalecendo os fundamentos adquiridos anteriormente à referida disciplina. Pois, assim como os demais sujeitos, A3 justificou sua visão no primeiro registro pelas dificuldades com certos conteúdos específicos da Matemática, como o logarítmo e a fração, os quais são decorrentes da escolarização básica e nada revelou sobre o segundo registro.

Um outro elemento, que contribui para a percepção de que a Metodologia de Ensino se constituiu em um dos meios de ampliar o perfil conceitual de Matemática, foi a própria justificativa apresentada por A1 e A2 para as suas mudanças de perspectivas registradas entre a cena 1 e a cena 2. Segundo esses sujeitos, só depois do contato com a Metodologia foi possível perceber que a Matemática não precisa ser ensinada da maneira como foi feita para 
elas. Tal idéia corrobora para o entendimento de que tanto a visão sobre a Matemática como ciência quanto como um objeto de ensino foram influenciadas pelos referenciais da Metodologia de Ensino de Matemática. Porém, percebeu-se que, apesar de os sujeitos terem apresentado certa evolução do perfil conceitual de Matemática, isso não se refletiu, em um primeiro momento, na prática pedagógica pré-profissional. A nova percepção sobre a Matemática permeou o planejamento e não emergiu durante a aula no estágio. A visão que prevaleceu foi aquela registrada na cena 1, ou seja, a prática pedagógica valorizava uma concepção de Matemática como um conhecimento pronto, estático e que serve como ferramenta para outras áreas e atividades do cotidiano.

Quando os sujeitos tiveram que pensar na Matemática como um objeto de ensino, constatou-se que eles estabeleceram certas conexões sobre o modo como esse conhecimento deve ser ensinado. Nesse sentido, na cena 4 foi indicada a relação da Matemática com situações do cotidiano e o uso de materiais didáticos diferentes da lousa e do livro didático como principais meios de ensinar Matemática. Desta maneira, seria possível permitir que o aluno visualizasse de onde surgiu o conceito e, também, para que o mesmo servia. Tal conexão foi evidenciada por todos os sujeitos e relacionada à zona Elaboração no aspecto como ensinar do perfil conceitual de ensino. Entretanto, na cena 5, o modo como esses elementos foram abordados em sala de aula pelos professores estagiários, continuou valorizando uma Matemática pronta e estática. Ou seja, tais elementos serviram apenas de mote para se dar o início da explicação da matéria, o que vem a constituir características próprias da zona Matemática Moderna do perfil conceitual. Assim, observando-se o perfil conceitual de Ensino de A1, A2 e A3, constatou-se um intenso movimento conceitual entre as cenas 4, 5 e 6, devido ao fato de que as intenções de ensino reveladas na cena 4 não correspondiam às concepções colocadas em prática durante o estágio (cena 5), suscitando em re-elaborações conceituais (cena 6).

Entretanto, o que fez com os sujeitos percebessem o contraste entre o planejado e o praticado foi a idéia que cada um deles estabeleceu como indício de aprendizagem em Matemática, ou seja, a ação produtiva dos alunos frente aos seus comportamentos diante das propostas feitas durante a aula. Nesse sentido, observando-se a cena 4, constatou-se que para A1 era imprescindível a participação do aluno, na realização dos exercícios ou na colaboração com os diálogos. Para A2, o indício de aprendizagem estava atrelado à idéia de que seus alunos deveriam usar o material dourado como ferramenta auxiliar nos cálculos matemáticos e, A3 considerava que o aluno teria aprendido se o mesmo fizesse anotações em seus cadernos sobre o conteúdo exposto na lousa. Assim, quando estes indícios não foram constatados, A1, 
A2 e A3 reagiram da mesma maneira, isto é, demonstraram descontentamento com a prática pedagógica desenvolvida na aula. Esse descontentamento foi a evidência da perturbação conceitual e emocional que os sujeitos estavam vivenciando. Uma atividade metacognitiva, intermediada pela professora de Metodologia de Ensino, realizada durante as entrevistas reflexivas auxiliou A1, A2 e A3 a fazerem uma auto-avaliação sobre o modo que conduziram a aula, possibilitando a elas constatarem o contraste existente entre certas atitudes adotadas em sala de aula e a concepção revelada no planejamento. A conseqüência de tal reflexão foi a re-elaboração da prática pedagógica com vistas às concepções de ensino e aprendizagem evidenciadas no plano de aula. Para A1 e A2 a acomodação conceitual foi atingida, visto que houve tomada de consciência sobre tais contrastes e foi colocado em ação uma nova proposta de aula. No caso de A3 não houve tomada de consciência e não foi possível colocar em prática uma nova proposta, já que ela não tinha mais aulas a serem ministradas no estágio. Nesse sentido, percebe-se que a conexão com a concepção de aprendizagem que o sujeito possui também se constitui em um meio de ampliar o perfil conceitual de Ensino da Matemática, quando este retrata a concepção veiculada na prática pedagógica.

Ainda em relação às conexões, observou-se que as mesmas foram influenciadas pelos aspectos subjetivos dos sujeitos, principalmente, em relação ao desenvolvimento da prática pedagógica. Durante as entrevistas reflexivas A1, A2 e A3 relataram sobre seus sentimentos com o desenvolvimento das aulas no estágio, por diferentes motivos, as sensações de frustrações, medo, insegurança, descontentamento permearam as atividades de sala de aula destes sujeitos e, acabaram por desencadear certo esforço para a superação das dificuldades provenientes das perturbações emocionais, desta maneira, suscitando em percepções sobre seus modos particulares de visualizarem o processo de ensino-aprendizagem e, também, mudanças em suas ações como docentes. Assim, resultando na manifestação de sentimentos de outra ordem, por exemplo, satisfação com os resultados obtidos com uma aula, tranqüilidade e segurança para desenvolver uma nova proposta, confiança na própria imagem como professora. Um outro fator que não se pode deixar de ressaltar é a influência da professora de Metodologia de Ensino de Matemática (P) sobre as conexões entre as concepções e a prática pedagógica por meio das mediações realizadas durante as entrevistas reflexivas. Percebeu-se, pela análise dos episódios relativos às concepções de ensino e de aprendizagem que, em certos momentos, para A1, A2 e A3 o contato com P foi importante para que elas conseguissem detectar alguns contrastes entre suas concepções registradas nos planos de aula e as reveladas pela prática pedagógica, assim como, para re-elaborar as novas propostas de aula. Nesse sentido, compreende-se que tanto os aspectos subjetivos que 
envolvem a dinâmica de uma sala de aula quanto as mediações exercidas pela professora de Metodologia de Ensino constituem importantes fatores que influem nas conexões entre as concepções e a prática pedagógica dos sujeitos.

Em relação à prática pedagógica desenvolvida por esses sujeitos durante suas atividades de estágio em docência, compreende-se que a mesma se constituiu em um importante elemento da tomada de consciência entre a concepção evidenciada nos planos de aula e a revelada durante as aulas propriamente ditas, por isso a variação de concepções entre as cenas 4 e 5 registradas no quadro 14. No entanto, o fato de um professor em formação inicial estar consciente sobre o que pensa a respeito de um dado conhecimento e seu respectivo processo de ensino-aprendizagem não se reflete como garantia na transposição dessas concepções para a ação em sala de aula. Faz parte da profissionalização docente, também, a tomada de consciência sobre essa outra vertente da formação inicial, ou seja, conhecer a maneira como as próprias concepções emergem durante a ação em sala de aula. Nesse sentido, o estágio foi o ambiente ideal para que os sujeitos se percebessem como professores e, portanto, tal espaço foi propício para que os mesmos começassem a elaborar outros conhecimentos sobre o ensinar e o aprender em relação à Matemática. Pelo mesmo viés, percebeu-se que as novas elaborações conceituais tinham como referência as conexões que os sujeitos estabeleceram entre suas concepções e a prática pedagógica, pois as mesmas são mais que elos entre o modo de pensar e agir dos futuros professores, elas são os parâmetros para que os sujeitos possam evoluir conceitualmente, como foi o caso com a concepção de ensino a qual teve como conexão a concepção de aprendizagem e o modo como cada sujeito aprendeu Matemática. Contudo, é primordial que o futuro professor tenha oportunidade de experimentar, ou melhor, colocar em prática as novas elaborações conceituais, caso contrário ele tende a se manter com o mesmo perfil conceitual e o estágio acaba sendo pouco aproveitado em termos da formação inicial do futuro professor. $\mathrm{Na}$ seqüência, encaminham-se as considerações finais e as conclusões sobre essa pesquisa. 


\section{CONCLUSÕES E CONSIDERAÇÕES FINAIS}

Chegar a esse ponto do trabalho significa que muito já foi feito. Para anunciar os resultados obtidos com a investigação se faz necessário lançar um olhar retrospectivo sobre a trajetória percorrida desde o seu momento inicial. Nesse sentido, as palavras que se seguem inspiram essa busca.

É preciso um pouco de atrevimento para apostar e saber que posso perder; é preciso ser meio diplomática para poder tratar de alguns "problemas de representação"; é preciso calcular os passos a dar para nem me adiantar nem me atrasar. Com isto, penso, componho um caminho, deitando laje por laje, para que ele possa existir. Não tarda, então, o tempo de ter de olhar para trás e criar uma história a respeito do que percorri, pois fiz uma escolha. Depois disto, esforço-me por achar alguém disposto a ouvir esta história para então poder contá-la (CABRAL, 1998, p. 220, destaque da autora).

Ler essas palavras é como se estivesse vendo um filme sobre o desenvolvimento deste trabalho. Vem à lembrança desde os motivos que levaram à proposição desta investigação até os estudos teóricos e escolhas de como tratar as informações obtidas junto aos sujeitos. Ao longo dos capítulos que o antecederam, foi se contando como esta história ocorreu, ou melhor, como esta pesquisa foi sendo composta e, agora, é o tempo de se olhar para trás e, então, contar de que maneira ela termina e ao mesmo tempo apontar caminhos para o início de outras possibilidades investigativas. Para tanto, considera-se importante, para este momento, o resgate de alguns aspectos sobre este estudo. Deste modo, lançando um olhar para cada etapa e sem desconsiderar o todo, apresenta-se na seqüência a reflexão conclusiva deste estudo.

Em um primeiro momento, esta pesquisa tratou da formação inicial do professor das séries iniciais do Ensino Fundamental, cujo campo de trabalho foi o curso de Pedagogia da UFPR e os sujeitos alunos das disciplinas de Metodologia de Ensino de Matemática e Prática Pedagógica-Estágio em Docência, mais especificamente, os alunos identificados por A1, A2 e A3, os quais constituem os três casos que possibilitaram a esta pesquisadora analisar em profundidade como esses sujeitos foram estabelecendo conexões entre suas concepções e a prática pedagógica pré-profissional. Assim, diante desta questão central, cada caso analisado foi único em sua situação particular e as informações obtidas mostraram que, o modo como o estágio foi desenvolvido, pôde proporcionar contribuições significativas para o futuro professor, no que se refere à sua aprendizagem para ensinar Matemática. Nesse sentido, essa investigação mostrou que a dinâmica de estabelecimento das conexões entre as concepções e a prática pedagógica se constituiu em um processo permeado por obstáculos, perturbações 
conceituais e emocionais, reflexões e re-elaborações da estrutura cognitiva. Desta maneira, observou-se em cada caso estudado que esse processo foi importante para que o futuro professor se percebesse em seu contexto formativo, conforme anunciado a seguir.

Percebeu-se que para A1, o contato com novos referenciais conceituais (os relativos à Metodologia de Ensino de Matemática) propiciou a este sujeito re-elaborar certos aspectos sobre sua concepção de Matemática e ampliar a concepção sobre o ensino e aprendizagem. Com o desenvolvimento do estágio em docência, ficou evidente que a experiência da prática pedagógica propiciou que as concepções em relação ao ensino e à aprendizagem fossem reestruturadas e a Matemática vista como um objeto de ensino e não como um campo científico. Nesse contexto é que emergiram os obstáculos durante o desenvolvimento das regências de A1, tais como: a falta de referência do trabalho com alunos da EJA, diferentes concepções de ensino permeando o plano e a prática pedagógica referentes a uma mesma aula e insegurança em relação à imagem pessoal, como professora, diante dos alunos em virtude do desenvolvimento da aula.

Identificou-se que A1 estabeleceu como conexão entre o ensino-aprendizagem da Matemática e a prática, a própria concepção de aprendizagem, isto é, para ela a participação do aluno seria um indício de que o ensino proposto estava atingindo os objetivos estabelecidos. Outra conexão em relação à Matemática e ao seu ensino foi a adoção de materiais didáticos como um modo de tornar essa ciência mais dinâmica, ou seja, de aproximá-la de questões e/ou situações reais, concretas e que permitam o desenvolvimento de problematizações e de interações dos alunos com seus pares, com a professora e com os materiais didáticos. E, ainda, vale ressaltar que em relação à concepção de Matemática, em um primeiro momento, a conexão que A1 estabeleceu foi a própria escolarização básica, ou seja, sua visão sobre a Matemática correspondia à imagem apresentada a ela quando cursou o Ensino Fundamental e/ou Médio, a qual foi re-elaborada em certos aspectos a partir do contato com novos referenciais.

O processo de aprendizagem de A1 foi composto por várias etapas, além do contato com novas idéias e da vivência do evento crítico também a atividade metacognitiva por meio das reflexões desenvolvidas entre uma regência e outra (entrevistas reflexivas). Foi durante essas sessões que ela revelou ter tomado consciência sobre a diferença entre sua intenção de ensino e a prática desenvolvida, gerando assim, re-significações sobre a participação do aluno e o uso de materiais didáticos para o ensino da Matemática. Então, entendeu-se que, em parte, a aprendizagem de A1 sobre o exercício da docência em Matemática foi resultante da vivência de um evento crítico gerado a partir dos obstáculos, causando perturbações 
conceituais e emocionais e, também, devido às associações que ela estabeleceu entre suas concepções e a prática pedagógica por meio das conexões, as quais foram fortemente influenciadas por aspectos subjetivos que surgiram durante o estágio e pela professora de Metodologia de Ensino de Matemática enquanto mediava as reflexões realizadas ao longo das entrevistas reflexivas.

Apesar de o processo de aprendizagem da docência para o ensino da Matemática de A2 ter sido muito parecido com o vivenciado por A1, o estudo deste caso contribuiu para um melhor entendimento sobre o modo como o futuro professor pode articular suas concepções com a prática pedagógica. Desta maneira, tem-se que o processo vivenciado por A2 esteve, também, permeado por obstáculos, reflexões e re-elaborações conceituais e, da mesma maneira, o contato com novos referenciais teóricos e os advindos da prática pedagógica propiciou a re-elaboração de certos aspectos sobre sua concepção de Matemática e a ampliação da concepção de ensino-aprendizagem.

Foi com o desenvolvimento do estágio e das reflexões sobre as regências que A2 percebeu um de seus obstáculos, isto é, sua intenção de ensino e aprendizagem não correspondia com a praticada em sala de aula e que esta poderia e deveria ser re-elaborada de modo a tornar a prática pedagógica compatível com seus perfis conceituais. Um outro obstáculo considerado relevante foi a falta de noção de A2 sobre o conhecimento matemático dos alunos da turma na qual estagiou. Nesse contexto é que as reflexões sobre a intenção de ensino e os resultados obtidos com a aula desenvolvida se demonstraram como uma estratégia eficiente na tomada de consciência do próprio perfil conceitual e, também, para a reestruturação do conjunto conceitual sobre o ensinar e aprender em Matemática. E, assim como ocorreu com A1, os obstáculos também se constituíram nos fatores para o desencadeamento da vivência do evento crítico, gerando perturbações conceituais e emocionais sobre as conexões estabelecidas entre suas concepções e a prática pedagógica.

Identificou-se que A2 estabeleceu como conexão entre o ensino-aprendizagem de Matemática e a prática pedagógica, o alcance dos objetivos propostos no plano de aula, os quais visavam ao aprendizado dos alunos sobre o uso do Material Dourado, ou seja, sua conexão estava apoiada em sua própria concepção de aprendizagem, já que, para ela, se o aluno aprendesse a usar o referido material didático, seu ensino teria sido bem sucedido. Outra conexão revelada por A2 em relação à Matemática e ao seu ensino foi a adoção de materiais didáticos e atividades lúdicas como meio de despertar o gosto pelo estudo desta ciência e de torná-la mais concreta, próxima da realidade e atraente aos olhos de quem a estuda. Em relação à concepção de Matemática sua conexão foi a própria escolarização básica 
e os referenciais da disciplina de Metodologia do Ensino da Matemática. Observou-se, também, que tais conexões eram influenciadas tanto por aspectos subjetivos quanto pela professora de Metodologia de Ensino, pois A2 se referiu a tais aspectos para justificar o motivo de ela ter considerado outros elementos e idéias para o desenvolvimento de sua nova prática pedagógica.

A análise dos dados de A2 reforçou a compreensão obtida com A1, isto é, o aprendizado da docência pode se constituir de um processo composto por várias etapas, as quais envolvem a vivência de uma perturbação (evento crítico) e as reflexões sobre a própria aprendizagem durante o período em que o futuro professor desenvolve suas atividades de estágio em docência. Foi desta maneira que A2 revelou ter tomado consciência da diferença entre sua concepção de ensino e a prática pedagógica e, também, da necessidade em se conhecer o aluno em sua dimensão pedagógica, vindo então, a re-significar o que é conhecer o aluno e a implicação disto com a prática em sala de aula.

Enquanto A1 e A2 vivenciaram um processo bastante similar sobre o aprender a ensinar Matemática, isso não se repetiu com A3. O percurso percorrido por este sujeito foi menor e os dados revelados eram relativamente limitados se comparados com os dos outros sujeitos. Mesmo assim, foi possível perceber que o processo vivenciado por A3 também foi permeado por obstáculos e reflexões. Observou-se que o contato com referenciais da Metodologia de Ensino de Matemática lhe possibilitou constatar novas idéias sobre o processo de ensino-aprendizagem e o desenvolvimento do estágio foi propício para o surgimento de um evento crítico, causando assim, perturbações conceituais e emocionais. $\mathrm{O}$ evento crítico foi gerado por obstáculos, tais como: a incompatibilidade entre a intenção de ensino registrada no plano de aula e a colocada em prática durante a regência; domínio superficial do conteúdo matemático; a falta de noção de uso da lousa e referências insuficientes para o trabalho com alunos da EJA.

Com a reflexão desenvolvida sobre a aula do estágio ficou evidente que A3 tinha pouca percepção sobre seus próprios perfis conceituais e, portanto, a análise sobre os resultados obtidos com a regência com vistas a possíveis re-elaborações conceituais praticamente ficou restrita à identificação dos elementos dificultadores do desenvolvimento da aula, os obstáculos. A implicação para isso é o entendimento de que esse sujeito parece não ter percebido que uma mesma concepção pode apresentar diferentes zonas conceituais, logo ela não viu necessidade de re-estruturar seu modo de pensar o ensino e a aprendizagem em Matemática. 
Tem-se a impressão de que o evidenciamento dos obstáculos serviu apenas de constatação dos fatores dificultadores da prática pedagógica, não suscitando em A3 tomada de consciência sobre a variedade de concepções entre as que permearam sua intenção de ensinoaprendizagem registrada no plano de aula e as reveladas durante a aula de Matemática no estágio. Quando A3 explicou como desenvolveria a mesma aula, não se percebeu novas estruturações conceituais em relação ao ensinar e aprender Matemática e, também, foi impossível a constatação pela prática pedagógica, já que ela não realizou outras aulas de Matemática no estágio.

Entretanto, teve-se a impressão que o evento crítico permitiu A3 re-elaborar alguns aspectos de sua concepção de ensino-aprendizagem em Matemática, uma vez que ela evidenciou consciência da necessidade de ensinar a partir do conhecimento do aluno como meio de facilitar a aprendizagem, re-significando a prática pedagógica de modo a permitir construções conceituais pelo discente e não somente usar tal conhecimento como mote para a apresentação do conteúdo. Contudo, ressalta-se que tal re-estruturação conceitual parece ter ocorrido pelo fato de A3 já atuar como professora em sua atividade profissional.

Provavelmente, tal re-elaboração conceitual seja decorrente da conexão que A3 estabeleceu entre a Matemática e seu ensino e a prática pedagógica, isto é, o vínculo desse conhecimento com questões da realidade. A re-significação parece residir no modo como tal vinculação com a realidade é estabelecida. Frente a este caso, entende-se ser essencial para o futuro professor que seja vivenciado durante seu estágio em docência situações que o leve a refletir e tomar consciência sobre seu modo de pensar e agir em sala de aula, caso contrário, ele apenas cumprirá certa carga horária de regências, vivenciará frustrações e dificilmente conseguirá se perceber no exercício profissional da docência e, assim, deixará de elaborar o próprio conhecimento sobre o ser professor, vindo a repetir aquilo visto até então.

Frente às sínteses dos estudos de cada caso, observa-se que o processo de estabelecimento de conexões entre as concepções e a prática pedagógica, além de ter sido permeado por perturbações, reflexões e re-elaborações conceituais, também foi influenciado por aspectos subjetivos e pela professora de Metodologia de Ensino de Matemática. Observase, também, que o conjunto de elementos mencionados anteriormente, aproxima tal processo das condições essenciais para a ocorrência de evoluções conceituais, por exemplo: instalação de conflitos cognitivos (perturbações); geração de insatisfações com as preconcepções; tomada de consciência do perfil conceitual (atividades metacognitivas) e a apropriação de uma nova zona conceitual (re-elaborações da estrutura cognitiva). 
Deste modo, a análise a partir da Noção de Perfil Conceitual permitiu perceber que as atividades de metacognição em associação com a vivência de um evento crítico, ou seja, de uma perturbação conceitual ou emocional são importantes elementos para provocar reelaborações conceituais. Frente aos casos estudados e, também, considerando um aspecto percebido a partir do trabalho de Mortimer (1994), a evolução conceitual tem que apresentar alguma relação com a ação do sujeito. $\mathrm{O}$ autor afirma que a evolução ocorre quando o sujeito se dá conta das várias zonas que compõem seu perfil e utiliza-as conforme o contexto. Nesse estudo, os sujeitos apresentaram contrastes entre o modo de pensar e o de agir em sala de aula. Essas diferenças é que suscitaram nas perturbações conceituais em relação ao ensinoaprendizagem da Matemática. O indício da evolução conceitual foi evidenciado pela proximidade, consciente, entre a maneira de pensar e agir dos futuros professores, isto é, quando a intenção de ensino e a aula desenvolvida apresentavam os mesmos aspectos conceituais. Entretanto, a harmonia entre o que o sujeito concebe com o que coloca em prática possui uma relação muito estreita com a reflexão sobre a situação em questão e com as oportunidades de experimentar outros modos de implementar o ensino de um certo conteúdo.

Essa possibilidade não existiu para A3. Ela refletiu sobre a situação e re-elaborou algumas estratégias em função do que estava concebendo sobre o ensino da Matemática, por exemplo: explicar o conteúdo a partir de situações do cotidiano experenciadas pelos alunos. A3 implementou essa idéia em sua prática pedagógica durante o exercício profissional, já que ela não teve mais oportunidade de desenvolver outras aulas no estágio. Mas, se fosse um aluno cuja prática profissional seja distinta do exercício da docência? Possivelmente, a reflexão suscitada na ocasião do estágio provocaria uma re-estruturação cognitiva superficial, tendendo a ser suprimida pelas concepções iniciais. Nesse sentido, fica evidente o quanto o estágio, dependendo do modo como é dinamizado é um elemento mediacional no desencadeamento das concepções sobre o ensino e, também, a aprendizagem. Deste modo, compreende-se que o estágio desenvolvido em paralelo a atividades metacognitivas pode permitir ao futuro professor não só entender o próprio modo de pensar, como também, se perceber no interior de um processo de ensino-aprendizagem. São pequenas nuances entre uma crença e uma atitude que podem distanciar ou aproximar a teoria da prática. A reflexão juntamente com a tomada de consciência sobre essas nuances é que vão determinar a existência ou não de conexões entre as concepções e a prática pedagógica. Tendo em vista esse processo, levanta-se como hipótese que as conexões estabelecidas entre as concepções e a prática pedagógica podem se constituir em elementos que diminuem a distância entre a 
teoria e a prática, isto é, as conexões seriam os parâmetros que vinculariam o modo de pensar e agir dos futuros professores.

Um outro aspecto evidenciado nesta pesquisa tem relação ao enfoque dado às concepções dos alunos-estagiários como uma das diretrizes deste estudo. Acreditava-se que elas norteariam a organização da ação em sala de aula e seriam reveladas na prática pedagógica do futuro professor. Com as análises dos dados coletados se percebeu que, de fato, as concepções que os sujeitos possuíam norteavam a organização do processo de ensinoaprendizagem e, também, permeavam a prática pedagógica dos mesmos. No entanto, observou-se que as concepções ativadas para a organização da prática pedagógica nem sempre corresponderam à mesma zona conceitual das veiculadas durante a ação em sala de aula.

Uma das consequiências dessa situação é que ela gerou perturbações para os futuros professores, tanto de ordem conceitual quanto emocional, pois o que eles acreditavam sobre o ensinar e o aprender em Matemática lhes parecia não funcionar em sala de aula. E, ainda, houve o abalo emocional, isto é, emergiu o sentimento de insegurança em relação a vários aspectos, por exemplo: com o conteúdo matemático; o trato com os alunos; o modo de explicar o conceito; entre outros. Isso tudo suscitou em reflexões em torno das conexões que haviam sido estabelecidas entre as concepções e a prática pedagógica. Essa situação até parecia uma validação de um velho ditado - na prática a teoria é outra - entretanto, entendese que ela é mais que isso. Pois, até certo ponto, a percepção de variação das concepções permite compreender parte da dificuldade sentida pelos alunos-estagiários de vincular a teoria com a prática pedagógica e, ainda, que tal percepção se refere a um indício de como o futuro professor pensa, organiza a ação em sala de aula e a desenvolve, como também, das respectivas consequiências. Em outras palavras, as concepções ativadas pelos futuros professores refletem diferentes contextos, sejam eles: o pessoal (durante o desenvolvimento da prática pedagógica) e o científico (revelados no planejamento da aula). Segundo Mortimer (1994), há uma tendência de os sujeitos usarem suas concepções pessoais para resolverem situações problemáticas, pelo fato de elas conterem estruturas conceituais mais familiares, visto que o novo conceito estaria em fase de elaborações. Nesse sentido, levanta-se como uma outra hipótese que a própria prática pedagógica pode se configurar como uma situação problemática ao futuro professor e, por conseqüência, se tornar uma estratégia para o desencadeamento de perturbações no que se refere às concepções sobre o ensino e a aprendizagem. Diante disto, pressupõe-se que tal situação causaria ao futuro professor abalos em sua estrutura cognitiva relativa ao ensino e à aprendizagem. 
Uma outra crença que permeou esse trabalho foi a idéia de que se fosse possibilitado ao futuro professor refletir sobre as próprias concepções com vistas à prática pedagógica, ele tomaria consciência sobre seu modo particular de pensar e, assim, poderia vir a re-elaborar suas concepções. Ao analisar outros trabalhos (MORTIMER, 1994; ABIB, 1998; CABRAL, 1998; FREITAS, 1998), percebeu-se que as atividades metacognitivas se constituem em opções interessantes para possibilitar a reflexão sobre o modo particular de pensar e de articular conexões entre as concepções e a prática pedagógica. Nesse sentido, os dados desta investigação permitiram compreender que as entrevistas reflexivas se constituíram em atividades de metacognição promissoras a serem consideradas e exploradas por trabalhos pautados na evolução conceitual. A partir da adoção desse tipo de estratégia foram coletados dados que permitiram entender que a reflexão sobre as próprias concepções não suscitam somente na elaboração de novas idéias, mas, principalmente, auxiliam na tomada de consciência sobre o próprio perfil conceitual; ajudam a superar abalos emocionais e a contornar perturbações conceituais. Com as entrevistas reflexivas emergiram não só lapsos e esquecimentos, como também, sentimentos que o futuro professor possui em relação à Matemática e à prática pedagógica pré-profissional, tais como: o medo de errar; insegurança em assumir uma sala de aula; (in) satisfação com os resultados obtidos com o trabalho desenvolvido no estágio; afinidade ou repulsão com o conhecimento matemático. Aspectos subjetivos como esses foram grandes influenciadores sobre as conexões estabelecidas. Porém, compreendeu-se, também, que o resultado da tomada de consciência vai além de reestruturações conceituais, atinge também, a conscientização sobre a prática pedagógica desenvolvida no estágio e a respectiva re-elaboração, ou seja, as mudanças envolvem as concepções e as ações em sala de aula. Agindo desta maneira, supõe-se que o futuro professor consegue se perceber em seu processo de formação e identificar aspectos que estão dificultando seu processo de aprendizagem da docência e, assim, trabalhá-los de modo que a prática seja como a teoria.

Entretanto, ressalta-se entender, também, que para a superação das dificuldades e das perturbações que os futuros professores evidenciavam durante as entrevistas reflexivas, a ação desempenhada pela professora de Metodologia de Ensino, a professora formadora, pôde ser considerada fundamental nesse tipo de atividade, visto que as conexões entre as concepções e a prática pedagógica eram influenciadas por suas mediações, tais como: fazendo questionamentos aos sujeitos para provocar reflexões em relação às dificuldades e/ou às perturbações percebidas entre o plano de aula e o desenvolvimento do estágio; apresentando exemplos de como encaminhar algumas questões de sala de aula, os quais algumas vezes 
foram adaptados pelos sujeitos e implementados em suas aulas; analisando juntamente com o sujeito os resultados obtidos com a aula desenvolvida no estágio, no intuito de direcionar a reflexão sobre a prática desenvolvida considerando o planejamento previamente elaborado e instigando o futuro professor a externar suas angústias, dúvidas, receios, lapsos e esquecimentos, assim como, os motivos de desencadeamento de tais aspectos subjetivos, cuja intenção foi a de minimizar as tensões emotivas e propiciar que o sujeito desempenhasse suas funções de modo mais tranqüilo e, ainda, conversando muito sobre os conteúdos específicos da Matemática, na tentativa de suprir certa fragilidade sobre o domínio desse conhecimento. Compreende-se que essas ações foram importantes para despertar, propiciar não só a reflexão sobre o próprio processo de aprendizagem dos sujeitos, como também desencadear a tomada de consciência sobre os perfis conceituais evidenciados por cada um. Tanto A1 quanto A2 reconheceram que tal mediação se constituiu em um importante fator para a melhoria de suas ações docentes durante o estágio.

Nesse aspecto, vem à tona o professor formador. Pelas análises dos dados dos casos estudados, percebeu-se que uma das conexões estabelecidas pelos sujeitos entre suas concepções e a prática pedagógica estava vinculada à escolarização básica vivenciada anteriormente, ou seja, certos aspectos do que concebiam sobre a Matemática e seu processo de ensino e aprendizagem eram decorrentes do modo como a Matemática havia sido ensinada aos sujeitos. Nesse sentido, entende-se que A1, A2 e A3, em certa medida, revelaram idéias sistematizadas a partir das visões de seus professores do Ensino Fundamental e Médio. Portanto, entende-se que a figura do professor exerce forte influência sobre o modo como cada um concebe um conceito. Estendendo-se essa linha de pensamento ao professor formador, pressupõe-se que tais influências continuem ocorrendo, provavelmente com outra intensidade, mas ainda assim, figurando como pano de fundo na elaboração dos conhecimentos relativos à atividade da docência. Logo, o professor formador pode ser considerado como um outro importante elemento na formação do futuro professor.

De um modo geral, pesquisas sobre formação de professores têm destacado a importância de se conhecer melhor o professor formador e seus processos formativos. Nesse sentido, Curi (2004) destaca a importância de o professor formador ter uma formação em consonância com as especificidades de cada área do conhecimento, especialmente em relação à formação inicial de professores que vão ensinar Matemática nas séries iniciais, pois ela constatou a existência de poucos docentes, atuando nos cursos de Pedagogia, com uma formação relacionada à Educação Matemática. Gonçalves e Fiorentini (2005), de certo modo, corroboram com tal perspectiva, apontando a necessidade de estudos sobre a formação 
matemática dos formadores, assim como, a formação científico-pedagógica e a relativa aos saberes da atividade profissional da docência. Jordão (2005) chama atenção para um outro viés de professor formador - o professor tutor, ela se refere àquele professor que recebe os alunos estagiários (futuros professores) em suas sala de aula. Segundo essa autora, esse professor pode assumir um papel central de facilitador do processo, "incentivando a elaboração de saberes dos licenciandos, a partir do estímulo ao desenvolvimento de suas capacidades reflexivas (p. 311)." Portanto, se a formação do professor que vai ensinar Matemática nas séries iniciais pode ser influenciada pelo professor formador, então é importante que este tenha um amplo conhecimento sobre as tendências de ensino e aprendizagem, como também, das evoluções conceituais da Matemática pesquisadas pela comunidade da Educação Matemática, visto que ele também pode se constituir em um importante elemento mediacional entre as concepções e a prática pedagógica do futuro professor durante seu processo de aprendizagem da docência.

Com a análise dos dados, percebeu-se que os resultados obtidos também evidenciavam certos limites deste estudo em relação às condições em que o mesmo foi desenvolvido. Assim, entendendo-se que o destaque a tais limitações pode apontar para outras possibilidades investigativas.

Pelos resultados obtidos, percebeu-se que o estágio foi mais propício para o trabalho com as concepções relativas ao ensino e à aprendizagem em Matemática do que com as concepções de Matemática. A análise evidenciou que no decorrer do desenvolvimento da prática pedagógica, o foco de atenção dos sujeitos, durante as reflexões, esteve voltado aos processos de ensinar e aprender, de modo que as questões relativas ao conhecimento matemático estiveram, basicamente, voltadas aos procedimentos de didatização desta ciência. Por outro lado, constatou-se, também, que a Metodologia de Ensino de Matemática foi mais favorável ao trabalho com as concepções sobre a Matemática, no sentido da evolução conceitual, sendo que questões sobre o ensino e a aprendizagem parecem ter suscitado, apenas, em constatações de novas idéias. Em outras palavras, as reflexões desenvolvidas no estágio praticamente não envolveram as visões relativas à Matemática e nem sempre estiveram associadas, diretamente, à prática pedagógica desenvolvida no estágio.

Alguns estudos voltados à investigação sobre o pensamento do professor em relação à Matemática e ao processo de ensino-aprendizagem têm defendido a importância da reflexão constante sobre a prática e a ligação desta com as concepções (THOMPSON, 1997; PAIVA, 1999; NACARATO et al, 2004). Esse tipo de trabalho pressupõe que o professor tenha certo conhecimento sobre a prática pedagógica e, também, esteja envolvido em um processo 
formativo que o instigue a reflexões e a elaborações de novos conhecimentos. No entanto, considerando que "apenas a explicitação não será suficiente; o futuro professor precisará viver situações, durante sua formação, que dêem a ele segurança para atuar profissionalmente. Não basta instaurar o conflito, é necessário trabalhar a partir dele" (NACARATO et al, 2004. p. 30). Assim, tendo em vista essa informação e mais o referencial da noção de perfil conceitual, buscou-se por possíveis elementos que tenham dificultado o desenvolvimento das reflexões sobre as concepções em relação à prática pedagógica, suscitando em uma hipótese relacionada à proposta curricular do curso de Pedagogia da UFPR.

A estrutura da proposta curricular do curso de Pedagogia da UFPR, garante, apenas, que as disciplinas de Metodologia de Ensino e a Prática Pedagógica - Estágio em Docência sejam ofertadas aos alunos de um mesmo ano escolar $\left(3 .^{\circ}\right)$. Conforme apresentado no capítulo 4, o fato de a Metodologia de Ensino ser uma disciplina semestral e a Prática, anual, implica na possibilidade de que o aluno curse a Metodologia e não chegue a desenvolver alguma regência no estágio ou venha a desenvolver as aulas sem ter cursado a disciplina de Metodologia. Tal fato, provavelmente, corrobora para que os futuros professores manifestem suas concepções de Matemática e de ensino e aprendizagem em momentos distintos e, principalmente, inviabiliza que a ativação destas concepções durante a Metodologia de Ensino esteja associada à prática pedagógica desenvolvida pelo próprio futuro professor, assim como, o respectivo desencadeamento de perturbações e reflexões em torno das concepções.

Um outro limite está relacionado às condições em que o estágio foi desenvolvido pelos sujeitos. Pois, percebeu-se que alguns sujeitos (grupo composto pelos 7 alunosestagiários), mesmo após as reflexões desenvolvidas durante as entrevistas reflexivas, em algumas situações, ao planejarem e implementarem suas aulas, ainda estavam apoiados em um conhecimento elaborado por outro, por exemplo, a professora de Metodologia de Ensino e os referenciais dos livros didáticos. Nesse sentido, Cabral (1998) fala da Mudança Conceitual pelo viés psicanalítico, cujas etapas, em linhas gerais, propiciam que o sujeito entre em análise, passe por uma transferência pedagógica, a qual se desfaz quando ele re-estrutura seu próprio conhecimento. Esse processo exige tempo para que as etapas não sejam aligeiradas e acabem tornando a re-estrutura conceitual superficial.

No caso desta pesquisa, percebeu-se que esse tempo não existia. Pois, quando os alunos iniciaram seus estágios lhes foi ofertado um período limitado e relativamente pequeno para que os mesmos pudessem desenvolver suas aulas. Geralmente, essas aulas ocorreram em dias ou semanas seguidas. Entende-se que tal ritmo acabou se tornando um obstáculo ao futuro professor, já que o tempo disponível era destinado à preparação da aula seguinte. Percebeu-se que alguns sujeitos chegaram a atingir a transferência pedagógica, pois estavam amparados no conhecimento do outro, ou seja, da professora de Metodologia de Ensino, da 
professora regente da turma estagiada e/ou dos manuais didáticos. Mas, não se conseguia encaminhá-los para a dissolução da transferência, isto é, fazê-los elaborarem seus próprios conhecimentos a partir das concepções evidenciadas, pelo fato de que, necessitavam reelaborar a próxima aula com certa urgência, já que seria a última a ser ministrada. Somente aqueles que já tinham alguma experiência em docência ou ministraram mais aulas durante o estágio é que parecem ter conseguido re-estruturar alguns aspectos de suas concepções sobre o ensinar e aprender em Matemática. Tal situação encaminha o olhar para o modo como a prática de ensino, ou melhor, o estágio em docência é propiciado ao futuro professor, pois levanta-se como hipótese que, quando o estagiário concentra a carga horária de suas atividades de ensino ministrando aulas em dias ou semanas seguidas, isso se torna um elemento dificultador para que o mesmo desenvolva uma reflexão mais sistematizada e aprofundada sobre a própria prática.

Problemas com propostas curriculares de cursos de formação de professores ou com a estrutura e o modo como certas disciplinas são propostas, correspondem a fatos que não surpreendem e, ao mesmo tempo, causam inquietação. No que se refere especificamente a propostas curriculares de cursos de formação de professores, tem-se que o referencial teórico adotado para esta pesquisa não fornece suporte para uma análise mais sistematizada e aprofundada sobre o tema. Contudo, observa-se que muitas ações têm sido geradas por diferentes instâncias no sentido de tentar minimizar problemas da formação de professores. Em se tratando de propostas curriculares de cursos de formação de professores para as séries iniciais na área de Matemática, trabalhos como o de Curi e Pires (2004) evidenciam como é frágil o conhecimento matemático dos docentes e o quanto limitado tem sido o tempo curricular das disciplinas destinadas ao trato das questões relativas ao ensino da Matemática em cursos de Pedagogia do Brasil. Outros trabalhos enfocam a visão de formação que permeia as propostas curriculares. De um modo geral, estudos que analisam propostas de formação de professores para o ensino da Matemática têm apontado para algumas mudanças necessárias aos cursos de formação, no intuito de propiciar uma relação mais harmoniosa e equilibrada entre teoria e prática. Nesse sentido, fala-se em desenvolvimento profissional; práticas colaborativas, reflexivas e investigativas em relação ao trabalho docente (POLETTINI, 1999; PEREZ, 1999; FIORENTINI e NACARATO, 2005) como meio de desencadear melhorias para a formação de professores. Ferreira (2003, p. 35) destaca, ainda, que "aos poucos, a formação de professores passa a ser entendida como um processo contínuo por meio do qual o sujeito aprende a ensinar", ou seja, aprende a ser professor.

Diante do quadro exposto, percebe-se que para desenvolver na disciplina de Metodologia de Ensino de Matemática do curso de Pedagogia da UFPR uma proposta de formação, que se preocupa em valorizar o processo de desenvolvimento profissional e de 
aprendizagem do futuro professor, tendo a prática pedagógica como referência na relação entre a teoria e prática, é preciso que o curso em questão esteja estruturado de modo a dar condições que isso ocorra e, também, que haja certo comprometimento dos professores formadores nesta direção. Assim, não basta um acréscimo da carga horária da disciplina de Metodologia de Ensino, se faz necessário também, uma estrutura curricular que viabilize o desenvolvimento sistematizado de reflexões, junto aos alunos do curso, sobre a própria prática pedagógica pré-profissional. Pois, observou-se pelos dados obtidos que a experiência da prática pedagógica foi indispensável para se provocar perturbações e promover alguma evolução conceitual em relação às concepções de ensino e aprendizagem. Caso contrário, os sujeitos apenas constataram algumas idéias novas pelo contato com os referenciais teóricos da Metodologia de Ensino e não conseguiram se perceber no processo de ensino-aprendizagem. Foi a partir do desenvolvimento da prática e da reflexão sobre a mesma que ocorreu a tomada de consciência sobre o modo próprio de pensar e agir. Nesse sentido é preciso que seja contemplada na proposta curricular do curso de formação inicial da docência a articulação entre as disciplinas que tratam da didática específica e do estágio em docência.

Para esse estudo, tal articulação foi viabilizada mediante trabalho colaborativo entre os professores formadores responsáveis pelas disciplinas envolvidas. As questões gerais do encaminhamento do estágio foram desenvolvidas pela professora da disciplina de Prática Pedagógica e as relacionadas às aulas de Matemática foram tratadas pela professora de Metodologia de Ensino de Matemática. Frente a essa sistemática, A2 e A3 revelaram que gostariam de, também, ter recebido esse tipo de orientação em relação às outras matérias que lecionaram durante o estágio. É claro que elas estavam cientes de que se tratava de um projeto de investigação. Porém, isso é um indício da necessidade de auxílio que o futuro professor tem para transpor a teoria para prática, uma vez que precisa de ajuda ao tratar das questões específicas de cada área do saber. O intuito não é apresentar receitas de como estruturar uma parte da proposta curricular de um curso de formação inicial, mas evidenciar um modo viável de constituir um canal de articulação entre disciplinas curriculares.

Com a realização do presente trabalho, tem-se a certeza de que o mesmo se distancia das respostas a todas as inquietudes envolvidas na aprendizagem da docência para o ensino da Matemática nas séries iniciais. Contudo, acredita-se que ele mostra aspectos ainda pouco explorados pelas pesquisas, em especial por aquelas que focam a formação inicial de professores em Matemática. Por outro lado, o caminho percorrido permitiu compreender melhor certos aspectos que envolveram o processo formativo de cada caso estudado. Assim, espera-se que tanto os resultados obtidos com A1, A2 e A3 quanto algumas características implementadas para o desenvolvimento desta pesquisa, possam se constituir como ferramentas para subsidiar outras reflexões sobre a formação de professores. 


\section{REFERÊNCIAS}

ABIB, M. L. V dos S. A Construção de Conhecimentos sobre Ensino na Formação Inicial do Professor de Física: “...agora, nós já temos as perguntas.” São Paulo: USP, tese de doutorado, 1996, 300p.

AMARAL, E. M. R. do e MORTIMER, E. F. Uma metodologia para análise da dinâmica entre zonas de um perfil conceitual no discurso da sala de aula. In.: A pesquisa em ensino de ciências no Brasil e suas metodologias. Org. Flávia Maria Teixeira dos Santos, Ileana Maria Greca. Ijuí: Ed. Unijuí, 2006, 440p.

ALVES-MAZZOTTI, A. J.; GEWANDSZNAJDER, F. O método nas Ciências Naturais e Sociais: Pesquisa quantitativa e qualitativa. SP: Pioneira, 2 ed., 2001.

ARIZA, R. PORlán; GARCÍA, A. R.; POZO, R. M. del. Conocimiento Profesional y Epistemología de los Profesores I: Teoría, Métodos e Instrumentos. In.: Enseñanza de las Ciencias. CIDADE: EDITORA, p. 155-171, 1997.

BACHELARD, G. A Filosofia do Não. Trad. Joaquim José Moura Ramos et al. São Paulo: Abril Cultural, coleção Os Pensadores, 1978.

BARBOSA, J C. Modelagem matemática: concepções e experiências de futuros professores. Tese. Rio Claro: UNESP. 2001.

BARDIN, L. Análise de conteúdo. Trad. Luís A. Reto e Augusto Pinheiro. Lisboa: Edições 70, 1977, 226p.

BAUER, M. W. e AARTS, B. A construção do corpus: um princípio para a coleta de dados qualitativos. In.: Pesquisa qualitativa com texto, imagem e som. BAUER, M. W. e GASKELL, G (ed.). Petrópolis: Vozes, 2004, p. 39-63.

BAUER, M. W. e GASKELL, G (ed.). Pesquisa qualitativa com texto, imagem e som. Petrópolis: Vozes, 2004.

BERTONI, N. E. Formação do professor: concepção, tendências verificadas e pontos de reflexão. In.: Temas \& Debates - Formação de professores de matemática. Sociedade Brasileira de Educação Matemática - SBEM. Ano VIII, nº. 7, jul./1995, p. 08-15.

Mudanças nas concepções e práticas profissionais de professores de matemática do ensino médio. In.: Anais do VII ENEM. Rio de Janeiro. 2001.CD.

BICUDO, M. A. V. e GARNICA, A. V. M. Filosofia da educação matemática. Belo Horizonte: Autêntica, 2001.

BOGDAN, R. e BIKLEN, S. Investigação qualitativa em educação. Portugal: Porto. Coleção Ciências da Educação, 1994.

BOYER, C. B. História da Matemática. Elza F. Gomide (tradução). São Paulo: Edgar Blücher LTDA, $2^{\mathrm{a}}$.ed, 2002. 
CABRAL, T C B. contribuições da psicanálise à educação matemática. São Paulo: Faculdade de Educação da Universidade de São de Paulo. Tese. 1998.

CANCIAN, A K. Mudanças via reflexão e colaboração: uma experiência de trabalho junto a professores de matemática. In.: Anais do VII ENEM. Rio de Janeiro. 2001. p. 15.

CARVAlHO, A. M. P. de. Construção do conhecimento e ensino de ciências. In.: Em Aberto. Brasília: s/n., ano11, jul./set, 1992.

. O uso do vídeo na tomada de dados: pesquisando o desenvolvimento do ensino em sala de aula. In.: Pró-Posições. Campinas: UNICAMP, v. 7, n. 1[19], mar. 1996, p. 5-13.

- A inter-relação entre a Didática das Ciências e a Prática de Ensino. In.: Formação docente em Ciências: memórias e práticas. Org.: Sandra Escovedo Selles e Marcia Serra Ferreira. Niterói: Eduff, 2003. p. 105-115.

CARVALHO, A. M. P de e GIL PEREZ, D. Formação de professores em ciências. São Paulo: Cortez, $7^{\mathrm{a}}$. ed, 2003.

CARVALHO, D L de. A concepção matemática de professores também se transformam. Dissertação. 1989. 153p.

CASTRO, M C $\mathrm{P}$ de. Os conflitos nos ideários no ensino da matemática: uma retrospectiva das concepções de ensino da matemática no Brasil e suas influências no ensino atual. Dissertação. Rio de Janeiro: Ciências Pedagógicas/Instituto Superior de Estudos Pedagógicos - ISEP. 2003. 122p.

CHEVALLARD, Y. La transposición didáctica: del saber sabio ao saber enseñado. Buenos Aires: Aique, 1991. 197p.

CHEVALLARD, Y; et al. Estudar Matemáticas: o elo perdido entre o ensino e a aprendizagem. Porto Alegre: ArtMed, 2001.

CUNHA, A. M. de O. A Mudança Conceitual de Professores num Contexto de Educação Continuada. São Paulo: USP, tese de doutorado, 1999, 479p.

CURI, E. Formação de Professores polivalentes: uma análise de conhecimentos para ensinar Matemática e de crenças e atitudes que interferem na constituição desses conhecimento. São Paulo: Universidade Católica de São Paulo. Tese de Doutorado, 2004.

CURI, E. e PIRES, C. C. A formação matemática de professores dos anos iniciais do ensino fundamental face às novas demandas nacionais. In.: Anais do VIII ENEM. Recife. 2004. CD

CYRINO, M C de C T. As várias formas de conhecimento e o perfil do professor de matemática na ótica do futuro professor. São Paulo: Faculdade de Educação da Universidade de São de Paulo. Tese. 2003.

D'AMBRÓSIO, U. Da realidade à ação: reflexões sobre educação e matemática. $2^{\mathrm{a}}$ ed. São Paulo: Summus; Campinas - SP: UNICAMP, 1986. 115p. 
Educação matemática: da teoria à prática. Campinas, SP: Papirus, 1996. 121p. (Perspectivas em Educação Matemática)

Educação para uma sociedade em transição. Campinas, SP: Papirus, 1999. Coleção Papirus educação. 167p.

Educação matemática: uma visão do estado da arte. In: Pro-Posições. Campinas - SP: UNICAMP, ano 1, vol. 4, março de 1993, p. 07-17.

Entrevista com Ubiratan D'Ambrósio. In: Educação Matemática em Revista. São Paulo: SBEM, ano 6, n ${ }^{\mathrm{o}}$ 7, julho de 1999, p. 05-10.

. Etnomatemática: elo entre as tradições e a modernidade. In.: Pesquisa Qualitativa em Educação Matemática. Belo Horizonte: Autêntica. Coleção Tendências em Educação Matemática, 2001.

Prefácio. In.: Pesquisa Qualitativa em Educação Matemática. Marcelo de Carvalho Borba e Jussara de Loiola Araújo (org,). Belo Horizonte: Autêntica. Coleção Tendências em Educação Matemática, 2004, p. 11-24.

Sociedade, Cultura, Matemática e seu Ensino. In.: Educação e Pesquisa - Revista da Faculdade de Educação da USP. São Paulo: FEUSP, v. 31, n. 1, jan./mar 2005, p. 99-120.

FERREIRA, A C. Metacognição e desenvolvimento profissional de professores de matemática: uma experiência de trabalho colaborativo. Campinas: UNICAMP. Tese. 2003. 367p.

Um olhar retrospectivo sobre a pesquisa brasileira em formação de professores de matemática. In.: Formação de professores de matemática: explorando novos caminhos com outros olhares. Dario Fiorentini (organizador). Campinas: Mercado das Letras, 2003, p. 1950.

FIORENTINI, D. Alguns modos de ver e conceber o ensino da matemática no Brasil. In.: Zetetiké. Campinas: UNICAMP, ano 3, nº. 4, nov./1995, p. 01-37.

FIORENTINI, D. et al. Os saberes da experiência docente em matemática e a formação continuada de professores. In.: Revista Quadrante. Portugal, 1999.

FIORENTINI, D. et al. Formação de professores que ensinam Matemática: um balanço de 25 anos da pesquisa brasileira. In.: Educação em Revista. Belo Horizonte: UFMG, n. 36, dez. 2002, p. 137-160.

FIORENTINI, D. e LORENZATO, S. Investigações em educação matemática: percursos teóricos e metodológicos. Campinas: Autores Associados LTDA, 2006, 240p.

FIORENTINI, D. e NACARATO, A. M. (orgs). Cultura, formação e desenvolvimento profissional de professores que ensinam matemática. Campinas: Musa, 2005, 223p.

FONSECA, S.G. Ser professor no Brasil: história oral de vida. SP: Papirus, 1997. 
FREITAS, D. Mudança conceitual em sala de aula: uma experiência com formação inicial de professores. São Paulo: Faculdade de Educação da Universidade de São de Paulo. Tese. 1998.

GASKELL, G. Entrevistas individuais e grupais. In.: Pesquisa qualitativa com texto, imagem e som. BAUER, M. W. e GASKELL, G (ed.). Petrópolis: Vozes, 2004, p. 64-89.

GASPARIN, J. L. Gênese histórica do campo da didática moderna. In.: Conhecimento local e conhecimento universal: pesquisa, didática e ação docente. Joana P. Romanowski; Pura L. O. Martins, Sérgio R. A. Junqueira (orgs.). Curitiba: Champagnat, v. 1, 2004, p. 8598.

GODED, P. A. Los Futuros Maestros ante el Estudio de la Enseñanza e Aprendizaje de las Matemáticas: un estudio de caso. In.: Investigación en la escuela. CIDADE: EDITORA, p. 45-54, 2000.

GONÇALVES, T. O. e FIORENTINI, D. Formação e desenvolvimento profissional de docentes que forma matematicamente futuros professores. In.: Cultura, formação e desenvolvimento profissional de professores que ensinam matemática. Dario Fiorentini e Adair Mendes Nacarato (orgs). Campinas: Musa, 2005, p. 68-88.

GRAÇA, M. M. et al. Representações sobre a matemática, seu ensino e aprendizagem: um estudo exploratório. In.: Investigações em Ensino de Ciências. Porto Alegre: UFRGS, vol. 9, n. 1, 2004, capturado de http://www.if.ufrgs.br/public/ensino em 11/05/2006.

GUÉRIOS, E. Metodologia do ensino de matemática. In.: Metodologia de diferentes disciplinas. E. Ribeiro e S. Müller (orgs.). Curitiba: CETEPAR, DMTE, Universidade Federal do Paraná, 1992, p.8-14.

Espaços oficiais e intersteticiais da formação docente: histórias de um grupo de professores na área de ciências e matemática. Campinas: UNICAMP, 2002, tese.

HERNÁNDEZ, F. e SANCHO, J. M. A formação a partir da experiência vivida. In.: Pátio - Revista Pedagógica. Porto Alegre: Artmed, ano X, n. 40, nov./2006 - jan. 2007, p. 09-11.

HEWSON, P. W. A conceptual change approach to learning science. European Journal of Science Education. v. 3, n.4, 1981, p. 383-396.

HEWSON, P. W. e THORLEY, N. R. The conditions of conceptual change in the classroom. Internacional Journal of Science Education, v. 11, n. especial, 1989, p. 541-553.

HUETE, J. C. S. e BRAVO, J. A. F. O ensino da matemática: fundamentos teóricos e bases psicopedagógicas. Tradução de Ernani Rosa. Porto Alegre: Artmed, 2006.

JACQUES, E M da V. A concepção matemática dos professores das séries iniciais. Dissertação. Blumenau: Centro de Ciências da Educação - FURB. 2002. 120p. 
JORDÃO. R. DOS S. Tutoria e Pesquisa - Ação no Estágio Supervisionado: contribuições para a formação de professores de Biologia. SP: São Paulo. Tese, Faculdade de Educação da Universidade de São Paulo. 2005, 315p.

JURAMILLO QUICENO, D V. Tese. Re constituição do ideário de futuros professores de matemática num contexto de investigação sobre a prática pedagógica. Campinas: UNICAMP. 2003. 269p.

LEONTIEV, A. Uma Contribuição à Teoria do Desenvolvimento da Psique Infantil. In: Linguagem, desenvolvimento e aprendizagem. VYGOTSKY, L S; LURIA, A R; LEONTIEV, A São Paulo: Ícone-Editora da Universidade de São Paulo, 1988.

LIBÂNEO, J. C. Didática. São Paulo: Cortez, 1994.

LOIZOS, P. Vídeo, filme e fotografias como documentos de pesquisa. In.: Pesquisa qualitativa com texto, imagem e som. BAUER, M. W. e GASKELL, G (ed.). Petrópolis: Vozes, 2004, p. 137-155.

LUFFIEGO GARCÍA, M. Reconstruyendo el constructivismo: hacia un modelo evolucionista del aprendizage de conceptos. In.: Enseñanza de las Ciencias. v. 19, n. 3, 2001, p. 377-392, capturado de http://www.raco.cat/index.php/Ensenanza/ em 18/10/2006.

MACHADO, N. J. Matemática e realidade. São Paulo: Cortez, 3ª ed., 1994.

MANFREDO. E C G. O professor de $1^{\text {a a }} 4^{\text {a }}$ série e o ensino de matemática: concepções e práticas na formação. In.: Anais do VIII ENEM. Recife. 2004. CD.

MEDRANO, C. El cambio de las Concepciones de los estudiantes a través del conocimiento compartido: una experiencia universitaria. In.: Investigación en la escuela. CIDADE: EDITORA, p. 89-101, 2002.

MELO, M.V. Saberes de matemática durante o processo de formação de professores. In.: Anais XI CIAEM, CD - ROOM, Blumenau: Comitê Interamericano de Educação Matemática e FURB, 2003.

MIORIM, M. A. Introdução à história da educação matemática. São Paulo: Atual, 1998.

MIZUKAMI, M. das G. N. Aprendizagem da docência: conhecimento específico, contextos e práticas pedagógicas. In.: A formação do professor que ensina matemática: perspectivas e pesquisas. Adair Mendes Nacarato e Maria Auxiliadora Vilela Paiva (orgs.). Belo Horizonte: Autêntica, 2006, p. 213-231.

MOLL, L. C. Vygotsky e a Educação. Trad. Fani A. Tesseler. Porto Alegre: Artes Médicas, 1996.

MORTIMER, E. F. e CARVAlHO, A. M. P. de. Referenciais Teóricos para Análise do Processo de Ensino de Ciências. In.: Cadernos de Pesquisa. São Paulo: EDITORA, n. 96, p. 5-14, fev. 1996. 
MORTIMER, E. F. Evolução do Atomismo em Sala de Aula: Mudança de Perfis Conceituais. São Paulo: USP, tese de doutorado, 1994, 281p.

Linguagem e Formação de Conceitos no Ensino de Ciências. Belo Horizonte: UFMG, 2006, 383 p.

MORTIMER, E. F.; MACHADO, A. H. Anomalies and Conflicts in Classroom Discourse. In. Science Education. New York: John Wiley \& Sons, p. 429-444, 2000.

MOURA, M O de. A construção do signo numérico em situação de ensino. SP: USP, 1992, 151p. Tese.

A atividade de ensino como ação formadora. In.: Ensinar a ensinar: didática para escola fundamental e média. A D de CASTRO e A M P de CARVALHO (org.) São Paulo: Thomson, 2001, p. 143-162.

NACARATO, A M. et al Os graduandos em pedagogia e suas filosofias pessoais frente à matemática e seu ensino. In.: Zetetiké. Campinas: UNICAMP. v. 12, n. 21, janeiro/junho 2004, p. 9-33.

NACARATO, A. M. e PAIVA, M. A. V. A formação do professor que ensina matemática: estudos e perspectivas a partir das investigações realizadas pelos pesquisadores do GT 7 da SBEM. In.: A formação do professor que ensina matemática: perspectivas e pesquisas. Adair Mendes Nacarato e Maria Auxiliadora Vilela Paiva (orgs.). Belo Horizonte: Autêntica, 2006, p. 07-26.

ONUCHIC, L. de la R. Ensino-aprendizagem de matemática a través da resolução de problemas. In.: Pesquisa em educação matemática: concepções e perspectivas. Maria Aparecida Viggiani Bicudo (organizadora). São Paulo: Ed. UNESP, 1999, p. 199-220.

ONUCHIC, L. de la R. e ALLEVATO, N. S. G. Novas reflexões sobre o ensinoaprendizagem de matemática através da resolução de problemas. In.: Educação matemática: pesquisa em movimento. Maria Aparecida Viggiani Bicudo e Marcelo de Carvalho Borba (organizadores). São Paulo: Cortez, 2 ed., 2005, p. 213-231.

PAIS, L. C. Ensinar e aprender matemática. Belo Horizonte: Autêntica, 2006.

PAIVA, M A V. As concepções de professores e sua prática docente. In.: Anais do VI ENEM. São Leopoldo. v. 2. 1998. p. 595.

As concepções do ensino de geometria: um estudo a partir da prática docente. Tese. Rio de Janeiro: PUCRJ. 1999.

. Educação matemática e formação de professores. In.: Anais do VII ENEM. CD ROOM. Rio de Janeiro: SBEM. 2001.

PIAGET, J. A Equilibração das estruturas cognitivas. Trad. Marion Merlone dos Santos Penna. Rio de Janeiro: Zahar Editores, 1976. 
. O nascimento da inteligência na criança. Trad. Álvaro Cabral. Rio de Janeiro: Zahar Editores, 1970.

PEREZ, G. Formação de professores de matemática sob a perspectiva do desenvolvimento profissional. In.: Pesquisa em educação matemática: concepções e perspectivas. Maria Aparecida Viggiani Bicudo (organizadora). São Paulo: Ed. UNESP, 1999, p. 263-284.

PINTO, N. B. Tendências no ensino da matemática. In.: Anais do XII ENDIPE. Curitiba, 2004. CD.

PLATÃO, 427-347 a.C. Diálogos III: a República. Trad. Leonel Vallandro. $25^{\mathrm{a}}$ ed. Rio de Janeiro: Ediouro, 1999. 236p.

POLETTINI, A. Análise das experiências vividas determinando o desenvolvimento profissional do professor de matemática. In.: Pesquisa em educação matemática: concepções e perspectivas. Maria Aparecida Viggiani Bicudo (organizadora). São Paulo: Ed. UNESP, 1999, p. 247-262.

PONTE, J. P. da. Concepções dos professores de matemática e processos de formação. 1992. Capturado em 08/11/2005 de http://www.educ.fc.ul.pt/docentes/jponte/artigos_pt.htm

PONTE, J P da; et al. Investigações matemáticas na sala de aula. Belo Horizonte: Autêntica, 2005.

PORLÁN ARIZA, R. et al. Conocimiento profesional y epistemología de los profesores I: teoría, métodos e instrumentos. In.: Revista Enseñanza de las ciencias, Investigación didáctica. Barcelona: Universitat Autònoma de Barcelona. V. 15, n. 2, p. 155-171, 1997. capturado em http://www.raco.cat/index.php/Ensenanza/issue/view/1786/showToc

POSNER, G. J. et al. Accommodation of a Scientific Conception: Toward a Theory of Conceptual Change. In.: Science Education. New York: John Wiley \& Sons, p. 211-227, 1982.

POWELL, A. B.; et al. Uma abordagem à análise de dados de vídeo para investigar o desenvolvimento de idéias e raciocínios matemáticos de estudantes. In.: Bolema. Rio Claro: UNESP, ano 17, n. 21, 2004, p. 88-140.

POZO, J. I. Aprendizes e Mestres: a nova cultura da aprendizagem. Trad. Ernani Rosa. Porto Alegre: ArtMed, 2002, 296p.

El Cambio sobre el Cambio: hacia una nueva concepción del cambio conceptual en la construcción del conocimiento científico. In.: La Construcción del conocimiento escolar. Org. María José Rodrigo e José Arnay. Barcelona: Paidós, p. 155-176, 1997.

REHFELDT, M J H. As concepções de professores e alunos acerca da construção do conhecimento matemático. In.: Anais do VIII ENEM. Recife. 2004. CD 
RICCI, D. Ser professor de matemática: concepções de alunos e professores de cursos noturnos de licenciatura. São Paulo: Pontifica Universidade Católica de São Paulo. Tese. 2003.

ROMBERG, T. A. Perspectivas sobre o conhecimento e métodos de pesquisa. In.: Bolema. Tradução de Lourdes de la Rosa Onuchic e Maria Lúcia Boero. Rio Claro: UNESP, ano 20, $\mathrm{n}^{\circ} .27,2007$, p. 93-140.

SANTOS, M. E. V. M. dos. Mudança Conceptual na Sala de Aula: um desafio pedagógico. Lisboa: Livros Horizonte, 1991, 261p.

SCHMITT, M.A.B. e BIEMBENGUT, M.S. Avaliação do conhecimento e da ação de educadores catarinenses atuantes nas séries iniciais do ensino fundamental. In.: Anais XI CIAEM, CD - ROOM, Blumenau: Comitê Interamericano de Educação Matemática e FURB, 2003.

SILVA, J. Filosofia da matemática e filosofia da educação matemática. In.: Pesquisa em educação matemática: concepções e perspectivas. Maria Aparecida Viggiani Bicudo (organizadora). São Paulo: Ed. UNESP, 1999, p. 45-58.

SILVEIRA, D.N. Possibilidade de inovação na formação de professores de séries iniciais - na matemática. In.: Anais XI CIAEM, CD - ROOM, Blumenau: Comitê Interamericano de Educação Matemática e FURB, 2003.

SILVÉRIO, M dos S. Concepções sobre matemática: visões de professores do ensino fundamental. Dissertação. São Paulo: USP. 2003. 253p.

STRYKE, K. A e POSNER, G. J. A revisionist theory of conceptual change. In.: Philosophy of Science Cognitive Psychology and Educational Theory and Practice. R. Duschl e R. Hamilton (eds.). Albany: SUNY Press. 1992.

SZTAJN, P. Prática de Ensino na Formação de Professores das Séries Iniciais - Onde está a Matemática. In.: VII ENEM. palestra, Rio de Janeiro: SBEM, 2001.

SZYMANSKY, H. (org.) et al. A entrevista na pesquisa em educação: a prática reflexiva. Brasília: Líber Livro. Série Pesquisa em Educação, v. 4, 2004.

THIOLLENT, M. J. M. Crítica metodológica, investigação social e enquête operária. São Paulo: Polis, 1982.

THOMPSON, A. A relação entre concepções de matemática e de ensino de matemática de professores na prática pedagógica. Tradução de Gilberto F. de Melo e Tadeu Oliver Gonçalves. In.: Revista Zitetiké. Campinas: UNICAMP, v. 5, n. 8, jul./dez, 1997

UNIVERSIDADE FEDERAL DO PARANÁ [a]. Setor de Educação. Departamento de Teoria e Prática de Ensino. Plano de Ensino: Prática Pedagógica C: Estágio em Docência. 2005.

UNIVERSIDADE FEDERAL DO PARANÁ [b]. Setor de Educação. Departamento de Teoria e Prática de Ensino. Plano de Ensino: Metodologia do Ensino de Matemática I. 2005. 
VIGOTSKI, L. S. A Formação Social da Mente. Trad. José Cipolla Neto, Luis Silveira Menna Barreto e Solange Castro Afeche. São Paulo: Martins Fontes, 4a . ed., 1991.

VILLANI, A. e ARRUDA, S. M. Mudança Conceitual no Ensino de Ciências. In. Caderno Catarinense de Ensino de Física. Florianópolis: UFSC, v. 11, n. 2, p. 88-99, ago. 1994.

VILLANI, A. e CABRAL, T. C. B. Mudança Conceitual, Subjetividade e Psicanálise. In.: Investigações em Ensino de Ciências. Porto Alegre: UFRGS, vol. 2, n. 1, 1997, capturado de http://www.if.ufrgs.br/public/ensino em 11/05/2006.

VILLANI, A. e FREITAS, D. de. Análise de uma Experiência Didática na Formação de Professores de Ciências. In.: Investigações em Ensino de Ciências. Porto Alegre: UFRGS, vol. 3, n. 2, 1998, capturado de http://www.if.ufrgs.br/public/ensino em 11/05/2006.

de. Formação de Professores de Ciências: um Desafio sem Limites. In.: Investigações em Ensino de Ciências. Porto Alegre: UFRGS, vol. 7, n. 3, 2002, capturado de http://www.if.ufrgs.br/public/ensino em 17/09/2004.

ZIMER, T. T. B. Mundos de Significados: saberes e práticas do ensino de Matemática na formação de professores das séries iniciais no curso de Pedagogia da Universidade Federal do Paraná. Dissertação Curitiba: UFPR. 2002. 198p. 


\section{APÊNDICES}

APÊNDICE 1 Roteiro do trabalho da disciplina de Prática Pedagógica C-Estágio em Docência.

APÊNDICE 2 Roteiro do trabalho da disciplina de Metodologia do Ensino de

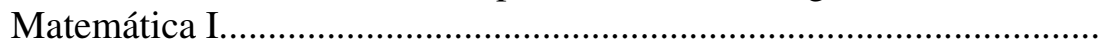

APÊNDICE 3 Roteiro das entrevistas.

APÊNDICE 4 Exemplo do modo de sistematização inicial dos dados..... 


\section{APÊNDICE 1 - ROTEIRO DE AULAS NO 1. ${ }^{\circ}$ E 2. ${ }^{\circ}$ SEMESTRES - PRÁTICA PEDAGÓGICA E FONTES DE DADOS}

continua

\begin{tabular}{|c|c|c|c|c|}
\hline AULAS & LOCAL & ALUNOS & FONTES DE DADOS & $\begin{array}{l}\text { ATIVIDADES NO } 1 .^{\circ} \text { SEMESTRE } \\
\end{array}$ \\
\hline 1 e 2 & UFPR & Todos & $\begin{array}{l}\text { Doc.:ficha } \\
\text { cronograma de } \\
\text { trabalho, ficha de } \\
\text { freqüência; autorização } \\
\text { para estágio e cadastro } \\
\text { de aluno. } \\
\text { Diário: p. 1-10 } \\
\text { Vídeo: 1P1d }\end{array}$ & $\begin{array}{l}\text { Contrato Didático: conversa inicial para acerto de cronograma de trabalho e } \\
\text { entrega de documentos para apresentação nas escolas campo de estágio. } \\
\text { Estudo da temática "O sentido do estágio na formação profissional". Aula } \\
\text { expositiva. }\end{array}$ \\
\hline 3 e 4 & Escolas & Todos & Não há fontes de dados & $\begin{array}{l}\text { Contato inicial dos alunos com as escolas. Estabelecimento de contrato de } \\
\text { estágio. }\end{array}$ \\
\hline 5 & UFPR & Todos & $\begin{array}{l}\text { Doc.: roteiro para } \\
\text { relatório de estágio; } \\
\text { lista de escolas campo } \\
\text { de estágio, lista dos } \\
\text { grupos de estágio. } \\
\text { Diário: p. 11-15. } \\
\text { Vídeo: 5P1d }\end{array}$ & $\begin{array}{l}\text { Organização do relatório: estudo de documentos que orientam a elaboração } \\
\text { do relatório sobre a caracterização do campo de estágio. Listagem de } 19 \\
\text { instituições públicas configuradas como campo de estágio. }\end{array}$ \\
\hline 6 a 8 & Escolas & Todos & Não há fontes de dados & $\begin{array}{l}\text { Exploração do campo de estágio para a respectiva caracterização. Alunos } \\
\text { organizaram-se em grupos com até } 3 \text { participantes. }\end{array}$ \\
\hline 9 & UFPR & Todos & $\begin{array}{l}\text { Doc.: cronograma da } \\
\text { sessões de leitura do } \\
\text { relatório. } \\
\text { Diário: p. 16-17. } \\
\text { Vídeo: 9P1d }\end{array}$ & $\begin{array}{l}\text { Agendamento de } 19 \text { sessões para a leitura da } 1 .^{\text {a }} \text { versão do relatório. Cada } \\
\text { sessão será de } 30 \mathrm{~min} \text {. Esclarecimento de dúvidas sobre a elaboração do } \\
\text { relatório. }\end{array}$ \\
\hline 10 a 13 & Escolas & Todos & Não há fontes de dados & racterização do campo de estágio e elaboração do relatório. \\
\hline
\end{tabular}




\begin{tabular}{|c|c|c|c|c|}
\hline AUIAS & IOCAL & ALUNOS & FONTES DE DADOS & ATIVIDADFS NO $1{ }^{\circ}$ SEMESTRF \\
\hline 14 & $\begin{array}{l}\text { UFPR } \\
\text { e } \\
\text { Escolas }\end{array}$ & $\begin{array}{l}5 \text { grupos } \\
\text { Os demais } \\
\text { ficaram no campo } \\
\text { de estágio }\end{array}$ & $\begin{array}{l}\text { Doc.: não há. } \\
\text { Diário: p. } 18-22 . \\
\text { Vídeo: } 14 \mathrm{P} 1 \mathrm{~d}\end{array}$ & $\begin{array}{l}\text { Leitura do relatório de cada grupo, realizada pela prof }{ }^{\text {a }} \text { de Prática na presença } \\
\text { dos respectivos alunos. Orientação para aprimoramento dos textos e } \\
\text { esclarecimento de dúvidas. Vale esclarecer que outros } 4 \text { grupos foram } \\
\text { atendidos fora do horário de aula. }\end{array}$ \\
\hline 15 & $\begin{array}{l}\text { UFPR } \\
\text { e } \\
\text { Escolas }\end{array}$ & $\begin{array}{l}5 \text { grupos } \\
\text { Os demais } \\
\text { ficaram no campo } \\
\text { de estágio }\end{array}$ & $\begin{array}{l}\text { Doc.: não há. } \\
\text { Diário: p. } 23 \\
\text { Vídeo: } 14 \mathrm{P} 1 \mathrm{~d}\end{array}$ & $\begin{array}{l}\text { Leitura do relatório de cada grupo, realizada pela prof }{ }^{\text {a }} \text {. de Prática na presença } \\
\text { dos respectivos alunos. Orientação para aprimoramento dos textos e } \\
\text { esclarecimento de dúvidas. Explicitação da idéia de que essa disciplina tem } \\
\text { por finalidade colocar em prática toda a teoria estudada até então. }\end{array}$ \\
\hline 16 & $\begin{array}{l}\text { UFPR } \\
\text { e } \\
\text { Escolas }\end{array}$ & $\begin{array}{l}5 \text { grupos } \\
\text { Os demais } \\
\text { ficaram no campo } \\
\text { de estágio }\end{array}$ & $\begin{array}{l}\text { Doc.: não há. } \\
\text { Diário: p. } 24 \\
\text { Vídeo: } 14 \mathrm{P} 1 \mathrm{~d}\end{array}$ & $\begin{array}{l}\text { Leitura do relatório de cada grupo, realizada pela prof }{ }^{\mathrm{a}} \text {. de Prática na presença } \\
\text { dos respectivos alunos. Orientação para aprimoramento dos textos e } \\
\text { esclarecimento de dúvidas. }\end{array}$ \\
\hline 17 & UFPR & Todos & $\begin{array}{l}\text { Doc.: relatório de } \\
\text { estágio em grupo. } \\
\text { Diário: não há. } \\
\text { Vídeo: não há. }\end{array}$ & $\begin{array}{l}\text { Entrega, pelos alunos, da versão final do relatório referente ao } 1^{\circ} \text { semestre à } \\
\text { prof }^{\mathrm{a}} \text {. de Prática.. }\end{array}$ \\
\hline JULHO & FÉRIAS & Todos & Não há. & Conforme res. 91/04 CEPE-UFPR \\
\hline AULAS & LOCAL & ALUNOS & FONTES DOS DADOS & $\begin{array}{l}\text { ATIVIDADES NO 2. }{ }^{\circ} \text { SEMESTRE } \\
\end{array}$ \\
\hline 18 a 21 & Escolas & Todos & Não há. & Observação em sala de aula e solicitação de conteúdos para a regência. \\
\hline 22 & UFPR & Todos & $\begin{array}{l}\text { Doc.: texto Método } \\
\text { Dermeval Saviani (6) e } \\
\text { Estrutura para relatório } \\
\text { individual de estágio. } \\
\text { Diário: p. } 25-26 \\
\text { Vídeo: 22P1d }\end{array}$ & $\begin{array}{l}\text { Abordagem teórica para elaboração dos planos de aula e roteiro para } \\
\text { construção do relatório do } 2 .^{\circ} \text { semestre. Agendamento de horários para leitura } \\
\text { dos planos de aula. Cada sessão terá } 15 \text { min e será individual. }\end{array}$ \\
\hline
\end{tabular}


conclusão

\begin{tabular}{|c|c|c|c|c|}
\hline AULAS & LOCAL & ALUNOS & FONTES DOS DADOS & $\begin{array}{l}\text { ATIVIDADES NO 2. }{ }^{\circ} \text { SEMESTRE } \\
\end{array}$ \\
\hline 23 & $\begin{array}{l}\text { UFPR } \\
\text { e } \\
\text { Escolas }\end{array}$ & $\begin{array}{l}13 \text { alunos } \\
\text { Os demais }\end{array}$ & $\begin{array}{l}\text { Doc.: cronograma das } \\
\text { sessões de leitura dos } \\
\text { planos de aula. } \\
\text { Diário: } \text { p. } 27-28 \\
\text { Vídeo: } 23 \text { P1d }\end{array}$ & $\begin{array}{l}\text { Identificação das aulas a serem dadas. Leitura dos planos e re (orientação). } \\
\text { Constatou-se que } 11 \text { alunos iriam dar aulas de Matemática, os quais } \\
\text { receberam auxílio da prof } \text {. de Metodologia para re-elaborarem seus planos de }_{\text {aula. Entre essa aula e a próxima houve o atendimento a outros } 21 \text { alunos fora }} \\
\text { do horário da mesma. Constatou-se a desistência da disciplina de } 1 \text { aluno. }\end{array}$ \\
\hline 24 a 30 & Escolas & Todos & $\begin{array}{l}\text { Doc.: notas de } \\
\text { observação de estágio. } \\
\text { Diário: não há. } \\
\text { Vídeo: } 24-30 \text { P1d }\end{array}$ & Exercício de docência no estágio. \\
\hline 31 & UFPR & Todos & $\begin{array}{ll}\text { Doc.:cronograma de } \\
\text { sessões de leitura de } \\
\text { relatório } \\
\text { Diário: } \text { p. } 29 . \\
\text { Vídeo: } 31 \text { P1d }\end{array}$ & $\begin{array}{l}\text { Estudo da estrutura do relatório individual de estágio e organização de } \\
\text { cronograma para leitura da } 1 .^{\text {a }} \text { versão do relatório individual. Serão } 5 \text { sessões } \\
\text { de } 20 \text { min para cada aluno. }\end{array}$ \\
\hline 32 & UFPR & 09 alunos & $\begin{array}{l}\text { Doc.: notas de } \\
\text { observação de estágio. } \\
\text { Diário: não há. } \\
\text { Vídeo:32P1d }\end{array}$ & $\begin{array}{l}\text { Leitura, pela prof }{ }^{a} \text {. dos relatórios e orientação para a redação final. Vale } \\
\text { esclarecer que entre essa aula e a próxima foram atendidos } 2 \text { alunos fora do } \\
\text { horário. }\end{array}$ \\
\hline 33 & UFPR & 09 alunos & $\begin{array}{l}\text { Doc.: notas de } \\
\text { observação de estágio. } \\
\text { Diário: não há. } \\
\text { Vídeo:32P1d }\end{array}$ & $\begin{array}{l}\text { Leitura, pela prof }{ }^{a} \text {. dos relatórios e orientação para a redação final. Vale } \\
\text { esclarecer que entre essa aula e a próxima foram atendidos } 13 \text { alunos fora do } \\
\text { horário. }\end{array}$ \\
\hline 34 & UFPR & Todos & $\begin{array}{l}\text { Doc.: relatórios de } \\
\text { docência. Individual. } \\
\text { Diário: não há. } \\
\text { Vídeo: não há. }\end{array}$ & $\begin{array}{l}\text { Entrega, para a } \text { prof }^{\mathrm{a}} \text {. de Prática Pedagógica, do relatório de docência, } \\
\text { referente ao } 2 .^{\circ} \text { semestre. }\end{array}$ \\
\hline
\end{tabular}

Fonte: pesquisa de campo. 


\section{APÊNDICE 2 - ROTEIRO DAS AULAS DE METODOLOGIA DE ENSINO DE MATEMÁTICA}

\begin{tabular}{|c|c|c|}
\hline AULAS & ATIVIDADES & FONTES DE DADOS \\
\hline 1 & $\begin{array}{l}\text { Estabelecimento de contrato didático com } \\
\text { apresentação da disciplina e da pesquisa. } \\
\text { Assunto: O que é Metodologia do Ensino de } \\
\text { Matemática? } \\
\text { Atividade: leitura e discussão da Fábula dos } \\
\text { Bichos. }\end{array}$ & $\begin{array}{l}\text { Registro escrito (grupo): } 4 \text { questões } \\
\text { orientadoras de leitura. } \\
\text { Doc.: ficha } 2 \text {; texto Fábula. } \\
\text { Diário: p. } 1-8 . \\
\text { Vídeo: } 1 \mathrm{M} 1 \text { e } 1 \mathrm{M} 1 \mathrm{~d}\end{array}$ \\
\hline 2 & $\begin{array}{l}\text { Resgate das idéias apresentadas pelos } \\
\text { alunos na aula anterior, sistematização no } \\
\text { quadro. Perspectivas tradicionais e } \\
\text { construtivistas. } \\
\text { Assunto: O que é Metodologia do Ensino de } \\
\text { Matemática? } \\
\text { Atividade: análise do texto por meio de } \\
\text { debate oral. }\end{array}$ & $\begin{array}{l}\text { Registro escrito: não houve. } \\
\text { Doc.: texto Metodologia do Ensino } \\
\text { de Matemática. Guérios. } \\
\text { Diário: p. 9-10. } \\
\text { Vídeo: } 2 \mathrm{M} 1 ; 2 \mathrm{M} 2 ; 2 \mathrm{~m} 3 \text { e 2M1d }\end{array}$ \\
\hline 3 & $\begin{array}{l}\text { Debate em grupo sobre a relação entre } \\
\text { conteúdo matemático e prática pedagógica. } \\
\text { Assunto: características da Matemática e do } \\
\text { processo ensino-aprendizagem. } \\
\text { Atividade: construção do quadro ação } \\
\text { didática e apresentação à turma de sala. }\end{array}$ & $\begin{array}{l}\text { Registro escrito (grupo): quadro } \\
\text { ação didática e questão sobre } \\
\text { finalidade de ensinar matemática. } \\
\text { Doc.: não houve. } \\
\text { Diário: p. 11-13 } \\
\text { Vídeo: 3M1 } \\
\text { Áudio: 3M1a }\end{array}$ \\
\hline 4 & $\begin{array}{l}\text { Sistematização de idéias no quadro. } \\
\text { Assunto: qual a finalidade de ensinar } \\
\text { Matemática? } \\
\text { Atividade: responder questionário, revisar } \\
\text { idéias exposta na aula anterior e analisá-las } \\
\text { mediante referencial teórico. }\end{array}$ & $\begin{array}{l}\text { Registro escrito: questionário } 1 . \\
\text { Doc.: texto Ensino de Matemática e } \\
\text { a Formação do Cidadão. Imenes. } \\
\text { Diário: p. 14-16. } \\
\text { Vídeo: 4M1 }\end{array}$ \\
\hline 5 & $\begin{array}{l}\text { Aula expositiva com poucas intervenções } \\
\text { por parte dos alunos. } \\
\text { Assunto: trajetória histórica do ensino da } \\
\text { Matemática. } \\
\text { Atividade: sistematizações orais e no } \\
\text { quadro da relação entre concepções pessoais } \\
\text { e abordagens históricas (localização). }\end{array}$ & $\begin{array}{l}\text { Registro escrito: não houve. } \\
\text { Doc.: cap. } 1 \text { da dissertação Mundos } \\
\text { de Significados. Zimer. } \\
\text { Diário: p. } 17-19 . \\
\text { Vídeo: } 5 \text { M1 e 5M1d. }\end{array}$ \\
\hline 6 & $\begin{array}{l}\text { Sistematização de idéias no quadro. } \\
\text { Assunto: diferentes modos de conceber o } \\
\text { conhecimento. } \\
\text { Atividade: estabelecer relações entre a } \\
\text { abordagem teórica da Etnomatemática e } \\
\text { situação hipotética. (texto Caitités). }\end{array}$ & $\begin{array}{l}\text { Registro escrito: não houve. } \\
\text { Doc.: livro Etnomatemática: o elo } \\
\text { entre tradições e a modernidade. } \\
\text { D’Ambrósio e exercício dos } \\
\text { Caitités. Moura. } \\
\text { Diário: p. 20-24. } \\
\text { Vídeo: 6M1 e 6M1d. }\end{array}$ \\
\hline 7 & $\begin{array}{l}\text { Sistematização de idéias no quadro. } \\
\text { Reflexos da Etnomatemática na organização } \\
\text { da prática pedagógica. } \\
\text { Assunto: Como ensinar matemática? } \\
\text { Atividade: resolver problema dos Caitités. }\end{array}$ & $\begin{array}{l}\text { Registro escrito: não houve. } \\
\text { Diário: p. } 25-26 . \\
\text { Vídeo: } 7 \mathrm{M} 1\end{array}$ \\
\hline
\end{tabular}


continuação

\begin{tabular}{|c|c|c|}
\hline AULAS & ATIVIDADES & FONTES DE DADOS \\
\hline 8 & $\begin{array}{l}\text { Sistematização de idéias no quadro. Alunos } \\
\text { escrevem no quadro. Diferentes modos de } \\
\text { resolver uma mesma situação, } \\
\text { evidenciamento da idéia de que não há } \\
\text { apenas um modo de resolver uma questão. } \\
\text { Assunto: Como ensinar matemática? } \\
\text { Atividade: análise de várias resoluções de } \\
\text { um mesmo problema. }\end{array}$ & $\begin{array}{l}\text { Registro escrito: não houve. } \\
\text { Doc.: cap } 4 \text { e } 6 \text { do livro Resolução } \\
\text { de Problemas. Smole. } \\
\text { Diário: p. } 27-30 . \\
\text { Vídeo: } 8 \mathrm{M} 1 .\end{array}$ \\
\hline 9 & $\begin{array}{l}\text { Resolução em conjunto do problema dos } \\
\text { Caitités, no quadro. Evidenciamento do } \\
\text { domínio do conteúdo específico para se } \\
\text { entender o pensamento do aluno. } \\
\text { Assunto: Como ensinar matemática, pela } \\
\text { Resolução de Problemas? } \\
\text { Atividade: organizar uma proposta de } \\
\text { ensino com o uso de problemas e da mídia } \\
\text { escrita. }\end{array}$ & $\begin{array}{l}\text { Registro escrito: texto justificado } \\
\text { sobre as dificuldades que teve no } \\
\text { problema dos Caitités. } \\
\text { Doc.: cap. } 7 \text { do livro da Smole e } \\
\text { livro de Didática da Resolução de } \\
\text { Problemas de Dante. } \\
\text { Diário: p. 31-34. } \\
\text { Vídeo: 9M1 e 9M1d. }\end{array}$ \\
\hline 10 & $\begin{array}{l}\text { Seminário sobre o tema avaliação. } \\
\text { Evidenciamento do que os alunos pensam } \\
\text { sobre o como avaliar em Matemática. } \\
\text { Assunto: O que e como os alunos aprendem } \\
\text { matemática? } \\
\text { Atividade: análise, individual, das } \\
\text { resoluções de problemas com a mídia } \\
\text { escrita. Parecer avaliativo. }\end{array}$ & $\begin{array}{l}\text { Registro escrito: parecer avaliativo, } \\
\text { individual. } \\
\text { Doc. Texto Avaliação em } \\
\text { matemática nas séries iniciais. Souza } \\
\text { e Sanchez. } \\
\text { Diário: p. } 35-40 . \\
\text { Vídeo: } 10 \mathrm{M} 1\end{array}$ \\
\hline 11 & $\begin{array}{l}\text { Sistematização de idéias no quadro sobre } \\
\text { como os alunos aprendem. } \\
\text { Assunto: Como os alunos aprendem e como } \\
\text { se ensina por meio da Modelagem } \\
\text { Matemática? } \\
\text { Atividade: elaboração de proposta de ensino } \\
\text { fundamentada nos princípios da modelagem } \\
\text { matemática. }\end{array}$ & $\begin{array}{l}\text { Registro escrito: proposta de } \\
\text { modelagem matemática, individual. } \\
\text { Doc. Textos Da medida linear à } \\
\text { medida cúbica... Guérios, Zimer e } \\
\text { Dias. E Guérios e Modelagem } \\
\text { Matemática. Jonei Serqueira. Vídeo } \\
\text { proposta Jardim Botânico. } \\
\text { Diário: p. 41-44. } \\
\text { Vídeo: } 11 \mathrm{M} 1 .\end{array}$ \\
\hline 12 & $\begin{array}{l}\text { Sistematização de idéias no quadro. } \\
\text { Conhecendo a brinquedoteca e sua proposta, } \\
\text { conhecendo jogos matemáticos da } \\
\text { brinquedoteca. } \\
\text { Assunto: Como os alunos aprendem e como } \\
\text { se ensina por meio de Jogos Didáticos } \\
\text { Matemáticos. } \\
\text { Atividade: brincar com os jogos e então } \\
\text { apresentar parecer, oral, sobre a experiência } \\
\text { em relação ao processo ensino- } \\
\text { aprendizagem. }\end{array}$ & $\begin{array}{l}\text { Registro escrito: re-escrita da fábula. } \\
\text { Individual. } \\
\text { Doc.: A séria busca no jogo: do } \\
\text { lúdico na matemática. Ori. E } \\
\text { proposta para realização de projeto } \\
\text { com jogos. Lino de Macedo. } \\
\text { Diário: p. } 45-47 \\
\text { Vídeo: } 12 \mathrm{M} 1 \text { e } 12 \mathrm{M} 1 \mathrm{~d} \text {. }\end{array}$ \\
\hline
\end{tabular}




\begin{tabular}{|c|c|c|}
\hline AULAS & ATIVIDADES & FONTES DE DADOS \\
\hline 13 & $\begin{array}{l}\text { Observação das idéias e esclarecimento de } \\
\text { dúvidas em cada equipe. } \\
\text { Assunto: como ensinar matemática por } \\
\text { meio do jogo didático. } \\
\text { Atividade: Criação da própria proposta de } \\
\text { jogo matemático. Atividade em grupo. }\end{array}$ & $\begin{array}{l}\text { Registro escrito: não houve. } \\
\text { Doc.: brincadeiras infantis nas aulas } \\
\text { de matemática. Smole. } \\
\text { Diário: p. } 48-50 . \\
\text { Vídeo: } 13 \mathrm{M} 1 \text { e } 13 \mathrm{M} 1 \mathrm{~d} \text {. }\end{array}$ \\
\hline 14 & $\begin{array}{l}\text { Registro das idéias pessoais sobre } \\
\text { matemática e o processo ensino- } \\
\text { aprendizagem. Retomada das concepções } \\
\text { apresentadas no início do período letivo. } \\
\text { Atividade em grupo para testar os protótipos } \\
\text { de jogos. Observação das propostas } \\
\text { construídas e orientação para possíveis } \\
\text { adequações. } \\
\text { Assunto: Como os alunos aprendem e como } \\
\text { se ensina por meio de Jogos Didáticos } \\
\text { Matemáticos. } \\
\text { Atividade: brincar com os jogos construídos } \\
\text { pelas outras equipes e dar um parecer } \\
\text { avaliativo. Atividade em grupo. }\end{array}$ & $\begin{array}{l}\text { Registro escrito: questionário } 2 \text { e re- } \\
\text { escrita do questionário } 1 . \\
\text { Doc.: sem documentos específicos } \\
\text { nesta aula. } \\
\text { Diário: p. } 51-58 \text {. } \\
\text { Vídeo: } 14 \mathrm{M} 1\end{array}$ \\
\hline 15 & Recebimento das atividades finais. & $\begin{array}{l}\text { Registro escrito: auto-avaliação. } \\
\text { Doc.: sem documentos } \\
\text { Diário: p. } 60 . \\
\text { Vídeo: sem vídeo. }\end{array}$ \\
\hline
\end{tabular}




\section{APÊNDICE 3 - ROTEIRO DAS ENTREVISTAS}

- ROTEIRO PARA SESSÃO DE ORIENTAÇÃO INDIVIDUAL DE PLANO DAS AULAS DE MATEMÁTICA

1 OBJETIVO GERAL DA SESSÃO - investigar a idéia do que consiste uma boa aula de matemática.

2 OBJETIVOS ESPECÍFICOS DA SESSÃO

O que quer ensinar?

Como quer ensinar e por quê?

O que pretende que o aluno aprenda?

Como gostaria que fosse a aula e por quê?

Você considera esse formato uma boa aula de matemática e por quê?

\section{QUESTÕES COMPLEMENTARES}

\section{Conteúdo.}

Série.

Planejamento.

Quantidade de alunos.

Tempo de duração da aula.

Explicação do que pensou sobre a aula.

Evidenciamento sobre o que pensou em ensinar.

Suposição do que vai acontecer na aula.

Evidenciamento sobre o que supôs que os alunos estarão aprendendo. 


\section{- ROTEIRO PARA ENTREVISTA FINAL}

1 OBJETIVO GERAL: Refletir juntamente com o entrevistado sobre suas concepções de ensino/aprendizagem em Matemática e de Matemática.

\section{OBJETIVOS ESPECÍFICOS}

Analisar as aulas desenvolvidas em relação às expectativas e resultados obtidos sob o aspecto do ensino/aprendizagem em matemática.

Esclarecer idéias sobre o ensino/aprendizagem em matemática evidenciadas nos questionários.

Evidenciar conflitos e contradições entre as idéias e as atitudes.

Conhecer aspectos relacionados a experiência profissional de cada sujeito e possíveis relações com a profissão de professor.

\section{QUESTÕES-GUIA}

a) Qual é sua atuação profissional? Possui experiência com o magistério? Quanto tempo?

Como chegou ao curso de Pedagogia? Como é ser professor?

b) Quais eram suas expectativas em relação à sua aula? Quais resultados você considera ter obtido? Por quê? Como esperava atender suas expectativas? O que mudaria em sua aula? (para quem ministrou aula de matemática) (nesse momento apresentar trechos gravados das aulas assistidas para esclarecimentos)

c) Quais eram suas expectativas em relação ao planejamento de sua aula de Matemática? Que resultados esperava obter com a aula? Por quê? De que maneira? (para quem teve a aula de matemática cancelada)

d) Agora observe o que você registrou durante o primeiro semestre sobre a Matemática e o processo ensino-aprendizagem. Como você responderia a essas questões hoje? Por quê? (nesse momento pedir esclarecimentos sobre alguns aspectos que me chamaram atenção na escrita de cada entrevistado - ver palavras sublinhadas na transcrição dos registros escritos)

e) Em relação à Matemática e seu ensino-aprendizagem você vem desenvolvendo um processo de formação durante o ano. Como é a sua percepção sobre essa temática atualmente? Ela se manteve ou alterou-se? O que você acha ter aprendido? Quais os indícios que considera para essa aprendizagem? Houve aspectos que dificultaram/inviabilizaram sua aprendizagem? Quais? Como é ser professor? 


\section{APÊNDICE 4 - EXEMPLO DO MODO DE SISTEMATIZAÇÃO INICIAL DOS DADOS}

- INTERPRETAÇÕES DAS CONCEPÇÕES DE A1 SOBRE A MATEMÁTICA

\begin{tabular}{|c|c|c|c|}
\hline \multicolumn{2}{|r|}{ IDÉIAS } & DADOS & OBSERVAÇÕES \\
\hline \multirow{7}{*}{$\begin{array}{c}\mathbf{Q} \\
\mathbf{U} \\
\mathbf{E} \\
\mathbf{S} \\
\mathbf{T} \\
\mathbf{I} \\
\mathbf{O} \\
\mathbf{N} \\
\mathbf{A} \\
\mathbf{R} \\
\mathbf{I} \\
\mathbf{O} \\
\mathbf{1} \\
\end{array}$} & Quando surgiu & Criada há muito tempo & \\
\hline & Por que surgiu & Para ajudar o Homem na vida & \\
\hline & $\begin{array}{c}\text { Foco do } \\
\text { conhecimento }\end{array}$ & $\begin{array}{l}\text { Ênfase nos cálculos }(+,-, \mathrm{x},:) \text { e } \\
\text { números }\end{array}$ & \\
\hline & $\begin{array}{c}\text { Características do } \\
\text { conhecimento }\end{array}$ & $\begin{array}{l}\text { Os conceitos são resultados de } \\
\text { estudos }\end{array}$ & \\
\hline & $\begin{array}{c}\text { Relação com } \\
\text { cotidiano }\end{array}$ & & \\
\hline & $\begin{array}{l}\text { Finalidade do } \\
\text { conhecimento }\end{array}$ & & \\
\hline & & & \\
\hline \multirow{6}{*}{$\begin{array}{c}\mathbf{Q} \\
\mathbf{U} \\
\mathbf{E} \\
\mathbf{S} \\
\mathbf{T} \\
\mathbf{I} \\
\mathbf{O} \\
\mathbf{N} \\
\mathbf{A} \\
\mathbf{R} \\
\mathbf{I} \\
\mathbf{O}\end{array}$} & Quando surgiu & Criada há muito tempo & \\
\hline & Por que surgiu & Para auxiliar o Homem na vidad & \\
\hline & $\begin{array}{c}\text { Foco do } \\
\text { conhecimento }\end{array}$ & $\begin{array}{l}\text { Ênfase no raciocínio, cálculo e } \\
\text { números }\end{array}$ & \\
\hline & $\begin{array}{c}\text { Características do } \\
\text { conhecimento }\end{array}$ & $\begin{array}{c}\text { É resultado dos estudos de } \\
\text { grandes pesquisadores }\end{array}$ & \\
\hline & Relação cotidiano & & \\
\hline & $\begin{array}{l}\text { Finalidade do } \\
\text { conhecimento }\end{array}$ & $\begin{array}{c}\text { Desenvolve habilidades de criar } \\
\text { estratégias para resolver } \\
\text { problemas }\end{array}$ & \\
\hline \multirow{4}{*}{$\begin{array}{l}\mathbf{O} \\
\mathbf{R} \\
\mathbf{I} \\
\mathbf{E}\end{array}$} & Quando surgiu & Criada há muito tempo & \\
\hline & Por que surgiu & Para auxiliar o Homem na vida & \\
\hline & $\begin{array}{c}\text { Foco do } \\
\text { conhecimento }\end{array}$ & $\begin{array}{l}\text { Não está centrado somente no } \\
\text { raciocínio, cálculos e números }\end{array}$ & Após desenvolver as regências no estágio \\
\hline & $\begin{array}{c}\text { Características do } \\
\text { conhecimento }\end{array}$ & É resultado de muitos estudos & \\
\hline \multirow{3}{*}{$\begin{array}{l}\mathbf{R} \\
\mathbf{E} \\
\mathbf{O} \\
\mathbf{R} \\
\mathbf{I} \\
\mathbf{E}\end{array}$} & $\begin{array}{l}\text { Conseqüência do } \\
\text { contato com o } \\
\text { conhecimento } \\
\end{array}$ & & \\
\hline & $\begin{array}{l}\text { Finalidade do } \\
\text { conhecimento }\end{array}$ & $\begin{array}{c}\text { Desenvolve habilidades de criar } \\
\text { estratégias para resolver } \\
\text { problemas }\end{array}$ & \\
\hline & Relação cotidiano & & \\
\hline $\begin{array}{l}\mathbf{E} \\
\mathbf{N} \\
\mathbf{T} \\
\mathbf{R} \\
\mathbf{E}\end{array}$ & $\begin{array}{l}\text { Afinidade com a } \\
\text { área }\end{array}$ & $\begin{array}{l}\text { Percebe que pode ser gostoso } \\
\text { ensinar Matemática }\end{array}$ & $\begin{array}{l}\text { Após ter cursado disciplina de MEM viu } \\
\text { que existe outras maneiras de aprender } \\
\text { Matemática e que pode ser gostoso. }\end{array}$ \\
\hline
\end{tabular}

Fonte: campo de pesquisa. 
- INTERPRETAÇÕES DAS CONCEPÇÕES DE A1 SOBRE O ENSINO DE MATEMÁTICA

Início

\begin{tabular}{|c|c|c|c|}
\hline \multicolumn{2}{|r|}{ IDÉIAS } & DADOS & OBSERVAÇÕES \\
\hline \multirow{5}{*}{$\begin{array}{l}\mathbf{Q} \\
\mathbf{U} \\
\mathbf{E} \\
\mathbf{S} \\
\mathbf{T} \\
\mathbf{I} \\
\mathbf{O} \\
\mathbf{N} \\
\mathbf{A} \\
\mathbf{R} \\
\mathbf{I} \\
\mathbf{O} \\
\mathbf{1} \\
\end{array}$} & $\begin{array}{l}\text { Uso de materiais } \\
\text { didáticos }\end{array}$ & $\begin{array}{l}\text { Para mostrar o conceito. } \\
\text { Torná-lo prático }\end{array}$ & \\
\hline & $\begin{array}{l}\text { Relação com o } \\
\text { cotidiano }\end{array}$ & X & \\
\hline & $\begin{array}{l}\text { Procedimento } \\
\text { metodológico }\end{array}$ & $\begin{array}{c}\text { Professor explica o conceito } \\
\text { demonstrando-o por meio da } \\
\text { manipulação de material didático }\end{array}$ & \\
\hline & O professor & $\begin{array}{c}\text { Mostra conceito e manipula } \\
\text { materiais }\end{array}$ & \\
\hline & O aluno & X & \\
\hline \multirow{6}{*}{$\begin{array}{l}\mathbf{Q} \\
\mathbf{U} \\
\mathbf{E} \\
\mathbf{S} \\
\mathbf{T} \\
\mathbf{I} \\
\mathbf{O} \\
\mathbf{N} \\
\dot{A} \\
\mathbf{R} \\
\mathbf{I} \\
\mathbf{O}\end{array}$} & $\begin{array}{l}\text { Uso de materiais } \\
\text { didáticos }\end{array}$ & Para mostrar o conceito & \\
\hline & $\begin{array}{l}\text { Relação com o } \\
\text { cotidiano }\end{array}$ & X & \\
\hline & $\begin{array}{l}\text { Procedimento } \\
\text { metodológico }\end{array}$ & $\begin{array}{l}\text { Professor explica conceitos por } \\
\text { meio de exemplos de situações } \\
\text { do cotidiano }\end{array}$ & \\
\hline & O professor & Mostra conceito & \\
\hline & O aluno & X & \\
\hline & $\begin{array}{c}\text { Resolução de } \\
\text { Problemas }\end{array}$ & Para ensinar o conteúdo & \\
\hline \multirow[t]{2}{*}{2} & $\begin{array}{l}\text { Integração entre } \\
\text { conteúdos }\end{array}$ & $x$ & \\
\hline & $\begin{array}{c}\text { Referência a } \\
\text { tópicos da MEM }\end{array}$ & X & \\
\hline \multirow{2}{*}{$\begin{array}{l}\mathbf{P} \\
\mathbf{L} \\
\mathbf{A} \\
\mathbf{N} \\
\mathbf{O}\end{array}$} & $\begin{array}{l}\text { Uso de materiais } \\
\text { didáticos }\end{array}$ & Para resolver exercícios & $\begin{array}{l}\text { Para mostrar como se usa e para que } \\
\text { serve o conteúdo }\end{array}$ \\
\hline & $\begin{array}{l}\text { Relação com o } \\
\text { cotidiano }\end{array}$ & X & \\
\hline \multirow{4}{*}{$\begin{array}{l}\mathbf{D} \\
\mathbf{E} \\
\mathbf{A} \\
\mathbf{U} \\
\mathbf{L} \\
\mathbf{A} \\
\mathbf{V} \\
\mathbf{E} \\
\mathbf{R} \\
\mathbf{S} \\
\tilde{\mathbf{A}} \\
\mathbf{O}\end{array}$} & $\begin{array}{l}\text { Procedimento } \\
\text { metodológico }\end{array}$ & $\begin{array}{c}\text { Conversa informal, explicação } \\
\text { do conteúdo com } \\
\text { exemplificações usando material } \\
\text { didático e proposição de } \\
\text { exercícios } \\
\end{array}$ & \\
\hline & O professor & $\begin{array}{c}\text { Explica o conteúdo e propõe } \\
\text { exercícios }\end{array}$ & $\begin{array}{l}\text { Se põe na condição de aluno, pois é } \\
\text { estagiária. Isto implica entender que } \\
\text { professor e aluno aprendem juntos. } \\
\text { Revela aspectos emocionais como } \\
\text { preocupação, nervosismo, medo e timidez } \\
\text { de atuar como docente pela primeira vez. }\end{array}$ \\
\hline & O aluno & $\begin{array}{l}\text { Revela o que sabe, pergunta e } \\
\text { resolve exercícios }\end{array}$ & \\
\hline & $\begin{array}{l}\text { Resolução de } \\
\text { Problemas }\end{array}$ & 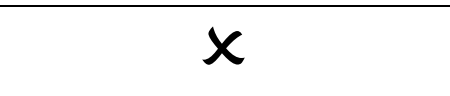 & \\
\hline \multirow[b]{2}{*}{1} & Tipos de exercícios & Situações problema & \\
\hline & $\begin{array}{l}\text { Conhecimento } \\
\text { prévio do aluno }\end{array}$ & $\begin{array}{l}\text { Conversa informal no início da } \\
\text { aula com perguntas para alunos } \\
\text { revelarem o que conhecem }\end{array}$ & Para fazer os alunos participarem da aula. \\
\hline
\end{tabular}




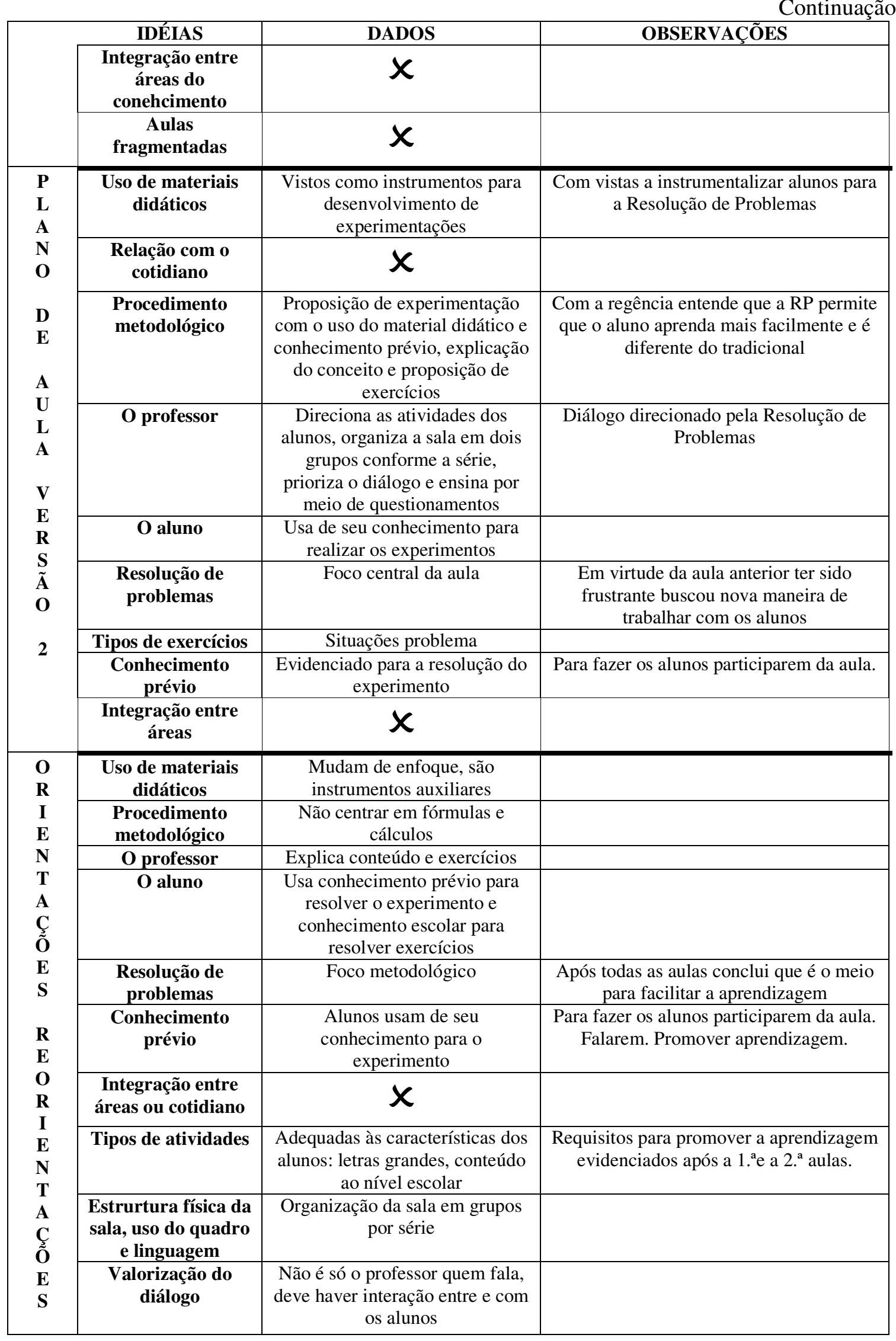


Final

\begin{tabular}{|c|c|c|c|}
\hline & IDÉIAS & DADOS & OBSERVAÇÕES \\
\hline $\mathbf{E}$ & $\begin{array}{c}\text { Domínio saber a } \\
\text { ser ensinado }\end{array}$ & $\begin{array}{l}\text { A dificuldade sentida complicou } \\
\text { a elaboração do plano }\end{array}$ & \\
\hline $\begin{array}{l}\mathbf{N} \\
\mathbf{T}\end{array}$ & $\begin{array}{c}\text { Domínio saber } \\
\text { ensinado }\end{array}$ & & $\begin{array}{l}\text { O pouco domínio gera medo de não saber } \\
\text { o que falar quando for ensinar o conteúdo }\end{array}$ \\
\hline $\begin{array}{l}\text { R } \\
\text { E } \\
\text { V } \\
\text { I } \\
\text { S } \\
\text { T } \\
\text { A } \\
\text { F } \\
\text { I } \\
\text { N } \\
\text { A } \\
\text { L }\end{array}$ & Plano de aula & $\begin{array}{l}\text { Dificuldade em elaborar por não } \\
\text { dominar o conteúdo e por não } \\
\text { saber como valorizar a } \\
\text { participação do aluno. } \\
\text { Após a segunda aula os planos } \\
\text { foram re-elaborados em virtude } \\
\text { das dificuldades sentidas }\end{array}$ & $\begin{array}{l}\text { Não sabe o conteúdo e tem receio de } \\
\text { escolher atividades inadequadas para } \\
\text { alunos da EJA (infantis). Toma como } \\
\text { fonte para a elaboração do plano livros } \\
\text { paradidáticos, livros didáticos e as } \\
\text { orientações da professora de MEM. } \\
\text { Também considera o modo como } \\
\text { aprendeu e as aulas observadas no } \\
\text { estágio, concluindo que gostaria de } \\
\text { elaborarar aulas diferentes dos modelos } \\
\text { vivenciados (alunos sem medo de falar, } \\
\text { participantes e não centrada em fórmulas) }\end{array}$ \\
\hline
\end{tabular}

Fonte: campo de pesquisa. 
- INTERPRETAÇÕES DAS CONCEPÇÕES DE A1 SOBRE A APRENDIZAGEM EM MATEMÁTICA

Início

\begin{tabular}{|c|c|c|c|}
\hline \multicolumn{2}{|r|}{ IDÉIAS } & $\begin{array}{l}\text { DADOS } \\
\end{array}$ & OBSERVAÇÕES \\
\hline \multirow{5}{*}{$\begin{array}{l}\mathbf{Q} \\
\mathbf{U} \\
\mathbf{E} \\
\mathbf{S} \\
\mathbf{T} \\
\mathbf{I} \\
\mathbf{O} \\
\mathbf{N} \\
\hat{\mathbf{A}} \\
\mathbf{R} \\
\mathbf{I} \\
\mathbf{O} \\
\mathbf{1}\end{array}$} & Memorizaçãa & $x$ & \\
\hline & Visualização & $\begin{array}{l}\text { O aluno vê a prática, i.é, } \\
\text { professor mostra conceito por } \\
\text { meio de material real (bolo) }\end{array}$ & \\
\hline & $\begin{array}{l}\text { Relação com o } \\
\text { cotidiano }\end{array}$ & $x$ & \\
\hline & $\begin{array}{l}\text { Resolução de } \\
\text { exercícios }\end{array}$ & $x$ & \\
\hline & Aprende & $x$ & \\
\hline \multirow{6}{*}{$\begin{array}{l}\mathbf{Q} \\
\mathbf{U} \\
\mathbf{E} \\
\mathbf{S} \\
\mathbf{T} \\
\mathbf{I} \\
\mathbf{O} \\
\mathbf{N} \\
\mathbf{A} \\
\mathbf{R} \\
\mathbf{I} \\
\mathbf{O} \\
\mathbf{2}\end{array}$} & Visualização & $\begin{array}{l}\text { Observação dos conceitos em } \\
\text { situações do cotidiano apontadas } \\
\text { pelo professor }\end{array}$ & \\
\hline & $\begin{array}{l}\text { Relação com o } \\
\text { cotidiano }\end{array}$ & 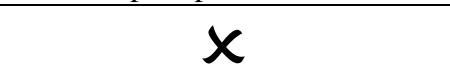 & \\
\hline & $\begin{array}{l}\text { Resolução de } \\
\text { exercícios }\end{array}$ & $\begin{array}{l}\text { Elabora forma própria de pensar } \\
\text { a resolução a partir do } \\
\text { entendimento do que o professor } \\
\text { explicou } \\
\end{array}$ & \\
\hline & Aspectos subejtivos & $x$ & \\
\hline & $\begin{array}{l}\text { Construção do } \\
\text { conhecimento }\end{array}$ & $x$ & \\
\hline & Aprende & $\begin{array}{l}\text { Apresentando sua forma de } \\
\text { pensar, independentemente de } \\
\text { estar certo ou errado }\end{array}$ & \\
\hline \multirow{2}{*}{$\begin{array}{l}\mathbf{P} \\
\mathbf{L} \\
\mathbf{A} \\
\mathbf{N} \\
\mathbf{O}\end{array}$} & Memorização & $x$ & \\
\hline & $\begin{array}{l}\text { Relação com o } \\
\text { cotidiano }\end{array}$ & $\begin{array}{l}\text { É o meio de explicitar o } \\
\text { conhecimento prévio }\end{array}$ & \\
\hline \multirow{2}{*}{$\begin{array}{l}\text { A } \\
\mathbf{U} \\
\mathbf{L} \\
\mathbf{A}\end{array}$} & $\begin{array}{c}\text { Resolução de } \\
\text { exercícios }\end{array}$ & $\begin{array}{l}\text { Elabora forma própria de pensar } \\
\text { a resolução de problemas a partir } \\
\text { da explicação do professor }\end{array}$ & \\
\hline & $\begin{array}{l}\text { Construção do } \\
\text { conhecimento }\end{array}$ & $\begin{array}{l}\text { Constrói conhecimento } \\
\text { manipulando materiais didáticos }\end{array}$ & \\
\hline \multirow{2}{*}{$\begin{array}{l}\mathbf{V} \\
\mathbf{E} \\
\mathbf{R} \\
\mathbf{1}\end{array}$} & $\begin{array}{c}\text { Conhecimento } \\
\text { prévio }\end{array}$ & $\begin{array}{c}\text { É explicitado quando aluno } \\
\text { informa como utiliza o conceito } \\
\text { em seu cotidiano }\end{array}$ & \\
\hline & $\begin{array}{c}\text { Aplica } \\
\text { conhecimento } \\
\text { passado pelo } \\
\text { professor }\end{array}$ & $\begin{array}{l}\text { Segue exemplo do professor } \\
\text { para resolver exercícios }\end{array}$ & \\
\hline \multirow{3}{*}{$\begin{array}{l}\mathbf{P} \\
\mathbf{L} \\
\mathbf{A} \\
\mathbf{N} \\
\mathbf{O}\end{array}$} & Visualização & $x$ & \\
\hline & $\begin{array}{l}\text { Relação com o } \\
\text { cotidiano }\end{array}$ & $\begin{array}{l}\text { Como utiliza o conceito a partir } \\
\text { do conhecimento prévio }\end{array}$ & \\
\hline & $\begin{array}{l}\text { Resolução de } \\
\text { exercícios }\end{array}$ & $\begin{array}{c}\text { Elabora estratégias para resolver } \\
\text { situação problema }\end{array}$ & \\
\hline
\end{tabular}


Final

\begin{tabular}{|c|c|c|c|}
\hline \multirow{4}{*}{$\begin{array}{l}\mathbf{U} \\
\mathbf{V} \\
\mathbf{2}\end{array}$} & IDÉIAS & DADOS & OBSERVAÇÕES \\
\hline & $\begin{array}{c}\text { Conhecimento } \\
\text { prévio }\end{array}$ & $\begin{array}{l}\text { Por meio da relação entre } \\
\text { conhecimento prévio e } \\
\text { conhecimento científico }\end{array}$ & \\
\hline & $\begin{array}{l}\text { Conhecimento } \\
\text { científico/escolar }\end{array}$ & $x$ & \\
\hline & Aspectos subjetivos & $x$ & \\
\hline \multirow{3}{*}{$\begin{array}{l}\mathbf{O} \\
\mathbf{R} \\
\mathbf{I} \\
\mathbf{E} \\
\mathbf{N}\end{array}$} & Memorização & $x$ & \\
\hline & Visualização & $x$ & \\
\hline & $\begin{array}{c}\text { Resolução de } \\
\text { exercícios }\end{array}$ & $\begin{array}{l}\text { Elabora estratégias para resolver } \\
\text { problemas }\end{array}$ & \\
\hline $\begin{array}{l}\mathbf{R} \\
\mathbf{E}\end{array}$ & $\begin{array}{l}\text { Construção do } \\
\text { conhecimento }\end{array}$ & $x$ & \\
\hline \multirow{2}{*}{$\begin{array}{l}\mathbf{O} \\
\mathbf{R} \\
\mathbf{I} \\
\mathbf{E} \\
\mathbf{N}\end{array}$} & $\begin{array}{l}\text { Conhecimento } \\
\text { prévio }\end{array}$ & $x$ & \\
\hline & $\begin{array}{l}\text { Conhecimento } \\
\text { científico/escolar }\end{array}$ & $x$ & \\
\hline \multirow{4}{*}{$\begin{array}{l}\mathbf{E} \\
\mathbf{N} \\
\mathbf{T} \\
\mathbf{R} \\
\mathbf{E} \\
\mathbf{V} \\
\mathbf{I} \\
\mathbf{S} \\
\mathbf{T}\end{array}$} & Aspectos subjetivos & $\begin{array}{c}\text { Participa da aula e demostra } \\
\text { interesse. (não vai embora, faz } \\
\text { perguntas e as atividades } \\
\text { propostas) }\end{array}$ & \\
\hline & Metacognição & $\begin{array}{l}\text { Sabe que existe o conceito e usa } \\
\text { o que aprende }\end{array}$ & $\begin{array}{l}\text { Evidência após todas as aulas do motivo } \\
\text { de se aprender }\end{array}$ \\
\hline & $\begin{array}{c}\text { Características dos } \\
\text { alunos }\end{array}$ & $\begin{array}{c}\text { Aluno da EJA aprende de modo } \\
\text { diferente do aluno criança }\end{array}$ & \\
\hline & Aprende & Quando demonstram interesse & $\begin{array}{c}\text { Não foram embora, agradeceram pela } \\
\text { aula é a evidência da aprendizagem após } \\
\text { a primeira aula }\end{array}$ \\
\hline
\end{tabular}

Fonte: campo de pesquisa. 
- RECORTES DAS IDÉIAS SOBRE A MATEMÁTICA E O ENSINO-APRENDIZAGEM DE A1 E INTERPRETAÇÃO DA PESQUISADORA

\begin{tabular}{|c|c|c|c|c|}
\hline \multirow[t]{2}{*}{ CÓDIGO } & \multirow[t]{2}{*}{$\begin{array}{l}\text { CONCEPÇÕES INICIAIS } \\
\text { QUESTIONÁRIO } 1\end{array}$} & \multirow[t]{2}{*}{$\begin{array}{c}\text { CONCEPÇÕES INTERMEDIÁRIAS } \\
\text { QUESTIONÁRIO } 2\end{array}$} & \multicolumn{2}{|c|}{$\begin{array}{c}\text { CONCEPÇÕES } \\
\text { FINAIS } \\
\text { PRÁTICA PEDAGÓGICA }\end{array}$} \\
\hline & & & ANTES DO EVENTO CRÍTICO & APÓS O EVENTO CRÍTICO \\
\hline 1 & $\begin{array}{c}\text { Foco na aritmética, centrada nos } \\
\text { cálculos e nos números } \\
\text { "A Matemática trabalha com os } \\
\text { números e sua finalidade é } \\
\text { calculcar." }\end{array}$ & $\begin{array}{l}\text { Foco na aritmética, centrada nos } \\
\text { cálculos e nos números } \\
\text { "A Matemática trabalha com números." } \\
\text { "A Matemática utiliza-se do cálculo." }\end{array}$ & & \\
\hline 2 & & $\begin{array}{c}\text { Ênfase no raciocínio, na lógica } \\
\text { “A Matemática utiliza-se do raciocínio } \\
\text { das pessoas." }\end{array}$ & & \\
\hline 3 & & & $\begin{array}{l}\text { Relevância ao aspecto formal do } \\
\text { conhecimento } \\
\text { "P - então veja, de primeira à quarta } \\
\text { séries, basicamente, trabalha-se a área } \\
\text { do quadrado. } \\
\text { A1 - com fórmula mesmo, aquela para } \\
\text { calcular a área do quadrado." (OP, } \\
01: 15 \text { a } 01: 25)\end{array}$ & \\
\hline 4 & $\begin{array}{l}\text { O conhecimento é resultado da } \\
\text { racionalização de alguns } \\
\text { pensadores } \\
\text { "Estudiosos formaram conceitos } \\
\text { como adição, multiplicação e } \\
\text { divisão." }\end{array}$ & $\begin{array}{l}\text { O conhecimento é resultado da } \\
\text { racionalização de alguns pensadores } \\
\text { "A Matemática surgiu através de muitas } \\
\text { pesquisas que hoje são reconhecidas } \\
\text { como grandes gênios." }\end{array}$ & & \\
\hline 6 & $\begin{array}{l}\text { As idéias matemáticas preexistem } \\
\text { "Os números foram criados há muito } \\
\text { tempo" }\end{array}$ & $\begin{array}{l}\text { As idéias matemáticas preexistem } \\
\text { "A Matemática surgiu há muito tempo" }\end{array}$ & & \\
\hline
\end{tabular}


continuação

\begin{tabular}{|c|c|c|c|c|}
\hline \multirow[t]{2}{*}{ CÓDIGO } & \multirow[t]{2}{*}{$\begin{array}{l}\text { CONCEPÇÕES INICIAIS } \\
\text { QUESTIONÁRIO } 1\end{array}$} & \multirow[t]{2}{*}{$\begin{array}{c}\text { CONCEPÇÕES INTERMEDIÁRIAS } \\
\text { QUESTIONÁRIO } 2\end{array}$} & \multicolumn{2}{|c|}{$\begin{array}{l}\text { CONCEPÇÕES } \\
\text { FINAIS } \\
\text { PRÁTICA PEDAGÓGICA }\end{array}$} \\
\hline & & & ANTES DO EVENTO CRÍTICO & APÓS O EVENTO CRÍTICO \\
\hline 7 & & & $\begin{array}{l}\text { A história da Matemática é importante } \\
\text { “Ah, isso! A professora [regente] pediu para } \\
\text { pegar na história. Mostrar de onde surgiu [o } \\
\text { conteúdo].” (OP, 03:29) } \\
\text { “Antigamente o homem media as coisas com } \\
\text { seu corpo, [...]. Algumas dessas formas de } \\
\text { medir são usadas até hoje." (Plano da 1." aula) } \\
\text { "Para dar sequiência a aula utilizando-se da } \\
\text { pluridisciplinaridade (Japiassú, 1998) contou- } \\
\text { se aos alunos a história do metro e para fazer } \\
\text { um elo entre a primeira e a segunda aula, } \\
\text { explicou-se a relação entre medidas de } \\
\text { comprimento e as não-padronizadas.” } \\
\text { (Relatório de Estágio, Plano da 2. }{ }^{\mathrm{a}} \text { aula) }\end{array}$ & \\
\hline 8 & $\begin{array}{l}\text { Possui caráter utilitário } \\
\text { "A Matemática surgiu para } \\
\text { ajudar o homem na sua } \\
\text { cidadania." } \\
\text { “A Matemática foi criada } \\
\text { para facilitar mais a vida do } \\
\text { homem, pois para tudo, hoje } \\
\text { em dia, é necessário } \\
\text { calcular. Exemplo: para } \\
\text { fazer compras é necessário, } \\
\text { entre outros.” }\end{array}$ & $\begin{array}{l}\text { Possui caráter utilitário } \\
\text { "Ela surgiu para auxiliar o homem em } \\
\text { tudo que vai fazer, a criar estratégias para } \\
\text { problemas, a ir para supermercados e ter } \\
\text { dinheiro suficiente para pagar contas. } \\
\text { Para que um engenheiro vá construir uma } \\
\text { casa e não deixe que caia." }\end{array}$ & & \\
\hline 12 & & & & $\begin{array}{l}\text { Sentimento de afinidade com a } \\
\text { Matemática } \\
\text { "Eu acho que aquilo que eu } \\
\text { conhecia de Matemática até fazer a }\end{array}$ \\
\hline
\end{tabular}


continuação

\begin{tabular}{|c|c|c|c|c|}
\hline \multirow[t]{2}{*}{ CÓDIGO } & \multirow[t]{2}{*}{$\begin{array}{l}\text { CONCEPÇÕES INICIAIS } \\
\text { QUESTIONÁRIO } 1\end{array}$} & \multirow[t]{2}{*}{$\begin{array}{c}\text { CONCEPÇÕES INTERMEDIÁRIAS } \\
\text { QUESTIONÁRIO } 2\end{array}$} & \multicolumn{2}{|c|}{$\begin{array}{c}\text { CONCEPÇÕES } \\
\text { FINAIS } \\
\text { PRÁTICA PEDAGÓGICA }\end{array}$} \\
\hline & & & ANTES DO EVENTO CRÍTICO & APÓS O EVENTO CRÍTICO \\
\hline 15 & & & & $\begin{array}{l}\text { Sente dificuldade em relação ao } \\
\text { conteúdo matemático } \\
\text { "Foi tão difícil. Não sabia nada. } \\
\text { Não sabia o que fazer. Procurei } \\
\text { livros, procurei, procurei e acabei } \\
\text { fazendo tudo por esse livro que } \\
\text { você [a pesquisadora] me } \\
\text { emprestou. Essas duas primeiras } \\
\text { aulas foram tudo com esse seu } \\
\text { livro. Estou pensando em fazer uma } \\
\text { lista com tudo o que tenho que levar } \\
\text { e falar, porque com esse plano tudo } \\
\text { apertadinho vou acabar me } \\
\text { perdendo" (RP, 31:00) } \\
\\
\text { "A1 não sabe em que consiste o } \\
\text { conteúdo Medidas a ser abordado } \\
\text { em seu plano de aula. Após } \\
\text { conversa sobre o assunto lhe } \\
\text { emprestei ulguns livros } \\
\text { paradidáticos sobre o assunto para } \\
\text { que a mesma se interasse do assunto } \\
\text { e elaborasse seus planos de aula" } \\
\text { (Diário de Campo, p. 48, }\end{array}$ \\
\hline
\end{tabular}


continuação

\begin{tabular}{|c|c|c|c|c|}
\hline \multirow[t]{2}{*}{ CÓDIGO } & \multirow[t]{2}{*}{$\begin{array}{l}\text { CONCEPÇÕES INICIAIS } \\
\text { QUESTIONÁRIO } 1\end{array}$} & \multirow[t]{2}{*}{$\begin{array}{c}\text { CONCEPÇÕES INTERMEDIÁRIAS } \\
\text { QUESTIONÁRIO } 2\end{array}$} & \multicolumn{2}{|c|}{$\begin{array}{c}\text { CONCEPÇÕES } \\
\text { FINAIS } \\
\text { PRÁTICA PEDAGÓGICA }\end{array}$} \\
\hline & & & ANTES DO EVENTO CRÍTICO & APÓS O EVENTO CRÍTICO \\
\hline & & & & 18/out/2005) \\
\hline 16 & $\begin{array}{l}\text { O professor, principal } \\
\text { fonte de informações, } \\
\text { repassa ao aluno o } \\
\text { conhecimento como } \\
\text { pronto e acabado } \\
\text { “[...] na frente dos alunos } \\
\text { dividiria [o bolo] em dois e } \\
\text { explicaria que cada parte é } \\
1 / 2 \text {, então dividiria cada } \\
\text { pedaço em dois e explicaria } \\
\text { que cada parte é } 1 / 4 \text { do bolo e } \\
\text { assim prosseguiria.” }\end{array}$ & $\begin{array}{c}\text { O professor, principal fonte de } \\
\text { informações, repassa ao aluno o } \\
\text { conhecimento como pronto e acabado } \\
\text { "Fração é a fração de alguma coisa, ou } \\
\text { seja, deseja-se comer só meio chocolate, } \\
\text { a fração que se utiliza é metade, ou } 1 / 2, \\
\text { enfim um pedaço." }\end{array}$ & $\begin{array}{l}\text { O professor, principal fonte de } \\
\text { informações, repassa ao aluno o } \\
\text { conhecimento como pronto e acabado } \\
\text { "Levar para a sala de aula diversas medidas de } \\
\text { garrafas e copos, a partir disso indagar os } \\
\text { alunos: o que é l e ml que aparece nas } \\
\text { embalagens. Mostrar uma escala de unidades } \\
\text { para saberem que essas não são as únicas para } \\
\text { capacidade, porém são as mais importantes. } \\
\text { Explicar o que é litro e mililitro e realizar } \\
\text { experiência para os alunos verem. Convidá-los } \\
\text { para fazerem a experiência também." (Plano } \\
\text { da } 3^{\mathrm{a}} \text { aula - } 1^{\mathrm{a}} \text { versão) }\end{array}$ & \\
\hline 17 & $\begin{array}{c}\text { O professor propõe } \\
\text { problemas relacionados ao } \\
\text { mundo real para } \\
\text { exemplificar a técnica } \\
\text { operatória ou o conceito } \\
\text { “[...] Então, solicitaria a um } \\
\text { aluno que pegasse para si } 3 \\
\text { bolas de gude e dividisse } \\
\text { igualmente a todos os seus } \\
\text { colegas o restante. As } \\
\text { crianças perceberiam que as } \\
90 \text { bolas que estavam com a } \\
\text { professora dividiram-se em } \\
\text { 30, ou seja, } 3 \text { para cada } \\
\text { aluno." }\end{array}$ & $\begin{array}{c}\text { O professor propõe problemas } \\
\text { relacionados ao mundo real para } \\
\text { exemplificar a técnica operatória ou o } \\
\text { conceito } \\
\text { "Fração é a fração de alguma coisa, ou } \\
\text { seja, deseja-se comer só meio chocolate, } \\
\text { a fração que se utiliza é metade, ou 1/2, } \\
\text { enfim um pedaço." }\end{array}$ & $\begin{array}{c}\text { O professor propõe problemas relacionados } \\
\text { ao mundo real para exemplificar a técnica } \\
\text { operatória ou o conceito } \\
\text { “[...] Exemplos: quantos copos de } 250 \mathrm{ml} \text { são } \\
\text { necessários colocar para encher uma garrafa } \\
\text { com } 11 \text { de capacidade? .” (Plano da } 3^{\mathrm{a}} \text { aula - } \\
1^{\mathrm{a}} \text { versão) }\end{array}$ & \\
\hline 18 & $\begin{array}{c}\text { O professor enfoca o } \\
\text { ensino de símbolos, } \\
\text { apresenta linguagem }\end{array}$ & & $\begin{array}{l}\text { O professor enfoca o ensino de símbolos, } \\
\text { apresenta linguagem matemática universal, } \\
\text { concisa e precisa e se preocupa com }\end{array}$ & \\
\hline
\end{tabular}


continuação

\begin{tabular}{|c|c|c|c|c|}
\hline \multirow[t]{2}{*}{ CÓDIGO } & \multirow[t]{2}{*}{$\begin{array}{l}\text { CONCEPÇÕES INICIAIS } \\
\text { QUESTIONÁRIO } 1\end{array}$} & \multirow[t]{2}{*}{$\begin{array}{c}\text { CONCEPÇÕES INTERMEDIÁRIAS } \\
\text { QUESTIONÁRIO } 2\end{array}$} & \multicolumn{2}{|c|}{$\begin{array}{c}\text { CONCEPÇÕES } \\
\text { FINAIS } \\
\text { PRÁTICA PEDAGÓGICA }\end{array}$} \\
\hline & & & ANTES DO EVENTO CRÍTICO & APÓS O EVENTO CRÍTICO \\
\hline & $\begin{array}{c}\text { matemática universal, } \\
\text { concisa e precisa e se } \\
\text { preocupa com abstrações } \\
\text { do conceito } \\
\text { "[...] na frente dos alunos } \\
\text { dividiria [o bolo] em dois e } \\
\text { explicaria que cada parte é } \\
\underline{1 / 2} \text {, então dividiria cada } \\
\text { pedaço em dois e explicaria } \\
\text { que cada parte é } \underline{1 / 4} \text { do bolo e } \\
\text { assim prosseguiria." }\end{array}$ & & $\begin{array}{c}\text { abstrações do conceito } \\
\text { "Levar para a sala de aula diversas medidas de } \\
\text { garrafas e copos, a partir disso indagar os } \\
\text { alunos: o que é l e ml que aparece nas } \\
\text { embalagens. Mostrar uma escala de unidades } \\
\text { para saberem que essas não são as únicas para } \\
\text { capacidade, porém são as mais importantes. } \\
\text { Explicar o que é litro e mililitro e realizar } \\
\text { experiência para os alunos verem. Convidá-los } \\
\text { para fazerem a experiência também." (Plano } \\
\text { da } 3^{\mathrm{a}} \text { aula }-1^{\mathrm{a}} \text { versão) }\end{array}$ & \\
\hline 19 & 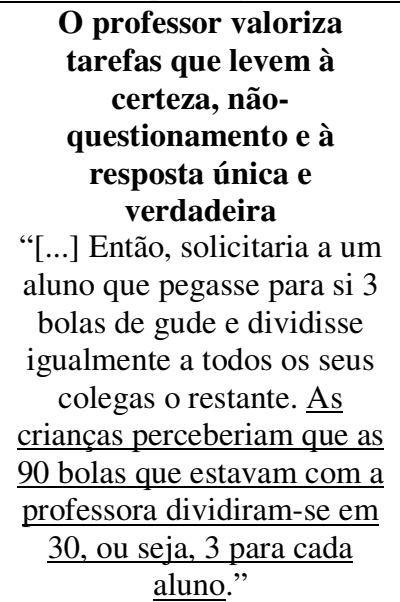 & $\begin{array}{c}\text { O professor valoriza tarefas que levem } \\
\text { à certeza, não-questionamento e à } \\
\text { resposta única e verdadeira } \\
\text { “[o ensino] deve ser de várias formas } \\
\text { para que a criança entenda de sua forma, } \\
\text { porém certo." }\end{array}$ & & \\
\hline 20 & $\begin{array}{l}\text { O professor exerce o papel } \\
\text { de instrutor } \\
\text { “[...] Então, solicitaria a um } \\
\text { aluno que pegasse para si } 3 \\
\text { bolas de gude e dividisse }\end{array}$ & $\begin{array}{l}\text { O professor exerce o papel de instrutor } \\
\text { "A divisão é repartir alguma coisa, tendo } \\
6 \text { laranjas e } 4 \text { crianças para comê-las, } \\
\text { cada criança, comerá uma e as restantes } \\
\text { serão divididas ao meio, para comerem }\end{array}$ & & \\
\hline
\end{tabular}


continuação

\begin{tabular}{|c|c|c|c|c|}
\hline \multirow[t]{2}{*}{ CÓDIGO } & \multirow[t]{2}{*}{$\begin{array}{l}\text { CONCEPÇÕES INICIAIS } \\
\text { QUESTIONÁRIO } 1\end{array}$} & \multirow[t]{2}{*}{$\begin{array}{c}\text { CONCEPÇÕES INTERMEDIÁRIAS } \\
\text { QUESTIONÁRIO } 2\end{array}$} & \multicolumn{2}{|c|}{$\begin{array}{c}\text { CONCEPÇÕES } \\
\text { FINAIS } \\
\text { PRÁTICA PEDAGÓGICA }\end{array}$} \\
\hline & & & ANTES DO EVENTO CRÍTICO & APÓS O EVENTO CRÍTICO \\
\hline & $\begin{array}{l}\text { igualmente a todos os seus } \\
\text { colegas o restante. As } \\
\text { crianças perceberiam que as } \\
90 \text { bolas que estavam com a } \\
\text { professora dividiram-se em } \\
\text { 30, ou seja, } 3 \text { para cada } \\
\text { aluno." }\end{array}$ & $\begin{array}{l}\text { igualmente uma laranja e meia, ou ainda, } \\
\text { duas crianças comerem duas laranjas e as } \\
\text { restantes apenas uma." }\end{array}$ & & \\
\hline 21 & & & $\begin{array}{l}\text { O professor desenvolve um ensino livresco } \\
\text { e expositivo, apresentando definições, } \\
\text { teoria e exercícios de aplicação do conteúdo } \\
\text { "A1 inicia a segunda aula revisando o } \\
\text { conteúdo da aula anterior, então apresenta os } \\
\text { instrumentos de medidas de comprimento, } \\
\text { nomeando-os: metro, trena e fita métrica. } \\
\text { Relata aspectos históricos de como surgiu o } \\
\text { metro e define quais são os submúltiplos do } \\
\text { metro. Então informa como utilizar a régua } \\
\text { para medir. Anota no quadro a equivalência } \\
\text { entre algumas medidas não padronizadas e } \\
\text { padronizadas para que os alunos copiem. } \\
\text { Solicita que os alunos meçam com a régua } \\
\text { suas mesas e lápis. Define os múltiplos do } \\
\text { metro, anota no quadro a equivalência entre } \\
\text { medidas não padronizadas e padronizadas e } \\
\text { apresenta as unidades padrão de comprimento. } \\
\text { Ao final da aula, entrega folha com lista de } \\
\text { exercícios e vai passando de carteira em } \\
\text { carteira para explcar como resolver o } \\
\text { exercício.” (Diário de Campo, p. } 37 \text { e } 38, \\
\text { 31/10/2005) }\end{array}$ & \\
\hline 22 & $\begin{array}{l}\text { O professor propõe } \\
\text { exercícios para }\end{array}$ & & $\begin{array}{c}\text { O professor propõe exercícios para } \\
\text { desenvolver a memorização de princípios e }\end{array}$ & \\
\hline
\end{tabular}


continuação

\begin{tabular}{|c|c|c|c|c|}
\hline \multirow[t]{2}{*}{ CÓDIGO } & \multirow[t]{2}{*}{$\begin{array}{l}\text { CONCEPÇÕES INICIAIS } \\
\text { QUESTIONÁRIO } 1\end{array}$} & \multirow[t]{2}{*}{$\begin{array}{c}\text { CONCEPÇÕES INTERMEDIÁRIAS } \\
\text { QUESTIONÁRIO } 2\end{array}$} & \multicolumn{2}{|c|}{$\begin{array}{c}\text { CONCEPÇÕES } \\
\text { FINAIS } \\
\text { PRÁTICA PEDAGÓGICA } \\
\end{array}$} \\
\hline & & & ANTES DO EVENTO CRÍTICO & APÓS O EVENTO CRÍTICO \\
\hline & $\begin{array}{c}\text { desenvolver a } \\
\text { memorização de } \\
\text { princípios e fórmulas, as } \\
\text { habildiades de } \\
\text { manipulação de } \\
\text { algorítmos e resolução de } \\
\text { problemas-padrão. } \\
\text { “Ensinaria Matemática para } \\
\text { fazer com a criança entenda } \\
\text { a noção de cálculos, pois ela } \\
\text { precisará durante toda a sua } \\
\text { vida. Como ir ao mercado } \\
\text { sem saber se R\$10,00 paga } \\
\text { um pacote de maçãs? Se é } \\
\text { caro ou não? Nos dias de } \\
\text { hoje é impossível viver sem } \\
\text { idéia de cálculo, de conta. } \\
\text { Para muitas coisas existe } \\
\text { esta necessidade.” } \\
\text { “[...] Então, solicitaria a um } \\
\text { aluno que pegasse para si } 3 \\
\text { bolas de gude e dividisse } \\
\text { igualmente a todos os seus } \\
\text { colegas o restante. As } \\
\text { crianças perceberiam que as } \\
90 \text { bolas que estavam com a } \\
\text { professora dividiram-se em } \\
\text { 30, ou seja, } 3 \text { para cada } \\
\text { aluno.” }\end{array}$ & & $\begin{array}{l}\text { fórmulas, as habildiades de manipulação de } \\
\text { algorítmos e resolução de problemas- } \\
\text { padrão. } \\
\text { "Exercícios } \\
\text { 1) Para encher uma jarra com } \\
\text { capacidade de } 21 \text {, quantos copos de } \\
\text { 250ml precisamos colocar? } \\
\text { 2) Dentro de um balde estão } 3.000 \mathrm{ml} \text { de } \\
\text { água. Quantos litros de água temos? } \\
\text { 3) Com quantos meios litros enchemos } \\
\text { um vasilhame de } 1 \text { litro? } \\
\text { 4) Temos uma garrafa de } 11 \text { cheia de } \\
\text { água e mais meia de outra. Quantos } \\
\text { ml temos de água ao todo?" (Plano } \\
\text { da } 3^{a} \text { aula - } 1^{\text {a versão) }}\end{array}$ & \\
\hline 23 & $\begin{array}{l}\text { O professor usa material } \\
\text { didático, estruturado ou }\end{array}$ & $\begin{array}{l}\text { O professor usa material didático, } \\
\text { estruturado ou não, para que o aluno }\end{array}$ & $\begin{array}{l}\text { O professor usa material didático, } \\
\text { estruturado ou não, para que o aluno veja e }\end{array}$ & \\
\hline
\end{tabular}


continuação

\begin{tabular}{|c|c|c|c|c|}
\hline \multirow[t]{2}{*}{ CÓDIGO } & \multirow[t]{2}{*}{$\begin{array}{l}\text { CONCEPÇÕES INICIAIS } \\
\text { QUESTIONÁRIO } 1\end{array}$} & \multirow[t]{2}{*}{$\begin{array}{c}\text { CONCEPÇÕES INTERMEDIÁRIAS } \\
\text { QUESTIONÁRIO } 2\end{array}$} & \multicolumn{2}{|c|}{$\begin{array}{c}\text { CONCEPÇÕES } \\
\text { FINAIS } \\
\text { PRÁTICA PEDAGÓGICA }\end{array}$} \\
\hline & & & ANTES DO EVENTO CRÍTICO & APÓS O EVENTO CRÍTICO \\
\hline & $\begin{array}{c}\text { não, para que o aluno veja } \\
\text { e descubra a técnica } \\
\text { operatória ou o conceito } \\
\text { "Começaria levando para a } \\
\text { sala de aula um bolo inteiro, } \\
\text { na frente dos alunos } \\
\text { dividiria [o bolo] em dois e } \\
\text { explicaria que cada parte é } \\
1 / 2, \text { então dividiria cada } \\
\text { pedaço em dois e explicaria } \\
\text { que cada parte é } 1 / 4 \text { do bolo e } \\
\text { assim prosseguiria." }\end{array}$ & $\begin{array}{l}\text { veja e descubra a técnica operatória ou } \\
\text { o conceito } \\
\text { “A divisão é repartir alguma coisa, tendo } \\
6 \text { laranjas e } 4 \text { crianças para comê-las, } \\
\text { cada criança, comerá uma e as restantes } \\
\text { serão divididas ao meio, para comerem } \\
\text { igualmente uma laranja e meia, ou ainda, } \\
\text { duas crianças comerem duas laranjas e as } \\
\text { restantes apenas uma.” }\end{array}$ & $\begin{array}{l}\text { descubra a técnica operatória ou o conceito } \\
\text { "Levar para a sala de aula diversas medidas de } \\
\text { garrafas e copos, a partir disso indagar os } \\
\text { alunos: o que é l e ml que aparece nas } \\
\text { embalagens. Mostrar uma escala de unidades } \\
\text { para saberem que essas não são as únicas para } \\
\text { capacidade, porém são as mais importantes. } \\
\text { Explicar o que é litro e mililitro e realizar } \\
\text { experiência para os alunos verem. Convidá-los } \\
\text { para fazerem a experiência também." (Plano } \\
\text { da } 3^{\mathrm{a}} \text { aula - } 1^{\mathrm{a}} \text { versão) }\end{array}$ & \\
\hline 24 & $\begin{array}{c}\text { O professor propicia ao } \\
\text { aluno o contato visual e/ou } \\
\text { táctil com os materiais } \\
\text { didáticos } \\
\text { “[...], na frente dos alunos } \\
\text { dividiria [o bolo] em dois e } \\
\text { explicaria que cada parte é } \\
\text { 1/2, então dividiria cada } \\
\text { pedaço em dois e explicaria } \\
\text { que cada parte é } 1 / 4 \text { do bolo e } \\
\text { assim prosseguiria." } \\
\text { "[...] Então, solicitaria a um } \\
\text { aluno que pegasse para si } 3 \\
\text { bolas de gude e dividisse } \\
\text { igualmente a todos os seus } \\
\text { colegas o restante. As } \\
\text { crianças perceberiam que as } \\
90 \text { bolas que estavam com a } \\
\text { professora dividiram-se em }\end{array}$ & $\begin{array}{c}\text { O professor propicia ao aluno o } \\
\text { contato visual e/ou táctil com os } \\
\text { materiais didáticos } \\
\text { "Fração é a fração de alguma coisa, ou } \\
\text { seja, deseja-se comer só meio chocolate, } \\
\text { a fração que se utiliza é metade, ou 1/2, } \\
\text { enfim um pedaço." } \\
\text { "A divisão é repartir alguma coisa, tendo } \\
6 \text { laranjas e } 4 \text { crianças para comê-las, } \\
\text { cada criança, comerá uma e as restantes } \\
\text { serão divididas ao meio, para comerem } \\
\text { igualmente uma laranja e meia, ou ainda, } \\
\text { duas crianças comerem duas laranjas e as } \\
\text { restantes apenas uma." }\end{array}$ & $\begin{array}{l}\text { O professor propicia ao aluno o contato } \\
\text { visual e/ou táctil com os materiais didáticos } \\
\text { "Levar para a sala de aula diversas medidas de } \\
\frac{\text { garrafas e copos, a partir disso indagar os }}{\text { alunos: o que é l e ml que aparece nas }} \\
\text { embalagens. Mostrar uma escala de unidades } \\
\text { para saberem que essas não são as únicas para } \\
\text { capacidade, porém são as mais importantes. } \\
\text { Explicar o que é litro e mililitro e realizar } \\
\text { experiência para os alunos verem. Convidá-los } \\
\text { para fazerem a experiência também." (Plano } \\
\text { da } 3^{\mathrm{a}} \text { aula }-1^{\mathrm{a}} \text { versão) }\end{array}$ & $\begin{array}{c}\text { O professor propicia ao aluno o } \\
\text { contato visual e/ou táctil com os } \\
\text { materiais didáticos } \\
\text { “[...] colocar sobre suas mesas } \\
\text { embalagens em forma de garrafas e } \\
\text { copos. [...] Cada grupo faz uma } \\
\text { experiência, ou seja, coloca água do } \\
\text { copo para a garrafa e vice-versa para } \\
\text { conhecer a relação entre litro (l) e } \\
\text { mililitro (ml).” (Relatório de Estágio, } \\
\text { p. 17, 2005) } \\
\text { “A sala está organizada em dois } \\
\text { grupos ( } 1^{\mathrm{a}} \text { e } 2^{\mathrm{a}} \text { séries) e ( } 3^{\mathrm{a}} \text { e } 4^{\mathrm{a}} \\
\text { séries). Em cada grupo há } \\
\text { embalagens (balde e garrafas pet de } \\
1,51,21 \text { e óleo de soja, copos } \\
\text { descartáveis). Cada grupo deverá } \\
\text { encontrar alguma relação entre as } \\
\text { medidas das embalagens" (Diário de }\end{array}$ \\
\hline
\end{tabular}


continuação

\begin{tabular}{|c|c|c|c|c|}
\hline \multirow[t]{2}{*}{ CÓDIGO } & \multirow[t]{2}{*}{$\begin{array}{l}\text { CONCEPÇÕES INICIAIS } \\
\text { QUESTIONÁRIO } 1\end{array}$} & \multirow[t]{2}{*}{$\begin{array}{c}\text { CONCEPÇÕES INTERMEDIÁRIAS } \\
\text { QUESTIONÁRIO } 2\end{array}$} & \multicolumn{2}{|c|}{$\begin{array}{c}\text { CONCEPÇÕES } \\
\text { FINAIS } \\
\text { PRÁTICA PEDAGÓGICA } \\
\end{array}$} \\
\hline & & & ANTES DO EVENTO CRÍTICO & APÓS O EVENTO CRÍTICO \\
\hline & $\begin{array}{l}\text { 30, ou seja, } 3 \text { para cada } \\
\text { aluno." }\end{array}$ & & & Campo, p. 41, 21/11/2005) \\
\hline 25 & & $\begin{array}{c}\text { O professor desenvolve o conteúdo por } \\
\text { meio de problemas e atividades } \\
\text { investigativas } \\
\text { [o ensino dever ser] de estratégias, de } \\
\text { possibilidade, deve ser de resoluçãa de } \\
\text { problemas não convencionais. }\end{array}$ & & $\begin{array}{l}\text { O professor desenvolve o conteúdo } \\
\text { por meio de problemas e } \\
\text { atividades investigativas } \\
\text { "A metodologia ficou da seguinte } \\
\text { forma: "[...] colocar sobre suas } \\
\text { mesas embalagens em forma de } \\
\text { garrafas e copos. Levantar a questão } \\
\text { se é possível estabelecer alguma } \\
\text { medida entre as embalagens e de que } \\
\text { maneira. Cada grupo faz uma } \\
\text { experiência, ou seja, coloca água do } \\
\text { copo para a garrafa e vice-versa para } \\
\text { conhecer a relação entre litro (l) e } \\
\text { mililitro (ml)." Relatório de Estágio, } \\
\qquad \text { p. 17, 2005) } \\
\text { "P - Uma questão que me chamou } \\
\text { atenção entre as suas aulas e o que } \\
\text { você escreveu nos questionários foi } \\
\text { o uso do material. } \\
\text { A1 - É, de nunca deixar vazio, } \\
\text { sempre com alguma coisa. } \\
\text { P - Exatamente, tinha o chocolate, a } \\
\text { pizza. A aula girava em torno do } \\
\text { material. Lá no estágio tinha o } \\
\text { material, mas a aula não girava em } \\
\text { torno do material e sim em torno da } \\
\text { problematização que você propunha } \\
\text { usando o material. }\end{array}$ \\
\hline
\end{tabular}


continuação

\begin{tabular}{|c|c|c|c|c|}
\hline \multirow[t]{2}{*}{ CÓDIGO } & \multirow[t]{2}{*}{$\begin{array}{l}\text { CONCEPÇÕES INICIAIS } \\
\text { QUESTIONÁRIO } 1\end{array}$} & \multirow[t]{2}{*}{$\begin{array}{c}\text { CONCEPÇÕES INTERMEDIÁRIAS } \\
\text { QUESTIONÁRIO } 2\end{array}$} & \multicolumn{2}{|c|}{$\begin{array}{c}\text { CONCEPÇÕES } \\
\text { FINAIS } \\
\text { PRÁTICA PEDAGóGICA } \\
\end{array}$} \\
\hline & & & ANTES DO EVENTO CRÍTICO & APÓS O EVENTO CRÍTICO \\
\hline & & & & $\begin{array}{l}\text { A1 - Sim, o aluno poderia ou não } \\
\text { usar o material. } \\
\text { P - Na sua segunda aula o uso do } \\
\text { material era essencial. A sua aula } \\
\text { estava apoiada no uso do material. } \\
\text { Na terceira e quarta aulas não, pois o } \\
\text { enfoque estava na Resolução de } \\
\text { Problemas e não na manipulação de } \\
\text { materiais. } \\
\text { A1 - Se eu tivesse feito diferente a } \\
\text { segunda aula seria bom. Não centrar } \\
\text { tanto no material. } \\
\text { P - É, talvez tivesse dado certo já } \\
\text { centrar na problematização. Mas isso } \\
\text { nós fomos aprendendo. } \\
\text { A1 - É mesmo, por isso não foi feito } \\
\text { antes. } \\
\text { P - Porque isso fez parte do processo } \\
\text { de aprendizagem.” (EF, 26:50 a } \\
\text { 28:22) }\end{array}$ \\
\hline 26 & & & $\begin{array}{l}\text { O conhecimento emerge do mundo sensível, } \\
\text { por meio de atividades práticas e com } \\
\text { materiais didáticos, manipulados pelos } \\
\text { alunos } \\
\text { "A1 - Sabe o que eu estava pensando, usar } \\
\text { jogos? Não sei se pode? } \\
\text { P - Pode. } \\
\text { A1 - Porque eu acho que eles são assim, eu até } \\
\text { percebi ontem quando fui ver a aula das } \\
\text { meninas que estavam terminando o estágio } \\
\text { delas, elas levaram uns gibis. Eu não faria, }\end{array}$ & $\begin{array}{c}\text { O conhecimento emerge do mundo } \\
\text { sensível, por meio de atividades } \\
\text { práticas e com materiais didáticos, } \\
\text { manipulados pelos alunos } \\
\text { “[...] Convidou-se os alunos para } \\
\text { realizarem experiências livremente, } \\
\text { já que um dos perfis observados } \\
\text { desta sala é gostar de realizar tarefas } \\
\text { práticas.” (Relatório de Estágio, p. } \\
17,2005 \text { ) }\end{array}$ \\
\hline
\end{tabular}


continuação

\begin{tabular}{|c|c|c|c|c|}
\hline \multirow[t]{2}{*}{ CÓDIGO } & \multirow[t]{2}{*}{$\begin{array}{l}\text { CONCEPÇÕES INICIAIS } \\
\text { QUESTIONÁRIO } 1\end{array}$} & \multirow[t]{2}{*}{$\begin{array}{c}\text { CONCEPÇÕES INTERMEDIÁRIAS } \\
\text { QUESTIONÁRIO } 2\end{array}$} & \multicolumn{2}{|c|}{$\begin{array}{c}\text { CONCEPÇÕES } \\
\text { FINAIS } \\
\text { PRÁTICA PEDAGÓGICA }\end{array}$} \\
\hline & & & ANTES DO EVENTO CRÍTICO & APÓS O EVENTO CRÍTICO \\
\hline & & & $\begin{array}{l}\text { não sei. Daí um senhor lá, mas ele tem uns } \\
\text { sessenta anos, deve ter trabalhado o dia inteiro } \\
\text { e foi lá para estudar, falou: ele foi para a } \\
\text { escola para estudar e não para ficar fazendo } \\
\text { esse negócio de artes. Ele falou assim: a gente } \\
\text { fica perdendo tempo fazendo figurinha, esse } \\
\text { negócio de teatro. Eles fizeram teatro e daí } \\
\text { não ficam estudando e a matéria vai ficando. } \\
\text { E, ele falou muito sério, a professora estava } \\
\text { nervosa e nem falou nada. } \\
\text { [...] } \\
\text { P - Talvez, você possa pensar em equilibrar } \\
\text { isso, dizer que é uma atividade para dar uma } \\
\text { descansada na mente. } \\
\text { A1 - É por pouco tempo, faz o joguinho e } \\
\text { depois faz outra atividade. } \\
\text { P - Isso. Eles podem fazer um exercício } \\
\text { enfocando o jogo. Faz um jogo de memória, } \\
\text { por exemplo, que relacione o conteúdo, que o } \\
\text { aluno consiga ver o conteúdo que está } \\
\text { trabalhando. Porque nesse seu caso não a } \\
\text { ocasião de propor exercício, por exemplo, de } \\
\text { calcular a distância de um lugar para o outro. } \\
\text { No que você está propondo, vai trabalhar os } \\
\text { conceitos das medidas. O que é medir, as } \\
\text { medidas não-padronizadas e as medidas } \\
\text { padronizadas. } \\
\text { A1 - E nada assim, por exemplo, de medir, } \\
\text { eles até podem pegar uma trena e medir uma } \\
\text { mesa, tudo coisas bem leve. Pois eu acredito } \\
\text { que eles tenham bastante dificuldade. Porque } \\
\text { eu vi ontem, tudo eles perguntavam como era }\end{array}$ & \\
\hline
\end{tabular}


continuação

\begin{tabular}{|c|c|c|c|c|}
\hline \multirow[t]{2}{*}{ CÓDIGO } & \multirow[t]{2}{*}{$\begin{array}{l}\text { CONCEPÇÕES INICIAIS } \\
\text { QUESTIONÁRIO } 1\end{array}$} & \multirow[t]{2}{*}{$\begin{array}{c}\text { CONCEPÇÕES INTERMEDIÁRIAS } \\
\text { QUESTIONÁRIO } 2\end{array}$} & \multicolumn{2}{|c|}{$\begin{array}{c}\text { CONCEPÇÕES } \\
\text { FINAIS } \\
\text { PRÁTICA PEDAGÓGICA }\end{array}$} \\
\hline & & & ANTES DO EVENTO CRÍTICO & APÓS O EVENTO CRÍTICO \\
\hline & & & $\begin{array}{l}\text { que escrevia isso, como escrevia aquilo. E, era } \\
\text { tudo bem básico." (OP, 16:14 A 19) }\end{array}$ & \\
\hline 27 & & & & $\begin{array}{l}\text { O professor, um mediador entre o } \\
\text { conhecimento e o aluno, estabelece } \\
\text { uma relação dialógica em sala de } \\
\text { aula } \\
\text { [...] Levantou-se,então, questões para } \\
\text { utilizar-se partindo do método de } \\
\text { Freire (1987) que é o diálogo." } \\
\text { (Relatório de Estágio, p. 17, 2005) } \\
\text { Compreendeu-se, então, que é } \\
\text { necessário considerar todo o } \\
\text { conhecimento prévio que o aluno } \\
\text { tem, ou seja, o saber de experiência } \\
\text { feita (Freire, 1987) e ainda que é } \\
\text { necessário a disponibilidade para o } \\
\text { diálogo (Freire, 1996). } \\
\text { "P - Você falou de participação dos } \\
\text { alunos. Estou lhe perguntando isso } \\
\text { porque preciso entender o que você } \\
\text { está pensando. Essa participação } \\
\text { seria aquela em que os alunos } \\
\text { estariam contando sobre as suas } \\
\text { experiências ou era uma participação } \\
\text { no sentido dos alunos estarem } \\
\text { resolvendo os exercícios que você } \\
\text { propunha? } \\
\text { A1 - Acho que tanto falando, } \\
\text { contando sobre as experiências, } \\
\text { quanto participando na resolução dos }\end{array}$ \\
\hline
\end{tabular}


continuação

\begin{tabular}{|c|c|c|c|c|}
\hline \multirow[t]{2}{*}{ CÓDIGO } & \multirow[t]{2}{*}{$\begin{array}{l}\text { CONCEPÇÕES INICIAIS } \\
\text { QUESTIONÁRIO } 1\end{array}$} & \multirow[t]{2}{*}{$\begin{array}{c}\text { CONCEPÇÕES INTERMEDIÁRIAS } \\
\text { QUESTIONÁRIO } 2\end{array}$} & \multicolumn{2}{|c|}{$\begin{array}{c}\text { CONCEPÇÕES } \\
\text { FINAIS } \\
\text { PRÁTICA PEDAGÓGICA }\end{array}$} \\
\hline & & & ANTES DO EVENTO CRÍTICO & APÓS O EVENTO CRÍTICO \\
\hline & & & & $\begin{array}{l}\text { exercícios. Eu queria que eles } \\
\text { participassem. Eu achei assim, se } \\
\text { eles falassem eles iam se sentir } \\
\text { iguais a mim. Eu estava falando e } \\
\text { eles estavam falando também. Só } \\
\text { que fui infeliz naquela hora em que } \\
\text { pedi para lerem. A professora } \\
\text { [regente] fez uma cara que não era } \\
\text { para fazer isso. Então, não era para } \\
\text { eles lerem. Mas, fazer eles contarem } \\
\text { achei que foi bom, eles falaram } \\
\text { sobre outras coisas que não tinha } \\
\text { nada haver com a aula, mas foi bom } \\
\text { saber. Eu achei que eles falarem foi } \\
\text { bom e eles se proporem a ir ao } \\
\text { quadro, achei que ninguém ia querer, } \\
\text { mas foram. Então, eu achei essas } \\
\text { duas coisas positivas na participação } \\
\text { deles." (RO-AU2, 04:22 a 04:50) }\end{array}$ \\
\hline 28 & & & & $\begin{array}{l}\text { O ponto de partida do ensino são } \\
\text { os problemas/problematizações } \\
\text { "A1 - Até porque pensei assim, } \\
\text { inicialmente pedir que eles [alunos] } \\
\text { me dissessem que experiências daria } \\
\text { para fazer com aquilo ali. Eles fazem } \\
\text { algumas coisas, depois eu proponho. } \\
\text { Então escrever o que eles fizeram e } \\
\text { também o que foi proposto. De } \\
\text { repente tem um lá que descobriu que } \\
\text { coube tantos copos na garrafa de } \\
\text { Mate Leão, então ele vai anotar que } \\
\text { descobriu aquilo. }\end{array}$ \\
\hline
\end{tabular}


continuação

\begin{tabular}{|c|c|c|c|c|}
\hline \multirow[t]{2}{*}{ CÓDIGO } & \multirow[t]{2}{*}{$\begin{array}{l}\text { CONCEPÇÕES INICIAIS } \\
\text { QUESTIONÁRIO } 1\end{array}$} & \multirow[t]{2}{*}{$\begin{array}{c}\text { CONCEPÇÕES INTERMEDIÁRIAS } \\
\text { QUESTIONÁRIO } 2\end{array}$} & \multicolumn{2}{|c|}{$\begin{array}{c}\text { CONCEPÇÕES } \\
\text { FINAIS } \\
\text { PRÁTICA PEDAGÓGICA }\end{array}$} \\
\hline & & & ANTES DO EVENTO CRÍTICO & APÓS O EVENTO CRÍTICO \\
\hline & & & & $\begin{array}{l}\text { P - Sim. Mas, você tem que colocar } \\
\text { bem claro para eles qual é a questão. } \\
\text { Porque, se simplesmente largo na } \\
\text { sua frente duas embalagens e digo: o } \\
\text { que você pode descobrir com isso? } \\
\text { Então, você tem que colocar: que } \\
\text { relações vocês conseguem perceber } \\
\text { entre essas duas embalagens? É } \\
\text { possível estabelecer alguma media } \\
\text { entre essas duas embalagens? De que } \\
\text { maneira? } \\
\text { A1 - Até pensei que eu levaria para } \\
\text { a sala de aula as garrafas e os copos } \\
\text { que aparecem o litro e o mililitro. } \\
\text { Então, talvez eu corte isso, porque } \\
\text { não fica significativo. } \\
\text { P - Talvez você não precise cortar. } \\
\text { Talvez isso você venha a falar depois } \\
\text { da experiência. Por que veja, o que } \\
\text { pode acontecer? Digamos que } \\
\text { tenhamos uma garrafa pet de dois } \\
\text { litros, um copinho de cafezinho e um } \\
\text { copo maior, desses de chá e uma } \\
\text { bacia, um balde com água. Nós } \\
\text { vamos estabelecer medidas. Então, é } \\
\text { possível estabelecer alguma medida } \\
\text { com essas duas embalagens? Eles } \\
\text { vão ter que olhar e vão chegar a } \\
\text { conclusão que é possível. De que } \\
\text { maneira? A gente vai colocando } \\
\text { água com esse copinho na garrafa e } \\
\text { aí acaba descobrindo que na garrafa }\end{array}$ \\
\hline
\end{tabular}


continuação

\begin{tabular}{|c|c|c|c|c|}
\hline \multirow[t]{2}{*}{ CÓDIGO } & \multirow[t]{2}{*}{$\begin{array}{c}\text { CONCEPÇÕES INICIAIS } \\
\text { QUESTIONÁRIO } 1\end{array}$} & \multirow[t]{2}{*}{$\begin{array}{c}\text { CONCEPÇÕES INTERMEDIÁRIAS } \\
\text { QUESTIONÁRIO } 2\end{array}$} & \multicolumn{2}{|c|}{$\begin{array}{c}\text { CONCEPÇÕES } \\
\text { FINAIS } \\
\text { PRÁTICA PEDAGÓGICA }\end{array}$} \\
\hline & & & ANTES DO EVENTO CRÍTICO & APÓS O EVENTO CRÍTICO \\
\hline & & & & $\begin{array}{l}\text { cabem vinte copos de cafezinho e } \\
\text { dez copos de chá. } \\
\text { A1 - ah, entendi. } \\
\text { P - Então eles vão chegar a essa } \\
\text { conclusão. Aí você coloca outra } \\
\text { questão: e se não tivesse esses } \\
\text { copinhos de que outra maneira } \\
\text { poderia estabelecer essa medida? } \\
\text { Observem se na embalagem tem } \\
\text { alguma informação sobre como deve } \\
\text { ser essa medida. } \\
\text { A1 - Ah, tá. Porque daí eles vão } \\
\text { chegar nessa conclusão. } \\
\text { P - Porque eles conhecem, eles jáá } \\
\text { ouviram falar em litro, já ouviram } \\
\text { falar em mililitro. Os copinhos } \\
\text { descartáveis, embaixo vem escrito } \\
\text { dez ml, duzentos ml. Não sei se } \\
\text { todos, mas muito têm. } \\
\text { A1 - Mas á eu procuro os que têm. } \\
\text { P - Então, você vai investigando } \\
\text { com eles. Observem a garrafa, } \\
\text { observem o copinho. } \\
\text { A1 - Ah, para eles investigarem." } \\
\text { (RO-AU3, 27:08 a 31:02) } \\
\text { "Realizou-se atividades práticas de } \\
\text { pesagem, tendo como base a aula } \\
\text { três. O registro também foi } \\
\text { realizado. Levando em consideração } \\
\text { os saberes dos alunos, questionou-se } \\
\text { a respeito do assunto estudado para }\end{array}$ \\
\hline
\end{tabular}


continuação

\begin{tabular}{|c|c|c|c|c|}
\hline \multirow[t]{2}{*}{ CÓDIGO } & \multirow[t]{2}{*}{$\begin{array}{l}\text { CONCEPÇÕES INICIAIS } \\
\text { QUESTIONÁRIO } 1\end{array}$} & \multirow[t]{2}{*}{$\begin{array}{c}\text { CONCEPÇÕES INTERMEDIÁRIAS } \\
\text { QUESTIONÁRIO } 2\end{array}$} & \multicolumn{2}{|c|}{$\begin{array}{c}\text { CONCEPÇÕES } \\
\text { FINAIS } \\
\text { PRÁTICA PEDAGÓGICA }\end{array}$} \\
\hline & & & ANTES DO EVENTO CRÍTICO & APÓS O EVENTO CRÍTICO \\
\hline & & & & $\begin{array}{l}\text { que pudessem dar opiniões. [...] } \\
\text { Através de perguntas, levou-se os } \\
\text { alunos a fazerem verificações das } \\
\text { experiências por meio de contas." } \\
\text { (Relatório de Estágio, p. 21, 2005) } \\
\\
\text { "A atitude de A1 mudou } \\
\text { completamente nessa aula, até sua } \\
\text { voz está mais segura. Ela iniciou } \\
\text { com uma questão problematizadora: } \\
\text { é possível estabelecer alguma } \\
\text { medida entre as embalagens } \\
\text { dispostas sobre as mesas das } \\
\text { equipes? Os alunos respondem que } \\
\text { sim. Então, A1 propõe que façam } \\
\text { experimentos com água. Vejo todos } \\
\text { envolvidos na atividade de encontrar } \\
\text { alguma relação entre as medidas das } \\
\text { embalagens, inclusive pedindo para } \\
\text { irem ao quadro para resolverem } \\
\text { algorítmos referentes aos cálculos da } \\
\text { quantidade de água utilizada na } \\
\text { experiência.”(Diário de Campo, p. } \\
41,21 / 11 / 2005 \text { ) }\end{array}$ \\
\hline 29 & & & $\begin{array}{l}\text { O professor adota estratégias que } \\
\text { propiciem o desenvolvimento de atitudes de } \\
\text { iniciativa, de interação entre alunos, } \\
\text { favorece a negociação do significado e a } \\
\text { construção de conceitos } \\
\text { "P - O que você está pensando? Está pensando } \\
\text { em uma aula mais tradicionalista ou uma aula } \\
\text { mais construtivista? }\end{array}$ & $\begin{array}{l}\text { O professor adota estratégias que } \\
\text { propiciem o desenvolvimento de } \\
\text { atitudes de iniciativa, de interação } \\
\text { entre alunos, favorece a } \\
\text { negociação do significado e a } \\
\text { construção de conceitos } \\
\text { “A1 deixou os alunos livre para } \\
\text { estabelecerem suas próprias relações. }\end{array}$ \\
\hline
\end{tabular}


continuação

\begin{tabular}{|c|c|c|c|c|}
\hline \multirow[t]{2}{*}{ CÓDIGO } & \multirow[t]{2}{*}{$\begin{array}{l}\text { CONCEPÇÕES INICIAIS } \\
\text { QUESTIONÁRIO } 1\end{array}$} & \multirow[t]{2}{*}{$\begin{array}{c}\text { CONCEPÇÕES INTERMEDIÁRIAS } \\
\text { QUESTIONÁRIO } 2\end{array}$} & \multicolumn{2}{|c|}{$\begin{array}{c}\text { CONCEPÇÕES } \\
\text { FINAIS } \\
\text { PRÁTICA PEDAGÓGICA }\end{array}$} \\
\hline & & & ANTES DO EVENTO CRÍTICO & APÓS O EVENTO CRÍTICO \\
\hline & & & $\begin{array}{l}\text { A1 - Eu não sei, eu queria que eles } \\
\text { aprendessem. Sei lá. Não ficassem com } \\
\text { dúvidas. Que fosse diferente do que assisti das } \\
\text { outras meninas. Porque eu achei que elas } \\
\text { fizeram tudo de qualquer jeito, porque } \\
\text { precisam estar lá. Eu achei ruim do jeito que } \\
\text { elas fizeram. Eu queria fazer diferente. Aquele } \\
\text { senhor de sessenta anos me sensibilizou } \\
\text { muito. Eu achei ele uma pessoa que precisa de } \\
\text { muito conhecimento. Ele não sabe muita } \\
\text { coisa, e eu, fiquei sensibilizada. Ele } \\
\text { perguntava muita coisa, tinha muita dúvida, } \\
\text { ele tinha medo de falar. Sabe, tinha uma } \\
\text { palavra escrita errada no quadro, ele percebeu, } \\
\text { mas perguntou primeiro para mim e aí falar. } \\
\text { Então, eu queria coisas diferentes que fizesse } \\
\text { eles participarem, fizesse eles se sentirem } \\
\text { como se estivessem cooperando. Isso é um } \\
\text { pouco construtivista, não é?" (OP, } 21: 53 \text { a } \\
22: 01) \\
\text { "P - Quais eram suas expectativas em relação } \\
\text { a essa primeira aula e que avaliação você } \\
\text { dela? } \\
\text { A1 - Na verdade eu queria que eles } \\
\text { participassem. Queria ver o que eles achavam, } \\
\text { se eles já tinham algum conhecimento. Se isso } \\
\text { era uma coisa infantil para eles, não sei. Até } \\
\text { cheguei a pensar se não era ridículo para eles. } \\
\text { Teve uma menina que falou para mim, ontem } \\
\text { na hora de ir embora, eu achei que ia ser tão } \\
\text { chato, tão chato, quando você falou achei que }\end{array}$ & $\begin{array}{l}\text { Passa pelas equipes afirmando que } \\
\text { estão realizando uma experiência. } \\
\text { Ela está tentanto valorizar a } \\
\text { opção/estratégia de cada aluno. Pois, } \\
\text { cada um escolheu uma maneira para } \\
\text { chegar ao resultado. A1 afirma que a } \\
\text { forma como cada um fez, escolheu } \\
\text { está certo, o importante é chegar no } \\
\text { mesmo valor" (Diário de Campo, p. } \\
41,21 / 11 / 2005 \text { ) } \\
\text { "Eu acho que está muito limitado só } \\
\text { naquilo, que não está como eu fiz } \\
\text { que foi uma aula bem ampla, } \\
\text { dinâmica que eles pudessem } \\
\text { construir a partir do próprio } \\
\text { interesse. Esta proposta está muito } \\
\text { limitada, é aquilo, que nem o } \\
\text { chocololate, é o chocolate dividido } \\
\text { no meio e pronto, acabou. Então a } \\
\text { aula fica bem limitada, né?” (EF, } \\
\text { 11:17) }\end{array}$ \\
\hline
\end{tabular}


continuação

\begin{tabular}{|c|c|c|c|c|}
\hline \multirow[t]{2}{*}{ CÓDIGO } & \multirow[t]{2}{*}{$\begin{array}{l}\text { CONCEPÇÕES INICIAIS } \\
\text { QUESTIONÁRIO } 1\end{array}$} & \multirow[t]{2}{*}{$\begin{array}{c}\text { CONCEPÇÕES INTERMEDIÁRIAS } \\
\text { QUESTIONÁRIO } 2\end{array}$} & \multicolumn{2}{|c|}{$\begin{array}{c}\text { CONCEPÇÕES } \\
\text { FINAIS } \\
\text { PRÁTICA PEDAGÓGICA }\end{array}$} \\
\hline & & & ANTES DO EVENTO CRÍTICO & APÓS O EVENTO CRÍTICO \\
\hline & & & $\begin{array}{l}\text { ia ser tão ridículo, mas foi tão legal. Então } \\
\text { quer dizer, ela teve uma expectativa e quem } \\
\text { bom que foi. Até no começo eu estava } \\
\text { pensando, por que eu vou dar aula disso? Vão } \\
\text { dar risada de mim que é uma coisa de criança. } \\
\text { Daí quando começaram: mas a gente usa, a } \\
\text { gente usa, ela mesma falou, claro que sim, não } \\
\text { viu que ela explicou que a gente usa. Então eu } \\
\text { achei que foi legal. Que foi bem positivo. Para } \\
\text { mim não tem nada para rever.” (RO-AU2, } \\
02: 10 \text { a 02:18) }\end{array}$ & \\
\hline 30 & & & $\begin{array}{l}\text { O professor resgata e parte do } \\
\text { conhecimento do aluno para explicar o } \\
\text { conteúdo } \\
\text { "P - [P inicia a leitura do plano da aula 2, a } \\
\text { qual se refere à Medida de Comprimento: } \\
\text { metro, centímetro, decímetro, milímetro, } \\
\text { quilometro. P sugere que A1 leve alguns } \\
\text { instrumentos de medidas por prevenção e } \\
\text { continua a leitura]. Questioná-los se sabem o } \\
\text { que é o quilometro e explicar o que é? Está } \\
\text { bem, e se eles souberem? } \\
\text { A1 - Pois é. } \\
\text { P - Pode acontecer. } \\
\text { A1 - Ah, então na verdade já deveria explicar } \\
\text { o que é. Não? } \\
\text { P - Não é isso, questionar se eles sabem. } \\
\text { A1 - Alguém fala? Então eu peço para dizer } \\
\text { onde usamos o quilometro. Onde ele já viu } \\
\text { usar isso?" (RO-AU1, 07:00 a 08:36) } \\
\text { "Levar para a sala de aula diversas medidas de }\end{array}$ & $\begin{array}{l}\text { O professor resgata e parte do } \\
\text { conhecimento do aluno para } \\
\text { explicar o conteúdo } \\
\text { “A1 - Será que ao invés de começar } \\
\text { todos separadinhos, já fazer grupos, } \\
\text { grupo de primeira e segunda e grupo } \\
\text { de terceira e quarta. Não sei. Que daí } \\
\text { faz. } \\
\text { P - Não sei. Formar o grupo para } \\
\text { fazer o quê? Vamos pensar. } \\
\text { A1 - Até de repente, não sei, isso das } \\
\text { embalagens conversar com todos, } \\
\text { para ver o que eles falam e aí depois } \\
\text { essas experiências com cada grupo. } \\
\text { Põe lá na mesa as jarrinhas em cada } \\
\text { grupo, os copos em cada grupo. O } \\
\text { que vocês acham? Sei lá. Eles } \\
\text { participarem de alguma coisa para } \\
\text { depois eu propor alguma coisa. O } \\
\text { que dá para fazer? Como a gente vai } \\
\text { medir com isso aí? Como vocês }\end{array}$ \\
\hline
\end{tabular}


continuação

\begin{tabular}{|c|c|c|c|c|}
\hline \multirow[t]{2}{*}{ CÓDIGO } & \multirow[t]{2}{*}{$\begin{array}{l}\text { CONCEPÇÕES INICIAIS } \\
\text { QUESTIONÁRIO } 1\end{array}$} & \multirow[t]{2}{*}{$\begin{array}{c}\text { CONCEPÇÕES INTERMEDIÁRIAS } \\
\text { QUESTIONÁRIO } 2\end{array}$} & \multicolumn{2}{|c|}{$\begin{array}{c}\text { CONCEPÇÕES } \\
\text { FINAIS } \\
\text { PRÁTICA PEDAGÓGICA }\end{array}$} \\
\hline & & & ANTES DO EVENTO CRÍTICO & APÓS O EVENTO CRÍTICO \\
\hline & & & 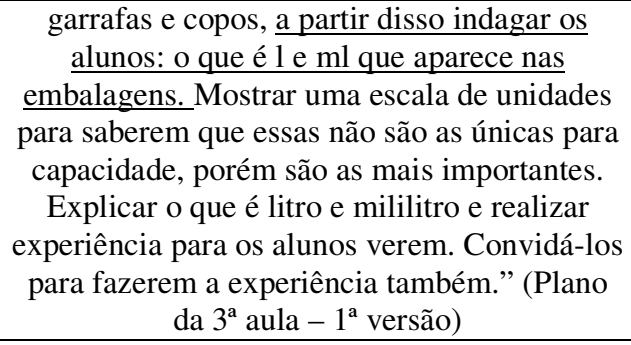 & $\begin{array}{l}\text { mediriam? } \\
\text { P - Certo. Pode ser bem por aí. (RE- } \\
\text { AU3, 24:15 a 25:02) } \\
\text { "[...] Levando em consideração os } \\
\text { saberes dos alunos, questionou-se a } \\
\text { respeito do assunto estudado para } \\
\text { que pudessem dar opiniões." } \\
\text { (Relatório de Estágio, p. } 21,2005 \text { ) }\end{array}$ \\
\hline 31 & & & & $\begin{array}{l}\text { O professor revela preocupação } \\
\text { com a organização didática da } \\
\text { aula: disposição das carteiras, uso } \\
\text { do quadro de giz, adequação das } \\
\text { tarefas, público alvo, elaboração } \\
\text { do plano de aula } \\
\text { "P - [a gravação começa com a a } \\
\text { conversa já iniciada, onde P fala } \\
\text { sobre autores da linha vigotskyana } \\
\text { que falam sobre a organização do } \\
\text { ensino sob a ótica da organização do } \\
\text { espaço da sala de aula] o que nós } \\
\text { temos conversado é sobre formas de } \\
\text { organizar seu ensino. } \\
\text { A1 - Sim, de que maneira seria } \\
\text { melhor. } \\
\text { P - Hum, hum. E nisso você tinha a a } \\
\text { organização do quadro, que para } \\
\text { cada série era uma coisa, de um lado } \\
\text { você escrevia com letra manuscrita e } \\
\text { do outro lado com caixa alta. } \\
\text { A1 - Sim. } \\
\text { P - Em um lado você precisava }\end{array}$ \\
\hline
\end{tabular}


continuação

\begin{tabular}{|c|c|c|c|c|}
\hline \multirow[t]{2}{*}{ CÓDIGO } & \multirow[t]{2}{*}{$\begin{array}{l}\text { CONCEPÇÕES INICIAIS } \\
\text { QUESTIONÁRIO } 1\end{array}$} & \multirow[t]{2}{*}{$\begin{array}{c}\text { CONCEPÇÕES INTERMEDIÁRIAS } \\
\text { QUESTIONÁRIO } 2\end{array}$} & \multicolumn{2}{|c|}{$\begin{array}{c}\text { CONCEPÇÕES } \\
\text { FINAIS } \\
\text { PRÁTICA PEDAGÓGICA }\end{array}$} \\
\hline & & & ANTES DO EVENTO CRÍTICO & APÓS O EVENTO CRÍTICO \\
\hline & & & & $\begin{array}{l}\text { escrever tudo e no outro lado você } \\
\text { não precisava escrever tudo. Você } \\
\text { tinha a organização do espaço físico. } \\
\text { Mesmo com eles sentados em } \\
\text { fileirinhas, você tinha na sala de um } \\
\text { lado os alunos de terceira e quarta } \\
\text { do outro lado alfabetização, primeira } \\
\text { e segunda." (EF, 00:00 a 00:46) } \\
\text { "Pensando que a segunda aula não } \\
\text { alcançou o esperado, mudou-se a } \\
\text { metodologia da terceira. Esta aula } \\
\text { iniciou com grupos divididos por } \\
\text { séries (1ª } 2^{\mathrm{a}} \text { e } 3^{\mathrm{a}} \text {, } 4^{\mathrm{a}} \text { ) para que } \\
\text { realizassem as atividades conforme } \\
\text { seus conhecimentos." (Relatório de } \\
\text { Estágio, p. 17, 2005) } \\
\text { "P - Do que você conseguiu observar } \\
\text { e em relação às suas expectativas } \\
\text { você que conseguiu atingir seus } \\
\text { objetivos na aula } 2 \text { ? } \\
\text { A1 - Eu acho assim, com aqueles } \\
\text { alunos de primeira e segunda não, } \\
\text { porque nem contar na régua eles } \\
\text { conseguiam. Eu entendo, aquelas } \\
\text { senhoras de muita idade, de repente } \\
\text { não conseguem enxergar todos os } \\
\text { risquinhos da régua. Isso me } \\
\text { preocupou muito, porque eu trocava } \\
\text { de régua, trocava de régua e não } \\
\text { adiantava. Ou, de repente ela não }\end{array}$ \\
\hline
\end{tabular}


continuação

\begin{tabular}{|c|c|c|c|c|}
\hline \multirow[t]{2}{*}{ CÓDIGO } & \multirow[t]{2}{*}{$\begin{array}{l}\text { CONCEPÇÕES INICIAIS } \\
\text { QUESTIONÁRIO } 1\end{array}$} & \multirow[t]{2}{*}{$\begin{array}{c}\text { CONCEPÇÕES INTERMEDIÁRIAS } \\
\text { QUESTIONÁRIO } 2\end{array}$} & \multicolumn{2}{|c|}{$\begin{array}{c}\text { CONCEPÇÕES } \\
\text { FINAIS } \\
\text { PRÁTICA PEDAGÓGICA }\end{array}$} \\
\hline & & & ANTES DO EVENTO CRÍTICO & APÓS O EVENTO CRÍTICO \\
\hline & & & & $\begin{array}{l}\text { tem paciência de contar, que uma } \\
\text { das coisas que falei que poderia ser } \\
\text { contado. Então, de repente fazer a } \\
\text { transformação e contar para ter } \\
\text { certeza, mas não conseguia. E o } \\
\text { outro aluno, o R não conseguia, } \\
\text { mesmo porque, ele ainda não sabe os } \\
\text { números. Isso não me toquei, } \\
\text { poderia ser números menores. } \\
\text { Coloquei lá o quinze, era muito } \\
\text { grande para ele. Poderia ser outro } \\
\text { diferente, então ele: um, dois, três, } \\
\text { oito, dez, então eu vi que era } \\
\text { dificuldade. Quando a outra senhora } \\
\text { me entregou a folha pronta, vi que } \\
\text { um por cento atingi. Talvez se os } \\
\text { alunos da terceira e quarta tivessem } \\
\text { ficado, todos teriam participado. Mas } \\
\text { de primeira e segunda, talvez os } \\
\text { exercícios ainda estavam muito } \\
\text { difíceis. Ou, talvez por eu não ter } \\
\text { pensado que aquelas senhoras não } \\
\text { iriam contar cada pontinho da } \\
\text { régua." (RO-AU3, 15:40 a 17:11) } \\
\text { "P - Tem mais uma questão aí que } \\
\text { você sempre comentou bastante, } \\
\text { aqui [nos q1 e q2] você vai direto na } \\
\text { questão da criança. } \\
\text { A1 - É mesmo. } \\
P \text { - você tinha uma angústia muito } \\
\text { grande com o fato de estar }\end{array}$ \\
\hline
\end{tabular}


continuação

\begin{tabular}{|c|c|c|c|c|}
\hline \multirow[t]{2}{*}{ CÓDIGO } & \multirow[t]{2}{*}{$\begin{array}{l}\text { CONCEPÇÕES INICIAIS } \\
\text { QUESTIONÁRIO } 1\end{array}$} & \multirow[t]{2}{*}{$\begin{array}{c}\text { CONCEPÇÕES INTERMEDIÁRIAS } \\
\text { QUESTIONÁRIO } 2\end{array}$} & \multicolumn{2}{|c|}{$\begin{array}{c}\text { CONCEPÇÕES } \\
\text { FINAIS } \\
\text { PRÁTICA PEDAGÓGICA }\end{array}$} \\
\hline & & & ANTES DO EVENTO CRÍTICO & APÓS O EVENTO CRÍTICO \\
\hline & & & & $\begin{array}{l}\text { trabalhando com adultos. } \\
\text { A1 - É. Isso eu nunca tinha tido } \\
\text { noção. Leitura, textos, é diferente de } \\
\text { estar lá com eles." (EF, 06:12 a } \\
06: 23 \text { ) } \\
\text { "P - É uma ênfase muito grande. } \\
\text { Você trouxe essa angústia de } \\
\text { trabalhar com o adulto. Talvez o teu } \\
\text { modo de organizar o ensino para } \\
\text { aquela turma também esteja } \\
\text { relacionado a isso. A essa "falta de } \\
\text { conhecimento" da relação do } \\
\text { trabalho com o adulto. Não sei se } \\
\text { você lembra da tua preocupação, } \\
\text { você dizia: não sei se posso, eles são } \\
\text { adultos, mais velhos. } \\
\text { A1 - Ah, que eu tenho medo. Se } \\
\text { fosse infantil. Até às vezes eu falava } \\
\text { alguma coisa no diminutivo, falo } \\
\text { assim no meu trabalho, aí me } \\
\text { espantava. Porque falar } \\
\text { diminutivo é ruim. } \\
\mathrm{P} \text { - Você tem um enfoque natural seu } \\
\text { do trabalho com a criança e se } \\
\text { deparou com o trabalho com adultos. } \\
\text { A1 - É por isso que eu estava com } \\
\text { medo, não sabia por onde começar. } \\
\text { Eu tinha medo de pegar o livro para } \\
\text { criança, usar para adulto e ficar uma } \\
\text { aula para criança. } \\
\text { P - E você acha que ficou? }\end{array}$ \\
\hline
\end{tabular}


continuação

\begin{tabular}{|c|c|c|c|c|}
\hline \multirow[t]{2}{*}{ CÓDIGO } & \multirow[t]{2}{*}{$\begin{array}{l}\text { CONCEPÇÕES INICIAIS } \\
\text { QUESTIONÁRIO } 1\end{array}$} & \multirow[t]{2}{*}{$\begin{array}{c}\text { CONCEPÇÕES INTERMEDIÁRIAS } \\
\text { QUESTIONÁRIO } 2\end{array}$} & \multicolumn{2}{|c|}{$\begin{array}{c}\text { CONCEPÇÕES } \\
\text { FINAIS } \\
\text { PRÁTICA PEDAGÓGICA }\end{array}$} \\
\hline & & & ANTES DO EVENTO CRÍTICO & APÓS O EVENTO CRÍTICO \\
\hline & & & & $\begin{array}{l}\text { A1 - Não." (EF, 08:30 a 09:34) } \\
\text { "Eu acho que foi muito bom ter a } \\
\text { ajuda da professora porque eu não } \\
\text { sabia por onde começar. Eu tenho } \\
\text { certeza que seria um fracasso a } \\
\text { minha aula. Eu tinha na minha } \\
\text { cabeça aquilo tradicional de explicar, } \\
\text { por quê? Porque eu sempre via } \\
\text { assim, sei lá, de repente uma aula } \\
\text { para criança, explica, explica e dá } \\
\text { atividade, explica, explica, porque eu } \\
\text { não sei se tem outra forma de saber, } \\
\text { foi assim que eu aprendi. Aí depois } \\
\text { fui ver a aula de uma estagiária e ela } \\
\text { fez igual, aquilo me deixou } \\
\text { revoltada. Aí quando chegou na } \\
\text { última observação falei que não ia } \\
\text { fazer, e a professora regente falou } \\
\text { que eu precisa fazer porque as } \\
\text { meninas não fizeram como tinha que } \\
\text { ser feito. Aí que percebi que tinha } \\
\text { alguma coisa errada. Só que eu jáa } \\
\text { tinha feito o plano de aula, estava } \\
\text { tudo pronto. Aí observei na última, } \\
\text { vi como ela fez, é bem diferente do } \\
\text { que elas tinham feito, fiz as minhas } \\
\text { observações comparando elas com a } \\
\text { professora, tudo para eu criar um } \\
\text { jeito. Só que quando chegou na hora } \\
\text { de elaborar o plano fiquei no } \\
\text { tradicional, porque não sabia fazer }\end{array}$ \\
\hline
\end{tabular}


continuação

\begin{tabular}{|c|c|c|c|c|}
\hline \multirow[t]{2}{*}{ CÓDIGO } & \multirow[t]{2}{*}{$\begin{array}{l}\text { CONCEPÇÕES INICIAIS } \\
\text { QUESTIONÁRIO } 1\end{array}$} & \multirow[t]{2}{*}{$\begin{array}{c}\text { CONCEPÇÕES INTERMEDIÁRIAS } \\
\text { QUESTIONÁRIO } 2\end{array}$} & \multicolumn{2}{|c|}{$\begin{array}{c}\text { CONCEPÇÕES } \\
\text { FINAIS } \\
\text { PRÁTICA PEDAGÓGICA }\end{array}$} \\
\hline & & & ANTES DO EVENTO CRÍTICO & APÓS O EVENTO CRÍTICO \\
\hline & & & & $\begin{array}{l}\text { outra coisa. Não tinha idéia de como } \\
\text { deixar mais dinâmico, de questioná- } \\
\text { loss, não imaginava que podia ser } \\
\text { feito isso. Das experiências não } \\
\text { imaginava. Até tinha uma idéia de, } \\
\text { talvez, levar uma balança, só que até } \\
\text { o último momento eu ia faze a } \\
\text { experiência. Eu ia fazer. [risos] então } \\
\text { eu continuei no tradicional. Só } \\
\text { depois entendi que não era assim. } \\
\text { Porque na verdade, na Educação de } \\
\text { Jovens e Adultos eu nunca tinha tido } \\
\text { uma aula. Nunca tinha entrado em } \\
\text { uma sala de aula com eles. Nem } \\
\text { observado, nem conversado com } \\
\text { ninguém que faça EJA, com } \\
\text { professor, com nada. Só com o que } \\
\text { está escrito, só que em nenhum texto } \\
\text { que eu li estava é assim, assim, } \\
\text { assim. Mesmo lendo Paulo Freire, é } \\
\text { difícil entender.” (EF, 19:27) }\end{array}$ \\
\hline 32 & $\begin{array}{c}\text { O aluno aprende perante o } \\
\text { contato visual da prática e } \\
\text { da explicação } \\
\text { desenvolvidas pelo } \\
\text { professor. } \\
\text { “[...] na frente dos alunos } \\
\text { dividiria [o bolo] em dois e } \\
\text { explicaria que cada parte é } \\
\text { 1/2, então dividiria cada } \\
\text { pedaço em dois e explicaria }\end{array}$ & $\begin{array}{l}\text { O aluno aprende perante o contato } \\
\text { visual da prática e da explicação } \\
\text { desenvolvidas pelo professor. } \\
\text { "Fração é a fração de alguma coisa, ou } \\
\text { seja, deseja-se comer só meio chocolate, } \\
\text { a fração que se utiliza é metade, ou } 1 / 2, \\
\text { enfim um pedaço.” } \\
\text { "A divisão é repartir alguma coisa, tendo } \\
6 \text { laranjas e } 4 \text { crianças para comê-las, }\end{array}$ & $\begin{array}{l}\text { O aluno aprende perante o contato visual } \\
\text { da prática e da explicação desenvolvidas } \\
\text { pelo professor. } \\
\text { "Metodologia: [...] mostrar régua, fita métrica, } \\
\text { entre outros. Explicar como a régua está } \\
\text { dividida e o que são milímetros e centímetros. } \\
\text { Pedir que os alunos meçam sua mesa com a } \\
\text { régua. [...]" (Plano da aula } 2-1^{a} \text { versão) }\end{array}$ & \\
\hline
\end{tabular}


continuação

\begin{tabular}{|c|c|c|c|c|}
\hline \multirow[t]{2}{*}{ CÓDIGO } & \multirow[t]{2}{*}{$\begin{array}{l}\text { CONCEPÇÕES INICIAIS } \\
\text { QUESTIONÁRIO } 1\end{array}$} & \multirow[t]{2}{*}{$\begin{array}{c}\text { CONCEPÇÕES INTERMEDIÁRIAS } \\
\text { QUESTIONÁRIO } 2\end{array}$} & \multicolumn{2}{|c|}{$\begin{array}{c}\text { CONCEPÇÕES } \\
\text { FINAIS } \\
\text { PRÁTICA PEDAGÓGICA }\end{array}$} \\
\hline & & & ANTES DO EVENTO CRÍTICO & APÓS O EVENTO CRÍTICO \\
\hline & $\begin{array}{l}\text { que cada parte é } 1 / 4 \text { do bolo e } \\
\text { assim prosseguiria. Escolhi } \\
\text { esta forma de ensinar, pois } \\
\text { entendo que vendo a prática } \\
\frac{\text { o aluno aprende com mais }}{\text { facilidade." }}\end{array}$ & $\begin{array}{l}\text { cada criança, comerá uma e as restantes } \\
\text { serão divididas ao meio, para comerem } \\
\text { igualmente uma laranja e meia, ou ainda, } \\
\text { duas crianças comerem duas laranjas e as } \\
\text { restantes apenas uma." }\end{array}$ & & \\
\hline 33 & $\begin{array}{c}\text { O aluno aprende } \\
\text { manuseando materiais } \\
\text { didáticos mediante a } \\
\text { reprodução de raciocínios } \\
\text { e procedimentos ditados } \\
\text { pelo professor ou livro. } \\
\text { “[...] Então, solicitaria a um } \\
\text { aluno que pegasse para si } 3 \\
\text { bolas de gude e dividisse } \\
\text { igualmente a todos os seus } \\
\text { colegas o restante. As } \\
\text { crianças perceberiam que as } \\
90 \text { bolas que estavam com a } \\
\text { professora dividiram-se em } \\
\text { 30, ou seja, } 3 \text { para cada } \\
\text { aluno. Acho esse método } \\
\text { bom, pois com a prática o } \\
\text { aluno aprende melhor.” }\end{array}$ & & $\begin{array}{l}\text { O aluno aprende manuseando materiais } \\
\text { didáticos mediante a reprodução de } \\
\text { raciocínios e procedimentos ditados pelo } \\
\text { professor ou livro. } \\
\text { Explicou-se aos alunos como se usa a régua e } \\
\text { foi lhes solicitado que monstrassem na régua } \\
\text { algumas medidas. Mediu-se os objetos da aula } \\
\text { anterior e as alturas dos alunos, realizou-se } \\
\text { exercícios de relação entre centímetro, } \\
\text { milímetro, metro e quilometro. (Relatório de } \\
\text { Estágio, 2005, p. 8) }\end{array}$ & \\
\hline 34 & $\begin{array}{c}\text { O aprendizado é um } \\
\text { movimento do concreto } \\
\text { para o abstrato } \\
\text { “[...] na frente dos alunos } \\
\text { dividiria [o bolo] em dois e } \\
\text { explicaria que cada parte é }\end{array}$ & & & $\begin{array}{l}\text { O aprendizado é um movimento } \\
\text { do concreto para o abstrato } \\
\text { "A metodologia ficou da seguinte } \\
\text { maneira: [...] colocar sobre as mesas } \\
\text { objetos para que os alunos peguem e } \\
\text { com as mãos tentem descobrir }\end{array}$ \\
\hline
\end{tabular}


continuação

\begin{tabular}{|c|c|c|c|c|}
\hline \multirow[t]{2}{*}{ CÓDIGO } & \multirow[t]{2}{*}{$\begin{array}{l}\text { CONCEPÇÕES INICIAIS } \\
\text { QUESTIONÁRIO } 1\end{array}$} & \multirow[t]{2}{*}{$\begin{array}{c}\text { CONCEPÇÕES INTERMEDIÁRIAS } \\
\text { QUESTIONÁRIO } 2\end{array}$} & \multicolumn{2}{|c|}{$\begin{array}{c}\text { CONCEPÇÕES } \\
\text { FINAIS } \\
\text { PRÁTICA PEDAGÓGICA }\end{array}$} \\
\hline & & & ANTES DO EVENTO CRÍTICO & APÓS O EVENTO CRÍTICO \\
\hline & 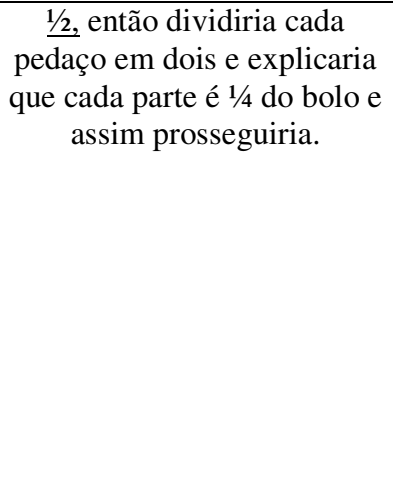 & & & $\begin{array}{l}\text { quanto pesam, fazer o registro de } \\
\text { quanto acham que pesa } \\
\text { individualmente. Verificar na } \\
\text { balança o peso correto e registrar } \\
\text { também. Solicitar que dêem } \\
\text { exemplos de oq ue podemso medir } \\
\text { em grama e quilograma. Questionar } \\
\text { se alguém sabe a relação entre essas } \\
\text { duas medidas, explicar sua relação. } \\
\text { Mostrar a escola de unidades de } \\
\text { medidas de massa e eexplicar que } \\
\text { essas são as mais usuais.” (Relatório } \\
\text { de Estágio, 2005, p. 21) }\end{array}$ \\
\hline 35 & & $\begin{array}{c}\text { O aluno deve ter um desempenho } \\
\text { correto, ele deve acertar nas respostas } \\
\text { "[o ensino de Matemática] [...] deve ser } \\
\text { de várias formas para que a criança } \\
\text { entenda de sua forma, porém certo." }\end{array}$ & & \\
\hline 36 & & $\begin{array}{c}\text { O aluno aprende desenvolvendo o } \\
\text { modo próprio de pensar, } \\
\text { independentemente de o procedimento } \\
\text { estar certo ou errado } \\
\text { "Não acho que existe certo ou errado, } \\
\text { cada um tem sua forma de pensar, tudo } \\
\text { depende de como entendeu o que o } \\
\text { professor ensinou e como expõe no } \\
\text { papel, como faz o desenvolvimento, entre } \\
\text { outros." }\end{array}$ & & $\begin{array}{l}\text { O aluno aprende desenvolvendo o } \\
\text { modo próprio de pensar, } \\
\text { independentemente de o } \\
\text { procedimento estar certo ou } \\
\text { errado } \\
\text { “A1 deixa os alunos livres para } \\
\text { estabelecerem suas próprias relações. } \\
\text { Passava pelas equipes afirmando que } \\
\text { estavam realizando uma experiência. } \\
\text { [...] Vejo todos os alunos envolvidos } \\
\text { na atividade e, inclusive, pedindo } \\
\text { para irem ao quadro resolver } \\
\text { operações referente ao cálculo da }\end{array}$ \\
\hline
\end{tabular}


continuação

\begin{tabular}{|c|c|c|c|c|}
\hline \multirow[t]{2}{*}{ CÓDIGO } & \multirow[t]{2}{*}{$\begin{array}{l}\text { CONCEPÇÕES INICIAIS } \\
\text { QUESTIONÁRIO } 1\end{array}$} & \multirow[t]{2}{*}{$\begin{array}{c}\text { CONCEPÇÕES INTERMEDIÁRIAS } \\
\text { QUESTIONÁRIO } 2\end{array}$} & \multicolumn{2}{|c|}{$\begin{array}{c}\text { CONCEPÇÕES } \\
\text { FINAIS } \\
\text { PRÁTICA PEDAGóGICA } \\
\end{array}$} \\
\hline & & & ANTES DO EVENTO CRÍTICO & APÓS O EVENTO CRÍTICO \\
\hline & & & & $\begin{array}{l}\text { quantidade de água utilizada na } \\
\text { experiência." (Diário de Campo, } \\
\text { Observação da aula 3, 2005, 41) }\end{array}$ \\
\hline 37 & & $\begin{array}{c}\text { O aluno aprende o conhecimento } \\
\text { matemático explorando, investigando, } \\
\text { expondo suas idéias para a turma, } \\
\text { resolvendo problemas e situações } \\
\text { problemáticas. } \\
\text { "[O ensino de Matemática deve ser] de } \\
\text { estratégias, de possibilidade, deve ser de } \\
\text { resolução de problemas não } \\
\text { convecionais, deve ser de várias formas } \\
\text { para que a crianças entenda de sua forma, } \\
\text { porém certo." }\end{array}$ & & $\begin{array}{c}\text { O aluno aprende o conhecimento } \\
\text { matemático explorando, } \\
\text { investigando, expondo suas idéias } \\
\text { para a turma, resolvendo } \\
\text { problemas e situações } \\
\text { problemáticas. } \\
\text { "A1 - Será que ao invés de começar } \\
\text { todos separadinhos, já fazer grupos, } \\
\text { grupo de primeira e segunda e grupo } \\
\text { de terceira e quarta. Não sei. Que daí } \\
\text { faz. } \\
\text { P - Não sei. Formar o grupo para } \\
\text { fazer o quê? Vamos pensar. } \\
\text { A1 - Até de repente, não sei, isso das } \\
\text { embalagens conversar com todos, } \\
\text { para ver o que eles falam e aí depois } \\
\text { essas experiências cada grupo. Põe lá } \\
\text { na mesa as jarrinhas em cada grupo, } \\
\text { os copos em cada grupo. O que } \\
\text { vocês acham? Sei lá. Eles partirem } \\
\text { de alguma coisa para depois eu } \\
\text { propor alguma coisa. O que dá para } \\
\text { fazer? Como a gente vai medir com } \\
\text { isso aí? Como vocês mediriam?" } \\
\text { (RE -AU3, 24:15 a 24:32) } \\
\text { "P - Já vimos que você levou a } \\
\text { questão da Resolução de Problemas } \\
\text { para a sua sala. O que você acha }\end{array}$ \\
\hline
\end{tabular}


continuação

\begin{tabular}{|c|c|c|c|c|}
\hline \multirow[t]{2}{*}{ CÓDIGO } & \multirow[t]{2}{*}{$\begin{array}{l}\text { CONCEPÇÕES INICIAIS } \\
\text { QUESTIONÁRIO } 1\end{array}$} & \multirow[t]{2}{*}{$\begin{array}{c}\text { CONCEPÇÕES INTERMEDIÁRIAS } \\
\text { QUESTIONÁRIO } 2\end{array}$} & \multicolumn{2}{|c|}{$\begin{array}{c}\text { CONCEPÇÕES } \\
\text { FINAIS } \\
\text { PRÁTICA PEDAGÓGICA }\end{array}$} \\
\hline & & & ANTES DO EVENTO CRÍTICO & APÓS O EVENTO CRÍTICO \\
\hline & & & & $\begin{array}{l}\text { sobre essa forma de ensinar em } \\
\text { relação a aprendizagem do aluno? } \\
\text { A1 - Eu acho que essa é uma forma } \\
\text { melhor dele aprender, essa forma de } \\
\text { resolver os problemas como foi na } \\
\text { minha aula que não é aquela forma } \\
\text { tradicional. Eu acho que é até mais } \\
\text { fácil de aprender. Porque daí você } \\
\text { não está usando só de números, } \\
\text { daquilo que você já sabe de cor, que } \\
\text { não tem como mexer de outra forma } \\
\text { com a cabeça deles, não é? Eu acho } \\
\text { que foi bem bom do jeito que eu } \\
\text { fiz." (EF, 15:52 a 16:30) } \\
\text { "Por se tratar de séries diferentes, o } \\
\text { grupo de séries menores fez registro } \\
\text { em desenho e o outro em texto, desta } \\
\text { forma utilizando-se ainda do } \\
\text { diálogo, cada um explicou o que } \\
\text { registrou." (Relatório de Estágio, } \\
\text { 2005, p. 17) }\end{array}$ \\
\hline 38 & & & $\begin{array}{l}\text { O aluno aprende perante a realização de } \\
\text { jogos e experimentos e/ou pelo contato } \\
\text { visual e táctil de materiais didáticos } \\
\text { "A1 - Sabe o que eu estava pensando, usar } \\
\text { jogos? Não sei se pode? } \\
\text { P - Pode. } \\
\text { A1 - Porque eu acho que eles são assim, eu até } \\
\text { percebi ontem quando fui ver a aula das } \\
\text { meninas que estavam terminando o estágio } \\
\text { delas, elas levaram uns gibis. Eu não faria, }\end{array}$ & $\begin{array}{l}\text { O aluno aprende perante a } \\
\text { realização de jogos e experimentos } \\
\text { e/ou pelo contato visual e táctil de } \\
\text { materiais didáticos } \\
\text { "A1 - Será que ao invés de começar } \\
\text { todos separadinhos, já fazer grupos, } \\
\text { grupo de primeira e segunda e grupo } \\
\text { de terceira e quarta. Não sei. Que daí } \\
\text { faz. } \\
\text { P - Não sei. Formar o grupo para } \\
\end{array}$ \\
\hline
\end{tabular}


continuação

\begin{tabular}{|c|c|c|c|c|}
\hline \multirow[t]{2}{*}{ CÓDIGO } & \multirow[t]{2}{*}{$\begin{array}{l}\text { CONCEPÇÕES INICIAIS } \\
\text { QUESTIONÁRIO } 1\end{array}$} & \multirow[t]{2}{*}{$\begin{array}{c}\text { CONCEPÇÕES INTERMEDIÁRIAS } \\
\text { QUESTIONÁRIO } 2\end{array}$} & \multicolumn{2}{|c|}{$\begin{array}{c}\text { CONCEPÇÕES } \\
\text { FINAIS } \\
\text { PRÁTICA PEDAGÓGICA }\end{array}$} \\
\hline & & & ANTES DO EVENTO CRÍTICO & APÓS O EVENTO CRÍTICO \\
\hline & & & $\begin{array}{l}\text { não sei. Daí um senhor lá, mas ele tem uns } \\
\text { sessenta anos, deve ter trabalhado o dia inteiro } \\
\text { e foi lá para estudar, falou: ele foi para a } \\
\text { escola para estudar e não para ficar fazendo } \\
\text { esse negócio de artes. Ele falou assim: a gente } \\
\text { fica perdendo tempo fazendo figurinha, esse } \\
\text { negócio de teatro. Eles fizeram teatro e daí } \\
\text { não ficam estudando e a matéria vai ficando. } \\
\text { E, ele falou muito sério, a professora estava } \\
\text { nervosa e nem falou nada } \\
\text { P - Talvez, você possa pensar em equilibrar } \\
\text { isso, dizer que é uma atividade para dar uma } \\
\text { descansada na mente. } \\
\text { A1 - É por pouco tempo, faz o joguinho e } \\
\text { depois faz outra atividade. } \\
\text { P - Isso. Eles podem fazer um exercício } \\
\text { enfocando o jogo. Faz um jogo de memória, } \\
\text { por exemplo, que relacione o conteúdo, que o } \\
\text { aluno consiga ver o conteúdo que está } \\
\text { trabalhando. Porque nesse seu caso não a } \\
\text { ocasião de propor exercício, por exemplo, de } \\
\text { calcular a distância de um lugar para o outro. } \\
\text { No que você está propondo, vai trabalhar os } \\
\text { conceitos das medidas. O que é medir, as } \\
\text { medidas não-padronizadas e as medidas } \\
\text { padronizadas. } \\
\text { A1 - E nada assim, por exemplo, de medir, } \\
\text { eles até podem pegar uma trena e medir uma } \\
\text { mesa, tudo coisas bem leve. Pois eu acredito } \\
\text { que eles tenham bastante dificuldade. Porque } \\
\text { eu vi ontem, tudo eles perguntavam como era } \\
\text { que escrevia isso, como escrevia aquilo. E, era }\end{array}$ & $\begin{array}{l}\text { fazer o quê? Vamos pensar. } \\
\text { A1 - Até de repente, não sei, isso das } \\
\text { embalagens conversar com todos, } \\
\text { para ver o que eles falam e aí depois } \\
\text { essas experiências cada grupo. Põe lá } \\
\text { na mesa as jarrinhas em cada grupo, } \\
\text { os copos em cada grupo. O que } \\
\text { vocês acham? Sei lá. Eles partirem } \\
\text { de alguma coisa para depois eu } \\
\text { propor alguma coisa. O que dá para } \\
\text { fazer? Como a gente vai medir com } \\
\text { isso aí? Como vocês mediriam?" } \\
\text { (RE -AU3, 24:15 a 24:32) } \\
\text { "Até mesmo quando foi o dos } \\
\text { palitos. Eles tiveram a iniciativa, eu } \\
\text { estava tentando ensinar a menina } \\
\text { como fazia um cálculo, então eles } \\
\text { falaram: você quer que eu peça para } \\
\text { a professora os palitos? Aí eu } \\
\text { concordei, mas achei interessante } \\
\text { que eles se preocuparam em } \\
\text { aprender." (EF, 23:05) }\end{array}$ \\
\hline
\end{tabular}


continuação

\begin{tabular}{|c|c|c|c|c|}
\hline \multirow[t]{2}{*}{ CÓDIGO } & \multirow[t]{2}{*}{$\begin{array}{l}\text { CONCEPÇÕES INICIAIS } \\
\text { QUESTIONÁRIO } 1\end{array}$} & \multirow[t]{2}{*}{$\begin{array}{c}\text { CONCEPÇÕES INTERMEDIÁRIAS } \\
\text { QUESTIONÁRIO } 2\end{array}$} & \multicolumn{2}{|c|}{$\begin{array}{c}\text { CONCEPÇÕES } \\
\text { FINAIS } \\
\text { PRÁTICA PEDAGÓGICA }\end{array}$} \\
\hline & & & ANTES DO EVENTO CRÍTICO & APÓS O EVENTO CRÍTICO \\
\hline & & & tudo bem básico." (OP, 16:14 a 19:00) & \\
\hline 39 & & & $\begin{array}{l}\text { Saber Matemática é ser capaz de realizar } \\
\text { tarefas propostas pelo professor, as quais } \\
\text { são aplicações do conceito e/ou reforço e } \\
\text { motivação para a aprendizagem. } \\
\text { "Metodologia: [...] relacionar milímetro, } \\
\text { centímetro, metro e quilômetro. Entregar } \\
\text { conteúdo digitado e exercícios de } \\
\text { transformação de unidades. } \\
\text { Avaliação: realização de exercícios em grupo } \\
\text { com o auxílio da professora, sobre } \\
\text { transformação de unidades de medidas." } \\
\text { (Plano da aula } 2-1^{a} \text { versão) }\end{array}$ & \\
\hline 40 & & & $\begin{array}{l}\text { A participação do aluno, seu interesse e } \\
\text { idéias pessoais são fundamentais para oa } \\
\text { aprendizagem do novo conhecimento. } \\
\text { "[o indício de que consegui atingir o objetivo } \\
\text { da primeira aula) Eu acho que pelo interesse } \\
\text { deles e porque eles já tinham conhecimento } \\
\text { sobre isso. Ah, não sei, várias coisas, não sei, } \\
\text { tenho que pensar. Ah, gostei, gostei, estava } \\
\text { bem preocupada, bem nervosa. Na verdade eu } \\
\text { cheguei lá, eles queriam saber quem eu era, eu } \\
\text { assisti várias aulas deles, até um dia eles } \\
\text { perguntaram se eu ia dar aula para eles, eles } \\
\text { disseram, ah, que bom. Só eu acho que eles } \\
\text { viram a minha preocupação, porque eu } \\
\text { cheguei e falei: hoje eu vou dar aula para } \\
\text { vocês e estou morrendo de vergonha. Se eu } \\
\text { falar alguma besteira, a professora ia estar na } \\
\text { sala [não ficou claro se é a professora da } \\
\text { turma ou eu] vocês não têm que dar risada de }\end{array}$ & \\
\hline
\end{tabular}


continuação

\begin{tabular}{|c|c|c|c|c|}
\hline \multirow[t]{2}{*}{ CÓDIGO } & \multirow[t]{2}{*}{$\begin{array}{l}\text { CONCEPÇÕES INICIAIS } \\
\text { QUESTIONÁRIO } 1\end{array}$} & \multirow[t]{2}{*}{$\begin{array}{c}\text { CONCEPÇÕES INTERMEDIÁRIAS } \\
\text { QUESTIONÁRIO } 2\end{array}$} & \multicolumn{2}{|c|}{$\begin{array}{c}\text { CONCEPÇÕES } \\
\text { FINAIS } \\
\text { PRÁTICA PEDAGÓGICA } \\
\end{array}$} \\
\hline & & & ANTES DO EVENTO CRÍTICO & APÓS O EVENTO CRÍTICO \\
\hline & & & $\begin{array}{l}\text { mim porque estou aprendendo. Aí eles deram } \\
\text { risada. Então quer dizer, que eu também estou } \\
\text { na minha condição como aluna. Eu acho que } \\
\text { isso foi bom, foi bom, porque aí me soltei, não } \\
\text { tive mais medo, não tive nada. Antes de eu } \\
\text { chegar lá eu estava nervosa, nervosa e não } \\
\text { precisa ser. Se eles realmente se interessaram } \\
\text { pela aula e não aconteceu que nem algumas } \\
\text { colegas minhas tinham contado que os alunos } \\
\text { saíam da aula. Então me apavorei. Imagine se } \\
\text { acontece isso? Acho muito triste. Mas, eles } \\
\text { ficaram até o fim e no final me agradeceram. } \\
\text { [P comenta que eles elogiaram a aula no final] } \\
\text { é, e eu achei isso muito bom. Nunca tinha } \\
\text { acontecido, e eu assisti aulas de estagiários. } \\
\text { Então quer dizer: eu fiz alguma diferença, } \\
\text { alguma coisa que eu fiz e eles gostaram.” } \\
\text { (RE-AU2, 47:55) }\end{array}$ & \\
\hline 41 & & & & $\begin{array}{l}\text { O aluno aprende fazendo, isto é, } \\
\text { construindo relações entre as } \\
\text { idéias matemáticas já conhecidas e } \\
\text { as novas. } \\
\text { "Eu acho que [a proposta de aula nos } \\
\text { questionários] está muito limitado só } \\
\text { naquilo, que não está como eu fiz } \\
\text { que foi uma aula bem ampla, } \\
\text { dinâmica que eles pudessem } \\
\text { construir a partir do próprio } \\
\text { interesse. Esta proposta está muito } \\
\text { limitada, é aquilo, que nem o } \\
\text { chocololate, é o chocolate dividido } \\
\text { no meio e pronto, acabou. Então a }\end{array}$ \\
\hline
\end{tabular}


conclusão

\begin{tabular}{|c|c|c|c|c|}
\hline \multirow[t]{2}{*}{ CÓDIGO } & \multirow[t]{2}{*}{$\begin{array}{l}\text { CONCEPÇÕES INICIAIS } \\
\text { QUESTIONÁRIO } 1\end{array}$} & \multirow[t]{2}{*}{$\begin{array}{c}\text { CONCEPÇÕES INTERMEDIÁRIAS } \\
\text { QUESTIONÁRIO } 2\end{array}$} & \multicolumn{2}{|c|}{$\begin{array}{c}\text { CONCEPÇÕES } \\
\text { FINAIS } \\
\text { PRÁTICA PEDAGÓGICA }\end{array}$} \\
\hline & & & ANTES DO EVENTO CRÍTICO & APÓS O EVENTO CRÍTICO \\
\hline & & & & $\begin{array}{l}\text { aula fica bem limitada, né?" (EF, } \\
\text { 11:17) }\end{array}$ \\
\hline 42 & & & & $\begin{array}{l}\text { Aprender Matemática é poder } \\
\text { aplicar, usar o conhecimento no } \\
\text { mundo real. } \\
\text { "Ah, não! Não. Na verdade assim, o } \\
\text { que que queria mesmo é que eles } \\
\text { ficassem, apredessem bem para usar, } \\
\text { para ter o conhecimento, para } \\
\text { aprender que existe. Mas acho que } \\
\text { não dessa maneira, impositiva, que } \\
\text { tem que ser." (EF, 05:46) }\end{array}$ \\
\hline 43 & & & & $\begin{array}{c}\text { A aprendizagem é resutlante da } \\
\text { ação interativa/reflexiva do aluno } \\
\text { com o meio ou com as tarefas } \\
\text { “A1 deixa os alunos livres para } \\
\text { estabelecerem suas próprias relações. } \\
\text { Passava pelas equipes afirmando que } \\
\text { estavam realizando uma experiência. } \\
\text { [...] Vejo todos os alunos envolvidos } \\
\text { na atividade e, inclusive, pedindo } \\
\text { para irem ao quadro resolver } \\
\text { operações referente ao cálculo da } \\
\text { quantidade de água utilizada na } \\
\text { experiência.” (Diário de Campo, } \\
\text { Observação da aula 3, 2005, 41) }\end{array}$ \\
\hline
\end{tabular}




\begin{abstract}
ANEXOS
ANEXO 1 Grade Curricular do Curso de Pedagogia - 1996 a 2008_................................. 279

ANEXO 2 Plano de Ensino da Disciplina Prática Pedagógica C: Estágio em Docência.... 280

ANEXO 3 Plano de Ensino da Disciplina Metodologia do Ensino de Matemática I......... 282

ANEXO 4 Modelo dos Questionários - Exemplos de Respostas …................................. 284

ANEXO 5 Exemplo de Relatório de Estágio....................................................................... 286

ANEXO 6 Exemplo de notas de diário de campo.................................................................. 303
\end{abstract}


ANEXO 1 - GRADE CURRICULAR DO CURSO DE PEDAGOGIA - 1996 a 2008

\begin{tabular}{|c|c|c|c|}
\hline ANO & \multicolumn{3}{|c|}{ DISCIPLINAS } \\
\hline $1^{\circ}$ Ano & $\begin{array}{l}\text { HC402 } \\
\text { ET419 } \\
\text { ET421 } \\
\text { ET423 } \\
\text { ET425 } \\
\text { ET030 } \\
\text { ET029 } \\
\text { EM437 } \\
\text { EP432. }\end{array}$ & $\begin{array}{l}\text { Sociologia } \\
\text { Psicologia da Educação E } \\
\text { História da Educação B } \\
\text { Filosofia da Educação B } \\
\text { Biologia Educacional B } \\
\left.\text { Fundam. Da Educação Infantil I ( } 1^{\circ} \mathrm{sem}\right) \\
\text { Fundam. Da Educ. de Jovens e Ad. I }\left(2^{\circ} \text { sem }\right) \\
\text { Prática Pedagógica A: Extensão Escolar } \\
\text { E.F. da Educação Infantil e do Ens. Fundamental A }\end{array}$ & $\begin{array}{l}60 \text { horas } \\
90 \text { horas } \\
90 \text { horas } \\
90 \text { horas } \\
90 \text { horas } \\
30 \text { horas } \\
30 \text { horas } \\
60 \text { horas } \\
60 \text { horas }\end{array}$ \\
\hline $2^{\circ}$ Ano & $\begin{array}{l}\text { ET416 } \\
\text { ET420 } \\
\text { ET422 } \\
\text { ET424 } \\
\text { EM440 } \\
\text { EM438. } \\
\text { EP433 }\end{array}$ & $\begin{array}{l}\text { Sociologia da Educação } \\
\text { Psicologia da Educação F } \\
\text { História da Educação C } \\
\text { Filosofia da Educação C } \\
\text { Didática C } \\
\text { Prática Pedagógica B: Introd. à Pesq. Educacional } \\
\text { E.F.E. Médio e da Educ. de Jovens e Adultos A }\end{array}$ & $\begin{array}{l}120 \text { horas } \\
90 \text { horas } \\
90 \text { horas } \\
90 \text { horas } \\
60 \text { horas } \\
90 \text { horas } \\
60 \text { horas }\end{array}$ \\
\hline $3^{\circ}$ Ano & $\begin{array}{l}\text { EP436 } \\
\text { EP435 } \\
\text { EM076 } \\
\text { EM084 } \\
\text { EM083 } \\
\text { EM079 } \\
\text { EM081 } \\
\text { EM082 } \\
\text { EM077 } \\
\text { EM080 } \\
\text { EM078 } \\
\text { EM441 } \\
\text { EM439 }\end{array}$ & 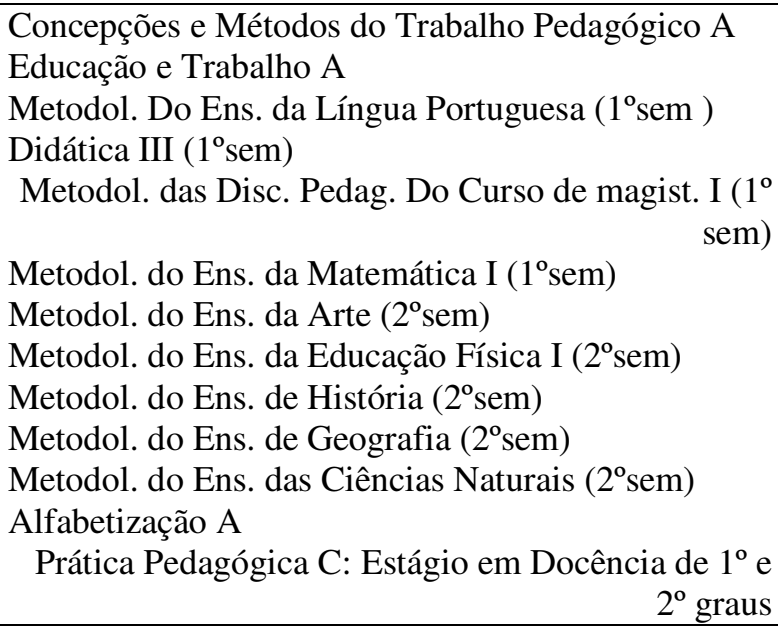 & $\begin{array}{l}90 \text { horas } \\
60 \text { horas } \\
30 \text { horas } \\
30 \text { horas } \\
30 \text { horas } \\
30 \text { horas } \\
30 \text { horas } \\
30 \text { horas } \\
30 \text { horas } \\
30 \text { horas } \\
30 \text { horas } \\
60 \text { horas } \\
120 \text { horas }\end{array}$ \\
\hline $4^{\circ}$ Ano & $\begin{array}{l}\text { EP434 } \\
\text { EP437 } \\
\text { EP438 } \\
\text { EP439 } \\
\text { EP441 } \\
\text { EP028 } \\
\text { EP440 } \\
\text { EP403 } \\
\text { EP045 }\end{array}$ & $\begin{array}{l}\text { Políticas e Planejamento da Educação no Brasil A } \\
\text { Organização do Trabalho Pedagógico na Escola A } \\
\text { Medidas Educacionais e Avaliação Escolar A } \\
\text { O Trabalho Pedagógico na Educ. Não-Escolar A } \\
\text { Currículos e Programas A } \\
\text { Fundamentos da Educação Especial I ( }\left(1^{\circ} \text { sem }\right) \\
\text { Prática Pedagógica D: Est. Sup. Na Org. Esc. } \\
\text { Educação Comparada } \\
\text { Tecnologia Aplicada à Educação I }\left(2^{\circ} \text { sem }\right)\end{array}$ & $\begin{array}{l}60 \text { horas } \\
90 \text { horas } \\
60 \text { horas } \\
60 \text { horas } \\
60 \text { horas } \\
30 \text { horas } \\
120 \text { horas } \\
60 \text { horas } \\
30 \text { horas }\end{array}$ \\
\hline
\end{tabular}

FONTE: UFPR. Proposta Curricular para o curso de Pedagogia. 1996.

NOTA: Dados trabalhados pela autora. 


\section{ANEXO 2 - PLANO DE ENSINO DA PRÁTICA PEDAGÓGICA C: ESTÁGIO EM DOCÊNCIA}

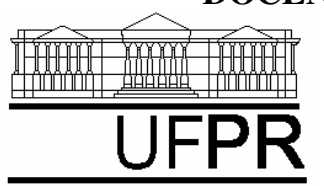

MINISTÉRIO DA EDUCAÇÃO E DO DESPORTO

UNIVERSIDADE FEDERAL DO PARANÁ

SETOR DE EDUCAÇÃO

DEPARTAMENTO DE TEORIA E PRÁTICA DE

ENSINO

\section{PLANO DE ENSINO}

\section{Ficha 2}

Disciplina: Prática Pedagógica C: Estágio em Docência

Curso: Pedagogia

Código: EM 444

Ano: 2005

\section{Objetivos didáticos:}

OBJETIVO GERAL: Vivenciar o cotidiano pedagógico escolar e/ou não escolar e analisar a prática docente.

OBJETIVOS ESPECÍFICOS: discutir sobre possibilidades e funcionamento dos campos de estágio.

Analisar a atuação do professor da educação básica.

em espaço escolar e/ou não escolar.

Elaborar e executar um projeto de ação pedagógica,

Avaliar o projeto de ação implementado, enquanto contribuição à formação do educador e ao campo de estágio selecionado.

\section{Ementa:}

Contextualização do processo educativo. Intervenção e análise crítica da ação pedagógica em espaços escolares e não escolares. Planejamento e prática de ensino na educação básica. A prática pedagógica e a indissociabilidade entre teoria e prática.

\section{Programa (os itens de cada unidade didática) :}

- Alternativas didático-metodológicas para a atuação docente em espaços escolares e não escolares

- Discussão de práticas educativas interdisciplinares e o cotidiano escolar.

- Caracterização do local de estágio: observação e diagnóstico

- Elaboração, implementação e avaliação do projeto pedagógico de estágio.

- Elaboração do Relatório do projeto de ação.

\section{Procedimentos didáticos.}

- Exposição dialogada; análise de textos; atividades individuais e em grupos; pesquisa; seminários temáticos; supervisão direta e/ou indireta das atividades dos estagiários no campo de estágio.

\section{Avaliação:}

Elaboração, implementação e avaliação do projeto de estágio: trabalhos escrito, participação nas aulas; desempenho no estágio, auto-avaliação. 
Referências Bibliográficas

ALVES, Nilda org. Formação de professores: pensar e fazer. São Paulo: Cortez, 1995.

FAZENDA, I.C et al. A Prática de Ensino e o Estágio Supervisionado. São Paulo: Papirus, 1991.

FAZENDA, I.C. Práticas interdisciplinares na escola. São Paulo: Cortez, 1990.

LELIS, I A O. A formação do professor para a escola básica: tendências e perspectivas. São Paulo: Caderno CEDES (17), 1986.

LIBÂNEO, J C. Didática. São Paulo: Cortez, 1992.

MASETTO, M. Aulas vivas. São Paulo: MG, 1992.

MELLO, G N. Formação inicial de professores da educação básica: uma (re)visão radical. SEADE (no prelo)

NOVOA, A. Os professores e a sua formação. Lisboa: Dom Quixote, 1992.

PERRENOUD, P. Dez novas competências para ensinar. Porto Alegre: Ates Médicas Sul, 2000.

PICONEZ, S (org) A prática de ensino e o estágio supervisionado. Campinas: Papirus, 1991.

PIMENTA, S G. O estágio na formação de professores: unidade teoria e prática. São Paulo: Cortez, 1994.

SILVA, E T. O professor e o combate à alienação imposta. São Paulo: Cortez, 1991.

UNIVERSIDADE FEDERAL DO PARANÁ. Sentido do Estágio na formação profissional. Caderno no. 3. Curitiba, 1990.

VASCONCELOS, C dos S. Construção do conhecimento em sala de aula. São Paulo: coleção Cadernos Pedagógicos Libertad, 1995. 


\section{ANEXO 3 - PLANO DE ENSINO DA METODOLOGIA DO ENSINO DE MATEMÁTICA UFPR MINISTÉRIO DA EDUCAÇÃO E DO DESPORTO UNIVERSIDADE FEDERAL DO PARANÁ SETOR DE EDUCAÇÃO DEPARTAMENTO DE TEORIA E PRÁTICA DE ENSINO}

\section{PLANO DE ENSINO}

\section{Ficha 2}

Disciplina: Metodologia do Ensino de Matemática Curso: Pedagogia Professora: Tania Teresinha Bruns Zimer Ano: 2005

\section{Objetivos didáticos:}

OBJETIVO GERAL: Propiciar um embasamento teórico-prático que permita ao alunomestre assumir uma postura metodológica compatível com as atuais concepções de Matemática e de seu ensino.

OBJETIVOS ESPECÍFICOS: Conhecer os enfoques da Matemática, interpretá-los e inferir suas implicações no processo educativo. Fundamentar teoricamente a ação docente, tornando-a consistente e significativa. Conhecer os conteúdos de Matemática referente às séries iniciais do ensino fundamental e adequá-los a este nível de ensino em termos de abrangência. Planejar unidades de ensino quer utilizando metodologias já desenvolvidas, quer criando metodologias inovadoras.

\section{Ementa:}

Implicações dos diferentes enfoques teórico-metodológicos da Matemática no processo educativo. Análise dos conceitos e métodos próprios das disciplina de Matemática, suas inter-relações com o processo ensino-aprendizagem e com a produção de conhecimento, produção de material didático e propostas pedagógicas.

\section{Programa (os itens de cada unidade didática) :}

- Finalidades educacionais e objetivos do ensino de Matemática.

- Conceito de Matemática, Educação e Educação Matemática.

- Etnomatemática: saber cultural, saber escolar e ação pedagógica.

- Teorias de aprendizado de conceitos matemáticos.

- Possibilidades de avaliação da aprendizagem em Matemática.

- Alternativas e diretrizes metodológicas para o ensino de Matemática.

- Problematização, resolução de problemas, modelação na prática didático-metodológia.

- Elaboração de material didático.

\section{Procedimentos didáticos.}

- Leitura de textos e/ou obras seguidas de reflexões, discussões, questionamentos e análise.

- Estudo de programas escolares de Matemática coletados pelos alunos em escolas da comunidade.

- Pesquisa das metodologias expressas através dos materiais didáticos disponíveis.

- Estudo de unidades do conhecimento matemático em livros didáticos do ensino fundamental e médio.

- Elaboração de unidades de ensino com a respectiva construção de material didático.

\section{Avaliação:}

Contínua, em função dos objetivos propostos. Instrumentos: provas escritas, trabalhos e seminários. 


\section{Referências Bibliográficas}

BICUDO, M. A. (org) Educação Matemática, São Paulo, Moraes, 1987.

BRASIL. Secretaria de Educação Fundamental. Parâmetros Curriculares nacionais: matemática. Brasília . MEC/Set, 1997.

---------. Secretaria de Educação Fundamental. Parâmetros Curriculares nacionais: ética. Brasília . MEC/Set, 1997.

---------. Secretaria de Educação Fundamental. Parâmetros Curriculares nacionais: meio ambiente. Brasília . MEC/Set, 1997.

---------. Secretaria de Educação Fundamental. Parâmetros Curriculares nacionais: orientação sexual. Brasília . MEC/Set, 1997.

---------. Secretaria de Educação Fundamental. Parâmetros Curriculares nacionais: pluralidade cultural. Brasília . MEC/Set, 1997.

--------. Secretaria de Educação Fundamental. Parâmetros Curriculares nacionais: saúde. Brasília . MEC/Set, 1997.

D'AMBRÓSIO, U. Da realidade a ação: reflexões sobre educação e matemática. São Paulo, Summus, 1986.

-Educação Matemática: uma visão do Estado da Arte, in Proposições, vol. 4, São Paulo, Cortez, 1983, pp. 7-18.

-Etnomatemática, São Paulo, Ática, 1991.

Etnomatemática: um programa, in A Educação Matemática em revista, revista da SBEM, SC, ano $1 \mathrm{n}^{\circ} 1,1994$, pp. 5-18.

D'AMBRÓSIO, B. Formação de professores de matemática para o século XXI: o grande desafio, in Proposições, vol. 4, SP, Cortez, 1993, pp. 35-42.

DANTE, Luiz Roberto, Didática da Resolução de problemas de Matemática. São Paulo, Ática, 1989.

DOMENICO, E. G. DE. Metodologia de ensino para a iniciação matemática fundamentada na pedagogia montessoriana. Paraná, UFPR, Dissertação de mestrado, 1988.

-Metodologia do Ensino de Matemática, in MULLER, S. M. (org), Metodologia de Ensino de diferentes disciplinas, 1992, Cap. III, 08-14.

FIORENTINI, D., A questão dos conteúdos e métodos no ensino de matemática, in ANAIS III EGEM, RS, 1993, pp. 38-46.

Algumas concepções de Educação algébrica: fundamentos para repensar o ensino da matemática elementar, in ANAIS III EPEM, SP, 1993, pp. 29-35.

KALEFF, Ana Maria et alii, Desenvolvimento do pensamento geométrico - o modelo de Van Hiele, in Bolema, ano $9 \mathrm{n}^{\circ} 10,1994$, pp. 21-30.

KLINE, M., O fracasso da Matemática moderna. IBRASA, 1970.

MACHADO, N. J., Matemática e Realidade. São Paulo, Moraes, 1987.

MOURA, M. O, A atividade de ensino como unidade formadora, texto apresentado no II Congresso Interamericano de Educação Matemática, SC, SBEM - FURB, 1994.

--Professor de matemática: a formação como solução construída, in Revista de Educação Matemática, SBEM, São Paulo, Ano $1 \mathrm{n}^{\circ}$ 1, pp. 1-15.

NASSER, L., Usando a Teoria de Van Hiele para melhorar o ensino secundário de geometria no Brasil.in Série Documental - eventos n ${ }^{\mathrm{o}} 4,2^{\mathrm{a}}$ parte, MEC - INEP, 1994.

\section{PERIÓDICOS}

A Educação Matemática em Revista, SBEM.

Boletim da Unesco, $n^{\circ}$ 53, Paris, 1992.

Boletim MEC - INEP/ Brasília, Mapeamento de pesquisa/ estudos/ trabalhos técnicos científicos na área de Educação Matemática no Brasil, 1994.

Boletim informativo da SBEM.

GEPEM - Boletim, USU/RJ

Proposições, vol. V, UNICAMP, SP

Revista do professor de Matemática, SBEM

Série Documental: eventos, $\mathrm{n}^{\mathrm{o}} 4,1^{\mathrm{a}}, 2^{\mathrm{a}}, 3^{\mathrm{a}}$ partes. MEC - INEP/ Brasília, Seminário sobre novas perspectivas da educação matemática no Brasil, 1994.

Temas e Debates, Sociedade Brasileira de Educação Matemática - ZETETIKÉ, UNICAMP/ SP

II Congresso Ibero Americano de Educação Matemática - livro de resumos, SBEM/ SC. 


\section{ANEXO 4 - MODELO DOS QUESTIONÁRIOS - EXEMPLO DE RESPOSTAS \\ - QUESTIONÁRIO 1}

Nome:.A1

Data: 23/03/05.

Primeiro, leia a questão, reflita sobre a mesma e depois responda de modo a expressar sua percepção pessoal sobre o assunto.

1) Um leigo lhe pergunta “de onde vem a Matemática?”. Como você explicaria essa questão?

Eu lhe diria que os números foram criados há muito tempo atrás para facilitar a vida das pessoas, mas não bastava cria-los, era necessário dar a eles uma melhor utilização. Foi a partir disso que estudiosos formaram conceitos como adição, multiplicação $e$ divisão para facilitar ainda mais a vida do homem, pois para "tudo" hoje em dia é necessário, entre outros. A matemática surgiu para ajudar o homem na sua cidadania.

2) Se incluísse em sua explicação as principais características da Matemática, quais você apresentaria?

Ela trabalha com números e sua finalidade é calcular. As principais operações são: adição (somar), subtração (diminuir), multiplicação e divisão.

3) Se durante o seu estágio, seu professor-tutor lhe pedir que ensine:

a) a noção de fração;

b) a operação da divisão entre números naturais.

Como você ensinará tais tópicos? Explique, de modo detalhado e justificado sua opção de ensino.

a) Começaria levando à sala de aula um bolo inteiro, na frente dos alunos dividiria em dois e explicaria que cada parte é $1 / 2$, então, dividiria cada pedaço em dois e explicaria que cada parte é $1 / 4$ do bolo e assim prosseguiria. Escolhi esta forma de ensinar, pois entendo que vendo a prática o aluno aprende com mais facilidade.

b)Levaria para a sala de aula bolas de gude, na mesa da prof ${ }^{a}$. ficaria cerca de 90 unidades. Então, solicitaria a um aluno que pegasse para si 2 bolas $e$ dividisse igualmente a todos os seus colegas o restante. As crianças perceberiam que as 90 bolas que estavam com a prof ${ }^{a}$. dividiram-se em 30, ou seja, 3 para cada aluno. Acho esse um método bom, pois com a prática o aluno aprende melhor.

\section{RESPOSTAS COMPLEMENTARES A ESSE QUESTIONÁRIO APÓS A1 RESPONDER AO QUESTIONÁRIO 2.}

1 - A matemática surgiu para auxiliar o homem a criar estratégias para resolver problemas, com ela aprende-se a raciocinar.

2 - Ela serve para que o indivíduo aprenda a raciocinar.

3 a-Acredito que esta seria uma boa prática.

3 b-Acredito que esta seria uma boa prática. 
Primeiro, leia o texto, reflita sobre o mesmo e depois o complemente de modo a expressar sua percepção pessoal sobre o assunto, no momento.

Era o último dia de aula. Todos estavam muito eufóricos pela chegada das férias. A professora, percebendo a agitação na sala, começou a indagar sobre o que cada aluno havia planejado fazer durante o período que não haveria aulas. Entre os vários planejamentos revelados, tais como: não fazer nada, assistir televisão, andar de bicicleta e visitar alguém, houve um que se diferenciava por sua temática.

-- Professora! Planejei para essas férias escrever um 'livro' sobre o que aprendi até agora. Mas, não sei ainda muito bem como vou escrever sobre a Matemática. A senhora poderia ajudar-me?

A professora surpresa com a situação começou a falar, tentando explicar-lhe de onde vem a Matemática, quais são suas características e como ela é construída.

A matemática surgiu há muito tempo através de muitas pesquisas de pessoas que hoje são reconhecidas como grandes gênios. Ela surgiu para auxiliar o homem em tudo que vai fazer, a criar estratégias para problemas, a ir a supermercados e ter dinheiro suficiente para pagar as contas, para que um engenheiro que vá construir uma casa não deixe que caia. Matemática se utiliza do raciocínio das pessoas, utiliza-se do cálculo. A matemática trabalha com números.

Quando a professora concluiu sua explicação, percebeu que outros alunos haviam se engajado neste projeto de férias, pois começaram a perguntar se estava correto o modo como resolviam os dois últimos exercícios do caderno de Matemática para que pudessem, também, escreverem seus livros. Antes de observar os cadernos dos alunos, ela, resolveu explicar novamente frações equivalentes e o algoritmo da divisão como se fosse a primeira vez que estivesse ensinando-os em sala de aula. Assim, fez o seguinte:

Fração é a fração de alguma coisa, ou seja, se deseja comer só meio chocolate, a fração que se

utiliza é metade ou $1 / 2$, enfim um pedaço.

Divisão é repartir alguma coisa, ou seja, tendo seis laranjas e quatro crianças para comê-las, cada criança comerá uma e as restantes serão divididas ao meio para comerem igualmente 1 laranja e meia, ou ainda, 2 crianças comerem duas laranjas e as restantes apenas uma.

Porque entende que o ensino da Matemática aos alunos das séries iniciais do ensino fundamental deve ser

De estratégias, de possibilidade, deve ser de resolução de problemas não convencionais, deve ser de várias formas para que a criança entenda de sua forma, porém certo.

Desta maneira quando terminou a explicação, a professora, solicitou aos seus alunos que dissessem para ela se o modo como estavam resolvendo os exercícios estava ou não correto. Ela agiu assim porque acredita que os alunos aprendem Matemática

Não acho que existe certo ou errado, cada um tem sua forma de pensar, tudo depende de como entendeu o que a professora ensinou e como expõem no papel, como faz o desenvolvimento, entre outros

Alguém observou que o tempo passou e está na hora de ir embora. Ouvem-se, de vários pontos da sala, muitos "tchau professora" e ela por sua vez:

-- Tchau! Aproveitem bem suas férias. 


\section{ANEXO 5 - EXEMPLO DE RELATÓRIO DE ESTÁGIO}

\section{- RELATÓRIO FINAL DE ESTÁGIO DE A1 - TEXTO PARCIAL}

\section{APRESENTAÇÃO}

O presente relatório refere-se ao estágio de docência, realizado na Escola Municipal Jardim Santo Inácio, situado na cidade de Curitiba, tendo como requisito a aplicação de regência em uma instituição escolar onde se desenvolve, e se reconhece as funções e o papel que um professor desempenha.

O Estágio é uma forma de proporcionar aos alunos uma vivência mais próxima á realidade do curso de Pedagogia, pois é por meio dele que se adquire experiências, demonstrando a importância e a necessidade da prática da educação, sem se esquecer da aquisição de estratégias e não somente de teorias.

É no Estágio que muitas vezes se apresentam algumas situações, que não são presenciada em sala de aula na faculdade, restando a prática para solucionar estas informações. E essa vivência por meio do Estágio fica mais evidente, pois com as observações feitas em sala de aula pode-se compreender melhor como a professora regente trabalha e assim poder produzir planos de aula de acordo com o estágio de desenvolvimento dos alunos.

Desta forma busca-se uma formação realmente concreta para trabalhar com alunos do ensino noturno da Educação de Jovens e Adultos, a fim de contribuir para a formação de cidadãos conscientes, pois em termos de educação essa perspectiva evidencia a necessidade de um trabalho vinculado aos princípios da dignidade do ser humano.

Como professores devemos estar aptos a decidir e saber atuar na realidade do aluno, de forma comprometida com o bem-estar de cada um para que se tornem seres atuantes na sociedade.

Após a regência, faz-se necessário o relato para que deixe-se registrado o que foi aprendido e realizado, para posteriores dúvidas, quando se estiver efetivamente trabalhando nesta área.

\section{RESUMO}

Este trabalho tem como finalidade registrar o estágio desenvolvido em docência, na Escola Municipal Jardim Santo Inácio, situada nesta cidade, onde primeiramente fez-se estudos de documentos da escola, após fez-se observações em sala de aula, para só posteriormente elaborar planos de aula e colocá-los em prática. A turma trabalhada foi de Educação de Jovens e Adultos, turma multisseriada, com alunos de $1^{\text {a }}$ a $4^{\text {a }}$ séries. Estagiar como docente foi uma ótima experiência, com ela pôde-se pesquisar teóricos e metodologias, pôde-se entrar em contato com o aluno sentindo na prática suas reais dificuldades, para só após desenvolver este relatório realizando um estudo detalhado de tudo que houve durante o estágio. Palavras-chave: Estágio, Docência, Experiência. 


\section{SUMÁRIO}

RESUMO i

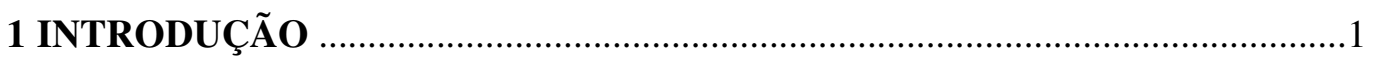

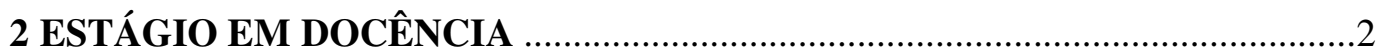

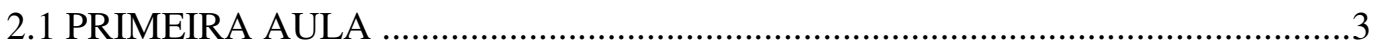

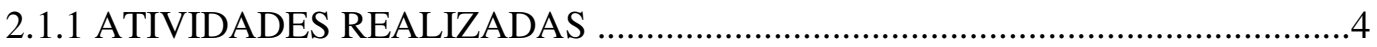

2.1.2 FOTOCÓPIA DE MATERIAIS UTILIZADOS ..................................................

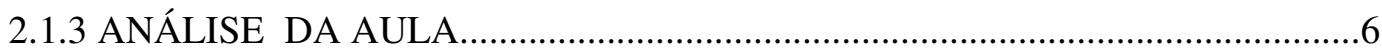

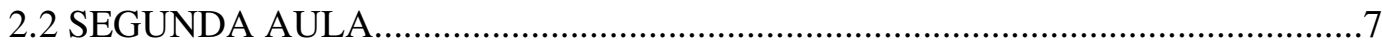

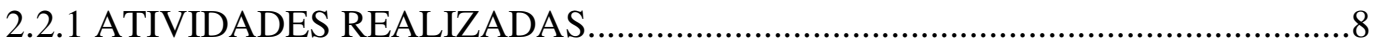

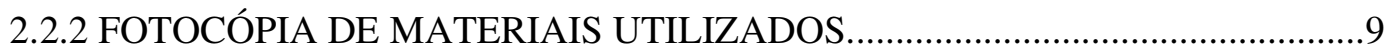

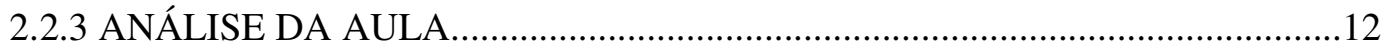

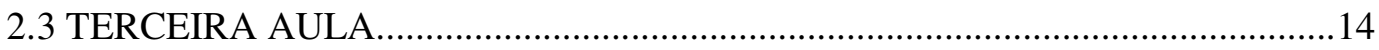

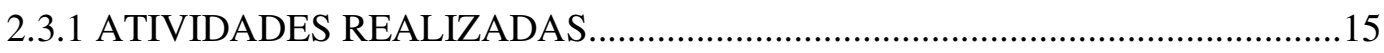

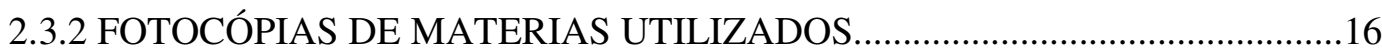

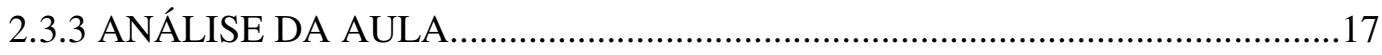

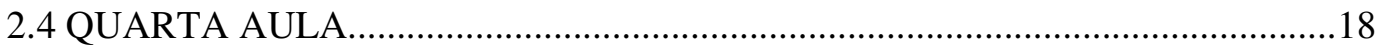

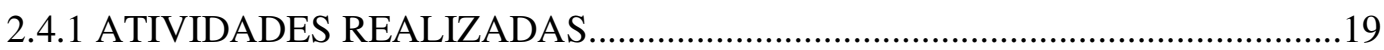

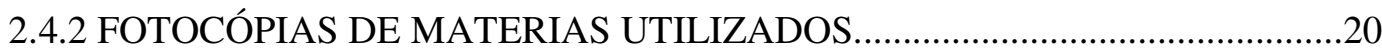

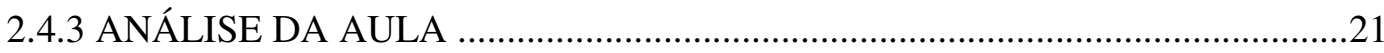

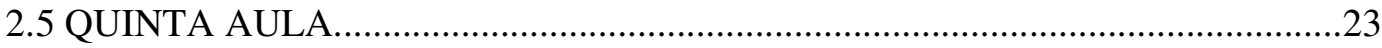

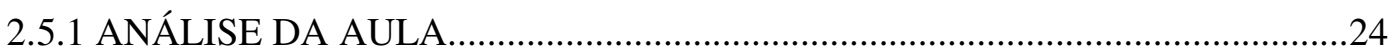

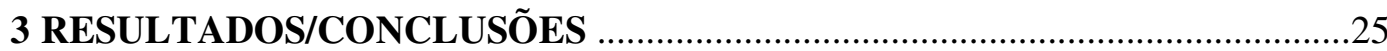

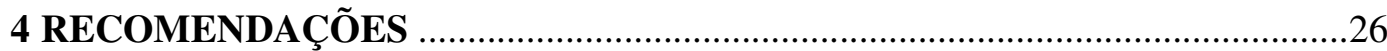

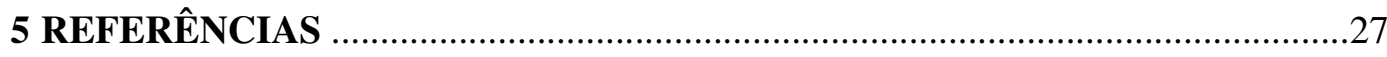

ANEXO 1- ATIVIDADE REALIZADA SOBRE COMPRIMENTO …………......28

ANEXO 2- ATIVIDADE REALIZADA SOBRE CAPACIDADE …………….......29

ANEXO 3- ATIVIDADE REALIZADA SOBRE MASSA …………………….......

ANEXO 4- FOLHA DE FREQÜÊNCIA NOS ESTÁGIOS .......................................31 


\section{INTRODUÇÃO}

Realizar estágio é entrar em contato com a prática, tendo-se por base apenas a teoria. Por este motivo estagiar na área de docência é de fundamental importância para o curso de Pedagogia, pois é por meio dele que se adquire experiências, demonstrando a importância e a necessidade da prática da educação.

O estágio foi realizado durante dois semestres na Escola Municipal Jardim Santo Inácio, para levantamento de documentos da mesma, observação em sala de aula, e por fim a docência.

Ao final do primeiro semestre foi elaborado um primeiro relatório, apenas sobre os documentos, ao final do segundo semestre foi elaborado este trabalho, no qual consta os planejamentos de aula, as atividades trabalhadas com alunos e as análises de cada aula.

\section{ESTÁGIO EM DOCÊNCIA}

Utilizar o conhecimento prévio dos alunos é o início do trabalho com a Educação de Jovens e Adultos (EJA), é necessário perceber antes de mais nada que estes alunos são portadores de saberes, e que eles levam para a sala de aula inúmeras informações. Desta forma é possível reportar-se a Freire (1987) quando fala em saber de experiência feita.

Ainda pensa-se em Freire (1987) quando trabalha-se o diálogo como prática de liberdade em sala de aula, aquela em que o educando pode dar suas idéias e expressar-se.

Para fazer uso do pensamento de Freire (1996), as aulas ministradas utilizaram-se de diálogo e respeito aos conhecimentos dos alunos. E mesmo que a forma em que o planejamento foi estruturado seja tradicional, pois foi entendido como de melhor clareza e entendimento, as aulas não foram desta maneira.

A turma em que as aulas foram ministradas é multisseriada, são jovens e adultos que freqüentam de $1^{\mathrm{a}}$ a $4^{\mathrm{a}}$ séries, cada um em um estágio de aprendizagem diferente.

Idéias de D'Ambrosio (2001) também fizeram parte da elaboração e realização das aulas, pois valorizou-se muito os conhecimentos prévios dos alunos, e a sua cultura, bem como a visão de ensinar a matemática do cotidiano e com trabalhos coletivos dos alunos. Desta forma é possível perceber que se utilizou da Etnomatemática para trabalhar com os alunos, "a proposta pedagógica da etnomatemática é fazer da matemática algo vivo, lidando com situações reais no tempo [agora] e no espaço [aqui]. E, através da crítica, questionar o aqui e 
agora. Ao fazer isso, mergulhamos nas raízes culturais e praticamos dinâmica cultural (...)” (D’Ambrosio, 2001, p.46).

\subsection{PRIMEIRA AULA}

Conteúdo: Sistema de medidas (medidas não-padronizadas).

Objetivos: Desenvolver nos alunos o interesse de como podemos medir as coisas de forma não-padronizada.

Metodologia: Iniciar a aula com apresentações. Questionar a todos se trabalham e em o quê. A partir de um dos trabalhos citados iniciar o assunto da aula, através de levantamento de perguntas, como por exemplo: usa medidas no trabalho; para quê; mede como; quem mais usa medidas no trabalho; se não existisse medidas como seria. Então entrar no assunto medidas não-padronizadas, quais são e exemplos de como podemos usá-las. Propor exercícios de medidas com unidades não-padrão, por exemplo: medir a mesa, o quadro, entre outros; explicar ainda porque para alguns a mesa mede 3 palmos e para outros 4, entre outros. Propor que achem as maneiras mais fáceis de medir algumas coisas, por exemplo: o lápis usem o polegar, a sala usem a braça, etc. Entregar digitado em caixa alta para que colem no caderno algumas explicações sobre a aula. Para a aula seguinte solicitar que tragam um instrumento usado para medir, pode estar ligado ao seu trabalho ou não.

Tempo: 2 horas/aula

Avaliação: Cada aluno registra em folha colada no caderno de que forma mediu objetos na sala de aula. Por exemplo: para medir o lápis usaram o polegar, etc.

\subsubsection{ATIVIDADES REALIZADAS}

Na primeira aula foram utilizados pelos alunos partes de seu corpo para medir objetos, pois a propostas eram medidas não-padronizadas. Foram medidas a mesa com o palmo, o lápis com a polegada, o quadro com a braça e a sala de aula com o passo. Os alunos apresentaram para os colegas oralmente outros tipos de medidas não-padronizadas que 
conheciam, como é o caso da chave. Cada objeto que havia sido medido da forma nãopadronizada foi também medido da forma padrão que é o comprimento, utilizando-se desta maneira ficou mais fácil compreender que cada pessoa tem um tamanho para as partes de seus corpos. Foram feito registros destas atividades em folha sulfite digitada.

\subsubsection{FOTOCÓPIA DE MATERIAIS UTILIZADOS}

AULA SOBRE MEDIDAS NÃO-PADRONIZADAS

O HOMEM COMO MEDIDA DAS COISAS

ANTIGAMENTE, O HOMEM MEDIA AS COISAS COM SEU CORPO. A FORMA EM QUE USARIA SEU CORPO DEPENDIA DO QUE FOSSE MEDIR

SURGIRAM, ENTÃO:
A POLEGADA
O PALMO
O PÉ
A JARDA
A BRAÇA
O PASSO

\section{ALGUMAS DESTAS FORMAS DE MEDIR SÃO USADAS ATÉ HOJE EXEMPLOS}

PARA MEDIR A MESA DA SALA DE AULA, PODE UTILIZAR PARA MEDIR O LÁPIS DE ESCREVER, PODE-SE UTILIZAR PARA MEDIR O QUADRO, PODE-SE UTILIZAR 


\subsubsection{ANÁLISE DA AULA}

A primeira aula foi a única que manteve-se sem modificação alguma na metodologia, apenas houve modificação do tempo, já que o planejamento foi realizado em uma hora e meia e não duas como planejado. Tudo o que estava no planejamento foi trabalhado exatamente como descrito. Todos realizaram muito bem as atividades propostas, a participação dos alunos foi ótima, pois todos se envolveram com a proposto. Ao final da aula houveram muitos comentários de como a aula foi boa. Os objetivos para esta aula foram alcançados.

\subsection{SEGUNDA AULA}

Conteúdo: Sistema de medidas (comprimento).

Objetivos: Despertar nos alunos o conhecimento de metro, centímetro, milímetro, quilômetro e quais são as relações entre si.

Metodologia: Solicitar que os alunos apresentem os instrumentos de medida que trouxeram e que falem o que conhecem sobre ele. A partir disso explicar o que é metro, e para que serve. Mostrar régua, fita métrica, entre outros. Explicar como a régua está dividida e o que são milímetros e centímetros. Pedir que os alunos meçam sua mesa com régua, entre outros. Questioná-los sobre o que é quilômetro, explicar o que é. Relacionar milímetro, centímetro, metro e quilômetro. Entregar conteúdo digitado e exercícios de transformação de unidades de medida. Medir os mesmos objetos da aula anterior com auxílio de réguas.

Recursos: Réguas, trenas, metros, etc.

Tempo: 2 horas/aula

Avaliação: Realização de exercícios em grupo com o auxílio da professora, sobre transformação de unidades de medida.

\subsubsection{ATIVIDADES REALIZADAS}


Cada um apresentou os instrumentos de medidas que levou para sala de aula e explicou para que serve. Explicou-se aos alunos como se usa a régua e foi lhes solicitado que mostrassem na régua algumas medidas. Mediu-se os objetos da aula anterior e as alturas dos alunos e realizou-se exercícios de relação entre centímetro, milímetro, metro e quilômetro. Portanto, nesta aula utilizou-se trena, fita métrica e régua para medir objetos.

\subsubsection{FOTOCÓPIAS DE MATERIAS UTILIZADOS}

\section{AULA SOBRE MEDIDAS DE COMPRIMENTO}

HOJE, EM QUASE TODO O MUNDO, É USADA UMA MEDIDA-PADRÃO PARA MEDIR: O METRO (m).

O METRO É UMA UNIDADE DE MEDIDA DE COMPRIMENTO UTILIZADA MUITO NA CONSTRUÇÃO CIVIL E INDÚSTRIA MECÂNICA.

ALGUMAS UNIDADES DE MEDIDAS DE COMPRIMENTO MENORES QUE O METRO E QUE SÃO MUITO UTILIZADAS SÃO O MILÍMETRO (mm) E CENTÍMETRO (cm). E A UNIDADE DE MEDIDA MAIS UTILIZADA QUE É MAIOR QUE O METRO É O QUILÔMETRO $(\mathrm{km})$.
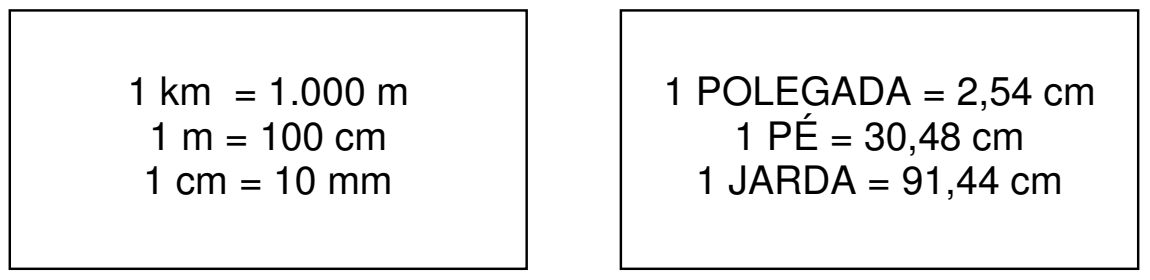

\section{EXERCÍCIOS PARA O GRUPO 1}

1- TRANSFORME EM CENTÍMETROS:
a) $37 \mathrm{~mm}$
b) $2,5 \mathrm{~mm}$

2- TRANSFORME EM MILÍMETROS:
a) $28 \mathrm{~cm}$
b) $140 \mathrm{~cm}$

3- RESOLVA OS PROBLEMAS.

a) UM PARAFUSO TEM 1,8 cm DE COMPRIMENTO. QUAL É A SUA MEDIDA EM MILÍMETROS?

b) QUANTO MEDE SEU CADERNO EM CENTÍMETROS? QUANTO ELE MEDE EM MILÍMETROS? 
c) QUANTO MEDE O ENCOSTO DE SUA CADEIRA EM CENTÍMETROS? QUANTO ELE MEDE EM MILÍMETROS?

d) QUANTO MEDE SEU LÁPIS EM CENTÍMETROS? QUANTO ELE MEDE EM MILÍMETROS?

e) QUAL É A SUA ALTURA? ELA É MAIOR OU MENOR QUE 1 METRO? QUAL É A SUA ALTURA EM CENTÍMETROS?

f) QUANTO MEDE A SUA SALA DE AULA EM SEU COMPRIMENTO? ELA É MAIOR OU MENOR QUE 1 METRO? QUAL É O TAMANHO DELA EM CENTÍMETROS?

\section{EXERCÍCIOS PARA O GRUPO 2:}

1- TRANSFORME EM METRO:
a) $1,23 \mathrm{~km}$
b) $0,02 \mathrm{~km}$

2- TRANSFORME EM CENTÍMETROS:
a) $37 \mathrm{~mm}$
b) $2,5 \mathrm{~mm}$

3- TRANSFORME EM MILÍMETROS:
a) $28 \mathrm{~cm}$
b) $140 \mathrm{~cm}$

4- RESOLVA OS PROBLEMAS.

a) CARLOS TEM UM CADERNO COM $30 \mathrm{~cm}$ DE COMPRIMENTO. QUANTOS MILÍMETROS ELE TEM?

b) A MESA DA SALA DE AULA TEM $57 \mathrm{~cm}$. QUANTOS ELA MEDE EM MILÍMETROS?

c) UM PARAFUSO TEM $1,8 \mathrm{~cm}$ DE COMPRIMENTO. QUAL É A SUA MEDIDA EM MILÍMETROS?

d) QUAL É A SUA ALTURA? QUAL É A SUA ALTURA EM CENTÍMETROS?

e) QUANTO MEDE A SUA SALA DE AULA EM SEU COMPRIMENTO? QUAL É O TAMANHO DELA EM CENTÍMETROS?

\section{HISTÓRIA DO METRO}

As pessoas da Antigüidade usavam partes do corpo para medir. Foi criado, então, o cúbico que era a medida do cotovelo até a ponta do dedo médio. Como as pessoas tinham 
medidas diferentes fixou-se numa barra de pedra o tamanho que deveria se usar sempre. Para medir grandes extensões dava-se nós nas cordas e cada intervalo tinha o tamanho de 1 cúbico.

Foi muito tempo depois que cientistas criaram o metro. Que era uma distância entre duas marcas feitas numa barra de platina. Esta medida é usada no mundo todo. Este 1 cúbico equivale a 52, 4 centímetros.

\subsubsection{ANÁLISE DA AULA}

Na segunda aula a metodologia foi alterada, levando em consideração o que Freire (1987) diz do diálogo e que a primeira aula foi bem aceita utilizando-se deste método, percebeu-se a necessidade de iniciar com uma questão para que os alunos tivessem suas opiniões escutadas. No decorrer da aula introduziu-se mais questões.

Para dar seqüência a aula utilizando-se da pluridisciplinaridade (Japiassú, 1998) contou-se aos alunos a história do metro e para fazer um elo entre a primeira e a segunda aula, explicou-se a relação entre medidas de comprimento e as não-padronizadas.

Por solicitação dos próprios alunos em aula anterior, explicou-se o que é légua e alqueire. Incluiu-se ainda nesta aula a escala de unidades de medidas de comprimento para que os alunos entendessem que não existe apenas as unidades estudadas em sala.

A metodologia ficou da seguinte maneira: iniciar a aula questionando sobre se precisássemos saber qual é o tamanho da sala de aula como faríamos. Pedir que cada um mostre o que trouxe de medir e como se usa. Questionar se cada um desses instrumentos serve para medir a sala. Contar a história do metro. Mostrar instrumentos de medida de comprimento, explicar o que é centímetro e milímetro e como se usa a régua. Explicar qual é a relação de medida de comprimento com as não-padronizadas. Medir os mesmos objetos da aula passada com réguas e trenas. Todos medem a sua altura. Perguntar o que é quilômetro, onde já viram esta medida e explicar o que é. Explicar o que é légua e o que é alqueire. Mostrar aos alunos a escala de medida de comprimento e explicar que as estudadas por eles são as mais utilizadas. Dividir a sala em dois grupos $\left(1^{\mathrm{a}}\right.$ e $2^{\mathrm{a}}$ séries e $3^{\mathrm{a}}$ e $4^{\mathrm{a}}$ séries $)$ entregar conteúdo digitado. Com o primeiro grupo trabalhar exercícios sobre tamanho, o que é maior ou menor que 1 metro, estudar a régua e medir com ela, e realizar exercícios fazendo conversão entre centímetros e milímetros. Com o segundo grupo trabalhar conversão entre milímetro, centímetro, metro e quilômetro.

Esta aula não foi tão bem aceita como a anterior, muitos alunos não realizaram as atividades propostas, e utilizaram do momento que seria a aula para fazer alguma outra atividade. 
Essa dispersão pode estar ligado ao não comparecimento da professora regente para assistir a aula, ou ainda ao conteúdo, que talvez não fosse tão interessantes aos alunos, ou ainda a falta de experiência por parte da estagiária, a qual não interveio com os alunos corretamente solicitando que participassem da aula.

Nesta aula foram preparados muitos exercícios de fixação. Percebeu-se que os alunos do grupo 1 , que são de $1^{\mathrm{a}}$ e $2^{\mathrm{a}}$ séries, conseguiram realizar 3 ou 4 exercícios, entende-se que essa era sua possibilidade, já que estão no início do contato com a escrita e com os números e por este motivo realizam as atividades mais lentamente, se comparados com os alunos do segundo grupo, que são de $3^{\mathrm{a}}$ e $4^{\mathrm{a}}$ séries. Estes por sua vez, resolveram todos os exercício, num total de 11 .

O conteúdo ensinado aos dois grupos foi o mesmo e ao mesmo tempo. O tempo para resolução de exercícios foi o mesmo também, porém com alguns exercícios diferentes, para respeitar o grau de conhecimento dos alunos.

\subsection{TERCEIRA AULA}

Conteúdo: Sistema de medidas (capacidade).

Objetivos: Desenvolver nos alunos o conhecimento de litro e mililitro, e sua relação.

Metodologia: Levar para sala de aula diversas medidas de garrafas e copos, a partir disso indagar aos alunos o que é 1 e $\mathrm{ml}$ que aparece nas embalagens. Montar uma escala de unidades para saberem que essas não são as únicas para capacidade, porém são as mais importantes. Explicar o que é litro e o que é mililitro e realizar experiências com as medidas levadas para sala de aula para entender sua relação. Convidar os alunos para realizarem experiências também. Exemplo: quantos copos de 250ml é necessário colocar para encher uma garrafa com 11 de capacidade. Entregar conteúdo e exercícios sobre a relação de litro e mililitro.

Recursos: Garrafas e copos descartáveis de diversos tamanhos.

Tempo: 2 horas/aula

Avaliação: Exercícios em grupo sobre a relação de litro e mililitro. 


\subsubsection{ATIVIDADES REALIZADAS}

$\mathrm{Na}$ terceira aula foram utilizadas embalagens plásticas para que os alunos realizassem experiências, já que este era o momento de estudar capacidade. Desta forma, os alunos puderam utilizar de sua criatividade e elaborar uma experiência. Realizaram também experiências solicitadas pela docente. $\mathrm{O}$ registro foi feito em forma de desenhos ou texto, e a verificação delas através de contas. Foram resolvidos alguns exercícios sobre este assunto em papel.

\subsubsection{FOTOCÓPIAS DE MATERIAIS UTILIZADOS}

\section{AULA SOBRE CAPACIDADE}

PARA MEDIRMOS A CAPACIDADE USAMOS LITRO (1). SE A SUBSTÂNCIA MEDIDA NÃO CHEGAR A SER 1 LITRO (l), PODE-SE USAR O MILILITRO (ml). PORTANTO,

$$
\text { 1LITRO (l) = } 1000 \text { MILILITROS (ml) }
$$

\section{RESOLVA:}

1- PAULA TEM 1 LITRO (1) DE SUCO. QUANTOS MILILITROS (ml) ELA TEM?

2- EM 2 DIAS TOMEI 3 LITROS (l) DE ÁGUA. QUANTOS MILILITROS (ml) DE ÁGUA TOMEI?

3- PARA ENCHER UMA GARRAFA COM CAPACIDADE DE 2 LITROS (1), QUANTOS COPOS DE 250 MILILITROS (ml) PRECISAMOS COLOCAR NA GARRAFA?

4- DENTRO DE UM POTE ESTÃO 2000 MILILITROS (ml) DE ÁGUA. QUANTOS LITROS DE ÁGUA TEMOS?

\subsubsection{ANÁLISE DA AULA}

Pensando que a segunda aula não alcançou o esperado, mudou-se a metodologia da terceira. Esta aula iniciou com grupos divididos por séries $\left(1^{\mathrm{a}}, 2^{\mathrm{a}}\right.$ e $\left.3^{\mathrm{a}}, 4^{\mathrm{a}}\right)$ para que realizassem as atividades conforme seus conhecimentos. Levantou-se, então, questões para utilizar-se partindo do método de Freire (1987) que é o diálogo. Convidou-se os alunos para 
que realizassem experiências livremente, já que um dos perfis observados desta sala é gostar de realizar tarefas práticas. Por se tratar de séries diferentes, o grupo de séries menores fez registro em desenho e o outro em texto, desta forma utilizando-se ainda do diálogo, cada um explicou o que registrou. Algumas experiências foram propostas pela docente e seu registro feito da mesma maneira. Através de pergunta levou-se os alunos a fazer verificação das experiências através de contas. Realizando um elo entre a segunda aula e a terceira foram comparadas as unidades de medida de capacidade com as de comprimento.

A metodologia ficou da seguinte forma: organizar a sala em dois grupos, um de $1^{\mathrm{a}}$ e $2^{\mathrm{a}}$ séries e outro de $3^{\mathrm{a}}$ e $4^{\mathrm{a}}$ séries, colocar sobre suas mesas embalagens em forma de garrafas e copos. Levantar a questão se é possível estabelecer alguma medida entre as embalagens e de que maneira. Cada grupo faz uma experiência, ou seja, coloca água do copo para a garrafa e vice-versa para conhecer a relação entre litro (l) e mililitro (ml). O primeiro grupo faz um registro da experiências individualmente, através de desenho e o segundo grupo através de texto individual. Cada um deve explicar o que registrou. A seqüência da aula é dada mostrando as embalagens que estão em litro e mililitro. Falar que 1 litro é igual a 1.000 mililitros. Propor experiências e fazer verificação de como cada grupo realizou. Perguntar se pode-se resolver através de conta e resolver. Mostrar a escala de unidades. Comparar as unidades de litro e mililitros com as de comprimento: metro e milímetro. Entregar conteúdo e ler com eles. Entregar exercícios escritos sobre a relação de litro e mililitro e ajudá-los a resolver.

Esta aula alcançou o esperado, acredita-se que foi porque trabalhou-se em dois grupos, portanto, os alunos realizavam as atividades conforme seu desenvolvimento e porque foi mais dinâmica, mais prática. Houve a solicitação por parte dos alunos até mesmo de realizar contas no quadro.

\subsection{QUARTA AULA}

Conteúdo: Sistema de medidas (massa).

Objetivos: Desenvolver nos alunos o conhecimento de grama e quilograma e sua relação.

Metodologia: Propor a discussão de porque certos alimentos, como sorvete e maionese, são medidos em litros e explicar por que. Mostrar uma balança propor que algumas pessoas se 
pesem, explicar o que é grama e o que é quilograma. Relacionar os dois. Trabalhar com os alunos receitas. Mostrar a escala de unidades de medidas de massa e explicar que essas são as mais utilizadas. Solicitar que para próxima aula os alunos tragam rótulos, caixas e embalagens, que estão na unidade de medida kg, g, 1 e ml. Exemplo: caixa de leite, pacote de arroz, etc.

Recursos: Balanças e receitas.

Tempo: 2 horas/aula

Avaliação: Exercícios em grupo sobre a relação de grama e quilograma.

\subsubsection{ATIVIDADES REALIZADAS}

$\mathrm{Na}$ quarta aula foi a vez de pesarem objetos, pois este foi o momento trabalhado sobre massa. O início da aula deu-se solicitando aos alunos que pesassem objetos com a mão e registrassem o que achavam pesar. Em seguida, os alunos pesaram os mesmos objetos na balança e registraram o encontrado também. Resolveram logo após, problemas simples sobre a relação entre grama e quilograma.

\subsubsection{FOTOCÓPIA DE MATERIAS UTILIZADOS}

\section{AULA SOBRE MASSA}

O GRAMA É A UNIDADE PADRÃO DE MEDIDA DA MASSA. QUANDO TEMOS 1.000 GRAMAS (g), ESSA MEDIDA É O MESMO QUE 1 QUILOGRAMA (kg). PORTANTO,

$$
1 \text { QUILOGRAMA }(\mathrm{kg})=1.000 \text { GRAMAS }(\mathrm{g})
$$

UMA MELÂNCIA DA FEIRA PESA 2 QUILOGRAMAS (kg). QUANTO ELA PESA EM GRAMAS (g)?

NO AÇOUGUE JOÃO COMPROU 1.000 GRAMAS (g) DE CARNE MOÍDA. QUANTOS QUILOGRAMAS (kg) ELE COMPROU? 
CARMEN COMPROU 3.000 GRAMAS (g) DE BATATAS. QUANTOS EM QUILOGRAMAS (g) ELA COMPROU?

NA CASA DE LIA TEM APENAS UM SACO DE ARROZ, ELE TEM 5 QUILOGRAMAS (kg). QUANTO DE ARROZ LIA TEM EM GRAMAS (g)?

\subsubsection{ANÁLISE DA AULA}

Nesta aula a metodologia foi alterada também, inclui-se nela a organização da sala em dois grupos, como a terceira aula, já que esta prática foi de grande importância. Realizouse atividades práticas de pesagem, tendo como base ainda a aula três. $\mathrm{O}$ registro foi realizado também. Levando em consideração os saberes dos alunos, questionou-se a respeito do assunto estudado para que pudessem dar opiniões. Fazendo um elo entre a aula de capacidade e massa mostrou-se sua relação.

Retirou-se do planejamento original a etapa em que algumas pessoas deveriam se pesar, pois pensando em pessoas adultas talvez não se sentissem bem ao se expor. O trabalho com receitas também não esteve presente, já que a cozinha não poderia ser utilizada e não foi encontrada nenhuma receita que pudesse ser realizada fora dela. Não foi solicitado também que levassem embalagens para aula seguinte, já que esta foi a última.

A metodologia ficou da seguinte maneira: organizar a sala em dois grupos um de $1^{\mathrm{a}}$, e $2^{\mathrm{a}}$ séries e o outro de $3^{\mathrm{a}}$ e $4^{\mathrm{a}}$ séries, colocar sobre as mesas objetos para que os alunos peguem nas mãos e tentem descobrir quanto pesa, fazer o registro de quando acham que pesa individualmente. Verificar na balança o peso correto e registrar também. Solicitar que dêem exemplos de o que podemos medir em grama e quilograma. Questionar se alguém sabe a relação entre essas duas medidas, explicar sua relação. Mostrar a escala de unidades de medidas de massa e explicar que essas são as mais usuais. Propor a discussão de porque certos alimentos, como sorvete e maionese, são medidos em litros e explicar por que, partindo disso explicar a relação entre capacidade e massa. Entregar conteúdo e exercícios e ajudar a resolver.

Essa aula alcançou as expectativas, foi muito boa e teve uma boa participação de todos.

Os alunos do primeiro grupo, nesta aula, fizeram seus registros através de tópicos, colocavam primeiro o valor que achavam pesar o objeto, após fez-se a verificação e escreveuse o certo ao lado. $\mathrm{O}$ grupo $2 \mathrm{fez}$ seu registro através de texto, escrevendo primeiro o que achava pesar e depois o certo. Esta aula foi dada em dois grupos também, com explicações 
separadas, o grupo 2 chegou ao fim da aula tendo realizada toda proposta, enquanto o grupo 1 não conseguiu finalizar. O segundo grupo copiou várias informações, que acharam úteis, do quadro, enquanto o primeiro grupo centrou-se mais nas pesagens e seus registros. Pelo grupo 2 foram realizados 4 exercícios em papel e pelo grupo 1 foram possíveis realizar, em virtude do tempo, apenas 2 .

\subsection{QUINTA AULA}

Conteúdo: Sistema de medidas (tempo)

Objetivos: Estimular os alunos para que compreendam a noção de tempo e sua organização, hora, minuto e segundo.

Metodologia: Cada aluno mostra as embalagens que trouxe e diz em que unidade de medida está. Perguntar como os alunos fazem para contar o tempo. Mostrar figuras e contar histórias de relógios que existiram ao longo da história. Explicar o que é hora, minuto, segundo e sua relação. Explicar que o dia tem 24 horas. Solicitar que todos organizam agenda de como gastam seu tempo de 1 dia. Cada um apresenta sua agenda para a sala. Entregar conteúdo e exercícios para os alunos. Tirar qualquer dúvida que tenha ficado de qualquer aula.

Recursos: figuras de diversos tipos de relógio.

Tempo: 2 horas/aula.

Avaliação: Agenda e apresentação e exercícios sobre a relação entre dia, hora, minuto e segundo.

\subsubsection{ANÁLISE DA AULA}

Esta aula não chegou a ser realizada por falta de data. Portanto, o planejamento apresentado acima é o original, sem modificação alguma. 


\section{RESULTADOS / CONCLUSÕES}

O estágio realizado foi de grande importância, pois possibilitou uma real vivência em sala de aula, e uma real experiência de se dar aula, o que é de fundamental importância para o curso de Pedagogia.

Este trabalho serviu para reflexão a cerca do que Paulo Freire fala sobre o ensino e a aprendizagem, já que ele é um dos teóricos mais conhecidos que dirige-se aos educandos jovens e adultos para escrever seu pensamento.

Compreendeu-se, então, que é necessário considerar todo o conhecimento prévio que o aluno tem, ou seja, o saber de experiência feita (Freire, 1987) e ainda que é necessário a disponibilidade para o diálogo (Freire, 1996).

Entendeu-se também, após a realização deste trabalho, que o professor deve ter postura correta em suas aulas, segundo Freire (1996) deve ter liberdade e autoridade, "tomando decisões, orientando atividades, estabelecendo tarefas, cobrando a produção individual e coletiva do grupo" (Freire, 1996, p. 68).

Ainda, faz-se necessário ressaltar, a importância da avaliação da aprendizagem do aluno, já que esta é a forma com que pode-se compreender o que o aluno apreendeu.

\section{RECOMENDAÇÕES}

Entende-se como necessário mais tempo para ficar na escola realizando estágio, quatro ou cinco docências é muito pouco para preparar bem o aluno para o mercado de trabalho, é necessário também mais tempo para se tirar dúvidas com a professora orientadora, tanto como realizar um bom trabalho em sala de aula, como sobre o relatório final de estágio.

\section{REFERÊNCIAS}

BONJORNO, Regina A.; BONJORNO, José R. Pode contar comigo: matemática. São Paulo: FTD, 1994

D’AMBROSIO, Ubiratan. Etnomatemática: elo entre as tradições e a modernidade. Belo Horizonte: Autêntica, 2001.

FREIRE, Paulo. Pedagogia da autonomia: saberes necessários à prática educativa. 18. ed. São Paulo: Paz e Terra, 1996. 
FREIRE, Paulo. Pedagogia do Oprimido, 17ª .ed. Rio de Janeiro: Paz e Terra, 1987.

GIOVANNI, José R.; CASTRUCCI, Benedito; GIOVANNI Jr., José R. A conquista da matemática. São Paulo: FTD, 1937.

IMENES, Luiz M.; JAKUBOVIC, José; LELLIS, Marcelo. Matemática ao vivo. $4^{\mathrm{a}}$ ed. São Paulo: Scipione, 1995.

MACHADO, Nilson J. Vivendo matemática: medindo comprimentos . $4^{\mathrm{a}}$ ed. São Paulo: Scipione, 1988.

NOGUEIRA, Nilbo R. Interdisciplinaridade aplicada. Érica, 1998

www.maxpages.com/elias/ artigo_sobre_paulo_freire. O método Paulo Freire de alfabetizar; acessado em 26/11/2005.

www.novaescola.abril.com.br. Eles têm muito a ensinar; acessado em 26/11/2005. 
ANEXO 6 - EXEMPLO DE NOTAS DO DIÁRIO DE CAMPO

- DIÁRIO DE CAMPO: OBSERVAÇÃO DA PRIMEIRA AULA DE A1

\section{DESCRIÇÃO DA AULA}

APRESENTAÇÃO

A1 se apresenta para os alunos e me apresenta como sua professora

supervisora de estágio.

1 - A1 começa a aula fazendo uma investigação sobre os serviços que cada aluno faz, se usam algum tipo de medida (construção civil, doméstica, dona de casa)

2 - E proposto a primeira atividade: medir a carteira com palmo. Cada aluno faz as medições indicadas no quadro e depois A1 se informa sobre os resultados, fazendo as devidas anotações.

PALMO - 3 OU 3,5 - MESA

LÁPIS - 1 CHAVE 5 POLEGADAS

QUADRO - 2,5 BRACAS

3- A1 volta a conversar com os alunos para investigar sobre o que os alunos conhecem sobre a medida (chave, soga, trena, $\mathrm{ml}$, fita, copos, alqueire, $\mathrm{m}^{3}$ )

4 - Atividade em folha

A1 entrega o folha de atividades e faz a leitura do texto sobre o conteúdo e resolução dos exercícios propostos.

Aluno A- O PALMO

\section{OBSERVAÇÕES DA PESQUISADORA}

continua

\section{rimeira aula}

- Sujeito A1, aula 1, assunto: sistema de medidas, unidades não padronizadas.

- É uma turma multisseriada de $1 .^{\mathrm{a}}$ a 4 . $^{\mathrm{a}}$ séries da EJA. A1 aguarda a chegada dos demais alunos da turma, estão presentes somente 7 alunos. Eu a professora regente da turma estamos sentadas no fundo da sala. Um dos alunos está com uma criança, seu filho. A lousa é dividida ao meio, ou seja, o lado esquerdo é destinado aos alunos da $3 .^{\mathrm{a}}$ e $4 .^{\mathrm{a}}$, onde se escreve com letra cursiva e o lado direito para os alunos da alfabetização, 1. e 2. ${ }^{a}$ séries, cuja escrita é em caixa alta.

- A1 anota no quadro o cabeçalho, isto é, o nome da escola e a data.

- Os alunos participam muito, dão sugestões.

- Os alunos apresentam a medida chave $\mathrm{L}$

- Em 36 min há uma boa discussão sobre a relação entre o $\mathrm{m}^{3}$ e a quantidade de areia em kg para equivalência das medidas.

- soga, trena, ml, fita, copos (p/arroz), alqueire - 24.000m, mamadeira $(50 \mathrm{ml}$ $1 / 4)$.

- há uma característica em especial na sala. Um dos alunos trouxe seu filho para a aula.

- os alunos vão chegando durante a aula, pois eles precisam trabalhar e saem tarde. 


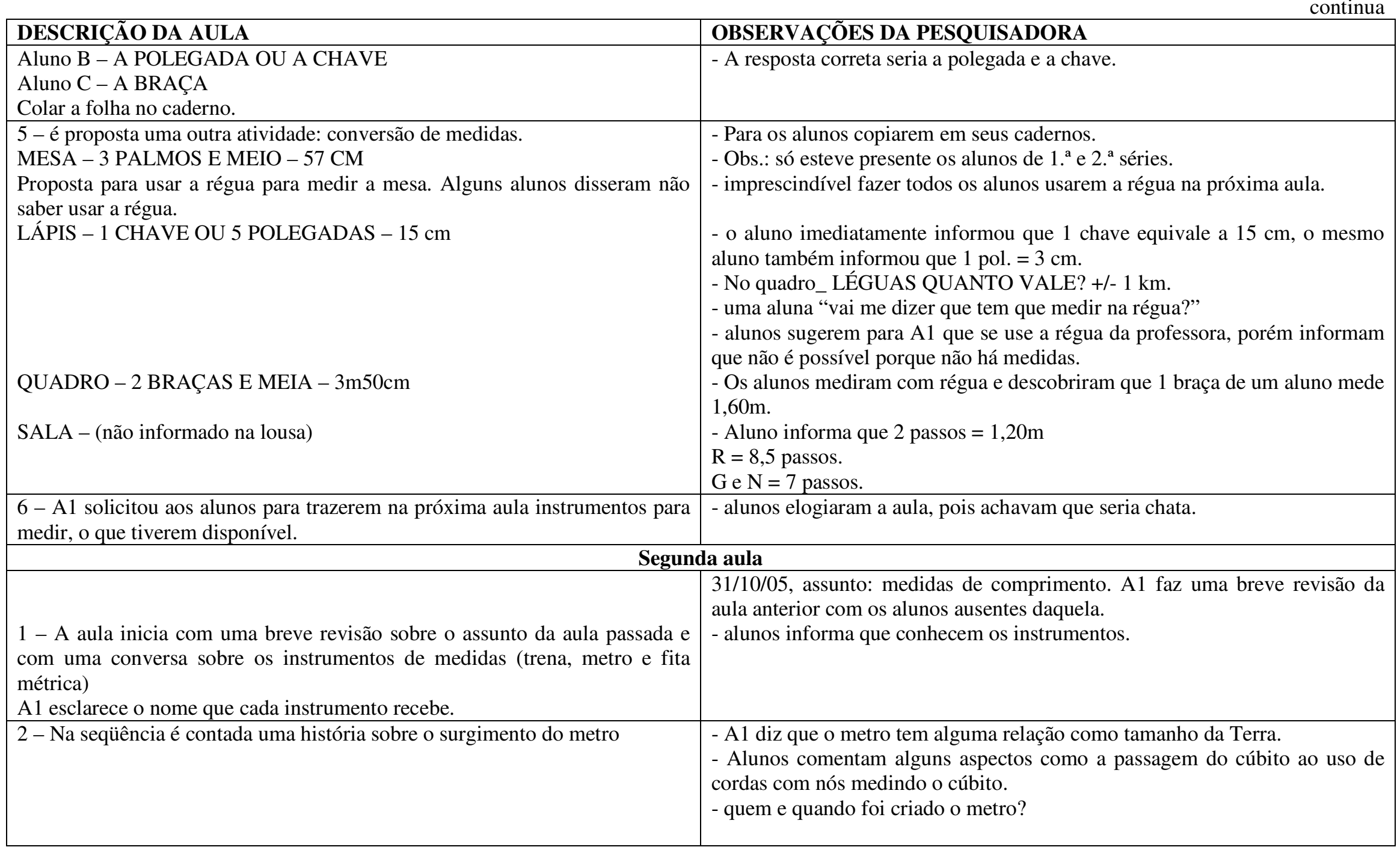


continua

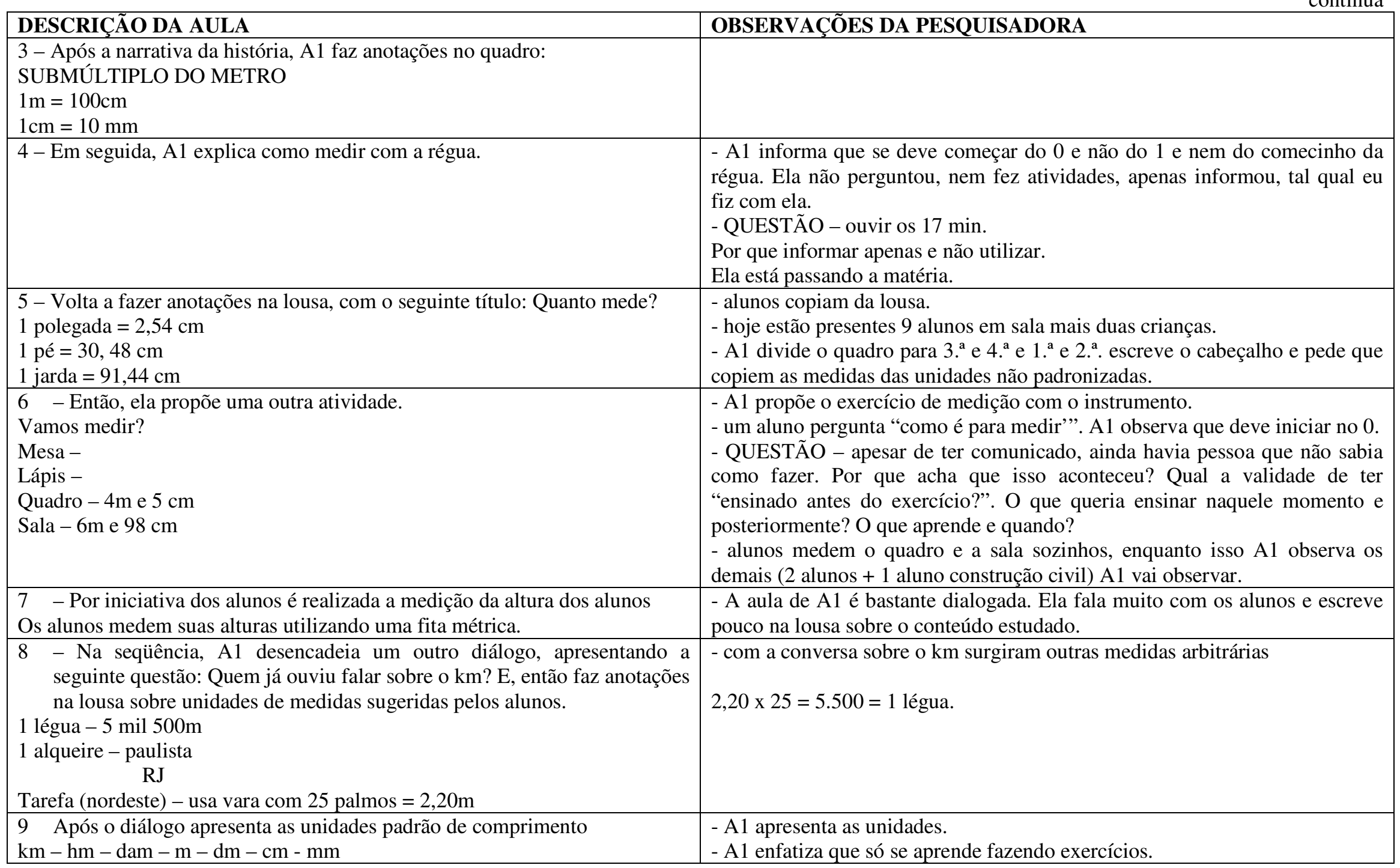




\section{DESCRICÃO DA AULA}

10 - A última ação de A1 é a entrega da folha de exercícios para que os alunos resolvam. A1 vai explicando de carteira em carteira.

\section{OBSERVACÕES DA PESQUISADORA}

continua

- A1 explica o exercício por indução $1 \mathrm{~cm}=10 \mathrm{~mm}$

$$
2 \mathrm{~cm}=20 \mathrm{~mm}
$$

$3 \mathrm{~cm}=30 \mathrm{~mm}$

No entanto, para outra aluna, A1 explica contando os milímetros na régua.

- G. ao contar $37 \mathrm{~mm}$ na régua conseguiu sistematizar que a cada $10 \mathrm{~mm}$ tem 1 $\mathrm{cm}$.

- 3 alunos foram embora 30 min antes de terminar a aula. Acho que estavam desestimuladas. A professora regente não estava na escola. Os alunos estavam muito ocupados em fazer a correção de uma prova.

\section{Terceira aula}

1- A1 inicia a aula fazendo o seguinte questionamento: é possível fazer

Alunos dizem que sim, equipe $1^{\mathrm{a}}$ e $2^{\mathrm{a}}$ séries diz com a garrafa e a outra equipe com o copo.

2 - A1 apresenta a proposta de experiência: cada grupo deverá encontrar alguma relação entre as medidas das embalagens.

3- Cada equipe/aluno, recebeu uma folha para registrar o que fizeram $\left(3^{\mathrm{a}} \mathrm{e} 4^{\mathrm{a}}\right.$ - escrever um texto) e ( $1^{\mathrm{a}}$ e $2^{\mathrm{a}}$ - desenhar). para que os alunos conferissem o quanto de água usaram para medir com as embalagens cedidas.

1 litro $(\mathrm{l})=1.000$ mililitros $(\mathrm{ml})$

$50+50=100$

$200+180=380+250=630+100=730$ $250+100=350$

$350+380=730$ alguma medida usando as embalagens?

4 - No grupo de $3^{\mathrm{a}}$ e $4^{\mathrm{a}}$, A1 leu os textos de cada aluno e, então, encaminhou

21/11/05. Assunto: medidas de capacidade. Estão presentes 5 alunos da turma de $1^{a}$. e $2 .^{a}$ e 6 alunos da turma de $3 .^{a}$ e $4 .^{a}$ séries. A1 organizou a sala em duas equipes, conforme a série, colocando as carteiras uma de frente para a outra em cada equipe. Em cada equipe há sobre as carteiras embalagens (balde, garrafas pet - 1,51; 21; óleo de soja - copos descartáveis - 4 medidas diferentes)

- Ela deixou os alunos livres para estabelecerem suas próprias relações. Passava pelas equipes afirmando que os alunos estavam realizando uma experiência.

- No registro do desenho ela direcionou o que os alunos deveriam desenhar (os copos de tamanhos diferentes e a inscrição de suas medidas - 50ml; $180 \mathrm{ml} ; 200 \mathrm{ml})$.

- A atitude de A1 mudou completamente nessa aula, até sua voz está mais segura. A aula está direcionada e vejo todos os alunos envolvidos na atividade. Inclusive pedindo para ir ao quadro resolver as operações referentes ao cálculo da quantidade de água utilizada na experiência.

- A1 nesse momento está tentando valorizar a opção/estratégia de cada aluno. Isso remete a Resolução de Problemas estudado na Metodologia.

- Cada aluno escolheu uma maneira para se chegar ao resultado e A1 afirma que a forma como cada um fez, escolheu fazer está certo. O importante é chegar no 730 .

5 - A1 propõe a resolução de atividades/situações problemas, para tanto ela entrega um enunciado de cada vez. divisão e, então A1 questionou, surgindo assim a multiplicação. A aluna 
continua

\section{DESCRIÇÃO DA AULA}

- Quantos copos de 200ml são necessários para 2.000ml?

$2000: 200=10$ copos $200 \times 10=2000$

6 - Para a $1^{\mathrm{a}}$ e $2^{\mathrm{a}}$ a questão é a seguinte -1 LITRO $=1.000$ MILILITROS (ml)

Um aluno resolveu a questão fazendo a experiência.

Outro aluno resolveu mentalmente dizendo que se o copo mede 200 , então são 10 copos.

A1 questiona como ele chegou nessa resposta, então ele explicou da seguinte

maneira: 1 copo $=200$

$$
\begin{aligned}
& 2 \text { copos }=400 \\
& 3 \text { copos }=600 \\
& 4 \text { copos }=800 \\
& 5 \text { copos }=1.000-10 \text { copos }=2.000
\end{aligned}
$$

Um outro aluno explica como resolveu o problema apresentando a solução na lousa: $200+200+200+200+200+200+200+200+200+200=2.000$

7 - A1 apresenta na lousa as unidades de medida de capacidade.

$\mathrm{Kl}-\mathrm{hl}-\mathrm{dal}-\mathrm{l}-\mathrm{dl}-\mathrm{cl}-\mathrm{ml}$

8 - A1 finaliza a aula entregando aos alunos uma folha com atividades para serem resolvidas em casa e avisa que as mesmas serão corrigidas na próxima aula.

1- A1 arruma a sala em dois grupos, $1^{\mathrm{a}}$ e $2^{\mathrm{a}}$ séries e $3^{\mathrm{a}}$ e $4^{\mathrm{a}}$ séries. Passa o (lousa, pede aos alunos que copiem nas folhas que cada um, enquanto isso, enche baldes com água e coloca outras embalagens/objetos, diferentes entre si em suas massas e formas sobre as carteiras em cada equipe.

2- A1 propõe a atividade de experimentação aos grupos, um de cada vez, da seguinte maneira:

- cada aluno deverá tentar descobrir quanto "pesa" cada objeto, fazendo apenas a medição com as mãos, as próprias mãos e, então fazer o registro.

- o grupo de $3^{\mathrm{a}}$ e $4^{\mathrm{a}}$ séries deverá escrever o nome do objeto e quanto

\section{OBSERVAÇÕES DA PESQUISADORA}

pensou no processo inverso.

- A1 faz uma explicação estabelecendo a equivalência entre o 1 e o ml e analisando as medidas registradas nas embalagens.

- A1 ao invés da dar a resposta pede ao aluno que ele explique como pensou.

28/11/05. Assunto: medidas de massa. A sala está novamente organizada em dois grupos relativos às séries, sendo que em cada um há 5 alunos. A professora regente da turma não está na sala, mas está na escola.

- A1 observa se os alunos já ouviram falar em grama e relaciona essa medida com medidas pequenas/leves e o quilo com objetos mais pesados.

- um aluno do grupo de $1^{\mathrm{a}}$ e $2^{\mathrm{a}}$ série observa que o rótulo da maionese apresenta a mesma medida em gramas e $\mathrm{ml}$.

- na atividade com a garrafa de água surgiu uma dúvida sobre a unidade de medida litro ou quilograma. 
conclusão

\section{DESCRIÇÃO DA AULA}

pesa e, também, deverão encher a garrafa com água para descobrir quanto pesa.

- A1 anota no quadro o nome dos objetos para que os alunos da $1^{\mathrm{a}}$ e $2^{\mathrm{a}}$ séries copiem e escrevam as medidas estimadas.

GARRAFA DE ÁGUA -

GARRAFA DE REFRI -

POTE DE MAIONESE -

POTE DE FARINHA -

BATEDOR DE BIFE -

3 - Após os alunos fazerem suas estimativas, A1 entregou para cada equipe uma balança de ponteiros (cozinha) para que os alunos façam a aferição das medidas estimadas.

4- A1 conversa com os alunos sobre o conteúdo da aula e, então propõe uma atividade: listar itens que são medidos em grama e em kg.

Após a listagem, A1 pede aos alunos que comentem sobre o que listaram.

5 - A1 entrega aos alunos a folha com exercícios e o conteúdo da aula.

6 - A aula é encerrada com a leitura do texto impresso (a folha com o

conteúdo da aula) em conjunto com os alunos.

Fonte: pesquisa de campo.

\section{OBSERVAÇ̃̃ES DA PESQUISADORA}

- os alunos pedem o alfabeto móvel para montar as palavras a serem copiadas.

- Essa atividade é para os alunos estimarem a massa de cada objeto.

- na dúvida, dois alunos resolvem comparar as medidas segurando um objeto em cada mão ao mesmo tempo.

- os alunos observam que suas medidas deram diferentes na maioria das estimativas.

- na conversa eu faria diferente, retomaria o que eles observaram de suas medidas/estimativas e aferição e, então falaria sobre o conteúdo. 